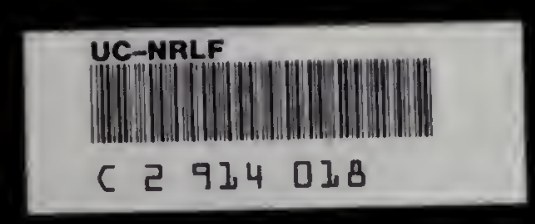




\section{LIBRARY}

UNIVERSITY $\cap$ CALIFOR VIA

1) $411=$ 

Digitized by the Internet Archive in 2007 with funding from Microsoft Corporation 



\title{
THE COAL MEASURES AMPHIBIA OF NORTH AMERICA
}

\author{
By \\ ROY LEE MOODIE \\ Associate in Anatomy, University of Illinois, Chicago
}

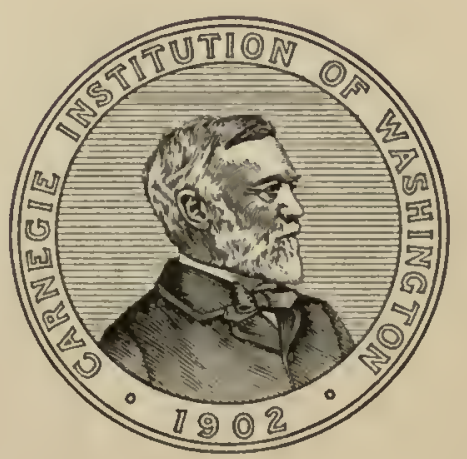

PUblished by the CARNEGIE INSTITUTION OF WASHINGTON WASHINGTON, 1916 
CARNEGIE INSTITUTION OF WASHINGTON

Publication No. 238

\section{Copies of this Book}

were first issued

SEP 281916 


\section{PREFATORY NOTE.}

The Carnegie Institution of Washington has already published several monographs upon paleobiological subjects, written by its research associates, Hay, Wieland, and Case. Each author has dealt with the subject-matter of his particular field, but each has brought to bear upon his work common factors which have placed his labors upon a broader basis than the mere morphological descriptions of fossil forms of life. Case has published four monographs upon the morphology and taxonomy of the Permo-Carboniferous vertebrates of North America, and has followed these by a fifth, in which all the known factors bearing upon the development of the life were assembled in an effort to discuss the paleogeography of the period. In his conception paleogeography is a very broad term, involving not only a study of the distribution of land, water, and life in any one interval of time, but a consideration of all the factors in the extremely complex inter-relations of organic and inorganic matter and causes which influence the development of each part.

Geologists and paleobiologists have alike suffered in their interpretation of past conditions, because of their lack of knowledge of the work done by others. Stratigraphy may not be interpreted from the preserved fossils without a knowledge of biological laws, and the formations of the earth may not safely be rearranged to account for the present or past distribution of life without a knowledge of geological processes.

It is obvious that such work is beyond the possibilities of any one man; it is rather the work of a group of men, each broadly trained and each master of his own field and able to contribute to and criticize the work of his fellows. Nowhere could close coöperation of this kind be better accomplished than under a system such as the Carnegie Institution of Washington has developed, whereby the research associates of the Institution and others of its staff may call in the assistance of men in related fields. Already the value of this procedure is apparent in the results accomplished by coöperation.

The following monograph, by Dr. Roy L. Moodie, adds an important link to the series of paleobiological publications of the Institution and is closely connected with the work already done upon the Permo-Carboniferous vertebrates, since it supplies a description of the life of the period immediately preceding. It is hoped that the volume will contribute in no small measure to an understanding of the broader problems of paleogeography and the recognition of the mutual problems of the paleobiologists and the geologists.

University of Michigan, March 15, 1916.

E. C. CASE. 


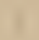

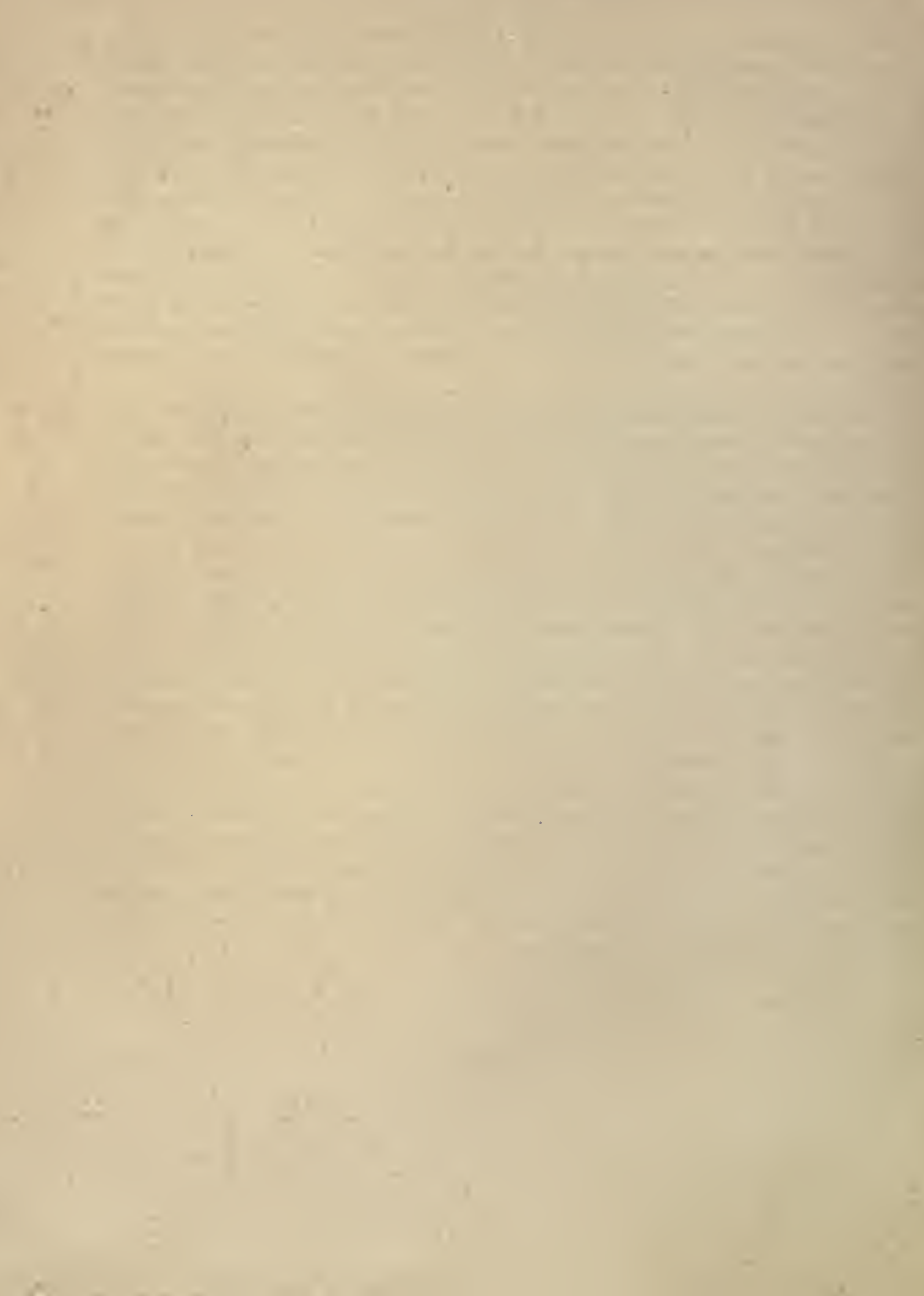




\section{PREFACE.}

The question of the origin of land vertebrates, which has appealed so strongly to students of fossil Amphibia, is by no means solved from the material furnished by the Coal Measures of North America. The Amphibia are, however, well known from several localities in the Coal Measures of this continent, where skeletons have been recovered which are sufficiently well preserved to afford a fair knowledge of their anatomy. The specimens rescued from the dumps of the coal mines are regrettably few in comparison with the number that must have been burned as fuel, or carried down the slopes as silt. Yet scanty as is the material thus collected, it is of great importance, because it represents such an early period in the recorded history of the air-breathing vertebrates.

The amphibian fauna in the Coal Measures of North America is represented by several hundred individual specimens, preserved in various museums. All of the collections have been available in the preparation of this memoir, with the exception of those species from Nova Scotia which are preserved in the Peter Redpath Museum of McGill University and in the British Museum of Natural History. The European material, which has been used in comparisons with the American forms, has been studied chiefly from the literature, although there have been available a series of specimens of Branchiosaurus amblystomus Credner, from Saxony, presented by the late Professor Credner, and a single specimen of Archegosaurus from Dr. von Huene, of Tübingen.

The collection which has been of the greatest value is that at the American Museum of Natural History, chiefly assembled by Dr. J. S. Newberry from the dumps of the coal mines at Linton, Ohio, while he was in charge of the Ohio Geological Survey (1869-1884). This collection, a part of which is at Columbia University, furnished Cope with the most of his type material for the "Synopsis of the Extinct Batrachia from the Coal Measures" (123). ${ }^{a}$ This entire collection, including all of Professor Cope's types and representing many new and hitherto undescribed forms, was generously placed at the writer's disposal for a period of five years through the kindness of Dr. Bashford Dean and Dr. Louis Hussakof. Dr. Hussakof made a trip through the Linton region and his description of the place occupied by the "Old Diamond Mine" is given on page $\mathbf{I} 6$.

An interesting collection of air-breathing vertebrates from the Coal Measures, representing I9 species, is in the U.S. National Museum (464). This is chiefly the collection of Mr. R. D. Lacoe and includes specimens from Mazon Creek, Illinois, from Kansas, and from Linton, Ohio. It is especially important in that it contains the skeleton (plate 20, fig. 3 ) of the oldest known reptile, Eosaurazus copei Williston (Jour. Geol., XVI, 295). It contains also, besides many of Cope's types, new forms which have been described by the writer $(464,470,471,472,473,474,478,479)$. Dr. Stuart Weller first secured the use of this collection for me, and its continucd use has been granted by Dr. C. D. Walcott. Mr. Charles Gilmore has called my attention to several interesting specimens and has kindly loaned them for description. 
A small but interesting collection of Mazon Creek Amphibia is that of the Peabody Museum of Yale University. Through the courtesy of the officers of this museum the writer was permitted to study these specimens and was given a grant for their illustration. The results of that study are contained in a previous paper $(478)$ and in the present memoir. Dr. Schuchert has offered suggestions as to the environmental conditions of the ancient Amphibia.

A few specimens of Coal Measures Amphibia are at the Walker Museum, University of Chicago. This collection includes the type of Micrerpeton cuidatum Moodie, the first branchiosaur discovered in the western hemisphere, and a few specimens from Linton, Ohio.

A single specimen of Amphibamus grandiceps Cope, very beantifully preserved, is in the possession of Mr. L. E. Daniels, of Rolling Prairie, Indiana. This specimen has been studied and described by Hay (316) and by the writer $(462,469,478)$.

The works of Cope and Dawson, published between 1860 and 1897, on the Amphibia from the Coal Measures, have been indispensable in the present study. It has been necessary to rely on the published descriptions and photographs of the interesting fauna from Nova Scotia, since it has not been possible for me to visit and examine the types preserved in the Peter Redpath Museum of McGill University and in the British Museum of Natural History. It has been possible to check Dawson's work, to a certain extent, by a study of a series of excellent photographs of the types of Coal Measures Amphibia collected by Dawson and Lyell and described by Dawson and Owen. The descriptions of these authors have been drawn on for the discussion of the Canadian forms.

The descriptions given below have been made full and complete in the belief that in this way our knowledge of these interesting vertebrates may be advanced. Many of the species have been described elsewhere in scattered papers by various authors. These descriptions have been revised and verified and are collected here in monographic form. The work is a morphologic and taxonomic revision of the Amphibia from the Coal Measures of North America. Especial attention has been paid to the factors which have been most active in the evolution of the group, so far as these factors may be interpreted. It is the author's hope that this review may open up the field for many more workers, since we are just beginning to learn about the evolution of this group of vertebrates.

The trustees of the Elizabeth Thompson Science Fund allotted a grant for the present investigation. This aid has enabled the writer to present his work in much better form than would have been possible otherwise. Dr. S. W. Williston has offered many suggestions and criticisms which have been gratefully adopted. It is with the greatest sense of pleasure that the author dedicates this memoir to his teacher and friend. After the manuscript was completed the author enjoycd a visit from Mr. D. M. S. Watson, of King's College, London, whose knowledge of the European and African forms enabled him to offer several very valuble suggestions.

It is fitting also to express my indebtedness to the Carnegie Institution of Washington for the privilege of publishing my work in the series of monographs contributed by Dr. E. C. Case, dealing with the anatomy and relationships of the early land vertebrates of North America. 


\section{CONTENTS.}

Prefatory Note

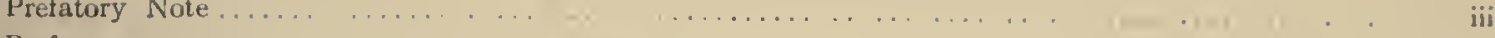

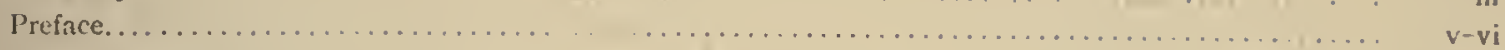

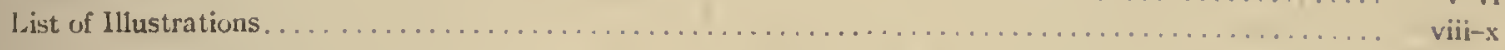

CHAP.

I. The Prorlem of tile Amplisbla from the Coal Mfasures................... $\ldots . \ldots$

II. History of the Discovery of Amplibia in the Conl Miasures................ 6 . 8

III. Stratigraphic and Geographic Distribution of Ampubia in the Coll Measukes of Nurtil

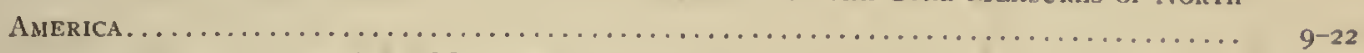

IV. The Morphology of the CoAl Measures Amphibia..................... 23-36

V. The Amphibia of the Devolian and Mississippian of North Amlerica............ $37-38$

VI. A History of tue Classification of the Ampuibia, with Especial Reference to the Species

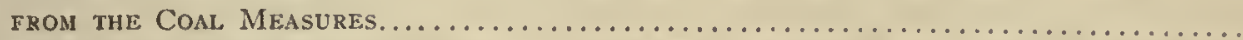

VII. Classification of AMpHibia Adopted in this Work, and a list of the Coal Measures

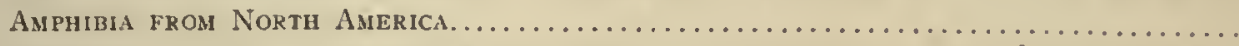

VIII. Definition of the Class Amphibia, the Subclass Euamphibia, and tife Order Branchio-

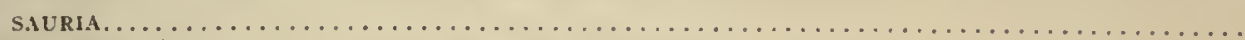

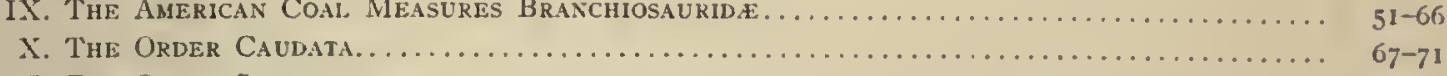

XI. The Order Salientia. . . . . . . . . . . . . . . . . . . . . . . . . . . . $72-74$

XiI. The Subclass Lepospondylia, the Order Microsauria, and the Group Aistopoda ...... $75-77$

XiII. Tile Microsaurian family Hrzonomide, from the Coal Measures of Nova Scotia.... $78-84$

yiV. The Microsaurian Family Tuditanide, from the Cosl. Measures of Ohio and Pennsyivania 85 -j I

XV. The Microsaurian Family Stegopida, from tile Conl Migasures of Ohlo.... . . . . 112-114

XVI. The Microsaurian Famil. Urocordylid.e, from the Coal. Measures of OhiO. . . . . . . 115-125

XVII. The Mícrosaurian Family Amphibamids, from the Coal Mleasures of Mizon Creek, Illixols $126-134$

XVili. The Microsaurian family Nyranide, from the Coal Measures of Ohio.......... 135 -138

XIX. Tile Aistopodous Microsaurian Family Ptyonild.e, from tile Coal Measures of Oilo ... I39-1 46

XX. The Mickosaurian family Molgoplinde, from the Coll Measures of Ollo and Mazon

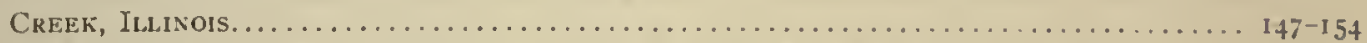

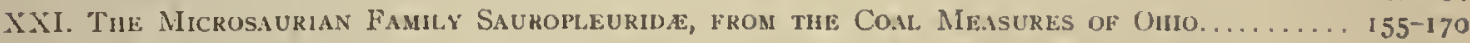

XXiI. The Microsaurian Family Ichtiycanthid.e, from the Coml Measures of OHIO........ 17i-i 74

.Xili. Supposed Microgaurian Species of Uncertain Relationship..................... 175-177

XXIV. The Temospondylous Ampilbia from the Coal Measures of Nortil Americi........ 178-ig7

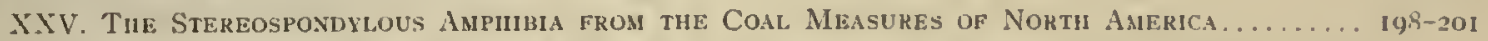

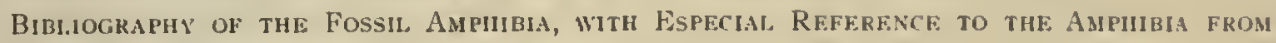

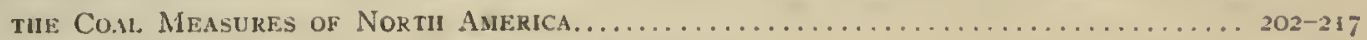

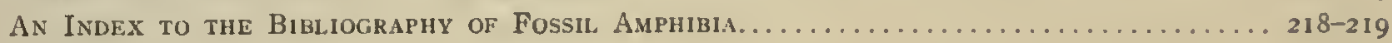

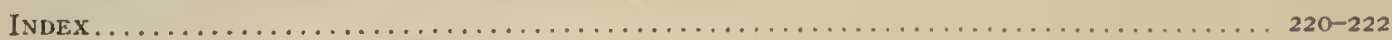




\section{ILLUSTRATIONS.}

PLATES.

PAGE.

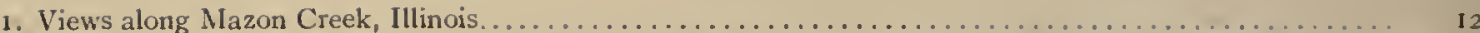

2. Drawing of type specimen of Micrerpeton caudatum Moodic, from the Coal Measures of Mazon Creek . . 52

3. Specimens of Eumicrcrpeton parvum, Erpetobrachium mazonensis, Erierpeton branchialis, Mazoncrpeton longicaudatum, and Amphibamus grandiceps. . . . . . . . . . . . . . . . . . . . .

4. ( 1 and 2) Vertebræ of Spondylerpeton spinatum Moodie. (3) Type specimen of Mazonerpeton costatum Moodic. (4) Type skeleton of Cephalerpeton ventriarmatum Moodic. (5 and 6) The halves of the nodule containing a practically complete skeleton of Amphibamus grandiceps Copc.............

5. (I) A reconstruction of the Coal Measures branchiosaurian, Eumicrerpeton parvum Moodic, a small

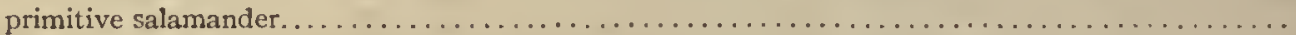

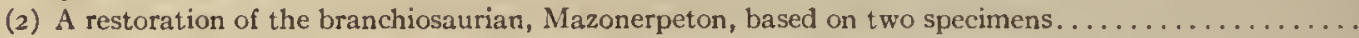

6. Dendrerpeton acadianum Owen. Mandibles, parts of anterior extremities, humerus, etc............

7. Hylerpeton dawsoni Owen. Mandible, teeth, rib, and bones of anterior extremity. Bones of pelvis and posterior limb and bony scales. .

8. Fritschia curtidentata Dawson. Bones of skull and anterior extremity, bony rods of belly, of pelvis, and

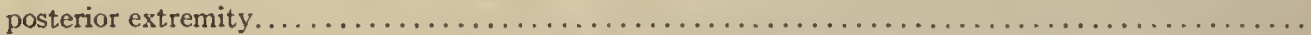

9. Hylonomus lyelli Dawson. (1) maxillæ and skull bones; ( $a$ ) sternal bones; (2) mandible; (3) lumerus, ribs, and vertebræ; $(4)$ posterior limb; $(5)$ pelvis; $(6)$ caudal vertebræ...................

10. Hylonomus latidens Dawson. Skull, portion of skeleton, foot, scapular, and sternal bones, humerus and rib, believed to belong to this species. Erect tree, Coal formation, of Nova Scotia . . . . . . . . . . .

11. Hylerpeton longidentatum Dawson. Mandible and other bones. Erect tree, Coal formation.........

12. Smilerpeton aciedentatum Dawson. Mandible, portions of skull, scales, and various bones. Errect tree, Coal formation.

13. Dendrerpeton oweni Dawson. Skull, mandible, and bones of anterior limbs, posterior limb, pelvis, and bony scales.

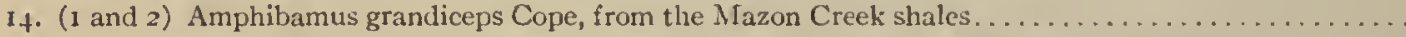

(3) Sauropleura (Colostcus) scutellata Newberry, from the Linton Coal Measures, the first known of the Ohio Coal Measures Amphibia; at first ascribed by Newberry to the fishes, but later correctly identified by Cope.

(4) Type of Diceratosaurus (Ccratcrpeton) punctolincatus Cope, from the linton Coal Mcasurcs...... .

15. (1) Dorsum of skull of Diccratosaurus punctolincatus (Cope), from the Coal Mcasurcs of Linton, (Nhio..

(2) Ventral surface of skul] of Diceratosaurus punctolineatus (Cope), from the Coal Mcasures of Linton. .

(3) Pectoral girdle of Diceratosaurus punctolincatus (Cope), from the Coal Measures of Linton........

(4) Cervical or antcrior dorsal vertcbra of Diceratosaurus punctolineatus (Cope), from the Linton Coal

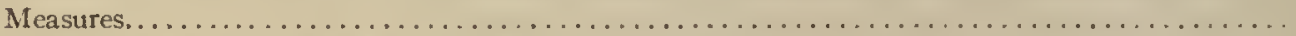

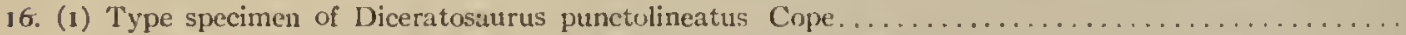

(2) Skull of Sauropleura longidentata Moodic, from the Coal Measures of Linton, Olio............

(3) Mandible of Sauropleura longidentati Moodie, from the Coal Measures of Linton, Uhic .........

(4) Type specimen of Sauropleura cnchodus Cope, from the Coal Measures of Linton, Olio..........

(5) Additional specimen of Diceratosaurus punctolineatus Cope, from the Coal Measures of Linton, Ohio.

17. Type of Saurerpeton lathithorax Cope.

18. (1) Type of Erpetosaurus sculptilis Moodic, from the Cannelton Shales of Pennsylvania .............

(2) Skeletal elements of Eryops sp. indet., from the Pittsburgh Red Shale at Pitcairn.............

(3) Amphibian footprints, Dromopus aduncus Branson, from the Mississippian shales of Giles County,

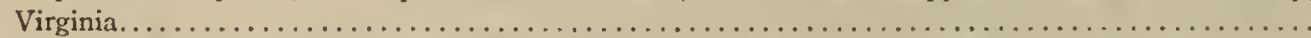

(4) Type of Thinopus antiquus Marsh, amphibian footprint from the Devonian of Pennsylvania......

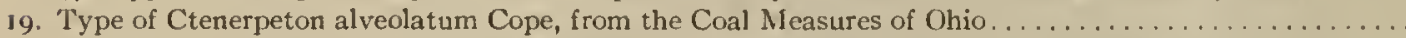

20. (1) Skull of Erpetosaurus minutus Moodie, from the Cannelton slates of Pennsylvania

...........

(2) Skull and anterior part of body of Ptyonius pectinatus Cope, from the Coal Measures of Linton.... .

(3) Skeleton of Eosauravus copei Williston, from the Coal Measures of Linton. "The oldest known reptile from North America" and closely related structurally to the Microsauria.................

(4) Part of ventral scutellation and ribs of Sauropleura digitata Cope, from the Coal Measures of Lintor. 
21. (1) Mandible of Macrerpeton deani Mloodie, from the Jinton Coal Mlcasures

(2) Portion of the skull of Macrerpeton deani Mloodic, possibly of the same individual as the mandible.

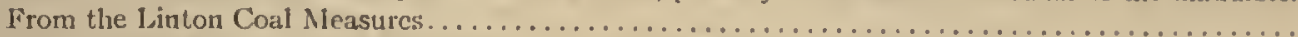

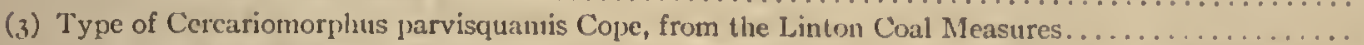

(4) An additional specimen of Cercariomorphus parvisquamis Copc, from the Linton Coal Measures. ...

(5) Skull of Sauropleura scutcllata Ncwberry. From the Coal Mcasures of Ohio.................

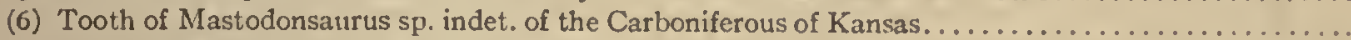

(7) Tooth of Mastodonsaurus giganteus Jaeger, from the Triassic of Germany. Introduccd for comparison with the tooth from the Kansas Carboniferous.

22. (1) Type of Leptophractus lineolatus Cope, from the Coal Measures of Linton. Portions of maxilla and

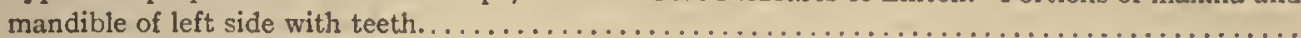

(2) Type of Proterpeton gurleyi Moodic, from the Coal Measures of Illinois, near Danville. Cervical of

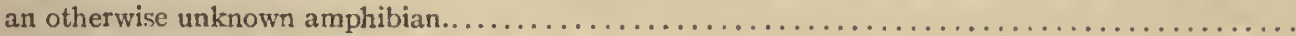

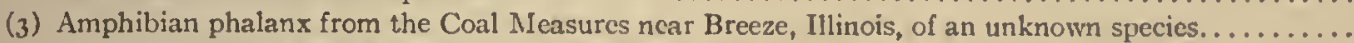

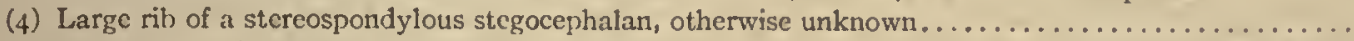

(5) Type of Cope's species Tuditanus mordax referred by him to the cranium, on account of the sculpturing of the elements, now known to be portions of the interclavicle and clavicles of Diceratosaurus

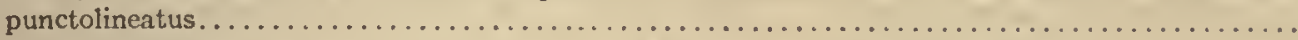

(6) Skull of Baphetes planiceps Owen, from the Coal Measures of Nova Scotia.................

23. (1) Ventral scitelle of Ctenerpeton alveolatum Cope, from the Cual Measures of Ohio.............

(2) Left leg and pelvis of Ichthyeanthus platypus Cope, from the Coal Measures of Ohio............

24. (1) Type specimen of Pelion lyelli Wyman, from the Coal Measures of Ohio. Supposed to represent the ancestral form of the Salientia.

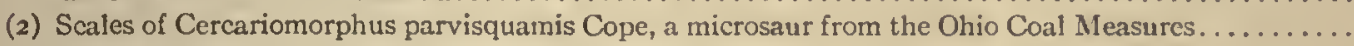

(3) Type specimen of Cercariomorphus parvisquamis Cope $\ldots \ldots \ldots \ldots \ldots \ldots \ldots \ldots \ldots \ldots \ldots \ldots \ldots$

25. (r) Photograph of type spccimen of Erpetosaurus (Tuditanus) radiatus Cope, from the Coal Mleasures of

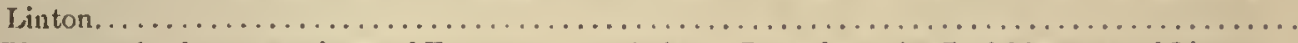

(2) Photograplı of type spccimen of Erpctosaurus tabulatus Cope, from the Coal Mcasures of Linton...

(3) Photograph of the impression of Stegops divaricata Cope, from the Coal Measures of Linton.......

(4) Type and only known specimen of Micrerpeton caudatum Moodie, a branchiosaur from the Coal

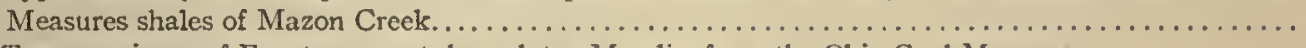

26. (1) Type specimen of Erpetosaurus tuberculatus Moodie, from the Ohio Coal Measures.............

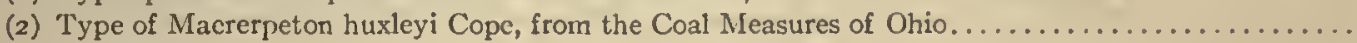

\section{TEXT-FIGURES.}

1. Map of the Coal Measures in North America.

2. Distribution of Coal Measures Amphibia in North America.

3. Topographical Map of Mazon Creek Region.

4. Topographical Map of Linton, Ohio, Region.

5. Fossil Tree Trunk in Position. .

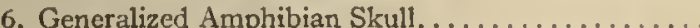

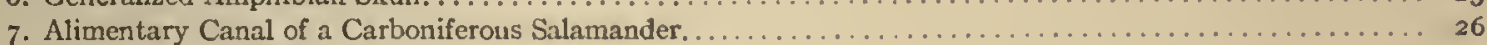

צ. Vertebre and Ribs of Coal Measures Amphibia. . . . . . . . . . . . . . . . . . . . . . . 28

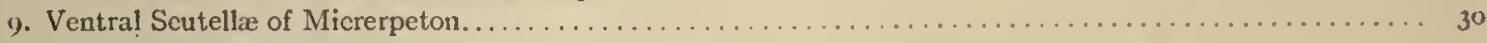

10. Horny Armor of Hylonomus. . . . . . . . . . . . . . . . . . . . . . . . . . . . . . . 31

11. The Skulls of two Microsaurians: A. Eoserpeton tenuicone; B, Ceraterpeton galvani............. 33

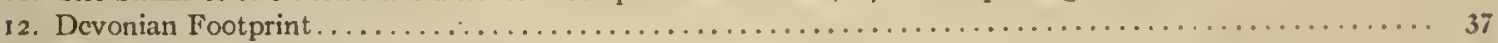

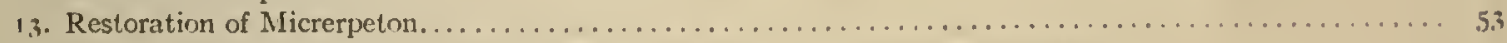

14. Mazon Creek Amphibia: A, Eumicrerpeton parvum; B, Amphibamus thoracatus.. ................ s9

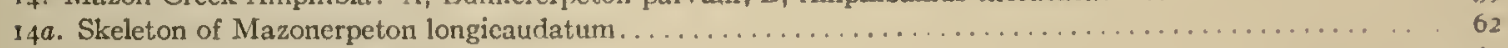

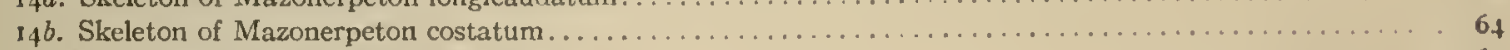

15. A. Impression of Erierpeton branchialis. . . . . . . . . . . . . . . . . . . . . . . . . 65

B. Eumicrerpeton parvum. . . . . . . . . . . . . . . . . . . . . . . . . . . . 65

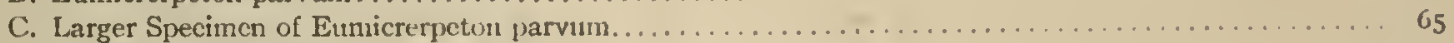

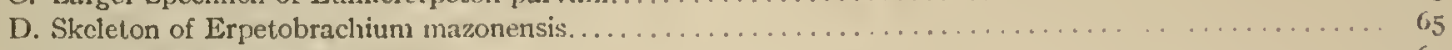

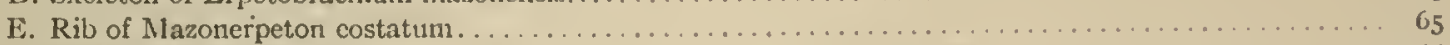

15a. Type Material of Sparodus. . . . . . . . . . . . . . . . . . . . . . . . . . . . 66

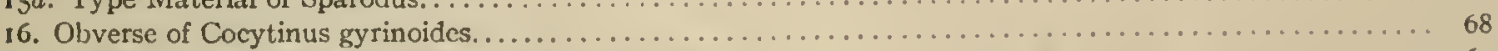

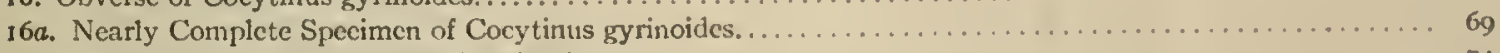

17. Pelion lyelli, supposed anccstral Salientian. . . . . . . . . . . . . . . . . . . . . .

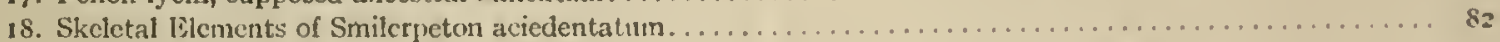




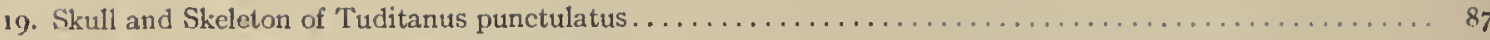

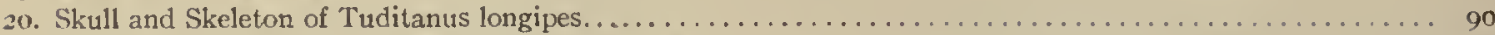

2I. Skeleton of Tuditanus walcotti: A, Body; B, Leg. ................................ 94

22. A. Ontline of Skull and Cranial Elements of Erpetosaurus minutus Moodie, from the Cannelton Slates of Pennsylvania...

B. Outline of Skull and Cranial Elements of Erpetosaurus radiatus Cope, from the Coal Measures of Linton

C. Palate of Erpetosaurus (tabulatus?), from the Coal Measures of Linton, Ohio.

D. Outline of Skull and Cranial Elements of Erpetosaurus acutirostris Moodie, from the Coal Measures of Linton, Ohio.

E. Outline of Larger Part of Skeleton of Odonterpeton triangularis Moodie, from the Coal Measures of

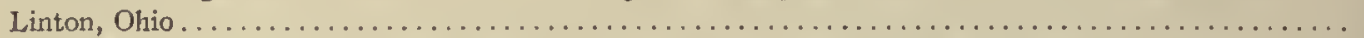

F. Right Mandible of Erpetosaurus tabulatus Cope, from the Linton, Ohio, Coal Measures.............. 99

G. Skull Elements and Lateral-line Canals of Erpetosaurus tabulatus Cope, from the Coal Measures of Linton 99

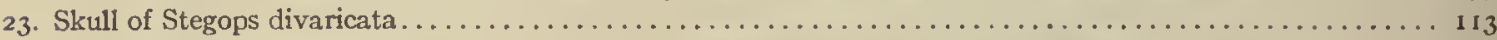

24. Microsaurian Skulls from Linton, Ohio: A, Diceratosaurus levis; B, Diceratosaurus robustus.......... I I9

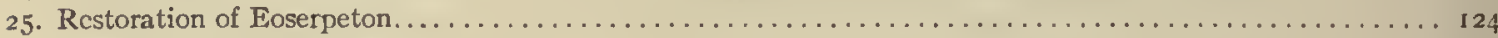

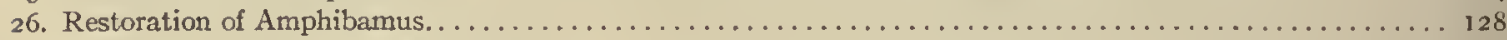

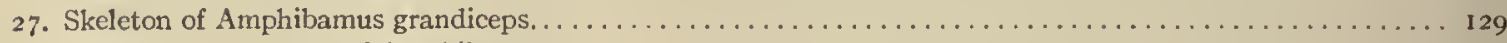

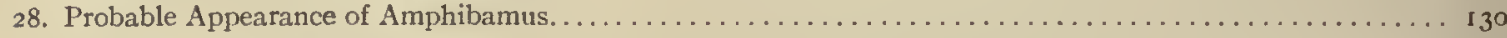

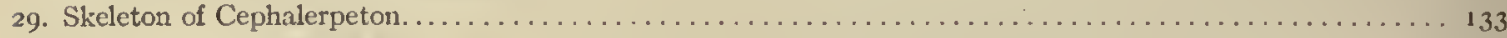

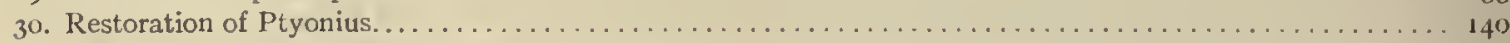

31. Restoration of Estocephalus. . . . . . . . . . . . . . . . . . . . . . . . . . . . . . $\ldots$

32. Vertebræ of Molgophis brevicostatus. . . . . . . . . . . . . . . . . . . . . . . . . .

33. Fore-limb of a Member of the Molgophida, Possibly Pleuroptyx...................... I52

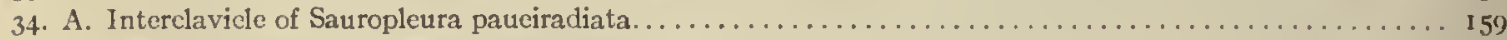

B. I.eft Clavicle of Sauropleura panciradiata . . . . . . . . . . . . . . . . . . . . . . . . .

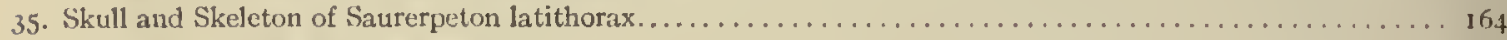

36. Mandible of Leptophractus dentatus. . . . . . . . . . . . . . . . . . . . . . . . . . I69

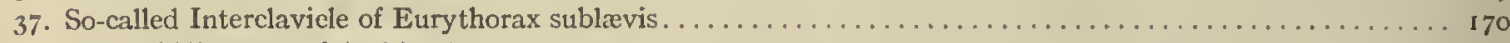

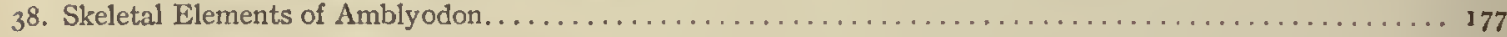

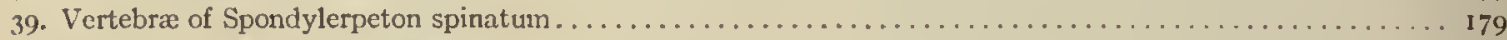

40. Mandible of Macrerpeton deani. . . . . . . . . . . . . . . . . . . . . . . . . . . . . . I 84

41. Vertebræ of Eosaurus acadianus: A, Oblique Lateral View; B, Oblique View; C, Posterior View; D, Trans-

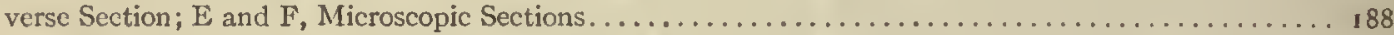

42. Skull and Mandible of Eobaphetes kansensis: A, Uuter View of Mandible; B, Portion of Skull; C. Inner Surface of Mandible . . . . . . . . . . . . . . . . . . . . . . . . .

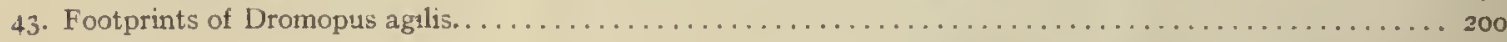


THE COAL MEASURES AMPHIBIA OF NORTH AMERICA 



\section{CHAPTER I.}

\section{THE PROBLEM OF THE AMPHIBIA FROM THE COAL MEASURES.}

The Amphibia from the Coal Measures of North America present the problem of the origin of the land vertebrates, since the air-breathing vertebrates in the Coal Measures of this continent are the earliest known in the western hemisphere. The difference in age between the chief amphibian-bearing deposits of North America and Europe is not great, although it has been asserted that Pholidogaster and its allied fauna, described by Huxley from Scotland (33I), is much older, probably Mississippian. It is interesting to note that these earliest representatives of the Amphibia in Scotland are all temnospondyles, of which there are very few representatives in the Coal Measures of North America.

The forms so far described from the North American Coal Measures present a very high degree of development and differentiation, the earliest known species being already specialized and well adapted for various modes of life. As far back in geological time as the middle Coal Measures, when the first well-defined forms are known, environmental conditions had effected a wide diversity of structure within the group. Thus, early in the geological history of the land vertebrates, we have, among the Coal Measures Amphibia, various forms which had specialized into strictly aquatic, terrestrial, subterrestrial, and arboreal, or at least partly arboreal. Specialization had extended to the loss of limbs, ribs, and ventral armature in a few species, and to the acquirement of claws, running legs, or a long propelling tail with expanded neural and hæmal arches in others. The forms range in size from small creatures less than an inch in length to large species which must have attained a length of several feet. A rather interesting parallel, though of no phylogenetic significance, can be drawn between the Amphibia of the North American Coal Measures and the reptiles of to-day. The snakes are represented by the limbless, snake-like forms, such as Ptyonius and Phlegethontia. The lizards find their counterpart in the Hylonomidæ and the Tuditanidæ. No known characters of these animals tend to ally them directly with any known group of fishes, except in the most general way. These facts all indicate a long antecedent history for the amphibian group or else a preceding period of greatly accelerated development of which we now know nothing.

The Amphibia whose remains have been brought to light from the Coal Measures have hitherto been regarded as pertaining to a single order, the Stegocephalia, characterized by the completely roofed-over cranium and a large parasphenoid. The writer (469) had previously assigned 5 suborders to the group: the Branchiosauria, Microsauria, Aistopoda, Temnospondylia, and Stereospondylia. All of these groups are represented in the Coal Measures of North America. It has seemed inadvisable, in the light of our present knowledge of the Amphibia, to retain these 5 groups as suborders, and, in the revised scheme of classification which has been 
published elsewhere (469), they are given the rank of orders-all excepting the Aistopoda, which are now regarded by the writer as specialized Microsauria.

The recent Caudata are possibly represented in the North American Coal Measures by forms which may be assigned tentatively to the Proteida. Such forms as Cocytinus gyrinoides, Hyphasma lcevis, and Erierpeton branchialis possibly represent this group in the Pennsylvanian. This relationship is based chiefly on the structure of the hyobranchial apparatus and on the general structure of the species. The three above-mentioned species are, however, very insufficiently known, and the relationship can hardly be regarded as more than suggested by the characters which are at hand.

The Salientia, or frogs, may possibly have their ancestral type in Pelion lyelli, the first known species from the Linton, Ohio, Coal Measures. Oddly enough, among the hundreds of specimens collected later from this horizon, not a fragment can be identified with this species. The type specimen is unique, and although incomplete its characters are suggestive.

The Branchiosauria are represented in North America by four species: Micrerpeton caudatum, Eumicrerpeton parvum, Mazonerpeton longicaudatum, and $M$. costatum. Three other genera which occur in North America have been placed (642) in this group, but they do not belong there, for reasons given below. The branchiosaurs were salamander-like in appearance. They were naked, with the exception of small ovoid scales on the back and the chevron-shaped armature of the ventral surface, the latter being almost universally present among the Paleozoic Amphibia. They were adapted for life in the water for at least the early part of their existence, as is shown by the possession of gills on many of the late Carboniferous and early Permian forms of Europe. The group is, without doubt, ancestral to the modern Caudata. No branchiosaurians have been described elsewhere from so low in the geological series as those here given and they are the first and only evidence of the occurrence of the group in the western hemisphere.

The Microsauria are represented in the Coal Measures by numerous forms which are usually characterized as lizard-like animals with a well-developed ventral scutellation. Other characters, such as the possession of lateral-line grooves on the cranium, the arrangement of the cranial elements, and the condition of the ribs, will be discussed further on. The pectoral arch is well developed and is composed of five dermal bones plus the regular skeletal elements. The skeletal membrane bones are sculptured after the manner of those of the cranium. The bodies of the animals were, in a few cases, covered with scales; but most of them appear to have been completely naked, even the ventral armature being absent in some cases. The ventral scutellation was especially strong and highly developed in some of the forms; e.g., in the genera Saurerpeton and Sauropleura. The vertebræ are uniformly of the hour-glass or notochordal type. This is so generally the case that the characters of the vertebræ and ribs are taken as the chief diagnostic characters of the major groups. Various peculiarities are seen among the Microsauria, such as the development of horns in various genera which are, apparently, related. The order seems to have gone completely out of existence during the early Permian, 
and if their descendants continued on as reptiles, as has been suggested (469), we do not know the intermediate stages.

The Aistopoda are without doubt specialized microsaurs, and, in the opinion of the writer, are not entitled to separate rank. Some of these forms reached a high degree of specialization. One American spccies has the skelcton reduced to a long, slender head and a slender series of elongate vertebræ, all other parts of the skeleton, even the ventral armature, being absent. The proportions attained by this species, Phlegethontia linearis Cope, recall those of the coach-whip snake, Zamenis flagellum Shaw, of the western plains. Some of the so-called Aistopoda have been credited by Fritsch with the possession of peculiar clasping organs, "Kammplatten." Newberry has written of the discovery of similar structures in the Ohio Coal Measures (498), but the statement of the actual association of these "Kammplatten" needs confirmation. Dr. R. H. Traquair wrote to the author under date of April 28, 1909:

"I maintain that the association of a bundle of 'Kammplatten' with a specimen of Ophiderpeton in the Bohemian gas coal was entirely accidental. Of such pitfalls the paleontologist has to beware or serious mistakes may be the consequence, as has happened more than once. I must, however, publish a short paper on the Kammplatten, for I think I know what they are now."

Fritsch, however, has very clearly figured a nearly complete specimen of Ophiderpeton (25I, Bd. IV) as possessing the Kammplatten in place near the cloaca, where he suggests they may have served the function of accessory copulatory organs or claspers.

The Temnospondylia are represented by scanty remains of species from Illinois, Pennsylvania, and Nova Scotia. The forms belonging to this group are all relatively large, and they had a wide geographical distribution during the Permian. This group contains two types of vertebræ, known as the embolomerous and the rachitomous, both of which are present in the Coal Measures. Such forms as Eosaurus, Baphetes, Eobaphetes kansensis, Macrerpeton, and Dendrerpeton are regarded tentatively as temnospondyles, but there is no definite assurance that they are such. It is possible that Eosaurus is a stereospondyle, but the species is too incompletely known for a definite statement to be made. The close resemblance between the vertebræ of Eosaurus and Anthracosaurus has been noted by Huxley (332).

The Stereospondylia are very scantily represented in the Coal Measures, if at all. Eosuurus may belong here as indicated above. The tooth and cranial fragments discovered and described by Williston from the Coal Measures of Kansas may represent a stereospondyle as he states (608), but the evidence is incomplete. A fragment of a large rib (plate 22, fig. 4) of a species from Linton, Ohio, otherwise unknown, may be a stereospondyle. We would expect an early development for this group, but it is an interesting fact that no stereospondyles are known definitely before the Triassic, during which period they had an extensive distribution. 


\section{CHAPTER II.}

HISTORY OF THE DISCOVERY OF AMPHIBIA IN THE COAL MEASURES.

Sir William Logan, in I84I, discovered in the Coal Measures of Horton's Bluff, Nova Scotia, some tracks of Amphibia which he carried to London and which Sir Richard Owen pronounced to be undoubted "reptilian" tracks. This fact was published in 1842 (380) and was the first recorded evidence of the occurrence of land vertebrates in the Carboniferous rocks of the world. To these tracks Sir William Dawson later gave the name of Hylopus logani.

Two years later Dr. Gergens (29I) wrote a letter to Professor Bronn, the founder and one of the editors of the "Neues Jahrbuch für Mineralogie, Geologie und Paleontologie," in regard to an important discovery in the Carboniferous rocks of Germany. The letter is of such exceptional interest in connection with the history of the fossil Amphibia that it is given here:

"In dem Brandschiefer von Münsterappel in Rhein-Bayern habe ich in vorigen Jahre einen Salamander aufgefunden und Hrn. H. v. Meyer in Frankfurt zur näheren Untersuchung und Beschreibung übergeben;--Gehört dieser Schiefer der Kohlen-Formation?in diesem Falle wäre der Fund in anderen Hinsicht interessant."

The form discovered by Dr. Gergens and described by Hermann von Meyer as an amphibian is a little puzzling as to its characters. Miall (449, p. I83) says that the remains are too imperfect for close definition. The form, as figured, resembles an immature branchiosaurian, as one is at once reminded, from an examination of Von Ammon's Branchiosaurus caducus (7, Taf. IV, fig. I). In 1844 Dr. Alfred King (356) announced the discovery of "reptilian" footprints in the Carboniferous of Pennsylvania.

The next announcement of fossil Amphibia was made by Goldfuss (296), who in I 847 described the famous Archegosaurus from the upper Carboniferous of Germany, from the remains which had as long ago as 1777 been regarded as a fish. Two ycars later Isaac Lea (37I) announced to the British Association for the Advancement of Science, through Buckland, the discovery of footprints in the old Red Sandstone (Mauch Chunk) of Pennsylvania. These objects occur not rarely in the Mauch Chunk shales, which are of upper Mississippian age. Barrell (2I, p. 460) records the finding of imperfect tracks in the same beds, and Rogers (Geology of Pennsylvania, pt. II, I 856, p. 83I) records three unnamed varieties from 2,200 feet below the top of the Mauch Chunk. Branson (50) has recorded the finding of other amphibian footprints from the Mississippian of Giles County, Virginia.

Lyell and Dawson (396), in 1853, read a paper before the Geological Society of London, in which they announced the discovery of remains of Amphibia in the Coal Measures of North America, although Dawson had previously, in I $85^{\circ}$, discovered the skull of Baphetes planiceps Owen, which was not described until the latter part of 1853 (509). The specimen had lain unnoticed in the collection of the Geological Society for more than two years. When, however, the announcement was made 
by Lyell and Dawson of the discovery of Amphibia in the Coal Measures of Nova Scotia, so much interest was excited that the skull, now known as Baphetes planiceps, was brought to light by the president or secretary and was described (509) by Sir Richard Owen. The only other known evidences of land vertebrates in the Paleozoic of North America, up to this time, had been the footprints described by Lea and King from the Mississippian (Mauch Chunk) and Pennsylvanian of Pennsylvania. The specimens presented to the Geological Society of London by Lyell and Dawson were found at the South Joggins, Nova Scotia, and consisted of scutes, a few limb bones, a fragment of a jaw, and a few vertebræ, a part of which were associated. The remains were found quite accidentally and unexpectedly by them in the petrified trunks of ancient Sigillariæ which were exposed on the coast. Dr. Jeffries Wyman, of Harvard College, had examined these remains in the United States and had pronounced (638) them to be amphibian, comparing them with similar elements in Menobranchus. On the arrival of the specimens in England they were submitted to Sir Richard Owen, who suggested the name (5I4) Dendrerpeton acadianum and compared the remains with Archegosaurus. At the same meeting of the London Geological Society, Owen read a paper on a small amphibian (508) from the British Carboniferous which he named Parabatrachus. Subsequent discoveries have shown, however, that this form belongs among the fishes. At the meeting of the Geological Society held in the latter part of the same year Owen announced (509) further discoveries in the Nova Scotia coal beds.

Hermann von Meyer (436), in I 857, described numerous stegocephalian remains from the upper Carboniferous of Germany. Dr. Jeffries Wyman, in the same year, described (639) a new form of amphibian from Linton, Ohio. This form he called Raniceps lyelli, but as the name Raniceps had been preoccupied by Cuvier for a genus of gadid fishes, Wyman later (I868) changed the name to Pelion. This was the first form to be described from the locality at Linton, which has since yielded the remains of half a hundred species.

Dawson (204), in 1859, made a further contribution to the fauna of Nova Scotia by the description of IIylonomus and other species of Dendrerpeton from the South Joggins deposits. Huxley (33I), in I 862, described the genera Loxomma and Pholidogaster from the Carboniferous of Scotland. The same year Owen made a further contribution (5I4) to the fauna of the Nova Scotia beds, and Huxley (332) discussed the anatomy of Anthracosaurus from Scotland. Marsh (404), in the next year, described, as an enaliosaurian, the interesting Eosaurus acadianus from the Nova Scotia Coal Measures, basing the species on two vertebra, apparently from the dorsal region. The vertebræ resemble the stereospondylous type, and Huxley (332) called attention to the similarity of these vertebræ to those of Anthracosaurus.

Cope (105), in I 865, began his researches among the Coal Measures Amphibia of Nortl America by the description of Amphibamus grandiceps from the Mazon Creek shales of Illinois. Ten years later (123) he published a complete synopsis of the Carboniferous Amphibia of North America, with especial reference to the Linton, Ohio, species, illustrating many of the forms now known from Linton. Between the years I 865 and 1897, Cope published numerous papers (105-177) on the Amphibia 
of the Paleozoic, and to his researches is due a large part of our knowledge of these forms.

Great credit is due Dr. J. S. Newberry $(495,498)$ for the enthusiasm and interest which his collections of Coal Measures Amphibia exhibit. He furnished Cope with the majority of the type material described by him, and it was through Dr. Newberry's instrumentality that the "Synopsis of the Extinct Batrachia from the Coal Measures" (123) was published. The material which Dr. Newberry had collected he took with him from Ohio to Columbia University, New York, and a part of his collection still remains in the geological collection of that institution, although the greater portion has been transferred to the American Museum of Natural History. The Newberry collection forms the basis for the larger part of this memoir.

Between the year I853 and the early nineties, Dawson continued (200-223) his researches on the Amphibia of the Coal Measures of Nova Scotia. His most notable single work (208) is "The Air-Breathers of the Coal Period," published in Montreal in 1863, in which he gives a complete account of the forms then known from Canada, attempting some restorations. Since his death there have been no new species described from Canada, and, so far as I can learn, there has been no further collecting at the South Joggins.

Recently G. F. Matthew (409) has rearranged the classification of amphibian footprints from Nova Scotia. Jaekel (347) has described very fully the remains of Diceratosaurus punctolineatus (Cope) from Linton, Ohio, basing the new genus on a species described by Cope as a member of Ceraterpeton. Hay (3I6) has added to the knowledge of the anatomy of Amphibamus, his most interesting contribution being the detection of long, curved ribs in this form. This character excludes the species from the order Branchiosauria and shows the relationship of the form to the Hylonomidæ and the Microsauria. Schwarz (540) has described the characters of the vertebræ and ribs of several genera of the Coal Measures Amphibia and has (54I) offered his views as to the descent of the Amphibia, based entirely on his work on the vertebræ of species from North America and Europe.

Since 1908 the writer has published several contributions $(457-489)$ on the Amphibia from the Coal Measures of North America. The results of these investigations are given in this work. 


\section{CHAPTER III.}

\section{STRATIGRAPHIC AND GEOGRAPHIC DISTRIBUTION OF AMPHIBIA IN THE COAL MEASURES OF NORTH AMERICA.}

There are but four localities in North America which have furnished any notable remains of Amphibia in the Coal Measures. These are, in the order of their discovery, the deposits at the South Joggins, Nova Scotia; the Linton, Ohio, Coal Measures; the Mazon Creek, Illinois, shales; and the Cannelton slates near Cannelton, Pennsylvania. There are, however, several other localities on the continent which have furnished evidences of Amphibia in the Coal Measures. The principal one of the latter localities is doubtfully of Coal Measures age, although recent discoveries would tend to show it is such. The deposits in question, those of the Clepsydrops shales of Vermilion County, Illinois, have, heretofore, been regarded as Permian, but the discovery of similar remains in rocks of undoubted Pennsylvanian age in Pennsylvania would seem to indicate that the Illinois deposits were contemporaneous with them.

(a) The deposits in Vermilion County, Illinois, lie along the north bank of Salt Fork Creek, at the tip of the "Horseshoe Bend," about 2 miles south of Oakwood, Illinois. They were discovered by Dr. J. C. Winslow, of Danville, in 1875 . The remains discovered by him were forwarded to Professor Cope for identification. Later the deposits were thoroughly explored by W. F. E. Gurley, and the specimens collected by him are now preserved (86) in Walker $\mathrm{Mu}^{-}$ seum, University of Chicago. In 1907, the writer, while working for the University of Chicago, in exploring the same locality, exhausted the beds so far as they could at that time be uncovered from the landslide which had overwhelmed them. The formation in which the bones occur is a soft gray or reddish shale, and it lies without any apparent stratigraphic break on shales of Pennsylvanian age. Below these shales are sev-

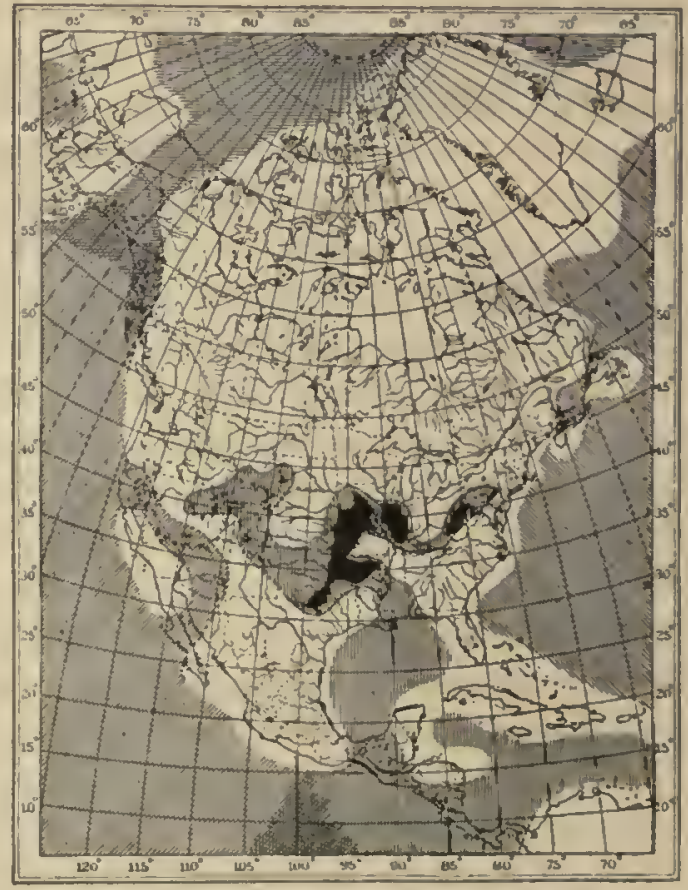

FtG. 1.-Map of Upper Pennsylvanian showing land and water conditions under which the Coal Measures amphibian fauna lived. It will be noted that the chief deposits which have fumished amphibian remains are on the margins of the heavily shaderl arcas. (After Schucliert.)

lixplanation of symbols: Lands are white. Water areas are lined. Formation outcrops are black or dotted. Known shore-lines are solid lines; probahle ones broken. Vertical lines in millule of continent indicate Gulf marine.

eral feet of limestone containing invertebrates of typical Pennsylvanian facies. There are indications of at least 3 species of Amphibia in the deposits. Case (86) has indicated with doubt a fourth species. The species are: Cricotus heleroclitus Cope, 
Cricotus gibsonii Cope, Diplocaulus salamandroides Cope. The remains are very fragmentary, and consist for the most part of incomplete vertebræ, with a few small skull fragments.

(b) In 1897 Dr. Williston (607) described some fragments of Cricotus from a deposit in Cowley County, near Winfield, Kansas. There has been some dispute as to the age of the deposit, but the consensus of opinion seems to be that the beds are of approximately the same age as those of Illinois and Pennsylvania in which similar remains are found, and those deposits are looked upon as Upper Pennsylvanic (Case (94), pp. 239-240). No new forms were described from Winfield, since only a few fragments were obtained. Williston referred the phalange, the fragment of a jaw, and the tooth to Cricotus heteroclitus Cope.

(c) Later in the same year Williston (608) announced the discovery of a tooth of typical labyrinthodont structure from near Louisville, Kansas (plate 2I, fig. 6). The tooth was accompanied by fragments of bone and was probably not far from the bed in which it was fossilized. Williston states that the remains were from the shales which are "nearly at the upper part of the Carboniferous, probably within one hundred feet of the Manhattan Limestone."

(d) In I 894 Marsh (406) and earlier (1873) Mudge (490) described footprints of vertebrates from the stone-quarries near Osage City, Kansas. The stone in which they were found was a fine-grained limestone which occurs near the middle of the Kansas Coal Measures.

(e) Two years later Marsh (407) announced the discovery of traces of the oldest known (Devonian) air-breathing vertebrate. The footprints of Thinopus antiquus were regarded by Marsh as "apparently amphibian." This still remains the oldest geological evidence of air-breathing vertebrates, although Lohest some years ago (38I) called attention to remains from the Devonian of France which he thought might be amphibian. The footprint described by Professor Marsh was "found in the town of Pleasant, one mile south of the Allegheny River, Warren County, Pennsylvania, by Dr. Charles E. Beecher, who presented it to Yale Museum, and also furnished the information in regard to its geological position. ... The geological horizon is near the top of the Chemung, in the upper Devonian. In the same beds are ripple marks, mud cracks, and impressions of rain drops, indicating shallow water and shore deposits."

( $f$ ) Among the collections of the American Museum there is an impression of a small amphibian foot obtained from Phœnix Tunnel, Pennsylvania. The impression is in hard black slate very similar to the slate of the Cannelton region. It is possible that the specimen may have been obtained from the Cannelton beds, since they would be expected to occur at Phœnix Tunnel. The impression is rather small. It is the footprint of a 5-toed animal, probably of the right foot, since no amphibian $(+65)$ so far is known from the Coal Measures with 5 digits on the hand. The first digit is short and thick, with a large ball at its base. The foot measures from the posterior edge of the palm to the tip of the longest digit $12 \mathrm{~mm}$. The length of the first digit is $7 \mathrm{~mm}$. The impression differs in some respects from the impressions so far known from the Coal Measures, but no attempt will be made to assign it to a 
species. It may have been made by either a branchiosaurian or a microsaurian, but more probably the latter, since we do not know of any of the former animals from the Cannelton beds, or in fact from any of the Coal Measures beds excepting the Mazon Creek shales. The specimen is No. 2872 of the American Museum.

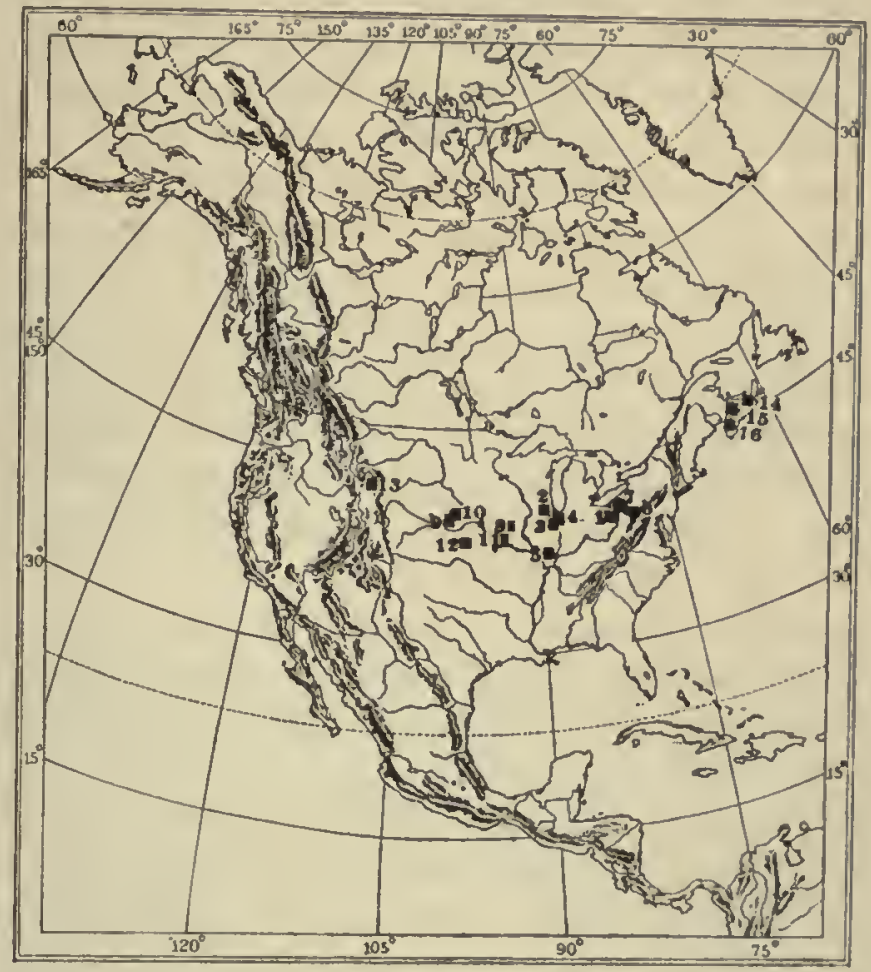

FiG. 2.-Distribution of Coal Measures Amphibia in North America.

I. Linton, Ohio, near Yellow Creek P. O., Jefferson County, Ohio, on the banks of Yellow Crcek, near the Ohio River, 16 miles north of Steubenville.

2. Mazon Creek shales, Grundy County, Illinois, near Morris.

3. "Clepsydrops shales," Salt Fork Creek, Vermilion County, Illinois, near Oakwood, on Tate farm, 8 miles west of Danville, Illinois.

4. Danville, Illinois, coal where the type of Proterpelon gurleyi Moodie was found.

5. Breeze, Illinois, where Dr.J.A. Udden, in 1907, found a fragment of an amphibian phalange on the dump of the Coonperative Coal Company.

6. Pitcaim, Pennsylvania, 15 miles east of Pittsburgh.

7. Cannelton, Pennsylvania, Beaver County, Cannelton slates, Kittanning formation, 45 miles northwest of Pittsburglı.

8. Fairfield, Iowa, where Dr. J. A. Udden found remains attributed by Dr. Eastman to Pleuroplyxx clavalus Cope.

9. Louisville, Pottawatomie County, Kansas, where Dr. S. W. Williston discovered remains of Maslodonsaurus in the Coal Measures.

10. Washington County, Kansas, source of type of Eobapheles kansensis Moodie, from the Coal Measures.

II. Osage City, Osage County, Kansas, amphibian footprints from the Coal Measures.

12. Winfield, Kansas, source of Cricolus material.

13. Lander, Wyoming, in Wind River Carboniferous.

14. Pictou, Pictou County, Nova Scotia, 84 miles northeast of Halifax. Source of Bapheles planiceps Owen.

15. Joggins (Joggins Mines), Cumberland County, Nova Scotia, 4 miles from River Hebert. Sounce of IIylerpeton and Dendrerpelon faunas.

16. South Joggins, Nova Scotia, source of the Eosaurus acadianus Marsh.

(g) Dr. J. A. Udden, in 1907 , discovered a fragment of a plalanx of some amphibian (plate 22, fig. 3) on the dump of the Coöperative Coal Company, a mile east of Breeze, Illinois. It was obtained from below the Shoal Creek limestone and somewhere above the (Illinois) Coal No. 6, according to Dr. Udden's notes. The maximum width of the phalanx is $10 \mathrm{~mm}$. and it probably had a length of $16 \mathrm{~mm}$. 
(h) Mr. N. H. Bromn, in 1914 , discovered in the Carboniferous rocks to the east of the Wind River Mountains, near Lander, Wyoming, a single fragment of an amphibian. The writer was accompanying Mr. Brown at the time of the discovery and there can be no doubt that the fragment was amphibian; the location of the beds was such that no later age than the Coal Measures can be assigned to them.

(i) Dr. J. A. Udden (577), in 1912, announced the discovery of an amphibian in the Des Moines formation of Iowa. These remains were identified by Dr. Charles Eastman as Pleuroptyx clavatus Cope. Since the Des Moines is probably nearly contemporaneous with the Mazon Creek shales of Illinois, the discovery does not extend the geological range to any extent, but is of interest as it adds another note to our knowledge of the geographical distribution of the Amphibia in the Coal Measures.

(j) The Gurley collection of the University of Chicago possesses a single cervical vertebra of some amphibian(?). The vertebra is unlike anything previously described and represents a new form (plate 22, fig. 2) which may be designated Proterpeton gurleyi, new genus and species. The material was collected near Danville, Illinois.

(k) Deposits have been discovered in Pennsylvania in which are found the remains of amphibians and reptiles, very similar to those from Vermilion County, Illinois, Cowley County, Kansas, and the Texas Permian. The remains (plate I 8 , fig. 2) were found in a thin stratum below the "Ames" limestone, and are therefore in the Coal Measures, fairly well below the top. The fossils, as described by Case (94), consist of fragments which he ascribes to pelycosaurian reptiles and to temnospondylous amphibians. The genus Eryops (94) is recognized in several fragments and a nearly complete dorsal vertebral centrum. Other types of Amphibia are likewise represented.

(l) The ironstone nodules, in which the Mazon Creek fossils (plate I) occur, are found in the shale which forms the roof of the Morris or "No. 2 " Coal of Illinois, which "lies probably somewhat lower than the horizon of the Lower Kittanning Coal of Pennsylvania" (599). "The nodules of iron contained in the Coal shales on the banks of Mazon Creek near Morris, Illinois, generally contain organic nuclei, and thousands of beautiful specimens have been obtained there. They are usually fragments of fern fronds, but are sometimes shells, crustaceans, myriapods, scorpions, spiders, cockroaches, . . . fishes" (498, p. 2 I4), and amphibians, of which Io species are at present known.

These species have been arranged zoölogically according to the following plan:

\section{Class Amphibia Linné, i 758.}

Subclass Euamphibia Moodie, I909.

Order Branchiosauria Lydekker, is8g.

Family Branchiosauride Fritsch, 1879 .

Micrerpeton caudatum Moodie, I909.

Eumicrerpeton parum Moodie, I910.

Mazonerpeton longicaudatum Moodie, 1912.

Order Caudata Duméril, I 806.

Mazonerpeton costatum Moodie, I9 2.

Suborder Proteida Cope.

Family Cocytinide Moodie, 1912.

Erierpeton branchialis Moodie, I9I2. 

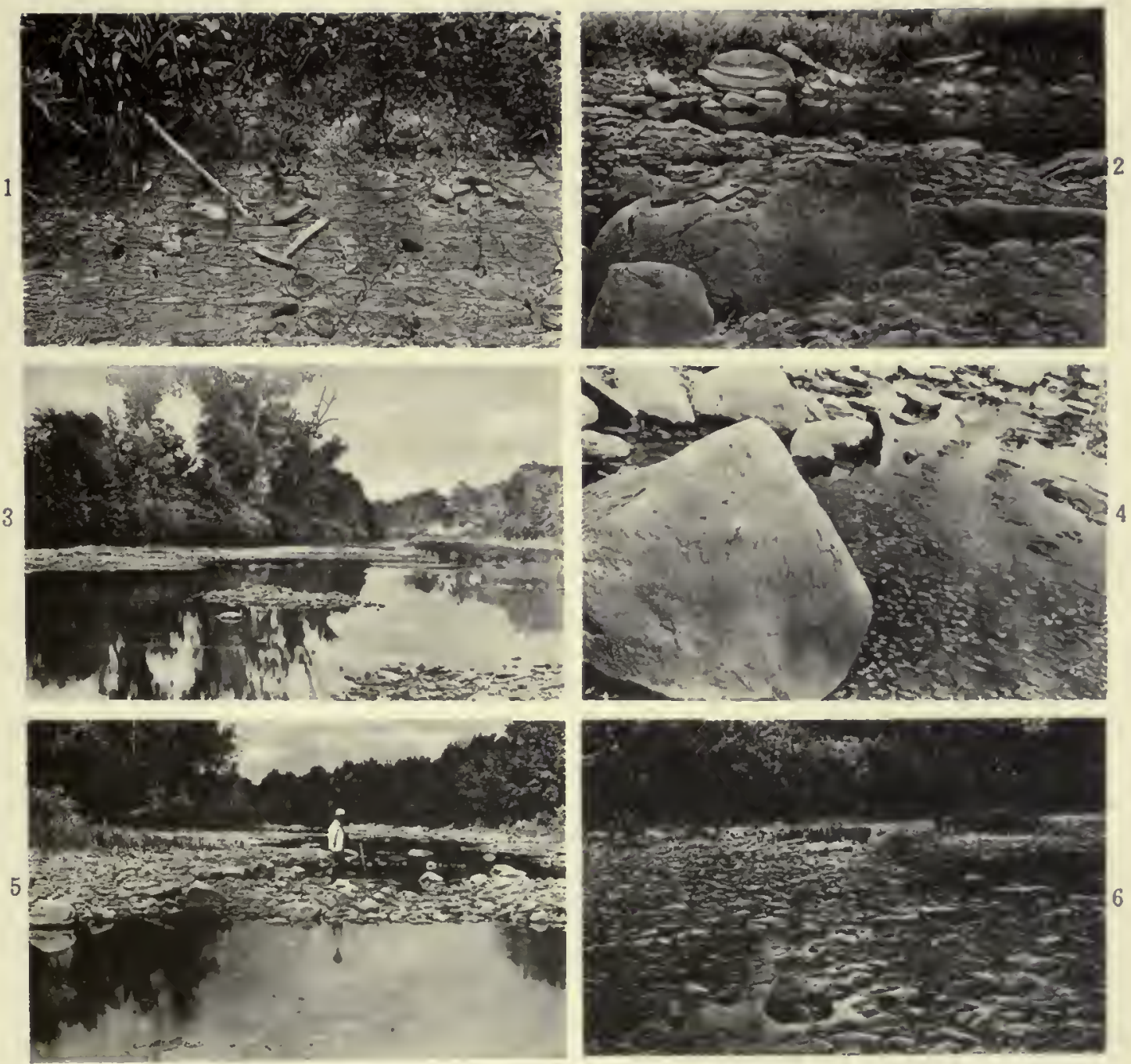

VIEWS ALONG MAZON CREEK, ILLINOIS.

1. A nodule weathering out of the shale, at the head of the hammer. Nost of the noduies at the so-called "lower beds" contain specimens of Neuropteris.

2. The nodules in the creek bed at the "upper heds." Many of them have been cracked open by the frost.

3. Looking south at the "upper beds." The nodules found in the background are non-fossiliferous.

4. Nodules may be seen through the clear water embedded in the siale. Neuropterid insects in the water.

5. Looking for nodules at the "upper beds." The uppermost reaches of the fossiliferous beds correspont with the extreme background of the picture.

6. Vodules in the stream bed at the "lower beds." Many of these are cracked open by the frost and good specimens are sometimes fout in the nodules. 

Class Ampinbia Linné, 1758 -Continued.

Subclass Lepospondylia Zittel, 1887 .

Order Microsauria Dawson, I 863.

Family Amphibamida Cope, 1875 .

Amphibamus grandiceps Cope, 1865.

Amphibamus thoracatus Moodic, 19 Ir.

Cephalerpeton ventriarmatum Moodie, 1912.

Family Molgophide Cope, 1875.

Erpetobrachium mazonensis Moodie, r912.

Subclass Stegocephala Cope, 1868.

Order Temnospondylia Zittel, I887.

Suborder Embolomeri Cope, 1885.

Family Cricotida Cope, I884.

Spondylerpeton spinatum Moodie, rgrz.

It will be seen from the above arrangement that nearly all of the orders of Amphibia are represented in the Mazon Creek fauna. These animals are the oldest known land vertebrates of North America.

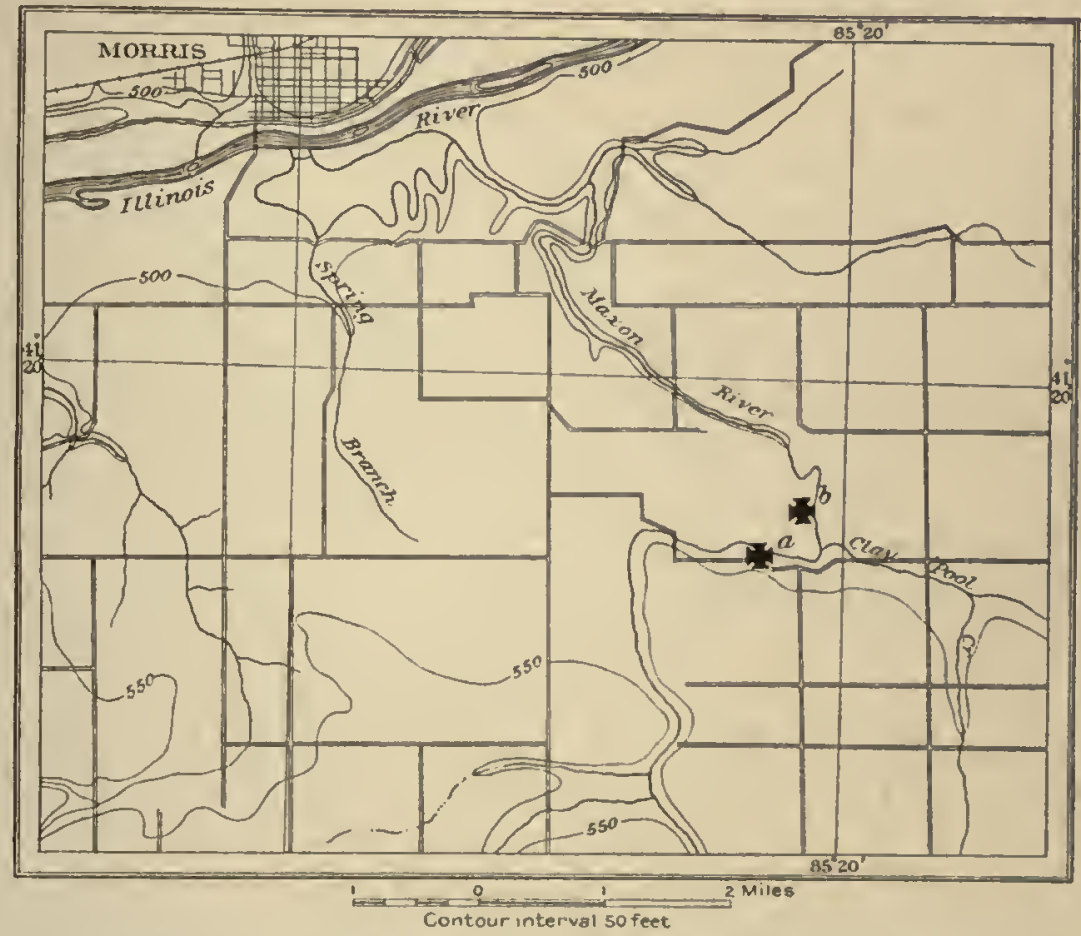

FIG. 3.-Portion of the "Morris sheet" of the U. S. Geological Survey, to show topography and situations of the exposures of fossil-bearing shales at Mazon River. $a$, the "Bartlett place," the so-called "upper beds"; $b$, "lower beds."

The writer was able, during July I91 I, to spend a week studying the fossil beds (479) at Mazon Creek. The object of the visit was primarily to collect Amphibia, but although several thousand nodules were examined, not one contained an amphibian nor a fragment of one. Mr. J. C. Carr, of Morris, Illinois, who has collected at Mazon Creek for more than 30 years, has never collected an amphibian. These facts interested me in making the following comparison: If we take 100,000 nodules as a basis for computation of the rarity of the various forms, something like the following will be the approximate result of the investigation: 
Of 100,000 nodules, 20,000 will be barren or contain only indeterminate fragments; 68,500 will contain plants; 7,500 will contain insects, crustacea, myriapods, scorpions, spiders, and other arthropods; 3,900 will contain fish coprolites or scales; 95 may contain fish or fragments of fish; 4 may contain mollusks; and I may contain an amphibian or a fragment of one.

Perhaps even 100,000 is low as a basis of estimate. Mr. Carr was of the opinion that I nodule in every 500,000 might contain an amphibian.

The beds from which the nodules are usually collected occur along both banks and in the bottom of the creek, in two localities. One locality known as the Bartlett place is situated 8 miles southeast of Morris, in Grundy County, Illinois, Wauponsee Township, N.W. quarter, section 30, Township 33, Range 8 , the land being now owned by Mrs. Emma Akerly, of Wilmington, Illinois.

The fossil-bearing nodules occur throughout 6 to 8 feet of shale along both banks of the creek at the "upper beds" (plate I, fig. 3), as the Bartlett place is called. They may also be seen in the bed of the creek, when the water is low (plate I, fig. 4), still embedded in the shale. With a potato fork the shale is easily turned and the nodules come out like potatoes. One sometimes finds a "pocket" of nodules from which as many as a peck may be secured. Nearly every nodule has a fossil at the "upper beds," but all of the fossils are not well preserved, possibly only I or 2 out of every Io being worth carrying to the museum. The nodules crack best when wet, and it requires some skill to crack them evenly. They seem quite light and, in one place where the stream curves, are piled in a long windrow. On this were found, in nodules cracked by the frost, several good crustaceans and many good plants.

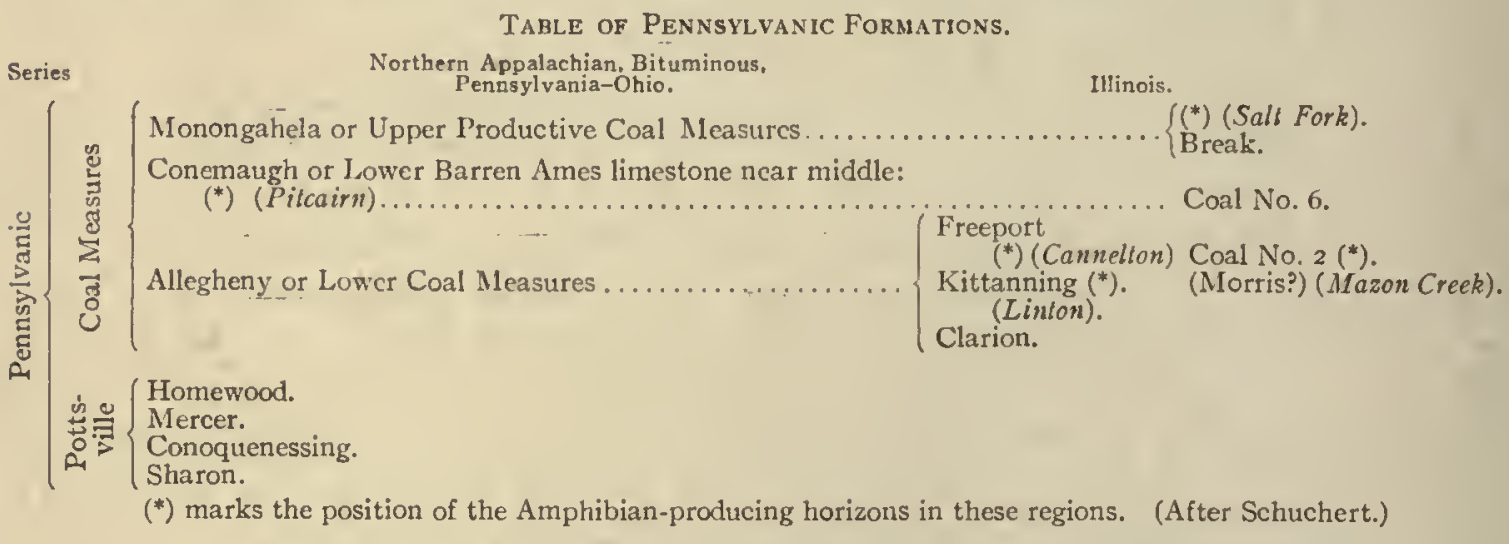

The fossils at the "upper beds" are localized into special strata. At one place in the upper part of the deposit, in a reddish shale, one finds that insects are more abundant than they are lower down. The Crustacea seem to come from apparently the same shale. At the lower end of the deposit certain definite species of Pecopteris are localized. It is an interesting fact that one seldom finds a Neuropteris at the "upper beds." The most abundant fossils are the various species of Pecopteris and Annularia. When specimens of Neuropteris are found they are usually discovered at the lower end of the exposures. In one place behind the "island" very blue nodules, hard and flinty and with sometimes well-preserved 
specimens of Pecopteris, are found quite definitely localized. These nodules are apt to assume an irregular shape. These localizations of the fossils are, of course, what we would expect from our knowledge of the recent fauna and flora. There is, to be sure, more or less intermingling of the species. The myriapods, so far as they have been found, are also localized. Mr. Carr found 3 within a space of a few feet, but again these are found widely scattered. The exposures at the "upper beds" are about a quarter of a mile long. They disappear under a heavy ledge of sandy limestone.

At the "lower beds" (plate I, fig. 6), those further down the creek, conditions are quite different from those just described, although of the same horizon; the banks of the creek are higher and almost perpendicular, so that the chances of collection from the shales are fewer. The bed of the creek, however, is wider and there are more nodules washed out. The most abundant fossil at this place is Neuropteris. The nodules at the upper end of the exposure are all, almost without exception, barren of fossils. The exposures here are of about the same extent as the "upper beds," though the species are not so varied. Judging from the collections made while there, Arthropoda are more abundant at the "lower beds."

Bradley (Geol. Surv. Illinois, IV, 196, I870) mentions the occurrence of these nodules at or near Morris. Other than these places the nodules have been thrown out of a coal mine near Braidwood, Illinois. Doubtless close search would reveal other localities where the shale is cut through in mining. The beds at both places are slightly folded. This is true especially of the "upper beds," where a conspicuous fold caused the beds to disappear in the bed of the creek and to reappear farther down stream. This is directly across the large "ox-bow" bend of the creek.

The beds at Mazon Creek were first explored in 1857 by Mr. Joseph Evans, who sent his specimens to Berlin, Germany, where they excited great interest. It was he who collected the type specimen of Amphibamus grandiceps Cope. Since the time of Mr. Evans many have collected at Mazon Creek, and without doubt the fossil-bearing nodules from this locality are more widely scattered in the museums of the world than are organic remains from any other one horizon.

So far as we know there was no upland vertebrate life at that time. The forms at present known were confined to the water or the margins of the water. The absence of knowledge of upland and terrestrial deposits of this time doubtless accounts for the absence of known vertebrates. It is, however, especially interesting to speculate on the ancestral types of the land vertebrates, and it must be admitted that the Coal Measures Amphibia as at present known throw the ancestry of landliving vertebrates far back into geological time.

(m) The Cannelton slates of Bcaver County, Pennsylvania, have furnished 3 species of Amphibia and fragments of other species are represented in the U.S. National Museum (462). The species so far known are: Tuditanus minimus Moodie, Erpetosaurus sculptilis Moodie, Erpetosaurus minutus Moodie.

They are the first evidence of the-occurrence of amphibian remains in these deposits. The Cannelton specimens are found in a thin stratum of slate which forms part of the Middle Cannelton Coal. The Cannelton slate, in which the fossils occur, forms the roof of the Middle Kittanning Coal, which is only 20 to 30 fect above the 
Lower Kittanning bed (I. C. White), so it becomes evident that the deposition of the Cannelton slates was at only a slightly later period than that of the shales in which the Mazon Creek nodules occur, since the Mazon Creek shales form the roof of the Morris, which "is probably somewhat lower than the Lower Kittanning of Pennsylvania." From the Cannelton slates are known the remains of plants, insects, crustacea, especially "Eurypterids found in shale immediately below the Darlington (Upper Kittanning) Cannel Coal, near Cannelton, Darlington Township, Beaver County, Pennsylvania, Horizon, Allegheny River Series" (Hall, 1884). In these shales occur also fishes and the 3 species of amphibians referred to above. The Amphibia known from this region are small, the largest of them not exceeding 6 inches in length.

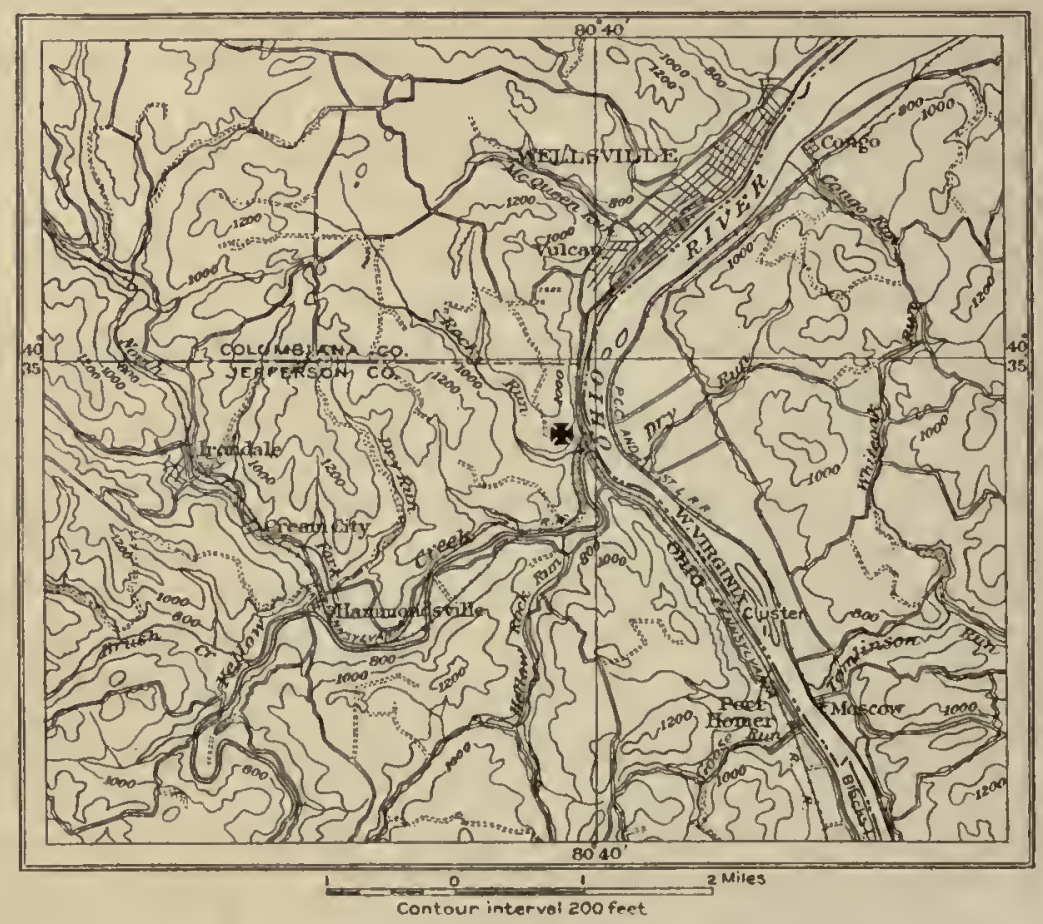

FIG. 4--Portion of "West Vinginia-Ohio-Pennsylvania, Wellsville Quadrangle" of the U.S. Geological Survey, to show topography and situation of Linton coal mines. Some fossil amphibians doubtless came from across the line in Columbiana County.

(n) The Linton, Ohio, beds outcropped near Linton post-office, which was formerly located at the mouth of Yellow Creek, a few hundred yards from the present station, Yellow Creek, Salem Township, Jefferson County, in the valley of Yellow Creek, near the Ohio River, and thus near the Pennsylvania state line.

In regard to the exact location of the town of Linton, which has long since been abandoned, I quote from a letter from Dr. Louis Hussakof, who visited the locality:

"The locality appears to have been known as Yellow Creek for many years past. That is the name used in the Geological Map of Ohio published by Orton in I 888 and which was based on the earlier maps of Newberry (I 869 and I879). When I visited the place in 1905 . and asked for Linton (which I had not been able to locate on any map then available to $\mathrm{mc}$ ), hardly anyone knew of such a locality. Only one old man in Steubenville, Ohio, recalled that Yellow Creek was identical with Linton. 
"Yellow Creek is not a village, but only a R. R. station (on the Pennsylvania R. R.), and marks a spot where once was an active and prosperous mine. Probably at a former day there was a small post-office somewhere in the neighborhood known as Linton. I did not take any photographs, as I was not certain of the spot, or the mine, from whicl the fossils had come. There are some cement mines within a few minutes' walk of the station, but no coal appears to be mined at present at Yellow Creek. 'Smith's Pit,' the coal mine best remembered by the younger men, is not worked.

"Now as to the question whether some of the Amphibia might have come from localities in Columbiana County. I believe it very probable that they did. I walked along the road from Yellow Creek (Jefferson County) to Wellsville (Columbiana County), a distance of about 2 or 2.5 miles, and the country seemed quite the same. Every where one sees outcrops of coal in the cuts along the road. Furthermore, I inclose a copy of a page in an old notebook of Professor Newberry from which you will see that Coal Measure fossil localities were known not only at Yellow Creek, but also from near Wellsville. There can be hardly a doubt that most of the specimens you have are from Yellow Creek; and quite a number are those collected by Sam Huston."

Newberry says, in regard to the fauna of the Linton Coal:

"The Linton locality is especially interesting and instructive. It has already (1889) yielded more than 20 species of fishes and nearly 40 species of aquatic amphibians, all inhabitants of the same body of water. These were found in a thin stratum of cannel which, over a limited area, underlies a thick bed of cubical coal (No. 6 of the Ohio reports), of which the place is near the top of the Lower Coal Measures. At Linton, . . . we have evidence that the great marsh in which the peat accumulated that formed coal No. 6 was for a time a lake or a lagoon, inhabited by the fishes and amphibians to which I have referred. . . . Many of the fishes and the amphibians were highly carnivorous and powerful, as we learn from their teeth and coprolites. The largest of the amphibians must have been 8 or 10 feet in length, having strong jaws, set with numerous lancet-shaped teeth an inch or more in length. . . . After a sufficient time had elapsed for many generations of fishes and aquatic salamanders to live and die, the lake was filled by the extension of its peaty shores into it - just as so many lakelets are filled and obliterated at the present time-and afterward over the cannel was formed a mass of peat, which has now become a stratum of cubical coal 7 feet in thickness.

"In the Linton cannel are buried fragments or entire individuals of all the inhabitants of this body of water which had hard parts, bones, scales, spines, or teeth, capable of preservation. Hence we get a locally complete picture of the life of the Carboniferous age, and we find it to be unexpectedly rich and varied. In that age fishes and amphibians were the highest forms of animal life, and the amphibians were comparatively newcomers on the earth's surface. Yet they had multiplied and differentiated until this little pool contained millions of them, varying in length from 6 inches to ro feet and curiously diversified in their forms, their scales, and spines, and in the ornamentation of their enamel-covered heads" (498).

"To the paleontologist there are few places in the world more interesting than the Diamond mine, at Linton, since here we get such a view of the life of the Carboniferous age as is afforded almost nowhere else, and of the great numbers of species found there, not more than three or four have been met with elsewhere" (497).

On page 18 is a list of the Amphibia which are thus far described from the Linton deposits. They all belong, so far as know1, to the Microsauria, the reference of any of the species to other orders being doubtful. 'The larger Amphibia seem to be indicated by a large rib which resembles very much that described by Huxley in 1863 for Anthracosaurus. 
Amphibia from the Linton Beds (5 Species).

Brachydectes nowberryi Cope. Fragment of a skull.

Cercariomorphus parvisquamis Cope. Impression of body.

Cocytinus gyrinoides Cope. A skull and anterior dorsal vertebræ.

Ctenerpeton alveolatum Cope. Large portion of skeleton, no skull.

Diccratosaurus lavis Moodie. Complete skull.

Diccratosaurus punctolineatus Cope. Anterior vertebræ, part of skull, with ribs and portion of ventral armature.

Diccratosaurus robustus Moodie. Incomplete cranium.

Eoserpeton (Ccratcrpeton) tennicorne Cope. Incomplete skull.

Erpetosaurus acutirostris Moodie. Complete skull.

Erpctosaurus obtusus Cope. Incomplete skull.

Erpetosaurus radiatus Cope. Incomplete skull.

Erpctosaurus tabulatus Cope. Incomplete skull, with clavicles.

Erpetosaurus tuberculatus Moodie. "Incomplete skull.

Eurythorax sublevis Cope. A single interclavicle. (Operculum of lung fish, Sagcnodus.)

Hyphasma laevis Cope. Incomplete skull and anterior vertebræ.

Ichthycanthus ohiensis Cope. Portion of dorsal region.

Ichthycauthus platypus Cope. Posterior portion of body.

Leptophractus dentatus Moodie. Mandible.

Leptophractus lineolatus Cope. Incomplete skull.

Leptopliractus obsolctus Cope. Portions of skull.

Macrerpcton deani Moodic. Mandible and part of skull.

Macrerpcton huxleyi Cope. Part of cranium.

Molgophis brevicostatus Cope. Part of vertebral column with ribs.

Molgophis macrurus Cope. Vertebral column.

Molgophis whcatleyi Cope. Part of skull with 25 vertebrx.

Odonterpeton triangularis Moodie. Skull and anterior part of body.

Estocephalus rectidens Cope. Part of mandible.

Estocephalus remex Cope. Skull and anterior part of body.

Pclion lyclli Wyman. Cranium, fore part of body, hind limb.

Phlegethontia linearis Cope. Skull and anterior part of body.

Phlegethontia serpens Cope. Series of 22 dorsal vertebræ.

Pleuroptyx clavatus Cope. Part of vertebral column and limbs.

Ptyonius marshii Cope. Part of skull and anterior vertebra.

Ptyonius nummifer Cope. Skull and greater part of vertebral column.

Ptyonius pectinatus Cope. Many specimens, some nearly perfect.

Ptyonius serrula Cope. Nearly complete skeleton.

Ptyonius vinchellianus Cope. Skull and anterior vertebræ.

Saurerpeton latithorax Cope. Skull and fore part of body.

Sauropleura digitata Cope. Greater part of body minus skull.

Sauropleura (Anisodexis) enchodus Cope. Part of jaw.

Sauropleura foveata Cope. A single interclavicle with impression.

Sauroplcura longidentata Moodie. Incomplete skull with mandible.

Sauropleura newberryi Cope. Two incomplete skulls with vertebræ.

Sauropleura pauciradiata Cope. Elements of a pectoral arch.

Sauroplcura scutellata Newberry. Imperfect skeleton.

Stegops divaricata Cope. Nearly complete skull.

Thyrsidium fasciculare Cope. Dorsal vertebræ.

Tuditanus brevirostris Cope. Skull and anterior vertebræ.

Tuditanus longipes Cope. Part of vertebral column with limbs.

Tuditanus punctulatus Cope. Skull and anterior part of body.

Tuditanus walcotti Moodie. Skull and portions of body.

Besides the above-listed species there are others indicated by fragments too poorly preserved to be worthy of specific designation. The Linton Amphibia are all apparently confined exclusively to that locality. Species from the Cannelton slates have been assigned, however, to genera which occur at Linton, i.e., Erpetosaurus and Tuditanus. This reference may be due to lack of knowledge, as the forms are insufficiently known. A single Linton species has been assigned to Ichthyerpeton, a genus 
known otherwise only from the Coal Measures of Kilkenny, Ireland. Cope referred species from Linton to the genus Ceraterpeton of Huxley, from Kilkenny, Ireland, but Jaekel (347) and the writer (462) have shown that the species were incorrectly assigned to the genus Ceraterpeton, and that in fact they represent widely distinct genera. A single species has been identified by Eastman from the Des Moines limestone of Iowa as identical with one from Linton, Pleuroptyx clavatus Cope. The Linton fauna is distinct from that of the Mazon Creck beds, and also from that of South Joggins, Nova Scotia.

(o) The deposits in Nova Scotia have been correlated with the Coal Measures strata of the United States (Bell, Summ. Rpt. Geol. Surv. Canada, 1912, 1914, 360$37 \mathrm{I}$ ). They are very near the same age as the Linton beds and come in near the base of the Allegheny River series. The exposures are at the South Joggins, along the seacoast. Here in strata of clay interstratified with coal are found the erect stumps of the Sigillarix, and it was in the rock within these stumps that Lyell and Dawson, in 1853, discovered the remains of the amphibians which they termed "reptiles."

"The bones of Dendrerpeton hitherto found, as well as those of the smaller species, have been obtained from the interior of erect Sigillarix, and all of those in one of the many beds which, at the Joggins, contain such remains. The thick cellular inner bark of the Sigillaria was very perishable; the slender woody axis was somewhat more durable; but near the surface of the stem, there was a layer of elongated cells, or bast tissue of considerable durability, and the outer bark was exceedingly dense and indestructible. Hence an erect tree, partly imbedded in sediment, and subjected to the influence of the weather, became a hollow shell of bark. When they remained open for a considerable time, they would constitute pitfalls into which animals walking on the surface might be precipitated. When the surface was inundated all such remains would be covered and imbedded in the sediment. These seem to have been the precise conditions of the bed which afforded these remains." (Dawson, 223, 1894.)

Fifteen species have been described from the Joggins deposits. Two are known from the Albion mines, south Nova Scotia, where were obtained the remains of Baphetes planiceps Owen and B. minor Dawson.

The following it species of Amphibia are known from the Carboniferous of Canada:

Amblyodon problematicum Dawson. Teeth and fragments.

Baphetes minor Dawson. An incomplete mandible.

Baphetes planiceps Owen. An incomplete cranium from Albion.

Dendrerpeton acadianum Owen. A jaw, limb bones, and fragments.

Dendrerpeton oweni Dawson. Phalangeal bone and fragments.

Eosaurns acadianus Marsh. Two dorsal vertebræ.

Fritschia curtidentata Dawson. A mandible, vertebra, ribs.

Hylerpeton dawsoni Owen. Mandible, teeth and incomplete maxilla.

Hylerpeton intermedium Dawson. Mandible and portions of skull.

Hylerpeton longidentatum Dawson. Fragments of mandible and skull.

Hylonomus latidens Dawson. Mandible and teeth.

Hylonomus lyelli Dawson. Incomplete skeleton and part of skull.

Hylonomus multidens Dawson. Fragments of skull.

Hylonomus wymani Dawson. Mandible and vertebra.

Platystegos loricatum Dawson. Incomplete skull, vertebrx.

Smilerpeton aciedentatum Dawson. Teeth, ribs, fragments.

Sparodus sp indet. Teeth, scales. 
(p) All the remains representing the above species were collected by Sir J. William Dawson at the South Joggins and at the mines of Albion, with the exception of Eosaurus, which was collected by O. C. Marsh. The collections of Dawson are now in the Peter Redpath Museum of McGill University in Montreal and in the British Museum of Natural History at South Kensington, London. The history of the discovery of the deposits and their amphibian fossils at the South Joggins is so interesting that it was thought worth while to reproduce in large part Dawson's paper "On the Mode of Occurrence of Remains of Land Animals in Erect Trees at the South Joggins, Nova Scotia," published in 1891 in the Transactions of the Royal Society of Canada, section IV, p. I27:

"The remarkable section of coal-formation rocks at the South Joggins, in Cumberland County, has long been known as one of the most instructive in the world; exhibiting as it does a thickness of 5,000 feet of strata of coal-formation in a cliff of considerable height, kept clean by the tides and waves, and in the reefs extending from this to the shore, which at low tide expose the beds very perfectly. It was first described in detail by the late Sir W. E. Logan (Report Geol. Surv. Canada, I844), and afterwards the middle portion of it was still more detailed by the author (Dawson), more especially in connection with the fossil remains characteristic of the several beds and the vegetable constituents and accompaniments of the numerous seams of coal (Jour. Geol. Soc. Lond., x, p. I, 1853). It was on occasion of a visit of the author in company with Sir Charles Lyell, and in the pursuit of these investigations, that one of the most remarkable features of the section was disclosed in $\mathrm{I} 85 \mathrm{r}$. ' This is the occurrence, in the trunks of certain trees imbedded in an erect position in the sandstones of Coal-mine Point, of remains of small reptiles, which with one exception, a specimen from the Pictou coal-fields, were the first ever discovered in the Carboniferous rocks of the American continent, and are still (I89I) the most perfect examples known of a most interesting family of coal-formation animals, intermediate in some respects between reptiles proper and batrachians, and known as Microsauria. With these were found the first-known Carboniferous land snails and millipedes. Very complete collections of these remains have been placed by the author with his other specimens in the Peter Redpath Museum and in the British Museum.

"A forest or grove of the large ribbed trees known as Sigillaric was either submerged by subsidence or, growing on low ground, was invaded with the muddy waters of an inundation, or successive inundations, so that the trunks were buried to the depth of several feet. The projecting tops having been removed by subaerial decay, the buried stumps became hollow, while their hard outer bark remained intact. They thus became hollow cylinders in a vertical position and open at the top. The surface having then become dry land, covered with vegetation, was haunted by small quadrupeds and other land animals, which from time to time fell into the open holes, in some cases nine feet deep, and could not extricate themselves. On their death, and the decomposition of their soft parts, their bones and other hard portions remained in the bottom of the tree intermixed with any vegetable débris or soil washed in by rain, and which formed thin layers separating successive animal deposits from each other. Finally, the area was again submerged or overflowed by water, bearing sand and mud. The hollow trees were filled to the top and their animal contents thus sealed up. At length the material filling the trees was by pressure and the access of cementing matter hardened to stone, not infrequently harder than that of the contained beds, and the whole being tilted to an angle of $20^{\circ}$, and elevated into land exposed to the action of the tide and waves, these singular coffins present themselves as stony cylinders projecting from the cliff or reef, and can be extracted and their contents studied. The singular combination of accidents above detailed was, of course, of very rare occurrence, and, 
in point of fact, we know only one set of beds at the South Joggins in which such remains so preserved occur; nor is there, so far as I am aware, any other known instance elsewhere. Even in the beds in question, only a portion of the trees, about 15 out of 30 , have afforded animal remains. We have, however, thus been enabled to obtain specimens of a number of species which would probably otherwise have been unknown, being less likely than others to be preserved in properly aqueous deposits. Such discoveries on the one hand impress us with the imperfection of the geologieal record; on the other, they show us the singular provisions which have been made in the course of geological time for preserving the relics of the ancient world, and which await the industry and skill of collectors to disclose their hidden treasures.

"There is evidence in coprolitic matter on one of the surfaces within the trunks, and also in certain trails on these surfaces, that some of the imprisoned animals lived for a time in their subterranean prisons; that they crept around their walls in search of a way of escape, and that the larger animals fed on smaller species entrapped along with them.'

After the discovery of these entombed amphibians Sir William Dawson was given a grant of $£_{5}$ o from the Government Fund by the council of the Royal Society of London, to aid in the extraction of these trees and the collection of their contents. The trees were carefully taken out and their contents examined; the portions containing the animal remains were carefully boxed to be taken to Montreal for final cleaning and study. Erosion goes on rapidly at the South Joggins, but no one has paid any attention to the occurrence of Amphibia along the coast of Nova Scotia within recent years.

(q) A deposit which will be of undoubted interest in connection with the occurrence of Amphibia in the Coal Measures is that which outcrops along the banks of Rock Creek in the southwestern part of Douglas County, Kansas,

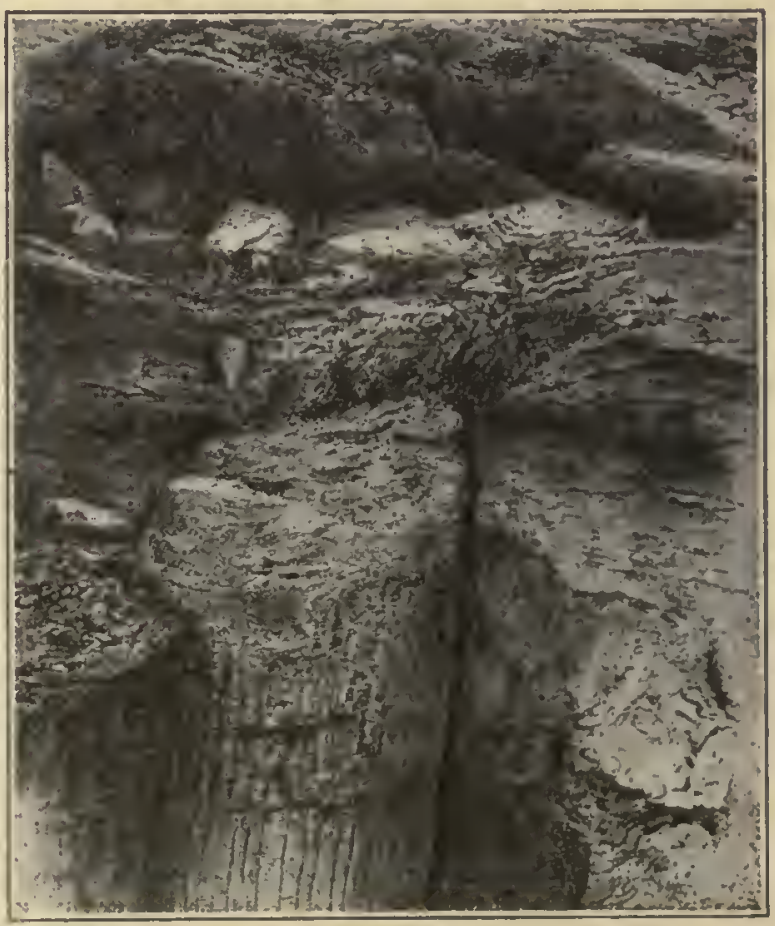

FIG. 5.-Dawson's tree No. I 3 at the South Joggins, Nova Sootia. Upper part, in silu, in the reef after it had been exposod by blasting. (After Dawson, basod on a photograph.) in Marion Township (Township I 4 south, Range I 8 east, SW. and SE. quarters of section 7), about 2 miles from the now-abandoned post-office of Twin Mounds, so called from the two flat-topped, elongated mounds of Oread limestone to the west of the town.

The interest in these beds is not due to the discovery of Amphibia in them, but the possibilities of such discoveries. This is indicated by the occurrence of fossils, in nodules similar to those obtained from Mazon Creek, which are identical generically, and in most cases specifically, with the Mazon Creek animals and plants. 
The fossils so far collected from this interesting locality are:

Insecta (Identified by Dr. E. H. Sellards).

Spiloblattina maledicta (Scudder). The basal half of a front wing.

Etoblattina sp. The hind wing of a cockroach.

Arachinida.

Anthrocomartus. Impression of the body.

Presturchia dance M. \& W. Nearly complete specimen.

Crustacea.

Acanthotelson stimpsoni M. \& W. Three nearly complete individuals.

Plants (Identified by Mr. J. C. Carr, of Morris, Ill.).

Pecopteris sp.

Sagittaria reticulata Lesquereux.

Annularia longifolia Lesquercux.

Annularia inflata Lesquereux.

Pecopteris villosa Brongniart.

Neuropteris decipiens Lesquereux.

Pecopteris serpulifolia Lesquercux. By far the most abundant plant is Pecopteris.

The fossils occur in definite strata of nodules immediately above a ro-inch coal seam which is worked for local consumption. The coal lies near the base of the exposure in the more western portion of the outcrop, but it is raised by an anticlinal fold to near the top of the creek-banks by the bridge across Rock Creck, along the banks of which the shales are exposed. Nodules containing fossils are found most abundantly at the western exposure on the McKinzie place, only a few having been found near the bridge.

Below the coal-seam, nodules of various shapes and sizes occur, but they seldom contain fossils and never good ones. Occasionally, as at Mazon Creek, fragments of plants adhere to the outside of the incrusting shale. A single nodule may have adhering to it fragments of 4 genera of plants. The fossiliferous nodules all occur above the coal and are most prolific and abundant immediately above the seam, within the first 10 inches. In the same stratum of shale with the nodules are found abundant impressions of plants in the shale, often perfect fronds being uncovered. (See, in this connection, Twenhofel and Dunbar, 1914, "Nodules with Fishes from the Coal Measures of Kansas," Amer. Journ. Sci., XxxviII, pp. I57-I63.)

G. F. Matthew (408-413) has described numerous genera and species of footprints, presumably amphibian, from the Carboniferous of Canada. The impressions indicate small creatures for the most part. Other imprints have been described by Logan, Dawson, Lyell, Marsh, Mudge, and Lea. Since the present work is intended largely for a morphological review, only passing notice can be given to the ichnites. The literature on the "Ichnites" has been brought together in Hay's "Bibliography and Catalogue of Fossil Vertebrata of North America," pp. 538-553. References since the publication of Hay's catalogue (3I7) will be found in the bibliography at the end of this work. Footprints are of interest in that they are the only evidence we have of the occurrence of land vertebrates in the Devonian and Mississippian of North America. 


\section{CHAPTER IV.}

\section{THE MORPHOLOGY OF THE COAL MEASURES AMPHIBIA.}

The anatomy of the Coal Measures Amplibia presents many primitive types of structure. Their organization represents a stage passed through in the ontogeny of higher vertebrates. The animals are similar in a general way, yet so diverse are the modifications which they have suffered under different environmental conditions, that close scrutiny is needed to discern the exact relationship of the forms. Our knowledge of this relationship is based on the structures preserved, which are largely skeletal, since little is known of the soft anatomy (47 I) of the air-breathing vertebrates of the Coal Measures. The pubis is ossified in the Paleozoic Amphibia

FIG. 6.-Generalized figure of dorsum of an early amphibian skull to show position of elements and terminology adopted in this work. The outline is based on that of Eryops, but is in no way intended to indicate that form.

a. com, anterior commissure of lateral-line canals; com, commissural communication between infra- and supraorbital lateral-line canals; $f r$, frontal; inf, interfrontal; inn, internasal; info, infraorbital lateral-line canal; if, intertemporal; $j l$, jugal lateral-line canal; $j$, jugal; lar, lacrimal; $m x$, maxilla; $n$, nasal; oc, occiput; occ, occipital cross-commissure of the lateral-line system; or, orbit; par, parietal; pof, postfrontal; pmx, premaxilla; $p f$, prefrontal; $p o$, postorbital; $p p$, postparietal; $q$. quadrate; $q j$, quadratojugal; $s p o$, supraorbital lateral-line canal; $s q$, squamosal; spl, supratemporal; $t$, temporal lateral-line eanal; $l a b$, tabulare.

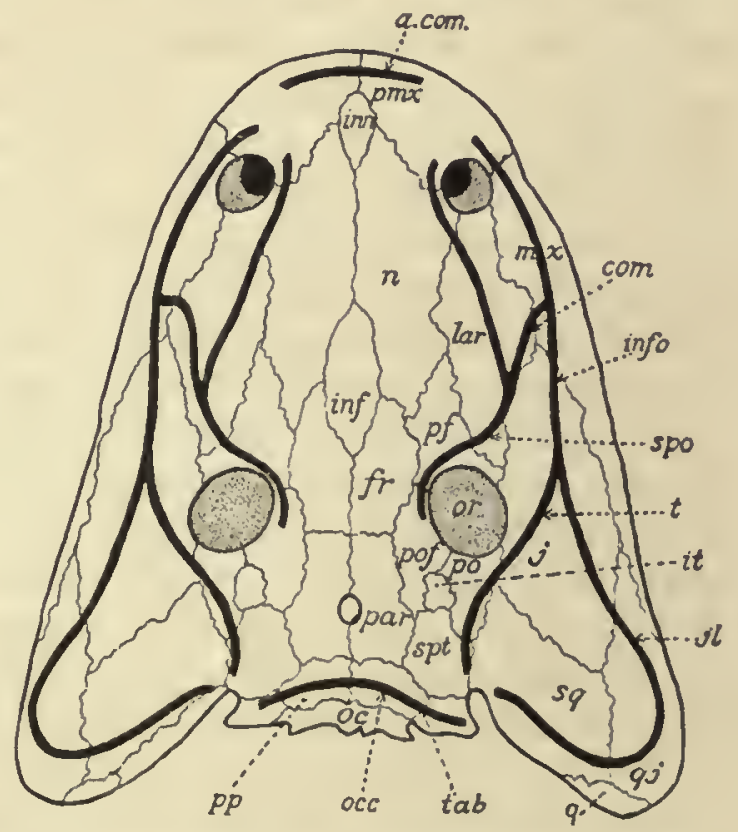

later than the ischium and ilium; the earpus and tarsus are cartilaginous; the vertebra consist of a pleurocentrum and two neurocentra, thus paralleling conditions in modern mammalian embryos.

(a) The skull of the Coal Measures Amphibia has (fig. 6) essentially the same structure in the different groups. It is largely formed of bones of intramembranous origin, representing the face bones of the mammalian skull. The skull in life was doubtless a chondrocranium with the membrane bones laid down upon the cartilaginous box containing the sense-organs, as in the sturgeon (Acipenser), where the surface bones of the face were probably originally scales, which later became consolidated into large bony scutes. The membrane bones of the early Amphibia may have been originally derived from seales, but at present nothing is known of this origin; doubtless the elements had an intramembranous origin in the ancestors of 
the group. Judging from Credner's studies on the series of specimens of Branchiosaurus amblystomus Credner ( 187 ), the skull bones do not ossify completely until relatively late in the life of the individual. The skull in the youngest individual figured by Credner (op. cit., Taf. xvi, fig. I) seems to be largely cartilaginous, with beginnings of separation into the skeletal elements. The manner and time of development and ossification of the skull seems to proceed much as it does in modern amphibians. The condition found in the skull of Cryptobranchus allegheniensis or Necturus maculosus will represent pretty accurately the condition of most of the Coal Measures Amphibia. The face bones in certain forms were sculptured and cut by lateral-line canals.

A median suture divides the skull into two equal regions dorsally. On the sides of this median suture lie pairs of elements which are common to all higher vertebrates. These elements are: the premaxillæ, nasals, frontals, parietals, and postparietals. All of these elements vary somewhat in shape and slightly in arrangement, but always occupy the same relative positions. To the side of these elements lie the prefrontal, the postfrontal, the supratemporal, the squamosal, and tabulare, and occupying the margin of the skull are the maxilla, the jugal, the quadratojugal, and possibly the quadrate in a few forms. The parietal foramen occurs usually within the parietal bone, but its position is subject to slight variations and it may occur on the suture between the frontal and the parietal, or even far posterior near the postparietal. The nostrils often lie well forward and are included by the premaxillæ, nasals, and prefrontals. The orbit is usually well posterior, but it may occur far forward. It is bounded by the prefrontal, the frontal, the postfrontal, the postorbital, and the jugal. Sometimes the lacrimal is present and has been clearly identified on the anterior margin of the orbit in a few cases.

(b) Sclerotic plates often occur within the orbits, and are not confined to any particular group, though they are quite constant among the Branchiosauria. They are usually delicate, thin, broad plates which evidently overlap and operate as in modern animals. The number varies, as many as 30 occurring within the orbit of one branchiosaur. Between the margin of the orbit and the sclerotic plates there often occur, in the Branchiosauria (I86) particularly, small scale-like particles which were doubtless embedded in the heavy skin above the orbit during life.

(c) The palate of the skull is very incompletely known, being indicated in a very few cases. These specimens, however, show that the characters of the palate were quite similar, if not identical, in essential respects with the palate among the European species of the same or slightly later time.

A large cultriform parasphenoid occupies the posterior portion of the palate, on either side of which in some species lies the posterior palatine foramen. On the sides of the anterior prolongation of the parasphenoid lie the vomers (I86), membranous bones often bearing minute tubercular teeth, apparently adapted for crushing. The vomers and the maxillæ, with sometimes the palatine, surround the anterior palatine foramen, which is almost always present; sometimes, however, quite small. The transverse or ectopterygoid unites the pterygoid, a broad plate of thin bone, with the maxilla and jugal. 
(d) The teeth of the Coal Measures Amphibia (194) are remarkably similar in the various forms. They are always slender, pleurodont denticles arranged in a single row on the jaws or as tubercular eruptions on the palate bones, with a large pulpcavity and the enamel often striated. The food of the creatures must have been small crustacea, worms, insects, and succulent vegetation, such as is the food of the modern Amphibia.

(e) The occiput is formed of partially ossified (465) ex- and basi-occipitals, though these elements are never firmly united by ossific union. Often a pair of condyles occur, one on either exoccipital. The occiput was usually, however, cartilaginous and no trace of its structure is preserved.

$(f)$ The mandible is usually as long as the skull and is slender. It is composed of 6 elements so far as known (465); these are the articular, the surangular, the angular, the coronoid, the dentary, and the splenial. Other elements may be present, but the anatomy of this portion of the animals is notvery completely known. The bones are sculptured and cut by lateral-line canals $\left(45^{8}\right)$ in a few forms. Whether the articular operated on an osseous or cartilaginous quadrate is unknown, though certain specimens seem to indicate an osseous condition for that element. The anterior symphysis was doubtless ligamentous, the halves always separating before fossilization. The dentary always bears a single row of pleurodont teeth, which may vary greatly in size and number.

(g) The hyoid apparatus is well preserved in a few forms (123). Doubtless it was present in all of them, though it has seldom been preserved. The condition of the hyobranchial apparatus in Cocytinus gyrinoides (text-fig. I6) from the Coal Measures of Linton, Ohio, seems to indicate that the species was a perennibranchiate salamander (123). It is well known from the studies of Credner that the European Branchiosauria, in the young, possessed external branchix (I87) supported by lateral basibranchials. The gill-arches seem to have been slightly calcified or ossified in a few cases, and they supported denticle-like projections which bore the gill-filaments. When the Branchiosauria had attained a length of $100 \mathrm{~mm}$. or more they lost their gills (187). This change was accompanied by the reduction of the tail, expansion of the pelvis, and increase in ossification of the skull and skeletal elements. Gills have not yet been detected among the American Branchiosauria.

(h) The eye in a few species had a large amount of black pigment, as indicated by the blackening of the stone in the Mazon Creek nodules. Professor Cope (107) thought that this would indicate a nocturnal and crepuscular habit for these vertebrates, since the pigmentum nigrum of the choroid is largely developed. Other than this suggestion nothing is known of the soft parts of the head.

(i) The alimentary canal (text-fig. 7) is beautifully preserved as a cast in three specimens of the American branchiosaur species Eumicrerpeton parrum Moodie (471) from the Mazon Creek beds. The nodules which contain these interesting little fossils measure less than 3 inches in long diameter. 'The fossil salamanders, about $30 \mathrm{~mm}$. in length, are preserved on their backs and occur as nearly as is possible in the center of the nodule. 
If it were not for the fact that the osophagus became loosened and dropped from its place shortly after death, the alimentary canal would be in place and would immediately recall a freshly dissected specimen of a recent salamander. The anterior end of the oesophagus lies obliquely across the chest region with its tip pointing slightly downward. The length of the oesophagus proper, in one specimen, is only about $3 \mathrm{~mm}$. As it is preserved, the osophagus lies in a semi-sigmoid curve with the convexity anterior, and enters the cardiac portion of the stomach by a gradual constriction. The stomach is clearly preserved as a distinct sac-like organ with two lobes which correspond to the cardiac and pyloric limbs. It measures about $7 \mathrm{~mm}$. in length by $2 \mathrm{~mm}$. in its greatest diameter. The muscular constriction which divides the organ into pyloric and cardiac divisions occurs at a distance of $4 \mathrm{~mm}$. from the upper end. The pylorus is designated by a rather pronounced constriction which may be partly accidental, although it recalls the pylorus of modern frogs. From this constriction, which lies on the left side of the fossil, as it is preserved, the duodenal portion of the intestine makes a straight course posteriorly to near the anal region, where it takes a sharp bend and curves back to run parallel with itself for the distance of $4 \mathrm{~mm}$. In its upward course the intestine enlarges, and practically the same enlargement continues throughout the remainder of the course to the anus. At a distance of I $\mathrm{mm}$. from the anal end, the rectum dilates probably 0.125 $\mathrm{mm}$. to form the cloaca. After the intestine has continued its parallel course for the $4 \mathrm{~mm}$., as above stated, it turns abruptly to the right for a distance of $2 \mathrm{~mm}$. It then runs posteriorly for a short distance, then bends back and under itself to again make a double sigmoid curve, when at a distance of $6 \mathrm{~mm}$. from the anus it assumes a straight course, which it continues to the end.

The anus lies at a level which is approximatcly that of the lower end of the femur, which is preserved as an impression on the left side of the fossil, thus agreeing in its position with that found in modern Caudata. Lying inside the curve

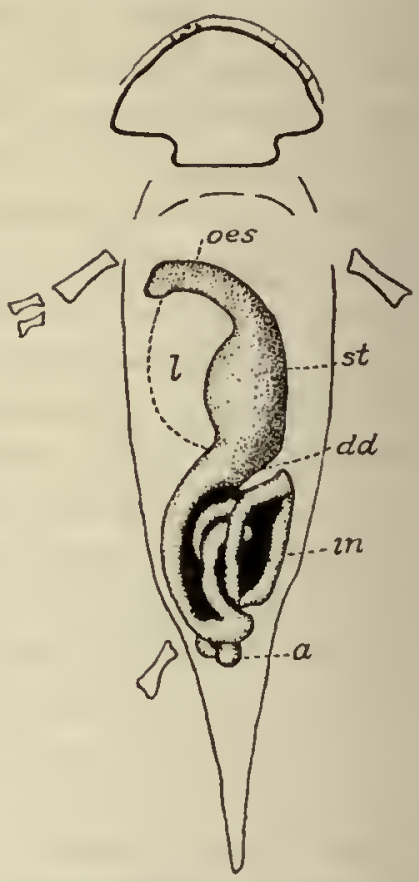

FIG. 7.-Alimentary canal of a Coal Measures salamander as illustrated by the smaller specimen of Eumicrerpelon parrum Moodie, from the Mazon Creek shales. $\times 3$. Original in Yale University Museum. $a$, anus; $d d$, duodenum; in, intestine; $l$, impression of liver(?); oes, œesophagus; st, stomaeh. of the stomach and partly inclosed by the oesophagus is a smooth area which may possibly represent the impression of some of the accessory digestive glands, such as the liver. Occurring in this smooth area are numerous fine lines which possibly represent the impressions of blood-vessels; but they are so imperfectly preserved that one can not be sure.

Representatives of several genera of the modern Caudata have been dissected in order to make a direct comparison of the fossil alimentary canal with that of the recent forms. The alimentary tract of Desmognathus fuscus Raf. from the vicinity of Ithaca, New York, resembles in a marked degree that of the fossil form. The nearest approach to the condition there represented is found, however, in an imma- 
ture branchiatc individual, some $47 \mathrm{~mm}$. in length, of Diemyctylus torosus Esch., from a fresh-water pond on Orcas Island in Puget Sound. The presence of this species on the island is very suggestive. It is of extreme interest, too, that the condition represented in the alimentary tract of the fossil branchiosaurs should resemble so closely that of an immature rather than a mature form.

(j) The vertebral column is clearly and readily separable into cervical, dorsal, sacral, and caudal regions. The neck is always short, with from 5 to ro vertcbre, cervical ribs often present. The dorsal region is not long, but varies from 20 to 30 in the constituent vertebra. There is a single sacral vertebra not always to be readily distinguished from those of the dorsal and anterior caudal series. The tail may be very short or extremely long, with ncural and hæmal spines elongatc and flattened into an oar-like appendage. The distal caudals are in some species cartilaginous, apparently always so in the Branchiosauria.

(k) The atlas and axis are unknown among the American specimens, but we are able to infer from the structure of the other vertebræ what this must have been; and our inferences are partly confirmed by the conditions existing in the European forms (187). The atlas, apparently, consisted of a pair of neurocentral plates which are partly ossified, partly embedded in cartilage, judging from the edges of the plates which have been preserved. The centrum seems not to have becn present in the atlas, or if present it was only very slightly developed and quite free from the neural pieces and largely embedded in cartilage. A fairly accurate picture of the condition of the atlas and axis may be seen on examining a cow, pig, or chick cmbryo (378) in the early stages of vertcbral development, which has becn cleared by the Schultze method (Amer. Journ. Anat., VII, No. 4, 1908).

(l) The dorsal zertebre, as well as those of the other series, present a primitive character (fig. 8) in the persistence of the notochord (540). Among the Branchiosauria the notochord was not at all or but slightly constricted intravertebrally, but among the Microsauria it was constricted so far that the notochordal remnants in each centrum resemblc an hour-glass.

The structure of the vertebræ among American forms agrces fully with that outlined by Credner, Fritsch, and others for the European species. The details of structure are so fully given by Zittel (642, pp. 346-353) and by Schwarz (540, 54r) that it will not be nccessary to state more here as to their structure, since there is nothing new to add concerning the American species.

The temnospondylous vertcbra of the same nature and type as cxhibitcd by the Permian forms has its representatives $(94,478)$ in the Coal Measures. Spondylerpeton spinatum Moodie (478) (platc 4, figs. I, 2) and Eryops sp. (plate I8, fig. 2) indicate the embolomerous and rachitomous types of vertebral structure. The occurrence of these widely different types of vertebral structure indicates a long history for the group prior to the Coal Measures. This history is further indicated by footprints in the Mississippian and Devonian of this continent.

$(m)$ The ribs (fig. 8 ) arc very diverse in structure and in their mode of articulation $(54 \mathrm{I})$ with the vertebral column. The characters of the ribs and vertebre constitute the best means of classification of these animals so far discovered. In the 
Branchiosauria the ribs are always straight, heavy, and short, and articulate intravertebrally upon a large and strong transverse process. They occur throughout the vertebral column. There is a single pair of sacral ribs which are not to be clearly distinguished from the pre-sacral and post-sacral series. The cervical and caudal ribs are shorter than the dorsal series. The branchiosaurian rib is composed almost entirely of perichondral ossification. It presents the same condition as does the humerus of the cow embryo of 2 to 3 inches in length. The ribs, of the branchio-
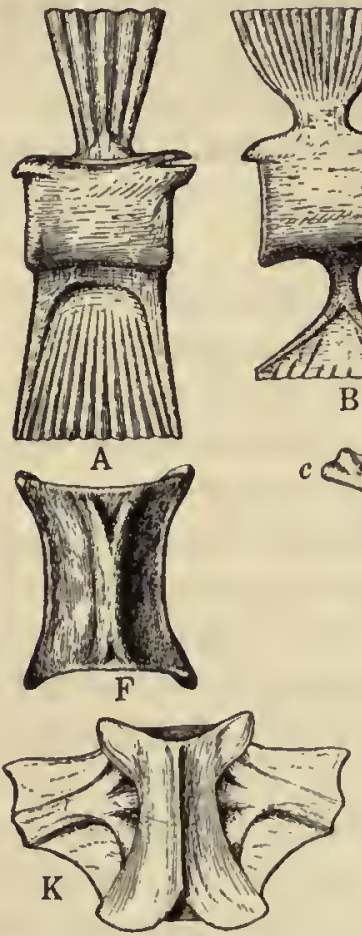

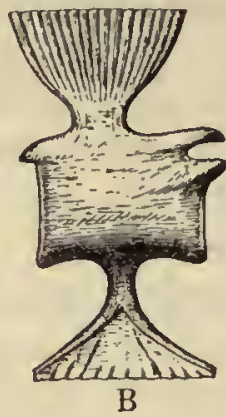

B
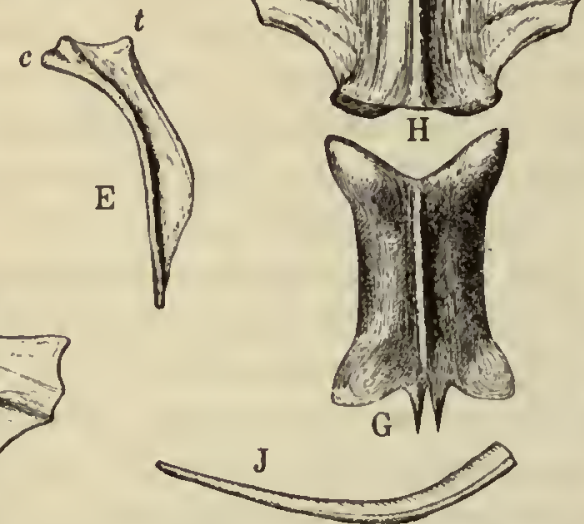

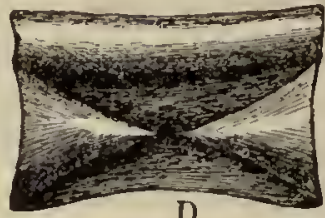

$\mathrm{D}$
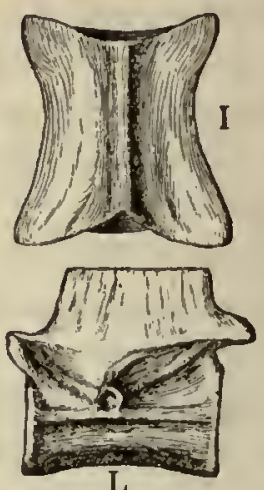

L

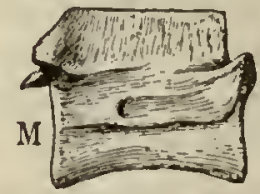

FIG. 8.-Vertebre and ribs of Amphibia from the Coal Measures of Linton, Othio. Originals in Geol. Inst. Berlin. (All after Schwarz.)

A. Caudal vertebra of (Estocephalus remex Cope. Lateral view. $\times_{4}$.

B. Caudal vertebra of Plyonius vinchellianus (?) Cope. Lateral view. $\times 6$.

C. Dorsal vertebra of Ptyonius pectinatus Cope. Lateral view. $\times 9$.

D. Notochordal cones and spinal canal of Thyrsidium fasciculare Cope. $\times 3$.

E. Rib of Molgophis sp. Cope. X I.75. $\quad c=$ capitulum; $t=$ tuberculum.

F. Vertebra of Molgophis sp. Cope, from ventral side. $\times 2$.

G. Dorsal vertebra of Ptyonius pectinatus Cope. From above. $\times 8$.

H. Dorsal vertebra of Thyrsidium fasciculare Cope, from below. $\times 2.5$.

I. Vertebra of Pllegethontia linearis Cope, from above. $\times 5.5$

J. Rib of Cestocephalus remex Cope, from posterior dorsal region. $\times 5$.

$\mathrm{K}$. Dorsal vertebra of Thyrsidium fasciculare Cope, from above. $\times 1.5$

L. Anterior dorsal vertebra (cervical?) of Thyrsidium fasciculare Cope. Lateral view. $X 1.5$.

M. Vertebra of Phlegethontia linearis Cope, from side. $\times 5$.

saurs are identical in every way with the ribs of modern salamanders and form one of the strong arguments in favor of the relationship of the Branchiosauria to the Caudata. Among the Microsauria the ribs are always long, slender, curved, and intercentral. They may be either single or double headed, but usually the former. They resemble in their characters the ribs of some of the early reptiles and an attempt has been made to relate the Microsauria (469) to the primitive reptiles on this basis. The ribs of the other groups are still unknown. Indeed, representatives of the Temnospondylia and the Stereospondylia are very scanty in the American 
Coal Measures. One large rib (plate 22, fig. .4) may represent a labyrinthodont, but nothing is known of the species to which the rib belonged.

(n) The pectoral girdle (187) is a very simple and uniform structure, although the details of the association of the elements still remain to be determined. A single, median, usually large and elongate interclavicle occupies the ventral line of the chest. This is morphologically the same element which occurs in the middle line of the chest of the lizards. It is a dermal bone and is usually, especially among the Microsauria (462), highly sculptured. It varies considerably in size and shape, but is remarkably uniform throughout the various groups. Lying anterior to the interclavicle and overlapping its antero-lateral margins lie the two clavicles, which are usually diamond-shaped and are sculptured, dermal bones. The position of the coracoid is still uncertain, and in fact its clear association in the pectoral girdle of these species is still a question. It seems to be constant in the European (I86, 25I) species and is usually represented by a small rounded plate of bone, which in life no doubt had a large amount of cartilage to form its borders. A cleithrum (285) has been ascribed to one of the Linton, Ohio, species (plate 15, fig. 3) by Jaekel (347), but this needs confirmation. An osseous scapula is usually present, resembling the scapula of modern salamanders, in that it was largely embedded in cartilage. The position of the pectoral girdle is largely a matter of doubt, especially for the Amcrican species. After death and before fossilization the girdle was always movel by postmortem shifting, so that its exact relation to the ribs and vertebral column is still in doubt. Credner (I 86) has restored the pectoral girdle close behind the head, which would cause an amount of rigidity in the body which probably did not exist.

(o) The arm consists of the humerus, radius, ulna, and 4 digits. The characters of the arm-bones are such as is constant among primitive animals and developing mammals. The osseous portion is perichondral. Epiphyses are totally lacking and it is doubtful if the endochondrium was at all ossified. The digits are often terminated by ungual phalanges, although usually the terminal phalanx was merely embedded in the web of the foot; and among the terrestrial forms a claw was well developed. An osseous carpus is not known in the species from the Coal Measures. Its impression indicates a broad hand, well adapted for swimming.

(p) The pelvic girdle consists uniformly (462) of the ilium and ischium. A small rounded pubis is present in some of the later forms of Amphibia; it is, however, totally absent from the Coal Mcasures species. The condition of the pelvis is paralleled by the partially grown pelvis of mammalian embryos in which the clements ossify in the order of ilium, ischium, and pubis. The ilium is always the larger of the elements. It supported or was attached to the sacral rib by means of a ligamentous union. The ischium did not ossify completely until the animal was nearly mature. The union between the elements of the pelvis was probably of a loose, membranous sort or else the whole mass was embedded in cartilage; of the two lyypotheses the former is the more probable.

The pubis is indicated as a calcified quadrangular plate in a specimen of $\mathrm{Amphi}$ bamus grandiceps Cope (478) from the Mazon Creek shales, and it is present as a rounded osseous element among some of the Permian forms. 
(q) The leg (fig. $2 \mathrm{I}, \mathrm{B}$ ) is composed of the femur, tibia, fibula, and 5 digits. The tarsus is usually cartilaginous, a single osseous tarsus $(483,484)$ being known (plate 23, fig. I) from America. The distal phalanges may or may not be clawed, depending on the habits of life of the animal. The elements of the leg are ossified in a similar manner to those of the arm.

$(r)$ The ventral scutellation (fig. 9), so commonly present among all groups of Amphibia in the Coal Measures, consists of a series of ossifications or calcifications in the myocommata. Among modern amphibians they occur as thin perpendicular planes of connective tissue which are sometimes cartilaginous, especially in Necturus, regarded by Wilder (Memoirs of the Boston Society of Natural History, vol. v, No. 9, p. 400, fig. 6, 1903) and by Wiedersheim $(605$, p. 58$)$ as a homologue or predecessor of the sternum, although Wiedersheim says:

"The sternum appears for the first time in Amphibians in the form of a small variously shaped plate of cartilage situatcd in the middle line of the chest. It arises as a paired cartilaginous plate in the inscriptiones tendincre of the rectus abdominis muscle, and therefore may be looked upon as corresponding to a pair of 'abdominal ribs.' Such cartilaginous abdominal ribs must have been present in greater numbers in the ancestors of existing Urodeles."

This supposition is fully sustained by the anatomy of the Branchiosauria (459), which must be looked upon as the actual ancestors of the Caudata. Wilder says of these structures in Necturus (op. cit., p. 400):

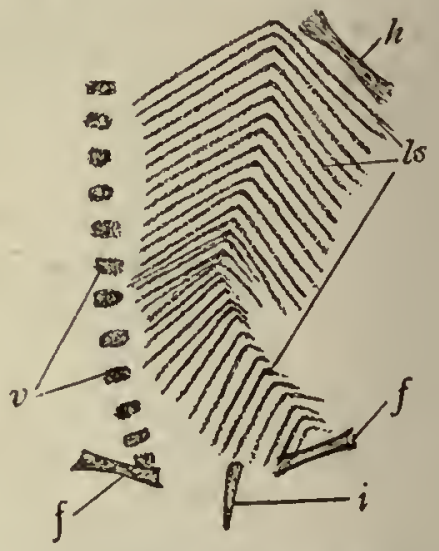

FIG. 9.-Ventral scutella of Micrerpelon caudahum, a Coal Mleasures salamander from Mazon Creek. $\times 5 . f$, femur; $h$, humerus; $l s$, lines of scutes; $v$, vertebral column.

"The scveral cartilaginous rudiments which represent this part (i.c., sternum) in Nccturus are somewhat difficult of detection and thus entirely escaped the attention of the earlier investigators. They consist of a number of thin cartilages found in several successive myocommata of the pectoral region and confined mainly to the area covered by the overlapping epicoracoids."

The homologue of the ventral scutelle is found in plesiosaurs, crocodiles, Sphenodon, and other reptiles in the "abdominal ribs," and the same myocommatous ossifications undoubtedly go to the formation of the chelonian plastron. What the causes were which produced the development of the ventral scutella to such a high degree among the primitive land vertebrates is uncertain, but they are certainly more highly developed among the primitive reptiles and amphibians than among the later members of those classes. Among the Amphibia of the Coal Measures they attained, in some forms, a high degree of development and differentiation. They are present in all families so far known, except the Tuditanidæ, in which the myocommata may have been cartilaginous. The Sauropleuridæ present the highest development of these structures among the American forms, in which the scutes are large and osseous. Among the Branchiosauria they are calcified or partially ossified and are always arranged en chevron on the belly, chest, arms, and throat, their arrangement and direction of the chevron being modified according to the myomeres of the various regions. The ventral scutella of the European Branchiosauria are figured and described fully by Credner (I92, p. 2 I, figs. 4 to II). 
(s) Scales (fig. Io and plate 24 , figs. 2 and 3 ) are present on the body of $(462,485)$ several species. It is a matter of regret that their preservation is so imperfect that nothing can be found out as to their structure. The Linton species, which possess scales, are, of course, carbonized and hence impracticable for microscopic study, and in the Mazon Creck species of Amphibamus and Micrerpeton the scales have been replaced by kaolin. The bodies of two species (Cercariomorphus parvisquamis

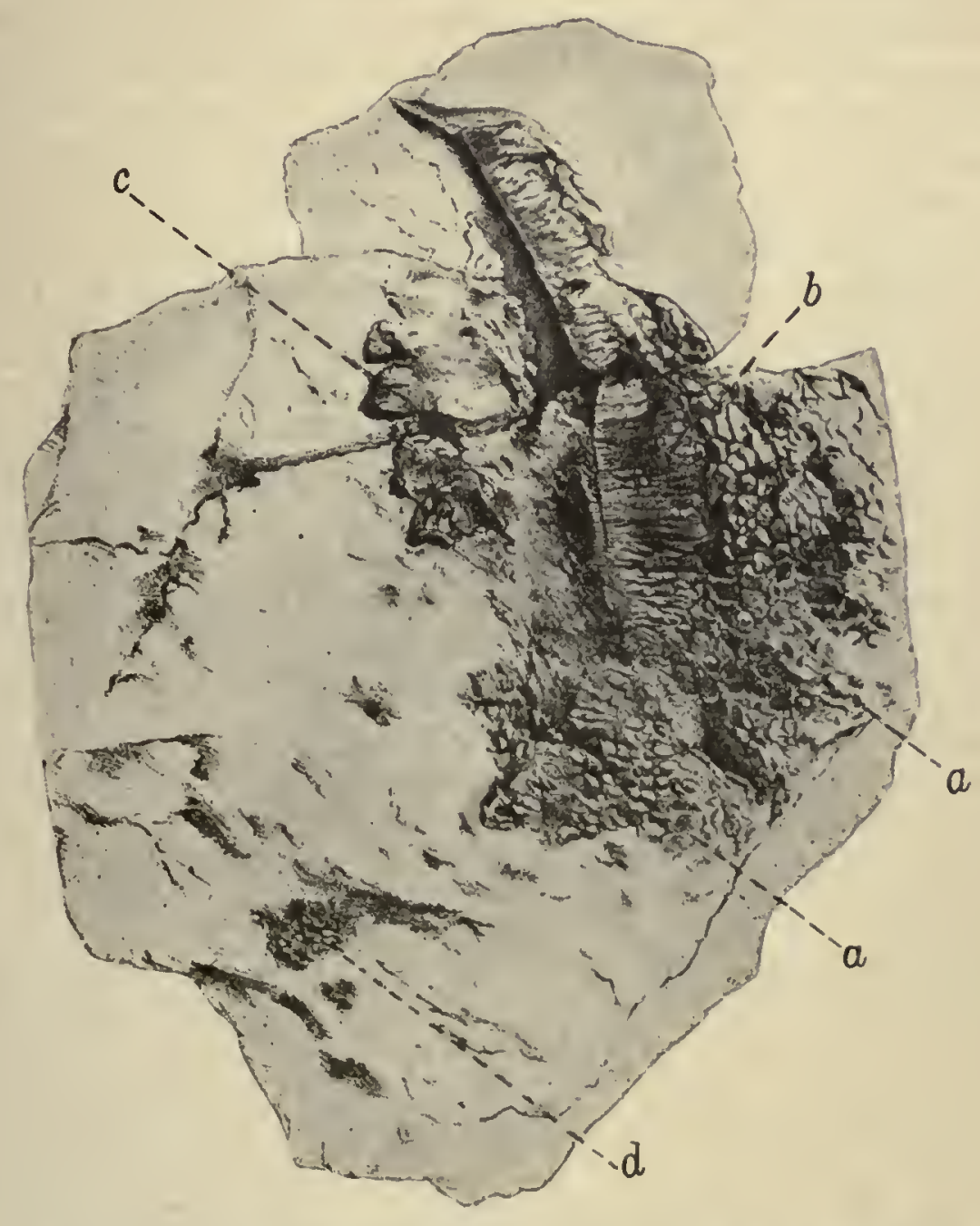

FIG. 10.-Horny armor of back of Hylonomus. $a$, imbricatod scales; $b$, horny plates; $c$, horny spines or tubercles; $d$, small imbricated scales. (After Dawson, based on a photograph.)

and Ichthyerpeton squamosum) of the Linton Coal Measures Amphibia were completely scaled. The scales in the Branchiosauria (462), so far as they have been observed, are slightly imbricated; rounded, with concentric markings after the manner of the modern cyprinoid fish-scale. They are extremely minute, and whether or not they covered the entire body of the animal is unknown. On the body of Cercariomorphus the scales have the appearance of being tubercular without imbrication, and they apparently covered the entire bodily surface of the animal. 
Among the Paleozoic Amphibia from Nova Scotia as described by Dawson and Owen $(193,201,485)$ scales are well developed and frequent, although the details as to their occurrence on the bodies of the animals are still unknown, since the Nova Scotian species are all based on very fragmentary remains. Dawson (208, p. 34) has given a detailed discussion of the discovery and anatomy of the various types of scales possessed by the species from the Coal Measures of Nova Scotia. Suffice it to say here that none of the scales appear to be bony, but have a cuticular appearance with concentric markings. Some of them are tubercular, and Dawson thought that a few specimens indicated that some of the species possessed scaly lappets and a dorsal nuchal fringe of scaly skin along the back. He has indicated these facts in his restorations of the forms. The scales were all carbonized and burned readily with a strong flame. A section of the scale shows a thick upper corium with a vascular body (208, pl. IV, fig. 29) much like a fish-scale. Fragments of the skin were also preserved with the scales. Dawson says of the skin:

"One of my specimens is a flattened portion of cuticle two and a quarter inches in length. The greater part of the surface is smooth and shining to the naked eye, and under the microscope shows only a minute grantulation. A limited portion of the upper and, I suppose, anterior part is covered with imbricated scales, which must have been membranous or horny, and generally have a small spot or pore near the outer margin, some having in addition smaller scales or points on thcir surfaces" (208, pl. Iv, figs. 22 and 25).

( $t$ ) Muscle tissue (fig. $2 \mathrm{I}$ ) is preserved in a single specimen, previously described by the writer $(464$, p. 17, pl. 7 , fig. I). The carbonized muscles show a myomeric arrangement and the portions preserved probably represent one of the recti muscles of the abdominal wall.

(u) The lateral-line system in the Coal Measures Amphibia will be best understood from a comparative review of the occurrence of these organs among all extinct Amphibia. Since all the orders of Amphibia are represented in the Coal Measures, such a review will not be out of place here.

The preservation of the lateral-line system among ancient Amphibia is due to the fact that the skull of many forms (especially the later and larger) are grooved and marked by a regular series of furrows and pits, in which the sense-organs of the lateral-line system were contained (sce fig. 6), as well as by the preservation of a series of clearly marked scales on the sides of the tails and bodies of others. The grooves are never arched over as in the Macropetalichthyidæ, where "in favorable specimens each is shown to be covered by a delicate roof perforated by two lines of minute openings" (Dean, N. Y. Acad. Sci. Men1., vol. II, pt. III, p. I I5). They are always widely opened canals, either with perfectly smooth bottoms and sides or roughened with large pits, or even becoming a series of well-marked pits. An attempt has been made $\left(45^{8}\right)$ to homologize the organs with those of fishes.

The nomenclature adopted here for the canals does not depart from that used by Allis for Amia (Journ. of Morphology, vol. II, I 889). The supraorbital and infraorbital canals are readily correlated with those of the same name in fishes, where they are very clearly marked. The anterior commissure is also homologous with that of the fishes, as is also the canal here called the "antorbital commissure." The 
others are not so readily homologized. The upper canal (sce fig. 6) in the postcrior part of the cranium is here designated the temporal canal. It is, however, clearly a part of the infraorbital of the fishes. Its relations in the Stegocephala are such that a new name is deemed necessary. The jugal canal is, I believe, a new formation in Amphibia. The transverse canal of the amphibian skull is homologous with the "occipital cross-commissure."

The figure (see fig. 6) is a composite picture of the lateral-line system of the higher or truly stegocephalous Amphibia. The outline of the skull is based on that of Eryops. All of the canals do not exist on any one skull or in any onc order, but all are found somewhere in the group.
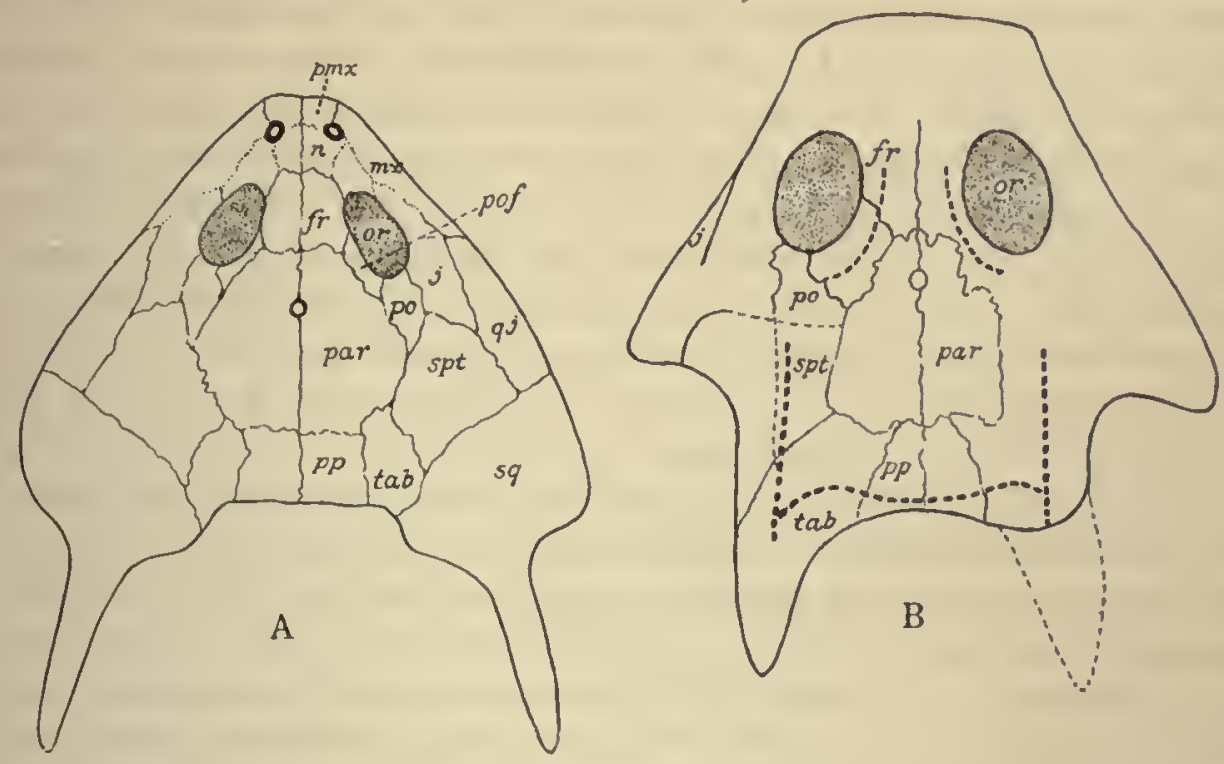

FIG. 11.

A. Skull of Eoserpeton tenuicorne Cope, showing arrangement of cranial elements. $\times 2$. fr, frontal; $j$, jugal; $m x$, maxilla; $n$, nasal; or, orbit; par, parietal; pof, postfrontal; pmx, premaxilla; po, postorbital; $p p$, postparictal; $q j$, quadratojugal; $s q$, squamosal; $s p l$, supratemporal; $t a b$, tabularc.

B. Outline of skull of Ceraterpeton galvani Huxley from the Carboniferous of England. Heavy broken lines show the distribution of lateral-line canals. $X r$. (After Andrews.) $f r$, frontal; par, parictal; or, orbit; $p o$, postorbital; $p p$, postparietal; $s p l$, supratemporal; $l a b$, tabulare.

The canals have been described in all known orders of fossil Amphibia and the system is found likewise in all the living orders, including the Gymnophiona, which have "a strong line of lateral sense-organs" (Gadow). In the Branchiosauria, the earliest of the true Amphibia (Euamphibia) and ancestral to the modern Caudata, the lateral-line system is known on the tails of two gencra $(462,478)$ from the Mazon Creek, Illinois, shales-Micrerpeton and Eumicrerpeton. 'The system as there defined has been fully discussed in the description of the anatomical details of the specics, to which reference may be made for further data (pp. 52-60). Suffice it to say here that the system of sense-organs there preserved is identical with that of the larval Necturus; the lines arising as a median from the tip of the tail and a dorsal springing from the median at a distance of a few millimeters from the tip of the tail. The lines are more evident on account of the fact that the lateral-line sense-organs were located under specialized pigmented scales. The significance of the close simi- 
larity between the arrangement of the lateral-line systems on the tail of Necturus, Micrerpeton, and Eumicrerpeton is doubtless of genetic (459) importance, indicating the origin of the caudate Amphibia from the Branchiosauria by a degenerative or recessive evolution in other structural characters. This system of sense-organs has been described in no other branchiosaurian.

The Mierosauria $\left(45^{8}\right)$ are exceedingly interesting in possessing a very peculiar type of lateral-line system. It is known in a few forms and in one specimen especially well (Erpetosaurus tabulatus) (fig. 22, G). In this species, which is represented by a single imperfect skull, there are evidences of a nearly complete lateral-line system of eanals and pits. The occipital cross-commissure is represented on the posterior border of the skull by a row of elongate pits such as Andrews described for Ceraterpeton (8). I fail to find in American species the pores described by Andrews. The temporal canal forms with the jugal canal a complete ring, much as it is in Trematosaurus, only in Erpetosaurus tabulatus the temporal canal does not touch the tabulare. I think there are indications of a connection of the temporal canal with the supraorbital. The temporal canal euts the supratemporal, the squamosal, and jugal. The jugal canal lies for the most part on the supratemporal and quadratojugal, and joins the infraorbital on the jugal. A portion only of the infraorbital canal is preserved. There is also a portion of the supraorbital canal. It seems not to be connected with the temporal canal, although there is a possible indication of this connection. The supraorbital crosses the frontal, prefrontal, and a part of the nasal. The squamosal element is peculiar in Erpetosaurus tabulatus in that it is excluded from the parietal by the extension of the tabulare and postorbital. This condition is found in several other species of the Microsauria. It will be noticed that with the changed condition of the squamosal the temporal canal has changed also, and this is further proof of the close connection between the cranial elements and the lateral-line canals, as Allis has maintained for Amia. (See in this connection C. J. Herriek, Journ. Comp. Neurol., vol. II, p. 224, I901.)

The Diplocaulia, an amphibian order allied to the Branchiosauria (477) and through them to the Caudata, have the lateral-line system apparently well-developed. The skulls are always erushed flat, so that the canals are nearly obliterated. On the mandible, however, the canals are clearly distinct and apparently run the entire course around the mandibular rami. On a well-preserved skull of Diplocaulus magnicornis Cope there are indications of three lateral-line canals $(477, \mathrm{pl}$. I). The infraorbital is clearly marked as a well-defined groove just below the orbit. The supraorbital is indicated only for a short distance, and there are indications of the temporal canal. The operculo-mandibular eanal has its course, for the most part, near the middle of the rami, but as it approaches the posterior angle of the mandible it suddenly changes its course and drops down to the lower edge, only to rise again and to come out strongly marked near the median plane on the posterior angle of the mandible.

The 'Temnospondylia, as represented by Eryops, Cricotus, and Archegosaurus, possess well-developed lateral-line eanals $\left(45^{8}\right)$. H. von Meyer (428) many years ago made out the course of the canals in Archegosaurus. The greater part of the fol- 
lowing description is based on Eryops megacephalus Cope from the Texas Permian. The entire surface of the cranial elements in Eryops, as in other of the Stegocephala $\left(45^{8}\right)$, is covered with coarse pits. The fossæ are present even in the bottoms of the grooves which represent the lateral-line system, and are more marked in the members of the 'Temnospondylia than in the Stereospondylia.

The occipital cross-commissure occurs in a well-developed form in Eryops. It is short and ends abruptly within the limits of the tabulare. Its ends are occupied by large pits. The commissure, as in Amia, grooves the postparietal and the tabulare clements. There is no evidence of an anterior commissure. I think there is evidence of a temporal canal on the left side of the skull, but am not sure. The jugal and infraorbital canals are well developed and strongly connected. The jugal canal starts far back on the supratemporal, and after curving around over the quadratojugal joins the infraorbital, or rather becomes a part of that canal, somewhere on the jugal. There is nothing unusual in the infraorbital. The antorbital commissure is well developed. It is longer and better developed than in any other known form. The supraorbital canal starts in the region of the orbit, and after curving downwards to meet the antorbital commissure, ends abruptly anterior to the nostril. There are faint traces of a lateral-line canal, the opcrculo-mandibular, on a poorly preserved mandible of Eryops. It does not differ greatly from that described below for Anaschisma.

Although Archegosaurus has been known for more than a century, we have had no adequate discussion of the manner of occurrence of the lateral-line canals. Burmcister (80) gave a figure of the canals as he thought they occurred on the cranium, but $H$. von Meyer (428) states that the representation is inaccurate, and they secm to be based largely on Trematosaurus.

The lateral-line canals occur in well-developed form on the skulls of the Stereospondylia. The sutures between the elements of the skull are usually clearly marked by smooth, narrow grooves. The lateral-line canals can always be distinguished from the sutural grooves by the shape of the bottom, being $U$-shaped in the former and $V$-shaped in the latter. The latcral-line canals also at times have their bottoms roughened by pits occurring in them; the sutural grooves always have smooth bottoms. The lateral-line canals are usually rather shallow and sometimes broad, with the edges of the grooves more or less perpendicular, but in Metoposaurus the canals are deep and the borders are sharply incised.

The temporal canals in Anaschisma from the Triassic (49) of Wyoming are represented by broken furrows. The portions prescrved exhibit the usual downward tendency to unite with the infraorbital on the postorbital element. In its course forward from the epiotic the temporal canal cuts the squamosal. The supraorbital canal has an unusually deviating course in Anaschisma, but aside from the minor twists and curves it does not differ essentially from the same canal in other forms. It ends abruptly on the anterior end of the muzzle. In its course it gives off the vestige of an antorbital commissure which tends to join a vestige from the infraorbital canal. The jugal canal begins broadly at the very posterior edge of the skull as though it were continued, as it undoubtedly was, to the body of the animal. In its 
course forward it joins the infraorbital canal on the jugal. The course of the infraorbital is not unusual in any respect. There is no anterior commissure on the skull, nor is the occipital cross-commissure developed on either skull of the genus at hand.

There are distinct evidences of an operculo-mandibular lateral-line canal on the mandibles. The canal enters the mandible on the surangular and passes forward around the mandible as described for Diplocaulus (477).

Other members of the Stereospondylia, such as Mastodonsaurus, Metoposaurus, and Trematosaurus possess well-developed lateral-line canals, but the above description fits, in a general way, the condition in all genera; and for our present purposes that will suffice. 


\section{CHAPTER V.}

\section{THE AMPHIBIA OF THE DEVONIAN AND MISSISSIPPIAN OF NORTH AMERICA.}

Evidences of the earliest land vertebrates are exceedingly scanty in the strata between the close of the Silurian and the opening of the Coal Measures, being represented solely by footprints. In the Devonian our knowledge of the group is confined to a single footprint, and in the Mississippian to series of footprints from several localities. These have been described by Lea (371), Rogers (Geology of Pennsylvania, pt. II, I856, p. 83I), Barrell (2I), Dawson (223), and Branson (50). The last-named author has described a new species from the Mississippian of Giles County, Virginia. His description of the footprints, with a photograph of one of the series, are published herewith (plate $\mathrm{I} 8$, fig. 3 ). Branson (50) has given a résumé of the knowledge of Mississippian Amphibia in North America.

Thinopus antiquus Marsh, 1896.

Макsн, Am. Jour. Science, Ir, p. 374, Nov. 18g6, with figure.

Type: Specimen No. 784, Yale University Museum.

Horizon: Near top of Chemung, in the upper Devonian.

[The] "specimen shows one vertebrate footprint in fair preservation, and with it part of another of the same series. These impressions are of much interest, both on account of their geological age and the size and character of the footprints themselves. The one best preserved [fig. I 2] is nearly 4 inches in length, 2.25 inches in width, and was apparently made by the left hind foot. On the inner side in front of the heel, a portion of the margin is split off, and this may have contained the imprint of another toe. The other footprint was a short distance in front, but only the posterior portion is now preserved in the present specimen. It is probably the imprint of the forefoot.

"The specimen [plate $\mathrm{I} 8$, fig. 4] . . was ... found in the town of Pleasant, one mile south of the Allegheny River, Warren County, Pennsylvania, by Dr. Charles E. Beecher, who presented it to Yale Museum, where it still remains.

"The geological horizon is near the top of the

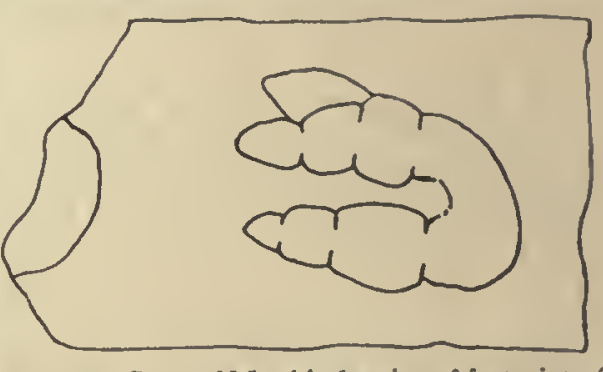

IG. 12.- Copy of Marsh's drawing of footprint of Thinopus antiquus, from the Devonian of Pennsylvania. $\times 1 / 3$.

Chemung in the upper Devonian. In the same beds are ripple marks, mud cracks, and impressions of rain drops, indicating shallow water and shore deposits. Land plants are found in the same general horizon. Marine molluscs also occur, and one characteristic form (Nuculana) is preserved in the footprint slab" (Marsh).

This still remains after nearly 20 years the only evidence of air-breathing vertebrates in the Devonian of the world.

\section{Dromopus aduncus Branson.}

Branson, Jour. Geol., xvil, No. 4, pp. 356-358, fig. I, 1910.

Type and other specimens in Oberlin College Museum.

Horizon and type locality: Near the bottom of the Hinton formation in Giles County, Virginia. (Plate I8, fig. 3.) 
The following description of the shales and footprints are from Dr. Branson's paper cited above:

"The Hinton shales, like the Mauch Chunk, seem to have been subaerial in origin and are made up for the most part of variegated shales interbedded with thin layers of argillaceous, fine-grained sandstone. The footprints occur in fine-grained sandstone, and remains of land plants are not uncommon in the same beds.

"Twenty-two footprints made by one animal walking in a straight course were collected in a slab. They give the impression of having been made by a bipedal animal for part of the distance, but after the fourth print of the right foot impressions of the forefeet appear. The hindfeet had 5 digits, the middle digit being longest and the 2 inside of it being only slightly shorter and lying close together. Their outer ends were slender and flexible and usually curved inward toward the middle toe. The 2 outer digits formed wide angles with the middle one and were shorter than the inner ones. The second toe was webbed to within $8 \mathrm{~mm}$. of the tip, the third toe to within $23 \mathrm{~mm}$. of the tip. The impression of the web is well preserved in only one impression of the hindfoot.

"The forefeet had 4 digits. The 3 inner digits were subequal in length, the 2 inner being more flexible and incurved near the ends. The outer digit is two-thirds as long as the second. The webbing extends about half the length of the digits. The heel impression is broader than that of the hindfoot.

"Measurements of Dromopus aduncus Branson.

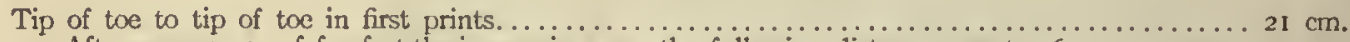
After appearance of forefeet the impressions are the following distances apart: $165 \mathrm{~mm} .40 \mathrm{~mm}$., $85 \mathrm{~mm}$., $70 \mathrm{~mm}$., $80 \mathrm{~mm}$., $40 \mathrm{~mm}$., $150 \mathrm{~mm}$., then back to 20 and $2 \mathrm{I} \mathrm{cm}$.

Length of hindfeet.

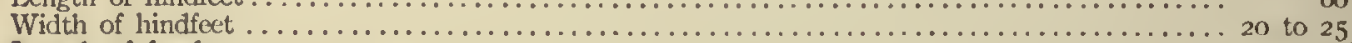

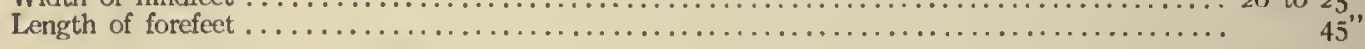




\section{CHAPTER VI.}

\section{A HISTORY OF THE CLASSIFICATION OF THE AMPHIBIA, WITH ESPECIAL REFERENCE TO THE SPECIES FROM THE COAL MEASURES.}

It has been necessary, in the course of the present study, to review thoroughly the classifications which have been proposed for the group. A classification of some sort is necessary for the proper grouping of the species which have been recovered from the Coal Measures deposits of this continent, and my reason for publishing this relatively dry material is that the classifications formerly proposed (469), as well as the one here given, may have a proper historical background.

The review of the proposed systems of classification has been much facilitated by the discovery, in the University of Chicago, of some notes by the late Dr. George Baur on the "Stegocephali." The notes were not discovered until after the literature had been pretty thoroughly covered, and it was a source of some gratification, on comparing notes with those of Dr. Baur, to find but few omissions. Whether Dr. Baur had ever contemplated a work on the Stegocephala or not I have been unable to learn, but it is certain that he carefully and laboriously went through the literature on the subject and copied by hand the classifications of each author from 1842 to 1895 , together with other notes of interest on the structure, distribution, and phylogeny, including many tracings. The classifications given below are taken, in part, from his notes, although all references have been verified with the original sources.

The first attempt to combine in classification the knowledge of the extinct and recent amphibians was made by Johannes Jacob von Tschudi in 1839 (574). Previous to that time Goldfuss (295) and von Meyer (418) had described various species of salamanders and frogs from the Tertiary deposits of Switzerland, and these Tschudi considered in his following classification:

A. Ranæ.
a. Hyla.
b. Cystignathi.
c. Rance.
d. Ceratophrydes.
c. Bombinatores.
f. Bufones.
g. Pipa.

B. Coccilix.

a. Cacilia.

C. Salamandrinx.

a. Pleurodeles.

b. Salamandra.

c. Tritones.

d. Tritonides.

D. Protoidex.

Although the remains of Mastodonsaurus had been known and widely commented on for sevcral years before Tschudi proposed this scheme, he does not include this genus in his classification of the Amphibia, for the reason that for nearly a quarter of a century after the discovery of the labyrinthodonts they were regarded as reptiles, even so eminent an authority as von Meyer (423) including them in his "System der fossilen Saurier." The view that the labyrinthodonts were 
reptiles was at times disputed, but no one seemed to pay any attention to the argument of Quenstedt in $185^{\circ}$ that "Die Mastodonsaurier im grünen Keupersandstein Würtemburgs sind Batrachier" (527), nor to the contention of Vogt $(58 \mathrm{I})$ in I 854 that "Archegosaurus und alle Labyrinthodonten sind Amphibien, nicht Reptilien."

In 1842 von Meyer (420) proposed to include all the early forms allied to the Mastodonsaurus in the "Labyrinthodontes." His definition of the group follows:

LABYRINTHODONTES: Saurier deren Zahn-Struktur jener ähnlich ist, welche in den nach prismatischer Art gebauten Säugethier-Zähnen wahrgenommen wird, u.s.w.

I. Mastodonsaurus Jaeger. (Salamandroides Jaeger, Batrachosaurus Fitzinger, Labyrinthodon Owen.) M. Jaegeri Meyer.

II. Capilosaurus Münster.

C. arenaceus Münst.

C. robustus Meyer.

III. Metopias Meyer.

$M$. diagnosticus Meyer.

Three years later von Meyer (423) proposed his "System der fossilen Saurier," where the extinct Amphibia are treated as follows:

LABYRINTHODONTES.

I. Prosthopthalmi (Augen-höhlen in der vordern Hälfte der Schädel-Länge) Metopias

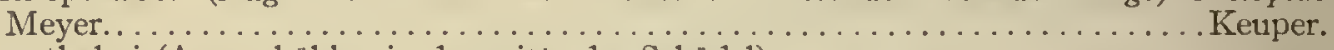

2. Mesopthalmi (Augen-höhlen in der mitte der Schädel)

Mastodonsaurus Jaeger-Keuper, Muschelkalk.

3. Opisthopthalmi (Augen-höhlen in der hintern Hälfte der Schädel-Iängc) Capitosaurus

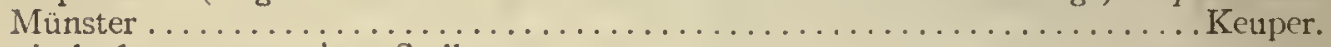

4. Labyrinthodonten ungewisser Stellung.

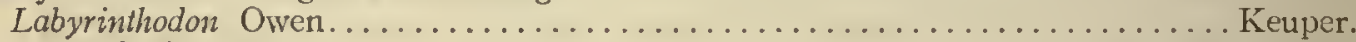

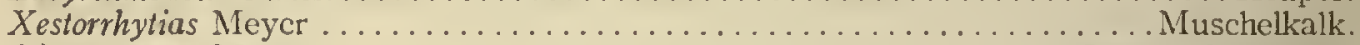

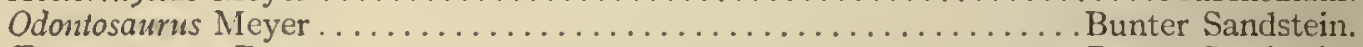

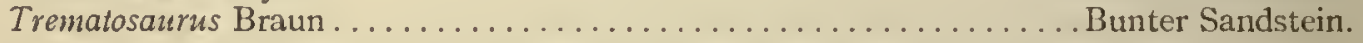

No other classification was proposed for the extinct Amphibia for I 5 years, when Owen (512) in 1859 proposed the new order Ganocephala and retained von Meyer's Labyrinthodontes under Labyrinthodontia. Owen's classification is as follows:

Class--ReptiLia.

Order I. Ganocephala.

Genera: Archegosaurus, Dendrerpeton, Raniceps.

Order II. Labyrinthodontia.

Genera: Mastodonsaurus, Anisopus, Trematosaurus, Metopias, Capitosaurus, Zygosaurus, Xestorrhytias.

In his Paleontology published in I86I, Owen gives the same classification, but adds new genera.

Huxley in I 863 (332) did not accept Owen's Ganocephala, but instead proposed the following:

LABYRINTHODONTIA.

A. Archegosauria. Archegosaurus, Pholidogaster.

B. Mastodonsauria. Mastodonsaurus, Labyrinthodon, Capitosaurus, Trematosaurus.

In the same year Dawson proposed (208) the term Microsauria to include the genera Hylonomus, Dendrerpeton, and Hylerpeton, all known from the Carboniferous 
rocks of Nova Scotia. 'Two years later Cope proposed the new order Xenorhachia (I05) for the reception of the form Amphibamus grandiceps from the Coal Measures of Illinois. He gave as the characters of this order cartilaginous vertebra and the absence of ribs.

In I 866 Owen proposed (516) the most elaborate and comprehensive scheme of classification which had thus far been offered. His classification is as follows:

Subclass DipNoA.

Order Ganocephala (extinct). Genera: Archegosaurus, Dendrerpelon, etc.

Order Labyrinthodontia. Genera: Labyrinthodon, Rhombopholis, etc.

Order Batrachia.

Suborder Ophiomorpha. Family: Coecilidx.

Suborder Ichthyomorpha. Family: Proteidæ, Salamandridæ.

Suborder Theriomorpha (Anura).

Family I. Aglossa.

Family 2. Ranide.

Family 3. Hylide.

Family 4. Bufonide.

Haeckel the same year proposed (312) an entirely different scheme of classification and in some respects more acceptable than Owen's. Haeckel's classification is as follows:

Class Amphibia.

Subclass I. Phractamphibia.

Ordnung I. Ganocephala.

Genera: Archegosaurus, Dendrerpeton, Raniceps.

Ordnung 2. Labyrinthodonta.

Genera: Baphetes, Zygosaurus, Mastodonsaurus, Trematosaurus, Capitosaurus. Ordnung 3. Peromela.

Subclass II. Lissamphibia.

Ordnung 1. Socobranchia.

Genera: Siren, Proteus, Menobranchus, etc.

Ordnung 2. Sozura (Caudata).

Genera: Cryptobranchus, Triton, Salamandra.

Ordnung 3. Anura (Ecaudata).

Families: Aglossa, Bufonida, Ranida.

This classification is further elaborated in the edition of 1895 .

Cope in 1868 proposed (IIO) the scheme of classification which was in use for some time, although it has since suffered some change. His classification follows:

BATRACHA.

Order I. Trachystoma.

Order 2. Proteida.

Order 3 . Urodela.

Order 4. Gymnophiona.

Order 5. Stegocephali.

Suborder Xenorhachia.

Amphibamus grandiceps Cope.

Suborder Microsauria.

Genera: Pelion Wyman, Hylonomus Dawson, Pariostegus Cope, Dendrerpeton Owen, Hylerpeton Owen, Brachydectes Cope, Sauropleura Cope, CEstocophalus Cope, Molgophis Cope.

Suborder Labyrinthodontia.

Genera: Dictyocephalus Leidy, Centenodon Lea, Baphetes Owen, Eupelor Cope. 
Huxley in 1869 proposed (335) the following classification, which does not differ essentially from that proposed in 1863 :

\author{
Amphibia. \\ Order ז. Urodela. \\ Order 2. Batrachia. \\ Order 3. Gymnophiona. \\ Order 4. Labyrinthodontia. \\ Suborder Archegosauria. \\ Suborder Mastodonsauria.
}

The next classification of the extinct Amphibia of any importance was that devised by the committee (450) for the British Association in 1874 . This committee was formed of Huxley, Harkness, Henry Woodward, Thompson, and Brigg, with Miall as secretary. This classification is, however, too cumbersome and has never come into general use, and indeed none but English authors have paid it a great deal of attention, although the contribution was a valuable one. The group Aistopoda, which was the ninth group proposed by the committee, has generally been accepted as the group represented by the snake-like forms. The committee's classification follows:

\title{
LABYR1NTHODONTIA.
}

Section I. Euglypta.

Genera: Mastodonsaurus, Jacger; Capitosaurus, Münst.; Pachygonia, Huxley; Trematosaurus, Braun; Gonioglyptus, Huxley; Mctopias, von Meyer; Labyrinthodon, Owen; Diadetognathus, Miall; Dasyceps, Huxley; Anthracosaurus, Huxley.

Section II. Brachyopina.

Gencra: Brachyops, Owen; Micropholis, Huxley; Rhinosaurus, Waldheim; Bothriceps, Huxley.

Section III. Chauliodonta.

Genera: Loxomma, Huxley; Zygosaurus, Eich.; Melosaurus, Meyer.

Scction IV. Arthroödonta.

Genera: Batrachiderpeton, Hancock and Atthey; Ptcroplax, Hancock and Atthey.

Section V. An uncharacterized group.

Genera: Pholidogaster, Huxley; Ichthyerpeton, Huxlcy; Pholiderpeton, Huxley.

Section VI. Archegosauria, von Meyer.

Genera: Archegosaurus, Goldfuss.

Section VII. Heleothrepta.

Genera: Lepterpeton, Huxley.

Section VIII. Nectridea.

Genera: Urocordylus, Huxley; Keraterpeton, Huxley.

Section IX. Aïstopoda.

Genera: Ophiderpeton, Huxley; Dolichosoma, Huxley.

Section X. Microsauria, Dawson.

Genera: Dendrerpeton, Owen; Hylonomus, Dawson; Hylerpeton, Owen.

The schemes of classification used for the next ro years did not depart in any appreciable degree from those already given.

In 1875 Cope, in his Check-list of North American Batrachia and Reptilia (120), with a systematic list of the higher groups, published the following classification as being "adopted provisionally by the Smithsonian Institution":

Class Batrachia.

Order Anura. (Anura, Duméril; Salientia, Merrem, Gray.)

Raniformia: (Raniformia, Cope, Nat. Hist. Rev., v, I 14, I865.)

Families: Ranide, Colostheidee.

Firmisternia. (Bufonoid Raniformia, Cope, Jour. Acad. Nat. Sci., Philadelphia, n.s., vı, 190, 1867.)

Families: Dendrobatide, Phryniscide, Engystomide, Breviceptide. 
Class Batrachia - Continued.

Order Anura-Continued.

Gastrechmia. (Gastrechmia, Copc, Jour. Acad. Nat. Sci., Philadelphia., n.s., vi, 198, 1867.)

Bufoniformia. (Bufoniformia, Duméril ct Bibron, partim; Copc, partim.)

Aglossa.

Families: Rhinophrynida, Bufonide, Batrachophrynida.

Family: Pipida.

Odontaglossa.

Family: Dactylethridce.

Arcifera. (Arcifcra, Cope, N. H. Rev., v, 104, 1865.)

Families: Cystignalhide, Hemiphractide, Hylida, Scaphiopide, Pelodytide, Asterophrydide, Discoglosside.

Order Stegocephali. (Stegocephali Cope, Proc. Acad. Nat. Sci., Philadelphia, 1868, 209.)

Labyrinthodontia.

Families: Baphetide Cope, Anthracosaurida Cope.

Ganoccphala.

Microsauria.

Family: Colosteida Cope.

Families: Phlegethontiida Cope, Molgophida Cope, Ptyoniida Cope, Tuditanida Cope, Peliontida Cope.

Order Gymnophiona. (Gymnophiona Müller.)

Order Urodela.

Family: Caciliidce Gray, 1850.

Families: Pleurodelide Gray, 1858; Salamandridce Gray, 1858; Hynobiidce Cope, 1866; Desmognathida Cope, I866; Thoriide Cope, 1869; Plethodontide Cope, 1866; Amblystomidae Cope, 1866; Menopomida (Protonopsida Gray,

Order Proteida. 1850), Anphiumida Cope, 1866; Cocytinidle Cope.

Order Trachystomata.

Family: Proteida Gray, 1850.

Family: Sirenidce Gray, 1850.

In 1885 Cope proposed 2 new orders, which he arranges with the other orders already known, as follows:

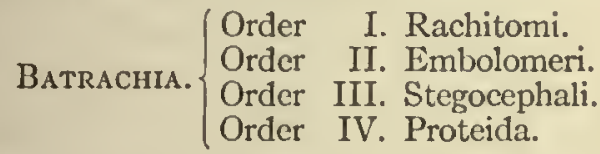
Order V. Urodela.
Order VI. Trachystomata.
Order VII. Anura.

The new order Rachitomi was to include forms like Eryops and the new order Embolomeri was to include forms like Cricolus; the other orders were as they had been given before.

Zittel in I 888 proposed (642) the next classification of any note in his "Handbuch der Paleontologie," where it stands as follows:

Classe Aм PнiвiA.

Ordnung r. Stegocephali.

Unterordnung $\mathrm{r}$. Lepospondyli.

Familie 1. Branchiosauridee Fritsch.

" 2. Microsauria Dawson.

“ 3. Aistopoda Miall.

Unterordnung 2. Temnospondyli.

Genera: Archegosaurus, Eryops, etc.

Unterordnung 3. Stereospondyli.

Familic I. Gastrolepidoti.

Ordnung 2. Coeciliæ.
Ordnung 3. Urodela.

Unterordnung I. Ichthyoidea.

Familie 1. Phanerobranchia.

2. Cryptobranchia.

Unterordnung 2. Salamandriıı.

Ordnung 4. Anura.

Unterordnung I. Phaneroglossa.

Familic I. Ranidc.

"2. Bufonide.

"3. Cystignatlida Cope.

“ 4. Pelobatide Boul.

“ 5. Discoglossida Cope.

- 6. Palaobatraclidida Cope. 
Lydekker (393) in the next year proposed a system of classification which did not depart widely from that proposed (450) by the committee of the British Association for 1874. Lydekker's classification is as follows:

Class Amphibia.

Order I. Labyrinthodontia.

Suborder I. Branchiosauria.

Family Protritonida.

A pateonida.

Suborder 2. Aistopoda.

Family Dolichosomatida.

Suborder 3. Microsauria.

Family Urocordylida.

" Limnerpetide.

“ Hyloplesionida.

" Microbrachide.

Suborder 4. Labyrinthodontia vera.

Family Archegosauridce.

" Diplospondylide.

"Nyraniide.

“ Dendrerpetidce.

“ Anthracosauride.

“ Mastodonsauride.

Uncertain family, Eosaurus.
Order II. Apoda.

Order III. Caudata.

Family Hylcobatrachide.

"Sirenide.

" Proteidce.

" Amphiumide.

"Salamandridce.

Order IV. Ecaudata.

Family Discoglosside.

" Pelobatidic.

"Palcobatrachidce.

" Cystignathidce.

" Ranidce.

In 1890 Doederlein proposed a scheme of classification which is notable on account of the peculiar relations which it expresses between the groups-relations which, in reality, do not exist. His classification is as follows:

Class Amphibia.

Ordnung I. Stegocephali.

A. Microsauria.

Unterordnung $\mathrm{I}$. Branchiosauri.

Genera: Branchiosaurus, Dawsonia, Melanerpeton, Pelosaurus.

Unterordnung 2. Sauromorphi.

Familie I. Hylonomida.

B. Ganocephala.

" 2. Nectrida.

Unterordnung I. Rhachitomi. •

Ordnung II. Urodela.

"2. Embolomeri.

3. Labyrinthodontia.

Ordnung III. Gymnophiona.

Ordnung IV. Anura.

In 1890 Lydekker used the same classification, with minor changes, which he had used in his Paleontology. Credner, who wrote at about the same time (193), followed Zittel's classification. Zittel in 1895 merely repeated his former classification. In I898 appeared Smith Woodward's Paleontology, where the following scheme is adopted:

Class Batrachia.

Order I. Stegocephalia. Suborder 1. Branchiosauria.

"2. Aistopoda.

“ 3. Microsauria.

4. Labyrinthodontia.

Order II. Gymnophiona.

Order III. Caudata.

Order IV. Ecaudata. 
Hay's Catalogue of Fossil Vertebrata of North America contains the next scheme for the classification of the Amphibia which pays especial attention to the extinct forms. His classification is as follows:

Class Batrachia Macartney, 1802 .

Order Stegocephali Cope, I 868.

Suborder Microsauria Dawson, I 863.

Family Protritonida Lydekker, 1889.

Genera: Amphibamus Cope, Pelion Wym.

Family Molgophide Cope, 1875 .

Genera: Phlegethontia Cope, Molgophis Cope.

Family Hylonomide Fritsch, 1883.

Genera: Hylonomus Dawson, Smilerpeton Dawson, Hylerpeton Owen, Fritschia Dawson; Brachydectes Cope.

Family Ptyoniida Cope, 1875.

Genera: Keraterpeton Huxley, Estocephalus Cope, Ptyonius Cope, Ctenerpeton Cope.

Family Tuditanida Cope, 1875.

Genera: Tuditanus Cope, Cocytinus Cope.

Family Diplocaulida Cope, 188I.

Genus: Diplocaulus Cope

Lepospondylous Genera of uncertain position: Amblyodon Dawson, Hyphasma Cope, Eurythorax Cope, Thyrsidiun Cope, Pleuroptyx Cope, Cercariomorphus Cope.

Suborder Apoccospondyli Hay, 1902.

Family Dendrerpetontide Fritsch, 1889.

Genera: Dendrerpeton Owen, Baphetes Owen, Platystegos Dawson.

Family Sauropleuridee Hay, 1902.

Genera: Sauropleura Copc, Leptophractus Cope.

Family Archegosaurida.

Genera: Trimerorhachis Cope, Dissorophus Cope.

Family Cricotide Cope, 1884 .

Genera: Cricotus Cope.

Family Anthracosaurida.

Genus: Eosaurus Marsh.

Family Eryopidec Cope, 1882.

Genera: Eryops Cope, Ichthycanthus Cope, Zatrachys Cope, Anisodexis Cope, Acheloma Cope.

Family Mastodonsantide Huxley, 1863.

Gencra: Mastodonsaurus Jaeger, Eupelor Cope, Pariostegus Cope, Dictyocephalus

Order Urodela. Leidy.

Genera: Scapherpeton Cope, Hemitrypus Cope.

Order Salientia Laurenti, I 768.

Family Ranidce.

Genera: Rana Linné, Eobatrachus Marsh.

This classification given by Hay is only for the forms which occur in North America. 


\section{CHAPTER VII.}

\section{CLASSIFICATION OF AMPHIBIA ADOPTED IN THIS WORK, AND A LIST OF THE COAL MEASURES AMPHIBIA FROM NORTH AMERICA.}

A few words of explanation will be necessary for an understanding of the following classification. The term Amphibia Linné, 1758, is, according to Stejneger (550), the correct term for the entire group, and this term is adopted. The term Stegocephala, formerly used as a group name for the entire Carboniferous, Permian, and Triassic Amphibia, regardless of structure, has been retained as a third subclass. The choice, so far as priority is concerned, between Labyrinthodontia and Stegocephala, is not easy. The terms, however, imply different structures. The labyrinthodonts proper have stereospondylous vertebræ, while the Stegocephala have either temnospondylous or stereospondylous vertebræ; so the latter term has been adopted.

The ordinal terms are those which have been used previously as subordinal, sectional, or family names, with the exception of the new ordinal term "Diplocaulia" (477). The term Branchiosauria is well-established, and it is here retained with the definitions previously given. The same may be said for the Microsauria, although Dawson first (208) regarded it as a family, though giving the term an ordinal form. The Aistopoda are not entitled to consideration as a group for reasons which are given subsequently. The Temnospondylia and the Stereospondylia, the Embolomeri and the Rachitomi may or may not be good group names, but they have priority, so far as our knowledge of structure goes. They have been retained in their original meanings. They have been variously regarded as sections, superfamilies, groups, and subfamilies.

The following list of species is arranged according to the proposed scheme of classification:

Class Amphibia Linné, i 758 . Devonian to Recent.

Subclass Euamphibia Moodic, i 909. Coal Measures to Recent.

Order Branchiosauria Lydekker, I889. Coal Measures to Permian.

Family Branchiosauridee Fritsch, 1879.

Micrerpeton caudatum Moodic, Mazon Creck.

Eumicrerpeton parvum Moodie, Mazon Creck.

Mazonerpeton longicaudatum Moodic, Mazon Crcek.

Mazonerpeton costatum Moodic, Mazon Creek.

(?) Sparodus sp. indet. Dawson, Nova Scotia.

Order Caudata Duméril, ı 806 . Coal Measures to Recent.

Suborder Proteida Cope, i 868 . Coal Measures, Eocene, and Recent.

Family Cocytinida Cope, 1875 .

Cocytinus gyrinoides Cope, Linton, Ohio.

Erierpeton branchialis Moodic, Mazon Creek.

Hyphasma laenis Cope, Linton, Ohio.

Order Diplocaulia Moodic, I9r2. Coal Measures to Permian.

Family Diplocaulide Cope, $188 \mathrm{I}$.

Diplocaulus salamandroides Cope, Salt Fork, Illinois.

(?) Order Salientia Laurenti, i 768. Coal Measures (?) to Recent.

Family Peliontide Cope, 1875 .

Pelion lyelli Wyman, Linton, Ohio. 
Class Amphibia - Continued.

Subclass Lepospondyla Zittcl, 1887 . Coal Measures.

Order Microsauria Dawson, 1863. Coal Measures.

Fannily Hylonsmide Fritsch, 1883 .

Hylonomns latidens Dawson, Nova Scotia.

Hylonomus lyelli Dawson, Nova Scotia.

Hylonomus multidens Dawson, Nova Scotia.

Hylonomus wymani Dawson, Nova Scotia.

Similcrpeton aciedentatum Dawson, Nova Scotia.

Hylerpeton dawsonii Owen, Nova Scotia.

Hylerpelon intermedium Dawson, Nova Scotia.

Hylerpeton longidentatum Dawson, Nova Scotia.

Fritschia curtidentata Dawson, Nova Scotia.

(?) Amblyodon problematicum Dawson, Nova Scotia.

Family Tuditanide Cope, 1875 .

Tuditanus punctulatus Cope, Linton, Ohio.

Tuditanus brevirostris Cope, Linton, Ohio.

Tuditanus ninimus Moodic, Cannelton, $\mathrm{Pa}$.

Tudilanus longipes Cope, Linton, Ohio.

Tuditanus walcotti Moodic, Linton, Ohio.

Erpctosaurus acutirostris Moodie, Linton, Ohio.

Erpctosaurus minutus Moodie, Cannelton, Pa.

Erpctosaurus obtusus Cope, Linton, Ohio.

Erpctosaurus radiatus Cope, Linton, Ohio.

Erpctosaurus sculptilis Moodic, Cannelton, $\mathrm{Pa}$.

Erpetosaurus tabulatus Cope, Linton. Ohio.

Erpctosaurus tubcrculatus Moodic, Linton, Ohio.

Odonterpeton triangularis Moodic, Linton, Ohio.

Family Stegopida Moodie, I gog.

Stcgops divaricata Cope, Linton, Ohio.

Family Urocordylide Lydekker, 1890.

Diccratosaurus punctolineatsus Cope, Linton, Ohio.

Diceratosaurus levis Moodie, Linton, Ohio.

Diccratosaurus robustus Moodic, Linton, Ohio.

Eoserpeton tenuicorne Cope, Linton, Ohio.

Family Amphibamida Moodie.

Amplibamus grandiceps Cope, Mazon Creck.

Amphibamus thoracatus Moodie, Mazon Creek.

Cephalerpeton ventriarmatum Moodic, Mazon Creek.

Family Nyraniide Lydekker, 1889.

Ichthycrpcton squamosum Moodic. Linton, Ohio.

Corcariomorphus parvisquamis Cope, Linton, Ohio.

Family Ptyoniida Cope, 1875 .

Ptyonius nummiter Cope, Linton, Ohio.

Ptyonius marshii Cope, Linton, Ohio.

Ptyonius vinchellianus Cope, Linton, Ohio.

Ptyonius pectinatus Cope, Linton, Ohio.

Plyonius scrrula Cope, Linton, Ohio.

CEstocephalus remex Cope, Linton, Ohio.

Eistocephalus reciidens Cope, Linton, Ohio.

Thyrsidium fasciculare Cope, Linton, Ohio.

Family Ichthycanthide Moodie.

Ichthycanthus olicensis Cope, Linton, Ohio.

Ichthycanthus platypus Cope, Linton, Ohio.

Family Molgophide Cope, 1875.

Molgophis macrurus Cope, Linton, Ohio.

Molgophis brevicostatus Cope, Linton, Ohio.

Molgophis whealleyi Cope, Linton, Ohio.

Erpetobrachitum mazonensis Moodie, Mazon Creek.

Pleuroptyx clavatus Cope, Linton, Ohio.

Phlegethontia linearis Cope, Linton, Ohio.

Phlegethontia serpens Cope, Linton, Ohio. 
Class AuphiB1A - Continucd.

Subclass LePOSPONDYLiA-Continued.

Order Microsauria-Continued.

Family Sauropleuride Hay, I902.

Sauropleura digitata Cope, Linton, Ohio.

Sauropleura newberryi Cope, Linton, Ohio.

Sauropleura scutellata Newberry, Linton, Ohio.

Sauropleura pauciradiata Cope, Linton, Ohio.

Sauropleura longidentata Moodie, Linton, Ohio.

Sauropleura foveata Cope, Linton, Ohio.

Sauropleura (Anisodexis) enchodus Cope, Linton, Ohio.

Sauropleura sp., Linton, Ohio.

Ctenerpeton alveolatum Cope, Linton, Ohio.

Saurerpeton latithorax Cope, I,inton, Ohio.

Leptophractus obsoletus Cope, Linton, Ohio.

Leptophractus dentatus Moodie, Linton, Ohio.

Leptophractus lineolatus Cope, Linton, Ohio.

Order Temnospondylia Zittel, i 887. Coal Measures and Permian.

Family Cricotide Cope, 1884.

Spondylerpeton spinatum Moodie, Mazon Creek, IIl.

Family Eryopide Cope, 1882.

Eryops sp. indet., Pitcairn, Pa.

Family Macrerpetida Moodie, rgog.

Macrerpeton huxlcyi (Cope), Linton, Ohio.

Macrerpeton deani Moodic, Linton, Ohio.

Family Anthracosauride Cope, 1875.

Eosaurus acadianus Marsh, Nova Scotia.

Eobaphctes kansensis Moodie, Kansas.

Baphetes planiceps Owcn, Nova Scotia.

Baphetes minor Dawson, Nova Scotia.

Dendrerpeton acadianum Owen, Nova Scotia.

Dendrerpeton oweni Dawson, Nova Scotia.

(?)Platystegos loricatum Dawson, Nova Scotia.

Genera and species of uncertain position:

Amblyodon problematicum Dawson, Nova Scotia.

Proterpeton gurleyi Moodie, Illinois.

Brachydectes newberryi Cope, Linton, Ohio.

Order Stereospondylia Zittel, 1887. Coal Measures (?) and Triassic.

Family Mastodonsaurida Huxley, 1863.

Mastodonsaurus sp. indet., Kansas.

The above list of species is interesting in that it shows the diversity of structure among the Coal Measures Amphibia. There are at present 88 species known, many of them incompletely, divided among $\mathrm{I} 7$ families and 5 orders. The majority of the species are from the Linton Coal Measures, there being 50 species described or indicated from these beds. The Mazon Creek shales have furnished Io species; Nova Scotia 18 species; the remainder of the species are from various localities. 


\section{CHAPTER V III.}

\section{DEFINITION OF THE CLASS AMPHIBIA LINNÉ, 1758, DEVONIAN TO RECENT.}

(World-wide distribution.)

Cold-blooded vertebrates; aquatic or partially terrestrial in habit; body scaled or naked or partly covered with bony or horny plates; abdomen sometimes protected by closely packed scutes, scales, or rods; skull completely roofed over or with a single vacuity; pterygoid-palatine arch complete or wanting; stapes always present; two occipital condyles, sometimes cartilaginous; skull bones pitted and grooved by the latcral-line canals, or smooth and lateral-line canals wanting; parasphenoid wcll developed; palatine vacuities, large, small, or absent; basioccipital partly or entirely cartilaginous; sclerotic plates present or absent; mouth always terminal; teeth sharply conical, smooth, or plicated, with walls sometimes extremely complicated by the infolding of the dentine and enamel. Vertebræ procoelous, opisthocœlous, amphicœlous, amphiplatyan, temnospondylous, stereospondylous, or cartilaginous; notochord often persistent; column divisible into cervical, dorsal, and caudal series; cervical series, so far as known, always short; dorsal region long or short; a single sacral or two; caudal series short, very long, or absent. Pectoral girdle composed of an osseous scapula, cleithrum, clavicle, interclavicle, and coracoid with various relations; sternum undeveloped; pectoral girdle of membrane boncs; in Triassic forms producing the effect of a plastron on account of the high development of the clavicles and interclavicle. Pelvis usually composed of an osseous ilium and ischium; pubis when osseous surrounded by large amounts of cartilage, usually cartilaginous, sometimes calcified. Limbs ambulatory, natatory, or wanting; limb bones composed either entirely of perichondrium or of perichondrium and a small amount of endochondrium; radius and ulna, and tibia and fibula free or fused. Digits 3 to 5 , usually 4 for the hand and 5 for the foot. Terminal phalanges sometimes clawed. Carpus and tarsus osscous or cartilaginous, usually the latter. Ribs never attached to a sternal apparatus, single or double headed or intermediate, long and curved or short and straight. Articulation with vertebral column inter- or intra-central. Respiration both branchial and pulmonary; branchia persistent and osseous in some forms. Development by metamorphosis either in the egg membrane, on the back of the mother, or in the water. No amnion or allantois. Heart with a single ventricle and 3 or 4 pairs of aortic arches; postcava always present in the recent forms.

\section{DEFINITION OF SUBCLASS EUAMPHIBIA, MOODIE, 1909. COAL MEASURES} TO RECENT.

(World-wide distribution.)

Moonie, Trans. Kans. Acad. Sci., 1909, p. 243.

Moodie, Geol. Mag., n. S., Dec. V, vol. vi, p. 220, May, Igog.

The present group was established for the reception of the Branchiosauria and their descendants, the Caudata, with the related forms, the Apoda. The Salicntia are included provisionally, since there is no evidence of the origin or relationship of this group of animals to other Euamphibia save that they have attained the sanue stage of evolution. They are in no way closely related to any known group of Amphibia, recent or extinct, but they stand on the same plane of development as the Caudata and present similar structures, i.e., a single ventricle in the heart, external branchiæ in the young, a glandular skin, perichondral bone, and a large parasphenoid. The origin of the Salientia is a puzzle and must remain so until further paleontological cvidence is forthcoming. Wyman, Cope, and the writer have all remarked on the similarity of structure between the Salientia and the single known specimen of Pelion lyelli Wyman from the Linton, Ohio, Coal Measures. 
The subclass Euamphibia may be defined as follows: Aquatic or terrestrial Amphibia; development by metamorphosis; external branchiæ present in the young; bones almost entirely perichondral; carpus and tarsus never ossified; osseous pubis absent; vertebræ usually amphicœlous with persistent notochord; ribs short and straight or flat and slightly curved, or absent; digits 4 in the hand and 5 in the foot; skull never grooved or pitted, nor cut by the lateral-line canals; lateral-line organs present in the skin; sclerotic plates present or absent; tail long and flattened or absent. Ribs in Triton walthi are secondarily long and curved.

DEFINITION OF THE ORDER BRANCHIOSAURIA LYDEKKER, 1890. COAL MEASURES AND PERMIAN OF NORTH AMERICA AND EUROPE.

LydekKer, Cat. Fossil Reptilia and Amphibia, pt. Iv, p. 208, 1890.

Extinct, salamander-like amphibians, with broad, obtusely rounded cranium; external branchiæ present in young; sclerotic plates present; bones of the cranium not ornamented with deep pits and grooves nor cut by the lateral-line canals, though sometimes ornamented with slight scorbiculations; notochord always persistent; vertebræ cartilaginous (in caudal region) or but partially ossified, the ossification being entirely perichondral; a single sacral vertebra; transverse process of vertebra large in dorsal region; ribs always short, straight, and heavy, present throughout the length of the vertebral column and borne on the transverse processes centrally; caudal region of moderate length with elongate fleshy tail; usually 20 presacrals, of which 4 or 5 may be considered cervicals; limbs natatory and always present, well developed; elements of the appendicular skeleton composed entirely of perichondrium; carpus and tarsus cartilaginous; digits 4 in the hand and 5 in the foot; phalangeal formula for the hand usually $2-2-3-2$ and for the foot $2-3-4-3-2$; distal phalanges not clawed; abdomen covered with closely packed corneous scutes or scales; body naked or covered with minute horny scales; median and dorsal lateral lines present on the posterior part of body and on tail. 


\section{CHAPTER IX.}

\section{THE AMERICAN COAL MEASURES BRANCHIOSAURIDAE.}

\section{Definition of the Family Branchiosauride Fritscii, i879. Coal Measures and Permian of Nortil America and Europe.}

Fritscir, Fauna der Gaskohle, Bd. I, p. 69, fig. 30, 1879.

Lydekker, Cat. Fossil Reptilia and Amphibia, pt. IV, p. 2 Io, I 890 (Protritonida).

Stegocephalic, salamander-like animals, with broad, anteriorly truncate skull. Tecth smooth with large pulp-cavity. The parasphenoid narrowed anteriorly, posteriorly expanded to a shield-shaped plate. Vertebræ with the notochord persistent and intravertebrally expanded. Pelvis well developed, the ilium and ischium osseous with large cartilaginous margins, the pubis unknown, possibly hyaline cartilage. Ribs short, straight, present on almost all vertebræ. Skin with delicately ornamented scales. Eyes with sclerotic plates. Palatal elements toothless or with small toothlike tubercles on pterygoids and palatines. Ventral armature on throat, chest, and abdomen, extending on to the limbs, consisting of small delicate scutellx arranged in a chevron pattern.

The above definition is modified from Fritsch (Fauna der Gaskohle, Bd. I, p. 69, I 879).

The North American species are: (?) Sparodus sp. indet. Dawson, Micrerpeton caudatum Moodie, Mazonerpeton longicaudatum Moodie, Mazonerpeton costatum Moodie, Eumicrerpeton parvum Moodie.

Genus MICRERPETON Moodie.

Moonte, Jour. Geol, I7, p. 39, figs. I to 6, 1909.

Type Micrerpeton caudatum Moodie.

The genus Micrerpeton, of which the single species is described below, was the first evidence of the occurrence of the Branchiosauria in America. There have been three other genera referred to the Branchiosauria from North American deposits, but there is good evidence that none of them belong there. The genus Amphibamus was originally referred to the Xenorhachia by Cope (105, pp. I34-137) on account of the supposed cartilaginous condition of the vertebræ and the absence of ribs. Later he abandoned this order and placed the form in the Branchiosauria, where it was retained by Zittel (642). Recently Hay has shown (316), and I am able to corroborate his statement, that ribs are present in the species, and that they are long and curved, not at all like the short ribs of the true Branchiosauria. These long, curved ribs undoubtedly exclude Amphibamus from the Branchiosauria and indicate its close affinities with the Microsauria. The genus Pelion has also been referred to this order on purely negative evidence $(642$, p. 375$)$. This genus is excluded from the Branchiosauria by the well-ossified condition of the limb bones, in which the endochondral ossification is seen to be well developed, a condition not found, so far, among the true Branchiosauria. The form of the head and the elongate hind limb would also tend to exclude the genus from the Branchiosauria. In the Branchiosauria 
the fore limb is usually larger than the hind limb, the reverse of which is the case in Pelion. The genus Sparodus, as it occurs in North America, is uncertain. It is indicated by remains which are almost impossible of determination.

The genus Micrerpeton may be distinguished from other known Branchiosauria by the large size and anterior position of the orbits, absence of a posterior table to the skull, the short, heavy limb bones, the slender ilium, and the expanded, elongate, and laterally compressed tail. The genus may be defined as follows: Small forms, the known representative attaining a length of less than 2 inches; head broad and short; sclerotic plates present; interorbital space less than the least diameter of the orbit; occiput concave; pineal foramen in the line which cuts the posterior edge of the orbits; teeth small, pleurodont denticles; presacral vertebræ 20 or $2 \mathrm{I}$, of which probably 5 are cervical; I sacral; ribs short, straight, and heavy, central; scapula ovoid; limbs stumpy and heavy, fore limb exceeding the hind in size; endochondral ossifications distinctly absent; tail long, expanded, and flattened, probably provided with a thin expanded membrane; body covered with minute, ovoid or rounded scales which are ornamented with concentric lines; color markings vertical to the long axis of the body and abundantly present on the tail; lateral-line organs represented by the dorsal and median lateral lines on the tail, the sensory pits probably occurring in specialized darkened scales. Coal Measures of Mazon Creek shales near Morris, Grundy County, Illinois.

Micrerpeton caudatum Moodie.

Moodie, Jour. Geol., 17, p. 39, figs. I-6, I909.

Type: Specimen No. 12,313, Walker Museum, University of Chicago.

Horizon and locality: Mazon Creek shales, near Morris, Illinois.

The species is represented by very complete remains (plate 2), which are preserved on opposite halves of a nodule. The specimen was collected many years ago by Mr. W. F. E. Gurley at Mazon Creek, but it has never before been studied, although Dr. Newberry examined it and said in a note that Professor Cope should see it. Unfortunately Cope did not see it and it lay unknown for more than a quarter of a century. I am indebted to Dr. Stuart Weller for calling my attention to the specimen, as well as for the privilege of describing it.

The specimen is exceptionally perfect (plate 25, fig. 4). Nearly all the skeletal elements are present, and the general contour of the body, the character of the dermal covering, the color-markings, the lateral-line system, and many other features of interest have been detected. Such completeness of preservation is very uncommon even among the remains obtained from this locality. In this case the entire form was preserved, but the collector, in cracking the nodule, lost the chips containing the feet, so that only portions of the limbs remain. It is thus impossible to determine the phalangeal formula, but the feet were probably like those of Branchiosaurus amblystomus Credner, as given by Credner, to which species the present form is closely allied and indeed must be placed in the same family with Branchiosaurus, Pelosaurus, and Melanerpeton.

The remains here described represent a small, salamander-like form, and they are among the earliest geological evidence of the group, which, without doubt, gave 


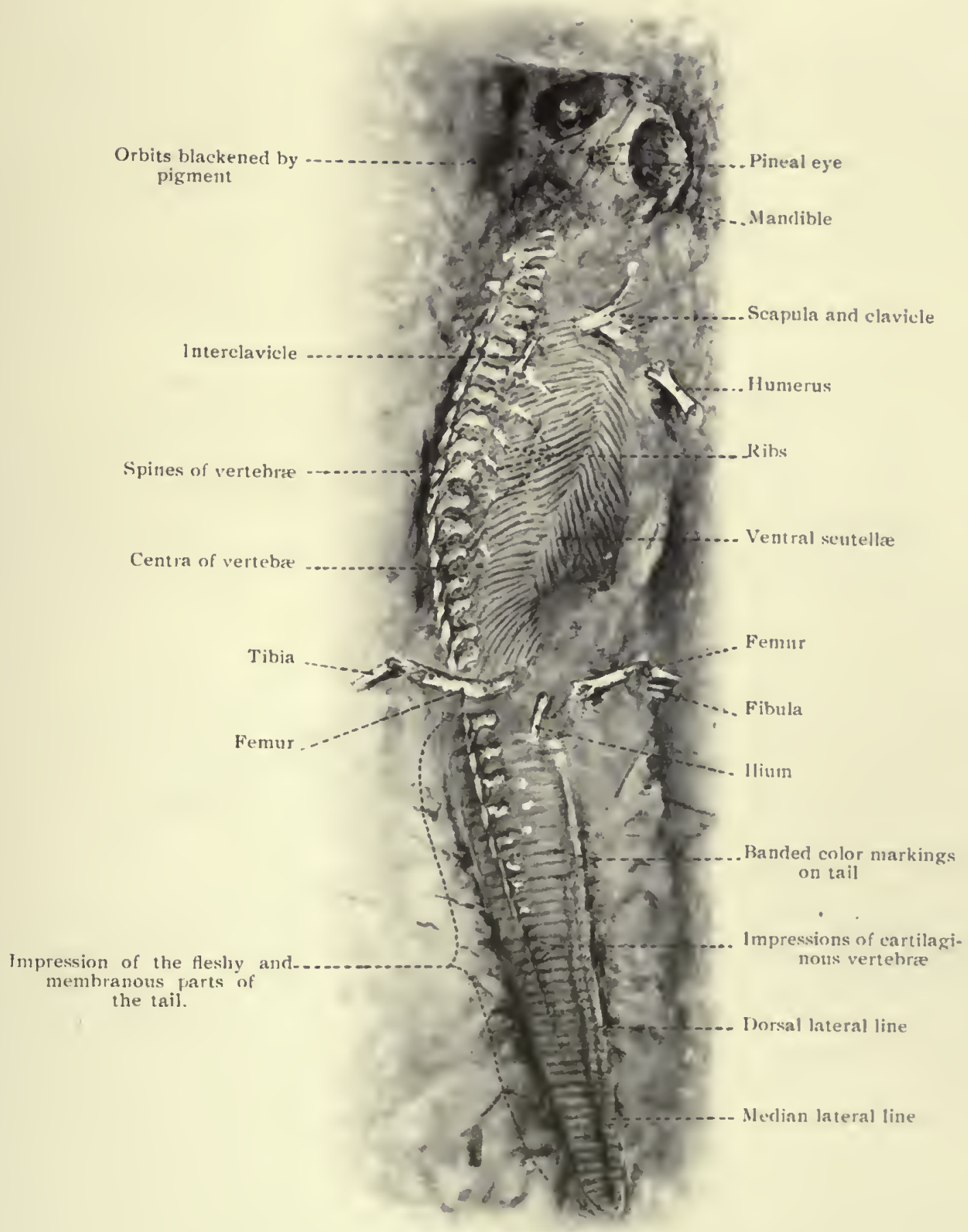

Jrawing $\times 3.5$. of type specimen of Micrerpelon caudatum Moodie, from the Coal Measures of Mazon Creek, Illinois, showing skeletal elements, form of head and tail, the lateral-line sense organs, banded colormarkings, and ventral scutella. On the elges of the tail impression are indications that in life the tail had a thin fold of skin above and below the fleshy portion, much as in the larva of Amblystoma at the present day. 

rise to the modern salamanders. The parts preserved in the specimen are: the complete outline of the head with most of the cranial elements clearly distinguishable, as well as the black pigment of the choroid; the entire vertebral column, including pits in the tail region, where the vertebræ were without doubt entirely cartilaginous; parts of the pectoral girdle; the ilium; the left humerus; the ventral scutellation; the ribs of one side of the body and indications of ribs on the other; portions of both hind limbs; and a complete impression of the fleshy tail. On this impression of the tail are preserved small, horny scales, transverse color-markings, and the distinct impressions of the lateral-line system.

The bones of Micrerpeton caudatum, as in so many of the fossils from this locality, have been replaced by a white, friable mineral which is probably kaolin. The animal is preserved on its back and it is thus illustrated from the ventral side. The entire length of the animal is only $49 \mathrm{~mm}$., of which the tail occupies nearly half.

The head has much the same shape as in the species of Branchiosaurus described and figured by Fritsch (25I), Credner (18I), and Theyenin (568). The eyes occupy relatively the same position as in that genus. The orbits are very large and broadly

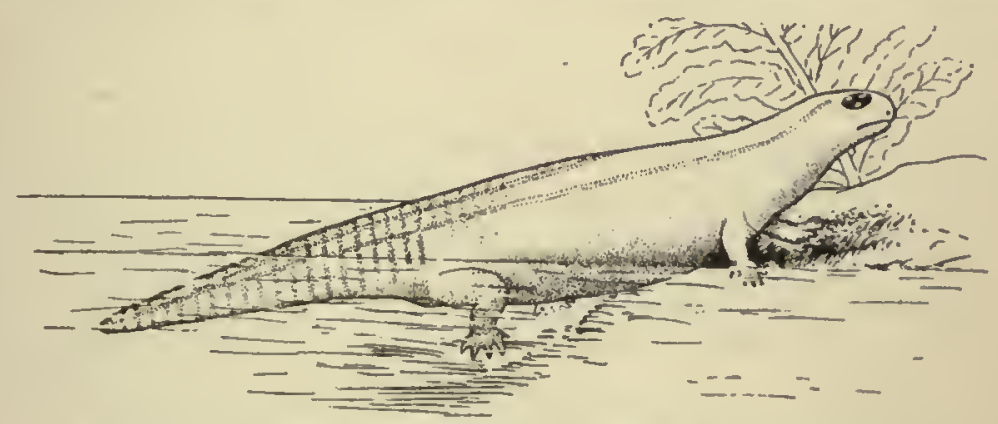

FIG. 13.- Restoration of Micrerpelon caudalum, a branchiosaur from the Coal Measures of Illinois. $\times 2$.

oval. Within the borders of the rim the stone is blackened as though by the black pigment of the iris, such as Cope has described in Amphibamus. Under a rather high power of magnification the cranial bones are seen to be represented by mere flakes of white mineral matter. The sutures separating the cranial elements are distinctly preserved on the main half of the nodule.

The openings of the skull are five-the two orbits, the two minute nostrils, and the pineal foramen. A median suture separates the skull into halves and the pineal foramen lies slightly anterior to the posterior third of its length. The boundaries of the premaxillæ are not distinct, but they are very small elements and form the inner border of the nostrils, which are clearly indicated by bosses of stone. The nasal element is nearly square and lies anterior to the frontal, which it borders broadly. The parietal is about the same size as the frontal and it apparently forms a portion of the inner border of the orbit, although this is not assured. The parietal is elongate and unites posteriorly with the postparietal. The postparietal, with the tabulare and the squamosal, form the posterior boundary of the skull, and they are hence not unlike the same elements in other Stegocephala. The prefrontal forms the anterior border of the orbit. The lacrimal has not been detected. The maxilla 
is elongate and forms the antero-lateral border of the skull. The jugal forms an important element in the lateral border of the cranium and joins the quadratojugal posteriorly. The postfrontal is triangular and with the postorbital forms the posterior border of the orbit. Both of the elements are acuminate posteriorly, although the suture between them is indistinct, and they inclose between their posterior acuminations an anterior projection of the supratemporal. The squamosal has the usual relations and borders the supratemporal laterally. The latter element forms the quadrate angle of the cranium.

The entire length of the vertebral column is preserved, although the nature and structure of its elements can not be determined. The impressions of a few of the vertebræ show that some of the centra were amphicœlous, but other than this nothing is definite. The cavities which the centra oceupied were filled by the white mineral matter and the force of the blow which cracked the nodule destroyed the form of the mold. It is possible that where the mineral matter has filled the cavities the centra were osseous or partly cartilaginous, and where the cavities were unfilled the centra were entirely cartilaginous. The length of the vertebral column from the base of the skull to the last impression of a cartilaginous centrum is $33 \mathrm{~mm}$.

The number of centra between the sacral vertebra and the skull is 20 as they are preserved, but there may have been one more, the atlas. Fritsch has represented $2 \mathrm{I}$ in his restoration of Branchiosaurus salamandroides, and this is a further indication of an affinity between the two genera, although Credner has represented 26 presacral vertebræ in Branchiosaurus amblystomus. The presacral vertebræ are thus seen to vary within narrow limits, but the number of presacrals is near 20 , and this may be taken as typical. It is interesting to notice that in modern forms of the salamanders the presacral vertebræ number about 20. There is but a single sacral centrum in Micrerpeton. The sacral rib has not been detected, but it is restored after the condition found in Branchiosaurus. The right femur partially covers the sacral vertebra, and its structure can not be determined. I count impressions of $\mathrm{I} 7$ caudal centra, of which at least $\mathbf{2} 2$ may have been partially ossified. In the cervical region there are distinct impressions of transverse processes on at least 5 vertebræ, and this number is assigned to the neck, although it is by no means certain that this is the correct number. The neck was at least short, if we may judge from the position of the remains of the pectoral girdle. No cervical ribs are definitely determined. There is a short rib lying between the fifth and sixth vertebrx, but to which it belongs is uncertain.

There are impressions of Io ribs preserved on one side of the vertebral column and one on the other side. They are short, straight, and heavy, as are the same elements in Branchiosaurus. This character alone is sufficient to place Micrerpeton among the Branchiosauria, since no such ribs are known in other groups of the extinct amphibians. The ribs preserved lie next the seventh to the seventeenth vertebræ on the left side, and there is one on the right side which may belong to either the fifth or sixth vertebra. They are central in their attachment, and in this they agree well with the mode of rib attachment in the modern salamanders. All of the ribs are single-headed and are composed, for the most part, of perichondral tissue. 
The position of the ribs in the matrix inclined backwards, and, making a small angle with the vertebral column, is very suggestive of the condition in Branchiosaurus.

The pectoral girdle is represented by three distinct clements of the left side, which are identified as scapula, clavicle, and coracoid, following the nomenclature given by Woodward (63I), although Credner (I86) would name them otherwise. The scapula is represented by an ovoid fragment lying next to the vertebral column. The clavicle was probably spatulate, as in Melanerpeton, but the inner end of the clement is not visible. The coracoid is represented by its outer end only, and its inner pointed extremity is not visible. The interclavicle has not been detected.

The humerus lies somewhat to one side of the pectoral girdle, as if there had been a large amount of epiphyseal cartilage. Its position may be due to post-mortem shifting, but there is little other evidence of any movement after deposition. The humerus is a large, heavy bone in comparison with the rest of the skeleton. It is expanded at each end, and its ends show concavities, proving that the bone is formed principally of perichondral tissue, as would be expected from such an early Branchiosaurian. The endochondrium has not yet developed in this form, which is evidently adult. There is no other element of the arm present.

There is but a single element of the pelvis preserved, a slender elongate rod which is undoubtedly the ilium, since it has the usual position for that element and is much too large for a sacral rib. It has much the same shape as the ilium in the modern Salamandra, and is not expanded as is the ilium of Branchiosaurus. This element, like the humerus, seems to have been but a hollow cylinder of bone and undoubtedly had cartilaginous ends, as in the ilium of the recent Salamandra. The two femora are preserved nearly entire, the right one lying upon and partly obscuring the sacral vertebra. The femur is much more slender than is the humerus, with slightly expanded ends, and, like the humerus, shows the concavities at the ends, indicative of the perichondral character of the tissue composing it. There are two elements of the leg preserved more or less entire. The larger bone may represent the tibia and the smaller the fibula. They both present characters similar to those of the femur and humerus. They are simple rods of bone tapering at the distal end. The feet have been lost, though doubtless they were present at one time.

The ventral surface of the body, as in other members of the Branchiosauria, was covered and protected by a series of small scutes arranged in the regular chevron pattern. The form of the scutes and their number can not be determined. The lines which represent them are, however, distinet. Some of the seutes are missing and some of them are obscured by lying over the vertebral column. They are all somewhat shifted to the left. The lines are very small and close together. I count I 6 of them in a distance of $2 \mathrm{~mm}$. In length the longest line preserved is a little more than $4 \mathrm{~mm}$., measuring from the point of the chevron. The lines representing the scutes come to a point in a median ridge which is now represented by a line. The dermal scutes on the abdomen were probably the forerunners of the abdominal ribs of the reptiles (fig. 9).

The impression of the tail contains some of the most interesting features in the entire specimen. Scattered over it and in places laid in mosaic are impressions of 
small dermal seales, which may have covered the entire body. In form the scales are ovoid, being half as wide as long, and the markings on the scales partake of the nature of radiating lines, much after the pattern of the sculpturing of the cranial bones in the Microsauria. The scales are less than $0.5 \mathrm{~mm}$. in diameter and their character can only be ascertained under high magnification. Near the middle of the tail there are preserved distinct transverse bands of dark color, which are more or less evident throughout the entire tail impression, but they are elsewhere not so distinct as in the central region. The lines are evidently due to rows of pigmented seales, and in all probability the animal's body was transversely striped.

The most interesting and important single structure discovered on the specimen is the impression of the lateral-line system, which is clearly evident as two dark lines on the impression of the fleshy part of the tail. The sense-organs are represented by two longitudinal rows of pigmented scales, one beginning at the tip of the tail, the other taking its origin from the median line somewhat further forward. I am indebted to Dr. Katashi Takahashi for calling my attention to the similarity of this arrangement to that found in the recent Necturus. The arrangement and disposition of the lines containing the sense-organs is practically the same in the two forms. The median lateral line takes its origin from the extreme tip of the tail and is continued to the base, where the impression is broken. The dorsal lateral line has its origin rather abruptly from the median lateral line at a distance of $6 \mathrm{~mm}$. from the tip of the tail. The sense-organs were undoubtedly located beneath specialized pigmented scales on the surface, and to this pigment is due the preservation of the lines.

The fact that the arrangement of the sense-organs of Micrerpeton corresponds so exactly to the condition found in Necturus is of considerable interest. Necturus alone among the modern tailed Amphibia has the arrangement described for the lateral-line system of Micrerpeton. All other forms of the Caudata, as also the larval forms of the Salientia, have an arrangement of the lateral-line system which is perfectly distinct from that found in Necturus, although the basis of the same arrangement is found in all. In Amblystoma, for instance, the median lateral line is not present on the tail, and the dorsal line is incompletely developed. The close similarity of the arrangement of the systems of sense-organs in the two forms, Micrerpeton and Necturus, may be of genetic significance with regard to the latter form. The lateral-line sense-organs are of a very fundamental significance, and it is not at all improbable that the same arrangement of the lines has existed from the Carboniferous period or earlier. We know that such has been the case in a great many of the fishes. The ancestors of the modern Caudata must have originated somewhere in the basal Carboniferous or earlier periods, and, in the writer's opinion, the Branchiosauria represent the ancestral group of the Caudata. This suggestion is by no means new, since Baur and others have held the same view. This topic has been discussed at length elsewhere (459) by the writer.

The relations of the form Micrerpeton caudatum are readily determined. The number of the presacral vertebræ, the form and position of the ribs, the shape of the skull, the arrangement of the cranial elements, the structure of the pectoral girdie 
and the character of the ventral armature all clearly bespeak a close relationship with Branchiosuurus, Melanerpeton, Pelosaurus, and other European branchiosaurian forms from the Upper Carboniferous and Lower Permian.

The above-described species, with others given below, is the earliest geological evidence of the Branchiosauria, since the oldest European forms are from the Stephanian (Upper Carboniferous), which probably lies somewhat above the horizon of the Allegheny series of North America. The presence of the Branchiosauria in America is of considerable interest in the bearing it has on the distribution and migration of the Paleozoic animals. Knowledge of how the group came to occur in such widely separated localities in approximately contemporary geological strata is an unsolved problem of paleontology. It is possible that the piscian ancestors of the Amphibia migrated across or along the borders of the seas and began the amphibian phase of development independently in the two continents. That evolution should, in this case, have followed almost exactly parallel lines seems incredible.

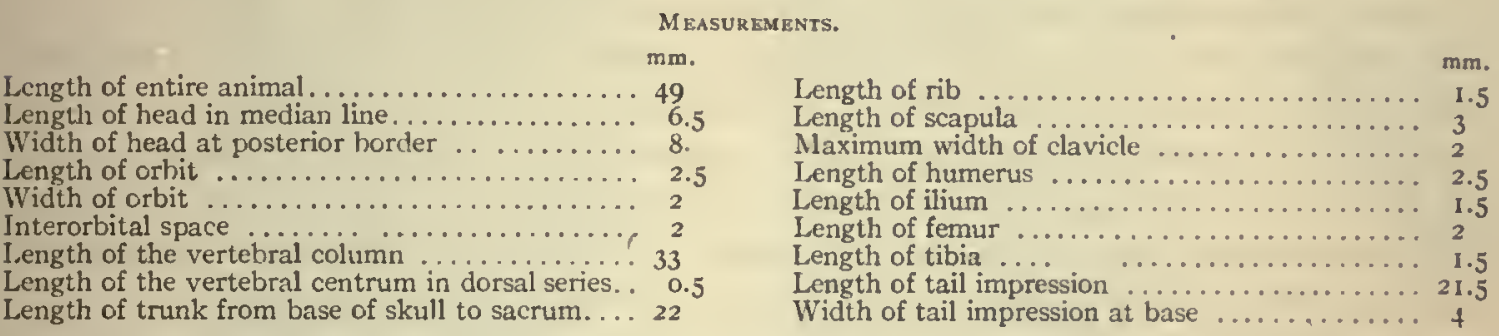

Genus EUMICRERPETON Moodie.

Moodre, Kans. Univ. Sci. Bull., vi, No. 2, p. 330, 1912.

Type: Eumicrerpeton parvnm Moodie.

The genus is established on three well-preserved specimens representing nearly the entire anatomy. The generic characters are found in the very broad posterior table of the skull, with its short length, reduction of tympanic notch, and shortness of body. The body-length of Eumicrerpeton (plate 5, fig. I) is less proportionately than that of other closely allied genera. Other generic characters are found in the sharp postero-lateral angle of the skull, and it is to be distinguished from Micrerpeton, especially, by the short, stumpy limb bones. The narrow, clongate eye, placed close to the edge of the skull, is a character not observed hitherto in the Branchiosauria. The genus is closely allied to Branchiosaurns of Europe.

\section{Eumicrerpeton parvum Moodie.}

Moodie, Proc. U.S. Nat. Mus., 40, p. 430, fig. I, I9II.

Moodie, Kans. Univ. Sci. Bull., vi, No. 2, pp. $331-336$, pl. 3, figs. 3 and 4 ; pl. 4 ; pl. 5, fig. 1 ; pl. 6, figs. 1 and 2,1912 .

Mood1E, Ámer. Nat., 44, pp. 367-375, figs. I-4, 1910.

Moodie, Science, n. S., XXXI, No. 789, p. 233.

Type: Specimen No. 803, Yale University Museum. Other specimens, No. 802, Yale University Museum, and No. 4400, U. S. National Museum.

Horizon and locality: Mazon Creek shales, near Morris, Illinois.

The impression of the outline of the entire body is preserved (plate 3 , figs. I and 2) in three specimens, and in all are found molds and impressions of the alimentary 
canal, which, in one specimen (47I), are remarkably complete and instructive. The three specimens will be discussed separately, since they show different features.

The impression of the larger animal (No. 803, Yale University Museum), which is probably an adult, presents the following elements: the entire skull, both humeri, impressions of posterior and anterior ventral armature, portions of the alimentary canal, one femur, portions of a fibula and tibia, and the entire impression of the tail, on which, as in Micrerpeton caudatum, there occur two definite dark lines, one beginning at the tip of the tail and running obliquely along the tail to where the impression is broken at the anal region; the other beginning at a distance of $4.5 \mathrm{~mm}$. from the tip and running almost parallel with the median line. These two lines undoubtedly represent the lateral-line system.

The skull is especially noted for its shortness and the great posterior width, as well as for the almost entire absence of the tympanic notch. The pineal foramen is located on a line with the posterior border of the orbits. The eyes themselves are narrow and acuminate at each end, with a pronounced convexity inwards and a flattening on the outer margin. They are located on the very border of the skull, but relatively more posterior than in Micrerpeton. No sclerotic plates are evident. The median suture can be indistinctly observed running the entire length of the skull. The sutures bounding the outside of the frontals and the squamosals are partially evident, but not satisfactorily preserved. The mandible is represented by a mold which in wax impression shows short, stumpy teeth.

Postcrior to the skull at a distance of a millimeter there are two sharp impressions which may represent the anterior edges of the interclavicle or they may be branchial elements. They are distinctly curved, however, and probably represent portions of the interclavicle. A wax impression does not show a discrete structure, but the boundaries of some larger element. No other remains of the pectoral girdle can be discerned. The humeri are short and relatively thick. Wax impressions show them to have had truncate or slightly concave ends, thus indicating the absence or slight development of the endochondrium. No other elements of the arm are prescrved.

The impression of an elongate femur and the heads of the tibia and fibula of the left side are preserved.

The ventral armature is preserved in two small patches, and these show the chevron-shaped rods to have been very fine-much more delicate than in Micrerpeton.

The body impression is very instructive and interesting, both in showing the form of the body and because in it are preserved the larger portions of the alimentary canal. The form of the body can best be discerned by reference to the figures (plate 3 , figs. 1 and 2 ; plate 5 , fig. I).

The portions of the alimentary canal preserved consist of the greater portion of the stomach, three coils or loops of the small intestine, the rectum, and a pit which undoubtedly represents the anal opening. The anus is found at a distance of $16 \mathrm{~mm}$. from the tip of the tail and is somewhat removed from the body portion, as in modern salamanders. On each side of the posterior end of the rectum there occur a pair of enlargements which probably represent theoviducts at their posterior ends (fig. I5, C). 

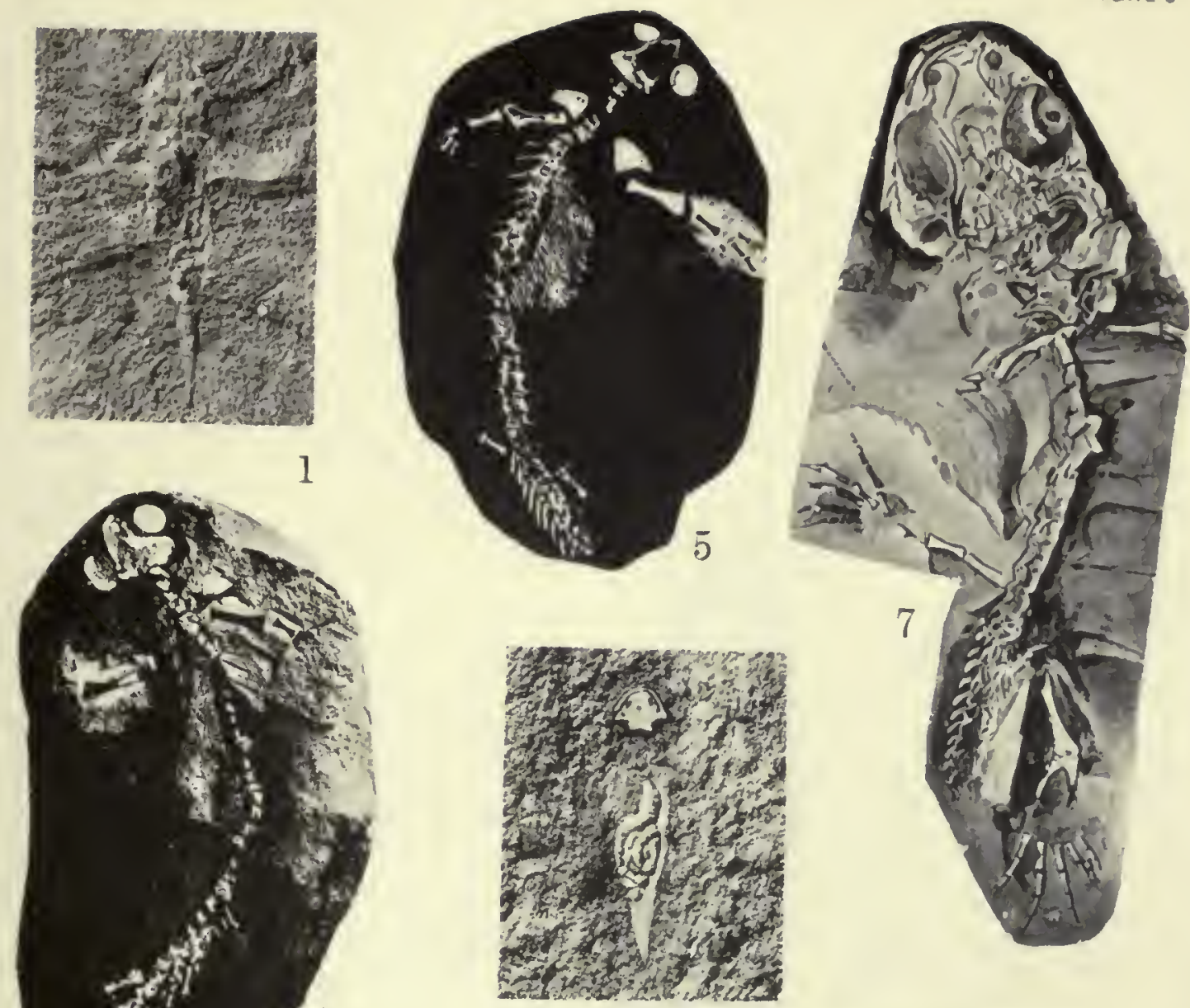

2
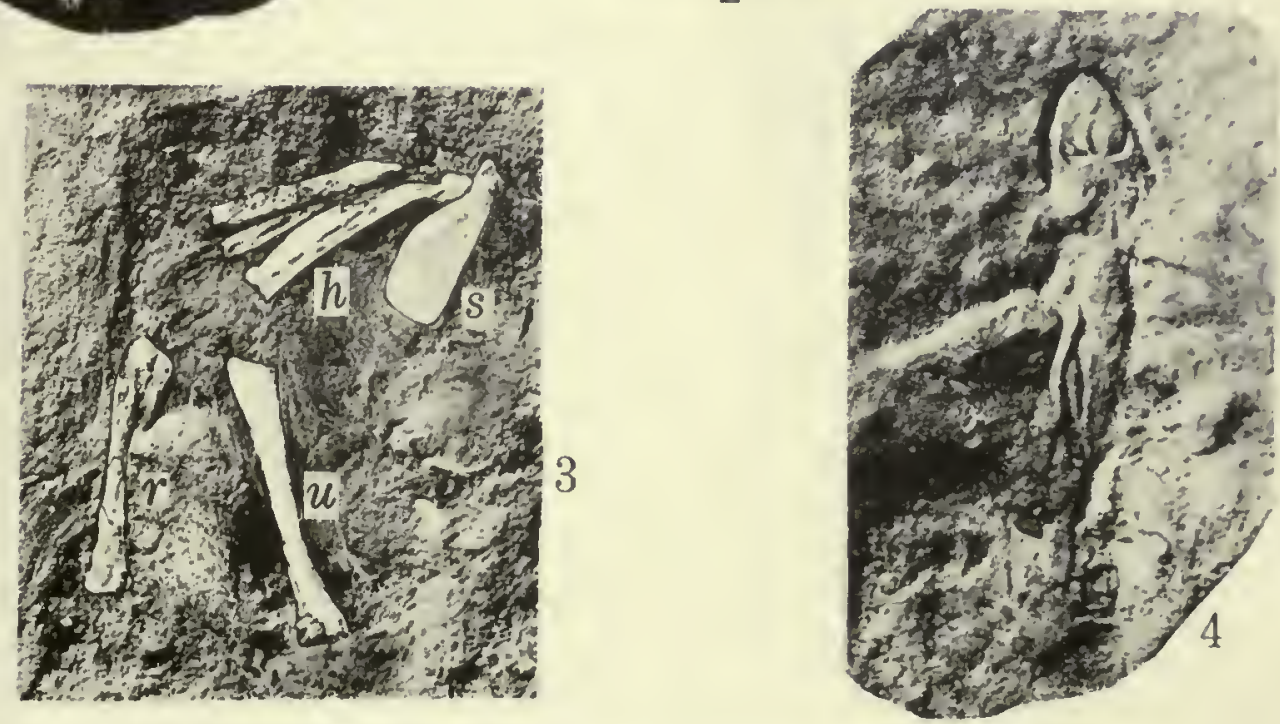

1. The larger specimen of Enmicrerpeton parzum Moodie. $\times 1$.

2. The smaller specimen of Eumicrerpeton parvm Moodie. $\times 1$.

3. Type specimen of Erpetobrachium mazonensis Mloodie. $\times 1$.

4. Type specimen of Erierpeton branchiatis . Noodie. $\times 1$.

5 and 6. Type specimen of Mazonerpeton longicaudatmm Moodie. $\times 1$.

7. A copy of Cope's drawing of the type specimen of Amphibamus granticeps Cope. The original was destroyed by fire. $\times 3$. 

The tail impression is more acuminate than in Micrerpeton, but shows the same structures as in that form, i.e., the lateral lines which have already been mentioned. Micrerpeton was a more rapid swimmer than the present form on account of the greater development of the tail.

The second specimen of the species (No. So2, Yale Museum) shows much the same character as the specimen already described, except that there are impressions of small, blunt teeth on the mandible. The two humeri and the femur of the left side are preserved and the interclavicle is represented by an identical impression, as in the first-described specimen. The tail impression, though similar in form, does not exhibit so much of the structure of the lateral lines (fig. 15, B).

The matter of especial interest in connection with this second specimen is the remarkably perfect preservation of the alimentary canal, which is entire, except for the very anterior end of the oesophagus. The posterior portion of the aesophagus, which measures $3.5 \mathrm{~mm}$., is clearly preserved. Its anterior end is thrown around posteriorly and indicates that this end was loosened after death and became displaced before fossilization. The length preserved may represent the entire œsophagus. The œsophagus is constricted before it enters the stomach, which shows the usual curvature found in modern salamanders. The stomach measures $6 \mathrm{~mm}$. in length by $2 \mathrm{~mm}$. in breadth, and consists of a single enlargement as in the modern Amblystoma punctalum. It increases in size somewhat toward the pyloric end and then very gradually constricts to the pylorus. Three divisions of the small intestine can be seen. The most anterior one, corresponding to the duodenum, is segmented, as though the intestine had been filled with food before interment. The remainder of the intestine, corresponding to the ileum, is looped in the form of two figures 8 which are superimposed, with the upper portions of the 8 at right angles to each other. The rec-

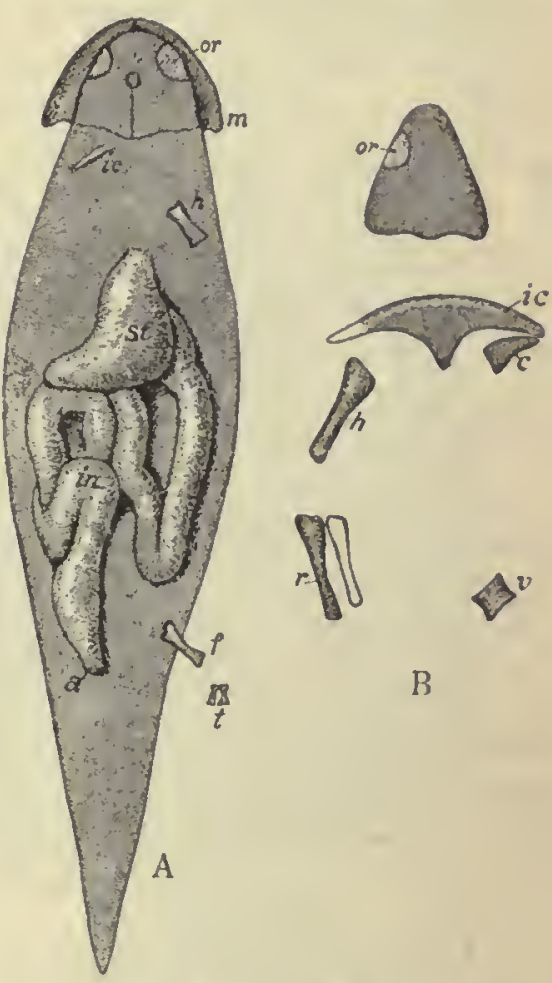

F1G. I4.-Mazon Creek Amphibia.

A. Third specimen of Eumicrerpelan parvum Moodie, which exhibits the alimentary canal well preserved. $\times 2$. Original in United States National Museum. $a$, anus; $f$ femur; $h$, humerus; $i c$, interclavicle; in, intestine; $m$, mandible; or orbit; st, stomach; $t$, tibia and fibula.

B. Type specimen of Amplibamus thoracalus Moodie. Original in U. S. National Museum. $\times 2$. (For description sec p. 132.) tum is clearly discernible, though its lower portion is somewhat obscured by having the lower part of the upper loop of the intestine lying over it. The anus lies at a distance of $1.5 \mathrm{~mm}$. posterior to the transverse line from the upper end of the femur, and is quite well back on the tail, as in modern salamanders. In this specimen also occur two oval bodies which may be identified as the lower ends of the oviducts, thus indicating, in all probability, that the animal was a female.

A dissection of several species of modern caudates has resulted in the discovery that the adult condition of the alimentary canal of all the species dissected $(A \mathrm{mb} / \mathrm{y}$ - 
stoma punctatum, Necturus maculosus, Diemyctylus torosus, D. viridescens, etc.) is much more complex than that exhibited by the specimen under discussion. A very near approach to the condition found in Eumicrerpeton parvum is found in an immature branchiate individual of Diemyctylus torosus, $56 \mathrm{~mm}$. in length, from a freshwater pond on Mount Constitution, on Orcas Island, Puget Sound, Washington.

The similarity of the intestinal structure is of considerable importance to our understanding of the relationship existing between the Carboniferous Branchiosauria and the modern Caudata, and only coinfirms other arguments, offered in another place (459), concerning their immediate relationship.

The branchiosaurian affinities of the present species are almost too evident to need discussion. The entire structure is essentially similar to that of other genera of the order.

The third specimen of this species (No. 4400 of the U. S. National Museum) is almost as perfectly preserved as were the other two specimens. The skull structure, the intermediate position of the pineal foramen, the epiotic notch, and the shape of the skull are essentially similar to the described specimens of the species. The present specimen is more developed than the other two and probably represents an adult. The alimentary canal is perfectly preserved.

It is nearly half again as long as the smallest of the above-described specimens, and the skull is proportionately longer and wider. There is preserved also an impression of the anterior ends of both clavicles. The right humerus is imperfectly preserved, as is also the right femur and tibia; other than these the fossil is merely an impression.

The skull is so similar to those described above that additional description is unnecessary. The pineal foramen is quite large and lies on a line which cuts the orbits into equal longitudinal parts. The interorbital space is about equal to the long diameter of the orbit. 'Traces of sclerotic plates are observed in the left orbit, but they are quite imperfect.

The alimentary canal (fig. I $4 a$ ) is unlike the previously described structures, in that the intestine is longer and more convoluted. It lies in five longitudinal folds and ends in an enlarged cloaca, near which there are impressions of two glands, or the posterior ends of the oviducts, as was suggested for the Yale specimens. The creatures undoubtedly fed on small plants and animals much as do the recent salamanders.

Measurements of Eumicrerpeton parvum Moodie.

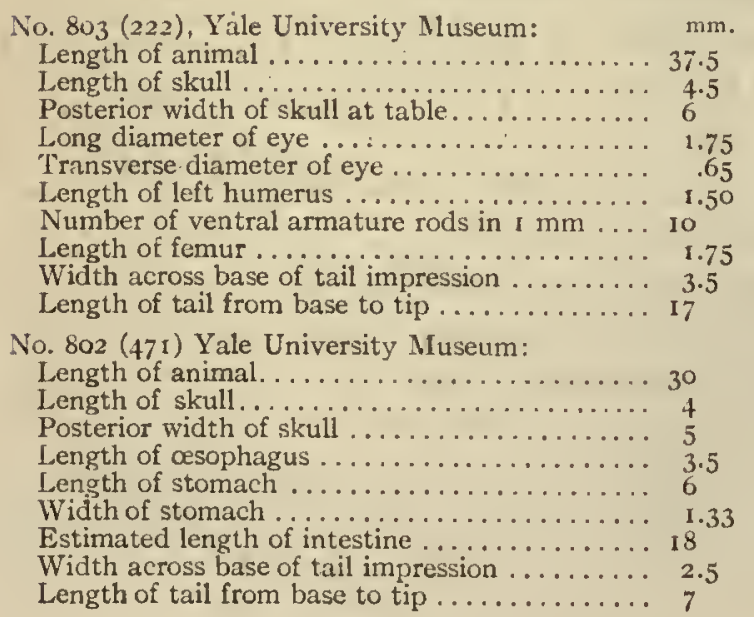

No. 4400, U. S. National Museum: $\mathrm{mm}$. Leng th of entire animal ................ 45

6

Width of skull .................... 9

Transverse diameter of orbit . . . . . . . . .

Long diameter of orbit.............. 2.25

Interorbital space $\ldots \ldots \ldots \ldots \ldots \ldots \ldots \ldots .2 .50$

Diameter of pineal foramen $\ldots \ldots \ldots \ldots \ldots . .5 \%$

Length of body from back of skull to pelvis ...222

Greatest width of body ................ 9

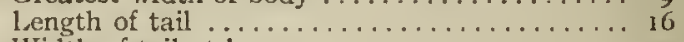

Wirth of tail at base ................ 5

Length of humerus .................. 3

Length of femur ..................... 2.50

Length of tibia (fibula?) ............... I.75

length of stomach ............... 7

Width of stomach $\ldots \ldots \ldots \ldots \ldots \ldots \ldots \ldots \ldots, 3$

Length of intestine (estimated) $\ldots \ldots \ldots \ldots \ldots \ldots \ldots, \quad 5.6$

Widtl of intestine................ 1 

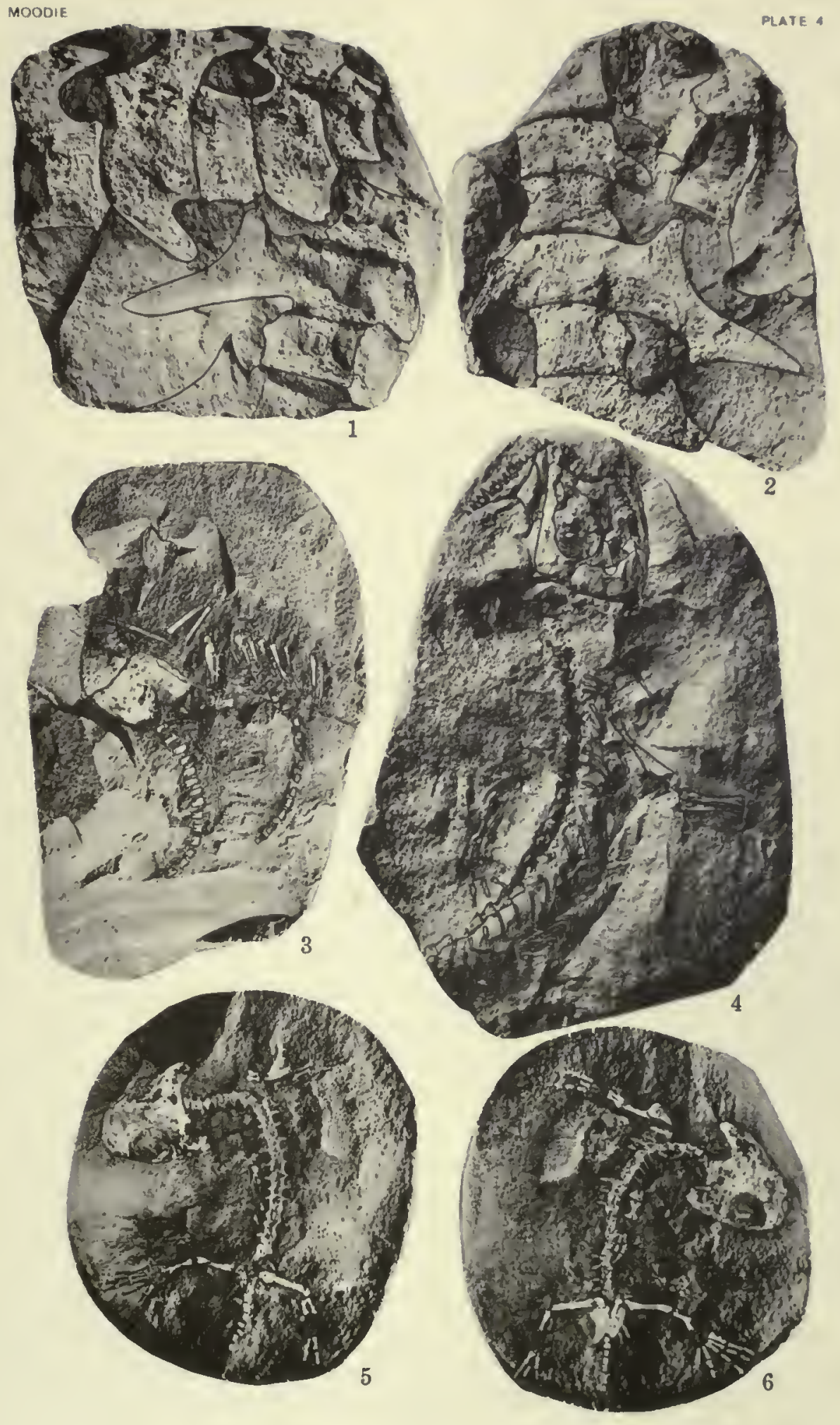

1 and 2. Vertebre of Spondyterpeton spinatum Noodie. $\times 1$.

3. Type specimen of Mazonerpeton costalum Moodie. $\times 1$.

4. Type skeleton of Cephaterpeton aentriarmatum Moodie. $\times 0.9$.

5 and 6 . The halves of the nodule containing a practically complete skeleton of Amphibamus grandiceps Cope. $\times 1$.

Originals of above figures in the Vale University Museum. 

Genus MAZONERPETON Moodie.

Moodı, Kans. Unir. Sci. Bull., vol. vi, No. 2, p. 336, 1912.

Type: M. longicaudalum Moodie.

The genus is distinguished from other known branchiosaurian genera by the great length of the dorsal region, the elongate tail (plate 5, fig. 2), with its welldeveloped caudal ribs, the reduction of the tympanic notch, the broad nature of the scapula, the elongate interclavicle, and the slender ilium. The number of dorsal vertebræ is identical with that of Branchiosaurus of Saxony.

\section{Mazonerpeton longicaudatum Moodie.}

Kans. Univ. Sci. Bull., vı, No. 2, p. 337, pl. 3, figs. 1-2; pl. 7, fig. 3; pl. 10. 19г2.

Type: Specimen No. 795 (I234), Yale University Museum.

Horizon and locality: Mazon Creek shales, near Morris, Illinois. (Plate 3, figs. 5 and 6.$)$

The remains consist of the following elements: an incomplete skull; nearly the entire vertebral column, consisting of cervical, dorsal, sacral, and caudal vertebra, 36 in number; several ribs preserved on each side of the vertebral column; a portion of the ventral armature; the scapulx; a clavicle; the interclavicle; both humeri; the radius and ulna of one side and the ulna of the other; portions of both hands; the ilium of the right side; both femora, and a partial impression of the left tibia.

The skull is, unfortunately, very poorly preserved. Enough remains, however, to determine the essential characters. The skull bones, unlike any other American branchiosaurian, have an ornamentation consisting of sharp pits and elevations which in places have a quincuncial arrangement and in others take the form of definite lines of pits or tubercles similar to the condition found in many of the Microsauria. The orbits are large and are situated back of the median transterse line of the skull. They are almost circular in form and contain 6 elongated sclerotic plates very closely arranged around the borders of the right orbit. The plates are twice as long as wide. The interorbital width is 1.25 times the transverse diameter of the orbit.

Not many of the sutures of the skull are discernible. Portions of the frontals, the nasals, the prefrontals, the parietals, and the supratemporals can be identified. Their arrangement is shown in figure I $4 a$. There is a decided posterior table to the skull, with truncate posterior border. The tympanic notch is shallow, with its outer border not so well protected as in Branchiosanrus.

The cervical vertebræ are incomplete, but their number was 4 or 5 , as in Micrerpeton. The structure of the dorsal vcrtebræ is also uncertain, although the shape can be discerned. The vertebræ are short and thick, very unlike the long, cylindrical vertebræ of Cephalerpeton. The heavy transverse process is quite evident on the best preserved vertebre. This process recalls that described by Credner for the Saxony Branchiosauria. Several of the vertebrie show the articulation of the ribs with this process. The ribs of the caudal region recall very strongly those of Branchiosaurus. They are quite heavy in the anterior caudal region and then diminish rather rapidly to the point where the tail is broken and lost. 
The ventral armature is represented by a patch of chevron rods $21 \mathrm{~mm}$. in length. The rods take a very peculiar form, being short crescentic bundles of fine rods, hair-like in appearance. In one of these bundles I count 5 smaller rods. The bundles are arranged in rows similar to the pattern so characteristic of the Carboniferous Amphibia, as described elsewhere. The patch of ventral armature preserved belongs to the abdominal region. A single row of the crescentic bundles measures II $\mathrm{mm}$.

Both scapulæ are preserved in their entire form. They are quite different from those of any other genus, being broadly crescentic with a posterior concavity and an anterior protuberance. The anterior surface of both scapulæ is obscured. Vascular foramina occur near the base of both scapula; there being three of them in the right scapula, arranged in the form of an isosceles triangle. The morphology of these foramina is uncertain. They have never been observed among the Carboniferous Amphibia, and, so far as I am aware, they are entirely unknown among higher vertebrates.

The temnospondylous Amphibia of the Carboniferous and Permian possess, in the co-ossified scapula-coracoid, three foramina, very similar to the oncs in the present form, but they are confined to the coracoidal region and, in the Branchiosauria, as identified by Credner, the coracoid is a free element, although I have never been sure of its identity among American forms. Williston has called these foramina the glenoid, the supraglenoid, and the supracoracoid foramina (Journal Geology, xVII, No. 7). They are not, however, to be correlated with the three foramina above mentioned, since in the Temnospon-

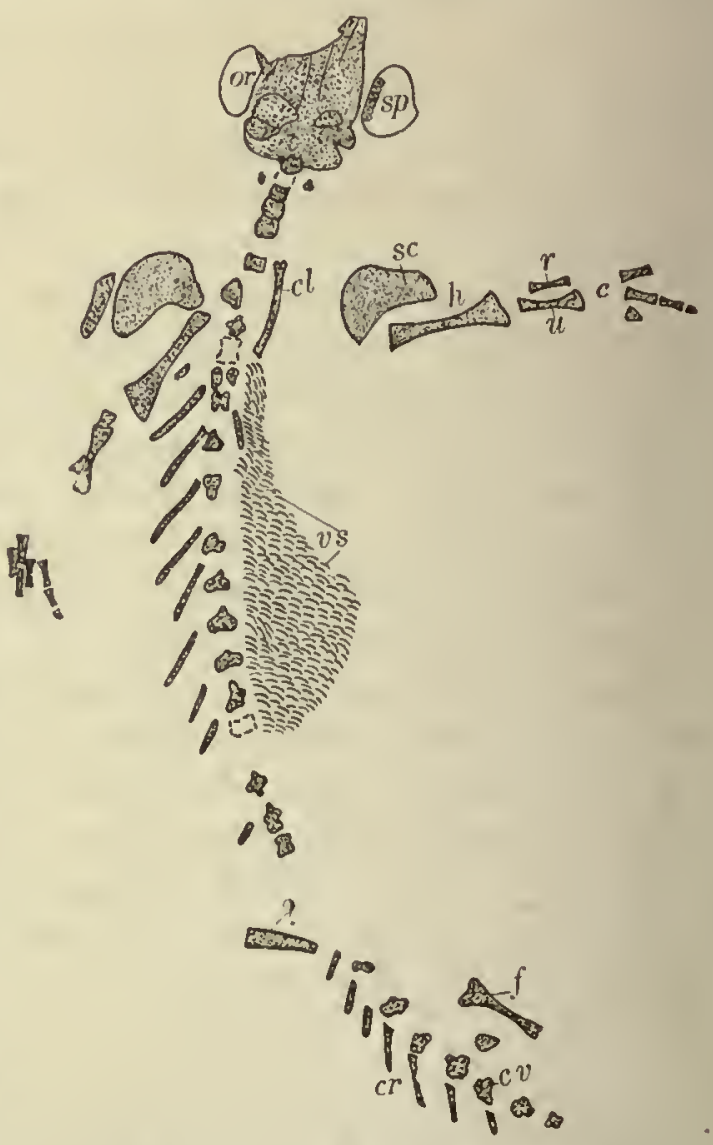

FIG. 14a.-Skcleton of Mazonerpeton longicandatum Moodie. $c$, carpus; $c l$, clavicle; $c r$, caudal ribs; $c v$, caudal vertebre; h, humerus; $f$, fenutr; or, orbit; $r$, radius; $s p$, selerotic plates; sc, scapula; $u$, ulna; vs, ventral scutelle. From Mazon Creek. Original in Yale University MI useum.

dylia the foramina belong with the coracoid and not with the scapula. The condition of the Temnospondylia occurs in the bony fish Xiphactinus audax Leidy, and an analogous condition obtains in the reptiles, as in the Mosasaurs and Dinosaurs.

Near the outer edge of the right scapula there is a large fragment preserved, which, I think, must be the misplaced clavicle. It is obscurely triangular or, more exactly, spatulate. The interclavicle is represented by fragments only, and seems to have had a narrow form. 
The humeri recall those of Micrerpeton. They are somewhat elongate and apparently cylindrical in their normal condition, although somewhat flattened in the fossil. The shaft is considerably constricted at the middle and the ends are expanded, in which expansion the lower end exceeds. The ends are abruptly truncate, indicating a small amount of endochondral ossification or its entire absence.

The mesopodial clements, unlike what is described for Cephalerpeton, are quite dissimilar in form, recalling the condition in Mesosanrus brasiliensis McGregor. The larger element is, apparently, the ulna. It has the lower end greatly expanded and the shaft is curved outward, resembling very much a reptilian ulna. The radius is much smaller than the ulna, lacks the lower expansion, and is shorter by $\mathbf{I} \mathrm{mm}$.

The carpus is represented merely by a blank space, with evidences of impressions of cartilage in the sandstone. The hand of the right side contains 4 phalanges. There are 2 phalanges preserved in the first digit, including a sharp-pointed terminal phalanx, and the second digit has only the metacarpal. The third has the metacarpal and the first phalanx, which does not differ in form, but only in size, from the metacarpal. The fourth digit contains only the metacarpal. Of the left hand there are portions of 3 digits preserved, including 3 metacarpals and a phalanx, which in structure are not different from those of the right hand.

The ilium of the left side is preserved, apparently entire. It is elongate and cylindrical, its upper end adjoining the twenty-eighth vertebra. The head of the femur lies close to the lower end of the ilium, so that that clement must have been suspended in the flesh, much as in modern salamanders. It could not have been of much uise as a support for the body. The form of the femur is not unlike that described for the humerus, save that its lower end is smaller than the upper, while in the humerus the extremities are of equal diameter. A portion of the right femur is preserved, extending in an opposite direction to the left.

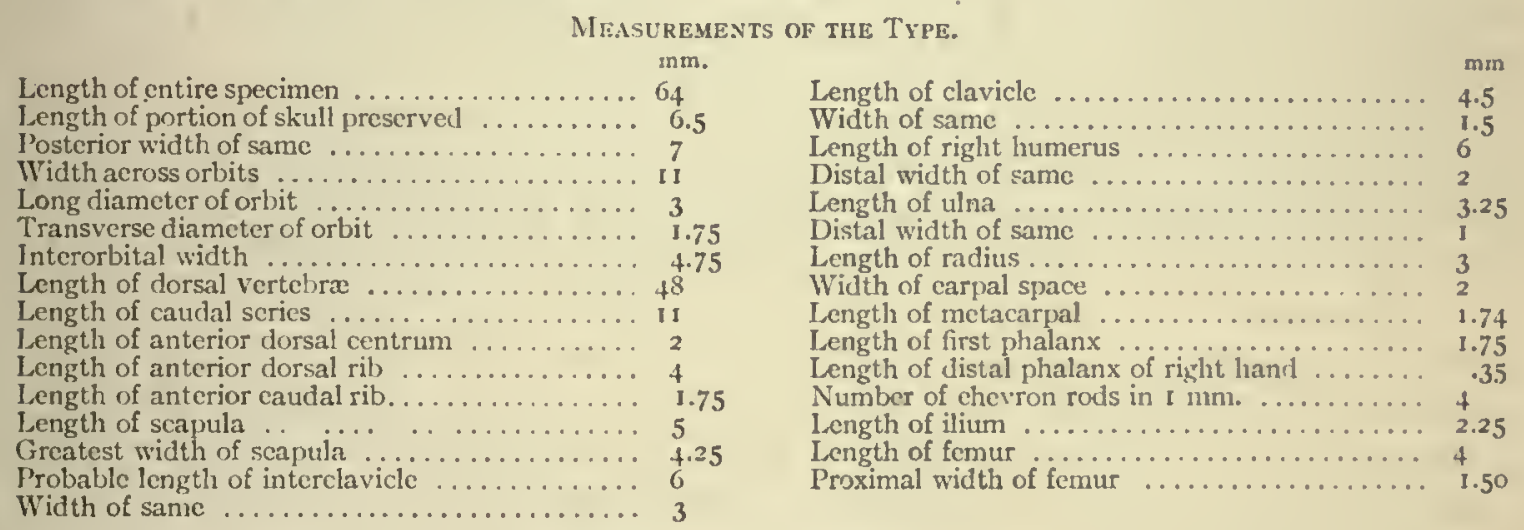

Mazonerpeton costatum Moodie.

Moodıe, Kans. Univ. Sci. Bull., vi, No. 2, p. 341, pl. 2, fig. 3; pl. 8, fig. 4; pl. 9, fig. 2; pl. 10.1912.

The remains on which the present species is based are inclosed in a much fractured nodule. The parts of the animal which have been identified are: a part of the skull and left mandible, two clavicles, a humerus, impressions of several vertebre, a portion of the dorsal region of the body with several ribs, two portions of the caudal region with several ribs and unidentified fragments. (Plate 4 , fig. 3.) 
The animal, from the shape and form of the ribs, is undoubtedly a branchiosaurian, since short, heavy, straight ribs have not yet been found to be associated with other than branchiosaurian structures. It is placed in the genus Mazonerpeton on account of the structure of the pectoral elements, the form of the humerus, and the length of the tail, all of which agrce in structure with Mazonerpeton longicaudatum. The animal attained, perhaps, a length of 4.5 inches, while that of $M$. longicaudatum was about 3 inches. The tail in the present species is very long and slender, more elongate than in any other known branchiosaurian.

The part of the skull preserved is very unsatisfactory and, aside from the fact that it seems to represent the under side of the left half of the skull, little can be said. Three sutures can be observed, but what sutures they are is undetermined. The left mandible lies crushed on the edge of the skull and partially obscures what little there is of that structure. The slightly curved impression, from which the bone has been either broken or weathered, measures 13 $\mathrm{mm}$. in length by $3 \mathrm{~mm}$. in posterior diameter by $\mathbf{I} \mathrm{mm}$. in anterior diameter. These measurements show the element to have bcen slender and pointed anteriorly.

Very little accurate information can be derived from the study of the vertebral column of the specimen, nor can the dorsal vertebral formula be made out, since only a portion of the length of that region is preserved and only a few rather indefinite impressions can be discerned. These impressions show the vertebræ to be short and higher than in most Branchiosauria.

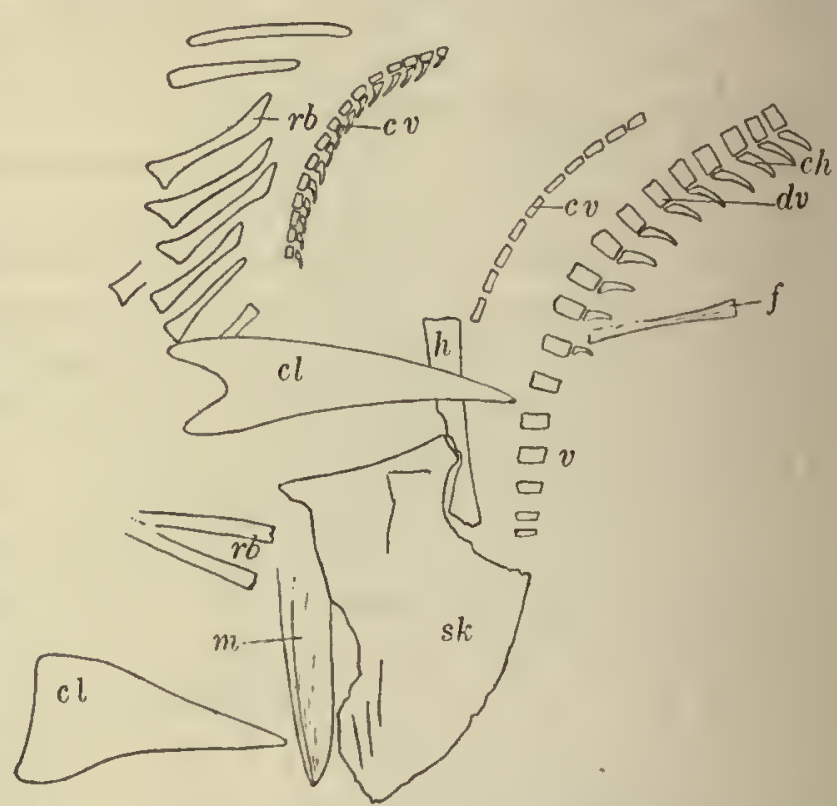

Fig. 14b.-Skeleton of Mazonerpeton costalum Moodie. X 1.5 . Original in Yale University Museum. $d v$, dorsal vertebræ; $c h$, neutral spines; $c l$, clavicle; $c v$, caudal vertebræ; $f$, femur: $h$, humerus; $m$, mandible; $r b$, rib; $s k$, skull; $v$, vertebra.

The caudal series is represented by two sections, one of which is, apparently, from near the base of the tail, judging from the size of the caudal ribs preserved; the other is from near the tip of the tail, and shows the constituents to have been long and slender. Ribs are apparently absent on this section. The position of the two caudal sections shows that when the animal died it was coiled up much like a snake, so that in the fractured nodule three sections of the body are visible. The tail was probably half as long again as the body.

The ribs throughout the body are short, heavy, and straight, with, in the dorsal series, a lateral and a distal expansion which is taken as a distinctive specific character. Judging from imperfect impressions in the dorsal series, the ribs were attached to a transverse process of the centrum, thus agreeing with other branchio- 

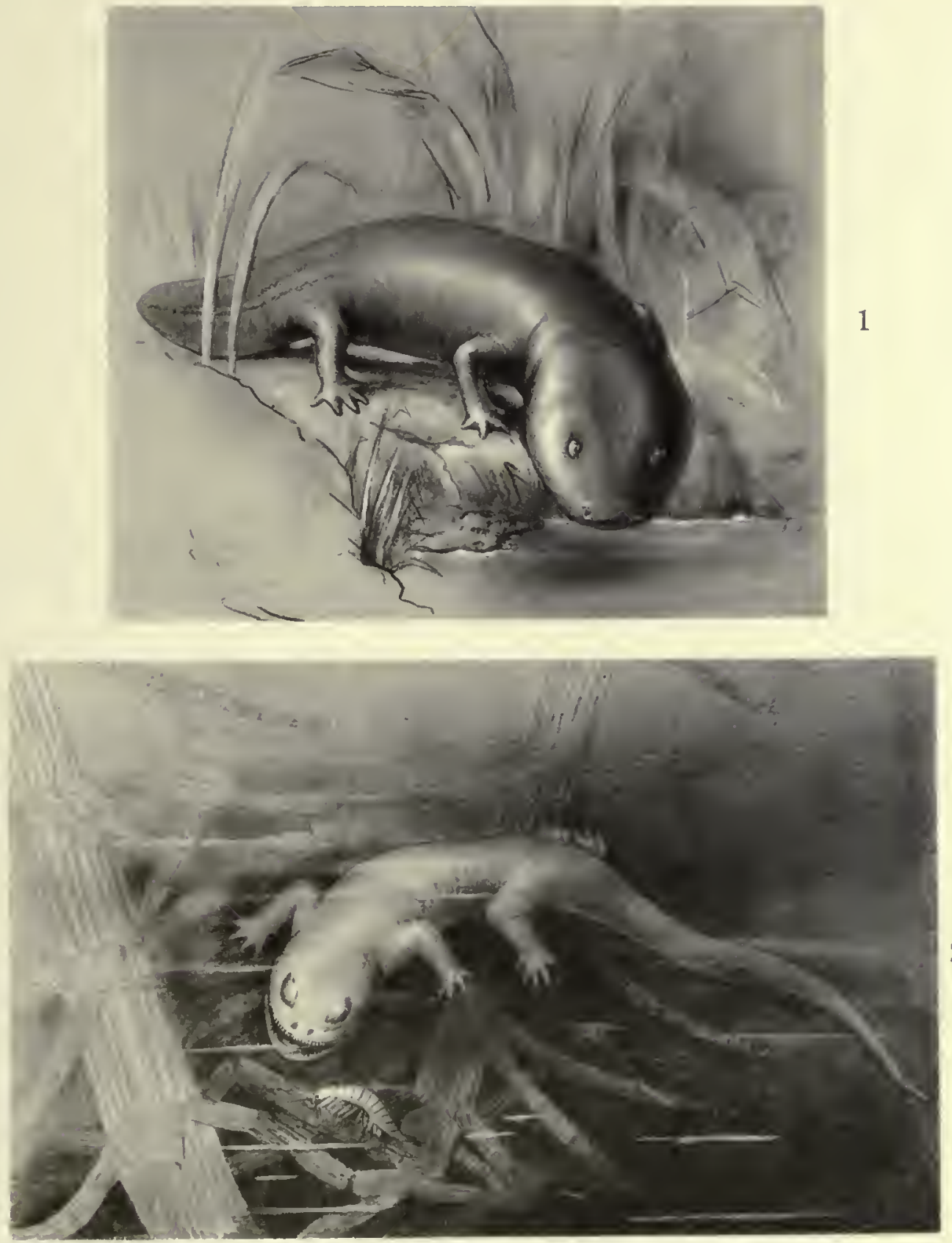

1. A reconstruction of the possible appearance in life of the Coal Measures branchiosaurian, Eumicrerpelon parvum Moodie, a small, primitive salamander, less than 2 inches in length, based on three specimens from the Mazon Creek Shales. The lateral-line organs are represented as dark bands on the tail, the sense organs being, apparently, situated beneath specialized pigmented scales, to which is due the preservation of the lines.

2. A restoration, natural size, of the branchiosaurian, Mazonerpelon, based on two specimens. The form of the animal is quite salamander-like. It is shown when about to feed on a specimen of Acanthotetson stimpsoni, which is said to be a brackish-water crustacean. The branchiosaur and crustacean may possibly have inhabited the same body of water. 

saurians in this respect. The ribs show a progressive decrease in length from the cervical region to the point of their disappearance on the tail.

The pectoral girdle is represented by two elcments, one of which is certainly the right clavicle, and the other is possibly the left clavicle, though its form is somewhat distorted by pressure. Both elements are in the form of an clongate spatula with the dorsal surface greatly concave and the inner end acuminate.

The right humerus is imperfectly preserved, though the impression allows one to gain an exact idea of its form. It lies under the right clavicle. Its ends are truncate with a contracted shaft and expanded extremities; the bone was apparently hollow.
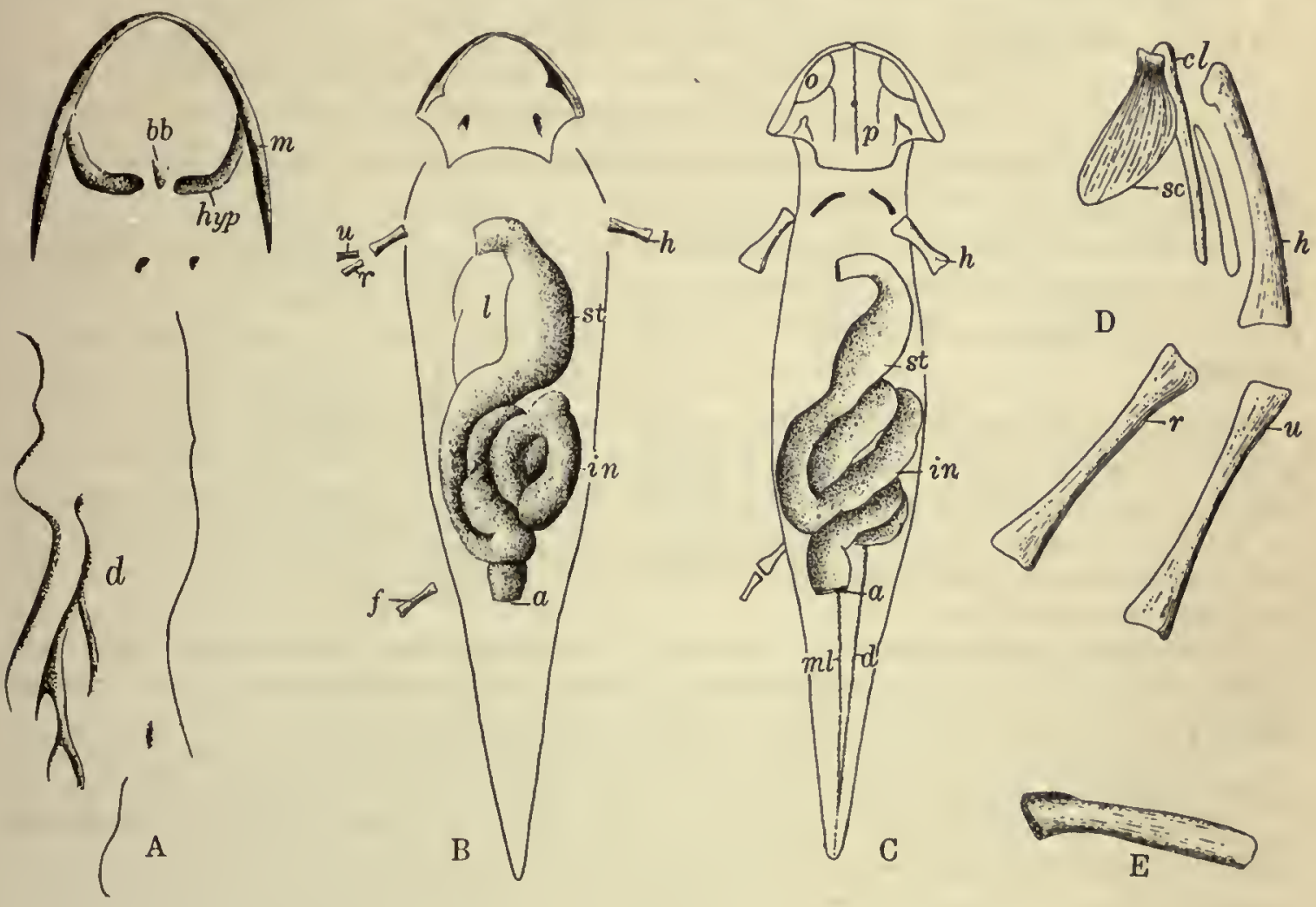

Fig. 15 .
A. Impression of Erierpeton branchialis MIoodie. $b b$, basibranchial; hyp, hypohyals; $m$, mandible; $d$, body impression. $\times 3$.
B. Eumicrerpeton paruum Moodie. $a$, anus; $f$, femur; $h$, humcrus; in, intestine; $l$, liver; st, stomach; $r$, radius; $u$, ulna. $\times 3.3$.
C. Larger specimen of Eunicrespeton parvum Moodie. $a$, anus; $d$, dorsal lateral line; $h$, humerus; in, intestine; $m l$, median lateral line; st, stomach. $\times 2.6$.
D. Skeleton of Erpetobrachium mazonensis Mloodic. $c l$, clavicle; $h$, humerus; $r$, radius; sc, scapula; $u$, ulna. $\times 2$.
E. Rib of Mazonerpeton coslatum Moodic. $\times 2.5$. Originals in the Yale University Muscum.

In another nodule (No. 804, Yale Museum) there is a single bone preserved which resembles, to a great extent, a rib of the present species (fig. I5, E), although somewhat larger, and it has been provisionally identified as such. The element is very slightly curved, but shows the expanded head of the rib of this species. 
Measurements of the Type or Mazonerpeton costatum Moodie.

No. 800 (777), Yale University Museum: $\mathrm{mm}$

Length of portion of skull preserved........ 14

Length of right clavicle............. 16

Width of right clavicle............. 4

Length of dorsal region represented.......... $3^{4}$

Length of cervical rib................ 8

Length of dorsal rib................ 6.5

Length of caudal rib.............. 3

Length of caudal portion of body preserved... 55 $\mathrm{mm}$.

Length of mandible................. I5

Greatest width...................... 6

Length of right humerus.................. 10

Greatest width of humerus............. 2

No. 804 (332), Yalc University Museum:

Length of rib...................... II

Width of head of rib....................

Diameter of shaft................. I

Sparodus sp. (?).

Dawson, Phil. Trans. Roy. Soc. London, pt. 11, p. 643 , pl. 40 , figs. 52 to $56,1882$.

Dawson, Proc. and Trans. Roy. Soc. Canada, Xil, p. 75, 1895.

Type: Specimen in the Peter Redpath Museum of McGill University.

Horizon and locality: Coal formation at the South Joggins, Nova Scotia.

The material on which the above determination is based was collected in 1878 by Sir J. W. Dawson in the coal formation at the South Joggins, Nova Scotia. Nothing has been collected since that date that would give additional information as to the nature of the form represented. I give here Dawson's description of the remains:

"In the coaly matter or mineral charcoal at the base of tree No. Io appeared a few fragments of an animal which may possibly belong to the above-named genus of Fritsch, though I am by no means certain of this identification or of the real nature of the animal.

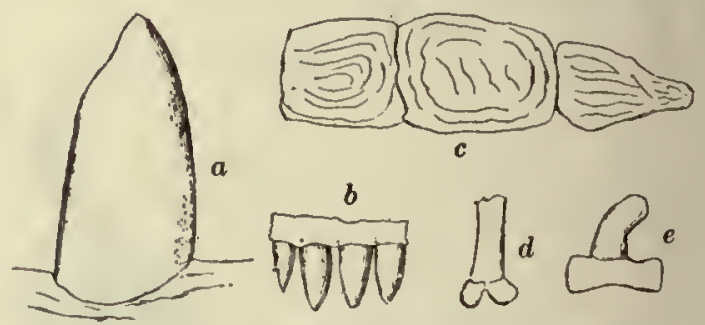

F1G. 15a.- Type material of Sparodus, consisting of $a$, a tooth $(\times 25) ; b$, four of the smaller teeth (in maxilla?) ( $\times 25) ; c$, three bony scales $(\times 5) ; d$, fragment of a limb bone $(X 2) ; e$, a vertebra $(X 2)$. (After Dawson.)

"The skull is represented by a fragment of a maxillary or intermaxillary bone, with blunt conical teeth. It is smooth or marked merely with microscopic dots. There is also a fragment which may be a palatal bone studded with minute teeth.

"A few vertebræ associated with the above bones are long and narrow, with large zygapophyses and long neural spines. Length of body (i.e., of the vertebra) about 3 millimeters.

"With these remains are a few bony scales different from those of any other species found in these trees, and more resembling scales of Ganoid Fishes. They are somewhat rectangular in form, enameled on the surface and beautifully sculptured with waving lines.

"In the same trunk were found some teeth and bones referable to Hylerpeton dawsoni, and it is not impossible that the remains above referred to may have belonged to some creature devoured by that animal, and which would not otherwise have obtained admission to the interior of an erect tree. The tree itself had been removed by the sea, all but a little of the base, and this was in a very unsatisfactory state, so that doubt might even cxist as to the limit between the deposit in the interior of the tree and that under its base." 


\section{CHAPTER $X$.}

ORDER CAUDATA DUMERIL, 1806. COAL MEASURES TO RECENT.

Naked-skinned, elongate, tailed salamanders, mud-puppics, efts, newts, etc. External gills present or absent in adult condition, but always present in young. Limbs short, with usually 4 digits on hand and 5 on foot, but this is subject to much difference. Limbs never very stout. Carpus and tarsus cartilaginous. Skull roof without the postparietal, postorbital, and supratcmporal. Skull elements never ornamented and never cut by the lateral-line canals. Vertebre consisting of a single c'cment; ribs short, attached to an elongate transverse process. Caudal ribs seldom present. Parictal foramen lacking. No ventral armature. Freshwater inhabitants.

\section{Suborder PROTEIDA Cope, 1868.}

This order agrees generally with the Caudata, but presents one most important feature of difference in the presence of the opisthotic. It is this point which gives the Proteida its intermediate position between the extinct amphibians and the recent species, and seems to indicate a connecting line from the Coal Measures down to the present. The structure of the hyobranchial arches sustains this view.

The hyoid apparatus differs from that of other adult Caudata and resembles that of their larvæ in having three epibranchials, instead of one only. The second basibranchial is also connected with the first, which is not the case with the other Caudata. Three extinct genera are placed tentatively in this suborder.

\section{Family COCYTINID $\&$ Cope, 1875 .}

Cope, Bull. U. S. Nat. Mus., No. I, p. 12, 1875 .

The present family, as here defined, includes the forms whose structure seems to ally them with the modern salamanders. The character on which most dependence is placed is that of the branchial apparatus, lacking in Hyphasma. The forms are all incompletely known and the family will doubtless require revision on acquisition of additional material. Three genera, each with a single species, are:

Cocytimus gyrinoides Cope. Linton, Ohio, Coal Measures. Based on the ventral impression of the skull, witl the well-developed branchial apparatus.

Erierpeton branchialis Moodic. Mazon Creck, Illinois, shales. Based on impression of mandibles and branchial apparatus.

Hyphasma levis Cope. Linton, Ohio, Coal Measures. Based on incompletc and obscure amphibian body, lacking limbs.

Genus COCYTINUS Cope, 1871.

CopI, Proc. Am. Phil. Soc., $1871,177$.

Cope, Geol. Surv. Ohio, 11, pt. 11, 360, 1875.

Type: Cocytinus gyrinoides Cope.

Vertebre and ribs osseous; teeth on the premaxillary bone, none on the maxillary; hyoid elements largely developed, an axialhyal with basihyal on cach side, closely united with the corresponding ceratohyal, at the end of which is an element in the position of a stylohyal; hæmal or basibranchials 3 , the anterior 2, each supporting I pleural branchilhyal, and the third supporting one also, the first hæmal branchihyal on the inner side of the ceratohyal, approaching the median line, and with elongate pleural element. 
The reference by Cope of this genus to the Caudata is one of the most interesting facts connected with the Paleozoic Amphibia. He says: "The present genus is, then, to be referred to the neighborhood of Amphiuma and Protonopsis, but forming the type of another family" (123). He regards the branchial apparatus as being more fish-like than that of any of the modern genera. It is possible that Cocytinus gyrinoides was a larval branchiate and consequently aquatic form. It should be more fully compared with Erierpeton branchialis from the Mazon Creek shales when better known, as well as with IIyphasma lavis from the Linton locality.

All three of these forms are included, provisionally, under the Cocytinida.

\section{Cocytinus gyrinoides Cope.}

Cope, Proc. Am. Phil. Soc., xu, p. 177, 1871.

Cope, Trans. Am. Phil. Soc., p. 278, 1874.

Cope, Gcol. Surv. Ohio, 11, pt. 11, pp. 36ł-365, pl. xxxix, fig. 4, 1875

Type: Specimen No. 86r3 G, American Museum of Natural History.

Horizon and locality: Linton, Ohio, Coal Measures.

Two specimens of this interesting amphibian are known, one of them fairly complete (No. 2564, Am. Mus. Nat. Hist.). The type specimen consists of the inferior bones of the cranium in a fairly complete state of preservation, with the muzzle and its teeth; also 8 anterior vertebræ, with their short recurved ribs.

The condition of the hyal elements in the type specimen is as follows: the hæmal elements of the first branchial arch are partially concealed on both sides of the ceratohyal. An expanded truncate face for attachment to the axial element is visible on both sides, but the body of the bone is flat and presents the edge of the specimen.

The first pleural element proceeds from just behind the axialhyal; it is longer than the other pleural elements. A slender bone is visible extending from the space between the ceratohyal and mandibular angle; it may, therefore, pertain to the suspensorium of the jaw as well as to that of the hyiod arch, or be squamosal as well as stylohyal. The second hremal bone is slender, but with an enlarged axial extremity; that of the right side is not so well preserved as to be safely determined. The third hæmal elements are the smallest, and originate immediately in front of the occipital condyles and diverge outwards and backwards. They are little curved, subcylindric, and slightly expanded at the extremities.

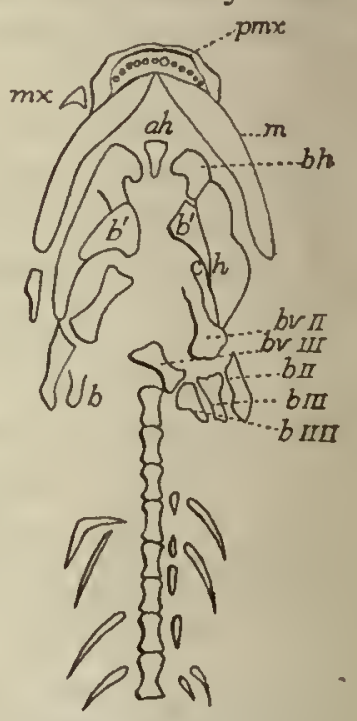

Fis. 16.-Obverse of Cocy. tinus gyrinoides Cope, from the Coal Meas. ures of Ohio $\times 2$. pmx, premaxilla: $m i x$, maxilla: $m$, mandible; $a h$, axialhyal; $h$, basal branchilyyal; ch, ceratohyal; $b v, h x m a 1$ branchihyal: $b, b I I$, $b I I I, \quad b I I I I$, pleural branchihyals.

Of the pleural elements the first and second are little curved and the first is marked by a pit or foramen on the under side near the distal end, which is clearly visible on both sides of the specimen. The third and fourth pleurals are more curved and the outer ends slightly expanded and directed backwards.

The obverse of the specimen (fig. I6) shows that the anterior axialhyal is wedgeshaped. The lateral basihyals are massive. The second hæmal branchihyal is 


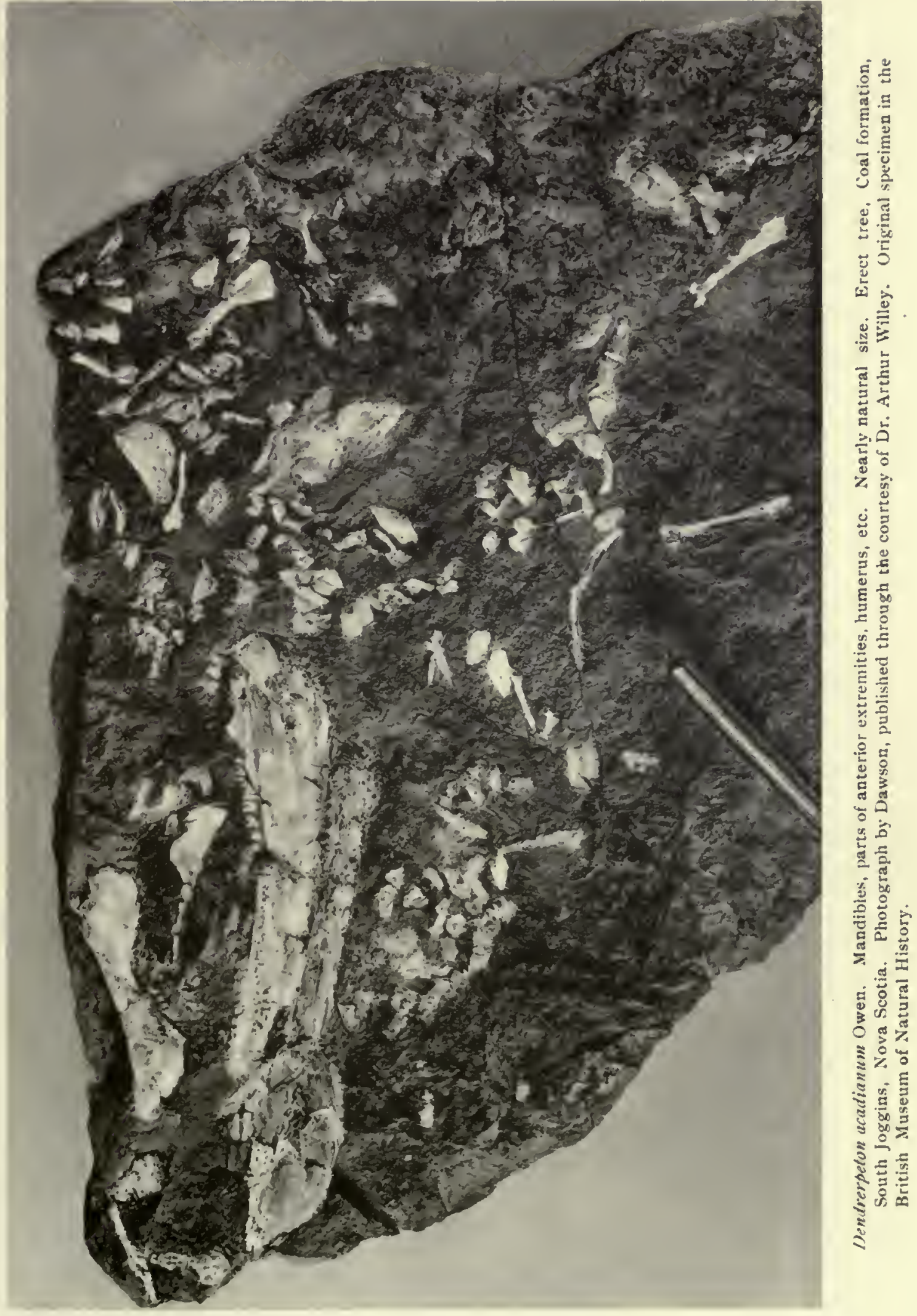



dilated, fan-shaped distally, and supports two pleural elements. The muzzle projects over the lower jaw and was rather broadly truncate. The premaxillary teeth are cylindric and 6 in number on each side. The maxillary bone is represented by a lamina at each lateral extremity of the premaxillary. The mandibular rami are very stout, as are also the ceratohyals. The vertebræ have possessed some apophyses, apparently keel-shaped diapophyses. The ribs are slightly curved.

Measurements of the, Type.

Length of specimen $\ldots \ldots \ldots \ldots \ldots \ldots \ldots \ldots \ldots \ldots \ldots$

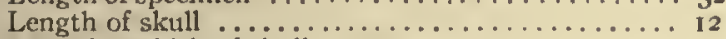

Posterior width of skull .................

Lcngth of premaxilla ................. 5

Length of mandible ....................

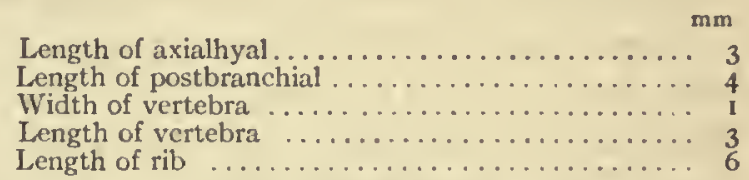

The other specimen of this species (fig. $16 a$ ) is interesting in having 40 consecutive vertebræ preserved, and 19 pairs of ribs attached in their natural relations to the skull and hyal elements. There are a few hyal elements preserved, but nothing is added to our previous knowledge. The ribs are quite as in the type specimen, as

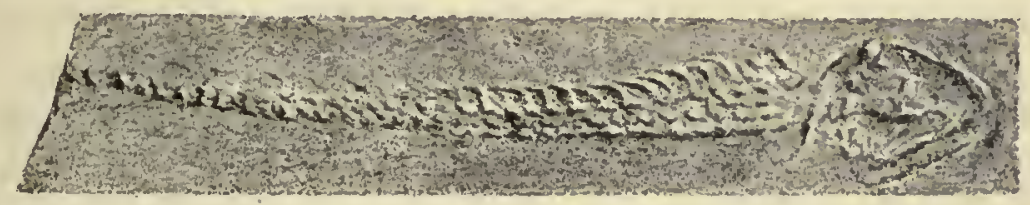

FIG. 16a.-Nearly complete specimen of Cocytimus gyrinoides Cope, from the Coal Measures of Linton, Ohio. Original in the American Museum of Natural History. $\times 0.95$.

are also the vertebræ. The animal was apparently a slender, eel-shaped amphibian comparing favorably with the modern Amphiuma in this respect. There are no indications of limbs or limb girdles.

Measurements (No. 256 4 , American Museum of Natural. History).

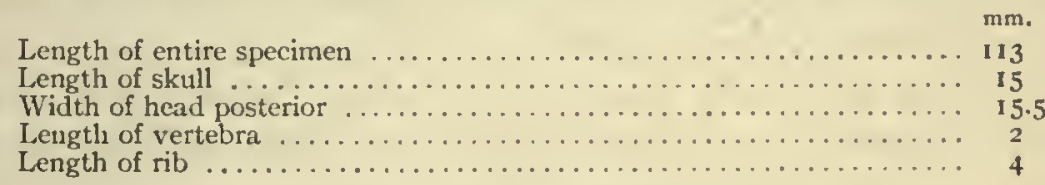

Genus ERIERPETON Moodie.

MoOde, Kans. Univ. Sci. Bull., vı, No. 2, p. 328, 1912.

Type: Erierpeton branchialis Moodie.

The generic characters are found, first of all, in the presence of hyobranchial arches which indicate its relationship to the formerly described Cocytinus gyrinoides Cope, from Ohio. The only other known extinct genera of Caudata which possess, or at least have preserved, the hyobranchial arches are the Jurassic IIylcobatrachus from Belgium and Lysorophus from the Permian of Texas. The present form is widely distinet from both of these genera in the shape of the mandible and the form and arrangement of the hyobranchial bars. The genus Erierpeton finds its closest ally in Cocytinus, in the family Cocytinidæ, which possibly belongs in the order Caudata and the suborder Proteida of Cope. 
Erierpeton branchialis Moodie.

Moodie, Kans. Univ. Sci. Bull., vi, No. 2, pp. 329-330, pl. I, fig. 3; pl. 2, fig. I, IgI2.

Type: Specimen No. 8o r (222) 5, Yale University, Museum.

Horizon and locality: Mazon Creek shales, near Morris, Illinois.

The amphibian remains designated by the above name consist of a distinct mandible and some rather indefinite body impressions (plate 3, fig. 4). Three elongate impressions occur between the rami of the mandibles (fig. I5, A), which, I suppose, must represent hyoid bones belonging to the hyobranchial arches. The lateral elements are paired and the median impression is straight and lies between the paired impressions of the hyoids. The paired portions probably represent the hypohyals or hypohyals plus the ceratohyals, and the unpaired portion of the first basibranchial, according to the nomenclature of Wiedersheim (Comparative Anatomy of Vertebrates, $\mathrm{I} 897, \mathrm{p} .86$ ). If the impressions have been correctly interpreted the present specimen is of very great interest, since it is the first evidence we have of the hyobranchial arches in the Amphibia of Mazon Creek, and the second in the Carboniferous of North America. Dawson doubtfully identified (2I6) some elements of the Joggins Amphibia as hyoids, but was uncertain as to their position. Cope described fully the well-developed hyobranchial apparatus of Cocytinus gyrinoides (I23) from the Coal Measures of Ohio. Among other Paleozoic Amphibia Williston (6I4) has described branchial arches in the peculiar form Lysorophus tricarinatus Cope, from the Permian of Texas.

The form of the impression of the mandible in the present specimen is unlike anything known to the writer among other Carboniferous or later Amphibia. The rami are long, slender, deep, slightly curved, and pointed anteriorly. The anterior symphysis was not a complete sutural union, but was occupied partly by cartilage or other connective tissue.

There are no definite traces of the appendicular skeleton. The traces of the body (fig. 15, A) indicate an elongated, rather slender animal, but further than this nothing can be said in regard to its structure.

The occurrence of a typically caudate form in the Carboniferous is unusual and complicates still further our understanding of the origin and relationships of the early Amphibia.

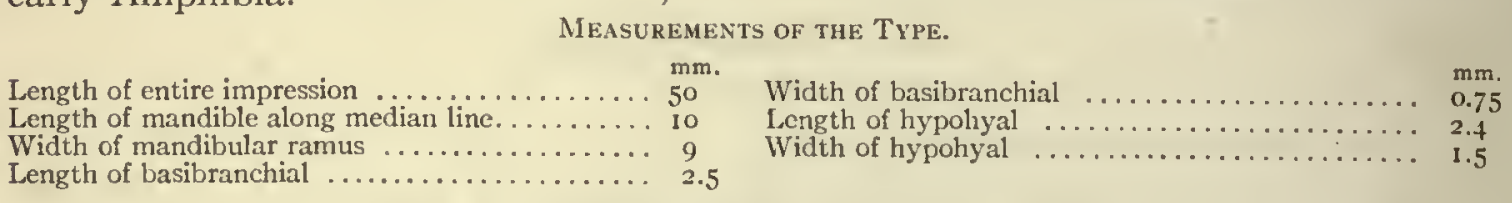

\section{Genus HYPHASMA Cope, 1875.}

Cope, Proc. Acad. Sci. Phil., p. 16, I875.

Cope, Geol. Surv. Ohio, II, pt. II, p. 387, I 875 .

Type: Hyphasma lcevis Cope.

"Vertebræ osseous, the posterior dorsals, and probably the caudals, furnished with fanlike neural spines; limbs unknown-(?) wanting. Thoracic shields present. Ventral armature, consisting of rhomboidal scuta, forming packed rows arranged in chevrons, directed backwards, on top of which are the usual rod-like scales arranged in packed chevrons, with the angle directed forward. 
"The general appearance of the type of this genus is that of a Ptyonius, but the ventral armature is different from anything observed in the known genera of this group. The larger external scuta are like those of the species of Colosteus (Sauropleura), but their series have a different direction. The inner chevrons are those of many other genera" (123).

Hyphasma levis Cope.

Cope, Proc. Acad. Sci. Phil., p. I6, I 875 ,

COPE, Geol. Surv. Ohio., 1I, pt. 1I, p. 387 , pl. 37, fig. 4, 1875 .

Type: Specimen No. 9023 (in counterpart), American Museum of Natural History.

Horizon and locality: Linton, Ohio, Coal Measures.

"In the only known specimen the vertebra have low and squarely truncate neural spines near the head, and some distance anterior to the tail they are quite conspicuous and delicately line-grooved. The body is slender and probably limbless. The thoracic scuta are large and close to the head; the median is produced at both ends, but chiefly anteriorly while the lateral are narrow; all are without sculpture The head is seen from below. The mandibular rami are not so slender as in most species of Ptyonius, but are rather stout. They are a little incurved distally, so that the form of the muzzle is somewhat narrowed, but not produced. The teeth are not visible. Ten rows of the outer layer of scuta in $0.005 \mathrm{~m} . "$ ( 123 ).

The specimen is very indistinctly preserved and the characters given by Cope can not all be made out. It is puzzling to see just on what he bases his conclusion. It is possible that the specimen is a poorly preserved Ptyonius. The outlines of the vertebræ are so indistinct that I am uncertain about them. In certain lights there appear to be regular impressions which resemble the spines of the vertebræ of Ptyonius, but they are doubtful. The skull appears totally distinct from any known species of Ptyonius, but it is very imperfect. The condition of the pectoral elements is very uncertain and I can not be sure that what Cope described as thoracic "scuta" are such. The interclavicle, however, is clearly preserved as a diamondshaped structure. It is almost smooth, with a few faint radiating lines near the base. It measures $5 \mathrm{~mm}$. in greatest breadth by $8 \mathrm{~mm}$. in length.

MeAsurements OF THE TYPE.

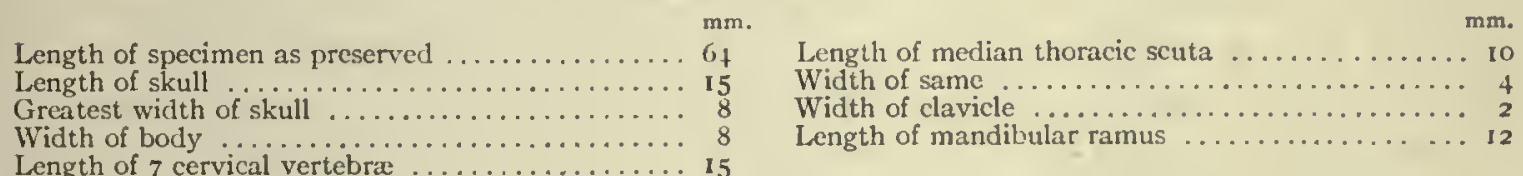

Width of body $\ldots \ldots \ldots \ldots \ldots \ldots \ldots \ldots \ldots \ldots \ldots \ldots$
Length of 7 cervical vertebra $\ldots \ldots \ldots \ldots \ldots$

Length of mandibular ramus ............. 12 


\section{CHAPTER XI.}

\section{DEFINITION OF THE ORDER SALIENTIA, LAURENTI, 1768.}

(World-wide distribution.)

Naked, tailless Amphibia of compact form, and with usually procœlous vertebræ. Caudal vertebræ coalesced into a slender elongate piece, the urostyle. Two elements of the tarsus ossified and greatly elongated. Development by metamorphosis; gills never present in adult. Ilium greatly elongated.

The order is suggested in the Coal Measures by a single species, known from a single poorly preserved specimen (plate 24, fig. I). The form Pelion lyelli Wyman was the first known of the Linton Amphibia, and its striking frog-like (123, 639) appearance was early noticed. There is no assurance that the species belongs with this order, but since a well-developed and highly specialized frog $(480,48 \mathrm{I})$ occurs in the Como Beds (405) of Wyoming, it is not impossible that we may have in the Pelion lyelli a suggestion (460), at least, of the ancestral structure. It is certain that the frogs have, in past ages, had a much greater length of vertebral column than they possess at present, as is witnessed by the coalescence of several vertebræ to form the urostyle. It is suggested that the ancestral vertebral column is represented in Pelion.

\section{Family PELIONTID\& Cope, 1875 .}

Cope, Bull. U. S. Nat. Mus., No. I, p. II, 1875.

The present family includes but a single species, that of Pelion lyelli Wyman, first described in $185^{8}(640)$, from Linton, Ohio.

The family characters are to be found in the broad and obtusely rounded cranium, in the frog-like scapular arch, the frog-like hind limb, and in the form of the palate, so far as these structures have been preserved.

It has been suggested that the present form shows decided affinities with the frogs of to-day and it may possibly be looked upon as the actual ancestor of the living frogs. The length of the vertebral column would seem to militate against such a relationship, since it is well known that frogs have had a short vertebral column since the Jurassic (480, 48I). But this is not a good argument, since the developing urostyles of modern tadpoles show metameric fenestrations in the developing bone which doubtless correspond to openings between the vertebræ. The notochord of the tail is segmented, apparently through the influence of former vertebral structure. At any rate, the suggestion is an interesting one and, whether sustained or disproven, the present discussion is based on the probabilities of the case.

\section{Genus PELION Wyman, 1868.}

Wyman, Am. Jour. Sci. (2), Xxv, p. I60, $185^{8}$ (Raniceps).

Cope, Proc. Acad. Nat. Sci. Phil., I 868, 2 I I (Pelion, suggested in letter to Cope by Wyman).

Type: Pelion lyelli Wyman.

"The only specimen of the species exhibits an inferior view of a portion of the skeleton; and the obverse, on which the thoracic and abdominal armor could have been preserved, has not come under my observation. The specimen, however, does not exhibit any ribs, although the vertebræ are well preserved. As observed by Professor Wyman, the genus presents some points of similarity to the Anura (Salientia). The prolongation of the angles of the mandible is of this character, as well as the general form of the head. The bones of the 


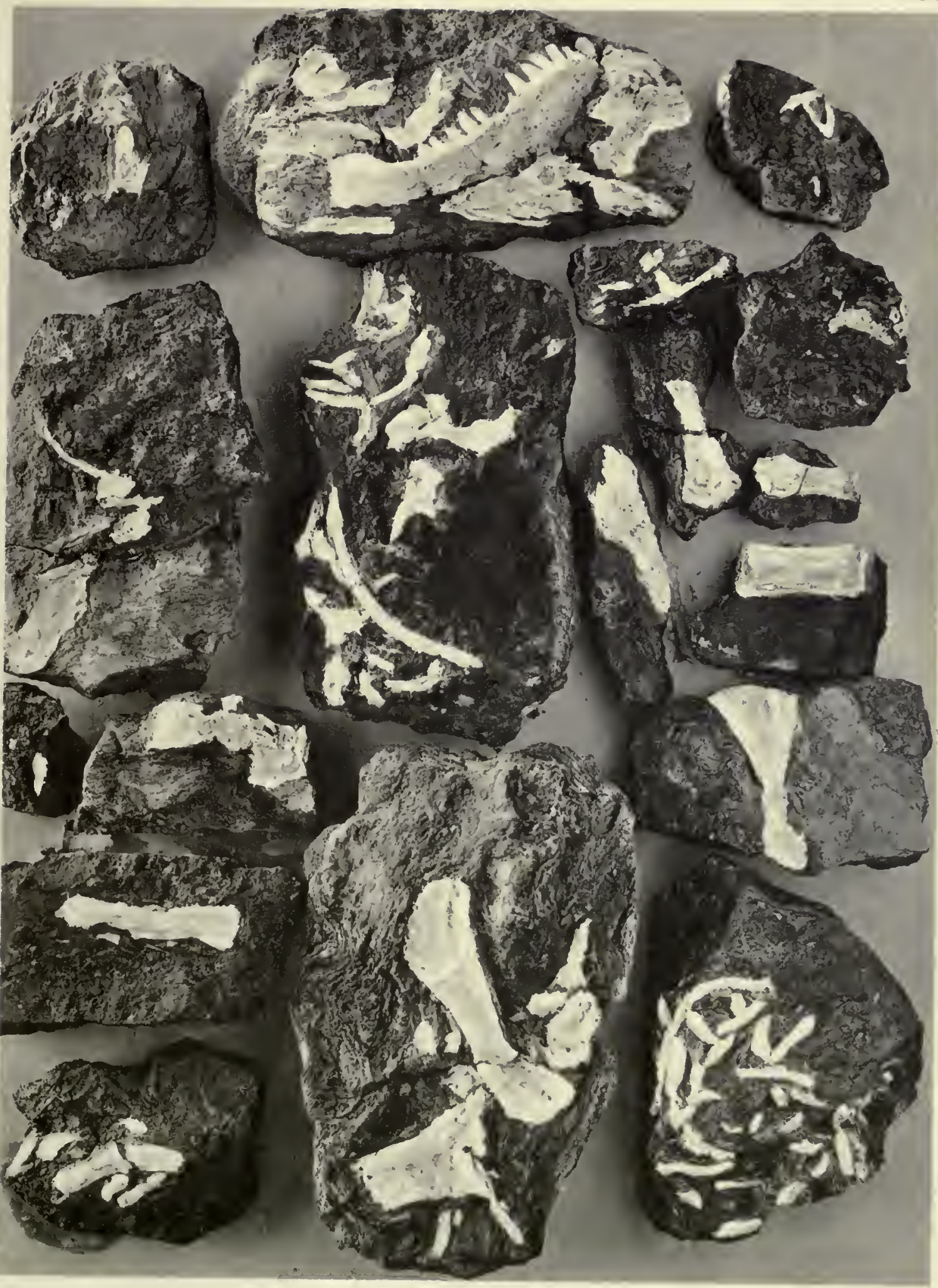

Hylerpeton dawsoni Owen. Above: Mandible, teeth, rib, and bones of anterior extremity. Below: Bones of pelvis and posterior limb and bony scales. Nearly natural size. Erect tree, Coal formation, South Joggins, Nova Scotia. Photograph by Dawson, published through the courtesy of Dr. Arthur Willey. Original specimens in Peter Redpath Museum of McGill University. 

forearm may be united as in the frogs, and the length and curvature of the femur are seen among these animals rather than the Salamanders. The form of the femur is different from that of Amphibamus grandiceps Cope, which also differs in the presence of dermal scales and ventral scutellæ." (123.)

Wyman, Am. Jour. Sci. (2), xxv, p. 160,1858 .

Pelion Iyelli Wyman.

Core, Proc. Acad. Nat. Sci. Phil., 1868, p.: 211 .

COPE, Geol. Surv. Ohio, t1, pt. It, p. 390, pl. xxvi, fig. 1, 1875.

Moodie, Pop. Sci. Monthly, Lxxu, p. 562, fig. 1, 1908.

Type: Specimen No. 7909 G, American Museum of Natural History.

Horizon and locality: Linton, Ohio, Coal Measures. (Plate 24, fig. I.)

This was the first species described from the Linton, Ohio, deposits. It was made known by Dr. Wyman in 1857 at the meeting of the American Association for the Advancement of Science for that year. 'The species was subsequently studied by Cope. He merely confirmed Wyman's observations. The following description is based on the descriptions of Cope and Wyman and on my own study of the type specimen.

This is the most frog-like, in appearance at least, of all the Amphibia which have so far been discovered in the Carboniferous. The skull especially has a shape which is strikingly frog-like, and the long hind limbs lend further likeness to the tailless forms. Pelion may have been a jumping creature, if we may judge from its long hind legs. Wyman and Cope have both called attention to the frog-like appearance of the specimen, and this is apparent at the first glance. It is probable that the resemblance has some significance as to the ancestry of the Salientia, and it may indicate the first step in the origin of the tailless Amphibia. It is possible that the frogs began to be separated from the other Amphibia during the Carboniferous. The first frogs we know are from the Jurassic, where they are well-developed ranids. If Pelion be a frog ancestor, then the history of the group from the Coal Measures to Jurassic is an unknown story.

The specimen is preserved on its back and it is thus impossible to tell as to the structure of the skull. Cope was of the opinion that the depressed areas on the sides of the elongate parasphenoid were the orbits, and if so the resemblance to the frogs is much more striking. In the frogs there is a strong process from the pterygoid which projects inward to meet a corresponding process from the parasphenoid. This forms a heavy rod behind the palatine vacuity. There is a heavy rod represented in the specimen and a part of it is certainly the external process of the parasphenoid, but whether it is to be interpreted as in the frog is an open question. The outline of the cranium is partially obscured by the mandibles, but the anterior part is represented by a raised line, as shown in figure $\mathbf{I 7}$. In the anterior part of this space there are two ridges which may be tooth ridges. If they are teeth there is a great similarity to the premaxillary and vomerine teeth of Necturus, since the ridges are widely separated at the median line and approximated distally, as they are in Necturus. The mandible is preserved entire and its form is strikingly froglike. Its posterior angles project over the quadrate area and seem to have had an upturned projection such as is found in the mandibles of the Crocodilia.

There are impressions of 20 vertebre preserved, and they cover a little more than half of the presacral region. There may have been 28 to 30 presacrals. The 
vertebræ, as preserved, are somewhat quadrate in outline and constricted at the middle, as though they were of the typical microsaurian type. No ribs are preserved.

There is an impression anterior to the right humerus which may represent a part of the pectoral girdle, but its form is so obscure that it can not be determined. The pelvic girdle is entirely wanting in the specimen. Remains of the fore and hind limbs are preserved. The arms are especially well preserved and consist of a strong humerus, a separate radius and ulna, and phalanges, the carpus having undoubtedly been cartilaginous, since there are no traces of carpal bones. Wyman has figured a small ossicle (fig. I7) which might be interpreted as a carpal, but it is further removed from the carpal region than his figure shows and I would interpret it as a fragment of a phalange, since the first digit seems to be turned aside over the vertebral column. The right hand is but imperfectly preserved, but the left hand is nearly entire. There are evidences of 4 digits, possibly 5 . The metacarpals are elongate and rather stout. The phalanges of the distal series have been lost, so the phalangeal formula can not be determined. On the whole, the hand has a very broad aspect and is not at all slender, as in the majority of the microsaurians from the Coal Measures of Ohio. It resembles in a great measure the broad hand of a toad and may thus be indicative of a terrestrial life. The humerus is well developed and has pronounced swellings, as though for the attachment of strong muscles. These indications would favor the view of the animal being a land dweller.

The femur and a part of the tibia (?) of the right side

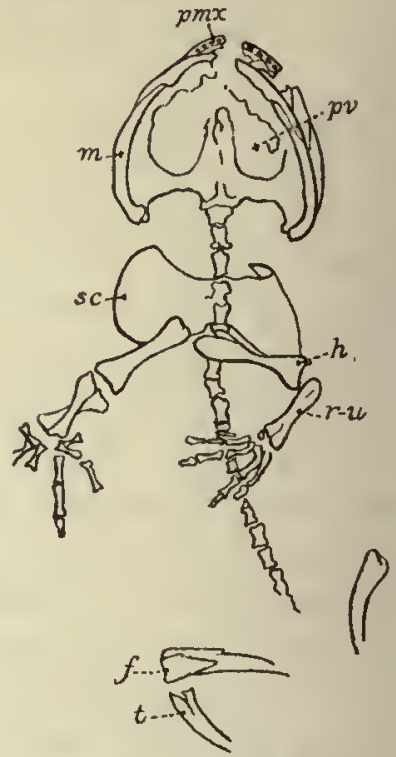

FIc. 17.-Pelimn lyelli Wyman, an amphibian from the Coal Measures of Ohio, the supposed ancestral salientian. (After Wyman.) $\times 0.75$. $p m x$, premaxilla; $p v$, palatine vacuity; $m$, mandible; $s c$, scapula-coracoid; $h$, humerus; $r-u$, radius and ulna; $f$, femur; $t$, tibia. are all there is preserved of the hind limb. These elements show the leg to have been quite long, though weaker than the fore limb. 'The femur has a large distal articular surface. The fibula is, apparently, absent, though it may simply be lost.

The genus Pelion stands alone among the Carboniferous Amphibia. The form can not be placed in the order Branchiosauria on account of the well-developed limb bones and the large mandible. It may belong with the Microsauria. I have placed it under the Salientia in the hope of learning more about the early relatives of the tailless forms. There is no, assurance at all that it is even ancestral to the Salientia, but the resemblances are striking.

The following gives the measurements of the type specimens:

\section{Measurements of the Type Specimen.*}

Length of specimen, $\mathrm{mm}$.

....... I10

mm.

Median length of the skull $\ldots \ldots \ldots \ldots \ldots 24$

Length of radius and ulna ............ I1.5

Width across the mandibular angles ..... 25

Width of distal end of radius ...........

Length of digit $I I$, as preserved $\ldots \ldots \ldots \ldots, 16$

Greatest width of skull .............. 30

Length of vertebral column from acciput to

Length of digit IrI, as preserved ......... I

sacral region $\ldots \ldots \ldots \ldots \ldots \ldots \ldots \ldots . .60$

Length of left humerus ............. 19

Width of distal end of left humerus .... 5.5

Length of femur ................. 24

Width of distal end of femur ..........

Length of tibia ................. 18

* The type specimen was collected in $8_{57}$ by Dr. John V. Lauderdale, who presented it to Dr. J. S. Newberry. 


\section{CHAPTER XII.}

\section{SUBCLASS LEPOSPONDYLIA ZITTEL, 1887. COAL MEASUIRES TO PERMIAN.}

(Europe and North America.)

The group is here defined according to the English edition of Zittel's Text Book of Palcontology, 1902, p. I25. "Notochord persistent and enclosed in constricted bony cylinders, hour-glass-shaped in longitudinal section. Teeth simple, conical, hollow." According to Zittel there are two families, the Microsauridæ and the Aistopodidæ. The latter family is dealt with under Aistopoda (p. 76) and it is there shown that the group is in no wise a valid one. The former family is regarded as an order and is fully entitled to that rank. As defined here the subclass Lepospondylia contains but a single order, the Microsauria.

Extinct, terrestrial, aquatic, or semi-aquatic amphibians; skull pitted and grooved by lateral-line canals and by sculpturing marks, or the skull may be smooth; teeth present on most of the palate bones; exoccipitals cartilaginous or calcified, never completely osseous; sclerotic plates sometimes present; skull of various shapes. Vertebre with notochord largely persistent, hour-glass-shaped; neural spines low or high, or absent; ribs intercentral and single-headed, with an incipient tubercle in some forms; vertebral column differentiated into dorsal and caudal series; cervical series not clearly defined. Limb bones with well-ossified perichondrium, endochondrium partly ossified; epiphyses absent; carpus and tarsus (tarsus osseous in two species) cartilaginous; phalanges clawed or not; digits 4 in hand and 5 in foot. Pubis sometimes calcified but never osseous.

\section{Definition of the Order Microsauria Dawson, i863. Coal Measures and Permian.}

(Europe and North America.)

Lizard-like, sometimes longicaudate, stegocephalous, lepospondylous, ambulatory or legless amphibians; skull bones usually sculptured with pits and grooves; lateral-line canals well developed on skull bones; skull with horns from tabulare and supratemporals or without horns; branchia never persistent; sclerotic plates present; orbits usually well forward. Vertebre hour-glass-shaped; endochondral bonc weakly developed throughout skeleton, especially in vertebræ; notochord largely persistent; neural spines low and rudimentary or long, fan-shaped, and highly ornamented. Dorsal series of vertebral column variable; usually from 22 to 30 ; tail containing sometimes over 75 vertebræ, or tail very short with 2 weakly developed vertebra; caudal ribs present, in those forms with long caudal series the distal vertebre sometimes exhibiting 2 pleurocentra. Ribs long and curved, always intercentral in position, single-headed, with at times an incipient tubercle. Pectoral girdle composed of scapula, clavicles, coracoids, and interclavicle. Pelvic girdle composed of osseous rod-like ilium, plate-like ischium; pubis cartilaginous, sometimes calcified. Limbs present or wanting or weakly developed, sometimes present in front and wanting behind. Radius and ulna and tibia and fibula frec; carpus and tarsus usually cartilaginous; digits 4 in hand and 5 in foot, terminal phalanges sometimes clawed. Phalangeal formula for the hand $2-2-3-2$, for the foot $2-2-3-4-3$. Abdomen covered with dermal armature composed of osseous or corneous rods or scutes; ovcrlapping scales, fish-like in appearance, somctimes present over the entire body; body also covered with lizard-like scales or naked. 
The order Microsauria was established by Sir William Dawson in I863 (208) as a family of "reptiles" for the reception of the genera Hylonomus, IIylerpeton, Smilerpeton, and Fritschia. Hylonomus lyelli is the type species of the order. Dawson (216, p. 635) says of the species Hylonomus lyelli Dawson: "It is the type of the genus IIylonomus and of the family Microsauria." The forms which have been referred to the genus Hylonomus, and hence to the order Microsauria, from the deposits of Europe are discussed under IIylonomus.

The Microsauria have been regarded by the writer and others as being ancestral in a sense to some of the later reptiles (469), but there seem to be insuperable obstacles in the way of a direct derivation of the reptiles from the Microsauria. One of these obstacles seems to be found in the structure of the hand. In all Microsauria, so far as is known, there is no evidence of more than 4 digits in the hand, while no true primitive reptile possessed less than 5. The carpus of all true reptiles is osseous, while that of the Microsauria is merely cartilaginous. It is possible that the Microsauria stand in some such ancestral relation to the later reptiles as the Crossopterygia (489b) do to the Amphibia. The Microsauria had undergone adaptive modifications as to structure and habit, so that they have paralleled many of the groups of reptiles, but their structure is quite different. The evidence, as far as we can see now, points to a close genetic relation between the reptiles and the Microsauria, but that this relation is ancestral $\mathrm{I}$, for one, am not ready to say.

The Group Aistopoda Miall, 1873 , is untenable.

The group Aistopoda was established in 1873 as section $\mathrm{Ix}$ by the Committee of the British Association for the Advancement of Science, in their "Tabular View of the Classification of the Labyrinthodonts." L. C. Miall $(449,450)$ was the secretary of the committee, and the report was published in two parts. Two genera were at that time attributed to the Aistopoda, Ophiderpeton and Dolichosoma, both described by Huxley from the Coal Measures of Kilkenny, Ireland.

Fritsch (25I, pp. 107-126) in I 883 refers to the group as "Familie" and describes 4 genera and 9 species as belonging to the group. Zittel $(642$, p. 383$)$ refers to the group as "Familie" and places 5 genera in it. Smith-Woodward (Vertebrate Paleontology, I898, p. 129) refers the Aistopoda to a suborder. In' Eastman's translation of Zittel's Paleontology the group is called a family, "Aistopodidx." Lydekker (393, p. 205) regards the group as a suborder. The writer (469) refers the Aistopoda to an order. The group Aistopoda has been adopted by practically all paleontologists and zoologists who have had occasion to refer to these animals.

Lydekker (393) in I 890 defined the group as follows:

"Body long and snake-like, without limbs, and apparently without pectoral or pelvic girdles. Vertebræ with elongated centra and aborted neural spines. Ribs slender, and barbed like those of fishes. Teeth smooth, without plications of the dentine. External gills probably persistent."

If now we take up a consideration of each of the characters mentioned by Lydekker we find that the first one holds good for all examples of the group. The second character, "without limbs," is not good. Species of Estocephalus, Ptyonius, Molgophis all possess limbs; and doubtless Ophiderpeton will be found to possess limbs. 


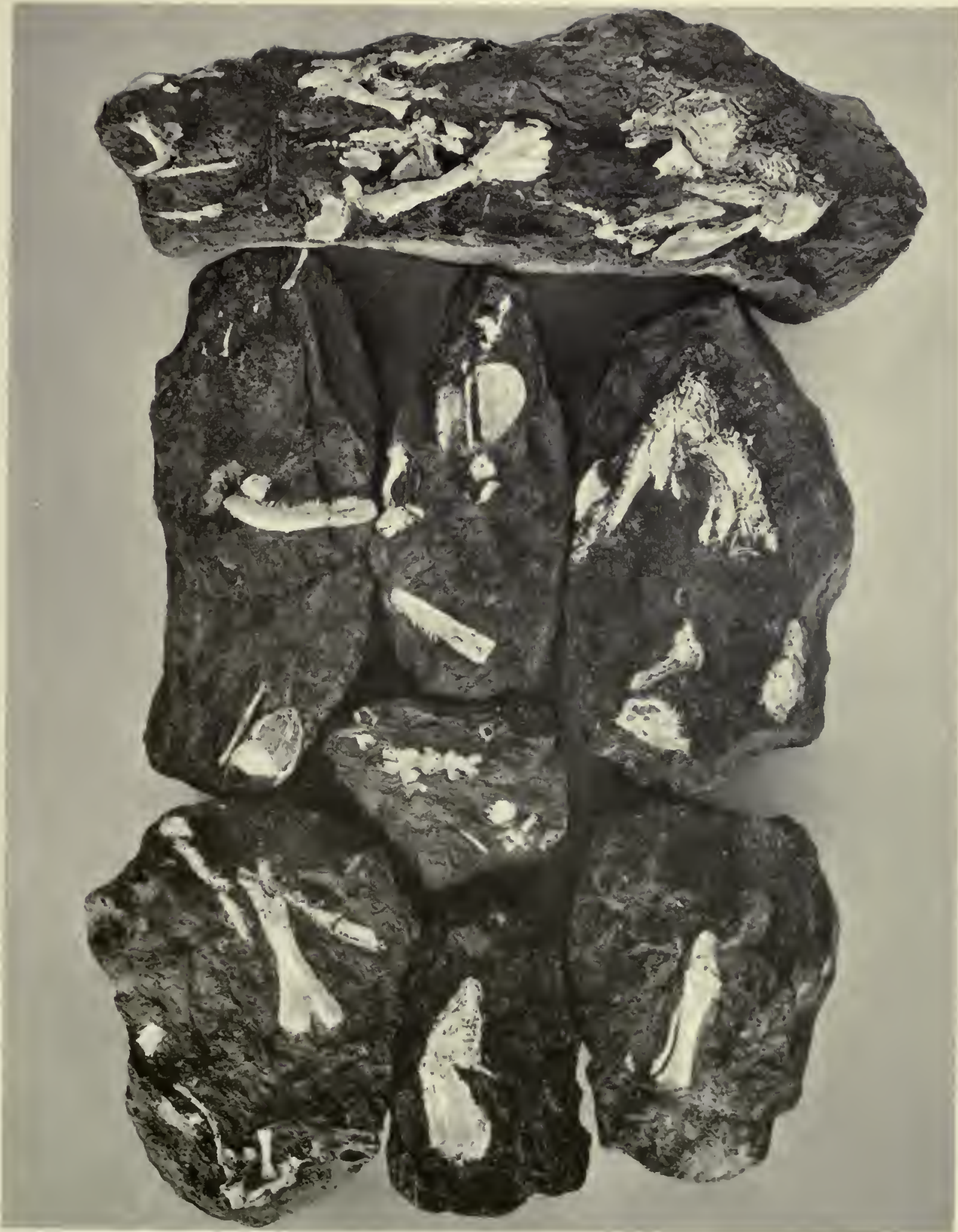

Fritschiacurtidentata Dawson. Above: Bones of skull and anterior extremity, and bony rods of belly. Below: Bones of pelvis and posterior extremity. Nearly natural size. Erect tree, Coal formation, South Joggins, Nova Scotia. Photograph by Dawson, published through the courtesy of Dr. Arthur Willey. Original specimen in the Peter Redpath Museum of McGill University. 

also, since it has a well-developed pectoral girdle. The limbs in all of these genera are small. The third eharacter, "apparently without pectoral and pelvic girdles," is not at all a good character, since nearly every specimen of some species and almost all species show evidences of pectoral girdles and a few exhibit pelvic girdles. The fourth character, "vertebræ with elongated centra and aborted neural spines," is not a good distinguishing character, since $A$ mphibamus, an undoubted microsaurian, possesses the same vertebral characters. "Ribs slender, and barbed like those of fishes" is a character which is common to several widely distinct genera. All Microsauria possess long, slender ribs, and the barbed condition is one which is possessed by only a few, Thyrsidium, Ophiderpeton, etc., the so-called "barb" being merely a highly exaggerated tuberculum. The teeth of nearly all Microsauria are smooth, so that the eharacter "teeth smooth" is not a good one for a group definition. It has not been possible to examine any of the American specimens for the plication of the dentine, since the forms are so rare and the fossils very fragile. The last character, "external gills probably persistent," is eertainly not true for the American species, and the evidence for the European species is negative. Fritsch described and figured (Fauna der Gaskohle, Bd. I, I883, p. II 4 , Tafeln I 8 and 23) structures which he regarded as supporting struetures for the external branchiæ. He says in regard to these structures:

"Bei dem Umstande, dass sie von der Kiemengegend aus sich büschelförmig verbreiten und man ihren Contakt mit einer Art von Branchiæ constatiren kann, zweifle ich nicht daran, dass diese Stäbchen dem Kiemenapparate angehören. Bedenklich ist nur ihre grosse Zahl und das Vorkommen bis zum i6ten Wirbel und ich erwog die Möglichkeit, dass diese Stäbchen einem zarten Bauchpanzer angehören könnten. Da abcr weiter im Verlaufe der ganzen Wirbelsäule nichts Aehnliches vorkömmt, so ist man gezwungen anzunchmen, dass Dolichosoma sehr grosse lange Kiemenbüschel besessen haben muss."

John Samuel Budgett (79, p. I62), in his discussion of the "Structure of the Larval Polypterus," refers to the above-described specimen of "aistopodous Stegoeephali," i.e., Dolichosoma longissimum Fritsch, and calls especial attention to the similarity of the external rod of segmented cartilage on the hyomandibular of Polypterus to this structure, to which Fritsch has assigned a branchiate nature in Dolichosoma. There is no doubt in the mind of the present writer, however, that the rod of cartilage, referred by Fritsch to the gills, can be other than scutellate rods of the ventral armature, these rods belonging to the armature of the breast or throat. The evidence for this conclusion is furnished by Fritsch himself (Fauna der Gaskohle, Bd. I, plate I8, fig. II), where all may read in the figure of the specimen the facts of the case. There is quite evidently no justification for Fritsch's conclusion of the branchiate nature of Dolichosomu. There is no evidence of any gill-like structure in the American snakelike amphibians of the Coal Measures.

Reviewing, then, the characters of the group which have been assigned by various observers, it will be seen that there is but a single eharacter which holds good: "body long and snake-like." This is totally insufficient for the retention of the group. I therefore propose to abolish the group entirely from zoological classification. It is not even a family. It will, however, be convenient to refer to the snakelike forms as "aistopodous." 


\section{CHAPTER XIII.}

\section{THE MICROSAURIAN FAMILY HYLONOMIDA, FROM THE COAL MEASURES OF NOVA SCOTIA.}

\section{Family HYLONOMIDÆ Fritsch, 1883.}

Fritscu, Fauna der Gaskohle und der Kalksteine der Permformations Böhmens, Bd. 1, p. I59, I883. LydekKER, Cat. Fossil Reptilia and Amphibia, IV, p. $201,1890$.

The following characterizations of the family are those given by Lydekker (393, p. 20I) based on Fritsch (25I): Body slender and lizard-like; skull narrow, with smooth or faintly sculptured bones; neural spines of vertebræ well developed, and long, slender ribs. Teeth smooth, or with grooved summits. The whole body covered with sculptured scutes. Internal gills may be developed.

Fritsch (25I, Bd. I, p. 159) gives the following in his original description:

"Stegocephali von Baue schlanker Eidechsen mit schlanken langen Rippen. Wirbel amphicoel mit stark entwickelten oberen Dornfortsätzen. Schädelknochen glatt oder schwach verziert. Schuppen gross, verziert, den ganzen Körper deckend. Zähne glatt oder mit verzierte 'Spitze. Kiemenbogen bei einigen angedeutet. Mittlere Kehlbrustplatte unbekannt. Coracoidea ähnlich wie bei Branchiosaurus schlank, winkelig gebogen."

Fritsch includes the following genera in the family:

Hylonomus, Hyloplesion, Smilcrpeton, Secleya, Orthocosta, and Ricnodon. The family includes the following specics:

Hylonomus lyelli Dawson, Nova Scotia. latidens Dawson, Nova Scotia. multidens Dawson, Nova Scotia. wymani Dawson, Nova Scotia. fritschii Gcin. and Deichm., Saxony. geinitzi Credner, Saxony.

(?) pictus Fritsch, Bohemia.
Hylonomus wildi Woodward, England. Smilerpeton aciedentatum Dawson, Nova Scotia. Hylerpeton dawsonii Owen, Nova Scotia. intermedium Dawson, Nova Scotia. longidentatum Dawson, Nova Scotia . Fritschia curtidentata Dawson, Nova Scotia.

\section{Genus HYLONOMUS Dawson.}

DAwson, Quart. Jour. Geol. Soc. London, Xvi, p. 274, figs. If-18, 1860.

DAwson, Air-breathers of the Coal Period, p. 44,1863 .

DAwson, Ihil. Trans. Roy. Soc. London, 1882 , pt. II, p. 634.

CREDNER, Zeit. d. deutsch. geol. Gesell., 1890 (IX Theil, die Stegocephalen und Saurier).

Type: Hylonomus lyclli Dawson.

The genus Hylonomus is a very important one from a taxonomic viewpoint, since it was regarded by Dawson (2 I6, p. 635) as the typical genus of the order Microsauria, the most abundant group in the Carboniferous. Unfortunately the species of the genus IIylonomus are known only from fragmentary remains. I have reproduced in plate 9 Dawson's figures of the remains of Hylonomus as published by him in 1891 .

Dawson (216) gave, in 1882 , the following definition of the genus Hylonomus: "Form lizard-like, with the posterior limbs somewhat large in proportion to the anterior. Size, small. Mandibular and maxillary teeth numerous, small, conical, pointed. Palatal teeth minute. Abdominal scales oval." 


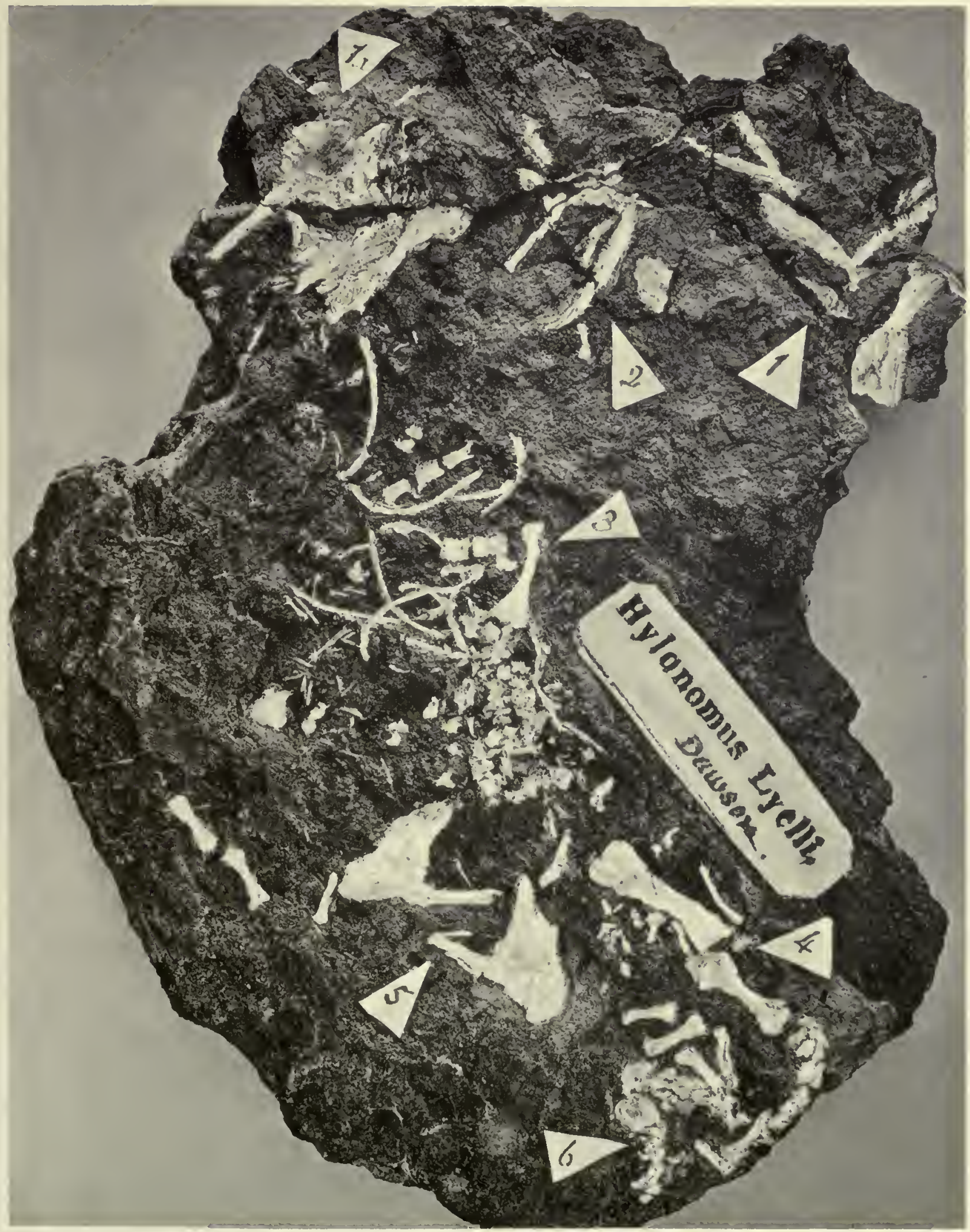

Hylonomus lyelli Lawson. 1, maxille and skull bones; $1 a$, sternal bones; 2 , mandible; 3 , humerns, ribs, and vertebre; 4, posterior limb; 5, pelvis; 6, caudal vertebra. Nearly natural size. Erect tree, Coal formation, South Joggins, Nova Scotia. Photograph by Dawson, published through the courtesy of Dr. Arthur Willey. Original in the British Musenm. 

Credner (186), Fritsch (251, Bd. 1, p. 89, Taf. 12, figs. I, 4, 15), and Woodward (629) have referred remains of Microsauria discovered in the Coal Measures or lower Permian deposits of Saxony, Bohemia, and Laneashire, England, to the genus Hylonomus. There is much uncertainty as to the validity of these references, due to the uncertain nature of the type of Hylonomus. There are 4 American species of the genus: IIylonomus latidens Dawson, II. lyelli Dawson, II. multidens Dawson, and II. roymani Dawson. All the species are from the Coal Beds at the South Joggins, Nova Scotia.

\section{Hylonomus lyelli Dawson.}

DAwson, Quart. Jour. Geol. Soc. Iondon, xvi, p. 274, figs. 14 to 18,1860 .

DAwson, Air-breathers of the Coal Period, p. 44, 1863 .

D.wson, Phil. Trans. Roy. Soc. London, 1882 , pt. II, p. 635, pl. 39, figs. I to 14 and 27 .

DAwson, Acadian Geology, 3d ed., I880, p. 370.

Type: Specimens Nos. R 443 to 445 in the British Museum (393, pt. IV, p. 223). Horizon and locality: Coal formation of the South Joggins, Nova Scotia.

This species is by far the most abundant (plate 9) in the erect trees examined by Dawson. Its characters Dawson (216) defines as follows:

"General form lizard-like, with the hind limbs rather larger than the fore limbs. Length when mature, 5 to 6 inches.

"Head somewhat clongate; bones of skull smooth or with microscopic striæ, perfectly united, except at the parietal foramen. Occipital condyle double, and apparently bony. Teeth simple, conical, numerous, about forty in each mandible, and nearly equal, except that a few of the anterior ones are rather larger than the others. The teeth are anchylosed to the jaw in a furrow protected by an external bony plate.

"Vertebre with cylindrical bodies, slightly concave at the ends. When partly exfoliated they appear hour-glass-shaped, in consequence of the internal cartilage having the form of two cones attached by their apices. Zygapophyses conspicuous above; neural arches united to the bodies of the vertebra, and with broad neural spines. Dorsal vertebræ with strong lateral processes. Caudal vertebræ apparently simple and cylindrical. Number of vertebræ in neck and trunk about thirty.

"Ribs long and curved, with capitulum and tuberculum, cartilaginous within.

"Anterior limb slender, humerus with distinct keel; radius and ulna separate; toes four or five.

"Posterior limb with well-developed femur; tibia and fibula shorter, separate; toes five, somewhat long and slender.

"Pelvis large, composed of ilium and ischium."

Interclavicle and numerous scutellæ are present. Upper surface protected with imbricated horny scales. In front two rows of horny tubercles and plates, with epaulettes composed of bristle-like fibers projecting from the skin.

The animal possibly fed on insects, as is indicated by the coprolitic matter associated with the remains of the species.

The following measurements are given by Dawson for the largest individual discovered: :

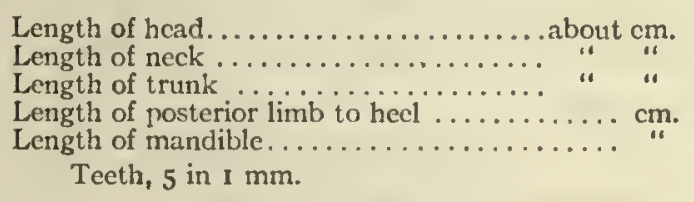

Length of hcad................... about $\mathrm{cm}$.

Length of neck $\ldots \ldots \ldots \ldots \ldots \ldots \ldots$ " "

Length of nosterior limb to heel ........... cm.

Teeth, 5 in $1 \mathrm{~mm}$.

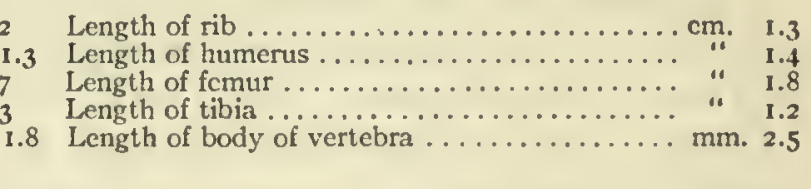

Length of rib ..................... 1.3

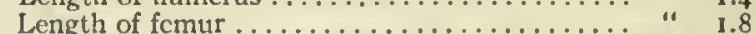

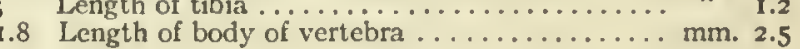


Hylonomus latidens Dawson.

Dawson, Phil. Trans. Roy. Soc. I.ondon, 1882, pt. 11, p. 637, pl. 39, figs. 18-22.

Dawson, Proc. and Trans. Roy. Soc. Canada, 1895, p. 74.

Type: Specimen No. 306I-1, Peter Redpath Museum, McGill University. The British Museum (393, pt. IV, p. 224) also has a specimen, No. R. 447.

Horizon and locality: Coal formation at the South Joggins, Nova Scotia.

Fragments of 3 specimens from 3 trees represent this species (plate Io). It seems to have been of stouter build than $I I$. lyelli, with the limbs shorter in proportion. Its generic affinities are somewhat doubtful, as it presents in some respects characters intermediate between Hylonomus and IIylerpeton.

Mandibular and maxillary teeth broadly conical, about 20 in each mandible3 in I mm.; anterior mandibular teeth somewhat larger than the others, and bent or hooked. Vomer or palate with minute teeth. Thoracic plate large. Scalcs of abdomen oval, but somewhat narrow, and tending to be oat-shaped.

Length of mandible (imperfect) ......... mm. 9

Length of humerus .................... mm. 7

Length of vertebra ................. mm. 2

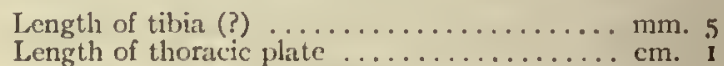

Length of six caudal vertebra $\ldots \ldots \ldots \ldots \ldots$ mm. 8

\section{Hylonomus multidens Dawson.}

Dawsox, Phil. Trans. Roy. Soc. London, I882, pt: II, p. 637, pl. 39, figs. 23-26.

DAwson, Proc. and Trans. Roy. Soc. Canada, 1895, p. 74.

Type: Specimen No. 306I-2, Peter Redpath Museum, McGill University.

Horizon and locality: Coal formation at the South Joggins, Nova Scotia.

This animal is known only by portions of bones of the head and a few other fragments. The scattered bones of the extremities are inseparable from those of II. lyelli occurring with it. As compared with that species, the bones of this are smoother and more delicate. The teeth are more numerous and slender. The crushed distal end of a femur or humerus found near the skull indicates that the limbs were well developed.

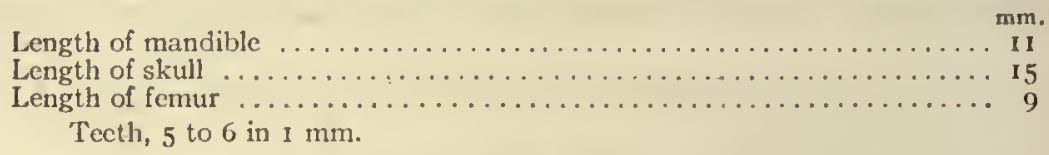

Hylonomus wymani Dawson.

DAwsos, Quart. Jour. Geol. Soc. London, xvi, p. 277, figs. 27-29, I 860.

Dawson, Air-breathers of the Coal Period, p. 52, 1863.

Dawson, Phil. Trans. Roy. Soc. London, 1882, pt. II, p. 637, plate 39, figs. 15-17.

DAwson, Acadian Geology, 3 d ed., p. 378 .

Type: Specimen No. 306I, Peter Redpath Museum, McGill University. There is also specimen No. R 446 in the British Museum (393, pt. Iv, p. 224).

Horizon and locality: Coal formation at the South Joggins, Nova Scotia.

As compared with the $I I$. lyelli the present species is smaller in size, more elongated in form, had the teeth less numerous (about 22 in the mandible), and shorter and more obtuse in form. There are 6 to 7 in $1 \mathrm{~mm}$.

This species is much more rare than $I I$. lyelli, but quantities of minute bones, probably belonging to it, occur in the coprolitic matter. In one specimen 38 verte- 


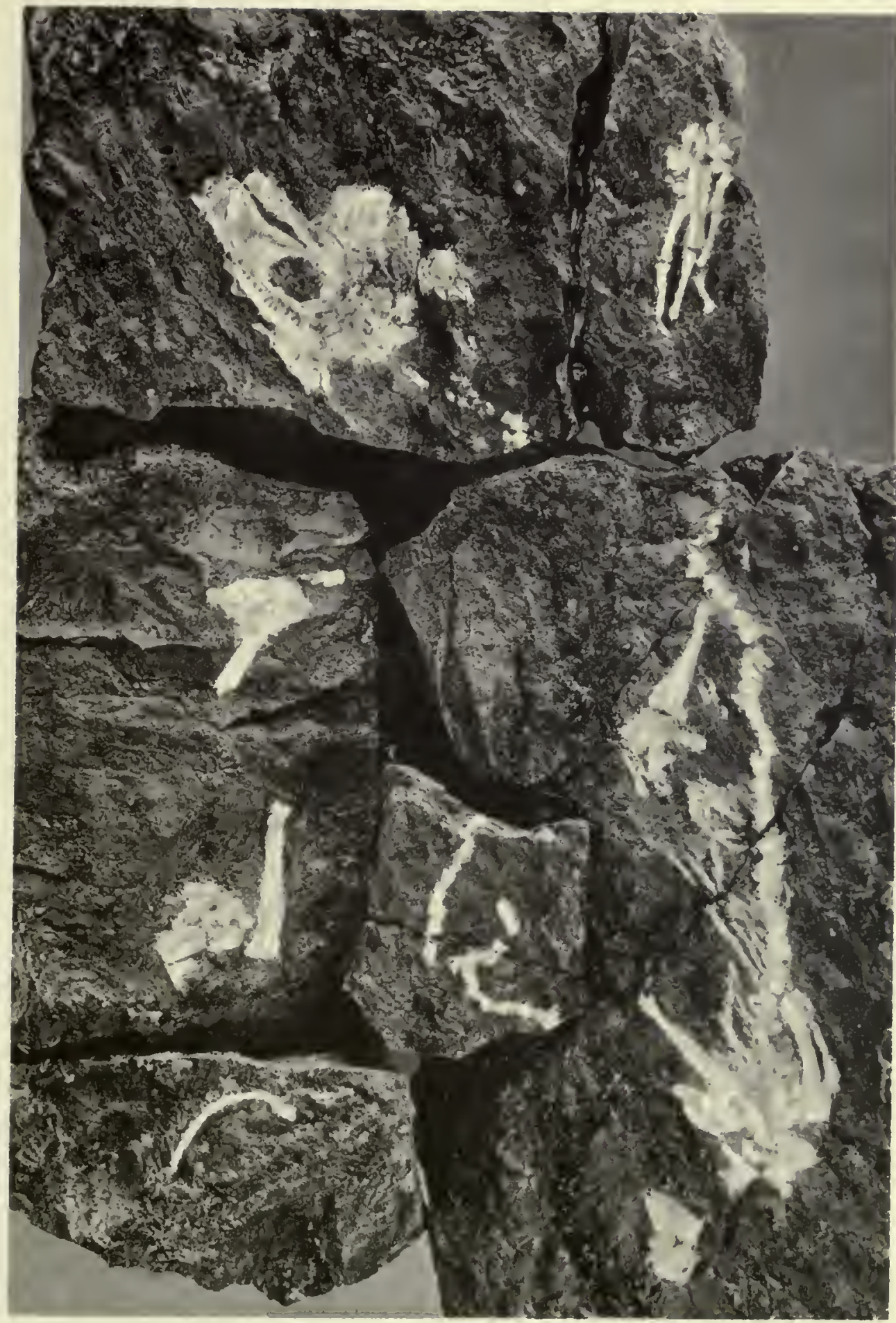

Hylonomus latidens Dawson. Skull, portion of skeleton, foot, scapula, sternal bones, humerus, and rib, believed to belong to this species. Erect tree, Coal formation, Nova Scotia. Nearly natural size. Photograph by Dawson, published through the courtesy of Dr. Arthur Willey. Original in the Peter Redpath Museum of McGill University. 

bræ of this species were found partially associated, indicating a long, slender body. The body is covered with scales and ventral scutellæ are present. Dawson questions whether this species may not be the young of $H$. lyelli.

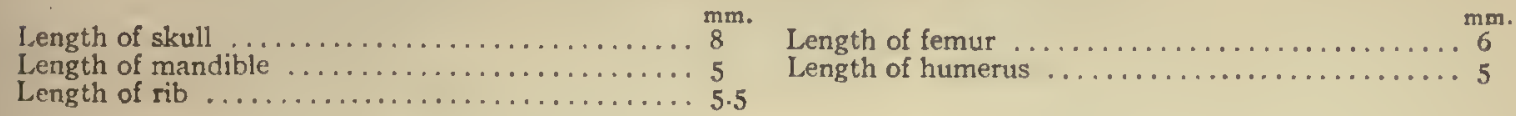

\section{Genus SMILERPETON Dawson.}

Dawsox, Phil. Trans. Roy. Soc., London, 1882, pt. II, p. 6.34.

D.1wson, Proc. and Trans. Roy. Soc. Canada, 1895, p. 74.

Type: Smilerpeton aciedentatum Dawson.

The type species was originally referred to IIylonomus, but further study induced Dawson to refer it to a new genus. Dawson gives (216) the following characteristics of the genus:

"Form somewhat elongated, and limbs short. Mandibular and maxillary teeth wedgeshaped, with cutting edges. Palatal teeth numerous, some of them large. Abdominal scales oval. A single species is known, S. aciedentatum, from the Coal Measures at the South Joggins, Nova Scotia."

\section{Smilerpeton aciedentatum Dawson.}

DAwson, Quart. Jour. Geol. Soc. London, Xv1, p. 275, figs. 19 to $23,1860$.

Dawson. Air-breathers of the Coal Period, p. 65, 1863.

Dawson, Phil. Trans. Roy. Soc. London, 1882, pt. II, p. 638, plate 40 , figs. 28 to 45 .

DAwson, Proc. and Trans. Roy. Soc. Canada, I 895, p. 75.

DAwson, Acadian Geology, 3d ed., p. 376.

Type: Specimen No. 306I-3, Peter Redpath Museum, McGill University. The British Museum (393, pt. IV, p. 224) also has a specimen, No. R 433.

The important characteristic (plate I2) is found in the form of the mandibular and maxillary teeth, which are of a peculiar wedge-shape, being broad and oval at the base and narrowed to a longitudinal edge at top. Thus, when viewed from the side they appear narrow and blunt, but when the jaw is broken across, and they are viewed from the rear or front, they appear broad and sharp-edged. The effect of this arrangement is that the jaw is armed with a closely placed series of chisels or wedges, giving an almost continuous edge. At the end of the mandible some of the tecth are longer and more conical.

Another important character is that the palatal and vomerine bones seem to have bristled with teeth, mostly of very small size; but there are also some larger palatal teeth, of which some are sharply pointed and others blunt with furrowed points.

The vertebræ are of the same type as those of Hylonomus; but some which appear to be caudal have a pointed spine above, indicating perhaps a flattened tail. The ribs are short and stout.

The body seems to have possessed an interclavicle and ventral scutellæ. Above it was, apparently, clothed with small tubercles and horny scales, and to have had cuticular pendants like those of Dendrerpeton. 
An additional species of this genus was apparently indicated by some fragmentary remains, but Dawson thought best not to deseribe them as such, since they might indicate only a young individual of the present species.

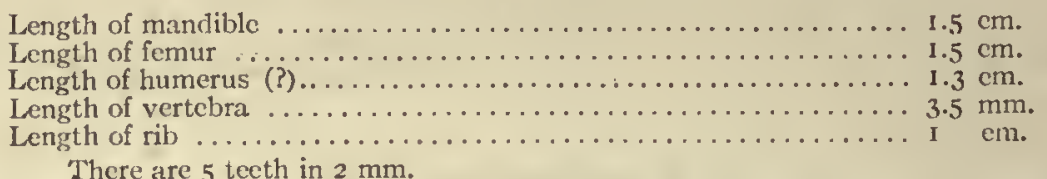
There are 5 teeth in $2 \mathrm{~mm}$.
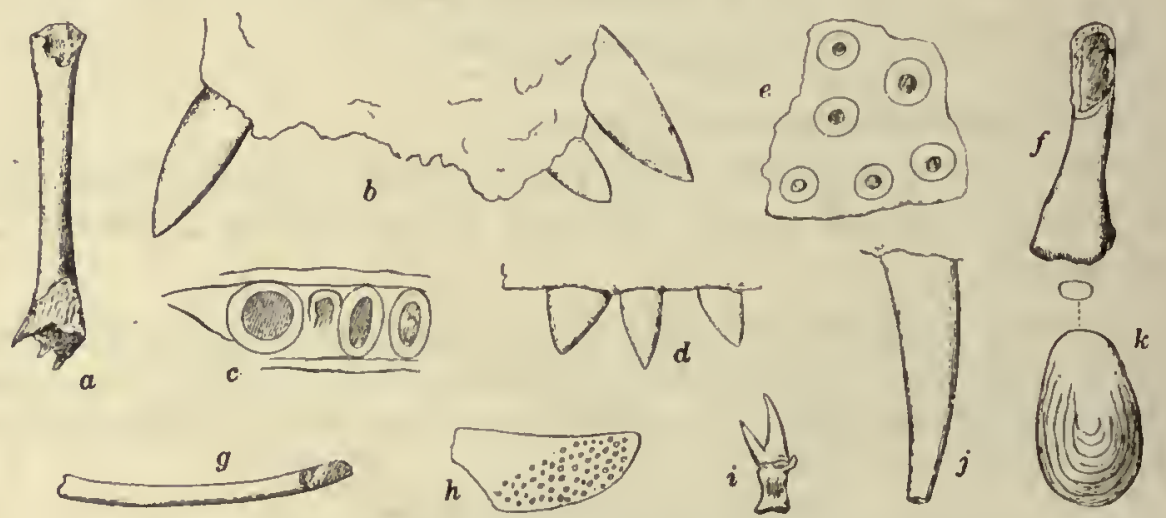

FIG. I8.- Skelctal elements of Smilcrpeton aciedentalum Dawson, from the Coal Mcasures of Nova Scotia. (After Dawson.) $a$, shaft of femur? $\times 2 ; b$, intermaxillary_and tceth, $\times 25 ; c$, scetions of teeth, $\times 25 ; d$ and $e$, palatal tecth, $\times 25 ; f$, feinur, $\times 2 ; g$, rib, $\times 2 ; h$, palate; $i$, caudal vertcbrx; $j$, long palatal tooth, $\times 25 ; k$, bony scale.

\section{Genus HYLERPETON Owen.}

OWEN, Quart. Jour. Gcol. Soc. London, XvıI, p. 24I, 1862.

Dawson, Amer. Jour, Sci. (3), x11, p. 443, I 876.

DAwson, Phil. Trans. Roy. Soc. London, 1882, pt. 11, p. 634.

Dawson, Proc. and Trans. Roy. Soc. Canada, 1895, p. 74.

Dawson, Air-breathers of the Coal Period, p. 55, pl. vi, figs. $32-46,1863$.

Body stout, with strong limbs. Mandibular and maxillary teeth strong, not numerous, grooved at apex. Palatal tecth numcrous, and some of them large. Thoracic plate broad. Abdominal scales pointcd or oat-shaped.

\section{Type: IIylerpeton dawsoni Owen.}

\section{Hylerpeton dawsoni Owen.}

OWen, Quart. Jour. Gcol. Soc., xvir, p. 241.

Dawson, Air-breathers of the Coal Period, p. 55, 1863.

DAwson, Acadian Gcology, p. 380.

Dawson, Phil. Trans. Roy. Soc. London, 1882, pt. I1, p. 639, pl. 41, figs. 62-85.

Dawson, Proc. and Trans. Roy. Soc. Canada, 1894, xir, p. 74.

Type: Specimen No. 306I-4, Peter Redpath Museum, McGill University. There are also specimens, Nos. R $44 \mathrm{I}$ and 442 , in the British Museum (393, pt. IV, p. 225). (Plate 7.)

Horizon and locality: Coal formation at the South Joggins, Nova Scotia.

Bones of skull slightly striated, but not sculptured as in Dendrerpeton. Lower jaw with distinct ascending ramus or coronoid process, a feature not known in any other of the Nova Scotia fauna, but observed by Cope in Brachydectes. Teeth, I2 in each ramus of the mandible, bluntly conical, slightly striated at the apex. Pulpcavities large and longitudinally striated at the sides, though the teeth are not 


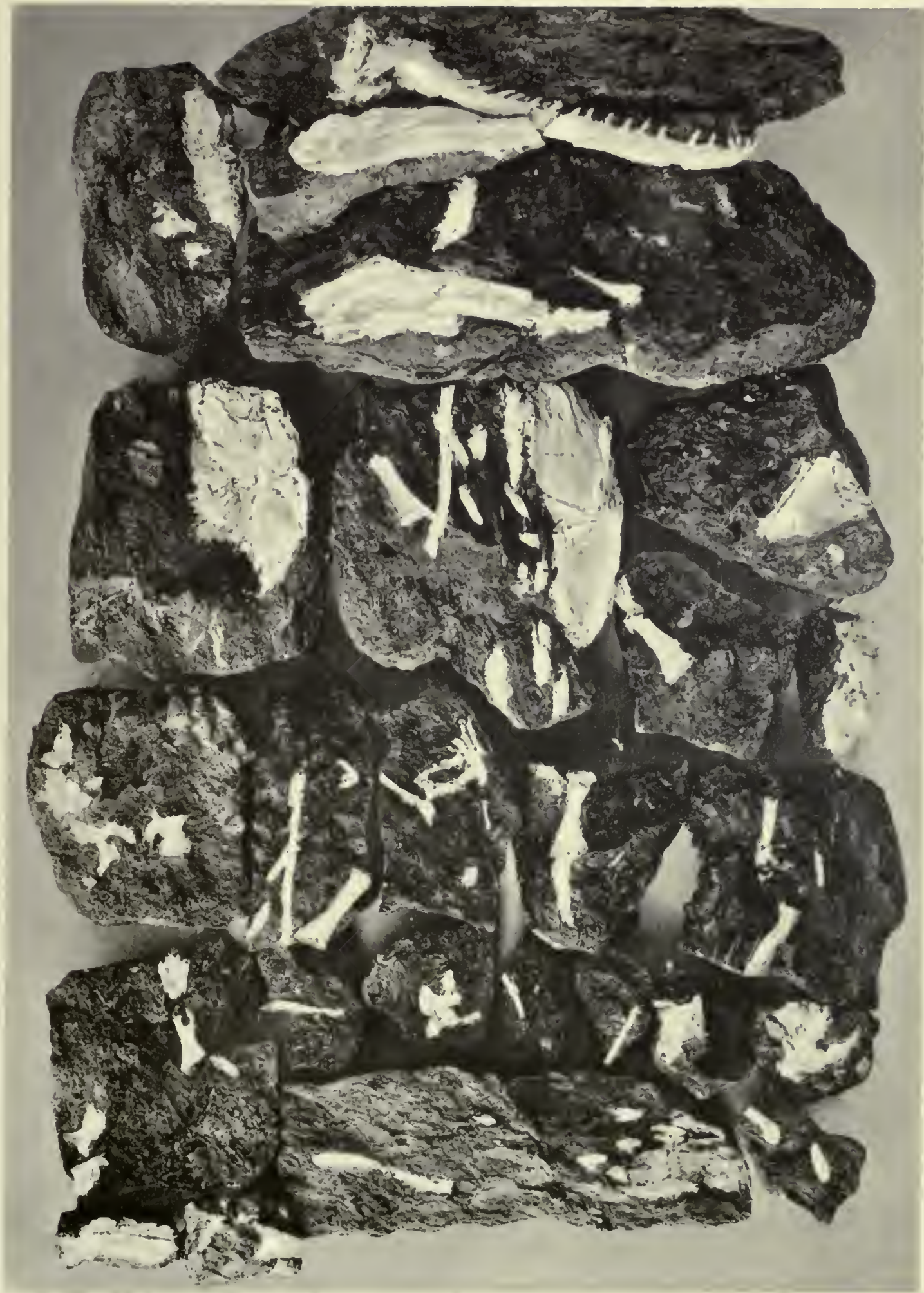

Hylerpeton longidentatum Dawson. Mandible and otherbones. Nearly natural size. Erect tree, Coal formation, South Joggins, Nova Scotia. Photograph by Dawson, published through the courtesy of Dr. Arthur Willey. Original specimen in the Peter Redpath Museum of McGill Iniversity. 



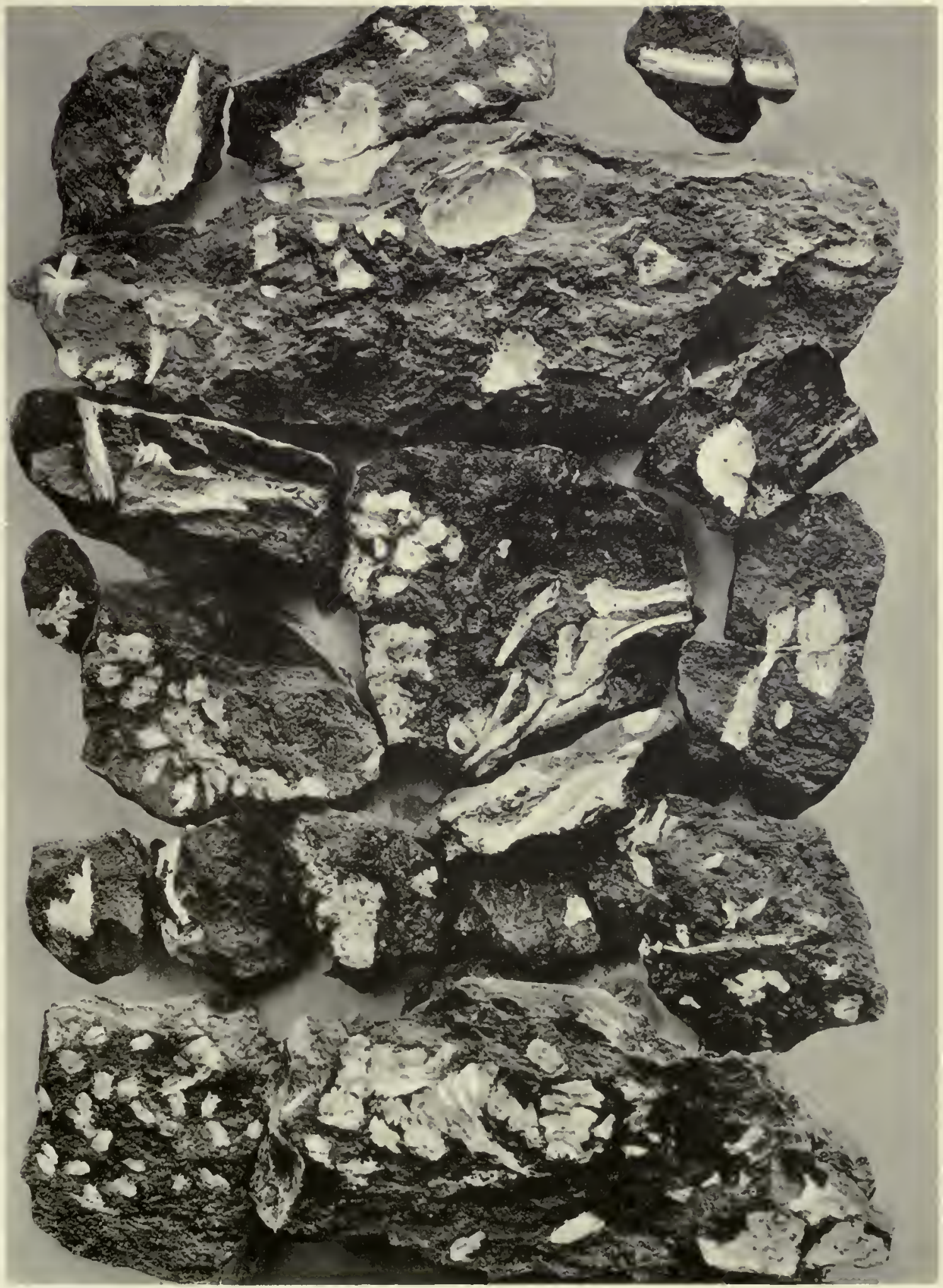

Similerpelon aciedenlalum Dawson. Mandible, portions of skull, scales, and various bones. Nearly natural size. Frect tree, Coal formation, South Joggins, Nova Scotia. Photograph by Dawson, puhlished through the courtesy of Dr. Arthur Willey. Original specimen in the Peter Redpath Museum of McGill Lniversity. 

folded. Maxilla furnished with similar teeth, one of which near the front is larger than the others. Palatal teeth numerous, small, conical, with a few large teeth at the sides.

Vertebra short, cylindrical, well-ossified, with well-developed zygapophyses and neural spines; ribs strong and much curved, with well-developed division of the proximal ends; pelvis imperfect, but apparently large, with broad ilium.

Humerus half the length of the mandible; radius half as long as humerus; femur very large and stout, nearly as long as the mandible; leg bones and phalanges correspondingly stout.

The thoracic plate (plate 7 ) is indicated only by some fragments. The abdominal scales are narrow and pointed (oat-shaped), smooth externally and with a ridge at one side within. The following are the dimensions of the largest specimen:

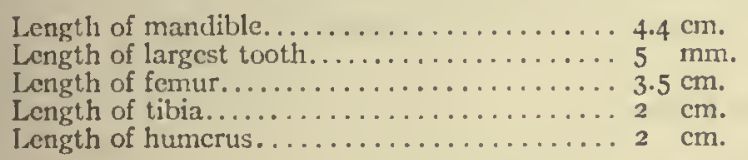

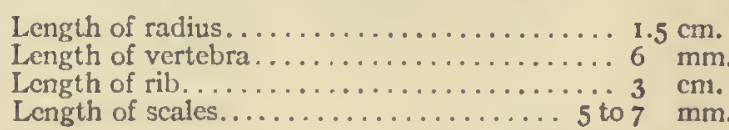

Length of scales.......................

\section{Hylerpeton longidentatum Dawson.}

Diwson, Am. Jour. Sci. (3), xu, pp. 440-447, 1876.

DAwson, Phil. Trans. Roy. Soc. London, I882, pt. 11, p. 640, pl. 42, figs. 86 to 109.

DAwson, Proc. and Trans. Roy. Soc. Canada, 1894, XI, p. 74.

Type: Specimen No. 3061-6, Peter Redpath Museum, McGill University. There is also a specimen, No. R 440, in the British Museum (393, pt. IV, p. 225). (Plate I I.)

Horizon and locality: Coal formation at the South Joggins, Nova Scotia.

Head much elongated, with the bones minutely pitted, and with delicate microscopic strix, but not sculptured. Mandibular and maxillary teeth long and acute, pointing backwards, with the apex of their inner sides finely striated; 20 or more in each ramus of the lower jaw; palatal bones with several long, slender teeth and many minute tceth. The mandibles found are not complete, but there are indications that there was an ascending process as in $H$. dawsoni, but less developed. The narrowness of the dentary bone is caused in part by the lower posterior edge being bent inward and by the posterior end being broken off above.

Vertebra short and stout, and apparently well ossified. Ribs long, with double head and much curved. Humerus longer than femur, which is short and stout, if the bone taken for it is rightly determined. Abdominal scales narrow, oat-shaped; thoracic plate large, broadly oval.

Measurements of HyLerpeton longidentatum Diwson.

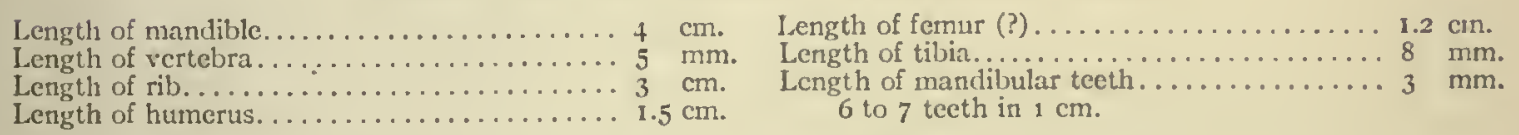

Hylerpeton intermedium Dawson.

Diwsos, Proc. and Trans. Roy. Soc. Canada, x11, p. 75, 1895.

Type: Specimen No. 3061-5, Peter Redpath Museum, McGill University. Horizon and locality: Coal formation at the South Joggins, Nova Scotia.

This species is known only by the mandibles and portions of the skull, which are rather shorter than those of adult individuals of the last species. The extremity of 
the mandible and the cranial bones have the same slightly waved surface as in the other species. Mandibles $3 \mathrm{~cm}$. long and the teeth, which are about 15 in each ramus of the lower jaw, are simple, with large pulp cavities, those of the maxillary bone slightly enlarging upwards, and intermediate in form between the long, slender teeth of $H$. longidentatum and the thick, obtuse teeth of $H$. dawsoni.

Coal formations, South Joggins, Nova Scotia, in erect tree, discovered by P. W. McNaughton, I 893 .

\section{Genus FRITSCHIA Dawson, 1882.}

Dawson, Phil. Trans. Roy. Soc. London, I882, pt. II, p. 634 .

LyDEKKER, Cat. Fossil Reptilia and Amphibia, pt. Iv, p. 225, I889.

Type: Fritschia curtidentata Dawson.

Body lizard-like; limbs large and well-ossified, mandibular and maxillary teeth conical, grooved at the apex. Abdominal scales slender and rod-like.

\section{Fritschia curtidentata Dawson.}

DAwson, Phil. Trans. Roy. Soc. London, I882, pt. II, p. 64I, pl. 43, figs. IIo-I 28 .

DAwson, Am. Jour. Sci. (3), XII, p. 444, 1876.

Type: Specimen No. 306I-7, Peter Redpath Museum, McGill University. There is also specimen No. R 449, in the British Museum (393, pt. Iv, p. 225).

Horizon and locality: Coal formation at the South Joggins, Nova Scotia.

Represented by 2 specimens (plate 8 ). Bones of the head very smooth, only a few microscopic punctures. Teeth conical, somewhat obtuse, striated at the inner side of the apices; there are about 30 in each ramus of the mandible, and about 27 in the maxillary bone. Teeth implanted in a furrow. Vertebræ short and well ossified, 3 in I cm. Ribs strong, curved, about I cm. in length. Limbs robust, the bones better ossified than in any other known species from Nova Scotia. Toes of foot probably 5, central ones long and slender. Interclavicle of moderate size and somewhat rounded. Ventral scutellæ needle-like.

Length of mandible (imperfect).......... $2.1 \mathrm{~cm}$. Length of maxilla.................. Length of rib.................. I $\mathrm{cm}$.

Length of humerus..............
Length of femur................. $2.4 \mathrm{~cm}$.

Length of radius and ulna................

Length of toe in foot.............. 8 teeth in $5 \mathrm{~mm}$. 


\section{CHAPTER XIV.}

\section{THE MICROSAURIAN FAMILY TUDITANIDA, FROM THE COAL MEASURES OF OHIO AND PENNSYLVANIA.}

\section{Family TUDITANID\&E Cope, 1875 .}

Cope, Geol. Surv. Ohio, II, pt. 11, p. 357, 1875.

Lizard-like microsaurians; cranial elements strongly sculptured with pits or grooves or almost smooth, with weak punctulations. Orbits usually well forward; squamosal sometimes excluded from the parietal; skull hornless; teeth pleurodont, conical and sharp, smooth or slightly plicate; clavicle of a triangular shape, which is characteristic of all the species; vertebræ well developed and phyllospondylous, the osseous portion being merely a hollow cylinder, hour-glass-shaped; ribs curved, long, attenuated and intercentral; digits clawed; ventral armature absent in all but a single species and the association of the species is doubtful; tail moderate in length. Three genera with 13 species included in the family. These species are:

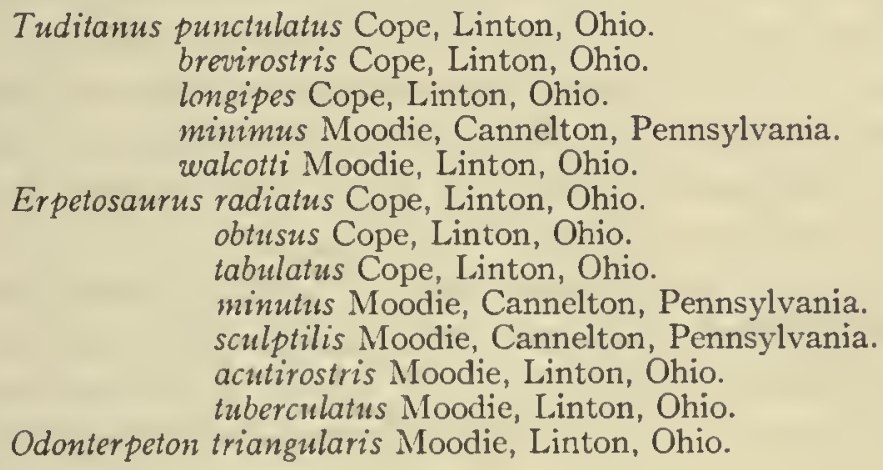

Odonterpeton triangularis Moodie, Linton, Ohio.

The association of these species in the one family is provisional and will need revision on the acquisition of new and more complete material.

\section{Genus TUDITANUS Cope, 1874.}

Cope, Trans. Amer. Phil. Soc., xv, p. $271,1874$.

Cope, Geol. Surv. Ohio, II, pt. II, pp. 39I, 1875.

\section{Type: Tuditanus punctulatus Cope.}

The genus as here defined is a somewhat composite group and it is quite probable that some of the species here included will have to be removed to another genus when the anatomy of the forms is better known. The species of the genus are all moderately small, the largest barely attaining a length of 8 inches.

There are 5 species of Tuditamus thus far known. All of the species are characterized by the possession of a peculiar triangular-shaped clavicle with radiating grooves, and this has been taken as one of the distinctive characters of the genus, as well as of the family. The structure of the cranium where known is quite uniform 
among the different species. The squamosal is quite large and the supratemporal is not always closely joined to the parietal. The species are:

Tuditanus punctulatus Cope, Linton, Ohio. brevirostris Cope, Linton, Ohio.

longipes Cope, Linton, Ohio.

minimus Moodie, Cannelton, Pennsylvania.

walcotti Moodie, Linton, Ohio.

\section{Tuditanus punctulatus Cope.}

Cope, Trans. Amer. Phil. Soc., xv, p. 271, 1874.

Cope, Geol. Surv. Ohio, II, pt. II, p. 392, pl. xxxiv, fig. I, 1875.

Type: Specimen No. I Io, American Museum of Natural History, where there is also specimen No. I I I.

Horizon and locality: Linton, Ohio, Coal Measures.

This species, together with the form, T. brevirostris, described on $p .88$, was used by Cope as the type of the genus Tuditanus. Cope subsequently associated some reptilian remains from the Linton mines with the type of $T$. punctulatus and changed the generic term to Isodectes, which was known by another species, I.megalops Cope, from the Permian of Texas. The remains associated by Cope with $I$. megalops undoubtedly represent a reptilian species and which has been described elsewhere under the name Eosauravus copei Williston. The species is of exceeding interest because it is the oldest known reptile and places the range of the Reptilia down towards the base of the Pennsylvanian.

The species Tuditanus punctulatus Cope was founded on well-preserved remains of nearly the entire skeleton of a single individual. The bones are represented by shining carbonaceous matter, and since both of the slabs containing the impression were preserved, a great many characters have been determined. The head, I forelimb, and 23 consecutive vertebræ with ribs are well defined, but of the pelvis and hind limbs nothing is visible.

The cranium (fig. I9) is very similar to that of T. minimus, from the Cannelton, Pennsylvania, slates. It is triangular in shape, with a narrowed obtuse muzzle. The orbit of the left side is well defined and lies well forward. It is oval in outline and its width is about two-thirds of its length. The nostrils are small and are located well toward the tip of the muzzle. The parietal foramen lies behind the median transverse line which divides the skull equally.

The cranial elements are for the most part destroyed, but the outlines of a few can be determined. Those elements which are preserved are ornamented with a sculpturing of minute punctulations which, on the postfrontal, assumes a radiating arrangement. The ornamentation of the other elements consists of inosculating pits, but they seldom assume the form of ridges or grooves. The bones of the premaxillary region of the cranium are lacking. The first element which can be detected is the prefrontal, which occupies a position in front of the orbit. There seems to be space for a lacrimal, but its outline is not distinct. The frontal can be readily separated and is seen to be an elongate element occupying the median region 
of the skull between the orbits. The parietal is apparently the largest element of the cranial roof and the pineal foramen is located in the anterior fourth of the median suture separating the parietal elements. The form of the postparictal and the tabulare can not be determined, as the greater part of this region is lacking. The squamosal secms to be located well forward and is rather small, but has the usual relation of this element. Only fragments of the other elements remain and nothing can be said of their form. The mandibles of both sides are represented by depressions, and they are ornamented with longitudinal grooves and ridges. The teeth are not preserved, but there are evidences of the maxillary teeth. These are minute and sharply conical. Just posterior to the skull there is preserved the impression of a short, round rod which is not definitely determined. It may be an element of the hyoid apparatus, although it is rather stout for such. It does not have the relations indicated by Cope in his figure (I23, pl. xxxiv, fig. I).

There are three elements of the pectoral girdle preserved. These undoubtedly represent the interclavicle and the clavicles. The interclavicle is rhomboid in shape and is attenuated posteriorly. The attenuation is abruptly truncate posteriorly and it is thus of quite a different character from the acutely pointed interclavicle of T.minimus. The clavicle has a somewhat semicircular form, but is not attenuated at either end. It seems to be uniformly broad.

The forearm of the right side is preserved in part. The humerus is seen to be a heavy, somewhat expanded element lying displaced with relation to the pectoral girdle. It is greatly expanded at the ends. The ulna presents characters similar to the humerus and only differs from it in being shorter and less stout. The radius is not preserved. The carpus is unossified and its position is occupied by a blank space. The digits are represented by 4 metacarpals, and this may have constituted the entire number of the fingers. The phalangeal bones preserved are a little scattered. They are clongate with expanded ends.

Evidences of 23 consecutive osseous vertebræ are preserved. Their character can not be determined, al-
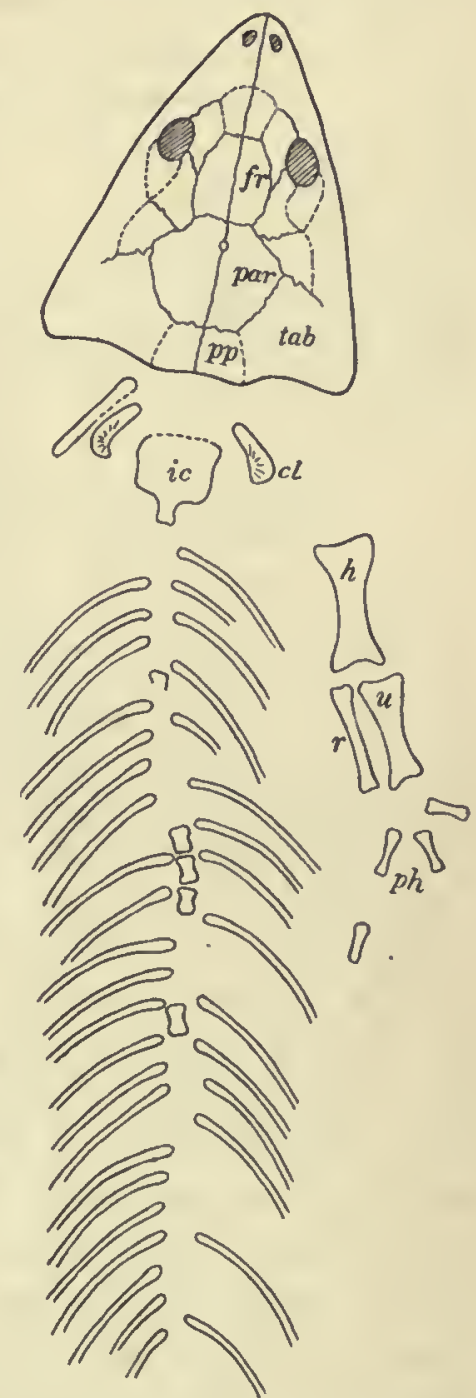

Fig. 19.-Drawing of skull and skeletal elements of Tuditanus punctulatus Cope from the Coal Mcasures of Linton, Ohio. $X$ 1.5. fr, frontal; $i c$, interclavicle; $c l$, clavicle: $h$, humerus; $p h$, phalanges; par, parictal; pp, postparietal; tab, tabulare, supratemporal and squamosal; $u$, ulna; $r$, radius. though Cope (123) describes them as amphicoelous. This may be inferred to be the case, but I am unable to verify his observation. In form the vertebræ are subquadrate. The neural spines are not evident. The osseous ribs articulate, apparently, between the bodies of the vertebræ. Cope figured them as intercentral. There are 22 
or 23 pairs preserved. They are single-headed and the extremities are attenuated. No traces of ventral scutellæ are present.

The entire length of the animal probably did not exceed 5 or 6 inches. Its form was quite lizard-like and it was probably of an ambulatory type, though it may have spent a part of its time in the old lagoon in which its remains were finally buried. No traces of external gills have been detected in this or any other Linton species.

Measurements of the Type of Tuditanus punctulatus Cope.

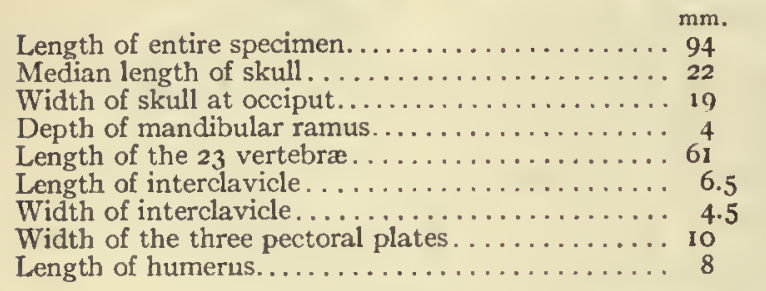

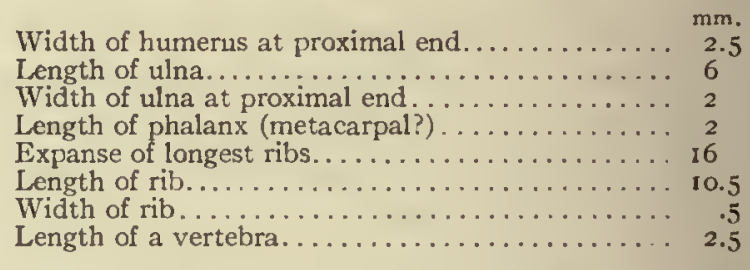

Tuditanus brevirostris Cope.

Cope, Trans. Amer. Phil. Soc., xv, p. 272, 1874.

Cope, Geol. Surv. Ohio, II, pt. II, p. 393 , pl. xxvi, figs. $3,4,1875$.

Moodie, Bull. Amer. Museum Natl. Hist., Xxvi, art. XXv, pl. Ixiv, fig. 4, I909.

Type: Specimen No. 8609 G, American Museum of Natural History.

Horizon and locality: Linton, Ohio, Coal Measures.

This species was associated by Cope with the type $T$. punctulatus in the description of the genus. Represented by a portion of the skeleton of one individual, the skull is preserved on one block, with a considerable part of the anterior ribs, pectoral girdle, and vertebral column, although this last is not clearly represented, but as in so many of the coal specimens the bones are covered with a thin layer of carbonaceous matter which makes it impossible to definitely determine the form.

The cranium is large in proportion to the size of the body. The skull is in the form of a wide oval and is wider than it is long. The elements of the skull were ornamented with a coarse sculpturing which partakes of the nature of incomplete radiations on the squamosal region. The different elements of the cranium can not be distinguished, although I think the outlines of the parietal are indicated. The position of the nostrils is well forward and they are slightly elongate transversely. The pineal foramen can not be determined. The orbits are oval in shape and their width is about equal to two-thirds of their length. The interorbital space is greater than the length of the orbit. Cope's figure of this specimen is not accurate, since he has the orbits drawn too far to the side. They are located near the central line of the skull and resemble in some respect those of the preceding species. Cope has described teeth in the maxillary region, but I am unable to detect them. There are portions of two pectoral elements which may represent a clavicle and a portion of the interclavicle.

The clavicle has much the same shape and practically the same ornamentations as has the clavicle in Tuditanus minimus. The clavicle preserved shows a somewhat triangular shape and is slightly acuminate at the anterior end, as preserved, and obtuse at the posterior end. The nature of the interclavicle can not be determined. 
The vertebral column is represented by a line which Cope suggests (I23) may be the chorda dorsalis (notochord). Osseous vertebræ were probably present, but their nature is obscured by the carbonaceous matter covering them.

The ribs as preserved are long and curved. They are slender and attenuated at the distal ends. They were probably single-headed, but whether their articulation was intercentral or not can not be determined.

The other specimens which are referred to this species show nothing of importance in the way of structure. They consist for the most part of fragments which may or may not represent the species.

The species differs from the type of the genus ( $T$. punctulatus) in the possession of a broadly rounded muzzle. This character will also separate it from other species of the genus. The sculpturing of the bones of the cranium is coarser in the present species than in the type. The form of the clavicle is different in the two species. The above-described species seems to be more closely allied to the form described as Tuditanus walcotti than to other species of the genus. I have been unable to detect the presence of limbs, although Cope says they are present.

Measurements of the Type of Tuditanus brevirostris Cope. $\mathrm{mm}$.

Median length of skull................. 15

Width of skull at posterior border.......... 18

Width of skull across orbits. ............. 11.5

Length of orbit................... 3

Width of orbit..................... 2

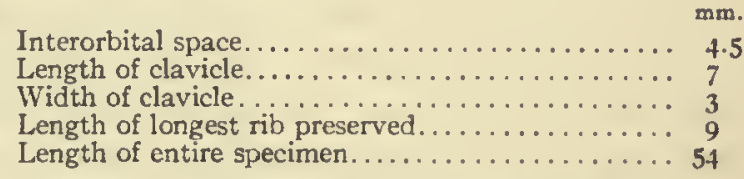

The material consists of the type specimen with counterpart and two fragments which probably are to be associated with this species. Collected by Doctor J. S. Newberry.

Tuditanus longipes Cope.

Cope, Trans. Amer. Phil. Soc., xv, p. 2 10, 1877 (Sauropleura).

Cope, Geol. Surv. Ohio, iI, pt. II, 398, pl. xxvi, fig. 2, 1875.

Type: Specimen No. 1099 G, American Museum of Natural History.

Horizon and locality: Linton, Ohio, Coal Measures.

The cranium of this species is quite unknown. The only genus with which the specimen can be compared in the structure of the skeleton is Tuditanus. From the other species of the genus the present form differs in the presence of ventral chevron rods and the elongate character of the limbs, as well as in the possession of large iliac bones, which, in the only other species in which the ilia are known, are small and slender. It seems best to locate the species in this genus for the present, although it may eventually have to be removed to another group. Very little is known of the main portion of the skeleton of the species of Tuditanus, other than in T. longipes, so an exact comparison is impossible. From all the species of Tuditanus thus far known the present species differs in the elongate character of the limbs and in the presence of ventral scutellation. There are three other species of Tuditanus in which the limbs are known. These are: T. walcotti Moodie, T. minimus Moodie, and $T$. punctulatus Cope. In these three species the limbs are short and weakly developed. From the other species of Tuditanus the present species may be separated by its size principally, since nothing of the bodies of the other species is known. 
The body of the present species is elongate and slender, with a long neck and probably a long tail. Ribs, as preserved, are 19 to 22 , though there may possibly have been more. They are moderately curved backwards, have intercentral articulation, are attenuated at the distal extremity, and are single-headed. The anterior ribs are stouter, with a widened upper portion and attenuated distal part. The posterior ribs are more slender.

There are evidences of 28 vertebræ present. All regions of the vertebral column are present and the dorsal region is preserved entire. The cervical series is represented by the posterior vertebræ only. These are very indistinctly preserved. The dorsal vertebræ are elongate and were probably amphicœlous, although this has not been definitely determined. They are expanded at each end, thus ending in a slightly raised rim. The single-headed ribs articulate between the vertebræ. The exact number of the dorsal series can not be ascertained, although this may have been 25 . The spines of the vertebræ are not determinable, since the animal is preserved on its back. The caudal vertebræ are represented by two patches of the remains of what was once probably the entire series. Cope ascribes 70 $\mathrm{mm}$. to the tail, but I do not find that much. The specimen may have been mutilated since he studied it. The caudals are slender and, like the dorsals, are expanded at the extremities.

The scapular arch is not preserved, but the pelvic arch is represented by the two iliac bones in good state of preservation. These are short, flat bones expanded at the anterior extremity, as preserved. They lie turned a little to each side of the vertebral column and partially obscure the femora. The iliac bones

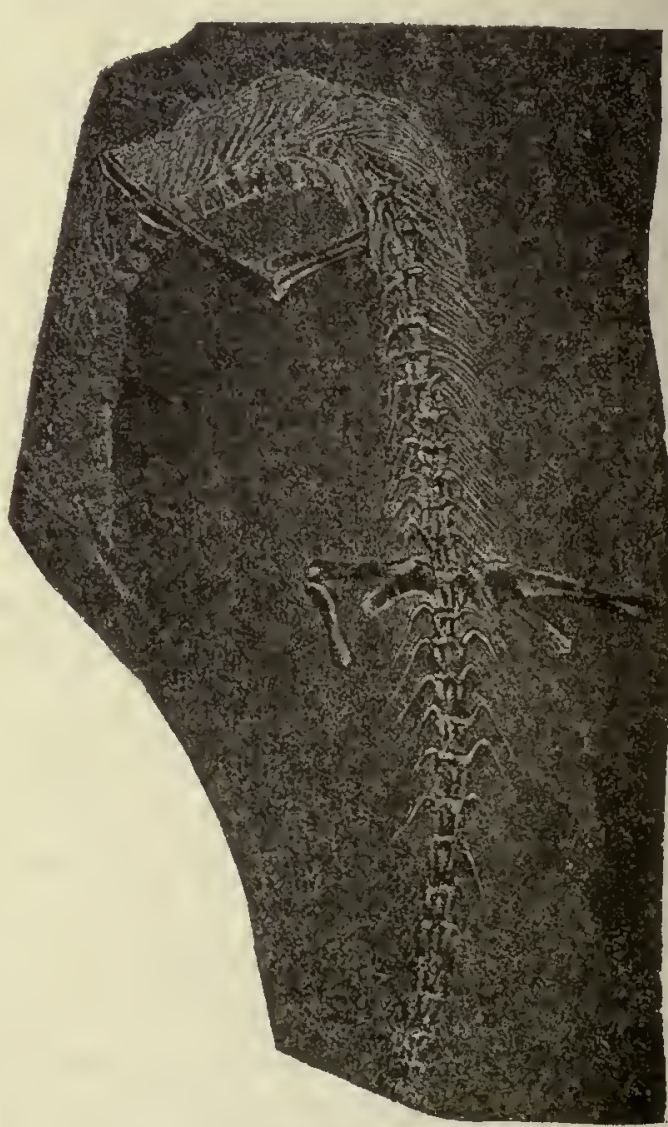

FIG. 20.-Cope's drawing of Tuditanus longipes, from the Linton, Ohio, Coal Measures. $X I$. are quite characteristic of this form, since similar-shaped elements have not been observed in any of the other Carboniferous forms from the same deposit.

The greater part of the forelimb is preserved, although much of the hand is missing. The humerus is an unusually elongate bone and lies somewhat across the vertebral column. It is crushed flat and the ends are partly destroyed. It shows evidences of expansion at the ends, although not a great deal. It is much longer than the radius and ulna, which are of about equal length. The ulna is larger than the radius and has expanded ends, with the upper end more expanded than the lower and both ends slightly truncate. The radius is a simple rod of bone and is but slightly expanded. The carpus was evidently cartilaginous, since there is no evi- 
dence of osseous material in its place. There is but one phalangeal bone preserved, and, since this is displaced with reference to the ulna and radius, its position can not be determined. It may have been a metacarpal. It is short and expanded at the ends.

The hind limbs are represented by the two femora and the upper portion of the tibia. The femur is almost as elongate as the humerus and is more slender. It is not so much expanded as the humerus. Its ends appear to have been cartilaginous and do not represent the well-formed articular surfaces preserved in the T. minimus. The upper part of the tibia is preserved, and appears to have been truncate.

If this species belongs with Tuditamus it is of interest in that the ventral chevrons are present. The species is particularly characterized by the clongate limbs.

Measurements of the Type of Tuditanus longipes Cope. $\mathrm{mm}$.

Length of vertebral column between pelvis and end of humerus........................ 70 Length of vertebral column anterior to humerus..... 18 Length of caudals present................ 42

Length of humerus................... 19

Width of humerus...................... 2

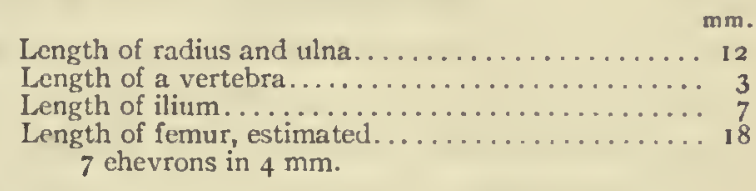

Tuditanus minimus Moodie.

Moodie, Jour. Geol., xvil, No. 1, p. 56, fig. 10, 1909.

Moodie, Proe. U. S. Nat. Mus., 37, p. 23, pl. 8, fig. 2, 1909.

Type: Specimen No. 4555, U. S. National Museum.

Horizon and locality: Cannelton slates of Pennsylvania (Upper Freeport).

The species is represented by a nearly complete skeleton preserved on a slab of slate from the Cannelton shales of Pennsylvania. The obverse slab has been lost, which is very unfortunate, since there is no doubt that the entire skeleton was originally present. The species is placed in the genus Tuditanus on account of the close resemblance to the type form $T$. punctulatus Cope, although it is much smaller than that species.

The type specimen of the species did not attain a length of more than 3.5 inches. Its form is very lizard-like, but its structure is typically amphibian. The form of the skull is especially similar to that of the type species $T$. punctulatus, which it resembles in the narrow posterior truncation of the skull, as well as in the anterior position of the orbits.

The skull is in the form of a narrow oval, sharply narrowed posteriorly and truncate. The orbits are located well forward and their posterior border lies in front of the line dividing the skull transversely into equal parts. The interorbital space is greater than the diameter of the orbit. Impressions of teeth are preserved on the premaxillæe and maxillæ; there are 8 of them in a distance of $3 \mathrm{~mm}$. The teeth appear to be mere blunt denticles and were possibly pleurodont.

The elements of the cranium are very poorly preserved. It has been impossible to determine all of the sutures. The bones of the premaxillary region have been destroyed, but the arrangement of them was probably not far different from that which obtains in other members of the genus. The posterior boundaries of the nasals 
are preserved and prove this element to have had an obtuse posterior border. The sutures bounding the frontals are clear and show that they were small and that they formed a part of the inner boundary of the orbits. The parietal is recognized as a large element, apparently the largest in the skull. Together the parietals form a wide oval inclosing, on the median suture, the circular pineal foramen. The parietals are sculptured with coarse radiating grooves and ridges, much after the manner of Erpetosaurus radiatus Cope. The pittings present on that form are, however, absent in T. minimus. The sutures bounding the postparietal are tolerably well defined and these show that element to have been rather large and quadrate, with the usual relations. The tabulare is distinct, triangular, and small. It is produced into an angle on the posterior border strongly recalling a similar condition in $T$. punctulatus. The boundaries of the prefrontals and the upper borders of the maxillæ are not clearly ascertained. The lacrimal has not been detected. The postfrontal and postorbital form the posterior boundary of the orbit, although all of the limits of the latter element have not been definitely determined. The position of the supratemporal is well assured, although its entire boundaries are not determined. It has the usual relations and joins the parietal broadly. The jugal is broad and widens posteriorly to join the squamosal, which, as usual, forms the quadrate angle of the skull. The sutures bounding the quadratojugal and the posterior end of the maxilla are not determined.

There are but two fragmentary vertebræ preserved and an estimate based on the length of these remains gives about 30 presacral vertebræ. The structure of the vertebræ preserved can not be ascertained, but the neural spines appear to have been low and stout.

There are six elements of the pectoral girdle preserved. These are: the six clavicles, the interclavicle, the coracoid of one side, and the two scapulæ. The interclavicle is rhomboid in form and acuminate posteriorly. It is sculptured with radiating grooves and ridges. It is quite different from the same element in $T$. punctulatus, in that the base is acuminate, not truncate. The clavicle presents much the same shape as does that element in Erpetosaurus tabulatus. It is ornamented by a sculpturing of radiating lines which take their origin from the lower external angle as the bone lies in the matrix. 'The clavicle is somewhat triangular in shape and lies close to the skull, but this close approximation of the pectoral elements to the cranium is due probably to post-mortem shifting, since the scapulæ are shifted backward. There can be little doubt, however, that the pectoral arch was close to the cranium. There is an oval fragment preserved on the left of the specimen which I take to be a portion of the coracoid. The scapula is preserved entire on the left side and is represented by fragments on the right side. It is almost semicircular in form and narrows externally until it is somewhat fan-shaped. There appears to be an ornamentation of lines on the surface of the bone. These lines follow the contour of the anterior border.

The arm is preserved nearly complete on the left side, and the right side shows the humerus and the forearm. The humeri are unusual in having well-developed 
articular ends as though the endochondral tissue was well developed. The humerus is expanded at the ends and it is larger at the upper than at the lower end. The ulna is expanded at the proximal extremity, but is more attenuated at the distal portion. It is shorter than the humerus by about one-third of its own length. The radius is a mere slender rod of bone and presents well-developed articular ends. It is slightly shorter than the ulna. The carpus is unossified and its position is represented by a blank space. There are phalanges of 4 digits preserved and they are 4 in number. The phalangeal elements, like the other bones of the extremity, have the articular surfaces prominent, with the terminal phalanx claw-like.

There are no ribs nor traces of them preserved, and a conjecture as to their character can not be hazarded, since they are known in but two other species, in which they are slender and curved. There is no evidence of a ventral scutellation, and so far as is at present known this structure is absent from all of the species of the genus, or at least it is weakly developed.

The ilium is all that is preserved of the pelvis. The bone itself has disappeared and has left a depression which shows this element to have been an elongate rod very similar to that described for Micrerpeton. The sacral vertebra seems to be indicated by a depression between the iliac depressions.

One hind limb is preserved nearly entire and the greater part of the other is also preserved, although some of the phalanges are disturbed. The femur is slender and more elongate than the humerus. It has well-formed, rounded, articular ends. The tibia presents unusual characters in that its ends are truncate, as though the cartilage composing its articular surfaces was not so highly calcified as in the other limb bones. It is somewhat expanded at the ends and is throughout its length broader than the femur. The fibula, like the tibia, is a slender rod of bone, although it is somewhat shorter than the tibia. The tarsus is unossified and its position is occupied by a blank space. Portions of both feet are preserved, but only one digit in the right foot is complete. The metatarsals are elongate and slightly expanded at the ends. There are 4 phalanges present in the complete digit, which possibly represents the fourth. The first digit is wanting, with the only terminal phalanx preserved claw-like.

Measurements of the Type of Tuditanus minimus MoOde.

\begin{tabular}{|c|c|c|c|}
\hline & $\mathrm{ms}$ & & \\
\hline Median length of $\mathrm{s}$ & & Width of scapula, maximum $\ldots \ldots \ldots \ldots$. & \\
\hline h of orbit. & & $\begin{array}{l}\text { Length of coracoid (?).... } \\
\text { Length of humerus...... }\end{array}$ & \\
\hline .......... & $\begin{array}{l}3.5 \\
2\end{array}$ & Length of radius and ulna... & \\
\hline th & 2.5 & Length of metacarpal. ............. & I \\
\hline $\mathrm{cl}$ & 6 & of ilium.............. & 2.5 \\
\hline imur & $3 \cdot 5$ & of femur.. & 4.5 \\
\hline estimated. & & 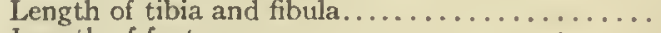 & 3 \\
\hline & 3. & Length of foot....... & 3.5 \\
\hline igth of scapula. & 3.5 & Length of metatarsal.......... & \\
\hline
\end{tabular}

Tuditanus walcotti Moodie.

Moodie, Proc. U. S. Nat. Mus., xxxvir, p. 16, pl. 6, figs. I, 2; pl. 7 ; 1909.

Type: Specimen No. 4474, U. S. National Museum.

Horizon and locality: Linton, Ohio, Coal Measures. 
A small species of Microsauria is preserved as a smooth impression on a block of soft coal from Linton, Ohio. Nearly the entire form of the body is discernible. The specimen is especially interesting and valuable as exhibiting for the first time among the Linton forms the shape of the body of the small microsaurians of the Tuditamus type. It differs so markedly in the form of the skull from other species of the genus that it is regarded as a distinct form, and the name Tuditamus walcolti was proposed for it as an expression of the writer's indebtedness to the Secretary of the Smithsonian Institution for the use of the material among which the present form was included.

The specimen includes, besides the body impression, the complete skull, a right clavicle, with portions of the left, a left humerus, 12 cervical and dorsal vertebræ, Io pairs of ribs somewhat disturbed as to position, and a portion of the mandible. There are no traces of ventral scutellæ nor body scales in the smooth impression of the carbonized skin. One would expect to find impressions of the ventral scutæ in this specimen if they were present. Cope remarked on the apparent absence of scutellæ from members of the genus Tuditanus as they were known to him, and no contrary evidence has since been brought to light. Until such evidence is forthcoming the absence of scutes will be taken as one of the generic characters of the genus Tuditanus. Under a magnification of 50 diameters the carbonized skin shows as folds and wrinkles, like muscle fibers, in some places; in others no traces of the muscular structure can be detected. The wrinkles may be impressions of the internal musculature of the body-wall of the abdomen. It is especially well preserved in the pelvic and pygal regions. Sections of the coal were made, but nothing definite could be determined as to the character of the impressions, as they were too poorly preserved and the coal was too soft to bear much handling.

The specimen is preserved on the belly, with the dorsum of the skull uppermost. It has been practically impossible to determine the arrangement of any of the cranial elements except the frontals, parietals, and postparietals, which have the relations indicated in

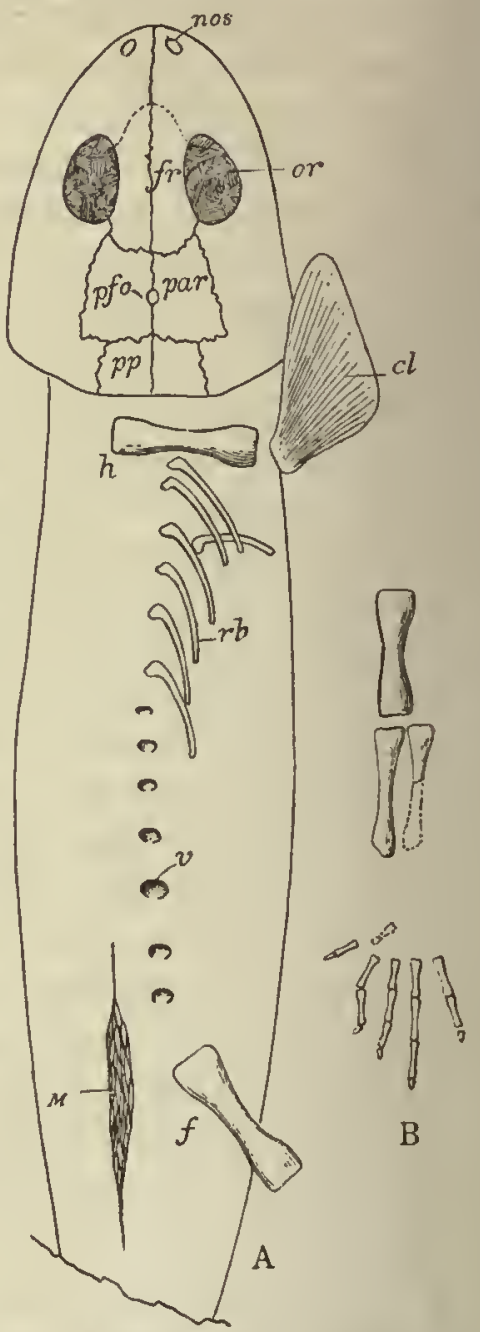

FIG. 21.-A. Outline drawing of type of Tuditanus walcotti Moodie, from the Coal Measures of Linton, Ohio, showing impression of body and muscle at $M$. $\times 25$. $c l$, clavicle; $f r$, frontal; $f$, femur; $h$, humerus; nos, nostril; or, orbit; par, parietal; $r b$, rib; $p p$, postparietal; $\varepsilon$, vertebra; $p f o$, pineal foramen.

B. Left leg of second specimen of Tuditanus walcotti. $\times 3$. figure $21, A$. A median suture is clearly evident, with the pineal foramen well back in this suture. The bones of the skull are marked with faint radiating lines. It is in the form of the skull and the position of the orbits that the specific characters are found, as follows: the backward position of the eyes and the oval, pointed shape of the skull. The species is closely related to Tuditanus minimus 
Moodie, from the Cannelton slates of Pennsylvania, and serves further to connect the forms from the Ohio and Pennsylvania localities. It differs from the last-named species in the position and form of the orbits, these structures being more oval in the present form and placed further back. The shape of the skull differs also in the almost entire absence of the posterior table. The median points of the orbits occupy the line which bisects the skull, and the interorbital width is less than the width of the orbit. The mandible is heavy and appears to have borne sharp, pleurodont teeth.

The vertebral column is represented by little more than a mold of the form of the vertebræ, so that little can be said of its character. 'The individual vertebræ are short and hour-glass-shaped. The ribs are borne intercentrally, as in all the microsaurians which have been studied from the Linton deposits. The ribs are rather long and somewhat heavy, slightly curved and expanded at the proximal end, as though an incipient bicipital condition were present.

The right clavicle, which is preserved as an impression, is entire. Its impression shows this element to have been ornamented on its ventral surface with radiating grooves and ridges which started at the lower angle of the bone. The elcment is distinctly triangular, which is characteristic of the genus Tuditanus, so far as known. The fragment of the left clavicle adds nothing to our knowledge of the element.

The left humerus recalls in a striking way that of Tuditanus longipes Cope, and it was once entertained as a possibility that the present form might be a member of that species, since the skull is lacking in $T$. longipes. Sufficient specific differences were found, however, in the ribs, which, in $T$. longipes, are very long, slightly curved, and delicate, but which, in the present form, are comparatively heavy. Other characters sufficiently diagnostic are found in the form assumed by the vertebræ in the two forms.

Measurements of the Type of Tuditanus walcotri Moodie.

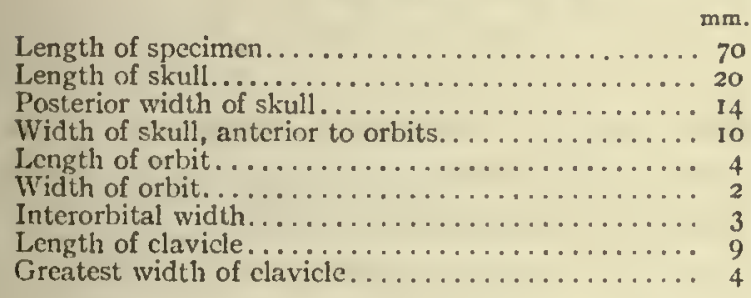

$\mathrm{mm}$

Length of vertebral column, as preserved..... 50

....... 1.75

Width of body impression............. 15

Length of humerus................ 6

Median width of humcrus............... .50

Width at end of humerus. . . . . . . . . . . $2_{2}$

Length of rib...................... 8

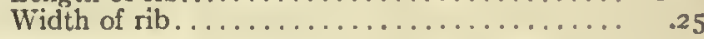

The above-described specimen was collected by Mr. R. D. Lacoe, of Pittston, Pennsylvania, from Linton, Ohio.

A second individual (No. 448I, U. S. National Museum) of this species is indicated by a rather poorly preserved specimen on a slab of soft coal from the Linton mines. The following portions of the animal have been detected and will be discussed: partial impression of the skull, with a fragment of a minute jaw, in which are minute teeth; right clavicle; part of the impression of the body; nearly cntire left hind limb; impressions of about a dozen vertebræ, very indistinct.

The impression of the skull is distinct only in a favorable light, and even then the boundaries of the cranium are a little uncertain. For this reason no representation 
of the form will be attempted. The sculpturing on the parietals is, however, distinct enough to show relationship with the previously described specimen, and the form of the body impression, the absence of abdominal scutes, the shape of the clavicle and its sculpture, and the proportions of the hind limbs all agree with the characters which have been assigned to the genus Tuditanus. The fragment of the jaw is interesting as giving the first information as to the character of the mandible in the genus Tuditanus. It is very slender and of uniform width as far as preserved. The teeth are short, blunt cones, apparently pleurodont.

The clavicle is of the typical Tuditanus form, with the sculpturing lines radiating out from the angle. The impression of the body adds nothing to that already described for the type specimen. The nearly entire hind limb is of great interest as adding another example of the phalangeal formula. The foot is almost perfectly preserved, and the formula was probably $2-2-3-3-2$. The endochondrium of the limb bones is not highly developed. About a dozen vertebræ are represented by molds in the soft coal, but nothing of their structure can be determined.

The sharp, reptile-like claws in which the toes end (fig. 2 I, B) recall those of Eosauravus and of Tuditanus minimus Moodie. It is another link in the chain of the suggested relationship between the microsaurians and the early reptiles.

Measurements of the Second Specimen of Tuditanus walcotti Moodie.

\begin{tabular}{|c|c|c|}
\hline & & $\begin{array}{r}\mathrm{mm} . \\
0\end{array}$ \\
\hline & 16 & f clavicle, maximum............... \\
\hline . ? & 17 & 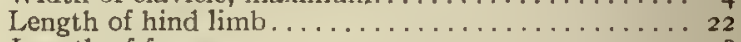 \\
\hline 11. & 14 & femur. \\
\hline i & 4 & (?). \\
\hline$\ldots \ldots$ & I. 5 & atarsal. \\
\hline tooth in jaw.. & .25 & ength of first digit. . \\
\hline
\end{tabular}

Genus ERPETOSAURUS Moodie, 1909.

Moodie, Bull. Amer. Mus. Nat. Hist., xxvi, p. 348, fig. 1, 1909.

Moodie, Proc. U. S. Nat. Mus., 37, p. 2 I, 1909.

\section{Type: Erpetosaurus radiatus Cope.}

Skull stout, elements sculptured with radiating grooves, ridges, and pits; orbits large and usually placed far forward; occiput sometimes with posterior table; skull more or less rounded; lateral-line canals consisting of supraorbital, suborbital, jugal, and temporal canals, the last two uniting to form a circular canal in one species; clavicle triangular, sculptured like the skull.

Our knowledge of the genus is confined to the skull. The genus was established for certain members of the genus Tuditanus and other forms which have been recently described. The species of the genus are: E. radiatus Cope type, E. tabulatus Cope, E. tuberculatus Moodie, E. obtusus Cope, E. minutus Moodie, E. acutirostris Moodie, E. sculptilis Moodie. All of the species are from the Linton, Ohio, Coal Measures, with the exception of E. sculptilis and E. minutus, which are from the Cannelton, Pennsylvania, slates:

The position of the genus as to family is a little uncertain, since family characters are not yet well understood among the Carboniferous forms on account of the lack of information as to the structure of the animals. If we take the absence of 
the ventral scutellæ as a family character, the genus will be in the family Tuditanidre, but the evidence on this point is negative. For the present we may place the genus only provisionally in the family Tuditanidæ. The arrangement will undoubtedly require revision later.

\section{Erpetosaurus radiatus Cope, 1874.}

Cope, Trans. Amer. Phil. Soc., xv, p. 273, 1874.

Cope, Geol. Surv. Ohio, II, pt. II, pp. 394-395, pl. xxvii, fig. 1; pl. xxxiv, fig. 3; text-fig. 10, 1875 . Moodie, Bull. Amer. Mus. Nat. Hist., XXvi, p. 348 , pl. lxii, fig. I, I 909.

Type: Specimen No. 8600 G, American Museum of Natural History.

Locality and horizon: Linton, Ohio, Coal Measures. (Plate 25, fig. I.)

Cope originally described this species from a portion of a skull. He (123) characterized the form as follows:

"The marked character of this form is seen in the very anterior position of the orbits and the contraction of the muzzle. The orbits are large and are separated by a little nore than their own diameter; their posterior border is in front of a line measuring the anterior third of the length to the supraoccipital crest, and nearly to the line marking the fourth of the length to the quadrate region. The posterior outline of the skull is deeply concave, the quadrate angle projecting beyond the occipital condyles."

The base of the specimen is broken and there is no place for the occipital condyles. Unless the specimen has been mutilated since Cope studied it, the occipital condyles are not present.

The restoration of the skull given in figure $22, \mathrm{~B}$ varies but little from that given by Cope in $\mathrm{I} 875$. The elements are practically as he represented them.

The premaxillæ are small and lie in the usual relations to the other elements. Minute conical teeth are present as impressions. They are quite similar to the teeth found in other Microsauria. The nasals are nearly square and form the inner boundary of the somewhat oval nostril, which is represented by a depression in the coal. The frontal.is elongate. It is about twice as long as wide. It forms a portion of the inner border of the orbit, the remainder being made up by the prefrontals and the postfrontal. The parietals are the largest elements of the skull, but they do not greatly exceed the jugals. Together the parietals form a somewhat obtuse oval in the median region of the skull and they contain between them, in their posterior third, the small circular pineal foramen. The postparietal forms the posterior boundary of the skull. The prefrontal forms the anterior border of the orbit and is triangular in shape. The lacrimal is not identified. The maxilla is an elongate element the boundaries of which are uncertain, though probably somewhat as given. The postfrontal and the postorbital form the posterior boundary of the orbit, inclosing between them the anterior projection of the squamosal. The squamosal is an elongate element and is acuminate at each end. The tabulare is a large element lying lateral to the postparietal. The jugal is a very elongate element, apparently acuminate anteriorly. The quadratojugal is small and elongate. The supratemporal is definitely bounded and its limits are as indicated (fig. 22 B), being a large element which forms the quadrate angle.

There are two other specimens of this species in the collections and a fragment of a fourth which it is difficult to make out. Cope identified and figured one of these 
with the parietals, the anterior extensions of which they inclose. The parietals are large elements and together form a broad oval, truncate posteriorly. They inclose between them the pineal foramen in the median suture. It lies in the posterior fourth of the parietals. The postparietals are elongate transversely, and have the usual relations. The prefrontal is somewhat triangular and forms the anterior boundary of the orbit. The lacrimal has not been detected. The maxilla is elon-
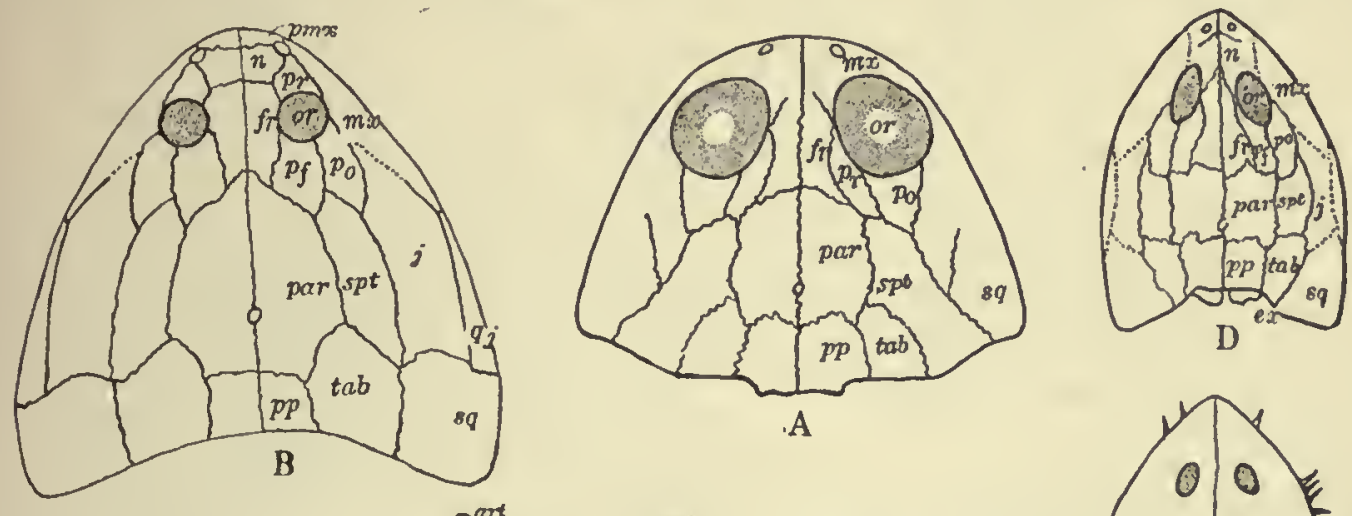

$\mathrm{D}$
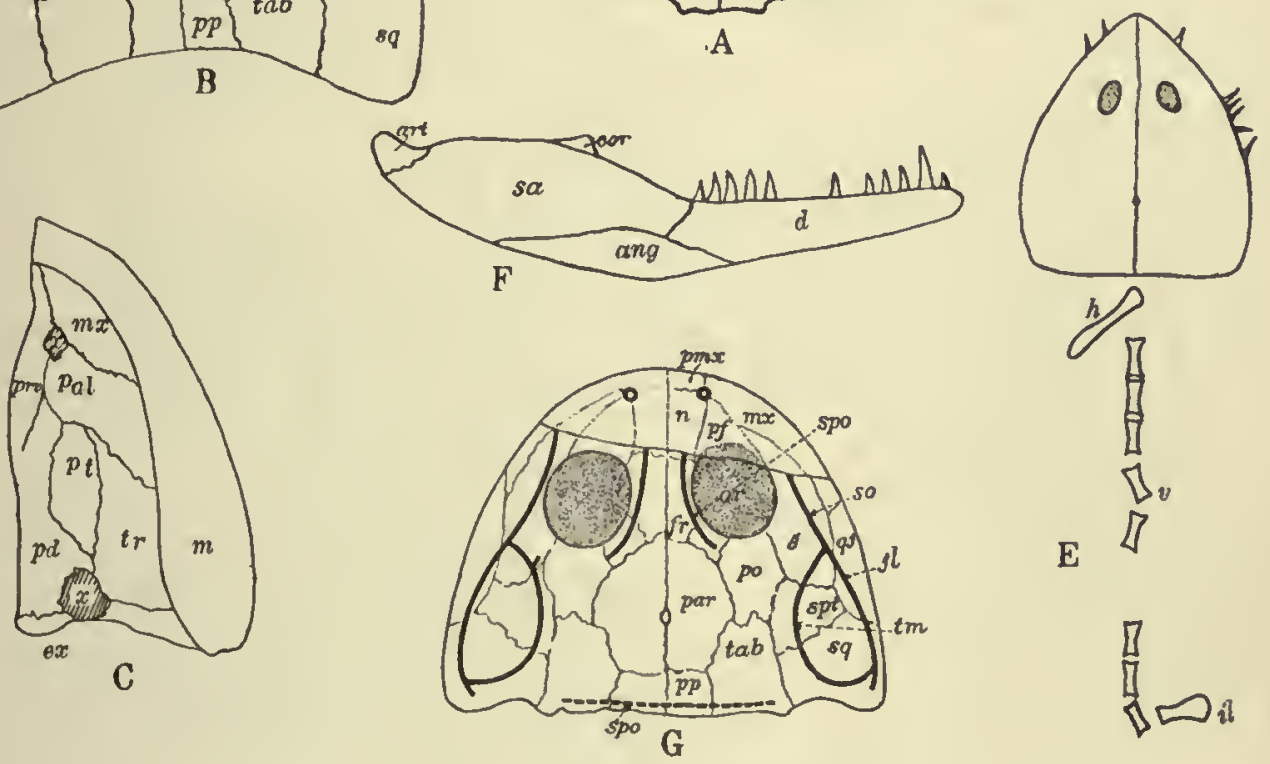

FIG. 22.

A. Outline of skull and cranial elements of Erpelosaurus minulus Moodie, from the Cannclton slates of Pennsylvania. Original in U. S. National Muscum. $\times 2$. fr, frontal; $m x$, maxilla; par, parictal; $p o$, postorbital; $p p$, postparietal; $p r$, postfrontal; $s q$, squamosal; $s p l$, supratemporal; $t a b$, tabulare.

B. Outline of skull and cranial elements of Erpetosaurus radialus Cope, from the Coal Measures of Linton, Ohio; partially restored. $X 0.75$. Original in American Mluseum of Natural History. fr, frontal; $j$, jugal; $m x$, maxilla; $n$, nasal; or, orbit; par, parietal; $p f$, postfrontal; po, postorbital; pr, prefrontal; $p p$, postparietal; pm $x$, premaxilla; $q j$, quadratojugal; $s q$, squamosal; $s p l$, supratemporal; $l a b$, tabulare.

C. Palate of Erpelasaurus (labulatus?), from the Coal Measures of Linton, Ohio. $X \mathrm{I}$. American Museum of Natural History. ex, exoccipital; $m$, mandible; $m x$, maxilla; pal, palatine; $p l$, pterygoid; prv, prevomer; $p d$, parasphenoid; $x$, anterior and posterior palatine vacuities.

D. Outline of skull and cranial elements of Erpelosauris aculirostris Moodic, from the Coal Measures of Linton, Ohio. Original in Ameriean Museum of Natural History. $X I$. ex, exoccipital; $f r$, frontal; $j$, jugal; $m x$, maxilla; n, nasal; $a r$, orbit; po, postorbital; par, parictal; $p p$, postparictal; $p f$, postfrontal; sq, squamosal; spl, supratemporal; $t a b$, tabulare.

E. Outline of larger part of skeleton of Odonterpeton lriangularis Moodie, from the Coal Mcasures of Linton, Ohio. Original in U. S. National Museum. $\times 4 . h$, humerus; $i l$, ilium?; v, vertebra, all of which are not represented.

F. Right mandible of Erpetosaurus tabulalus Cope, from the Linton, Ohio, Coal Measures. Original in American Nuseum of Natural History. $\times 2$. arl, articular; cor, coronoid; $d$, dentary; ang, angular; sa, surangular.

G. Skull elements and lateral-line canals of Erpelosaurus labulatus Cope, from the Coal Measures of Linton, Ohio. $X$ I.5. $\mathrm{fr}$, frontal; $j$, jugal; $j l$, jugal lateral-line canal; $m x$, maxilla; $\pi$, nasal; or, orbit; par, parictal; po, postorbital; $p f$, laerimal or prefrontal; so, suborbital lateral-line canal; $p p$, postparietal; $p m x$, premaxilla; $q j$, quadratojugal; spo, supraorbital lateral-line canal; sq, squamosal; spt, supratemporal; $/ m$, temporal lateral-line canal; $t a b$, tabulare; so, supraoccipital cross-commissure of lateral-line canal. 
gate, and with the quadratojugal forms the exterior border of the cranium. No teeth are observed on the maxilla. The postfrontal and the postorbital form the posterior border of the orbit, and between them inclose the anterior extension of the squamosal. The supratemporal is pointed anteriorly and has the usual relations of that element, joining the postorbital, the postfrontal, the parietal, the tabulare, and the squamosal. The tabulare is larger than the postparietal and is acuminate, the point being inclosed by the squamosal and the supratemporal. The jugal widens fan-shaped posteriorly. It forms a portion of the border of the orbit. The supratemporal, as usual, forms the quadrate angle of the skull. In front of it lies the elongate quadratojugal.

Dendrerpeton is not well enough known for an exact comparison with Erpetosaurus obtusus, but Cope separated the latter from Dendrerpeton on the position of the orbits and the broadly rounded muzzle. This species differs from the other species of the genus in the form of the cranium, as well as in the characters which separate it from Dendrerpeton.

Measurements of the Type of Erpetosaurus obtusus Cope.

\begin{tabular}{|c|c|c|c|}
\hline ength of the skull. & $\mathrm{mm}$. & & $\mathrm{mm}$. \\
\hline rior bord & $\begin{array}{l}40 \\
56\end{array}$ & Interorbital space. & $\begin{array}{r}7 \\
15\end{array}$ \\
\hline its & 37 & Diameter of nostril. & 1.5 \\
\hline st & 12.5 & Diameter of pineal foramen. . . . . . . & 1.75 \\
\hline
\end{tabular}

Two other specimens, Nos. $8602 \mathrm{G}$ and $8608 \mathrm{G}$ of the American Museum, are associated in this species.

Erpetosaurus tabulatus Cope.

COPE, Proc. Amer. Phil. Soc., Xvi, p. 577 (Tudilanus tabulatus).

Moodie, Jour. Geol., 17, p. 52, figs. 8, 9, 1909.

Moodie, Bull. Amer. Mus. Nat. Hist., Xxvi, pp. 347, 351, pl. 59, fig. 2 ; pl. 62, fig. 2, 1909 .

Type: Specimen in the Zoological Collection of Columbia University.

Horizon and locality: Linton, Ohio, Coal Measures. (Plate 25, fig. 2.)

The species is known from a single well-preserved skull and its obverse in the collection of Columbia University in New York City. I am indebted to Dr. Bashford Dean for the privilege of studying this interesting form. It is from the Linton deposits of Ohio. The remains include a nearly complete cranium and a complete clavicle of the right side. The species agrees in all essential respects with the characters of the genus Erpetosaurus, presenting a broad, flat head and a triangular clavicle.

The cranium is wider than long, the muzzle broadly rounded. The orbits are wide ovals, and their posterior borders fall little behind the transverse line dividing the skull equally. The interorbital width equals the long diameter of the orbit. The posterior, outline of the cranium is truncate in a straight transverse line between the prominent tabulare angles. The composition of the cranium is different from that of any other species of Erpetosaurus in the large size of the tabulare and the fact that the supratemporal is excluded from the parietal by the extension of the postorbitals and the tabulare. This may be a generic character and entitles the species to be placed in a new genus, but it will be retained here until more of the anatomy of the 


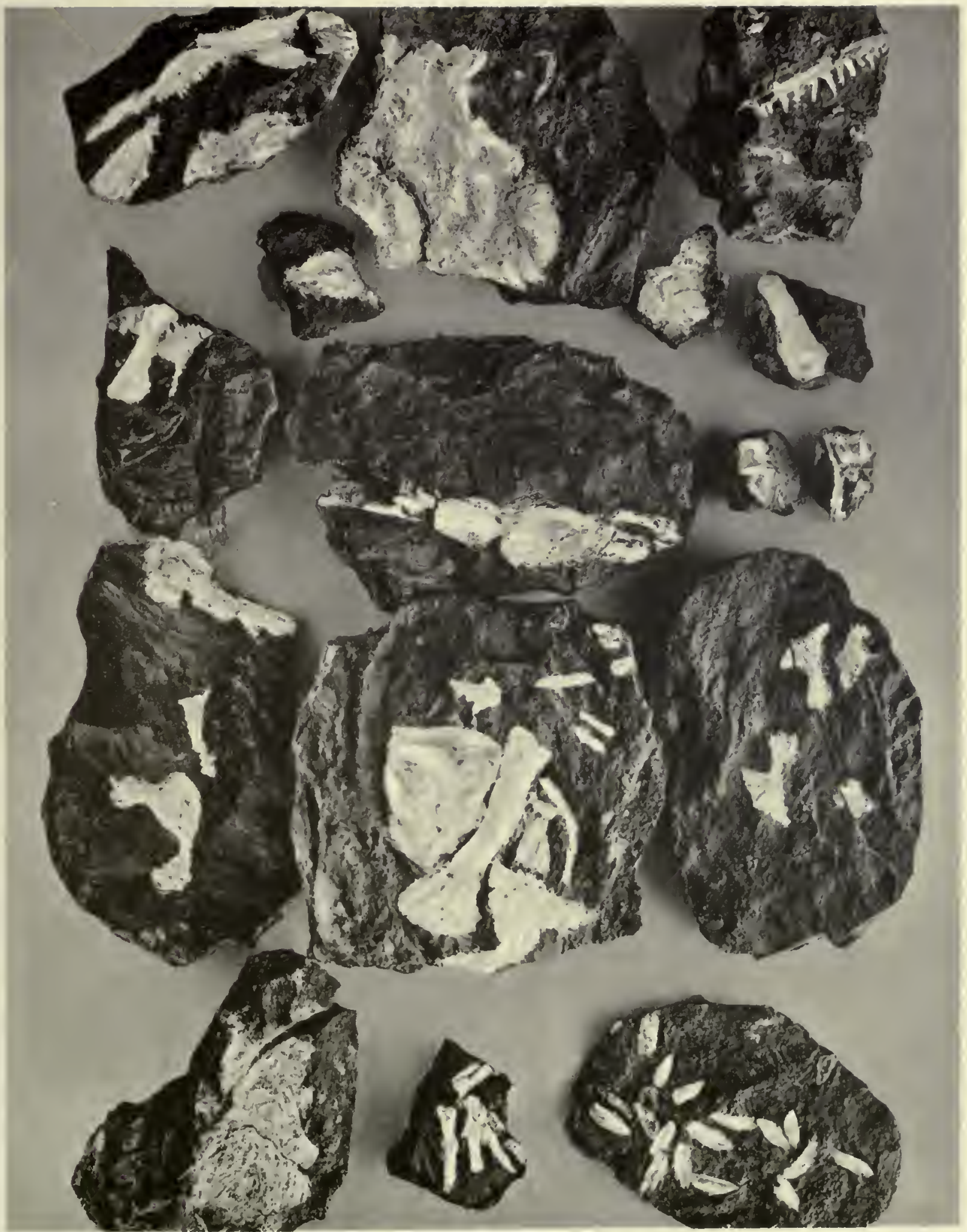

Dendrerpelon onveni Dawson. Above: Skull, mandible, and bones of anterior limbs. Below: Posterior limb, pelvis, and bony scales. Nearly natural size. Erect tree, South Joggins, Coal formation, Nova Scotia. Photograph by Dawson, published through the courtesy of Dr. Arthur Willey. Original specimen in the Peter Redpath Iuseum of McGill University. 

species is known. The elements of the anterior part of the skull are not preserved, but they are indicated by the broken lines in the drawing (fig. 22, G). The nostrils are, however, clearly indicated as bosses of shale. There is a mere fragment of the nasal preserved posterior to the crack indicated by the transverse line in the drawing. The frontal is elongate as in other species of the genus and forms the inner border of the orbit. The parietal, as usual, is one of the larger bones of the skull roof and the pineal foramen is inclosed in the median suture by the two parietal elenents. The pineal opening lies in the posterior half of the parietal. The postparietal is almost square, being slightly elongate transversely, uniting laterally with the tabulare, with which it forms the truncate table of the skull. The suture separating the tabulare from the supratemporal is clearly distinct. Although such a position for the supratemporal is unusual it is not unique, since the same character has been observed in Diceratosaurus lavis Moodie, described elsewhere (p. I20) in this paper. The postfrontal is rather small and it, together with the postorbital, forms the posterior boundary of the orbit. The postorbital is truncate posteriorly and joins the tabulare broadly. The supratemporal lies posterior to the postorbital and jugal and borders the quadratojugal, which is an unusual condition, but what significance the condition has remains to be determined. Posterior to the supratemporal lies the squamosal, which forms the quadrate angle of the skull. The quadratojugal is a small element and forms part of the lateral boundary of the skull. The jugal is a large element and forms the entire lateral border of the orbit. There are no teeth preserved on the fragment of the maxilla, but there are some impressions farther forward which resemble the pleurodont denticles of the modern Amphibia.

The sculpture of the surface of the cranial bones consists of parallel ridges which are separated by grooves equal to them in width. The ridges radiate inward on the squamosals and frontals and outward on the supratemporals. They are somewhat interrupted on the other skull elements. The right clavicle is ornamented with a sculpture of similar radiating grooves and ridges.

Cope described an atlas in connection with this skull, but I do not find it. The slender impressions to the right of the clavicle may possibly represent ribs. They are gently curved and truncate at the inner end.

A nearly complete system of lateral-line canals has been detected on this skull. The canals preserved are: the temporal, the jugal, the infraorbital, the occipital crossconmissure, and the supraorbital. These terms were used for the first time for the Amphibia by the writer $(458)$ in a discussion of the organs and their significance in the correlation of the skull elements. The occipital cross-commissure in the present skull is represented by a row of elongate pits, such as Andrews (8) has described for Ceraterpeton galvani Huxley from the Coal Measures of England. The crosscommissure is contained within the tabulare. The jugal and temporal canals form a complete ring, much as the same canals do in Trematosaurus. The supratemporal in Erpetosaurus tabulatus Cope is excluded from the parietal by the extension of the tabulare and the postorbital, and it is to be noticed that the temporal canal has a changed position to correspond with the changed condition of the squamosal. This is of considerable interest in connection with the correlation of the supratemporal 
in fishes and amphibians. This subject has been fully treated in another place (458) and it will only be necessary to state here that on the basis of the lateral-line canals and their arrangement in fishes and the Amphibia the true correlation of the supratemporal elements in amphibians and fishes has been made. The temporal canal in the present specimen has, apparently, an indication of a connection with the supraorbital canal, but of this I am not sure. The jugal canal occurs on the supratemporal and quadratojugal, and it joins the infraorbital on the jugal. The infraorbital is indicated by a short portion a few millimeters long under the orbit and the remainder, i.e., its connection with the jugal canal, is restored (fig. 22, G). There is, nothing unusual to be observed in that portion of the infraorbital canal which is preserved. The supraorbital canal is indicated by a curved, broad, shallow groove on the inner side of each orbit. As stated above, there seems to be a connection between this canal and the temporal, but I am not sure. The primitive conditions shown in the lateral-line canals in Erpetosaninis tabulatus Cope are the presence of the occipital cross-commissure and the ring-like formation of the temporal and jugal canals, which is too clearly indicated to be overlooked.

\section{Measurements of the Type of Erpetosaurus tabulatus Cope.}

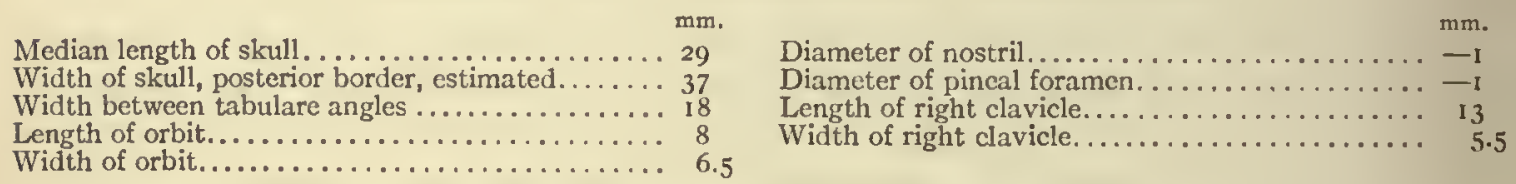

MANDIBLE PROVISIONALLY ASSOCIATED WITH ERPETOSAURUS TABULATUS COPE.

Moodie, Bull. Amer. Mus. Nat. Hist., xxvı, pp. 351-352, pl. lix, fig. 2 ; pl. lxiv, fig. 3, 1909.

This specimen is preserved almost completely on a slab of soft coal. It is impossible to determine positively to what microsaurian species the mandible belongs, but it may, for the present, be associated with Erpetosaninus tabulatus Cope on account of its size and the character of its sculpture. This is the first and almost the only known example of a mandible of an American microsaurian. The form of the jaw is perfectly preserved, although the condition of the articular surface can not be determined.

The proportions of the mandible, as may be judged from the table of measurements, are rather stout and the teeth are strong and numerous. There are evidences of 19 teeth preserved. The sutures separating the articular (art), angular (ang), surangular $(\mathrm{sa})$, coronoid (cor), and the dentary ( $d$ ) (fig. 22, F) are clear for at least the greater part of their length and they may be easily restored for the remainder of their course. The surangular is thus seen to rival the dentary in size and on it occurs the peculiar sculpturing which approximates so closely that on the skull of Erpetosaurus tabulatus Cope. The presence of the long anterior tooth is strikingly characteristic of many Microsauria. It is well developed in Sanropleura longidentata Moodie and Sanropleura (Anisodexis) enchodus Cope. It is also present in well-developed form in the later labyrinthodonts. The teeth are all, with the exception of the fourth from the anterior end, rather short, curved, and sharply pointed, with an indication 
of longitudinal fluting. The arrangement of the mandibular elements recalls in a striking way the mandible of Eryops megacephalus Cope as figured by Branson (49).

Measurements of the Manmible Provisionally Associated with Erpetosaurus tabulatus Cope.

(No. 8542 G, American Museum of Natural History.)

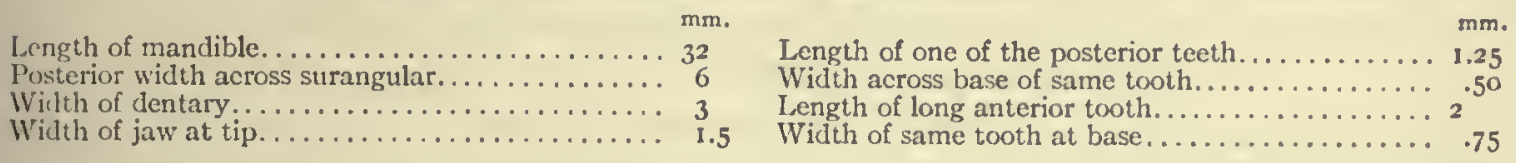

Another specimen of this same species is $855^{\circ} \mathrm{G}$, of the American Museum. Linton, Ohio, Coal Measures.

PALATE OF ERPETOSAURUS TABULATUS COPE.

Moodie, Bull. Amer. Mus. Nat. Hist., xxvi, pp. 352-354, pl. 1xi, fig. 2, 1909.

The specimen is half a cranium with its impression. It is referred to Erpetosaurus on the basis of the sculpturing of the mandible and the posterior table of the skull. On the surangular there is seen the rugosity which is common to other members of the genus. The characters presented are those of Erpetosaurus tabulatus Cope, but the reference is rather uncertain.

The specimen is unique among the known American material in showing the structure of the palate. Jaekel (347) has figured and described the palate of Diceratosaurus punctolineatus Cope from the Linton beds. The present palate differs from that species only in the enlarged ectopterygoid and the smaller palatine.

The parasphenoid, in the present form, does not differ from that element in other Paleozoic Amphibia. Its form is slender, arising from an enlarged base and separating the pterygoids by its own width. The exoccipitals are probably represented in the specimen and they have been indicated in the drawing (fig. $22 \mathrm{C}$ ). They are rather large and extend some distance under the base of the skull to unite anteriorly with the pterygoids, a very unusual arrangement. The pterygoids are elongate elements and are bounded anteriorly by the vomer and laterally by the ectopterygoid. The vomer shows no evidence of being toothed, although it may have been so anteriorly. The same may also be said for the palatines. The relations of the ectopterygoids are rather unusual for the Amphibia, especially in the posterior extension of the element. The bone lies all along the side of the pterygoid and anteriorly projects forward between the pterygoid and the palatine. In this unusual posterior projection the ectopterygoid has almost obliterated the infratemporal foramen, which possibly may be still represented by the triangular space between the bases of the pterygoid and the ectopterygoid. The anterior palatine foramen (internal nares) lies between the anterior ends of the palatine and the vomer, its usual relations in the labyrinthodonts. The foramen may be recognized as the rounded depression slightly anterior to the palatine.

The mandible is rather heavy and is coarsely sculptured with radiating grooves and ridges. The character of the teeth can not be determined, save to say that they were present. The posterior end of the mandible projects somewhat beyond the quadrate angle of the skull. 
The interest in the present specimen is heightened by the light it throws on the characters for the separation of the Amphibia and Reptilia. The wide separation of the pterygoids by the parasphenoid is an amphibian character of undoubted value. The reduction of the parasphenoid in this specimen is noteworthy.

Measurements of the Skull of Erpetosaurus tabulatus Cope.

(No. 8607 G, American Museum of Natural History.)

mm.

Length of skull in median line.............. 45

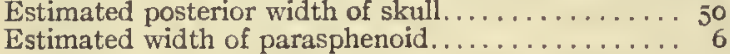

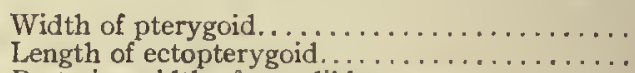

Posterior width of mandible..................

$\mathrm{mm}$.

Erpetosaurus minutus Moodie.

Moonie, Proc. U. S. Nat. Mus., 37, pp. 2 I-23, pl. 8, fig. I, Igog.

Type: Specimen No. 4545, U. S. National Museum.

Horizon and locality: Cannelton slates, Pennsylvania (Upper Freeport). (Plate 2oD.)

The specimen on which the species is based is composed of the greater portion of a small skull preserved in the hard shale from Cannelton, Pennsylvania, and was collected by Mr. R. D. Lacoe, of Pittston, Pennsylvania. The characters of the specimen had not previously been determined, since the museum label and number had partially obscured the snout of the skull. The skull is very small, but has the form assumed by other members of the genus. The specimen may belong to a young individual, but even though it does, it is, nevertheless, quite distinct from the other species of Erpetosaurus. At first sight the specimen looks like a broken scute of some larger form. Close inspection, however, revealed the two impressions representing the orbits, and a Zeiss binocular revealed the characters. The large size and anterior position of the orbits, the character of the sculpturing, the presence of the posterior table of the skull, as in Erpetosaurus (Tuditanus) tabulatus Cope, are the characters on which a specific diagnosis is possible. The specific characters which distinguish this form from $E$. tabulatus Cope, its nearest ally, are the slight development of the posterior table, the more delicate form of the sculpturing, the more posterior position of the orbits, and the varying shape assumed by the parietals in the two species. Any one of these characters would be valid as a specific character.

The pineal eye is indistinct, but is observed to lie in the broken tract in the median line of the skull, in the middle of the portion posterior to the orbits. The interorbital space is equal to the width of the orbit. The orbits themselves are slightly oval and not round, as in the case of E. tabulatus Cope.

The skull elements are sculptured with radiating grooves and ridges, and on the postparietals and tabulare the grooves take the form of pits in a row, which undoubtedly represent the occipital cross-commissure of the lateral-line system first observed in a microsaurian by Andrews (8) in the skull of Ceraterpeton galvani Huxley. The supraorbital canal is represented by a slight elongate depression observable over each orbit and extending, in one case, for about $5 \mathrm{~mm}$. The presence of the circular arrangement of the lateral-line canals in the jugal region is suggested by a depression on the posterior edge of the squamosal. 
The portion of the skull anterior to the orbits is wanting, curiously enough, just as in Erpetosaurus tabulatus Cope. In the remainder of the skull, the post-parietals, the tabulare, the parietals, the supratemporal, and a portion of the right frontal can be detected, although the boundaries of but three can be accurately defined. The depression bounding the anterior outline of the skull is taken to be the impress of the mandible, in which case this structure would be of some depth, as in the case of the mandible associated with $E$. tabulatus Cope, described below.

This specimen is of interest in respect to the presence of the lateral-line canals, its small size, and its generic identity with forms from Ohio. There is still another form known from the Cannelton slates, described below as Erpetosaurus (Tuditanus) sculptilis Moodie.

Measurements of the Type of Erpetosaurus mutus Moode.

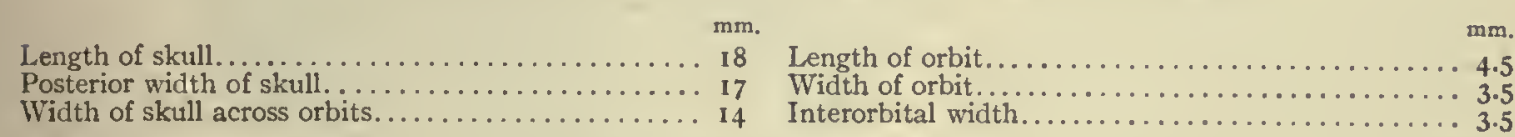

\section{Erpetosaurus sculptilis Moodie.}

Mloodie, Jour. Geol., 17, No. 1, p. 61, figs. I1, 12, 1909 (Tuditanus sculpilis).

Moodie, Bull. Am. Mus. Nat. Hist., Xxvi, p. 347, 1909 (Erpetosaurus sculplilis).

Moodie, Proc. U. S. Nat. Mus., 37, p. 22, 1909 (describes pectoral girdle).

Type: Specimen No. 12,315, University of Chicago, Walker Museum.

Horizon and locality: Cannelton slates, Pennsylvania (Upper Freeport). (Plate I8.)

There is preserved in the collections of Walker Museum of the University of Chicago a small amphibian skull pressed flat on a slab of slate from Cannelton, Pennsylvania. It formed part of the Hall collection acquired by the University of Chicago in 1908.

The specimen presents only a portion of the skull and fragmentary pectoral plates. The skull is wider than long and the muzzle is broadly rounded. The orbits are narrow ovals and their posterior border falls on the transverse line dividing the skull equally. The interorbital width is slightly greater than the width of the orbits and about equal to their length. The posterior outline of the skull is somewhat truncate, as in E. tabulatus Cope and other species of the genus. The distal extremities of the quadrates do not project as far backward as do the supraoccipitals. The skull roof is formed of the regular elements, except that a quadrate seems to be indicated by a scale of bone on the posterior angle. The nostrils are oval and the pineal opening is small.

The premaxillæ are apparently relatively large elements, though their boundaries are not definite. The nasal is of an oblong shape and borders the frontal anteriorly. The frontal forms the whole of the interior border of the orbit and borders the parietal broadly behind. The parietal is a large element and the pineal foramen is inclosed in the median suture about midway of the parietals. The postparietal is wider than long and with the tabulare forms the greater part of the posterior border of the skull. The prefrontal (plate I8, fig. I) apparently forms the entire anterior border of the orbit and sends an acuminate projection to the side of it. The 
maxilla is excluded from the orbit and is an elongate element with sharp conical teeth. of which there are 4 preserved. These measure about I $\mathrm{mm}$. in length. The jugal lies along the lateral border of the orbit and it is acuminate both anteriorly and posteriorly. It borders the supratemporal broadly. The postfrontal forms the greater part of the posterior boundary of the orbit. It is triangular and acuminate behind, and is bordered broadly by the parietal and supratemporal. The supratemporal is also triangular and it borders the parietal broadly. The squamosal is evidently the largest element in the skull and on its posterior corner there is a flake of bone which may represent the quadrate, though this is by no means certain. The quadrate has not been detected in any of the Carboniferous Microsauria so far studied. The tabulare is an elongate element in the transverse.line of the skull. Its entire boundary is uncertain, though part of the sutures are present. The quadratojugal is elongate and lies posterior to the maxilla and with that element forms the lateral boundary of the skull.

The canals of the lateral-line system have not been detected on the skull. The sculpturing of the cranial elements consists of grooves and ridges which radiate from a center. They are more prominent on the parietals than clsewhere, although the other skull elements present a strong sculpturing.

There are also preserved on the slab of slate, about Io mm. posterior to the skull, fragments of the pectoral plates, probably representing the clavicles and the interclavicle. They are so badly fractured that their form can not be determined. No limbs or vertebræ have been observed.

Measurements of the Type of Erpetosaurus sculptilis Moode. $\mathrm{mm}$.

Length of skull in median line............. 20

Width of skull at posterior border (estimated).....24

Diameter of orbit . . . . . . . . . . . . . . . 3

Length of orbit..................... 4

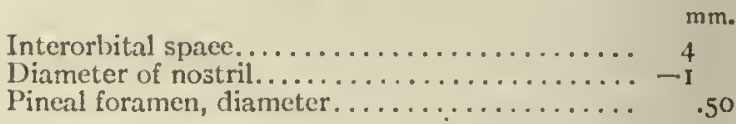

Pectoral Girdle Provisionally Associated with Erpetosaurus sculptilis Moodie.

Moodie, Proc. U. S. Nat. Mus., 37, p. 22, 1909.

The present specimen is preserved on a block of slate from Cannelton, Pennsylvania. It is associated with the previously described Erpetosaurus sculptilis Moodie on account of its size, the geological and geographical distribution, and the character of the sculpture. It may pertain to an unknown species. Other remains besides the 3 elements of the pectoral girdle are preserved on the block of slate, but they are, for the most part, too imperfectly preserved for recognition. Some of them are phalanges, and I believe I detect a scapula in the rounded curved plate lying near the right clavicle. The 3 pectoral elements, the interclavicle and the 2 clavicles, are preserved intact, with the ventral surface uppermost.

The specimen is particularly important in that it furnishes further evidence of the simplicity of the microsaurian pectoral girdle, which Jaekel regarded (347) as being extremely complex, in one species at least, Diceratosaurus punctolineatus Cope. The 3 elements are broken, but either the elements or their impressions are present, so that identification is possible. The elements are sculptured with radiat- 

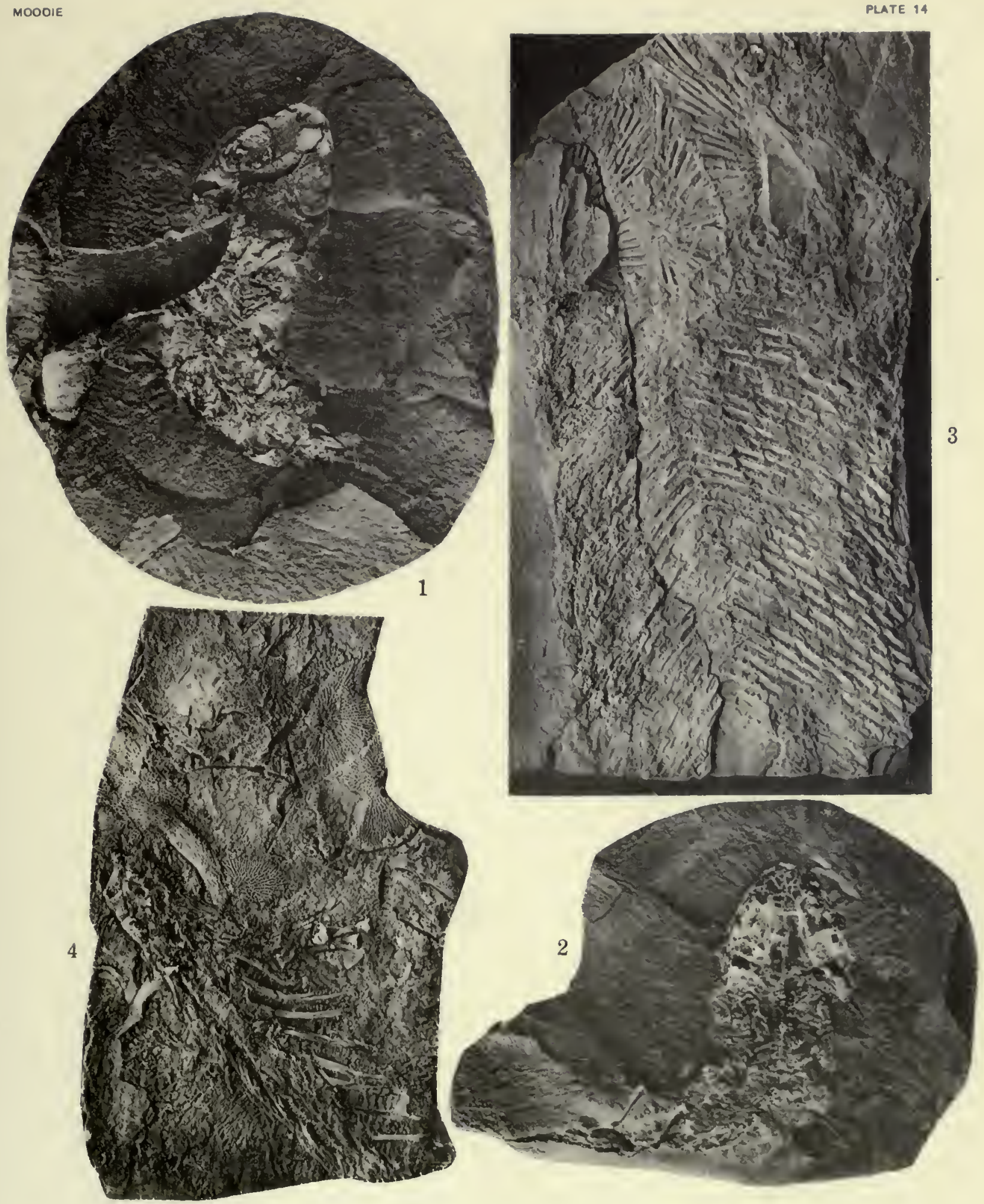

1 and 2. Photograph of the specimen of Amphibamus grandiceps Cope, from the Mazon Creek shales. $\times$ 1.5. Original in possession of Mr. L. E. Daniels, Rolling Prairie, Indiana.

3. Specimen of Sauropleura (Colosteus) scutetlata Newberry, from the Linton Coal Measures. The species was the first known of the Ohio Coal Measures Amphibia; at firstascribed by Newberry to the fishes, but later correctly identified by Cope. $\times 1$. Original in American Museum of Natural History.

4. The type of Diceratosanrus (Ceraterpeton) punctolinealus Cope, from the Linton Coal II asures. $\times 1$. Original in American Museum of Natural History. 

ing grooves and ridges, as in so many of the Microsauria. The interclavicle is spatulate and bears a general resemblance to the same element of Metoposaurus fraasi Lucas from the Triassic $(383)$ of Arizona. The clavicles are triangular, with rounded angles and the hypothenuse on the interior border.

Measurements of Pectoral Girdle of Specialen No. 4539, U. S. National Museum.

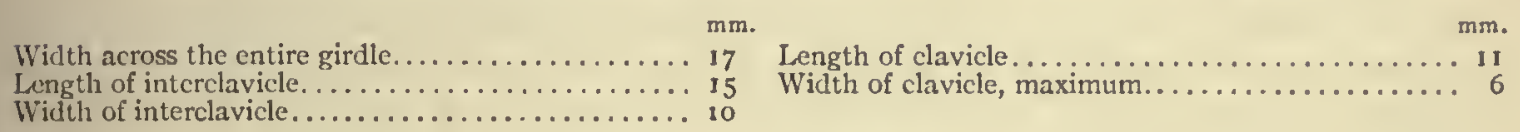

\section{Erpetosaurus acutirostris Moodie.}

Moodı, Bull. Amer. Mus. Nat. Hist., Xxvi, pp. 349-35r, pl. 1xi, fig. 1, 1909.

Type: Specimen No. 8598 G, American Museum of Natural History.

Horizon and locality: Linton, Ohio, Coal Measures.

The present species adds another form to the diversity of structure presented by the Carboniferous Microsauria. It is closely allied to Erpetosaurus (Tuditanus) obtusus Cope, from the same beds (Linton, Ohio), but differs from it especially in the position and shape of the orbits and the acute form of the skull. Other characters which amount almost to generic significance are found in the posterior prolongation of the frontal and in the triangular form of the skull. Only the skull of the animal is preserved. The character which is common to all members of the genus Erpetosaurus, the cranial rugosity, is present in this species on the squamosal and supratemporal. This character alone would not, however, suffice to separate the form generically, but the general morphology and arrangement of the cranial elements is such that reference to any other genus save Erpetosaurus would not be possible.

The skull of E. acutirostris takes the form of a rounded triangle. Its base is some $50 \mathrm{~mm}$. in extent, and this width gradually narrows to $31 \mathrm{~mm}$. across the orbits and still more towards the snout. The form of the skull is not widely different from that of the type species, $E$. radiatus Cope, but the differences are sufficiently apparent.

Nearly all the elements of the cranium can be detected (fig. 22, D). The bony portion of the cranium has nearly all been lost, leaving only the impression; and the matrix in which the skull was embedded has been forced up into the sutures between the cranial elements, thus forming ragged ridges where the bones of the skull joined.

The position of the nostrils can not be determined accurately. The orbits are placed well forward, a character common to several species of the genus. The interorbital space is equal to the long diameter of the eye. The orbits are separated by narrow prolongations of the postfrontals and by the anterior portion of the frontals. The frontals are remarkable in their great backward extension. In E. obtusus the frontals are nearly confined to the interorbital space. The parietals, which, on the median suture, inclose the parietal foramen, lie well posterior, and the parietals and the tabulare are small. A portion of the sculpturing of these elements has been preserved and 
it is seen to be made up of pits and elevations much as we find in the skull of Saurerpeton latithorax Cope. The left squamosal also shows sculpturing, which here tends to take the form of grooves and ridges, and also of pits and elevations. It is quite probable that the anterior portion of the skull was ornamented with grooves and ridges and undoubtedly the lateral-line canals were well developed. The postfrontals and the postorbitals are both large and elongated. The postorbital is especially large. The supratemporal apparently separates the tabulare and the squamosal in their posterior extremities. The squamosal projects posteriorly to the tabulare and apparently even goes beyond the limits of the exoccipital. The outlines of the jugal are fairly definite, as are also the limits of the maxilla.

\section{Measurements of the Type of the Skull of Erpetosaurus acutirostris Moodie.}

Length of skull.................

Interorbital space.......................

Width of orbit...................... 7

Length of orbit..................... I0

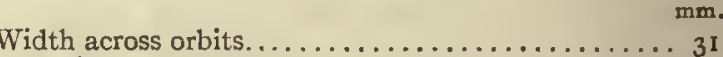

Posterior width of skull ...................... 31

Diameter of pineal foramen................

Length from tip of snout to posterior angle of skuli. . 65

An additional specimen shows that the skull, of which the anterior half is preserved, is practically of the same size as the type and shows much the same characters, though more extensively. The sculpture of the squamosal region is not confined to that portion of the skull, but extends throughout the cranial elements, apparently including the premaxillæ.

The sutures, which are clearly distinct, are of the same type as has been described for the type specimen. Perhaps one of the most interesting characters discovered on the present specimen is that of the greater part of the left supraorbital lateralline canal, which is exhibited as a rather deep and broad canal running in a slight curve across the lower edges of the postorbital and the parietals and partly cutting the jugal.

On the left of the fossil, as it is preserved, there is an indistinct impression of the clavicle, with the sculpture in radiating lines from the apex as a center, such as have been found in other species of the Tuditanidæ.

Measurements of Additional Specimen.

(No. 8607, American Museum of Natural History.)

Length of skull as preserved............. 40

Anterior width across orbital region............... 22

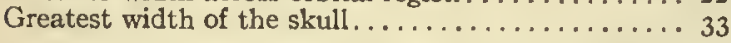

Length of clavicle..................

Greatest width of clavicle................ I8

Still a third specimen of this species is possibly represented by a nearly complete skull of a small individual which exposes the mandible and the ventral portion of the skull. The remains are crushed flat, though not at all distorted. It is quite possible that the present specimen represents a distinct species, but only a small portion of the dorsum is present and the shape of the cranium is indistinct, so it is retained in this species. The portion of the skull shows the sculpture to be quite similar to that of Erpetosaurus acutirostris, so far as the species is known; and the skull apparently tapers to a point anteriorly. It may be a dwarfed or immature form. The sculpturing of the jaw is such as we would expect of this species. 
The specimen is about half the size of the type. The palate of the skull is well preserved and is extremely interesting. The sutures separating the various palatal elements are not distinct. The parasphenoid is especially large and the exoccipitals are partly ossified, if we may judge by the projecting condyles. Anteriorly the parasphenoid contracts and then expands and on each side of the expanded part lie fragments of the palatines. To the right of the posterior end of the parasphenoid lies a portion of the dorsal element showing the cranial sculpture.

The left mandible is somewhat displaced to the right of the skull, and crushed and weathered to such an extent that the sutures are entirely obliterated. There are 3 teeth, with indications of others. They are typically pleurodont and sharp and slender. The mandible tapers somewhat anteriorly and at the tip bears an elongate enlarged tooth.

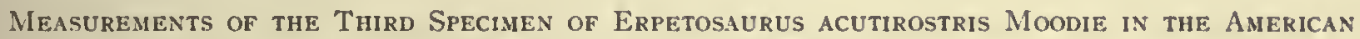
Museum of Natural. History.

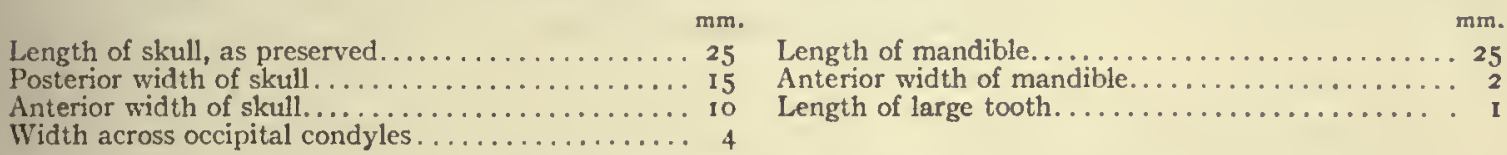

Erpetosaurus tuberculatus Moodie.

MIoodie, Bull. Amer. Mus. Nat. Hist., xxvı, pp. 348-349, pl. Iviii, I9o9.

Type: Specimen Nos. 8693 G and 86ro G, American Museum of Natural History.

Horizon and locality: Linton, Ohio, Coal Measures.

This species is based on a fragmentary cranium (plate 26, fig. I) consisting of the posterior part of the right side of the skull. Its association in the genus is solely on the character of the sculpturing of the cranial elements. It is most closely related, in the characters preserved, to the form described by Cope as Tuditanus radiatus, from which it differs especially in the character of the sculpture and in the position of the orbits, as well as the arrangement and size of the various cranial elements, so far as these elements can be detected in the present specimen. In Erpetosaurus radiatus the skull is sculptured by radiating grooves and ridges which did not arise from a definite center. In E. tuberculatus this center of radiation is marked by an elevation or tubercle on each cranial element exposed, from which the grooves and ridges radiate outward. These tubercles have an elevation of $4 \mathrm{~mm}$. above the cranial element proper. The orbit is located near the median line of the skull, so far as can be determined. In E. radiatus Cope the orbits are located well forward. In that species also the postparietal is smaller than in the present species and the squamosal is longer and more slender. (Plate 25, fig. I.)

The fragment of a skull on which the above comparison has been made consists of the right postparietal, a portion of the tabulare, the parietal, the frontal, and a portion of the squamosal. The other elements are not clear. The elements in the median line are elongate, as in Erpetosaurus radiatus. The pineal foramen is located well back on the median line and lies posterior to two-thirds of the length of the 
parietals. The sutures separating the frontal and parietal elements from each other in the median line are of the zigzag form so characteristic of the labyrinthodonts.

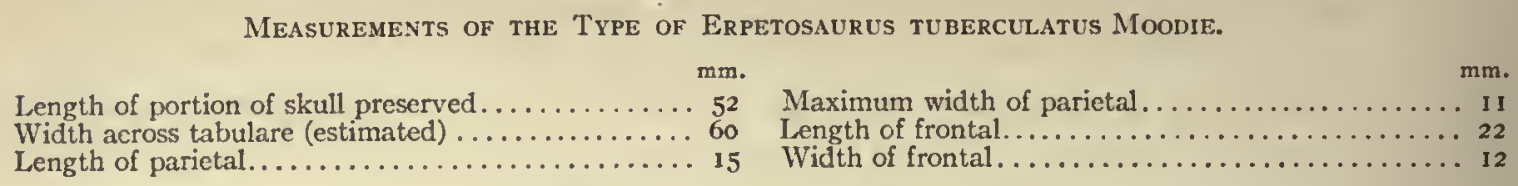

\section{Genus ODONTERPETON Moodie.}

MIoodie, Proc. U. S. Nat. Mus., 37, p. 19, 1909.

Type: Odonterpeton triangularis Moodie.

The generic characters may be found in the triangular shape of the skull, the large size of the teeth, the shape of the vertebræ, the small size of the orbits, and their anterior position as shown in the type specimen (fig. 22, E). The name of the genus is derived from the remarkable size of the teeth as compared with the size of the skull.

Odonterpeton triangularis Moodie.

Moodie, Proc. U. S. Nat. Mus., 37, p. 19, pl. 6, fig. 3, 1909.

Type: Specimen No. 4465, U. S. National Museum.

Horizon and locality: Linton, Ohio, Coal Measures.

The specimen described under the above name is a representative of the smallest species of the Microsauria so far described from North America. Orthocosta microscopica Fritsch, from the Carboniferous of Bohemia, is a rival of the present form in size, but the form described by Fritsch is an entirely different animal and was formerly included among the so-called Aistopoda, which are regarded by the writer as merely specialized microsaurians. The present form shows clear affinities with the Microsauria.

As may be seen by referring to the list of measurements, the skull of this form measures only $6.5 \mathrm{~mm}$. in length. The form may possibly be larval, though I do not think so, if I may judge from the well-developed condition of the skull bones and the complcte ossification of the vertebræ. The sides of the skull are equal and the occiput is a straight table, so that the skull forms almost an exact equilateral triangle. The orbits are very small and are placed well forward. The interorbital space is four times that of the diameter of the orbit, a very unusual character and in itself worthy of ranking as a generic character. 'The median suture of the skull is zigzag and incloses the minute parietal foramen near the posterior end of the skull. The relations of the elements of the skull, with the exceptions of those of the frontals and parietals, can not be determined with accuracy, although there are here and there indications of sutures. The characters of the cranial elements, so far as they can be determined, are those of the family Tuditanidæ, and the form may, for the present, be regarded as a member of that group. The teeth are very long, slender, and sharp, and are placed close together. There is no indication of fluting on the teeth. They are slightly curved inward.

There are 13 vertebræ present. The centra are hour-glass shaped, and are apparently phyllospondylous, with the notochord largely persistent. The vertebral 
centra are unusually long and slender, with the ends rounded. The humerus of the right side is preserved. It is a long, slender bone with expanded extremities. There is no evidence of abdominal armature nor of ribs (fig. 22, E).

The discovery of this form in the Linton deposits is of considerable interest in that it indicates a wide range in size and character of the fauna of the time. The forms now known from the Linton beds range from Odonterpeton, which possibly had a total length of 2 inches in life, to the form designated Macrerpeton huxleyi Cope, with a skull of at least 8 inches in length and whose body may have attained a length of some feet. The large rib described below undoubtedly indicates a large form of the ancient Amphibia from Linton, as do also the vertebræ described by Marsh in I 863 from Nova Scotia.

MEAsurements of the TYPE.

\begin{tabular}{|c|c|c|c|}
\hline ength of animal & $\mathrm{mm}$. & & \\
\hline & 6.5 & $\begin{array}{l}\text { Length of tooth........ } \\
\text { Length of vertebra.... }\end{array}$ & $\begin{array}{l}0.25 \\
1.45\end{array}$ \\
\hline & 5.5 & Width of vertebra........... & .35 \\
\hline . & 6.5 & Length of humerus. . . . . . & 2.25 \\
\hline neter of orluit & .65 & 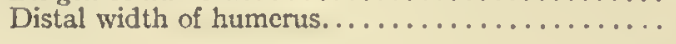 & .35 \\
\hline
\end{tabular}




\section{CHAPTER XV.}

THE MICROSAURIAN FAMILY STEGOPIDA, FROM THE COAL MEASURES OF OHIO.

Family STEGOPID $Æ$ Moodie, I909.

MOodIE, Jour. Geol., xvil, No. 1, 79, 1909.

The chief family characters are the large lacrimal, unknown in other species of Coal Measures Amphibia, the central position of the orbits, the general form of the skull, and the peculiar, short, divaricate horns from the squamosal. If an intertemporal element is present in the skull, which is suggested as a possibility, the family is further distinct. The type species is Stegops divaricata Cope from the Linton, Ohio, Coal Measures.

The group seems to be distinct and has no immediate allies, being confined to the American Coal Measures.

Genus STEGOPS Moodie, 1909.

Moodie, Jour. Geol., Xvir, 79, 1909.

Type: Stegops divaricata Cope.

This genus has been erected for the reception of the peculiar form described by Cope as Ceraterpeton divaricatum, but there are good reasons why the form can not be retained in the genus. The position of the orbits in Stegops (plate 25, fig. 3 ) is different from Ceraterpeton and the muzzle is rounded, not truncate as in the latter form. The horns are of a different type and there is no indication of the tabulare protuberance which is present in Ceraterpeton. The sculpturing of the cranial elements is also distinctive in the present form, consisting of radiating grooves and ridges; the cranium of Ceraterpeton appears to be but slightly sculptured. There is no lateral projection from the border of the skull in Stegops, as there is in the other genus. The structure of the skull of Ceraterpeton is practically unknown, except in a very general way, although Andrews (8) was able to make out some of the elements and to trace the lateral-line canals. A structural comparison is thus impossible, but on the basis of form alone there are good generic distinctions. The present genus is apparently distinct from other genera in the presence of an intertemporal, but additional material will be required before a satisfactory determination is possible. The genus Diceratosaurus of Jaekel (347) is distinct in the arrangement of the elements of the cranium, the general form of the skull, and in the two known species of Diceratosaurus the orbits are located well anteriorly, but in Stegops they are in the median transverse line of the cranium. The genus Stegops is distinct from Eoserpeton in the smaller size of the prosquamosal, in the broadly rounded muzzle, in the larger and more posteriorly placed orbits, and in the presence of an intertemporal bone, or at least in the elongate character of the postorbital if the intertemporal is not present. The species on which the genus Eoserpeton is based was first described by Cope as Ceraterpeton tenuicorne. The form is 
quite distinct, in spite of Jaekel's protestations to the contrary. The genus Stegops stands alone among the Carboniferous Amphibia of North America, so far as I am aware, in the possession of a well-defined lacrimal of the labyrinthodont type.

\section{Stegops divaricata Cope.}

COPE, Proc. Am. Phil. Soc., XxII, p. 406, 1885 (Keralerpeton divaricalum).

Moodie, Jour. Geol., xvII, No. I, p. 79, fig. 22, 1909 (Slegops).

Type: Specimen No. 2559 G, American Museum of Natural History. The obverse of this is No. I2,3I I, Walker Museum, University of Chicago.

Horizon and locality: Linton, Ohio, Coal Measures.

The skull on which this species is based consists of the impressions on two slabs of coal, one belonging to the Newberry Collection of the American Museum of Natural History, No. 2559 G, and the other to the Gurley Collection of the University of Chicago, No. I2,3II. The slab belonging to the University of Chicago contains the better-preserved remains, so that the description is based largely on that portion (plate 25, fig. 3). Nearly all of the elements of the skull are determined with considerable certainty and many important characters in the morphology of the Microsauria are thus brought out.

The skull is oval, elongate, truncate behind, and the quadrate angles project into sharp horns. The orbits are elongate ovals and their center lies in the median line which divides the skull transversely. The nostrils are elongate and have an oblique position. The pineal foramen lies in the posterior third of the skull. Teeth are preserved on both maxillæ and premaxillæ. They are simply sharp pleurodont denticles, and seem to have been fairly abundant. The bones have been completely carbon-

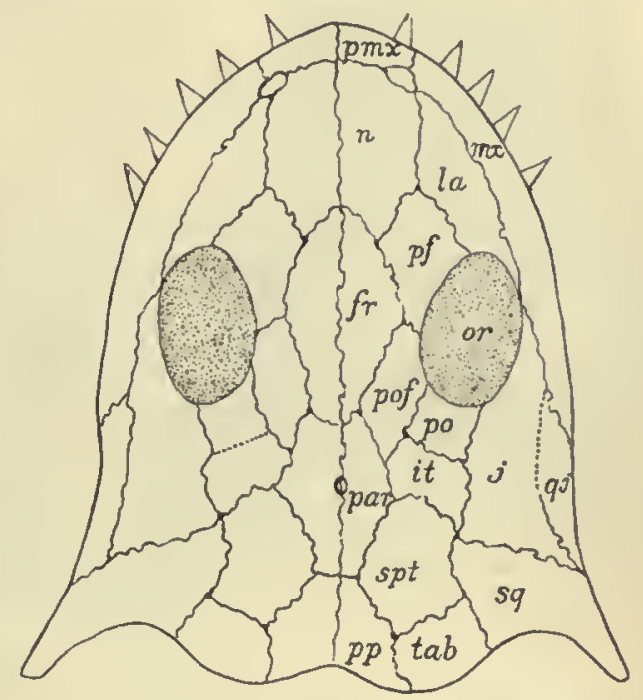

FIG. 23.-Skull elements of Slegops divaricala Cope. $f r$, frontal; $i l$, intertemporal; $j$, jugal; $l a$, lacrimal; $m x$, maxilla; $n$, nasal; par, parietal; pf, prefrontal; po, postorbital; pof, postfrontal; $p m x$, premaxilla; $s q$, squamosal; spl, supratemporal; $y j$, quadratojugal; $l a b$, tabulare; $p p$, postparictal. $\times 1.3$. ized and nothing of the original texture is preserved, although the details of the structure are beautifully preserved. (Plate 25 , fig. 3.)

The skull is somewhat triangular in its general form. The premaxilla lies on the anterior border of the cranium, and forms the median border of the nostril. The suture which separates the maxilla and the premaxilla is not evident, and it may not be correctly defined in the figure (fig. 23). The nasal is a very large element and is elongate. It unites with the premaxilla, the lacrimal, the prefrontal, and the parietal. It is acuminate behind and the point is inclosed by the prefrontal and the parietal. The frontal is quite narrow and elongate, and does not border the orbit; its posterior boundary is not accurately represented. The radiations on the surface indicate the extent of the element. The parietals are remarkable in being smaller than the frontal and nasal. The pineal foramen is 
inclosed in the median suture in the anterior third of the parietals. The parietal has the usual relations of that element. The postparietal lies posterior to the parietal, but a portion of its bounding sutures are destroyed. The prefrontal forms the antero-interior border of the orbit and borders the postfrontal posteriorly, in an unusual manner. The lacrimal is a large element and is clearly separable from the other cranial elements. It, with the prefrontal, forms the anterior border of the orbit. The maxilla is very elongate and forms the larger part of the lateral border of the skull. Sharp-pointed teeth are present on it and they may have becn pleurodont. The lateral border of the orbit probably received a portion of the maxilla. The postfrontal and the postorbital form the greater part of the posterior boundary of the orbit. The postorbital seems to be divided by a median suture which would indicate an intertemporal bone, but this is not certain. The appearance may be due to a fracture. The supratemporal is a large element bordering the parietal and lies in front of the tabulare. The squamosal is elongate to form the posterior horn-like extension of the skull. The tabulare is transversely elongate and has the usual relations. The jugal widens to a fan-shape backwards, and helps to form the lateral border of the orbit. Its lateral and anterior boundaries are not assured. The quadratojugal seems to lie as indicated, although the anterior part of the suture is not distinct. It is apparently an elongate element and with the maxilla forms the lateral border of the skull. The base of the skull as restored (fig. 23) is irregular and may have had a slightly different form.

The genus Stegops is exceptional in the elongate character of the cranial elements of the single species known. In this respect it recalls the species Diceratosaurus levis described below. The large size of the nasals, frontals, and lacrimals and the small size of the parietals are, so far as I am aware, unparalleled among the other Coal Measures Amphibia of North America.

Measurements of the Type.

Median length of the skull ................ 56

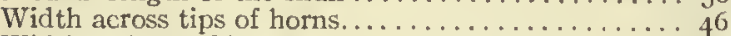

Width at base of horns................. 40

Width across orbits................... 44

Diameter of the orbit................... 4

Length of the orbit...................... I5

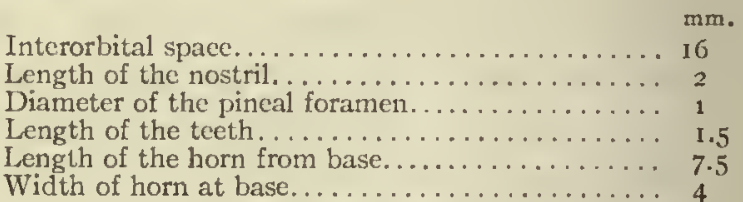



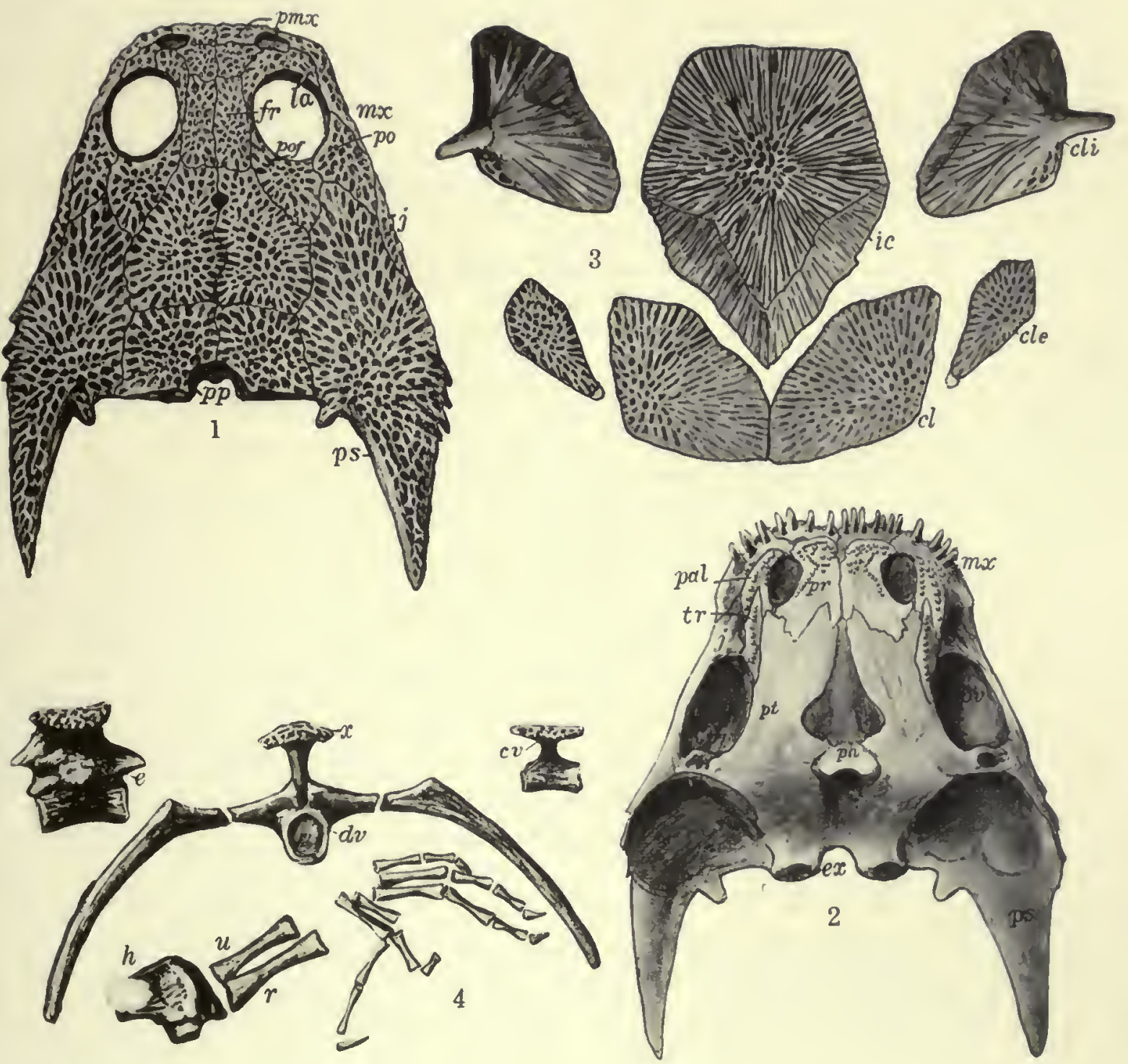

1. Dorsum of skull of Diceratosaurus punctolineatus (Cope), from the Coal Measures of Linton. Ohio. Original in the Musenm at Berlin University. $\times 2$. After Jaekel. po=postorbital: $f r=$ frontal; $p o f=$ postfrontal; $j=$ jugal; $l a=$ lacrimal; $m x=$ maxilla; $p s=$ "perisquamosal;" $p p=$ post-parietal; $p m x=$ premaxilla.

2. Ventral surface of the skull of Diceralosaurus punctolinealus (Cope), from the Coal Weasures of Linton, Ohio. $\times 2$. After Jaekel, $a=$ anterior palatine vacuity; $e x=$ exoccipital: $j=j u g a l:$ $m x=$ maxilla; $l r=$ transverse: $p a l=$ palatine $p l=$ pterygoid: $p r=$ prevomer; $p s=$ "perisquamosal:" $p y=$ posterior or suborbital palatine vacuit $y ; p h=$ parasphenoid.

3. I'ectoral girdle of Diceratosaurus punctolinealus (Cope), from the Coal Measures of Linton, Ohio. Original in the paleontological IJ useum at Berlin. $\times 2$. After Jaekel. $c l i=i n n e r$ side of clavicle; $i c=$ interclavicle; $c l=$ elavicle (lower side); $c l e=$ cleithrum.

4. (e) Cervical or anterior dorsal vertebra of Diceralosaurus punclolinealus (Cope), from the Linton. Ohio, Coal Measures. $c y=$ caudal vertebra shown with its cap of dermal bone; $d t^{\prime}=d o r s a l$ vertebra with ribs; $r=$ dermal plate on neural spine; $h=$ humerus; $u=u$ lna: $r=$ radius. 



\section{CHAPTER XVI.}

\section{THE MICROSAURIAN FAMILY UROCORDYLIDA, FROM THE COAL MEASURES OF OHIO.}

\section{Family UROCORDYLIDE Lydekker, 189o.}

I, DEKKER, Cat. Fossil Reptilia and Amphibia, pt. Iv, p. 196, 1890.

Moodie, Bull. Am. Mus. Nat. Hist., xxvi, art. xxv, p. 357, I909.

Type of the family: Urocordylus wandesfordii Huxley.

Locality and horizon: Coal Measures of Kilkenny, Ireland.

Stout and long-tailed forms, with the tabulare cornua frequently much produced and pitted cranial bones; lateral lines well-developed; palate with tecth on palatines, vomers, premaxillæ, and maxillæ, the two latter elements bearing conical teeth and the others bearing short, stumpy cones, at least in one species; pincal foramen well forward; nostrils and orbits in the anterior part of skull; scapula peculiarly curved and pointed; other pectoral elements sculptured; neural spines and chevrons of caudal vertebræ much dilated at their extremities, and pectinated; no caudal ribs; vertebræ in one genus apparently capped with a sculptured plate as in Zatrachys; tail very long and tapering to a point, 50 to 80 caudal vertebræ; dorsal region short; limbs well developed, with clawed digits; carpus and tarsus cartilaginous; endochondrium well formed.

There are 4 genera which constitute this family: Urocordylus, from the Coal Measures of Ireland; Ceraterpeton, from the Coal Measures of Ireland and England; Diceratosaurus, from the Coal Measures of Linton, Ohio; Eoserpeton, from the Coal Measures of Linton, Ohio.

These may be distinguished by the following characters:

I. Skull triangular, truncated behind, with rounded muzzle and aborted tabulare cornua, neural spines of caudal vertebre long, slender, and expanded in a fan-like manner; tail with about 80 vertebra;

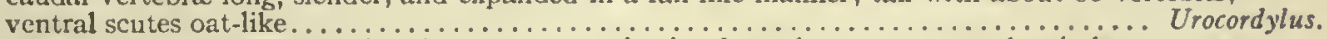

II. Skull parabolic and of great width, with short cornua projecting from the supratemporal; tabulare cornua nearly twice as long; neural spines of caudal vertebra low and wide; ventral scutes oblong; caudal

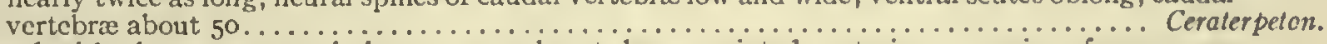

II. Skull broad with obtuse snout, tabulare comua absent, large, pointed posterior expansions from supratemporal, posterior table within the cornua truncatc; vertebre with an apical sculpturcd plate; caudal vertebræ numcrous, over 75 ; ventral scutellæ bristle-like, arranged en chevron. . Diceralosaurus.

IV. Skull a broad oval, with large posterior projecting supratemporal horns, posterior table of skull between cornua truncate without the small lateral projection from the supratempcral, orbits a long oval, ribs long, curved and slender, tail unknown, possibly shorter than in other members of the family; it is restored as short in Journal of Geology, xv11, p. 77, fig. 20, 1909, but this is uncertain;

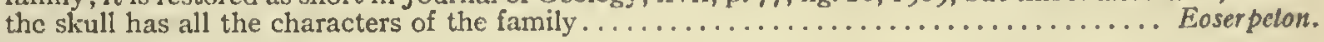

The relationships of the family are not far to seek. They fall in immediately with the Amphibamidæe and Hylonomidx in being among the most reptile-like of the Paleozoic Amphibia. The group is, however, distinctly amphibian in the possession of 4 fingers, with the usual microsaurian phalangeal formula.

Genus DICERATOSAURUS Jaekel, 1903.

JAEKEL, Ncues Jahrbuch f. Mincral., Gcol. u. Palcon., Bd. 1, p. 112, 1903.

Mlood1e, Jour. Gcol., xvir, pp. 63-69, figs. 13-15, 1909.

Type: Diceratosaurus punctolineatus Jaekel.

Orbits in the anterior two-thirds of the axial skull length, nostrils near to the anterior end of the skull; pineal foramen in the center of the skull roof; skull 
provided with tabulare cornua and a broad backwardly directed process; quadrate angle does not project on the border of the skull; sculpture of the cranial elements impressed as radial grooves; 12 presacral vertebræ, I sacral with expanded neural spine which is sculptured at the top, with simple long, apparently separately ossified transverse processes; extremities small; foot with 5 digits; phalangeal formula $2-3-3-4-3$.

The most important differences between Diceratosaurus and Ceraterpeton, the most nearly allied genus, is (in Diceratosaurus) in the more anterior position and small size of the orbits, the backward extension of the quadrate region, and the dorsal expansion of the vertebral spines. A further, and more important, difference between the genera is in the location of the backwardly directed processes from the skull. In Ceraterpeton they project backward from and are a portion of the tabulare element, while in Diceratosaurus the projection consists almost entirely of squamosal and supratemporal.

\section{Diceratosaurus punctolineatus Cope.}

Cope, Proc. Phila. Acad. Nat. Sci., 1875, p. I6.

COPE, Geol. Surv. Ohio, II, pt. II, p. 372, pl. xli, fig. 4, I875.

Moodie, Bull. Am. Mus. Nat. Hist., Xxvi, art. Xxv, p. 356, pl. 1xv, 1909.

Type: Specimen No. 8606, American Museum of Natural History.

Horizon and locality: Linton, Ohio, Coal Measures.

The species was first described by Cope as Ceraterpeton punctolineatum (122). It was redescribed on more abundant material (plate 19) by Jaekel (347), and the following is taken from the discussions of these two authors, checked by my own observations on the type specimen. This shows a portion of the skull, consisting of the squamosal and supratemporal with a projecting, convergent horn. The sculpturing on the skull is similar to that on the pectoral plates, of which there are three preserved (plate I4, fig. 4). The bones of the fore limbs are stout and short. The ribs are only slightly curved. The character of the vertebræ can not be ascertained. The sculpturing of the bones consists of radiating ridges, grooves, and pittings.

Jaekel (347) described from the museum collection at Berlin 3 specimens of this species, among which were 2 skulls. There were associated with these remains some pectoral plates and limb bones with a nearly complete series of vertebræ. A modified translation of Jaekel's description follows:

The skull of the largest specimen has, including the horns, a length of $35 \mathrm{~mm}$. and a width of $30 \mathrm{~mm}$. on the occipital border. From the anterior end to the posterior border of the skull (exclusive of the horns) there is a length of $25 \mathrm{~mm}$. The pineal foramen lies about midway of this length. The orbits are rather large, almost circular, and lie about midway between the pineal foramen and the anterior border of the skull. The nostrils, which lie anterior to the orbits, are a rather oblique oval and narrowed on the lateral ends. The distance between them is about the same as that between the orbits, which measures $7 \mathrm{~mm}$.

The skull roof is sculptured with pits much like those of Archegosaurus. The larger the bones, the rougher the sculpture. The bones of the middle of the skull (that is, the parietals, frontals, premaxillæ, nasals, and postparietals) are of the 


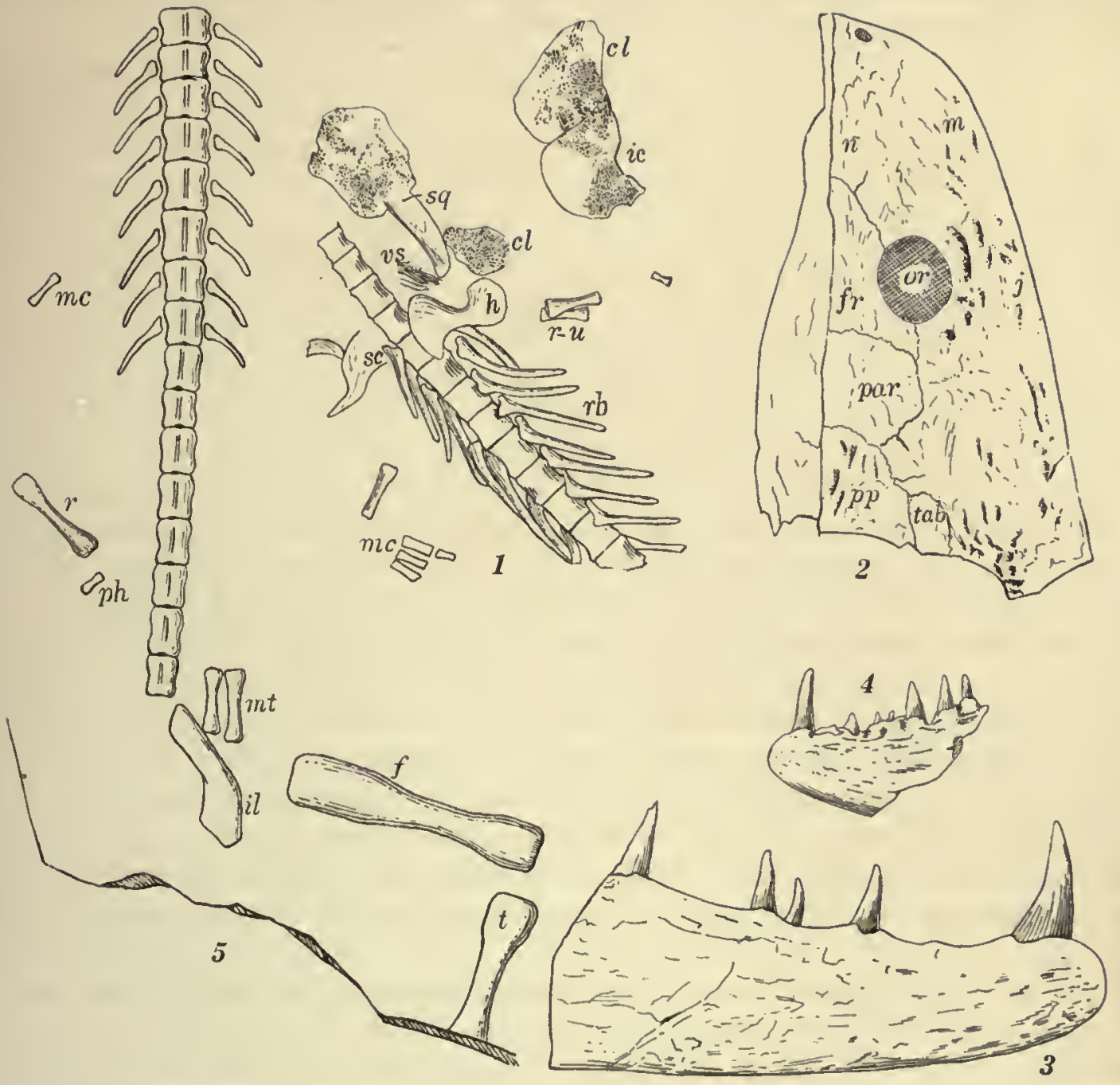

I. Type specimen of Diceralosaurus punctolincatus Cope, from Linton, Ohio, beds. $X$ I. Drawn from photograph. $\quad c l=$ clavicle; $h=$ humerus; $i c=$ interclavicle; $m c=$ metacarpals; $r-u=$ radius-ulna; $r b=r i b$; $s c=$ scapula; $s q=$ squamosal; $v s=$ ventral scutell .

2. Skull of Sauropleura longidentala, Moodie, from the Coal Measures of Linton, Ohio. X I. Drawn from photograph. $f r=$ frontal; $m=$ maxilla; $n=$ nasal; $o r=$ orbit; $p a r=$ parietal; $p p=$ postparietal; tab $=$ tabulare.

3. Mandible of Sauropleura longidentola, Moodie, from Coal Measures of Linton, Ohio. $\times 1.5$. Drawn from photograph.

4. Type specimen of Souropleura enchodus Cope, from the Coal Measures of Linton, Ohio. $X \mathrm{r}$.

5. Additional specimen of Diceratosaurus punctolineatus Copc, from the Coal Measures of Linton Ohio. X I. $f=$ femur; $i l=$ ilium; $m c=$ metacarpal; $m t=$ metatarsal; $p h=$ phalanx; $r=$ radius; $t=$ tibia. 

normal form and only show an unusual difference in that they are large in the inverse order. The pineal foramen lies in the anterior third of the parietals; that is the primitive condition which occurs in the young forms of the Branchiosauridæ. The nostrils are inclosed by the premaxillæ in front, in the median line by the nasals and laterally by the maxillæ. The jugals, by their backward prolongation, form, behind the maxillæ, the border of the skull, and only attain to some size on the upper side of the cranium.

Jaekel's "perisquamosal" (see plate 15), which is of a doubtful nature, is not indicated in the type specimen nor in the specimens of the other two species (462) assigned to this genus. In $D$. robustus and $D$. lavis the "perisquamosal" region is easily separable into its component elements. The sutures between the elements may have been indistinct in his specimen, but it is hardly conceivable that a union of the skull bones would occur in one species and not in another of the same genus. Jaekel's suggestion (347) that "Etwas mehr Wahrscheinlichkeit möchte ich der Vorstellung beimessen, dass diese Ausbreitungen zum Schutz freier Kiemen dienten, wie sie z. B. bei den Perennibranchiaten als baumförmige Organe weit am Halse herausragen" can hardly find acceptance with students of the Paleozoic Amphibia, since there is not the slightest evidence that the Microsauria ever possessed external gills and considerable presumptive evidence that they did not. His comparison of the "perisquamosal" to the "Kiemendeckel" of the fishes is also very unhappy on morphological grounds, since the elements of his "perisquamosal" form constituent parts of the skull roof, which the operculum never does.

The palate of the skull (plate I 5 , fig. 2 ) has been determined by removing the skull bones of one specimen. Anteriorly the premaxillæ and maxillæ are clearly recognizable as large dentiferous elements. The premaxillæ have 4 to 7 teeth, the short maxilla has 3 to 4 . All the teeth are of nearly equal size. Smaller teeth seem to be indicated by impressions found between the larger ones. The vomers, which are tolerably large, unite with the premaxillæ behind and inclose at least half of the palatine foramen on the inner side. They are furnished with small teeth, which in the anterior part are very irregularly placed, but they are more regular posteriorly.

The palatines and transverse bones are questionably identificd. They seem to lic posterior and lateral to the vomers, but the sutures are indistinct. The large parasphenoid seems wcll displayed and is more or less heart-shaped. There would secm to be a slight indication of double occipital condyles. The pterygoids are broad plates which inclose the parasphenoid and form the lateral boundary of the palate. The cotyli are very indistinct, but appear as elongate grooves.

The pectoral girdle (plate $\mathbf{I}_{5}$, fig. 3 ) consists, apparently, of seven elements, three paircd and one unpaired. The unpaired element (the interclavicle) is truncate posteriorly and acuminate in front, with its surface radially grooved and the anterior borders beveled for articulation with the clavicles. The clavicles are triangular, as is usual with the Microsauria. They are sculptured with radiate grooves and ridges, with decided inosculations at the ossific center. The coracoids have only part of their surface ornamented; most of their surface is smooth for articulation with the interclavicle and scapula. A long spine projects from the inner surface of the cora- 
coid. A pair of small elements lie one on either side of the clavicles and Jaekel (347) interprets them as the cleithra. If they are cleithra they are unique among the Microsauria. The pectoral girdle does not, however, indicate that Diceratosaurus is "unique among all known quadrupeds."

Jaekel regards the limb which is preserved with the material as an arm (plate I 5, fig. 4), but there is no reason stated for his conclusion. It has all of the characters of the leg and may be regarded as such. Only a part of the lower end of the femur is preserved. The tibia and fibula are preserved as separate rod-like elements with one of the bones longer and larger, probably the tibia. There are 5 toes which have the customary phalangeal formula for a microsaurian foot of $2-3-3-4($ ?) -3 . The tarsals are unossified.

The vertebræ (plate I5) were perforated for the notochord, and are hour-glassshaped, with the neural arch thickened to support a heavy spine which bore a sculptured plate. These apical plates occur in the dorsal region, but diminish toward the caudal vertebræ. The number of the vertebræ in the dorsal region is very small and in the tail very large. There are possibly 2 vertebræ in the cervical, I I in the dorsal series; the thirteenth carries the pelvis. There are over Ioo vertebræ in the tail.

The ribs have an expanded head and the transverse processes of the vertebræ are long.

The following account is based on the writer's study of the type specimen and he is able to add several points of interest to a knowledge of the anatomy of the type of this interesting microsaurian.

The type specimen consists of I I consecutive vertebræ with a portion of the skull, the greater portion of the pectoral girdle, parts of both fore limbs, ribs, and ventral scutellæ (plate I4, fig. 4). The species is represented in the collection by yet another specimen, on which Cope based his Tuditanus mordax (plate 22, fig. 5), of which he himself says: "Further examination of the specimen on which the latter (T. mordax) was founded leads to the belief that it is an imperfect cranium of Ceraterpeton (Diceratosaurus) punctolineatum Cope." The plates referred to are rather to be regarded as clements of the pectoral girdle and I believe they represent the clavicle and a portion of the interclavicle.

The skull of the present species is fully described by Jaekel. The type specimen does not offer any evidence in support of Jaekel's "perisquamosal,": but rather tends to the idea that he is incorrect in his assumption of the fusion of these elements of the skull. The direction taken by the ridges and grooves on the elements preserved indicate a separation between the supratemporal and the squamosal. I do not find that the grooves have the tendency to arise from a common center of ossification in the squamosal, as suggested in the figures of Jaekel. The horn which projects backward from the squamosal is rather large and heavy for the size of the skull, and after curving slightly inward ends in a blunt point and not sharply, as Jaekel figures in his specimens. The vertebral column is indistinctly preserved and I have nothing to add to Jaekel's account given above.

In the structure of the pectoral girdle my results are greatly at variance with those of Jaekel. I do not find the remarkable elements which Jaekel has figured 
$(3+7)$ in his specimens. On the other hand, I find a normal microsaurian pectoral arch (464), such as has been described for numerous other forms. There are present, distinctly preserved in the type specimen, the scapulæ, the clavicles, and the interclavicle, with the possibility of the coracoid. The peculiar element referred to by Cope as resembling a "lacertilian pubis" is without doubt the left scapula of the animal (plate I6, fig. I). Its form compares very favorably with that of Ceraterpeton as figured by Woodward (630). The coracoid may be represented by the fragment which lies close to the scapula. The sculptured element lying next to the supratemporal horn of the skull is the right clavicle preserved bottom side up. Of the other two sculptured elements, one is the interclavicle, only a portion of which is preserved. The left clavicle lies beside it. The clavicles in this species have a tendency to assume the triangular shape so common in other species of Microsauria, and the
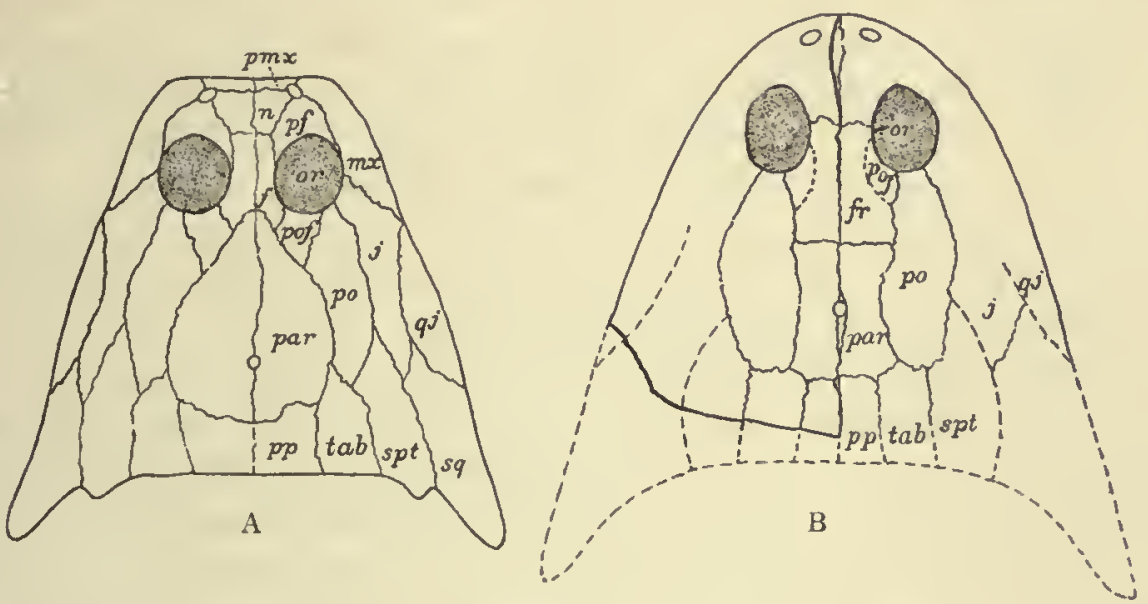

FIG. 24.

A. Skull of Diceratosaurus lavis Moodie, from the Linton Coal Measures. $\times$ I. $f$, frontal; $j$, jugal; $m x$, maxilla; $n$, nasal; or, orbit; por, parietal; pof, postfrontal; po, postorbital; $p f$, prefrontal; $p p$, postparietal; $s q$, squamosal; $s p t$, supratemporal; $q j$, quadratojugal; pmx, premaxilla; $t a b$, tabulare.

B. Reconstruction of skull outlines of Diceralosaurus robustus Moodie, from the Coal Measures of Ohio. $X 0.75$. $f r$, frontal; $j$, jugal; or, orbit; par, parietal; pof, postfrontal; po, postorbital; $p p$, postparictal; $q j$, quadratojugal; $s p t$, supratemporal; $k a b$, tabulare.

interclavicle, so far as can be determined, was shield-shaped. The upper surfaces of the pectoral elements are marked by grooves for the attachment of the pectoral muscles.

The ventral scutellation is present in a small patch (plate I6, fig. I) near the horn of the skull. The scutæ are oat-shaped and take the usual form. The ribs are not long, are rather stout, and beyond the proximal curve are nearly straight to the obtuse tips. The heads of the ribs are so obscure that it is impossible to determine whether they were two-headed or not. They are expanded proximally and there is a slight tendency to a division of the head.

Portions of both fore limbs are preserved. The right limb possesses the humerus, separate radius and ulna, and 2 metacarpals. The other possesses only the radius, 3 metacarpals, and a portion of a phalanx. The humerus is a very stout bone and at once recalls that of $A$ mblyrhynchus. The ends are expanded and there 
are roughnesses on the bone for the attachment of muscles. The radius and ulna are subequal in size. They are both expanded more proximally than distally. The carpus was cartilaginous. An additional specimen of this species is figured on plate 16, fig. 5. This adds to our knowledge of the pelvis especially.

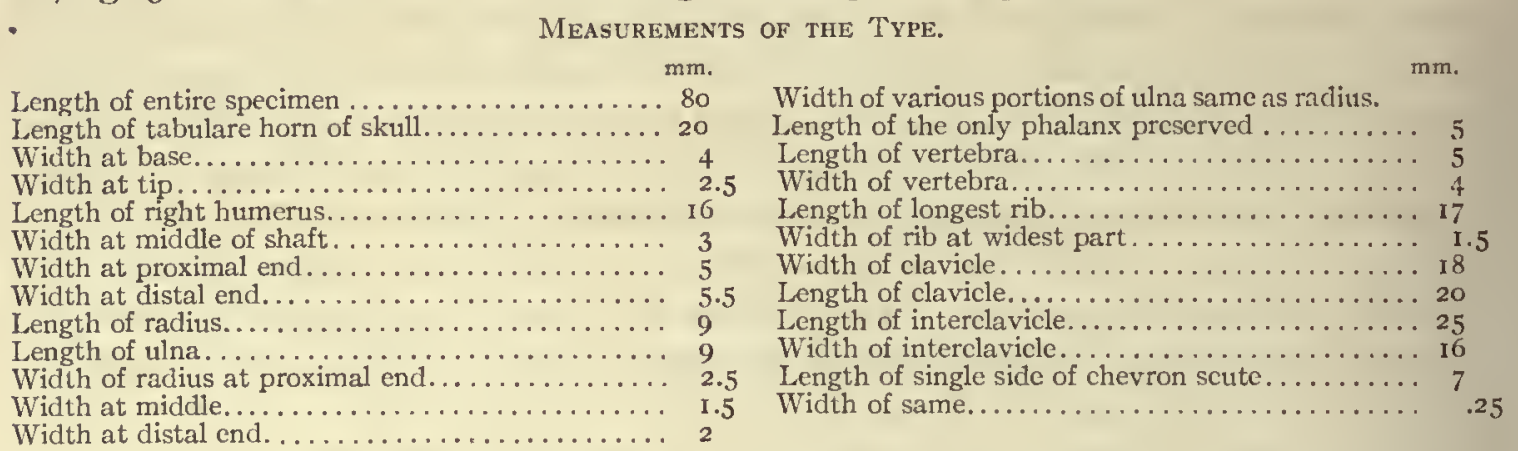

The specimen (No. 2566, Am. Mus. Nat. Hist.) on which Cope based his Tuditanus mordax is composed of two plates of the above-described species.

\section{Diceratosaurus lævis Moodie.}

Moodie, Jour. Geol., xvit, No. I, p. 63, figs. 13, 14, 1909.

Type: Specimen No. 102 ( 8680 G), American Museum of Natural History, where it forms part of the Newberry collection.

Horizon and locality: Linton, Ohio, Coal Measures.

The species is represented by an almost complete skull, which had been identified previously by Cope as Tuditanus radiatus. The specimen consists of the impressions of the bones of the cranial roof, the bones themselves having disappeared. It is not probable that the dorsum of the skull was smooth. The details in the structure of the skull have been ascertained quite definitely. There can be no doubt that the arrangement of the elements is accurate, as shown in figure $24 \mathrm{~A}$. The supratemporal, as in Erpetosaurus tabulatus Cope, is excluded from the parietal.

The form of the skull at once recalls that of the species $D$. punctolineatus, as figured by Jaekel (see plate 15 ). The orbits are located in nearly the same region of the skull and the sutures separating the cranial elements are quite similar in the anterior portions. The species $D$. leeris is based on the divergent character of the horn-like protuberances which project from the squamosals. The horns of $D$. punctolineatus are convergent. The present skull is also smaller and the parictals in $D$. lavis are much larger than in the type species. In the type species, also, the pineal foramen is located well forward in the parietal, while in the present form the foramen is located well posterior.

The skull is almost rectangular. The nostrils are elongate ovals. The orbits are circular and the distance between them is equal to two-thirds of the dimensions of the orbit. They are located well forward in the skull and are bounded laterally by the maxillaries. The nostrils have much the same character as in the type form, being broadly oval.

The premaxillæ are elongate transversely, being about twice as long as wide. They are identical in shape and relations with the same elements in D. punctolineatus Cope. The nasal is nearly square and forms the interior boundary of the nostril. The frontal is elongate in the median length of the sku1l and it is acuminate 
posteriorly, where the acumination is inclosed by the parictal and postfrontal. The parietals are by far the largest elements in the cranium. They form together an oval which is elongate in the longitudinal diameter of the skull. They inclose between them, in the median suture, the small pineal foramen. They are acuminate in front, with a broad truncate posterior base, where they are bounded by the postparietals. The postparietal is nearly square, being somewhat wider than long. It joins the tabulare and the parietal. The tabulare is elongate in the long diameter of the skull. It ends anteriorly in a point which is inserted between the postorbital and the parietal, and bears a short protuberance posteriorly, much as does the same element in the type species.

There are four elements which take part in the formation of the posterior border of the skull. These are the postparietal, the tabulare, the squamosal, and the supratemporal. It is very unusual for the supratemporal to reach the posterior edge of the cranium. The prefrontal lies anterior to the orbit, of which it forms the anterior border. The lacrimal has not been detected, although Jaekel (347) has indicated it in his drawings of the skull of the type species. The maxilla is elongate and forms the lateral border of the skull. No teeth have been detected, although they were doubtless the same as Jaekel has figured in D. punctolineatus. 'The jugal is an elongate element joining the maxilla posteriorly. Jaekel included this element in his "perisquamosal," but the sutures are clearly evident in the present specimen and there is no evidence of a structure at all similar to a "perisquamosal." The postorbital is fully as large as the jugal which it joins, forming a part of the posterior border of the orbit and ending posteriorly in a point which is inclosed by the tabulare and the squamosal. The postfrontal with the foregoing element forms the entire posterior border of the orbit and it likewise ends in a point inclosed by the parietal and the postorbital. The quadratojugal has much the same shape and relations as in $D$. punctolineatus, although it is located further back. The squamosal is also elongate, as are most of the posterior cranial elements, and it also has an acumination which is directed forward and is inclosed by the postorbital and jugal. The anterior suture of this element is rather indistinct, but it is, I believe, as represented (fig. 24). The element is elongate and is prolonged posteriorly to form the horn, which ends in a blunt point and is not sharp, as in the type species.

Jaekel (347) regards the species Diceratosaurus punctolineatus Cope as being unparalleled among known vertebrates in the possession of a "perisquamosal" element. In closely allied species the "perisquamosal" is easily separated into its component elements, and the morphology of the present skull would throw considerable doubt on Jaekel's interpretation of the skull of the type species. Another specimen, described below as another species of this genus, shows no evidence of this fusion. So far as I can learn, there have been no cases of true fusion of cranial elements correctly reported, unless it be that which possibly exists between the two frontals in the skull of Diplocaulus. It was on the basis of such fusions that Maggi (397) proposed to derive the interparietals of the primates from the tabulare of the stegocephalians. 
The posterior outline of the skull in the present specimen is not well preserved and the outline as given may be slightly inaccurate. The indentation figured by Jaekel in the posterior border of the skull of the type form is not present in the species under discussion.

Measurements of the Type Skuli of Diceiratosaurus lavis Moodie.

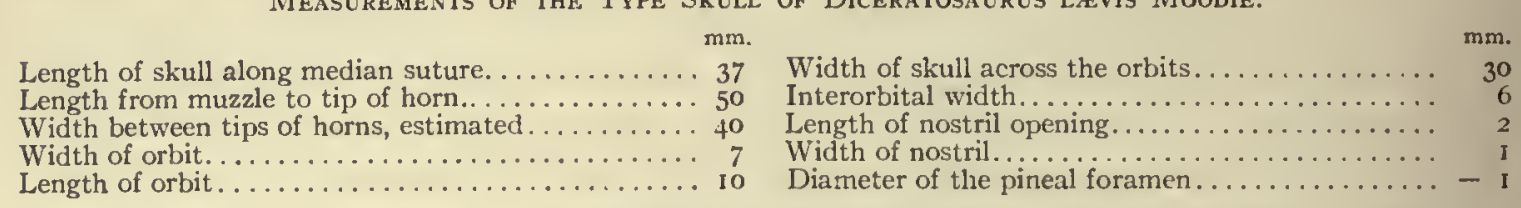

Diceratosaurus robustus Moodie.

Moodie, Jour. Geol., Xvir, No. 1, p. 67, fig. I5, 1909.

Moodie, Bull. Am. Mus. Nat. Hist., XXvi, art. XXv, p. 355, pl. lxiii, fig. 2, 1909.

Type: Specimen No. 861 i G, American Museum of Natural History.

Horizon and locality: Linton, Ohio, Coal Measures.

The present species is indicated by the left portion of a cranium representing a large individual. The characters of the skull are so clearly marked that it seems worthy of description. The presence of horns as given in the restoration of the skull (fig. 24, B) is based on the analogy with the other two species of this genus, in both of which horns are present. The generic determination of the species is based on the large size of the postorbital, which is essentially characteristic of the other species of Diceratosaurus.

The characters which distinguish the species from others of the genus are the large postorbitals and the small parietals, which are excluded from union with the postfrontals on account of the large size of the frontal. In the other two known species the frontal is small and the parietal comes forward to join the postfrontal. The present species exhibits a skull which is nearly twice as large as that of $D$. lavis and nearly three times the size of the skull of D. punctolineatus.

The portion of the skull preserved shows the cranium to have had a rather acuminate snout, not blunt as in the type species. The orbit is an elongate oval, although it has the same relative position in the skull as in the other specics. The nostril is indicated by an oval depression near the anterior edge of the skull. The frontals, as indicated by the sutures present on the portion of the skull which is preserved, are fully as long as the parietals. Whether they were as wide as is represented is uncertain. The postfrontals are very small bones, the sutures of which are somewhat uncertain, although they can not be far from what is represented (fig. 24, B). The postorbital is large and elongate, and is distinctive of this species on account of its unusual size, although it does not attain the same proportions as in other members of the genus. The parietals are elongate and narrow. The pineal foramen is represented by its lateral edge and its position is about midway of the longitudinal diameter of the parietals. The narrow postparietal is represented by its anterior border; as restored (fig. 24, B) it may be too long. The tabulare, also, is represented by an anterior portion and it shows this element to have the position and form which is typical of the form Diceratosaurus lavis. Such other of the cranial elements as are indicated are based on the relations discovered in D. laevis. 
The heavy line on the left of the drawing (fig. 24, B) represents the outline of the preserved portion. The skull, as restored, may be a little too long, and the shape of the horns is conjectural. In the orbit there are preserved 2 misplaced teeth showing longitudinal fluting. The longest tooth is about $3 \mathrm{~mm}$.

Measurements of the Type Skull of Diceratosaurus robustus Moode.

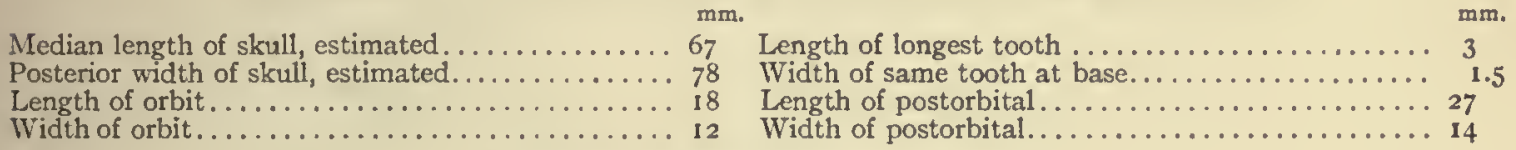

Genus EOSERPETON Moodie, 1909.

Moode, Jour. Geol., Xv1I, pp. 76-79, fig. 20, 1909.

Moovıe, Bull. Am. Mus. Nat. Hist., Xxvi, p. 355, pl. 1xiii, fig. I, 1909.

Type: Eoserpeton tenuicorne Cope.

The genus was proposed for the reception of a single species originally referred by Cope to Ceraterpeton (C. tenuicorne). The species can not be placed in the genus Ceraterpeton on account of the form and structure of the skull, which varies widely from that of the type species, Ceraterpeton galvani Huxley, from the Kilkenny Coal Measures of Ireland. The most important character in which the present species differs from C. galvani is the peculiar form taken by the squamosal and by the position of the "horn." These characters will be evident on referring to figure 25. No undoubted remains of Craterpeton have been found outside the British Isles. Fritsch referred (25I) a species, previously described as Scincosaurus crassus, to this genus, but Andrews (8), Jaekel (347) and Woodward (630) all unite in placing the species in the genus where it was formerly described. Jaekel even says that the Scincosaurus has no horns, so far as he can determine. Cope referred 3 species (123) from the Linton Coal Measures of Ohio to the genus Ceraterpeton, but it has been shown elsewhere (347) that no one of them belongs in the genus, nor in fact do they all belong in one genus.

\section{Eoserpeton tenuicorne Cope.}

COPE, Geol. Surv. Ohio, II, pt. II, pp. 372-373, pl. xlii, fig. 2, 1875 .

Cope, Proc. Am. Phil. Soc., Xxir, p. 407,1885 .

COPE, Proc. Am. Phil. Soc., xxxvi, p. 85, pl. iii, fig. 2, 1897.

Moonie, Proc. U. S. Nat. Mus., vol. 37, p. 23, 1909.

Type: Specimen in the American Museum of Natural History. There are also specimens Nos. 4472 and 4473 in the U.S. National Museum.

Locality and horizon: Linton, Ohio, Coal Measures.

The species was founded on a complete skull preserved on obverse sides of a block of coal. Cope (123, pl. XLII, fig. 2) figured this skull. The figure is poorly executed and does not do justice to the specimen, which is really well preserved. In general the skull is oval, with the orbits located well towards the acuminate snout. The interorbital space is equal to twice the width of the orbit. The pineal foramen lies near the center of the skull. The quadrate angles are drawn out into slender acuminate, longitudinally striate horns, processes from the squamosal. The "horn" arises from an expanded base, which is a portion of the cranial element at the postero-lateral angle of the skull. This character is taken as the distinctive 
one of the genus. It is possessed by no other form of Carboniferous air-breathing vertebrate, in association with the other characters of the form.

The boundaries of the premaxillæ are indefinite, but what remains of the sutures indicates that the elements were small. No teeth have been detected. The nasal is likewise not clearly defined, but the frontal is an elongate element which occupies the space between the orbits and joins the parietal posteriorly. The parie-

Measurements of the Type of EoserpeTON TENUICORNE.

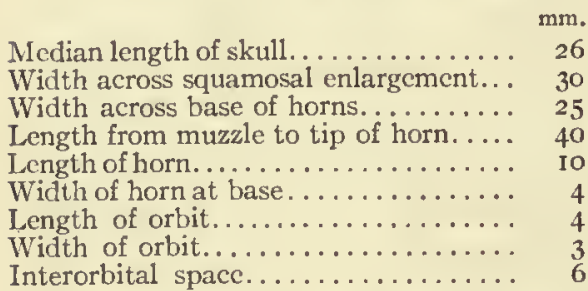

Nos. 4472 and 4473 , U. S. National Museum, from Linton, Ohio, Coal Measures.

Median length of skull .......... 16

Maximum width of skull. ............. 20

Length of horn from base......... 7

Length of orbit.................. 3

Interorbital width.................. 3.5

Length of vertebral column to sacrum. . 33

Length of femur................ 5.5

Length of tibia and fibula............ 3

Length of second digit (incomplete)..... 7

Length of metatarsal............

Length of clavicle............. 6

Width of clavicle.............. 3.5

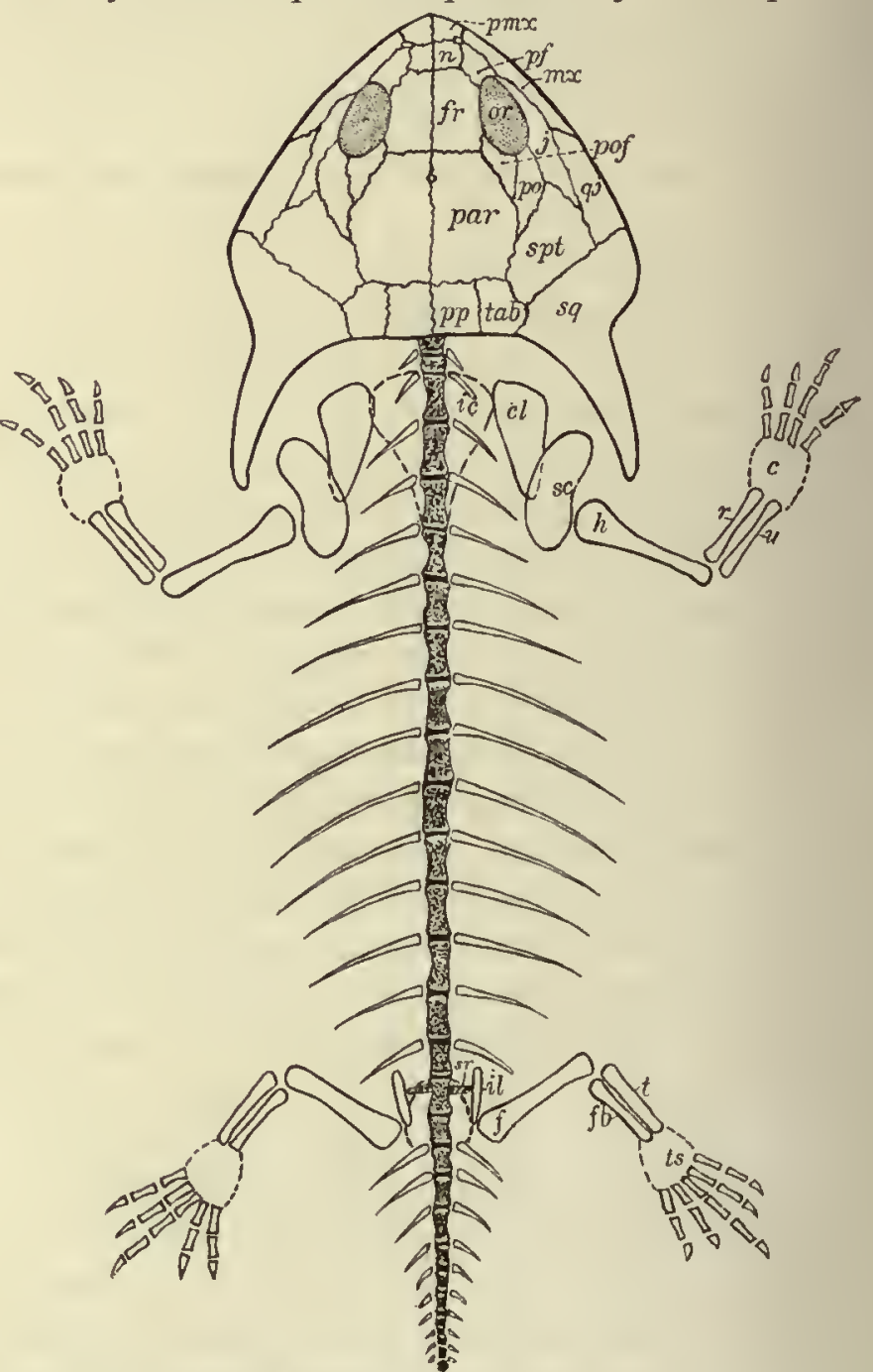

FIG. 25.-Restoration of skeleton of Eoserpeton tenuicorne Copc. $\quad \times \mathbf{I} .5$.

Skull: pmx, premaxilla; $n$, nasal; $f r$, frontal; par, parietal; $p f$, prefrontal; $m x$, maxilla; pof, postfrontal; po, postorbital; $p p$, post parietal; $j$, jugal; $q j$, quadratojugal; $s p t$, supratemporal; $s q$, squamosal; $t a b$, tabularc.

Skeleton: $i c$, interclavicle; $c l$, clavicle; sc, scapula; $h$, humerus; $r$, radius; $u$, ulna; $c$, carpus; $s r$, sacral rib (uncertain?); $i l$, ilium; $f$, femur; $f b$, fibula; $t$, tibia; $t s$, tarsus.

tals form a large oval space, so characteristic of many of the Carboniferous Microsauria, in the anterior third of which occurs the median parietal foramen. The postparietal is almost square, and forms part of the posterior boundary of the skull. The tabulare has the usual position and relations. The prefrontal is ill defined. The postfrontal is small and forms a slender rod on the postero-inner boundary of the orbit. The postorbital is small and its bounding suture with the postfrontal is 
indefinite. The jugal is only partially represented in the specimen, and that part forms the outer boundary of the orbit. The maxillary sutures are not defined. There are no evidences of teeth, since the skull is compressed dorso-ventrally. The quadratojugal is, apparently, a larger element than usual, with the usual relations. The supratemporal lies in great part in front of the squamosal, but still has the normal relations of that element. The squamosal is the characteristic feature of the skull. It is very tumid at its base and projects into a long, slender, acuminate horn, the tumid portion being ornamented by radiating strix.

Another specimen of this species presents the greater part of the skeleton. However, very little can be added to our knowledge of the skull structure. It is barely possible that the second specimen may be distinct from the type. The horns are curved inward, but otherwise there is little or no difference. One of the most interesting and important features of the complete specimen is the unusual preservation of a leg, with impressions of 15 or more vertebræ, and traces of curved ribs which are intercentral in position.

The femur is slender and expanded at the ends, with the articular surfaces well formed. The tibia and fibula are mere rods of bone, although the tibia has slightly expanded extremities. There is no osseous tarsus. There are 5 digits in the foot; the second one is entire and contains 4 phalanges; the other digits are incomplete. The foot is remarkably long and slender, and is fully as long as the tarsal space plus the tibia, with the terminal phalanx clawed.

There are impressions of 2 oval and elongate clavicles in the pectoral region. The outer end is not expanded as is usual, and the surface is ornamented with grooves and ridges which radiate from a common center.

The entire remains measure scarcely 3 inches in length and it is to be doubted if the creature attained a length of more than 4 inches. It is probably a young form, but there are no evidences of external gills. The chevron armature is but poorly preserved, but so far as can be determined it is not different from that of other Microsauria, such as Amphibamus. 


\section{CHAPTER XVII.}

\section{THE MICROSAURIAN FAMILY AMPHIBAMIDAE, FROM THE COAL MEASURES OF MAZON CREEK, ILLINOIS.}

\section{Family AMPHIBAMIDÆ new family.}

Small, lizard-like, terrestrial or semi-aquatic, megacephalic microsaurians, known from 3 species. The family characters are the huge size of the head as compared to the body, the short, stumpy body with about 25 short dorsal vertebræ, a very short tail, phalanges clawed, pubis of calcified cartilage, sclerotic plates in the orbit to the number of 29 or 30 in each, ventral armature well developed. Teeth anisodont, sharp, conical, non-striate.

Two genera are associated in this family: Amphibamus grandiceps Cope, known from three nearly complete skeletons; $A$. thoracatus Moodie, known from a single incomplete skeleton; Cephalerpeton ventriarmatum Moodie, anterior portion of body and skull. The species are all from the Mazon Creek shales and the family seems unrepresented elsewhere. It may be necessary to compare the Amphibamidæ with the Hylonomidæ when the latter group is better known, but in the light of our present knowledge the two families are distinct.

-The genera may be distinguished as follows:

I. Size small, less than 3 inches in total length, skull with deeply incised tympanic notches (ear-slits) ..Amphibamus -II. Size relatively large, body-length 6 inches or more, teeth distinctly anisodont, skull with nearly even posterior table, limbs very long, ventral armature highly developed.............. Cephalerpeton

\section{Genus AMPHIBAMUS Cope, 1865.}

Cope, Proc. Phila. Acad. Nat. Sci., 1865, pp. 134-137. Geol. Surv. Ills., Ir, pp. 135-141, pl. xxxii, I text-fig. Hay, Proc. Am. Phil. Soc., Xxxix, p. I20, 1900.

Moodie, Jour. Geol., xv11, p. 81, fig. 24, Igog.

Type: Amphibamus grandiceps Cope.

The publication of the type species of this genus began the researches of Professor Cope on the extinct Amphibia of North America, which he continued for so many years with such excellent results (I05-I 77). The description was based on a single specimen (plate 3, fig. 7) belonging to Mr. Joseph Evans, of Morris, Illinois, who loaned it to Dr. Worthen for the Illinois Geological State Survey (I07), in order that it might be described. The type has been destroyed by fire; so I am informed by Mr. L. E. Daniels, of Rolling Prairie, Indiana. There are two other known specimens of the species. One is in the collection of Mr. Daniels and the other No. 794, of Yale University Museum.

This genus may be clearly separated from all the other microsaurians by characters which are peculiar to the form. Among these may be mentioned the possession of sclerotic plates in the eyes; the large size of the orbits in comparison with the dimensions of the skull; the short, broad form of the body; the very short tail; the possession of a calcified cartilaginous pubis; clawed phalanges; presacrals 22. The character which places the genus distinctly in the Microsauria is the possession of long, slender, curved ribs, first detected on Mr. Daniels's specimen (plate I4, figs. 


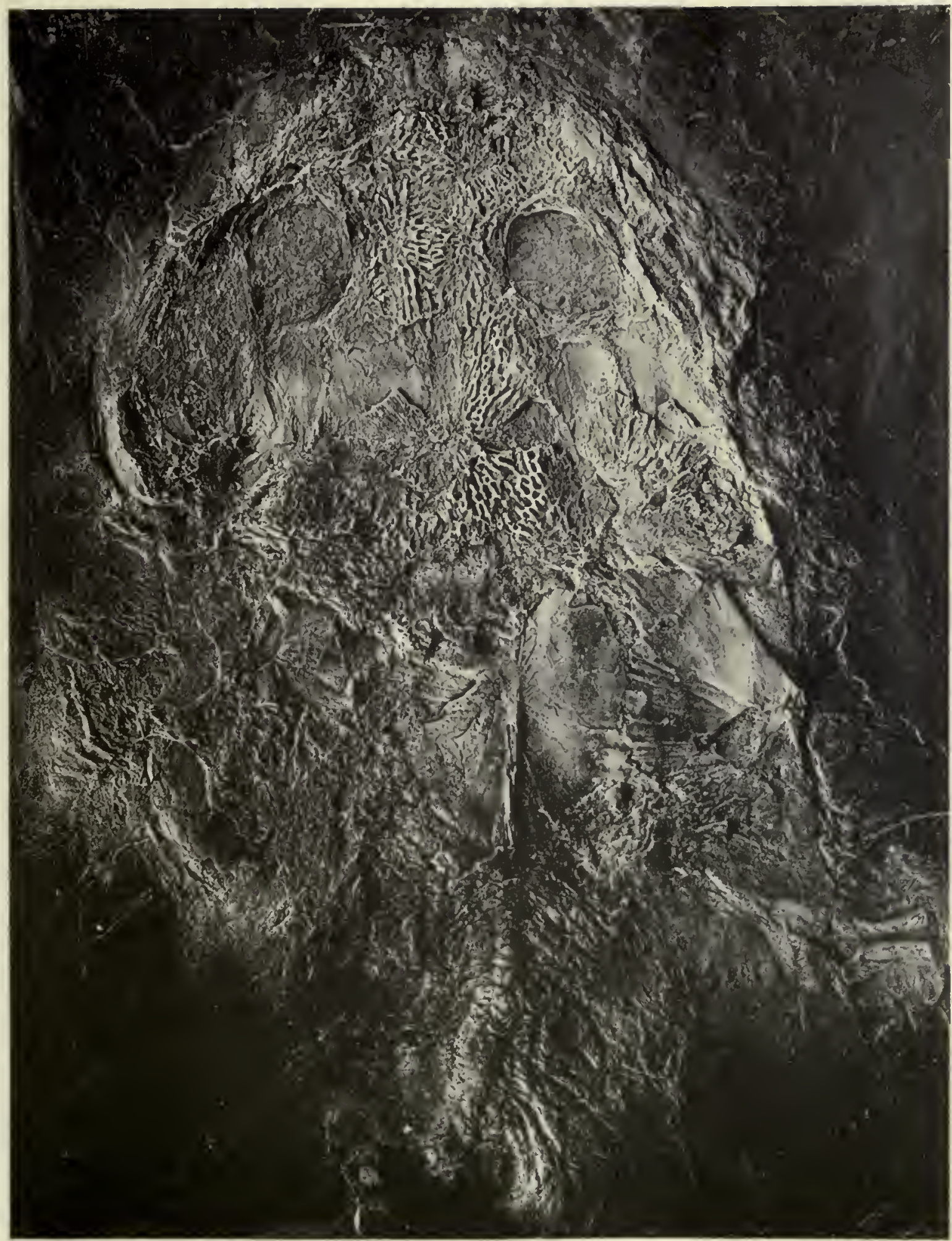

Type of Saurerpeton latithorax Cope. $\times 1.5$. Original in U. S. National Museum. 

I, 2), by Dr. Hay (316). Its stegocephalian characters are evident in every particular of its anatomy-the roofed skull, the arrangement of the cranial elements, the presence of a well-developed ventral armature, and the digital formula ( 4 for the hand and 5 for the foot).

The genus Amphibamus was regarded by Cope as a representative of a new order of vertebrates which he called (105) Xenorachia. He later (I23) abandoned this, however. Fritsch (251), Zittel (642), and others regarded Amphibamus as a branchiosaurian. The exact position of the form was uncertain until 1900, when Dr. Hay (316) described the long, curved ribs and suggested its place among the Microsauria. He, however (Cat. Foss. Vert., p. 410), made the mistake of including the branchiosaurian family Protritonidæ, under Microsauria, thus confusing the subject further. The genus (462) has not the slightest relationship with the Branchiosauria.

\section{Amphibamus grandiceps Cope.}

Cope, Proc. Phila. Acad. Nat. Sci., pp. I34-137, I 865; Geol. Surv. Ills., 11, pp. 135-141, pl. xxxii, and I woodcut, I 866.

Hay, Proc. Am. Phil. Soc., xxxix, p. $120,1900$.

Moodie, Jour. Geol., xvir, No. I, p. 82, fig. 24, 1909.

Moodie, Kan. Univ. Sci. Bull., vi, No. 2, pp. 343-349, pl. r, figs. I and 2; pl. 5, fig. 3; pl. 7, fig. r; pl. II, $12,13,1912$.

Type: Specimen has been destroyed. There is an excellent specimen (plate 4, figs. 5, 6), No. 794 (1234), in Yale University Museum, and another nearly as good in the possession of Mr. L. E. Daniels, of Rolling Prairie, Indiana.

Horizon and locality: Mazon Creek shales, near Morris, Illinois.

The form of the skull of Amphibamus grandiceps Cope is not unlike that of Tuditanus minimus Moodie (462) from the Linton, Ohio, beds, but it is less acuminate than in that form. The large size of the orbits is especially striking. The shape of the skull is triangular, with concavities in the posterior table which correspond to the ear-slits so characteristic of Metoposaurus (242) from the Keuper of Germany. The narrowed posterior table of the skull is truncate, as in several other genera of Microsauria, notably Tuditanus and Saurerpeton. In structure the skull differs but little from many of the other Carboniferous forms, but the arrangement of the elements of the skull is more regular than in other genera.

The premaxillaries are very small elements in the anterior tip of the skull. They border the nares. The skull is rather peculiar among the Microsauria in the possession of a distinct lacrimal. I have detected this element in the cranium of Stegops divaricata Cope. As here defined the lacrimal is triangular, with its posterior border formed exclusively by the prefrontal. Its other relations are the normal ones. The nasal is elongate, with the usual relations of that element. The frontal is slightly longer and broader than the nasal. It apparently forms a portion of the inner border of the orbit. The parietal foramen lies in the anterior fourth of the parietal, a rather unusual position for this structure. The parietals, as in so many of the Microsauria, together form the largest element of the skull and are roughly a triangular area in the postero-median portion of the skull. 'The postparietal and the tabulare are clearly distinguishable and they have the usual relations for those elements. The maxillary, jugal, and quadratojugal together form the greater part of the maxillary border. The postero-lateral angle of the skull is, 
as usual, formed by the squamosal. The orbit is bounded posteriorly by the postorbital and the postfrontal, which include in the angle between them the quadrangular squamosal. The orbit is especially remarkable for its size as compared with the dimensions of the skull, being without a parallel among other known Microsauria. Around the border of the orbit in the specimen Cope studied (I05) there were found I4 quadrangular plates which he called "superciliary plates." Hay (3I6) was inclined to regard them as sclerotic plates. In the Yale Museum specimen (plate 4, figs. 5, 6) there are 20 . of these plates, and there seems to be no doubt that they are sclerotic elements. In therestoration (fig. 26) 29 sclerotic plates are given, but there is no assurance that this number is the exact one. They may alsohave been slightly larger, but not as large as in Branchiosaurus.

The vertebral column is preserved nearly entirc in the Daniels specimen and quite entire (478) in the Yale specimen. Cope, in his study of the type (105, I07), thought there could be no more than I 3 presacrals, but the specimen was poorly preserved and indecisive on this point. Dr. Hay (3I6) was inclined to the opinion that there were less than 20 . The Yale specimen shows 22 centra, which are elongate, hour-glassshaped bodies, with the neural spine a long, low crest running the entire length of the centrum,

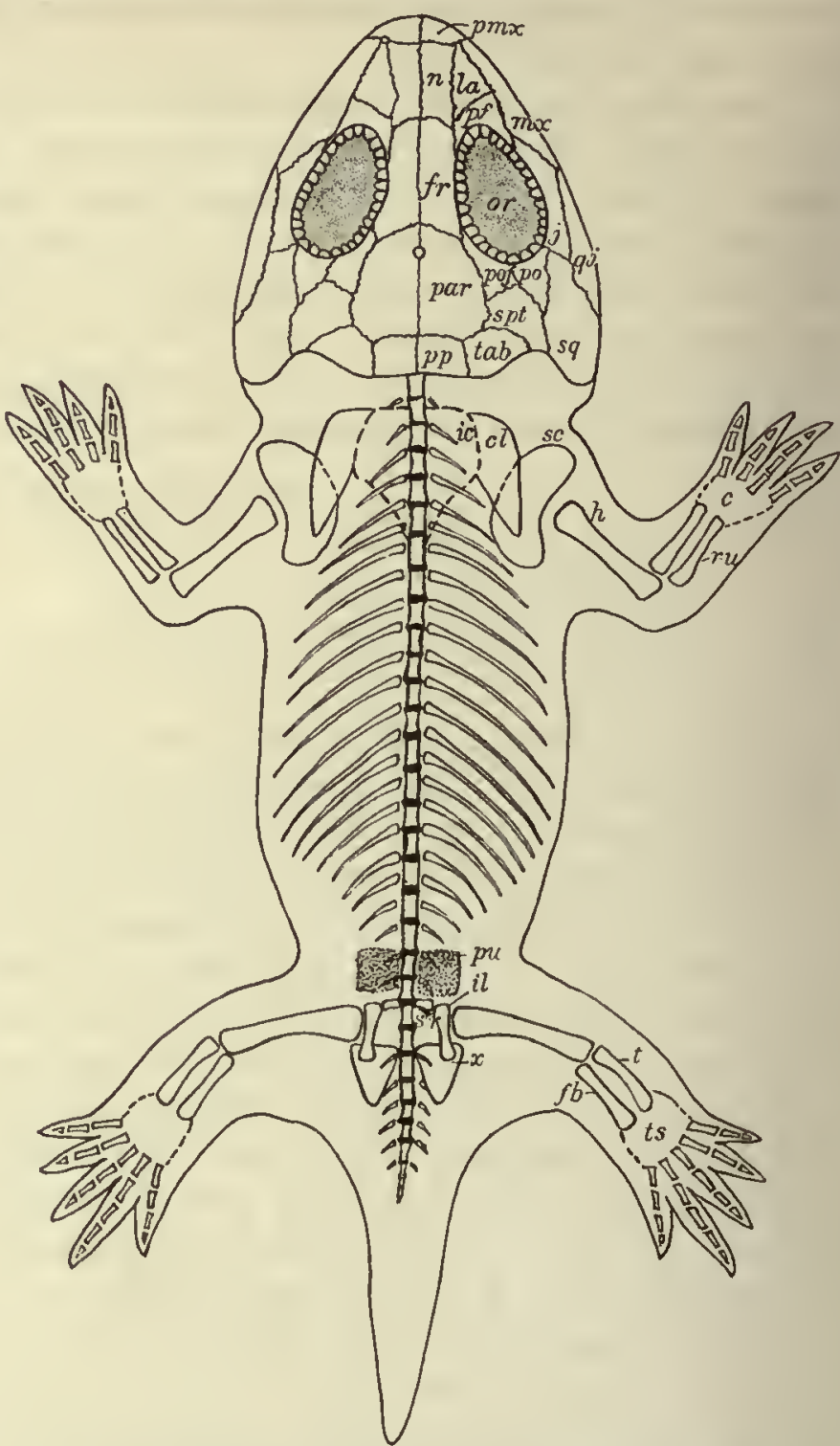

FIG. 26.-Restoration of body outline and skeleton of Amphibamus grandiceps Cope, from Mazon Creck, Illinois, shales. Restoration is based on complete specimens of the species and on Cope's drawing. Form of body is indieated in one specimen, tliat in possession of Mr. Daniels. $\times \mathbf{I . 5}$.

Skull: $p m x$, premaxilla; $n$, nasal; $f r$, frontal; par, parietal; la, lacrimal; $p f$, prefrontal; pof, postfrontal; po, postorbital; $p p$, postparietal; $s p t$, supratemporal; $m x$, maxilla; $j$, jugal; $q j$, quadratojugal; $s q$, squarnosal; $t a b$, tabulare.

Skeleton: $i c$, interclavicle; $c l$, elavicle; $s c$, seapula; $h$, humerus; $r-u$, radius, ulna; $c$, carpus; $p u$, pubis; $i l$, ilium; $f$, femur; $\ell$, tibia; $f b$, fibula; $t s$, tarsus; $x$, isehium. with a median elevation, so that in lateral view the spine would be triangular in form. The body of the centrum is expanded laterally into a diapophysis which extends anteriorly. The posterior vertebræ, at least, had the notochord largely persistent. 
The osseous part of the vertebra seems to have been but a thin shell, and the structure of the zygapophyses can not be determined. That they were dorsal in position is, however, evident from several vertebræ. The points of these structures project laterally. The tail is short and the caudal vertebra weakly developed.

There are distinct impressions of at least $\mathbf{I} 2$ pairs of ribs in the Daniels specimen. They are long, slender, and curved, and there is no definite assurance that there were as many ribs as are indicated (fig. 26) in the restoration (462). The ribs are intercentral (469) and probably occupied the full length of the vertebral column. There may have been as many as.indicated in the restoration.

One of the most interesting features of the Yale specimen is the preservation of a small patch of skin, evidently from the back, lying to one side near the head, measuring $5 \mathrm{~mm}$. in length by 3 $\mathrm{mm}$. in width. The fragment shows the skin to be of tuberculated scales, 4 of which occupy the length of $\mathrm{I} \mathrm{mm}$. The scales are somewhat hexagonal, almost rounded, and were relatively quite thick. They lie in a close mosaic (fig. 27).

The Yale specimen has, very well preserved, a portion of the ventral scutellx, of the throat,
chest, and belly. The arrangement of the plates on the throat

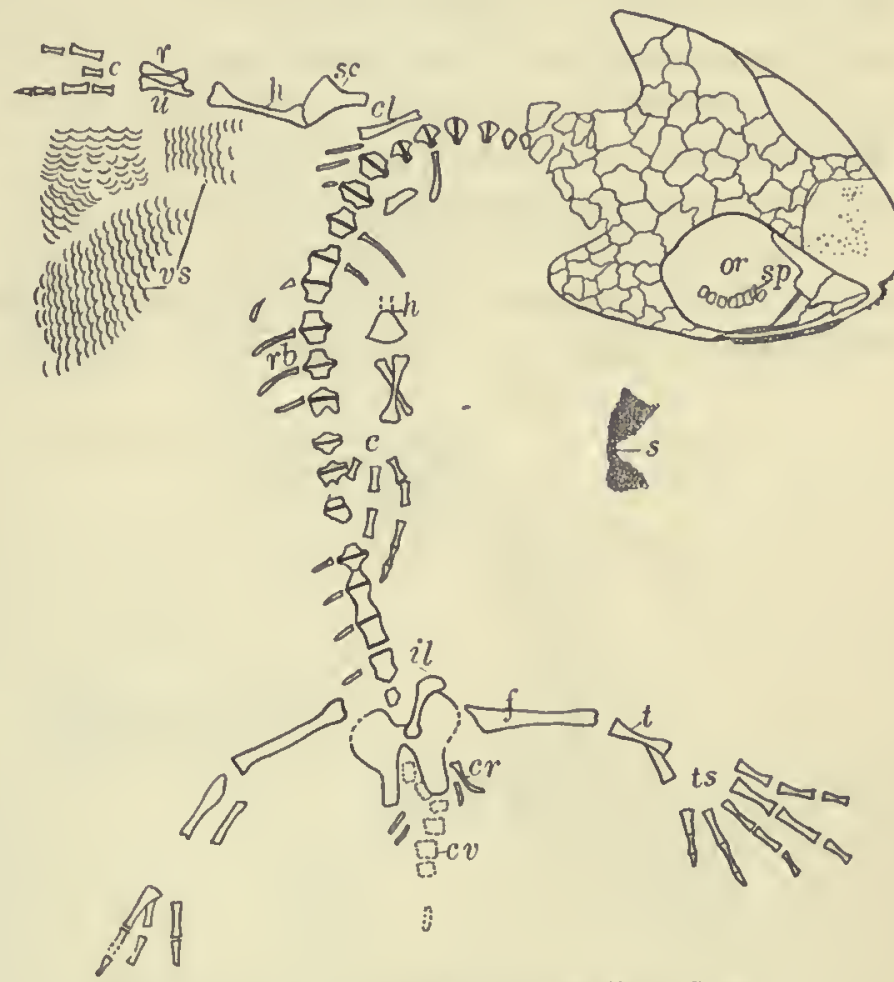

FIG. 27.-Skeleton of Amphibamus grandiceps Copc. $\times 1.4$.

$c$, carpus; $c l$, clavicle; $c r$, caudal rib; $c v$, caudal vertebra; $f$, fernur; $h$, humerus; $i l$, ilium; $s$, skin; or, orbit; $r$, radius; $u$, ulna; $s c$, scapula; $s p$, sclerotic plates; $\ell$, tibia and fibula; $t s$, tarsus; $v s$, ventral scutellæ. Specimen No. 794, Yale University Museum. and chest is almost exactly the reverse of what Credner has described (190) for Branchiosaurus amblystomus Cred. On the throat, in the present form, the chevron points anteriorly, and it is the anterior prolongation of the belly scutes with the posterolateral projection of the gular scutes which form the chest and arm seutellation. The belly chevrons point anteriorly, as in Branchiosaurus, the rods formed by the scutes being straight and not curved as in Branchiosaurus. The entire ventral armature preserved is displaced to the left of the animal and only the anterior portion is preserved.

The pectoral girdle is only partially known. The scapula is crescent-shaped. The other elements are indicated only by fragments and nothing is known of their form.

The arm elements are nearly all known. The humerus is slender and expanded at the ends, with its articular surfaces well developed. The separate radius and ulna are of approximately the same size and length. The carpus is unossified. The com- 
plete phalangeal formula for the hand of Amphibamus is unknown. The third digit seems to have 4 elements. The formula $2-2-3-2$ has been suggested (462).

The pelvis is very satisfactorily known. The ilium is a long, slender, straight rod, with expanded ends. The ischium is shown on both sides of the vertebral column in the Yale specimen. Its form is almost identical with that of Paleohatteria longicaudata Credner, from the Rothliegenden of Saxony. The ischia are apparently approximate in the median line, though this character is somewhat obscured by the impression of the caudal vertebræ. Their relation with the ilium, other than that they were posterior to it, is uncertain. The pubis is, apparently, calcified cartilage. It is a squarish plate, somewhat corrugated, lying anterior to the ilium in the Daniels specimen. The elements of the pelvis were undoubtedly hung loosely in the flesh, as in modern salamanders, since there is no indication of articular surfaces.

The hind limb is well known, the type having a nearly complete leg with the foot. The Daniels and the Yale specimens supplement and substantiate the type. The femur is longer than the humerus, but more slender, with its articular surfaces

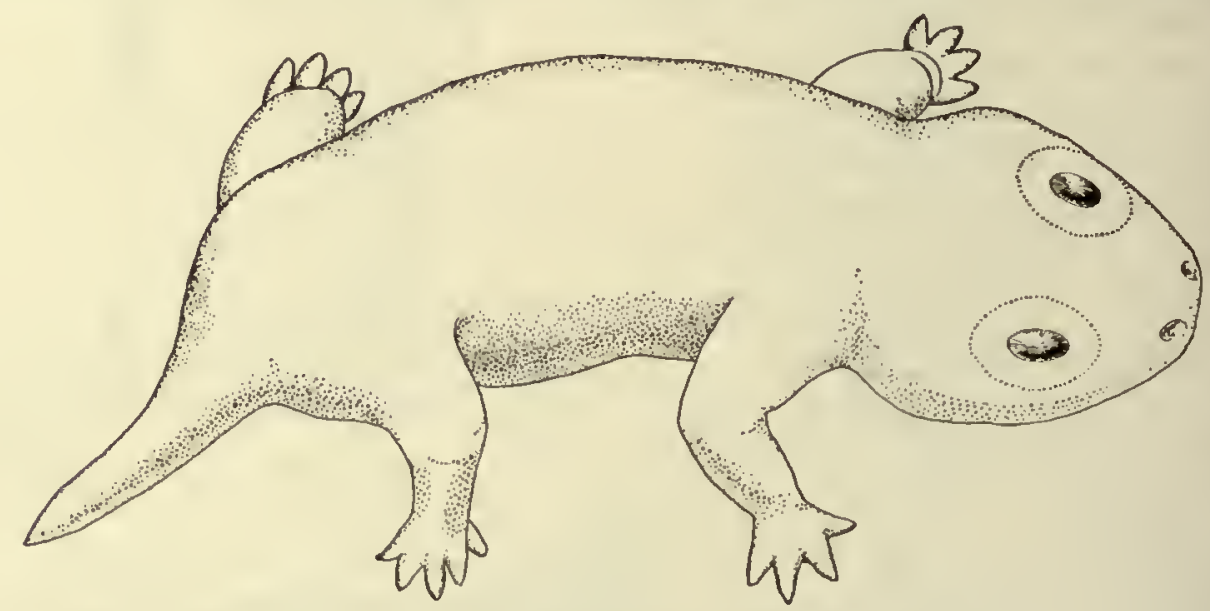

FIG. 28.-Restoration of probable appearance of Amphibamus grandiceps Cope on the basis of the material described herewith. $\times 1.5$.

about as well developed as in the humerus. The element is a simple rod of bone without muscular crests of any kind. The tibia and fibula are, likewise, slender separate rods of bone. The tarsus is unossified. The phalangeal formula is $2-2-3-$ $4-3$, and is fairly definite.

In the type specimen the matrix in the orbit was blackened as if by the pigmentum nigrum of the choroid. The same has been noticed in other specimens. Professor Cope thought this indicated that the animal was nocturnal.

There are many characters in Amphibamus which seem to approximate the reptilian type of structure. Among these may be mentioned the character of the articular surfaces of the limb bones, the intercentral position of the ribs, the incipient double-headedness and the curvature of the ribs, the presence of a cartilaginous calcified pubis, the length of the limbs, and the clawed character of the phalanges.

Amphibamus was a low, flat, short, and undoubtedly a creeping, crawling animal, possibly spending a portion of its time in the water; but it could not have been a swimmer. It was one of nature's first attempts at constructing a land vertebrate. 
Measurements of Ampilbamus grandceps Cope.

Collection of Mr. L. E. Daniels, of Rolling

Prairie, Indiana:

\begin{tabular}{|c|c|}
\hline & \\
\hline ridth of head...... & \\
\hline 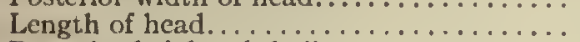 & \\
\hline or height of skull. & \\
\hline . & \\
\hline$\ldots \ldots$ & \\
\hline th. & \\
\hline bits. & \\
\hline st back of orbits......... & \\
\hline $\begin{array}{c}\text { ral region of the vertebral } \\
\end{array}$ & \\
\hline ail. & \\
\hline nb & \\
\hline & \\
\hline ult & \\
\hline served... & \\
\hline rve....... & \\
\hline ....... & \\
\hline & \\
\hline um $\ldots \ldots \ldots \ldots$ & \\
\hline $\begin{array}{l}\text { of scapula }(?) \text { f } \\
\text {.............. }\end{array}$ & \\
\hline th of impression of body midway...... & \\
\hline
\end{tabular}

No. 794 (1234), Yale University Museum:

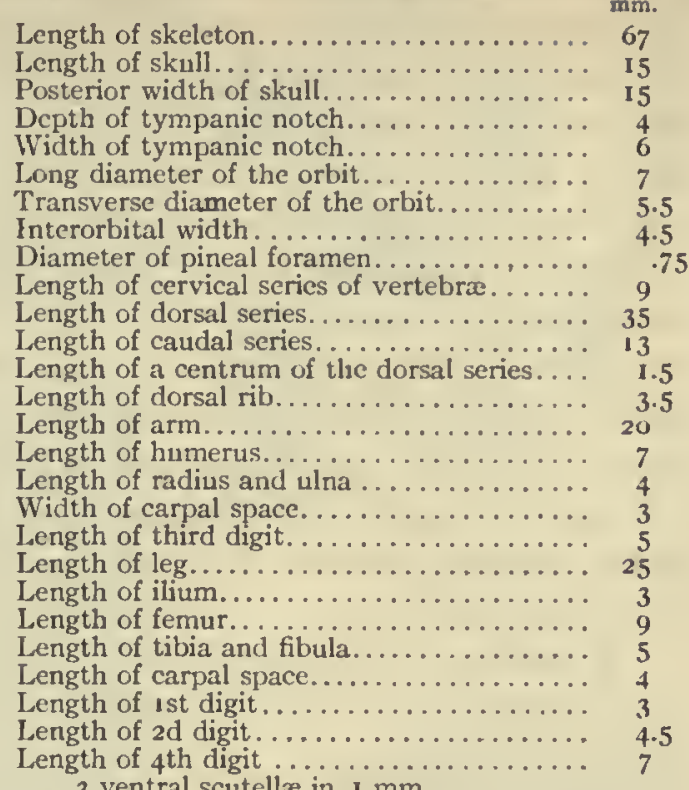

Amphibamus thoracatus Moodie.

Mloonie, Proc. U. S. Nat. Mus., 40, pp. 43I-433, fig. 2, 19 II.

Moode, Kans. Univ. Sci. Bull., vi, No. 2, pp. $347^{-3}-39$, pl. 5, fig. 2, I9I 2.

Type: Specimen No. 4306, U. S. National Museum.

Horizon and locality: Mazon Creek shales, near Morris, Illinois.

The type is a part of the collection of Mr. R. D. Lacoe, in the U.S. National Museum. The fossil is very poorly preserved, but the remains are to be seen on both halves of the nodule, so that considerable can be made out as to its structure.

The chief diagnostic characters which will at once distinguish the species are the elongate arm, large interclavicle, shape of the vertebra, and triangular skull.

The portions of the animal which are preserved are the impression of the skull with one orbit, the right humerus and radius with portions of others, and traces of ventral scutellæ. These remains are so intermingled with the remains of plants that it has been quite difficult to distinguish bone impression from plants. This, however, has been done by whitening the fossils with ammonium chloride, when the texture of the fossils serves to distinguish the one from the other. Parts of the plants have been converted into galena and kaolin, as have also parts of the bones, so the task has been rendered doubly difficult. There can be no doubt, however, that the observations recorded below are correct. The position of the arm in relation to the pectoral girdle and the position of the girdle in relation to the skull impression first called attention to the possible presence of a fossil amphibian.

There is little to be said of the skull. It is merely an impression in the nodule. It is triangular in form, with the snout an acute angle. The angle is, however, exaggerated by the compression to which the fossil has been subjected. The right side of the skull lies over a portion of some plant. The animal is preserved on its back, so that this gives a good opportunity for the study of the pectoral girdle, which is par- 
tially preserved. The interclavicle is very large and from it the species has been given its specific name (thoracatus - armed with a breast plate). It is an exaggerated $\mathrm{T}$, with the stem very short with its anterior margin curved, and ending in a rather sharp, elongate point. The interclavicle recalls, in a measure, the same element of the Branchiosauria, although it is much more expanded anteriorly and has a shorter spine. In these respects it resembles more nearly a reptilian interclavicle (fig. I4 B).

The clavicle is of the simple triangular shape so characteristic of the Microsauria. It is somewhat displaced backward and its inner margin is slightly obscured. The humerus is elongate, apparently cylindrical, and with expanded ends, resembling very closely the humerus of Amphibamus grandiceps, although its proportions are much greater than in that species. Its length is almost equal to the length of the skull, while in $A$. grandiceps the length of the humerus is only half that of the skull. The radius (ulna?) resembles in its general proportions those of the humerus. It is a more elongate, slender, lighter bone. The impression of the other bone of the forearm is obscured.

A portion of a single vertebral centrum from the posterior part of the dorsal series is preserved. It is apparently amphicolous; its width is nearly half greater than its length.

Measurements of the Type of Amphibamus thoracatus Moode.

(No. 4306, U. S. National Museum.)

\begin{tabular}{|c|c|c|c|}
\hline Length of entire specimen, as preserved........ & $\begin{array}{l}\mathrm{mm} \text {. } \\
60\end{array}$ & Greatest transverse diameter. . & mm. \\
\hline 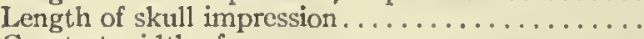 & 18 & Length of humerus........... & 10 \\
\hline 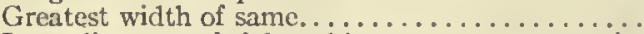 & I 5.5 & Greatest diameter of same. & 4 \\
\hline Long diameter of right orbit... & 4 & Least diameter of same... & I.5 \\
\hline Transverse diameter of same... & 3 & Length of radius (ulna?). & II \\
\hline ansverse width of interclavicle............ & I4 & Length of verteloral centrum. & 2 \\
\hline ing diameter of same $\ldots \ldots \ldots \ldots \ldots \ldots \ldots$ & $7(?)$ & Width of same............ & 3 \\
\hline ng diameter of clavic & & & \\
\hline
\end{tabular}

\section{Genus CEPHALERPETON Moodie.}

MoonIe, Kans. Univ. Sci. Buil., vr, No. 2, p. 349, I912.

Type: Cephalerpeton ventriarmatum Moodie.

This genus is founded on remains of a nearly entire individual of a relatively large microsaurian from the Mazon Creek shales. The genus is most immediately related to the Amphibamidx, of which two species are already known, Amplibamus grandiceps Cope and $A$. thoracatus Moodie. The present genus differs from these species in many respects, notably in size. The skull in Cephalerpeton is nearly as long as half the entire body of Amphibamus grandiceps Cope, inclusive of the tail. Other structural differences are the anisodont teeth, the large size and the more median position of the orbits, and the absence of the posterior tympanic notch in Cephalerpeton. The form of the skull recalls that of Melanerpeton and Pelosaurus (190) of Europe, but those genera are branchiosaurian, while the present form, from the structure of the vertebræ and the long, curved ribs, is an undoubted microsaurian. Nothing like it occurs in any of the amphibian faunas thus far made known. It is most nearly approached by a member of the genus Erpetosaurus, but from this genus the present form is readily distinguished by the smooth skull bones, the absence of a posterior table to the skull, and the presence of a highly developed ventral armature. The interorbital width is less than the transverse diameter of the orbit. 

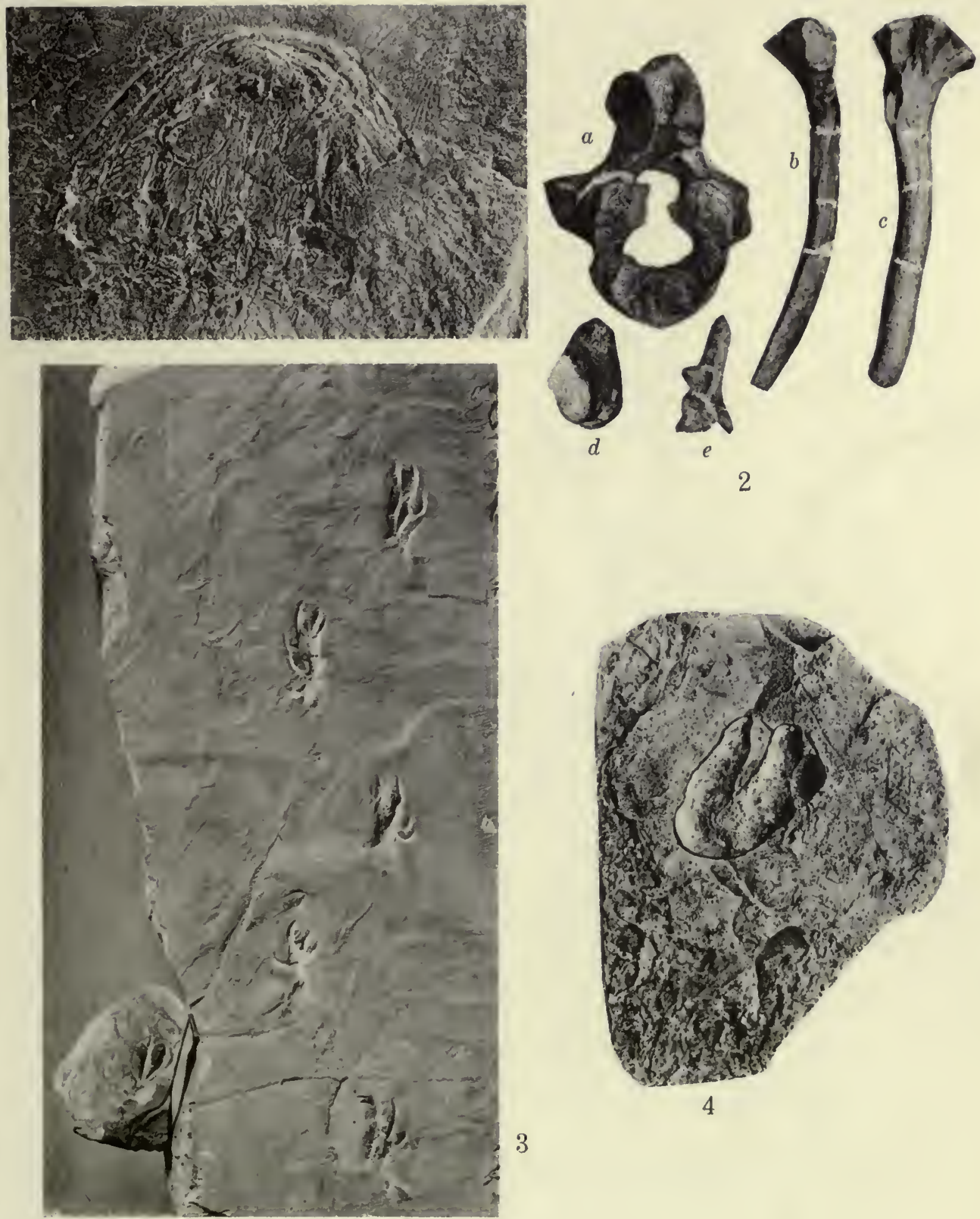

3

1. Type specimen of Erpetosaurus sculptilis Moodie, from the Cannelton Shales of Pennsylvania. Original in the University of Chicago, Walker Museum.

2. Skeletal elements of Eryops sp. indet., from the Pittsburgh Red Shale at Pitcairn, Pennsylvania. $a=$ nearly complete vertebra; $b$ and $c=$ ribs; $d=$ pleurocentrum; $c=$ nevral arch and spine. Originals in the Carnegie Museum at Pittsburgh. After Case.

3. Photograph of amphibian footprints, Dromopus aduncus Branson, from the Mississippian shales of Giles County, Virginia. $\times \frac{1}{3}$. Courtesy of Dr. Branson. Original in the Museum at Oberlin College.

4. Photograph of type of Thinopus antiquus Marsh, the amphibian footprint from the Devonian of Pennsylvania. $\times 1 / 4$. Courtesy of Dr. Lull. Original No. 784, Yale University Museum. 

Cephalerpeton ventriarmatum Moodie.

Moodie, Kans. Univ. Sci. Bull., vi, No. 2, pp, 350-352, pl. I, fig. 4; pl. 7, fig. 2, I 912.

Type: Specimen No. 796, of Yale University Museum.

Horizon and locality: Collected at Mazon Creek in I87I, near Morris, Illinois.

The remains on which the present species is based consist of an almost entire skull, 26 consecutive vertebræ, both fore limbs, 20 ribs preserved on the right side of the body, and a portion of the ventral armature (plate 4, fig. 4).

The skull is very broad posteriorly, its width being one-third greater than its length, with due allowance for crushing. A pineal foramen is not preserved. The sutures bounding the premaxillaries, the maxillæ, the nasals, the prefrontals, the frontals, a portion of the parietals, the squamosal, the supratemporal, the quadratojugal, and the quadrate (?) are fairly well preserved. The arrangement of these elements can be discerned by reference to figure 29. The prefrontals are unusually large and are triangular in shape. The supratemporal is also quite large. The surface of the skull bones is smooth and there is nowhere an indication of sculpture.

Portions of 4 sclerotic plates are preserved in the right orbit. These measure 0.5 by 0.75 $\mathrm{mm}$. The orbits are large and the interorbital space is less than the transverse diameter of the orbit. Thirteen teeth, apparently pleurodont, are preserved on the left maxilla. They

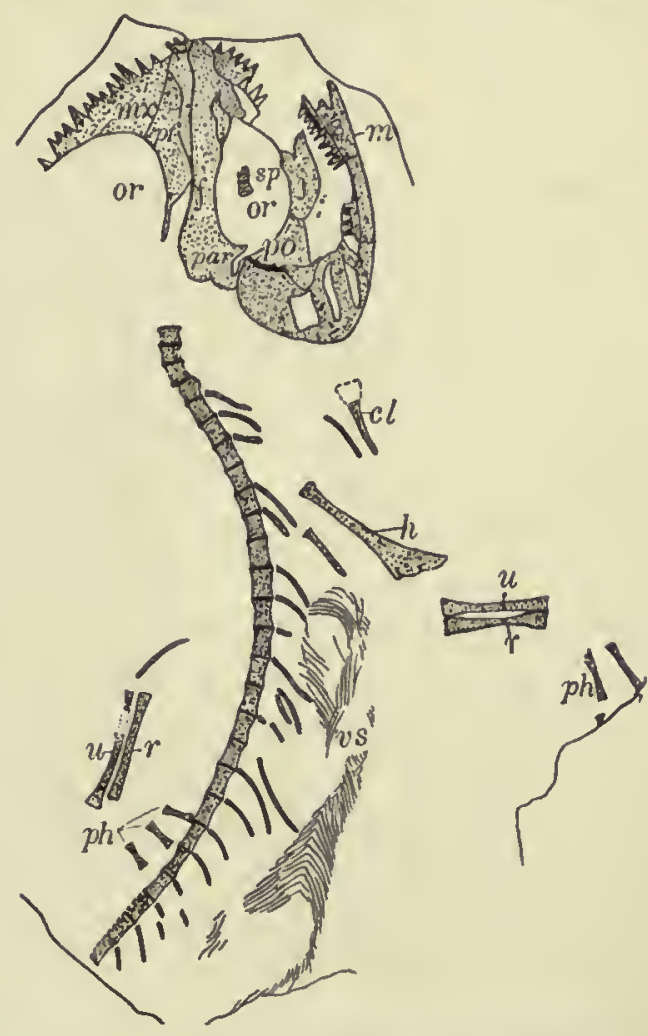

FIG. 29.-Skeleton of Cephalerpeton ventriarmatum Moodic. XI.

$p f$, prefrontal; $c l$, clavicle; $m$, mandible; $h$, humerus; $j$, jugal; $m x$, maxilla; or, orbit; ph, phalanges of hand; par, parietal; po, postorbital; $r$. radius; $s p$, sclerotic plates; $u$, ulna; $v s$, ventral scutcllix.

are short, sharply pointed, smooth, and unequal. The first 2 left maxillary teeth from the anterior end are short; then follows a tooth which is one-third longer than these two; the fourth tooth is somewhat shorter than the third; the fifth and sixth are still shorter and are practically equal in size, though somewhat larger than the first two.

The right mandible is preserved almost entire, though so badly eroded that little can be said of its structure. Impressions of 12 teeth are present on the mandible and all are, apparently, equal. The cotylus seems to have been far posterior and an angle of the mandible projected slightly back of the skull.

There remain only a few indefinite impressions of the cervical vertebra. The union of the skull with the vertebral column is obscured and lost. Impressions of the dorsal vertebræ are well preserved, and wax molds made from these show the structure of the dorsal vertebre surprisingly well. They are long and eylindrical, with the median portions slightly constricted by a deep pit on each side of 
the low neural ridge, which takes the form observed in Thyrsidium, Molgophis, Phlegethontia, Dolichosoma (fig. 8) and other genera. The vertebræ are strongly amphicoelous and the notochord was probably persistent. The sides of the vertebræ are smooth.

The ribs are all intercentral in position; the anterior ones very broad near the base, recalling the broadly expanded ribs described by Schwarz (540) for Scincosanrus, Ptyonius, Thyrsidium, and other genera. Posteriorly the ribs become slender and cylindrical. They are all rather long and distinctly curved, with probably a cartilaginous tip.

There is preserved a single element of the right side of the pectoral girdle. This is, I think, the coracoid, an element which has hitherto escaped observation among the American Microsauria. It is long and spatulate at both ends, with the median portion apparently almost cylindrical, not unlike that described by Credner (I8I) for the coracoid of Branchiosaurus, save that the lower end of the branchiosaurian coracoid is acuminate. In the present form it is spatulate. Its relations with the other elements of the pectoral girdle have never been satisfactorily determined.

The fore limbs are both partially preserved. The humerus of the right side is complete. It is greatly elongated for a microsaurian. The form of the element is not unlike that of a lizard, with the lower end of the bone spatulate and endochondrium well developed. Very little difference can be seen between the form of the arm bones, which represent the radius and ulna. They are both elongated, with constricted median portion and expanded truncate ends. The carpus is unossified and the cartilage has left no trace of the elements.

The right hand has two metacarpals preserved, which are fully half as long as the radius and ulna. They are separated some little distance from the ends of these elements, though this may be due to post-mortem shifting. The carpus may, however, have been broad. On the left side are preserved portions of the humerus, radius, ulna, and 3 metacarpals, lying close to the vertebral column. The carpal space is not so large on the left as on the right. The ventral armature is well preserved in a narrow patch about an inch in length. The chevron-shaped rods are quite large, there being 2 of them in $\mathbf{I} \mathrm{mm}$.

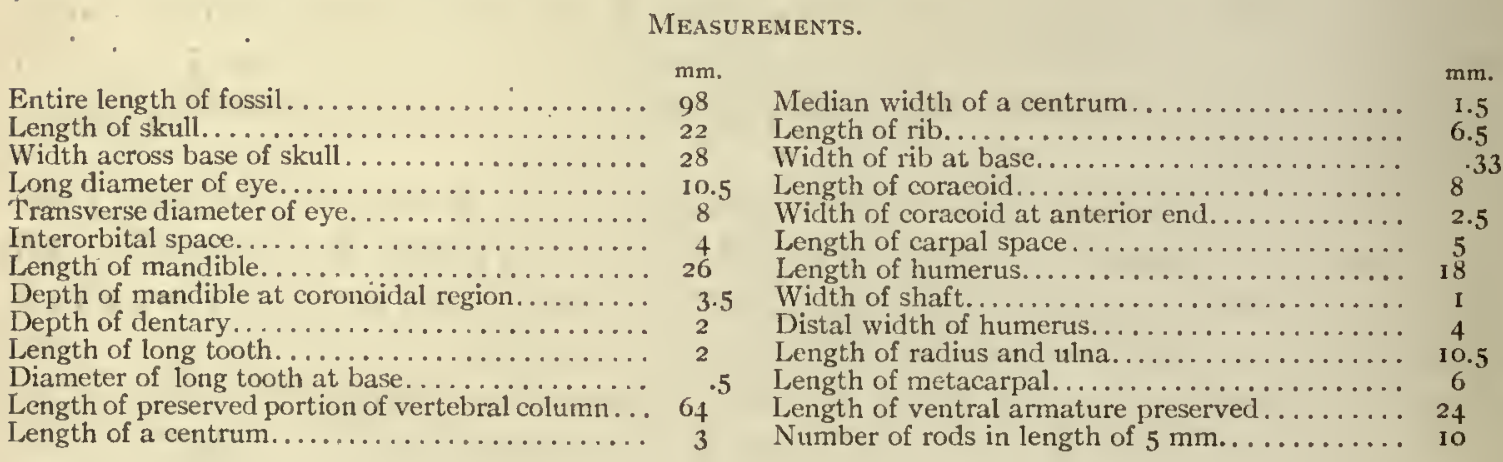




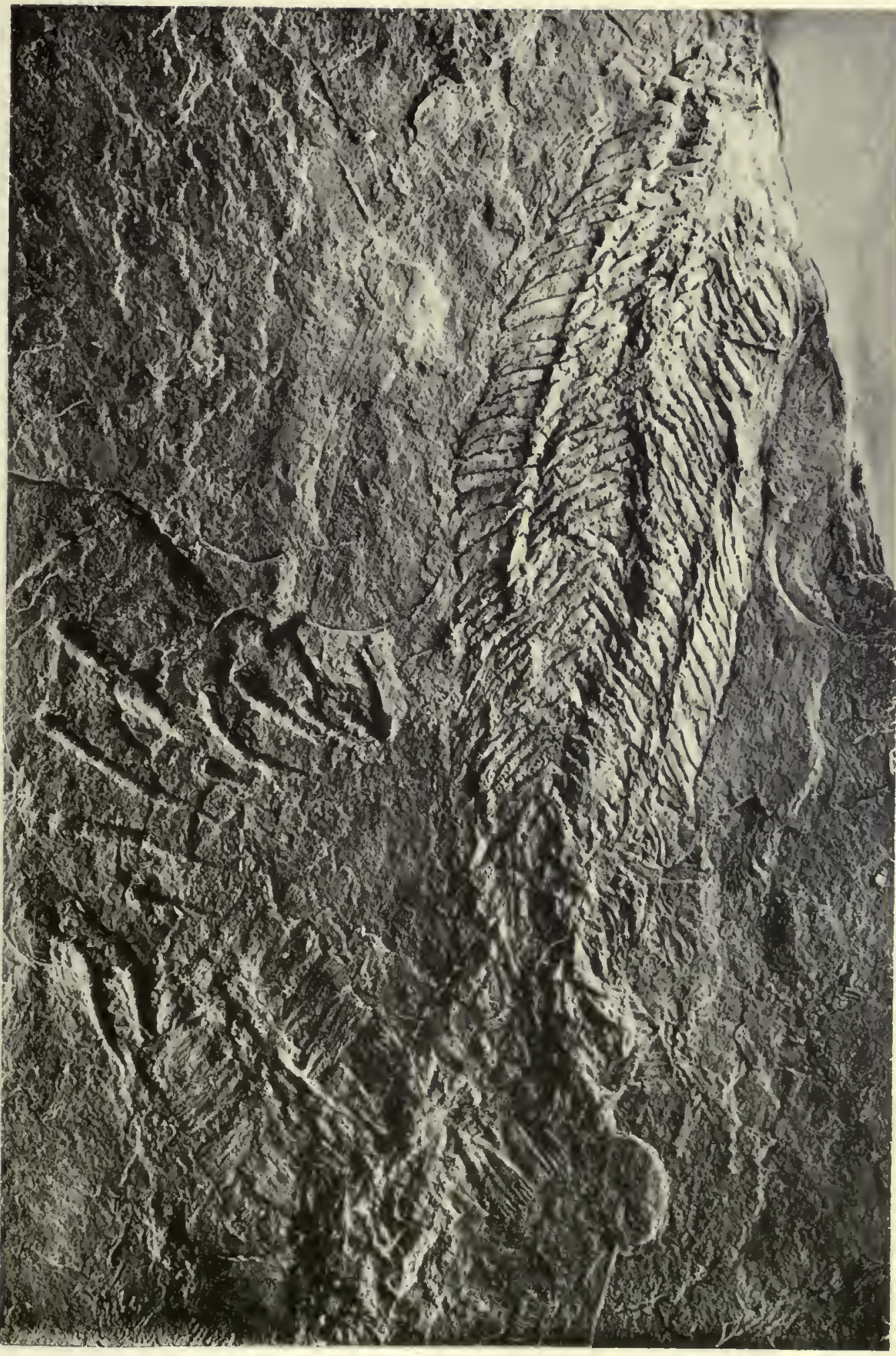

Type specimell of Clenerpeton alveolatum Cope, from the Coal Measures of Obio. $\times 1.33$. Original in U. S. National Museum. 


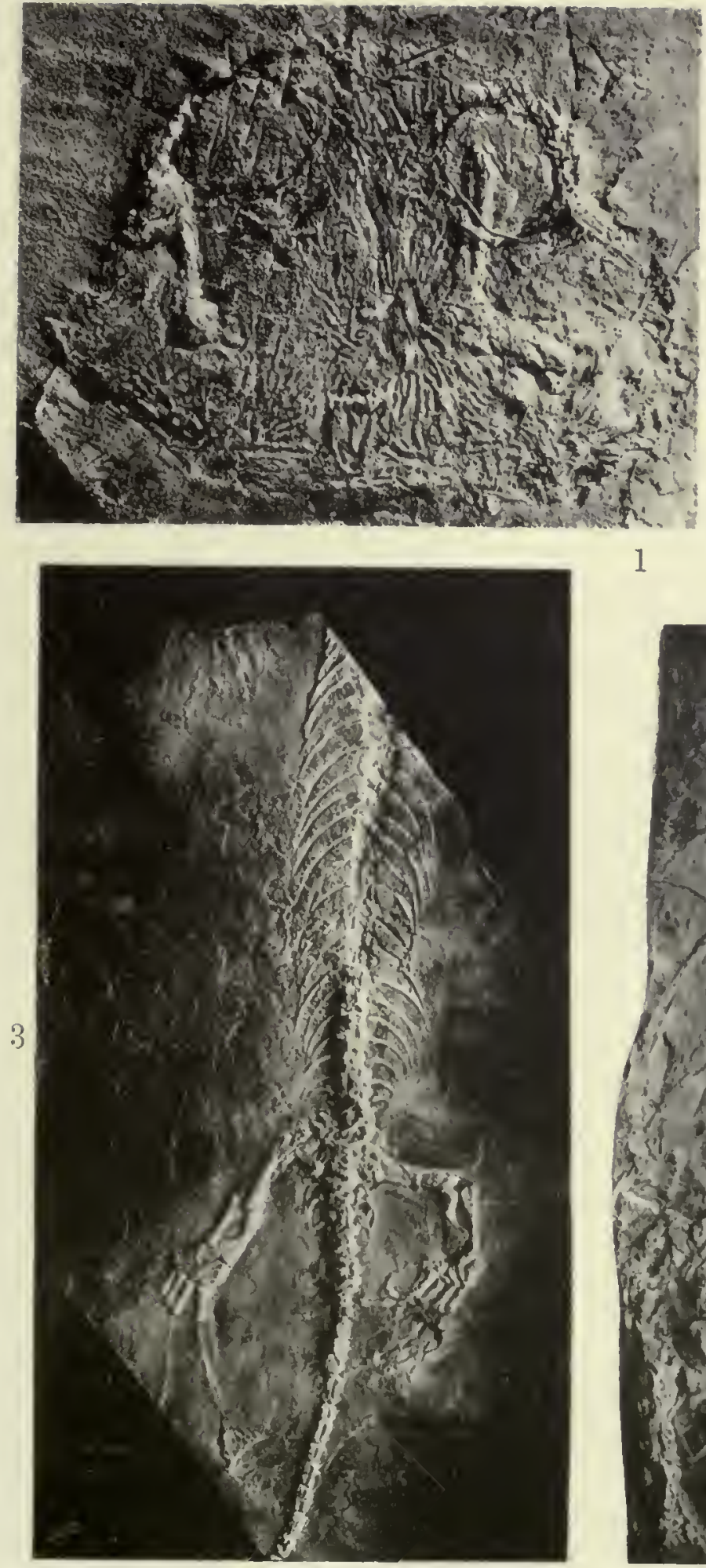
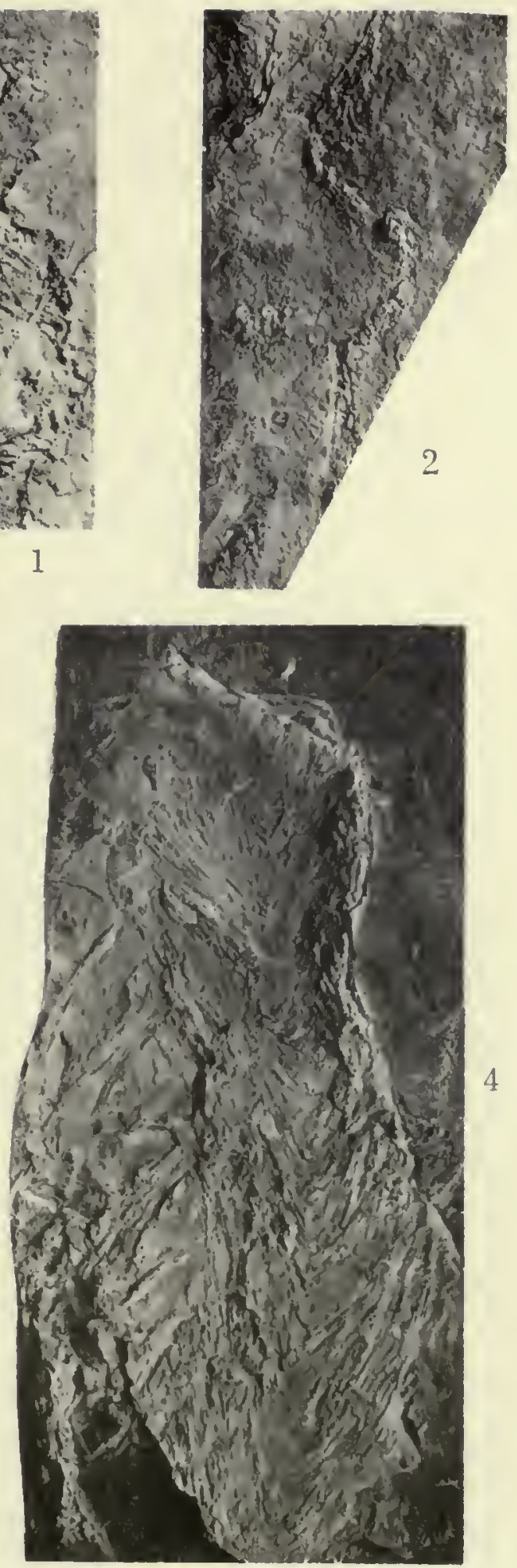

1. Skull of Erpetosaurus minutus Moodie, from the Cannelton slates of Pennsylvania. Original in U.S. National Museum. Enlarged $\times 3.3$.

2. Skull and anterior part of body of Plyonius pectinatus Cope, from the Coal Neasures of Linton, Ohio. Original in U.S. National Museum. $\times 1$.

3. Skeleton of Eosaurazus copei Williston, from the Coal Measures of Linton, Ohio. "The oldest known reptile from North America" and closely related structurally to the Microsauria. Original in U. S. National Museum. $\times 1$.

4. Part of the ventral scutellation and ribs of Sauroplenra digitata Cope, from the Coal Measures of Linton, Olin. Oricinal in American Museum of Natural History. $\times 1$. 



\section{CHAPTER XVIII.}

THE MICROSAURIAN FAMILY NYRANIIDA, FROM THE COAL MEASURES OF OHIO.

\section{Family NYRANIID E Lydekker, I890.}

Lydek ker, Cat. Fossil Reptilia and Amphibia, p. 166, 1890.

Skull with the palatines situated near the middle line, internally to the vomers and pterygoids, and the palatine vacuities small and placed far back. Vertebræ (Ichthyerpeton) discoidal. Teeth less complex than in the Anthracosauridx. A ventral armor present and the entire body covered with small cycloid imbriated scales.

The type genus of this family was placed by Fritsch (25I) with the Archegosauridæ, although its resemblance to Anthracosaurus was pointed out; it was subsequently made the type of a family by Lydekker (393) in I890, and placed next the Archegosauridx. Known from the Coal Measures of Bohemia, Ireland, and Ohio.

Two genera from North America, Ichthyerpeton and Cercariomorphis, are assigned tentatively to this family, both known from the Coal Measures (462) of Linton, Ohio, and both with the body completely scaled. The distinguishing characters are found chiefly in the shape and arrangement of the scales, the structure, form, and size of the body, all of which are given full treatment in the discussion below.

\section{Genus ICHTHYERPETON Huxley, 1866.}

Huxley, Trans. Roy. Irish Acad., xxiv, p. 195, pl. xxiii, fig. 1; Scientific Memoirs, 111, p. 195, pl. 23, fig. 1, 1866.

The genus was founded by Huxley (334) for the reception of the species Ichthyerpeton bradleyce from the Kilkenny Coal Measures of Ireland. The remains of the type specimen represent "the hinder moiety of the trunk, with the greater part of the tail, of an animal whose scaly integument and laterally compressed, fin-like tail might easily lead one to take it for a fish, were not its true position among higher vertebrata settled at once by the digitate hind limb; while its alliance with the labyrinthodonts is indicated by the delicate spicular ossicles, which form a rudimentary dermal shield along the belly." (Huxley.)

\section{Ichthyerpeton squamosum Moodie.}

Moodie, Jour. Geol., xvi1, No. 1, p. 69, 1909.

Moodie, Iroc. U. S. Nat. Mus., 37, p. 24 , 1909.

Type: Specimens Nos. 4476 and 4459, U. S. National Museum.

Locality and horizon: Linton, Ohio, Coal Measures.

The present species is based on well-preserved remains from the Linton, Ohio, beds. There are two specimens of the species preserved on blocks of coal and together they represent the greater part of the length of the animal. The species is located in the genus Ichthyerpeton, which was founded by Huxley $(334$, p. 35I) on remains from the Coal Measures of Ireland, on account of the character of the der- 
mal covering, which consists of small scales such as Huxley described in the form from Ireland. The specific characters of this form are the small size of the rounded scales, the attenuated tail, the apparent absence of limbs, the character of the ventral scutellation, and the slightly curved condition of the ribs.

It is estimated, from the portions preserved, that the animal attained a length of not less than 3 feet and its body was long and slender. It may have had an appearance similar to the modern caudate genus Siren, though there were doubtless 4 limbs present instead of 2 . The slenderness of the body is at variance with the condition found in the type species Ichthyerpeton bradleyce Huxley, in which the trunk was rather stoutly built. The character of the anterior portion of the body in the present species can not be determined and the skull is wanting. There are no evidences of anterior limbs, although the ventral scutellation preserved would seem to include the pectoral region. No pectoral shields are preserved, nor are there any traces of pelvic girdle or limbs.

The preserved portions on one block include nearly the entire tail and the posterior region of the body, and on the other block the dorsal region of the body and the anterior portion of the tail, so that the two specimens supplement each other in an interesting manner. There are impressions of several vertebræ preserved. They are much the same in character as Huxley has described for the type species (I. bradleyce). They are short and thick and were probably amphicœlous. There are likewise preserved the remains of rather slender recurved ribs mingled in with the remains of the ventral scutellation and distinguished from the elements of the abdominal shield by their size and curvature. They are, apparently, single-headed, but the character of their articulation can not be determined. The ventral scutellation consists of fine continuous rods arranged in the regular chevron pattern. They do not seem to be divided into oat-shaped scutes, as is the case with the form described by Huxley. The ventral rods are closely packed for a distance of more than 6 inches, but as they are scattered their exact arrangement can not be determined. They seem to have extended to the cloacal region, but there are no evidences of the specialized clasping organs such as Fritsch (25I) has described in the ventral scutellæ of Ophiderpeton. The scales, which are well preserved on the tail, may have covered the entire body, since there are many scattered scales in the dorsal region of one of the specimens. They are slightly oval, tuberculate, and measure scarcely I mm. in their longest diameter. They show but slight evidences of having been imbricated, though it is likewise possible that they were simply inclosed within the integument, and somewhat separated from one another. The most posterior part of the tail preserved seems to indicate that the tip was attenuated. It was probably flattened from side to side. We may thus regard Ichthyerpeton squamosum as an elongate aquatic animal with a long, flattened tail, and since there were possibly no limbs or very small ones, it would be an animal highly adapted for life in the water. The present species is of interest because it represents an additional discovery of the scaled Amphibia in North America. The species previously known from the Linton, Ohio, deposits is Cercariomorphus parvisquamis Cope. Dermal scales have also been observed in specimens of Amphibamus grandiceps Cope and 

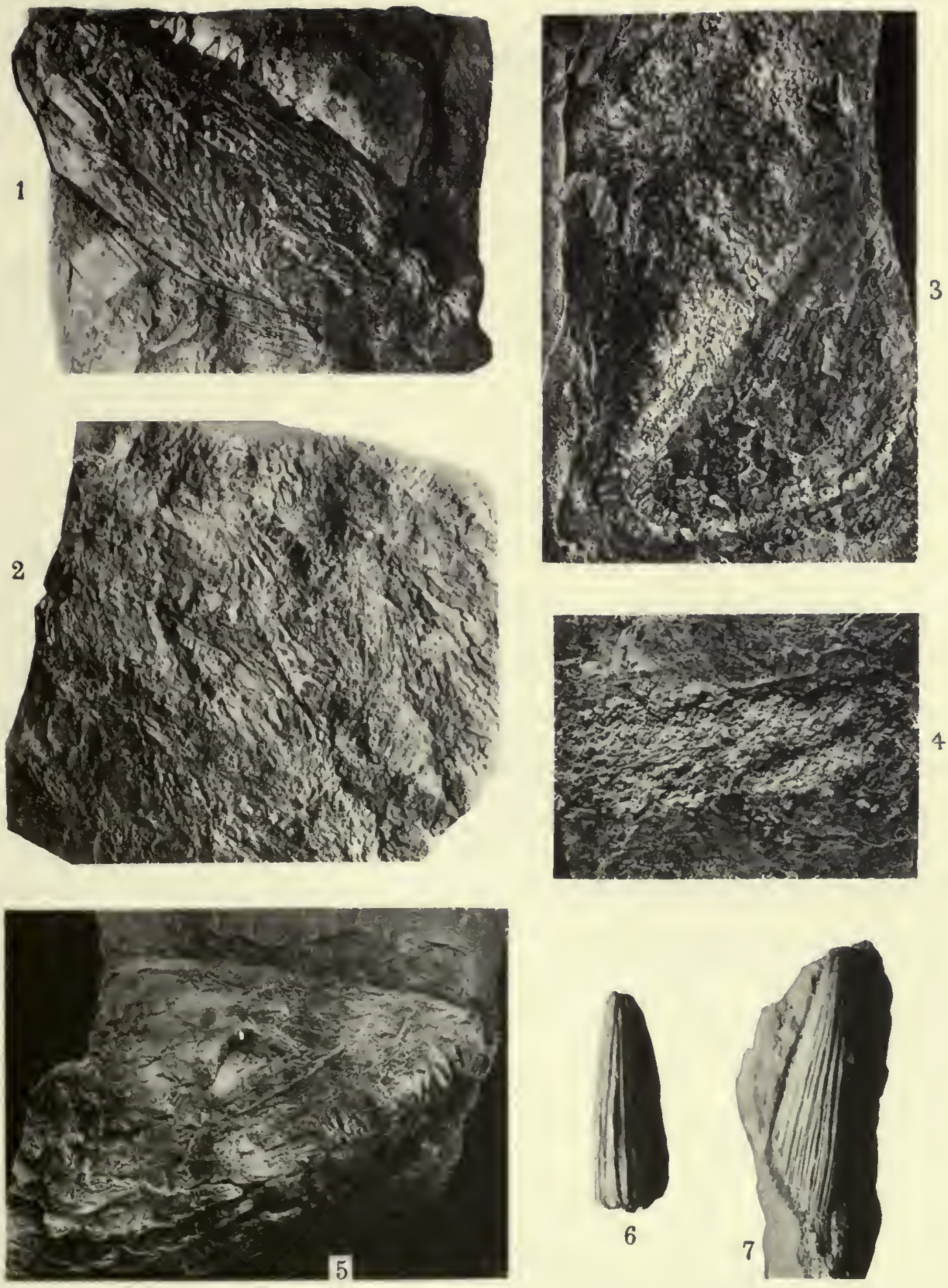

1. Mandible of Macrerpeton deani Moodie, from the Linton, Ohio, Coal Measures. Original in American Museum of Natural History, No. $2934 . \times 0.6$.

2. P'ortion of the skull of Macrerpeton deani Moodie, possibly of the same individual as the mandible. From the Linton, Ohio, Coal Measures. Original in American Musenm of Natural History, No. 8535 G. $\times 0.4$.

3. Type of Cercariomorthus parrisquamis Cope, from the Linton, Ohio, Coal Measures. Original in American .Museum of Natural Histnry, $\times 1$.

4. An additional specimen of Cercariomorphus parisquamis Cope, from the Linton, Ohio, Coal Measures. Original in American . Musentm of Natural History. $\times 1$.

5. Skull of Sauroplenra scutellata Newberry. Fron the Coal Measures of Ohio. $\times 1$.

6. Tooth of Nastodonsaurus sp. indet. of the Carboniferous of Kansas. Original in University of Kansas Museum. $\times 1$.

7. Tooth of Mastodonsaurus gigantens Jaeger, from the Triassic of Gemany. Intronucer for comparison with the tooth from the Kansas Carhonifernus, $X$ i. 

Micrerpeton caudatum Moodie $(462,478)$ from the Mazon Creek, Illinois, beds, and Sir William Dawson (208) described scales accompanying several forms from the Joggins deposits of western Nova Scotia.

Measurements of the Types of Icutiuyerpeton squamosum Moode.

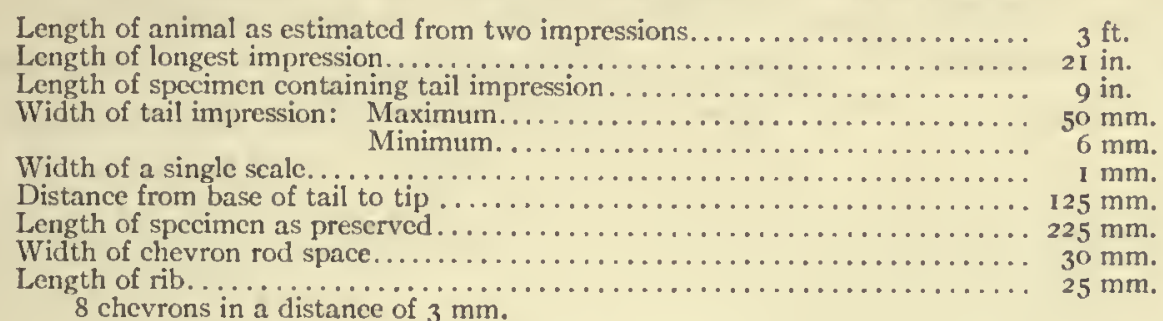

8 chevrons in a distance of $3 \mathrm{~mm}$.

Cope, Proc. Amer. Phil. Soc., 1885, p. 405.

\section{Genus CERCARIOMORPHUS Cope.}

Type: Cercariomorphus parvisquamis Cope.

The type specimen of this genus is supplemented by a portion of the body of another specimen which adds a little to our knowledge of the animal's form, but nothing as to structure. Cope's original description is as follows:

"Represented by a fusiform body which terminates in a long, slender, cylinclrical tail, and which is covered with small subquadrate scales quincuncially arranged. No fins or limbs are preserved, and the form of the head can not be made out. Probably a portion of the skull is preserved. There are some scattered bodies in the body portion, which look like deeply concave vertebræ with the zygapophyses of batrachians. There are some linear impressions at one point, which resemble the bristle-like rods on many Stegocephali. They are so few as to be of little importance. The scales are like those of fishes. There are traces of segmentation in the axis of the long tail.

"The position of this curious form is quite uncertain. It is quite different from anything observed hitherto in the American Coal Measures."

\section{Cercariomorphus parvisquamis Cope.}

Copr, Proc. Amer. Phil. Soc., I885, p. 405.

Moonm, Science, n.s., XLI, No. 1056, p. $463,1915$.

Type: Specimen No. 2560, Newberry Collection, American Museum of Natural History.

Horizon and locality: Discovered by Samuel Huston at the Linton, Ohio, Coal Mines. (Plate 21, figs. 3, 4; 24, figs. 2, 3.)

The scales (plate 24, fig. 2) in their present condition are entirely smooth. At a distance of $20 \mathrm{~mm}$. from the base of the tail they are in 20 longitudinal series. At that point the transverse diameter of the body is I $40 \mathrm{~mm}$. The outline contracts rather abruptly to the tail, of which $66 \mathrm{~mm}$. are preserved. The surface of the tail is obscured by a thin layer of carbonaceous matter not sufficiently thick to obscure scales, which are evident at distances of $16 \mathrm{~mm}$., $43 \mathrm{~mm}$., and $52 \mathrm{~mm}$. from the tip. The scales on the tail are smaller than those on the body and are without markings of any kind. The anterior half of the body is depressed and distorted, but the remainder is well preserved and shows a fairly good outline of an apparently limbless body. 
An additional specimen (No. 8683 G, of the Newberry Collection, American Museum of Natural History) reveals no new facts as to structure, but serves to show that the body of the animal was long and slender (plate $2 \mathrm{I}$, fig. 4 ). The portion studied comes undoubtedly from the middle of the body. No limb elements are preserved. The scales are somewhat larger, especially toward the sides of the body, than in the type. The fragment measures $70 \mathrm{~mm}$. in length by $18 \mathrm{~mm}$. and $26 \mathrm{~mm}$. in width. One of the largest scales measures I mm. in diameter.

Measurements of TyPe.

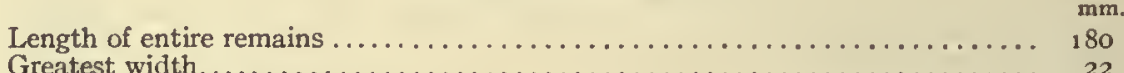

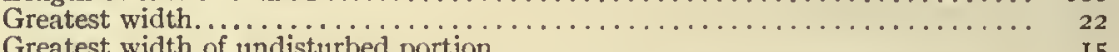

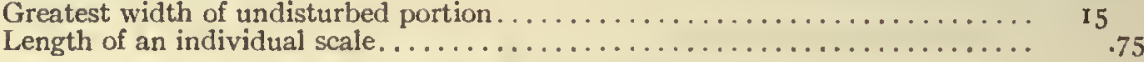




\section{CHAPTER XIX.}

\section{THE AISTOPODOUS MICROSAURIAN FAMILY PTYONIIDA, FROM THE COAL MEASURES OF OHIO.}

\section{Family PTYONIIDEE Cope, 1875 .}

Cope, Geol. Surv. Ohio, II, pt. II, p. 357, 1875 .

Elongate, slender, weak-limbed, aquatic microsaurians. Neural and hæmal spines of vertebrace elongated, expanded and sculpturecl. Ventral armature weakly developed or absent. Skull lanceolate, with long, slender teeth.

Three genera are assigned to this family: Ptyonius, Estocephalus, and Thyrsidium. The forms are very closely related, and when additional material is secured the three genera may be found to be identical. The species included in this family are: Ptyonius pectinatus Cope, $P$. vinchellianus Cope, $P$. marshii Cope, $P$. nummifer Cope, $P$. serrula Cope, Estocephalus remex Cope, O. rectidens Cope, Thyrsidium fasciculare Cope. The species are all exclusively from the Linton, Ohio, Coal Measures, and most of them are known from abundant material.

\section{Genus PTYONIUS Cope, 1875.}

Cope, Geol. Surv. Ohio, II, pt. II, p. 373, I875.

Cope designated no species as the type, but we may regard Ptyonius pectinatus as typical.

Form elongate, with long tail and lanceolate cranium. Limbs weak, a posterior pair only discovered. Three clavicular elements; abdomen protected by packed osseous rods, which are arranged en chevron, the angle directed forward. Neural and hæmal spines of caudal vertebræ expanded and fan-like. Ribs well developed. The various species vary in length from 3 to Io inches. They are the most abundant amphibian in the Linton beds. The present genus resembles Lepterpeton Huxley (334), of the Kilkenny, Ireland, Coal Measures. But that genus possesses divided abdominal rods, or "oat-shaped scales," and the form of the cranium and proportions of the body are different.

The genus is closely related to, possibly identical with, Estocephalus, but additional material will be required to settle this point.

Cope (123) gives the following key for the separation of the 5 species:

$x$. Abdominal rods coarser, not more than 10 in $5 \mathrm{~mm}$.

Median pectoral shield discoid, radiate ridged; muzzle short.................. P. nummifer

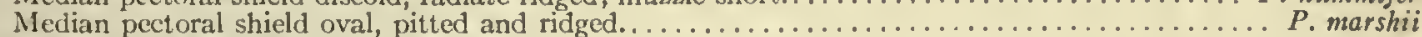
$x x$. Abdominal rods hair-like, 15 or more in $5 \mathrm{~mm}$.

Median pectoral shield with radii from the center, the principal forming a cross; form wider.. P. vinchellianus

Middle pectoral with pits at the center and few or no radii; form narrow.............. P. pectinalus

Middle pectoral shield narrow, closely reticulate medially, and radiate towards the circumfercnce; size

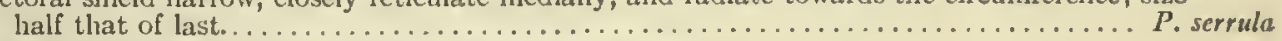

\section{Ptyonius pectinatus Cope.}

Core, Proc. Acad. Nat. Sci., 1868, p. 216.

Core, Trans. Am. Phil. Soc., XIV, p. $20,1869$.

Cope, Trans. Am. Phil. Soc., xv, p. 266, 1874.

Cope, Geol. Surv. Ohio, II, pt. II, p. 377 , pl. xxvii, fig. 7 ; xxviii, figs. 2, 3, 6; pl. xxix, fig. 2 ; pl. xxx, fig. 2 ; pl. xxxv, figs. 1-3; pl. xli, fig. 1, I875.

Moode, Proc. U. S. Nat. Mus., 37, p. 24, pl. 8 , fig. 3, 1909.

Schwarz, Beitrage zur Paleontologie und Geologie Osterreich-Ungarns und des Orients, Bd. xxi, p. 83, figs. $23,24,26,1908$. 
Type: It is impossible to determine which one of the specimens is the type. There are numerous representatives of the species, as follows: Nos. I40, I096 G, 8345 G, 8555 G, I089 G, 2, I32, I 33, no number, I094 G, 8545 G, 8677 G, II 59 G, I05, no number, r09I G, $7 a, 1092 \mathrm{G}, 1093 \mathrm{G}, 1095 \mathrm{G}, \mathrm{I} 53$, and others unnumbered in the American Museum of Natural History; in the U. S. National Museum are the following: Nos. $4458,4463,4464,45$ I 4 . (Plate 20, fig. 2.)

Horizon and locality: Linton, Ohio, Coal Measures.

The most abundant species of the Linton Coal Measures. There are over three dozen specimens preserved in the Newberry collection. The species is a clearly marked one, as a rule, though there is great variation in the size of the body and the form of the vertebræ. Though there are several apparently complete skulls preserved in the collection, it is impossible to make out the morphology of the elements on account of the amount of crushing to which the skulls have been subjected.

The head is lancet-shaped, and the muzzle very elongate, slender, and acute at the extremity. The head is in fact a miniature of an ichthyosaur cranium. (Plate 20, fig. 2.) The orbits are large and posterior to the median line. The anterior portion of the skull is narrow, posteriorly truncate, and the mandibular angle is projecting. The posterior portion of the mandible is sculptured. Possibly the entire cranium was also, and this has been lost; in fact, this sculpturing is indicated in one or two specimens. The teeth are conical and sharp, longitudi-

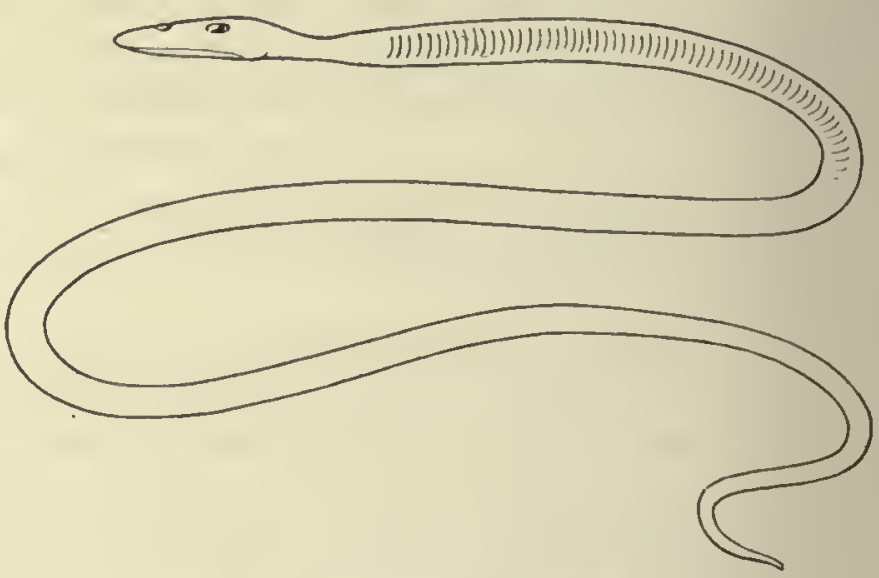

FIG. 30.-Restoration of Ptyonius. $\times \mathbf{r}$. nally striate, and anisodont. 'There seemsto be evidence of palatine or pterygoid teeth, though this needs confirmation. The pectoral plates are well preserved, with the interclavicle a narrow oval, with anterior and posterior prolongations. In one specimen it is sculptured. The clavicles are narrow and slightly sculptured. The abdominal scutellæ are bristle-like.

The vertebræ are short, with expanded neural and hæmal spines. The expanded condition of the neural spines begins over the thoracic region, where they are low. They become well developed in the posterior dorsal region. The caudal fan-shaped spines are larger. The dilated portions form equilateral triangles which stand on moderately short pedicels. They are weakly ridged, and each ridge is prolonged into a narrow acute tooth beyond the margin, II of which may be counted on one of the best-preserved spines. The longitudinal strix are terminated near the pedicel by two others which cross obliquely from each side, and, meeting, present the appearance of the margin of a cup sculptured in relief, from which the strix arise. Pedicels smooth. The spines are in contact at their angles, thus forming a continuous line. In a typical specimen there are 6 in half an inch, in another 7 , and in a third 8 . The ribs are well-developed and slender. 
No traces of fore limbs have been detected in the numerous specimens, but clements of hind limbs are preserved. In one of these the femur is a small bone, contracted at the middle. The form of the body is snake-like.

There were probably from 75 to 100 vertebrx in a single animal. The form may be well compared to the modern Amphiuma so far as appearances are concerned; structurally they are widely separate. This species is one which is peculiarly characteristic of the Linton fauna.

Measurements of Ptyonius pectinatus Cope.

Nos. 107 and 1094 G, American Museum.

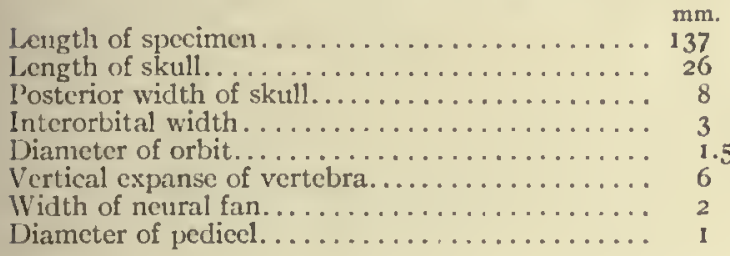

Mcasurcments of a small jaz, No. 8555 G, American Muscum.

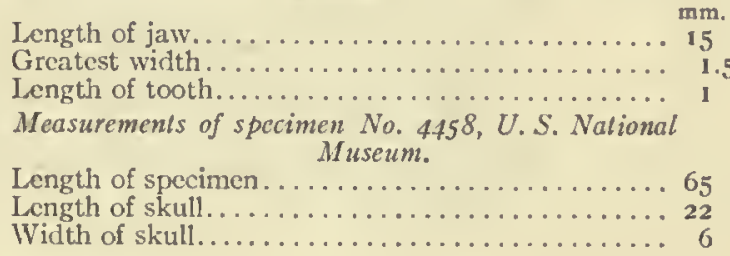

Ptyonius vinchellianus Cope.

Cope, Proc. Am. Phil. Soc., p. 177, 1871.

Col'E, Gcol. Surv. Olio, 11, pt. 11, p. 376, pl. xxviii, fig. 1, 1875.

Type: Specimen in the American Museum of Natural History.

Horizon and locality: Linton, Ohio, Coal Measures.

The species is represented by the opposite halves of a single specimen, which includes only the cranium and anterior half of the body. The fan-shaped neural spines commence but a short distance behind the line of the pectoral shiclds. They are low, with a few coarse ridges, the margin being entire. The abdominal rods are delicate and hair-like. The interclaviele is oval, with a few radiating crests, which originate at the center; in the areas behind there are a few scattered tubercles. The clavicles are ridged near the margin.

The cranium is lanceolate in form, and the bones of the dorsum are marked with a few raised points and ridges. The species is about the size of Ptyonius pectinatus Cope, and differs, apparently, from that species in the rather insignificant character of a narrower interclavicle and in the ornamentation of the same. Dedicated to Professor Alexander Winchell, of the University of Michigan.

Meisuremints of Ptronius vinchellanus Cope.

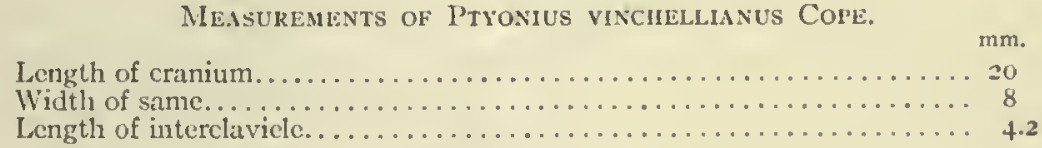

Ptyonius marshii Cope.

Cope, Trans. Amer. 1'hil. Soc., xIV, p. 24, 1869 (Colostcus marshii).

Cope, Geol. Surv. Ohio, 11, pt. 11, p. 375, pl. xxvii, fig. 6; pl. xxviii, fig. 3, 1875.

Core, Proe. Ani. I'lili. Soc., xil, p. 177, I871.

Type: Specimen No. I 57 G, American Museum of Natural History.

Horizon and locality: Linton, Ohio, Coal Measures.

The head is elongate lanceolate. The upper surface of the frontal bones is punctate-rugose in relief, with short radii toward the margin. The distal two- 
thirds of the mandible is narrow wedge-shaped; the external surface is coarsely pitted. There are no teeth preserved. The pectoral elements are displaced, but the clavicles are subtriangular, and are strongly ridged toward the inner margin. The interclavicle is short spatulate, the narrow portion directed anteriorly; the posterior rounded. It is coarsely pitted medially, and coarsely and strongly radiate-ridged to the margin. The abdominal armature commences immediately behind the pectoral girdle. It consists of elongate, narrow, subcylindric scales, which meet on the median line, converging anteriorly. Small limbs are present.

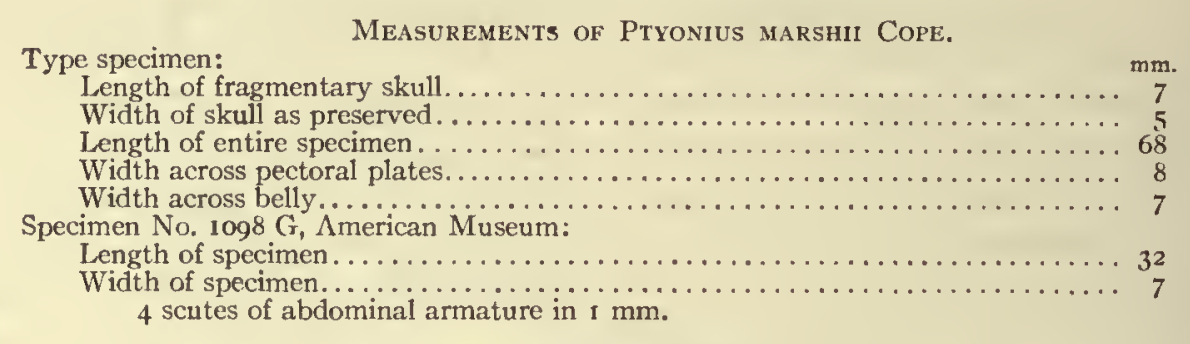

Ptyonius nummifer Cope.

Cope, Geol. Surv. Ohio, 11, pt. 11, pp. 374, 375, pl. xli, figs. 2 and 3,1875 .

Moodie, Bull. Am. Mus. Nat. Hist., XXvi, p. 356, pl. 63, fig. 3, 1909.

Type: Specimen No. 8546 G, American Museum of Natural History. No. $8614 \mathrm{G}$, same museum, is associated with the type specimen.

Horizon and locality: Linton, Ohio, Coal Measures.

Two well-preserved individuals display peculiarities which indicate specific distinctness from the previously known species of Ptyonius. The abdominal rods are of the coarse type of those of $P$. marshii. The caudal fans are well developed, and not so wide as in $P$. pectinatus. The interclavicle is a discoid body of different form from that of $P$. marshii and I can not detect the clavicles. The sculpture consists of strong ridges, which radiate from the center to near the border. Immediately in front of this interclavicle is the head, which has a different form from that of the other known species. The interorbital width is two-thirds the long diameter of the orbit. The structure of the skull can not be made out. A slender, elongate hind limb is present in the second specimen, and a humerus is well preserved in the type.

Measurements of the Trpe of Ptyonius nummifer Cope.

(No. 8546 G, American Museum of Natural History. No. 8614 G is associated in the same species.)

Length to beginning of caudal fans........... 65

Length of head. ...

Length from muzzle to orbits. . . . . . . . . . . . .

Length of interclavicle............................

Width of interclavicle.

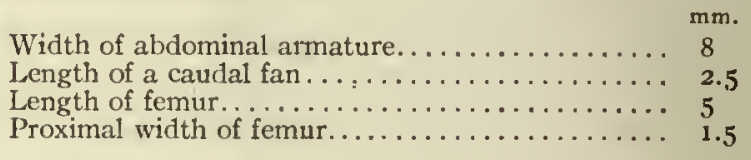

\section{Ptyonius serrula Cope.}

Cope, Proc. $\Lambda \mathrm{m}$. Phil. Soc., 1871, p. 177.

Cope, Geol. Surv. Ohio, 11, pt. II, p. 379, pl. xxviii, fig. 5; pl. xxx, fig. 1, 1875.

Type: Specimen No. 86I 5 G, American Museum of Natural History.

Horizon and locality: Linton, Ohio, Coal Measures.

The specimens of this species indicate that the form was only about half the size of Ptyonius pectinatus. The interclavicle is narrower and more reticulately sculp- 
tured. The tail is relatively longer. Abdominal rods hair-like. Ribs distinct. Small limbs are present in one specimen.

Measurements of Cope's Type of Ptyonius serrula.

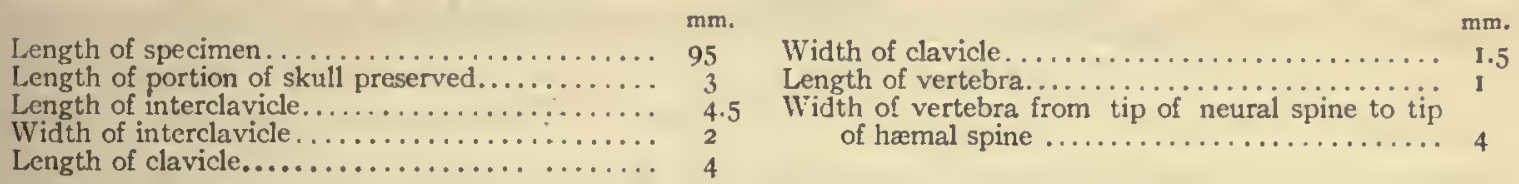

Another specimen (456 G, American Museum of Natural History) shows some of the same characters. There is not the slightest basis for the support of this species, so far as I can observe. The ones mentioned by Cope are insufficient. It is in all probability a mutant or variety of Ptyonius pectinatus.

\section{Genus CESTOCEPHALUS Cope, 1868.}

Cope, Proc. Phila. Acad. Nat. Sci., 2 18, 1868.

COPE, Trans. Amer. Phil. Soc., XJv, I6.

Cope, Proc. Phila. Acad. Nat. Sci., I 868, 217.

Cope, Proc. Amer. Phil. Soc., I 871, 41.

COPE, Geol. Survey Ohio, II, pt. II, 380,1875 .

Type: Estocephalus remex Cope.

Form slender and snake-like; caudal vertebræ with elongated, dilated, sculptured neural and hæmal spines. Cranium lanccolate. Tceth numerous, of nearly equal size. No pectoral shields known; abdomen protected by very numerous bristle-like rods, which converge forwards. A pair of weak posterior limbs; branchihyal bones present.

In the only well-preserved species the cranial bones exhibit no sculpture from the parictal region forward. The genus is not very distinct from Ptyonius, but it can not be united with that genus until more complete material is available. The species of the genus share with Ceraterpeton, Urocordylus (334), and Ptyonius, as well as Crossotelos (98), from the Permian of Oklahoma, the elongation, sculpture, and expansion of the neural and hæmal spines. There are but 2 species, which Cope distinguishes by the following characters:

I. Vertebrx elongate; fan-like caudal processes narrowed. Size large; mandibular teeth of unequal lengths,

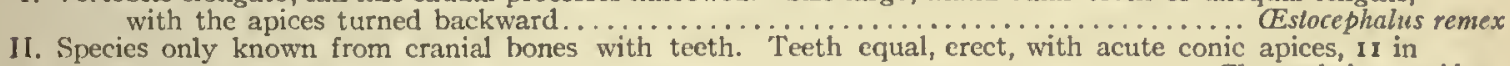

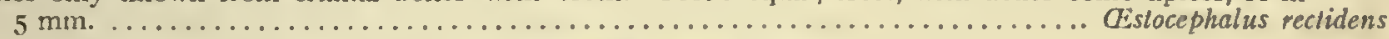

\section{Estocephalus remex Cope.}

Cope, Proc. Phila. Acad. Nat. Sci., p. 217,1868 (Sauropleura remex).

Cope, Proc. Phila. Acad. Nat. Sci., p. 218,1868 (CEslocephalus amphiumianus).

COPE, Trans. Amer. Phil. Soc., xiv, p. 17.

Cope, Geol. Surv. Ohio, vol. I1, pt. II, p. 381, pl. xxvii, fig. 5; pl. xxxi, fig. 1; pl. xxxii, fig. I: pl. xxxiii, fig. 2: pl. xxxiv, fig. 4,1875 .

Moodie, Proc. U. S. Nat. Mus., 37, p. 27, 1909.

Type: Specimen undetermined. The following specimens are to be found: Specimens of Estocephalus remex Cope in the National Museum, Nos. 45 I I, 4460, 4478. There is one specimen of Estocephalus remex in the University of Chicago. Specimens of the species in the American Museum of Natural History: Nos. I21, $8322 \mathrm{G}, 8694 \mathrm{G}$, no number, $8656 \mathrm{G}, 8583 \mathrm{G}, 8659 \mathrm{G}$, I9, I20, $8655 \mathrm{G}, 8662 \mathrm{G}$, $8708 \mathrm{G}, 8665 \mathrm{G}$, I I2, $8663 \mathrm{G}, 858$ I G, $8658 \mathrm{G}, 8660 \mathrm{G}, 8700 \mathrm{G}, 8469 \mathrm{G}$, I IO2 G, I I $52 \mathrm{G} \mathrm{I42,} \mathrm{838I} \mathrm{G,} \mathrm{and} \mathrm{obverse,} 2$ I , $8664 \mathrm{G}, 8672 \mathrm{G}, 8592 \mathrm{G}, 8684 \mathrm{G}$.

Horizon and locality: Linton, Ohio, Coal Measures. 
This species is one of the most abundant of the Linton Amphibia. Cope based his description of the species on 9 specimens. There are more than two dozen available at the present time, the majority of them being in the possession of the American Museum of Natural History. There is a single specimen in Walker Museum of the University of Chicago and 3 in the United States National Museum. The numbers of all of these specimens are given above. The material consists, for the most part, of fragmentary portions of the vertebral column, but there are a fcw skulls more or less complete, though none are sufficiently well preserved for a complete analysis of the characters. The specimens indicate an animal slightly smaller than the modern Amphiuma means of the Mississippi River.

It will not be necessary here to enter into a detailed account of each specimen, since this has been done by Cope, and a careful comparison of his descriptions with the originals indicates that his observations are correct. The species, as suggested in the discussion of the genus, is not clearly distinct from those of Ptyonius, and it has largely the characters of that genus. The cranium is long, slender, and wedge-

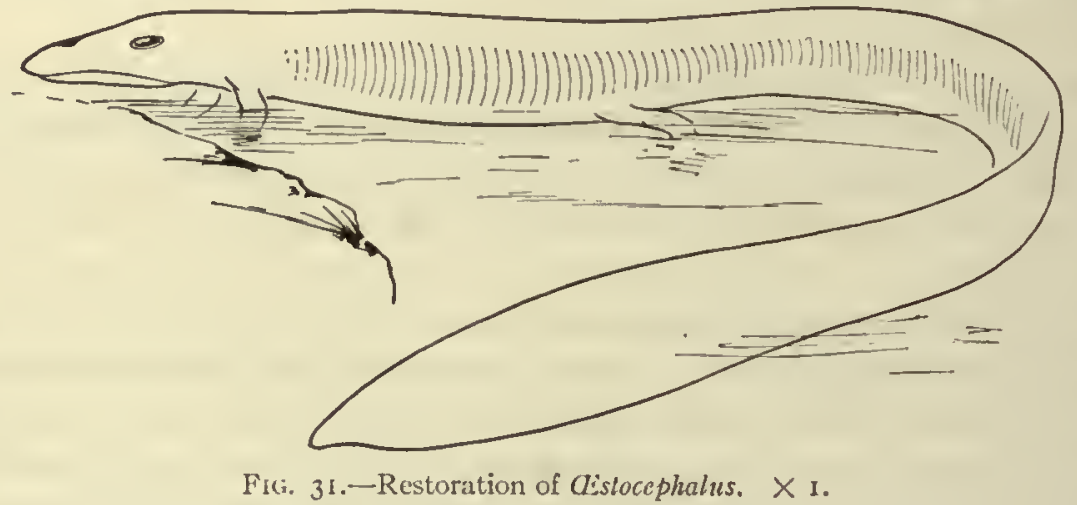

shaped. The teeth are numerous both in the maxillary and in the mandible, one specimen indicating about 30 in a single series. They are all uniformly cylindrical, except at the extremity, where they are flattened and expanded so as to produce a longitudinal edge, which is carried backward on a recurvature of the apex. The bases are anchylosed equally and without enlargement, and no part of the shaft is striate or grooved. The upper surface of the cranium is narrow, with the median suture distinct. The skull surface, with that of the mandible, is smooth.

Characteristic of the species are the remarkable length and slenderness of the fan-shaped neural and hæmal spines, and the absence of an acute serration on their margins. In this species the spines have a laminiform expansion at the base in their plane. One specimen exhibits the pelvic region, including a portion of the tail. The ilium has an expanded anterior extremity and is dirceted backwards and somewhat inwards on either side of the vertebral column. The femur is nearly straight, short, contracted medially, and cxpanded distally. The tibia is shorter and is subcylindrical. Beneath the ilitum the last chevron of the abdominal rods appears, the outer extremities rising on the base of the tail.

The pectoral arch is almost unknown, and Cope based the distinction of Plyonius and CEstocephalus on the absence of these plates in the latter genus--an uncer- 
tain characterization. The fore limbs are indicated by a humerus. There werc possibly from 75 to Ioo vertebræ in the entirc column. The animal was exclusively adapted to life in the water and was, without doubt, an excellent swimmer. There are preserved in one specimen portions of what seem to be hyobranchial elements.

Measurements of CEstocepilalus remex Cope.

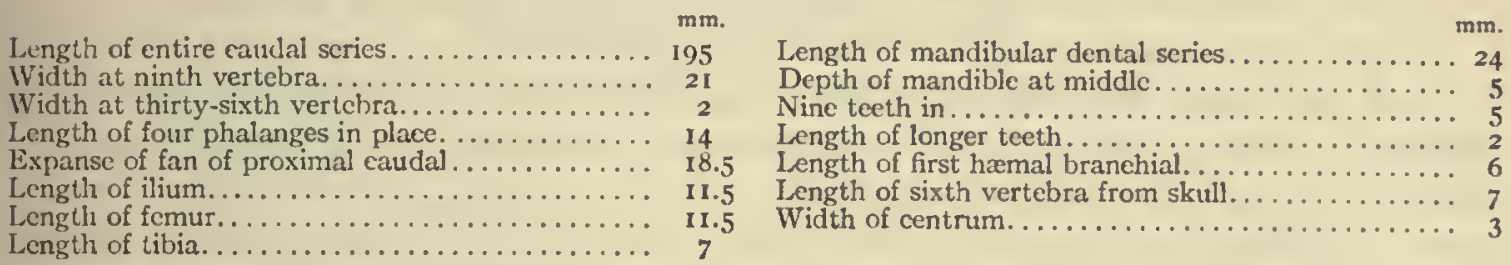

Estocephalus rectidens Cope.

Cope, Trans. Amcr. Phil. Soc., p. 268, Apr., 1874.

Cope, Geol. Surv. Ohio, II, pt. 11, p. 386, pl. xxvii, fig. 3,1875 .

Type: Specimen No. 9033, American Museum of Natural History, collection of J. S. Newberry.

Horizon and locality: Linton, Ohio, Coal Measures.

The species is indicated by a left dentary bone, with its teeth and external surface preserved. The latter is nearly smooth and without sculpture. The outer face is convex, and the general form is slender, but not curved upward at the extremity. The extremity of the dentary does not show any evidences of teeth. Teeth straight and conic, apex acute, non-plicated.

Cope also associated with this species a portion of a caudal series, consisting of 25 vertebræ. The centra are elongate and expanded at the extremities. The neural arches have a close union. The neural and hæmal spines are fan-shaped and striated. The bases are quite narrow.

Measurements of CEstocephalus rectidens Cope.

mm. Length of 3 centra of the eaudal ser. $\mathrm{mm}$.

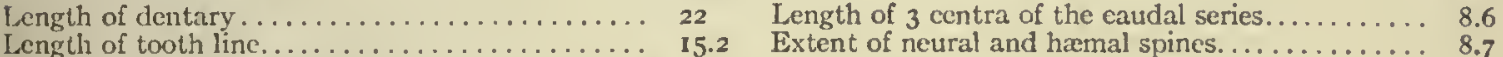

lepth of dontary at last tooth

2.7

\section{Genus THYRSIDIUM Cope, 1875.}

Cor'E, Geol. Surv. Ohio, Ir, pt. II, p. 365, pl. xxxi, fig. 2, r875.

Type: Thyrsidium fasciculare Cope.

Established on a species which presents its principal peculiarities in the structure of the vertebra. Two specimens present inferior views of the spinal column, showing that the genus possesses, like Siren, enlarged diapophyses, but they are peeuliar in their fan-like form. They resemble slightly the neural spines of the caudals of Ptyonius, but are present on the dorsal vertebre. Whether the caudals of the present species possess ornamented neural spines the specimens do not indicate. The abdomen is proteeted by the usual hair-like rods arranged en cherron, the angle directed forwards. No indications of limbs can be discovered on the blocks. 
Without the cranial bones the affinities of this genus can not be determined; while it may be allied to Cocytinus, the vertebræ of that form are without peculiar diapophyses.

\section{Thyrsidium fasciculare Cope.}

Cope, Geol. Surv. Ohio, 11, pt. 11, p. 365, pl. xxxi, fig. 2, 1875 .

Type: Specimen No. 8552 G, American Museum of Natural History.

Horizon and locality: Linton, Ohio, Coal Measures.

The best preserved example of this species includes 9 vertebræ and the corresponding ventral armature. The centra, seen from below, are much contracted in their form, presenting an obtuse median rib, which expands to the articular extremities. In one or two instances the latter are divided by fracture, and the moderately concave form of the adjacent surfaces is displayed. The diapophyses are of complex form, but the details are concealed by the prevalent thin layer of coal which invests them. An inferior prominence runs parallel to the centrum; outside of this the process is obscurely trilobate and thickened, not flattened, as in the caudal vertebræ of Ptyonius. Several ribs (fig. 8) of moderate thickness appear by the side of the diapophyses. Eleven abdominal ribs in $5 \mathrm{~mm}$.

The second specimen was originally referred to Estocephalus remex, as a posterior portion of its vertebral column, immediately preceding the caudal series.

This reference appears to be incorrect, although the resemblance between the corresponding parts in the two genera is no doubt considerable, and the alternative of proposing a new genus and species was not at that time advisable.

The neural spines are longer than high, and are nearly in contact at their margins; each is marked by about 5 obtuse vertical ribs. A fractured section of the abdominal spines in place displayed at least six layers of them.

The material on which the above account is based is imperfect. The specimen figured by Cope (Geol. Surv. Ohio, vol. II, pt. II, pl. xxxi, fig. 2, I875) is undoubtedly a portion of the vertebral column of Estocephalus remex. Nos. 4462 and 4480 of the United States National Museum may be representatives of Thyrsidium fasciculare, but they are more probably Estocephalus remex; if they are the latter this leaves the type as the only known specimen of the species.

Measurements of Type of 'Thyrsidium fasciculare Cope.

Length of portion of vertebral column preserved.............

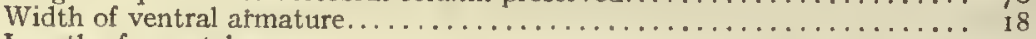

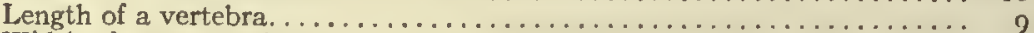

Width of same vertebra............................ 4 


\section{CHAPTER XX.}

\section{THE MICROSAURIAN FAMILY MOLGOPHIDÆ, FROM THE COAL MEASURES OF OHIO AND MAZON CREEK, ILLINOIS.}

\section{Family MOLGOPHIDÆ Cope, 1875 .}

Core, Geol. Surv. Ohio, II, pt. II, p. 357,1875 .

CopE, Bull. U. S. Nat. Mus., No. 1, p. 11, 1875 .

Type of family: Molgophis.

Body long, serpentine, a few species apparently limbless, ribless, and with abdominal armature lacking. Vertebræ elongate, neural and hæmal spines short or absent. Ribs long, heavy, and broad. The vertebre seem to bear the characteristic marks of the family. One species has the skeleton reduced to a lanceolate skull and a string of about 50 slender vertebræ, all the rest of the skeleton being absent. The family is very poorly known, but was apparently of wide distribution in North America and confined to this continent. The representatives of the group are known from Iowa, Illinois, and Ohio.

Four genera are assigned to the family, but future discoveries will undoubtedly demand revision of the present classification. The genera are Molgophis, Pleuroptyx, Phlegethontia, and Erpetobrachium. The distinguishing characters of these genera are apparent from the descriptions of the various forms. The skeletons of the species are too incompletely known to allow the establishment of a tabular key to the genera.

\section{Genus MOLGOPHIS Cope, 1868.}

COpE, Proc. Phila. Acad. Nat. Sei., p. 220, I 868.

Cope, Trans. Amer. Phil. Soc., X1v, p. 20, 1869.

Cope, Geol. Surv. Ohio, II, pt. II, p. 368,1875 .

COPE, Trans. Amer. Phil. Soc., Xv, p. 263, 1874.

Type: Molgophis macrurus Cope.

Cope (123) gives the following:

"'The characters of this genus are: body long, serpentine, without dermal armature, so far as known; vertebra long and broad, with very prominent zygapophyses and moderate ncural spines; ribs large, curved. No limbs or cranium can be ascribed to the type of the genus. The ribs are long, and though the head is not bifurcate, there appears to be both tubercle and head on the dilated extremity. Where crushed they display a large median vacuity.

"This genus differs from Ophiderpeton Huxley (334) in the characters of the dorsal vertebræ, which, in their projecting zygapophyses, resemble those of Amphiuma. The lack of ventral armature distinguishes it from CEstocephalus, while its well-developed ribs separate it from Phlegethontia."

\section{Molgophis macrurus Cope.}

Cope, Proc. Phila. Acad. Nat. Sci., p. 220, 1868.

Wrmis, Am. Jour. Sci. and Arts, p. I1, fig. 1, $185^{8}$ (refers to a batrachian reptile).

Cope, Trans. Amcr. Phil. Soc, XIv, p. 20, 1869.

Cope, Trans. Amer. Phil. Soc., Xv, p. 263, 1874.

Cope, Geol. Surv. Ohio, II, pt. 11, p. 368, pl. xlii, fig. I, 1875.

Type: Specimen No. 8617 G, American Museum of Natural History, collection of Dr. J. S. Newberry.

Horizon and locality: Linton, Ohio, Coal Measures. 
This species is established by remains of 2 individuals, one embracing 16 and the other 14 vertebræ, with ribs. The neural arches, viewed from above, have a $V$-shaped outline posteriorly, from the fact that the broad zygapophyses meet on the median line and spread out distally over the broad anterior ones adjoining. The latter appear to be somewhat concave and to border the former exteriorly as well as inferiorly. The base of the neural spine extends to the posterior emargination, but not quite to the anterior. The breadth of the dorsal vertebræ above is equal from the emargination behind to the anterior margin of the anterior zygapophyses.

The ribs are long for an amphibian, but not long for a reptile. They are well curved, chiefly near the proximal extremity. The longest found, measured by a cord, equals two and two-fifths vertebræ. These vertebræ, measured along the median line above, equal I l lines; one of these is 3.6 lines in width above. This animal has been, like $A m$ phiuma, a snake-like amphibian, but was probably still larger. How near the affinities to this genus may be can not now be determined, owing to the want of many important parts of the skeleton, but it differs in the important feature of large, well-developed ribs. The size of the vertebræ would indicate a body of the size of the common rattlesnake (Crotalus horridus) and too large for Brachydectes newberryi, which is only known from jaws.

Molgophis brevicostatus Cope.

Cope, Geol. Surv. Ohio, II, pt. II, p. 369, pl. xliv, fig. I, I875.

Moodie, Proc. U. S. Nat. Mus., 37, p. 27, 1909.

Type: Specimen No. 834I G, Amer. Mus. of Nat. History. Horizon and locality: Linton, Ohio, Coal Measures.

Represented by portions of the vertebral column of several individuals. One of these includes 9 pairs of ribs, with vertebræ, and another 13 pairs. The vertebræ are subquadrate in section, and the concavity of the two articular faces is not deep. They support strong lateral ridges separated by deep concavities. The heads of the ribs are somewhat contracted, and the shafts present outward a tubercular angle at a distance of one-fourth the length from the head. The remaining part of the shaft is stout, nearly straight, and gradually con-

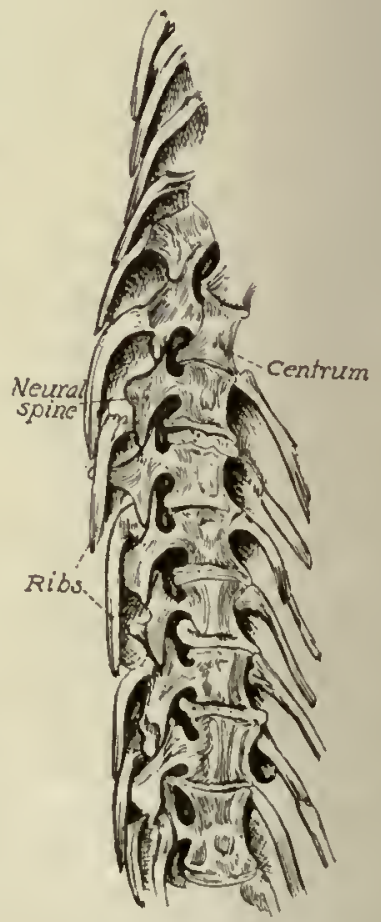

FIG. 32.-Drawing from Cope's figure of Molgophis brevicostalus Cope. $\times 0.5$. tracts to an obtuse extremity. It possesses a narrow medullary cavity. In none of the specimens is there any trace of abdominal armature, but abundant remains of the contents of the abdominal cavity, in proper position, are preserved on the blocks. This species is more massive than Molgophis macrurus, and the ribs are shorter, thicker, and less curved.

Ventral scutellæ are present in one specimen of this species. There are a number of specimens. They have the following numbers at the American Museum: ${ }_{5} 5^{8}$, I Ioo G, no number, 834I G (type), no number, $8466 \mathrm{G}$; and 4477 in the U. S. National Museum. 
Measurements of Type Specimen of Molgopuis brevicostatus Cope.

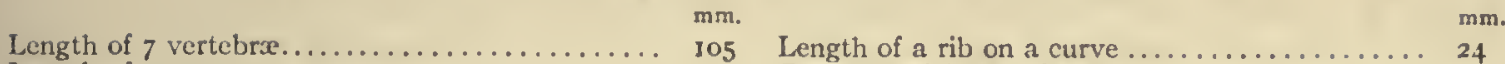

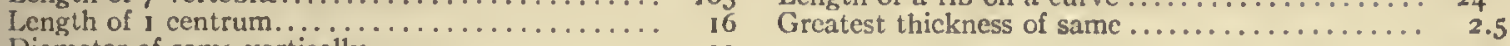

Diameter of same vertically............. II

Molgophis wheatleyi Cope.

Cope, Geol. Surv. Ohio, II, pt. II, pp. 369, 370, pl. xlv, fig. I, 1875 .

Cope, Trans Am. Phil. Soc., xv, p. 26.3, 1874 .

Type: Specimen No. I IOI G, American Museum of Natural History.

Horizon and locality: Linton, Ohio, Coal Measures.

A critical study of the type specimen of this species does not reveal anything essentially different from the description of Cope. The following is taken from his report (I23):

"Established on a specimen which exhibits about twenty-five vertebræ with ribs, and the posterior portion of the cranium. No traces of abdominal scales or rods, thoracic shields, or limbs are visible. By such negative characters it is referable to the genus Molgophis, although the definition of this genus is incomplete. The present batrachian may, indeed, be ultimately found to be an Ophiderpeton, to which it also bears some resemblance.

"The specimen is that of an animal of very much smaller size than the M. macrurus. The vertebræ are of moderate length, with a low neural spine, and centrum angular at the sides and truncate at the articular extremities when in place. The ribs are rather short, slightly curved, apparently hollow and intercentral in position. Although the vertebral centra are ossified, the elements of the cranium have a larval appearance. These consist of two parallel bony plates, which resemble the fronto-parietal bones of the frog; they are slightly scparated from each other, but do not inclose a fontanelle. A wedgeslaped bone extends from the outside of the front of each of these, acuminate behind, and widening anteriorly in the position of a postfrontal bone. In front of the posterior border of each parietal, on its outer side, a bony enlargement arises which contracts outward and forward into a narrow element which curves forward beneath the postfrontal. These look like an anteriorly directed quadrate with articular bone, such as seen in the larvæ and some adults of existing batrachians. These determinations will require confirnation from additional material. In the meantime it is evident that the present specimen can not be referred to any of the other species herein described. The elements of the cranium are cntirely smooth with no sign of sculpture, and in this respect the present species is unlike any of the other known from the Carboniferous."

The vertebræ are not so clearly marked as one is led to believe from Cope's figure.

Measurements of tue Type of Molgophis wieatleit Cofe.

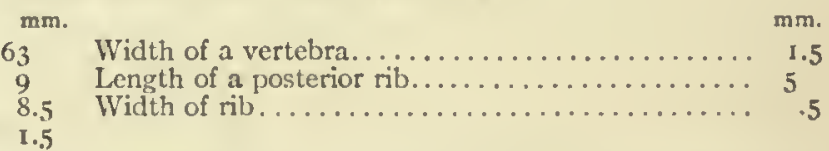

Length of entire specimen............. 63

length of portion of skull prescrverl............

Posterior width of same............... 8.5

Length of a vertebra.................... I.

The species is dedicated to Charles M. Wheatley, of Phonixville, Pennsylvania, one of the original investigators of the Linton deposits. It is a part of the Newberry Collection.

Additional material of this species is represented by specimens Nos. 7 and 8699 G of the American Museum of Natural History. They are both very unsatisfactory. They consist of molds of the vertebral column, with in one case an enlargement at one end which may represent the head, and if such, the specimen probably represents a distinct species. The impression, No. 7 , contains molds of abont 30 ver- 
tebræ which are very similar in form to those exhibited by the type of the species. To the vertebræ are articulated short, curved ribs of a slender nature. The vertebræ themselves are short and somewhat constricted in the middle.

The other impression, $8699 \mathrm{G}$, contains impressions of about 20 vertebræ, apparently immature, though one can not be entirely sure as to the nature of the structures. They are covered over with a thin layer of carbonaceous material which is impossible to remove satisfactorily. The two specimens remind one of what Huxley has written in regard to the forms of Microsauria (334) from Kilkenny, Ireland.

Measurements of Nos. 7 and 8699 G (Molgophis wheatleyi).

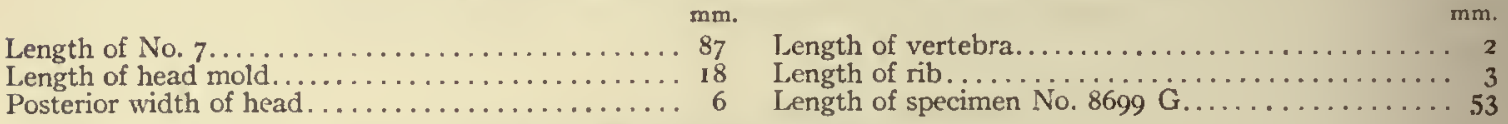

Genus ERPETOBRACHIUM Moodie, rgi2.

Moodie, Kans. Univ. Sci. Bull., vr, No. 2, p. 353, 1912.

Type: Erpetobrachium mazonensis Moodie.

The generic characters are apparent in the greatly elongated fore limb, in the exceptionally broad scapula, the long radius and ulna, which slightly exceed the humerus in length, a character hitherto unknown among Carboniferous Amphibia.

Erpetobrachium mazonensis Moodie.

Moodie, Kans. Univ. Sci. Bull., vi, No. 2, pp. 353-354, pl. 2, fig. 2; pl. 8, fig. 3, 1912.

Type: Specimen No. 799 (222), Yale University Museum.

Horizon and locality: Mazon Creek shales, near Morris, Illinois.

The scapula of the present form is exceptional in its shape. It resembles an asymmetrical pyramid, the anterior side of the lower edge of the bone being contracted so that the anterior edge of the element is arcuate. Its top is very thin and possibly terminated in a broad cartilage. The lower end is thick and heavy and the articular surface is, apparently, well formed, though somewhat obscured.

The element identified as a clavicle is lying on its edge and has the proportions of the clavicle of Mazonerpeton costatum. The exterior edge is somewhat rounded and small. A portion of another element which I suppose to represent the coracoid lies alongside the humerus, although its form is quite obscured. (Plate 3, fig. 3.)

The humerus has a remarkably well-formed head. In perfection of formation it corresponds well with that of the higher reptiles. This surface can even be divided into an anterior and a posterior articulation. The element projects posteriorly for the distance of $\mathrm{I} \mathrm{mm}$. from the surface of the shaft. The shaft immediately below the head is somewhat flattened and has an ovoid section. Further on it becomes flattened, a part of which is probably due to pressure during fossilization.

The elements of the forearm are both preserved and are approximately equal in size. They are remarkable in that they exceed the humerus in length, although they are not so heavy as that element. They are greatly elongate and slender, with the middle of the shaft only moderately contracted. The articular surfaces are well formed and both bones were hollow, as was also, apparently, the humerus. The ulna may be represented by the most posterior of the two elements, though the relations of the elements may have been reversed (fig. 15, D). 
The base of the left wing of an orthopterous insect possibly allied to Paolia gurleyi Scudder lies between the radius and ulna. The nodule also contains impressions of plants, a portion of a frond of a Neuropteris and the impression of one of the Cordaites. Lying next the radius is a slender elongate element which may be a rib or a portion of a metacarpal. If a rib, it indicates that the animal belongs among the Branchiosauria. The fragment is only half as long as the radius and is entirely too obscure to base any conclusions. The other characters of the specimen point quite strongly to its microsaurian affinities.

The structure of the articular surfaces of the limb bones alone would indicate the microsaurian relationship of Erpetobrachium. It may be provisionally associated in the family Molgophidæ with such forms as Molgophis brevicostatus Cope, Molgophis (Pleuroptyx) clavatus Cope, and Molgophis macrurus Cope from the Coal Measures of Linton, Ohio.

Measurements of the Type.

\begin{tabular}{|c|c|c|c|}
\hline & $\mathrm{mm}$. & & $\mathrm{mm}$. \\
\hline th of scapula. & 14 & Diametcr of shaft. & \\
\hline .... & 6 & 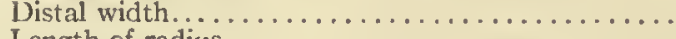 & 3 \\
\hline r.... & 3 & Length of radius & 25 \\
\hline cle $(?) \ldots \ldots \ldots \ldots \ldots \ldots \ldots \ldots \ldots$ & 24 & Proximal width & \\
\hline$\cdots \cdots$ & 25 & Diameter of shaft & \\
\hline 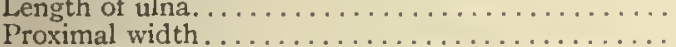 & $\begin{array}{r}24 \\
4\end{array}$ & ath of distal end....... & \\
\hline
\end{tabular}

Genus PLEUROPTYX Cope, 1875.

COPE, Geol. Surv. Ohio, II, pt. 11, p. 370, pl. xlii, fig. 1 ; pl. xliv, fig. 2, 1875 .

COPE, Proc. Phila. Acad. Nat. Sci., p. 16,1875 .

MIoodie, Proc. U. S. Nat. Nus., 37, p. $27,1909$.

Type: Pleuroptyx clavatus Cope.

The specimens on which the species of this genus repose do not exhibit crania. The 5 , probably 6 , specimens which represent them offer various views of the vertebral column, and in none is there any trace of ventral or thoracic armature. Limbs can be ascribed to them with probability only. The vertebræ are of moderate length, with well-developed zygapophyses, and a short and not very elevated neural spine in the dorsal region, which is not sculptured in any way. The generic character is seen in the ribs. These are rather short and very stout and support an ala on the posterior or convex border, which expands downwards, and then suddenly contracts to the shaft. The extremity of the latter is broad and truncate, and includes a medullary cavity, which is only partially fitted with cancellated tissue.

Pleuroptyx clavatus Cope.

Cope, Gcol. Surv. Ohio, 11, pt. Ir, p. 370, pl. xlii, fig. 1; pl. xliv, fig. 2, 1875.

Cope, Proc. Phila. Acad. Nat. Sci., p. 16. 1875 ,

Moodik, Proc. U. S. Nat. Mus., 37, p. 27, 1909.

Type: Specimen No. 8617 G, American Museum of Natural History.

Horizon and locality: Linton, Ohio, Coal Measures.

The general appearance of the species of Pleuropty.x is that of the Molgophis, so far as known, but nothing resembling the peculiar structure of the ribs is seen in any other. There is no assurance that the genus is distinct from Molgophis. 
Parts of two individuals express the typical characters of this species, while a third only differs in being considerably smaller. A fourth may very probably be referred here, and another, bearing several elements of a leg, should be most likely associated with the last mentioned.

The ribs are considerably narrowed near the head, and appear to possess a low tubercular process some distance below it. The shaft is curved throughout; the laminar expansion is quite thin; while the distal end is expanded and concave, perhaps for the attachment of cartilage, although no trace of this remains on the shale. The neural spines have short bases, oblique anterior and nearly straight posterior borders, with obtuse extremity. I perceive no essential difference in the smaller specimen, which is one-third less than the types.

The limb is appropriate in its proportions to the present species, and may be described in this place. The first segment is one-third longer than the second, and has a transversely expanded head. The shaft is stout, the distal extremity not expanded and concave. The second segment is stout, more expanded proximally than distally, the proximal end truncate and slightly concave. A bone, much displaced, lies near it, and is probably ulna or radius; it is as stout as the first, the end not expanded. Of metatarsals there are 2, three-fifths the length of the second bone of the leg, and of phalanges 2 , of 2 digits

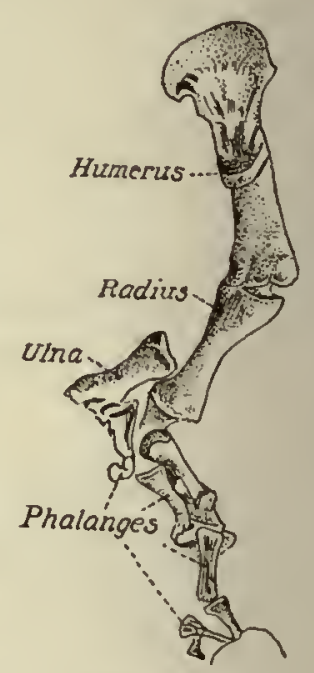

FIG. 33. - Fore limb of a member of the Molgophide, possibly Pleuropty.x clavalus Cope. $\times 0.75$. each. The proximal are three-fourths the length of the metatarsals, and indicate elongate toes. The obverse of the specimen is preserved, and contains no additional toes or phalanges.

Measurements of tie Type of Pleuroptyx clavitus Cope.

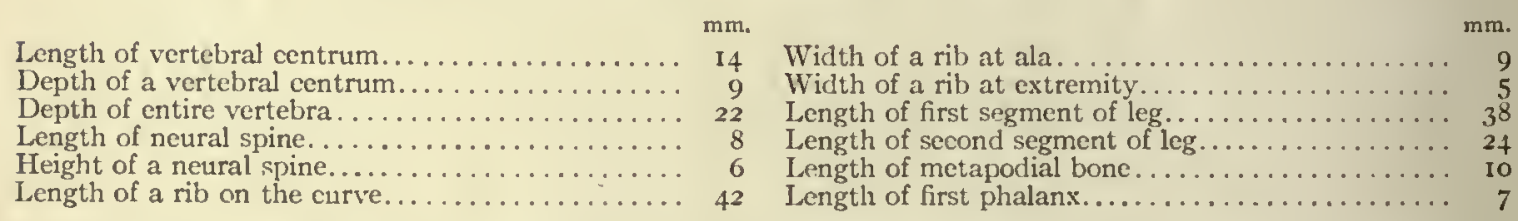

Hitherto only two portions of the dorsal series and a left limb have been assigned to this species. The present specimen (No. 4479, U. S. Nat. Mus.) thus proves of interest in determining that the creature was long-tailed, like CEstocephalus, Ptyonius, and Phlegethontia, but unlike the first two genera the neural and hrmal spines are not elongate nor marked with radiating lines. The neural spines are indistinct and if developed at all were very low and short.

The centra are short, cylindrical, and thick. They gradually decrease in size to where they are lost, since the portion preserved does not represent the entire length of the tail. There may have been 15 more vertebræ distally and 5 more proximally, thus making about 75 caudal vertebræ, as Woodward (630) has determined obtains in Ceraterpeton galvani Huxley. 
The ribs are continuous throughout the length of the tail preserved and have preciscly the same structure as is found in the dorsal region with the possible exception that the posterior alar expansion is not so well developed in the caudal ribs. The ribs are decidedly fan-shaped and articulate by a single head with a short transverse process. They are distinctly curved like all microsaurian ribs.

Measurements of Specimen of Pleuroptyx clavitus Cope.

(No. 4509, U.S. National Museum, Linton, Ohio, Coal Measures.)

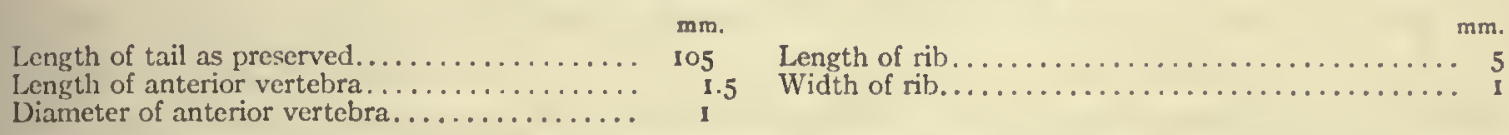

The above-described specimen represents what I suppose to be the posterior part of the body of Pleuroptyx clavatus Cope. The characters of the ribs and vertebræ are the same. The fragment is interesting, since it gives an insight into the form of the body, which was slender, conforming thus to other long-tailed microsaurs. Length of specimen, $65 \mathrm{~mm}$.; width of specimen, $30 \mathrm{~mm}$.

There is still a third example of this species among the collections belonging to the National Museum (No. 4484). The specimen includes a badly crushed posterior portion of a skull and a series of about I6 crushed vertebræ, with several pairs of ribs and ventral scutes.

Very little can be said of the skull save that the maxilla of the right side was long and bore from 15 to 20 teeth, of which 9 are preserved more or less completely. The mandible is likewise crushed and one can not determine its elements. Portions of 2 or 3 teeth are preserved. The form of the mandible is long and slender.

The ventral scutes are of the pectoral region. They are long, slender, and threadlike. They are not closely packed, but I count 12 in a distance of a millimeter.

So far as can be determined the vertebræ are the same as has been described for other specimens. They are short and heavy. The ribs show, for the most part, the same characters as the type specimen.

Me.isurements of Tiurd Specimen (No. 4484 , U. S. Nat. Mus.).

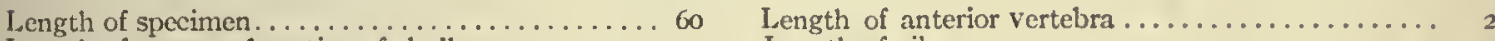

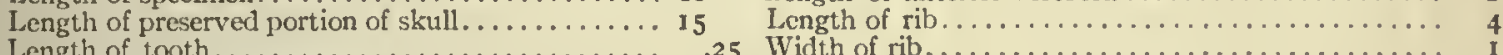

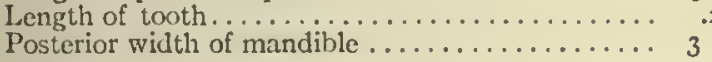

\section{Genus PHLEGETHONTIA Cope, $187 \%$.}

Cope, Proc. Am. Phil. Soc., p. 177, 1871.

Core, Geol. Surv. Ohio, II, pt. 11, p. $366,1875$.

\section{Type: Phlegethontia linearis Cope.}

This is one of the most interesting genera of the present series. It rests chiefly on a single specimen of one species, which is not perfect, but which displays the following characters: Head elongate-triangular; body and tail extremely elongate, the dorsal vertebræ without ribs, and the caudals without dilated spines; no ventral armature nor limbs. As a great portion of the length is presented, and no ventral rods or scales are visible, and as this character is confirmed by a second specimen, it probably belongs to the genus. The pectoral shields are also wanting in the spec- 
imen, but as there is a considerable vacuity behind the skull of the specimen, it may be that these were lost with other parts. Chevron bones are not observable on the caudal vertebræ. This form is a true amphibian snake.

Phlegethontia linearis Cope.

Cope, Geol. Surv. Ohio, II, pt. II, p. 367, pl. xliii, fig. 2, 1875 .

Type: Specimen in the American Museum of Natural History.

Horizon and locality: Linton, Ohio, Coal Measures.

In the only specimen the dorsal vertebræ are much involved anteriorly, so that the length is not readily ascertained. There is an outline of a triangular object which may represent the skull of this specimen, although it is so far removed from the vertebræ that there is some doubt as to whether it belongs with the vertebræ or not. Indeed, there is even doubt whether it is a skull. The vertebræ have longitudinal diapophysial keels, and have a zig-zag interlocking of neural arches. The latter are distinctly turned outward. The vertebræ are very numerous, and the tail very attenuated. The number preserved is about 60 . The total length of the coils unwound is about $295 \mathrm{~mm}$., or II coils in 8 lines; but there are interruptions not measured and confusions not unraveled.

This is the most elongate and slender of all the species of the Carboniferous Amphibia. The vertebræ are apparently ribless and there are no evidences of limbs or pectoral plates. It may be said that the body consists entirely of skull and vertebræ.

Measurements of the Type of Phlegethonti linearis Cope.

Entire length of skull (?).......... $18 \mathrm{~mm}$.

Width of same............... $8 \mathrm{~mm}$.

Length of vertebral column as preserved.. $295 \mathrm{~mm}$.

Length of single vertebra.......... $2.50 \mathrm{~mm}$.

Height of vertebra........... $1.50 \mathrm{~mm}$.

Estimated length of body .......... 15 in.

No. 8370 G, American Museum of Natural History, shows a few vertebræ.

Phlegethontia serpens Cope.

Cope, Geol. Surv. Ohio, Ir, pt. II, p. 367, pl. 32, fig. 2, 1875 .

Type: Specimen No. I I02 G, American Museum of Natural History.

Horizon and locality: Linton, Ohio, Coal Measures.

This amphibian is much larger than the last, approaching nearly in its dimensions the Molgophis macrurus. It is represented by a series of 22 vertebræ, which, like those of Phlegethontia linearis, are devoid of ribs, abdominal armature, dilated neural spines, etc. The series when complete must have been very long, as there is little difference in size between the first and the last of the 22. They are marginate fore and aft, and much contracted medially, owing to the transverse expanse of the diapophyses. There may be, indeed, a diapophysial element beneath these, but, if so, the two are indistinguishable. They are connected by longitudinal impressions, indicating the existence of the tendinous bands in the longitudinal muscles seen in Amphinma, or the osseous spicules seen in the same situation in birds. The neural spines, as indicated by their narrow bases, occupy the length of the neural arch, and remind one of Amphiuma. Width of one of the vertebræ, 3 lines. 


\section{CHAPTER XXI.}

\section{THE MICROSAURIAN FAMILY SAUROPLEURIDA, FROM THE COAL MEASURES OF OHIO.}

\section{Family SAUROPLEURIDA Hay, rgo2.}

Hay, Bull. U. S. Geol. Surv., No. 179, p. 419, 1902.

The present family is an association of related forms due to similar structure of vertebra, ribs, ventral scutellation, and limbs. There is no character in the skull which would indicate a separation of the genera here included, at least in the light of present knowledge.

The family may be characterized as: Subaquatic or terrestrial vertebrates with a typically amphibian development of the ventral armature; ribs intercentral, as in all members of the order; skull elongate and slender or broad and obtuse; cranial and dermal elements of the pectoral girdle sculptured; lateral-line canals indicated in one genus, Saurerpeton; limbs well developed, with well-developed digits and ungual phalanges claw-like; body usually slender, broad in Saurerpeton; the ribs broad and heavy; the vertebræ relatively stout; ventral armature highly developed, reaching the height of specialization among the Microsauria; scutellæ consisting of rods, plates, or stout bristles. The family is represented by 5 genera: Sauropleura, Saurerpeton, Ctenerpeton, Leptophractus, and Eurythorax, the association of the last two genera being provisional. The genera may be distinguished as follows:

I. Pectoral elcments sculpturcd, clavicles triangular, interclavicle diamond-shaped, ventral scutellæ rods,

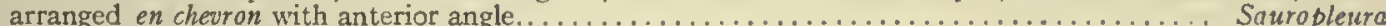

II. Pectoral elements slightly sculptured, cranium broad, obtuse and sculptured, ventral armature broad

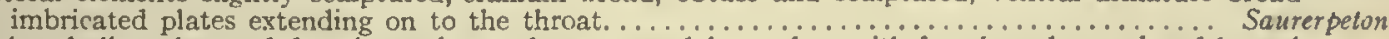

1II. Limbs, skull, arches and dorsal vertebræ unknown, caudal vertebræ with fan-shaped neural and hæmal spines which may indicate relationship with Ptyonius and Estocephalus, but in those genera the ventral armature is weakly developed; ventral scutcllæ curved rod-like plates arranged en chetron with anterior angle, marked in abdominal region by distinct rounded pits................ Clenerpeion

IV. Known only from fraginents of the skull, teeth large and flutcd; association in family provisional.. Leplophractus

V. Known only from a single interclavicle of peculiar form which rescmbles that of Saurerpeton; association

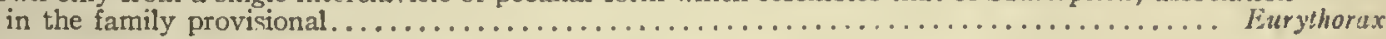

The members of this family are confined to the deposits of the Coal Measures at Linton, Ohio. Ctenerpeton, and possibly Sauropleura, were highly developed swimmers, but the strength of the limbs as exhibited, especially by Sauropleura and Saurerpeton, indicates that they had not entirely forsaken the land.

Genus SAUROPLEURA Cope, 1868.

Newberry, Proc. Phila. Acad. Nat. Sci., viti, p. 98, 1856 (Pygoplerus sculellalus).

CoPE, Trans. Am. Phil. Soc., p. 22, 1869.

Cope, Geol. Surv. Ohio, Ir, pt. II, p. 402,1875 .

HaY, Bull. U. S. Geol. Surv., No. 179, p. 419, 1902.

Type: Sauropleura scutellata Newberry.

Vertebræ and ribs well developed; limbs 4, rather large; 5 digits in the forefoot; carpus cartilaginous. Ventral armature of closely arranged rhomboidal scuta, arranged in lines, which are closely placed in chevrons, with the angle anterior. 
In none of the species of this genus have the usual 3 thoracic shields (clavicles and interclavicles) been observed. The abdominal scutæ, on the other hand, are much like those of Saurerpeton, being, however, smaller.

The species formerly described by Cope in the genus Colosteus are included in Sauropleura, where they find their closest allies.

There are 7 species belonging in this genus: Sauropleura digitata Cope, S. newberryi Cope, $S$. foveata Cope (Colosteus), S. scutellata Newberry (Colosteus) (type of genus), S. pauciradiata Cope (Colosteus), S. longidentata Moodie, S. enchodus Cope (Anisodexis). The species described by Cope as Sauropleura latithorax is regarded as belonging to a distinct genus, Saurerpeton.

\section{Sauropleura scutellata Newberry.}

Newberry, Proc. Phila. Acad. Nat. Sci., p. 98, 1856 (Pygopterus scutellaius).

Cope, Proc. Phila. Acad. Nat. Sci., p. $215,1868$.

Cope, Trans. Am. Phil. Soc., p. 22, 1869.

Cope, Geol. Surv. Ohio, II, pt. II, p. $402,1875$.

Type: Specimen No. 8669 G, American Museum of Natural History.

Horizon and locality: Linton, Ohio, Coal Measures. (Plate 14, fig. 3.)

This species was first described by Newberry as a fish belonging to the genus Pygopterus. Cope later placed it under the genus Colosteus and clearly showed its amphibian characters. The genus Colosteus was, however, based on a misconception. Cope in I897 and Hay (3I7) referred the species to Sauropleura, where it is retained. The species is represented by a single individual preserved on a block of coal from Linton, and is also indicated by an interclavicle and its obverse; this element is of larger size than that of the type and was referred by Cope to Colosteus pauciradiatus. The characters of the plate are, however, so identical with those of the interclavicle in the type specimen that it is unhesitatingly referred to the present form.

The type specimen consists of the supero-lateral view of a crushed cranium with the anterior part of the body, exhibiting the interclavicle and the ventral scutellation. No limbs have been observed in this species. The mandibles are crushed across the cranium in such a way as to obscure its structure. The boundary of the left orbit is doubtfully determined as being a little back of the median line of the skull. There are small teeth present on the mandibles, but their number can not be determined. The cranial elements are sculptured with radiating grooves and ridges, but these are weakly developed. The snout is broad and but little narrower than the base of the skull. (Plate 2I, fig. 5.)

The interclavicle, somewhat displaced, is the only element of the pectoral girdle preserved. It is peculiar in the possession of a backward extension which shows a beveled edge. The plate is ornamented by radiating grooves and ridges which are strongly developed. The larger specimen of an interclavicle shows the same characters as the one described, and it differs only in being about twice as large. There are no traces of limbs.

The ventral armature of the body is rather weak as compared to that of Santropleura panciradiatus, but it is still composed of closely packed scutes arranged en chevron. The character of the ventral armature and the sculpturing of the inter- 
clavicle are taken as the principal specific characters. From the other species of the genus the present form differs in its more slender elements of the ventral armor and in the form of the skull. The ribs are not clearly defined.

\begin{tabular}{|c|c|c|c|}
\hline \multicolumn{4}{|c|}{$\begin{array}{l}\text { MeAsurements. } \\
\mathrm{mm} \text {. }\end{array}$} \\
\hline Mcdian length of skull.. & 70 & Length of mandibular tooth. & I. \\
\hline Posterior width of skull. & 40 & Length of entire specimen..... & 150 \\
\hline Anterior width of skull. & 20 & Width across belly, maximum... & 47 \\
\hline Length of jaw.. & 50 & Length of interelavicle......... & 27 \\
\hline terior width of jaw. & 7 & Width of interclavicle. & 13 \\
\hline Posterior width of jaw. & 12 & Width across postcrior extension. & 4 \\
\hline
\end{tabular}

\section{Sauropleura digitata Cope.}

Cope, Proe. Phila. Acad. Nat. Sci., p. $216,1868$.

Cope, Trans. Am. Phil. Soc., XIV, p. I5, 1869.

Cope, Geol. Surv. Ohio, II, pt. II, p. 403, pl. xxxvii, fig. I, I875.

Type: Specimen No. 8004 G, American Museum of Natural History.

Horizon and locality: Linton, Ohio, Coal Measures. (Plate 20, fig. 4.)

This species is represented by a single individual which is quite distinct from other members of the genus. The specimen has been spread over a surface of the coal, and exhibits ventral armature, dorsal region with ribs, and anterior and posterior limbs. Skull and caudal region not present.

The ventral armature is arranged in parallel lines directed obliquely forwards and continuous on the median line, forming there a chevron. The individual elements are oat-shaped, and acuminate at both ends. They are moderately imbricate in an antero-posterior section. On the pectoral region between the fore limbs the series of scutellæ assume different directions, forming chevrons directed backwards, and forming with those of the belly a complete $X$.

The humerus, ulna, and radius are rather stout, and of a size relative to the body, as in common types of existing lizards; the ulna and radius separate. The carpus is cartilaginous; the digits are 5 well-developed fingers having phalanges in the following numbers, commencing on the inside: $3,4,5,6,5$. The last phalanx of the second is obscured, and it is not positive that the number is as given; it is more probable that it was 4 than 3 . The outer toe was more slender than the others; the distal phalanges of all the toes are stout, as in modern Caudata.

The ribs are long and curved as in reptiles, and judging by their distances the vertebra are short; the latter are not well-defined, but there is no indication of prominent spines of any kind. The pelvic bones and portions of the hind limbs are present, but so obscured and confused as not to be easily made out. Enough remains to show that the hind limbs were longer than the fore. Thirteen ribs on one side and twelve on the other are preserved, with short ribs in the sacral region. The specimen is very indistinct and it is difficult for one to be sure of all the characters deseribed by Cope.

Measurements of tile Type of S.Auropleura digitata Cope.

$\mathrm{mm}$.

Length of specimen. . . . . . . . . . . 115

Grcatest width.

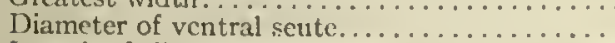

Length of rib.

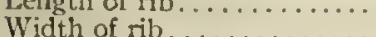

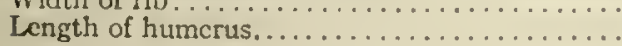

115 Length of radius.

Length of ulna..

.75 Lesigth of metacarpal.

15

I

20

Length of fourth digit of hand .............. 4

Iength of interclavicle.................. 20

Width of interelavicle.................. II 
The interclavicle is diamond-shaped, with surface punctate and edges radiately grooved at a distance of $1.5 \mathrm{~mm}$. from the edge. The hand on the right side of the specimen contains $3,3,3,6,3$ phalanges. The vertebræ are all imperfectly preserved.

Other specimens of this species are 2567 (48), $8376 \mathrm{G}, 8704 \mathrm{G}$, American Museum of Natural History. Coal Measures of Linton, Ohio. Collected by Dr. J. S. Newberry.

\section{Sauropleura newberryi Cope.}

Cope, Geol. Surv. Ohio, II, pt. II, p. 404, pl. xxxvii, figs. 2 and 3; pl. xli, fig. 5,1875 .

Type: Specimen No. 8612 G, American Museum of Natural History.

Horizon and locality: Linton, Ohio, Coal Measures.

The type specimen of the species exhibits a portion of the posterior part of the skull, a considerable part of the body, with the fore limbs and abdominal scutellæ. No vertebræ can be definitely discovered and the ribs are not distinctly visible. The cranial fragment is the upper surface of the tabulare and adjacent elements, and a broad band of the posterior parts of these is seen to be smooth, and is preceded by a slightly roughened surface. The abdominal scutæ are diamond-shaped, and are thin and light, not massive, as in S. scutellata, and are sometimes marked with a median longitudinal keel. The fore limb is large, especially the humerus, which is much dilated distally, and has a strong crest on the outer side from near the proximal end. The ulna and radius are much shorter, and more dilated proximally than distally; they are well separated. No phalanges are preserved.

The species is represented by other specimens, all of which are unsatisfactory in determining the structure of the form. A skull, apparently complete, is crushed out flat, so that little can be said of structure. The teeth are rather long, straight, acute, and striate at the base. The orbits are long and narrowed in front.

Measurements of Sauropleura Newberryi Cope.

(No. 86I2 G, and two unnumbered specimens, American Museum of Natural History.)

Length of humerus.

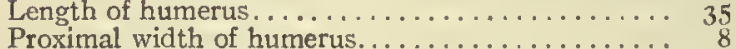

Distal width of humerus.

I.ength of ulna.

Proximal width of uina.

Posterior width of skull .

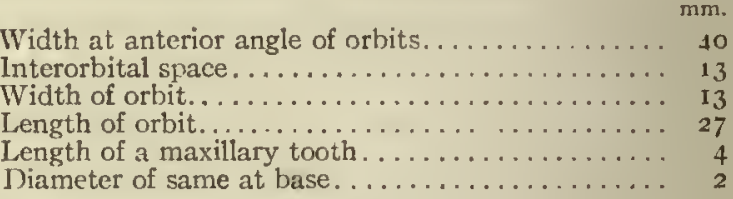

Sauropleura pauciradiata Cope.

Cope, Trans. Am. Phil. Soc., xv, p. 275, 1874.

Cope, Geol. Surv. Ohio, II, pt. II, p. 408, pl. xl, figs. I-2, I 875 .

Type: Specimen No. $867 \mathrm{I}$ G, and obverse, American Museum of Natural History.

Horizon and locality: Linton, Ohio, Coal Measures.

The species was founded on a median and a lateral plate of 2 individuals. The clavicle is here associated with $S$. scutellata and the interclavicle thus remains as the type specimen. There are other remains associated by Cope with S. scutellata which are here shown to have closer affinities with the $S$. panciradiata.

The clavicle is a right-angled triangle, the inner and thin edge concave posteriorly, the posterior convex. The ridges and grooves are well developed on the specimen. The visceral side of the element is smooth. 
Cope referred to $S$. scutellata the larger part of an individual with strongly developed ventral scitellation. 'This he figured on plate xxxvi, fig. 2 (I23). Even a cursory glance will, however, suffice to show that the sculpturing of the clavicle just described and that exhibited by the specimen there figured are identical. Closer examination shows important differences between the species, the principal distinctions being the strongly developed ventral scutellæ in Sauropleura scutellata, the difference in form and sculpture of the interclavicles, and the posterior extension of the interclavicle in S. scutellata which is wanting in S. pauciradiata. The sculpturing of the interclavicle in the form figured by Cope as $S$. scutellata, just referred to, is identical with the sculpture of the clavicles, as would be expected. The ridges on all of the pectoral elements of $S$. pauciradiata are strong and are rather few in number, while in $S$. scutellata the sculpturing is more in the form of interrupted grooves.

The specimen (plate 14, fig. 3) exhibits the great part of the body with one fore limb. The skull is wanting. The belly was very broad and strongly protected by broad, long scutes arranged en chevron. The scutes are close together and form a compact ventral armor for the animal. The fore limb is very weak. The humerus is represented by its distal end only. The radius and ulna are very short and weakly developed in comparison to the size of the animal. The limbs could not have supported the animal on land and served, probably, merely as organs of equilibration, for the animal was undoubtedly aquatic. The fingers are not all preserved and there is no carpus.

Numerous other remains formerly associated with $S$. scutellata are here referred to $S$. pauciradiata, on account of the strongly developed ventral armor, which is different from that of the type of $S$. scutellata. The remains do not, however, add to our knowledge of the anatomy of the forms, as they are very fragmentary.

Two skulls are provisionally associated with this species. One of these skulls is figured by Cope (I23) on plate xxxIII, fig. I. It is there referred to $S$. scutellata. That it can not, however, be referred to that species is manifest when

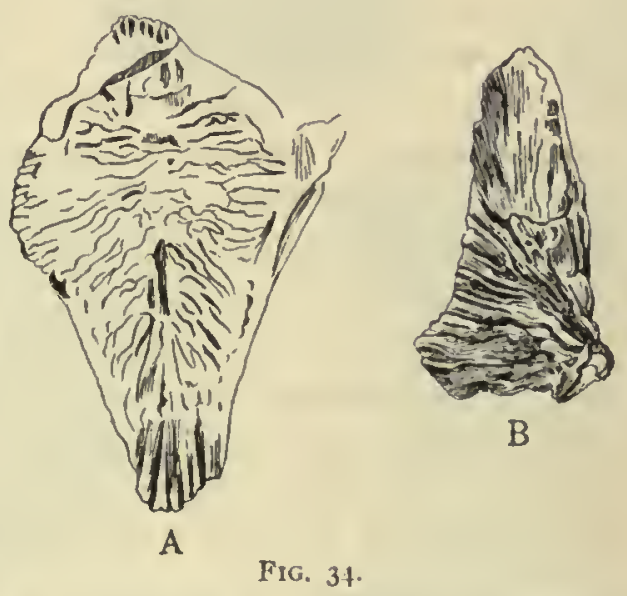

A. Interclavicle of Sauropleura pauciradiata Cope. $\times$ i. (After Cope.)

B. Left clavicle of Sauropleura pauciradiala Cope. $X$ I. (After Cope.) the teeth are observed. In the type of $S$. scutellata the teeth are very small, sharp denticles, while in the skull under discussion the teeth are well developed and their bases are longitudinally grooved. The teeth are elongate in the anterior part of the skull and are shorter posteriorly. They are, however, all strong. The skull is acuminate and the orbit is located about midway of its length. The jaw is slightly longer than the cranium. The structure of the cranium can not be determined in either skull, and in one only the position of the orbits and the teeth. 
Measurements of the Specimens of Sauropleura pauciradita Cope.

Length of clavicle, left. ............... 43

Width of clavicle................... 25

Space between ridges

Large specimen No. $8657 \mathrm{G}$ and obverse (13) described as Colosleus sculellatus Nevob.

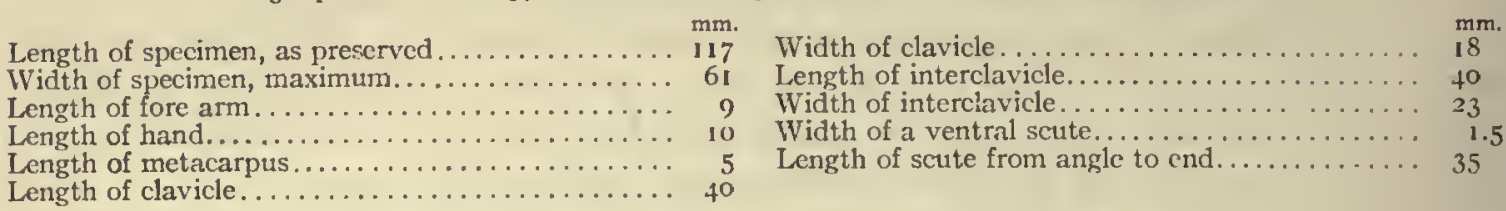

Skull No. 8666 G, plate xxiti, fig. I (Cope, 123), Colosteus scutellatus.

Length of skull, as preserved............. 65

Width of skull..................... 40

Diameter of orbit...................... 6

I.ength of mandible.................. jo $^{\circ}$

Width of mandible, maximum............

Length of longest tooth................

Width of tooth at basc................ $\quad 1.5$

Skull Nus. $8602 G$ and 8609 G.

I.ength of skull, as preserved............ ${ }_{50}^{\mathrm{mm}} \quad$ Dianeter of orbit.................

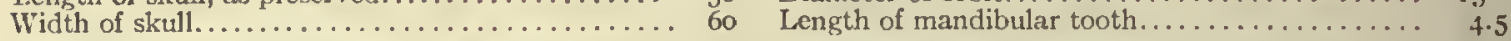

Other specimens associated with this species: Nos. $8668 \mathrm{G}, 8674 \mathrm{G}, 8554 \mathrm{G}$, 8661 G. All specimens in the American Museum and all from Linton, Ohio.

SCUTES OF SAUROPLEURA.

There are found associated with the remains of the genus Sauropleura a number of heavy scutes or scales. There are three of them on the same block as the specimen of $S$. longidentata and are provisionally referred to the genus. There are a number of scutes preserved separately, but they agree in their characters with those discovered on the specimens. The scutes arc elongate and usually acuminate at one end and having a broad base at the other. The acuminate end is slightly bent to one side so as to present the appearance of a hook. Others are shield-shaped and are quite large, while the majority of the hook-shaped ones are small. The shield-shaped elements have a rounded boss near the center of the plate and the edges are imbricated. Their nature and their proper location on the animal are a puzzle. They may not belong to the genus, but have been noticed with the remains of at least 3 species.

Measurenents (in Mili.imeters) of Scutes Associated with the Specimens of Sauropleura.

No. 4513 U. S. National Museum:

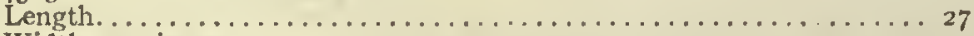

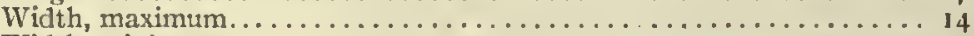

Width, minimum ........................ 3

Scutes associated with the specimen of Sauropleura longidentala:

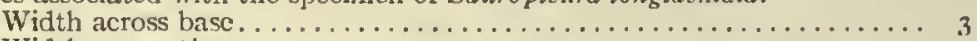

Additional specimens are: Nos. $3,8673 \mathrm{G}$ and $8470 \mathrm{G}$, American Museum of Natural History.

\section{Sauropleura longidentata Moodie.}

Moonie, Jour. Gcol., 17, No. 1, pp. 7ł-76, figs. 18, 19, 1909.

Type: Specimen No. 8619 G, American Museum of Natural History.

Horizon and locality: Linton, Ohio, Coal Measures.

This species may be distinguished from other members of the genus by the large size and shape of the cranium (462) and the broad mandible (plate 16 , figs. 2,3 ) 


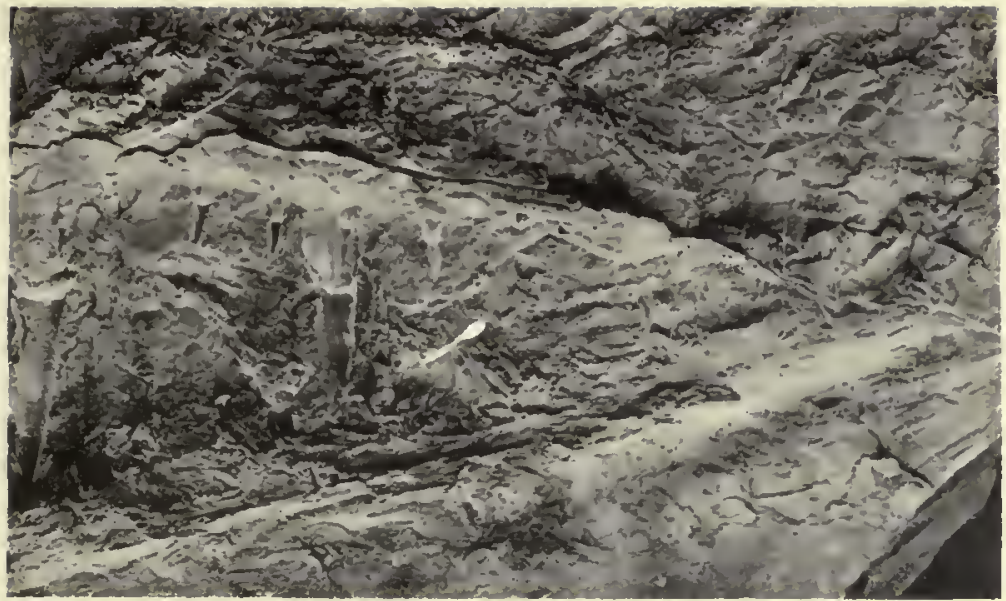

1
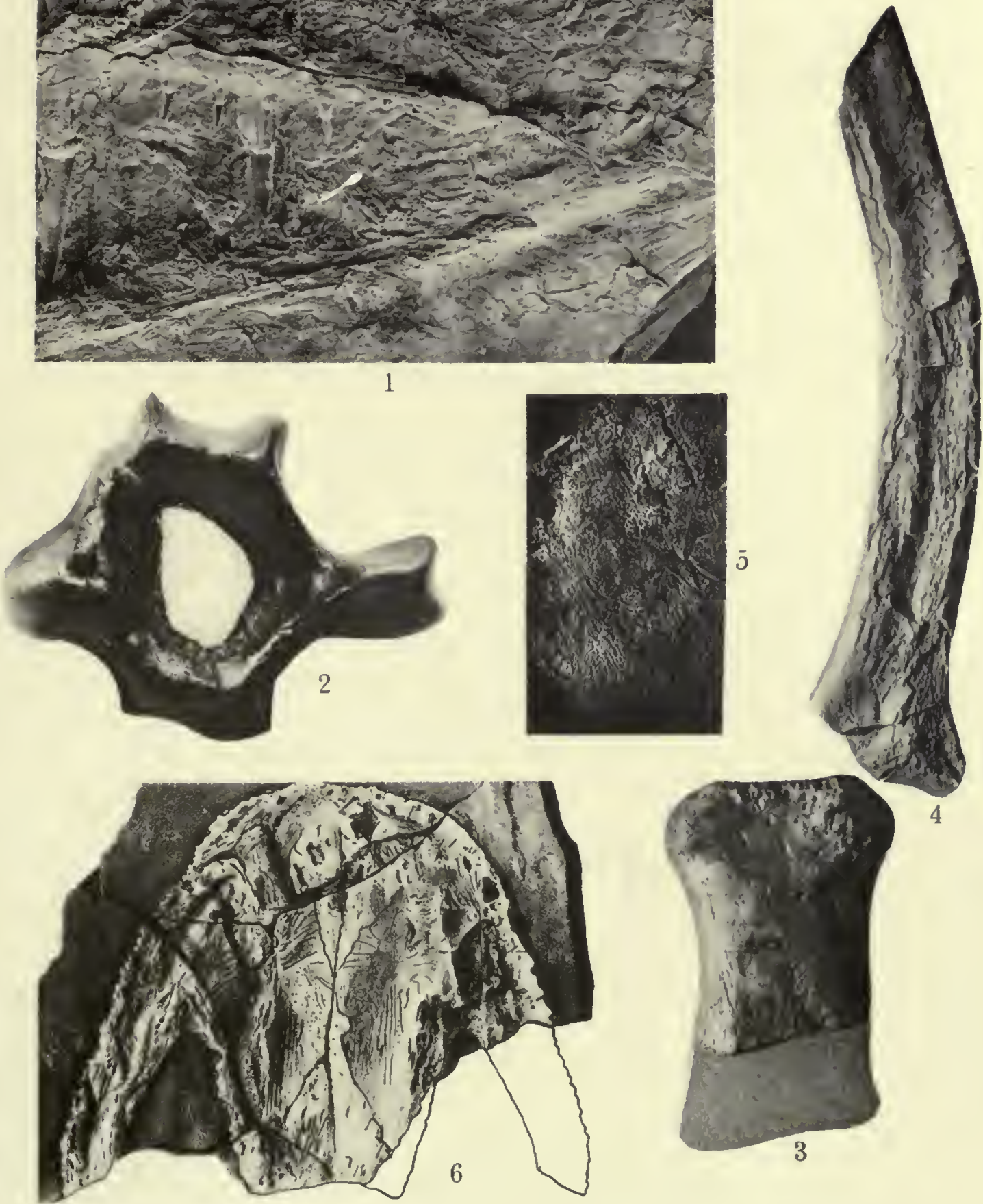

1. Type of Leptophractus lineolatus Cope, from the Coal Measures of Linton, Ohio. Portions of maxilla and mandible of left side with teeth. $\times 1$. Original in American Museum of Natural History.

2. Type of Proterpeton gurleyi Moodie, from the Coal Measures of Illinois, near Danville. Cervical of an otherwise unknown vertebrate. Neural spine to the right. Original in Walker Museum, University of Chicago $\times 2$.

3. Amphibian phalanx from the Coal Measures near Breeze, Illinois, of an unknown species. The probable form of the element is represented. $\times 3$.

4. Large rib of a stereospondylous stegocephalan otherwise unknown. The rib may represent a species of MFacrerpeton or may even belong with Macrerpeton deani Moodie, but exact identification will have to wait for future discoveries. From the Conl Neasures of Linton, Ohio. Original in U. S. National Museum. X I.

5. Type of Cope's species Tuditanus mordax referred by him to the cranium, on account of the sculpturing of the elements. We now know the specimen to be portions of the interclavicle and clavicles of Diceratosnurus punctotineatus, as Cope suggested they might be. Original in American Museum of Natural History. $\times 1$.

6. Skull of Baphetes planiceps Owen from the Coal Measures of Nova Scotia. 0.45. Original in the British II useum, South Kensington. After Owen. 

with its very long teeth. The skull of Sauropleura digitata Cope is not known, but the body of that animal as preserved represents far too small a form for the skull to be referred to that species. The skull is fully half as long as the dorsal region of $S$. digitata Cope, so that an association of the remains would be incongruous. It differs from the skull of $S$. scutellata Newberry in size and proportions. The skull of $S$. scutellata is narrow, while in S. longidentata it is quite broad. The teeth of the latter are also characteristic of the species, since in all other known species of this genus in which the skull is preserved the large anterior tooth is wanting.

The bones of the skull show the coarse sculpturing of the larger species of Microsauria. It consists more of radiating grooves than of pits. The skull, as restored (462), is broadly ovate, with the posterior border truncate. The muzzle is broad and the nostrils are, apparently, located near the anterior margin.

The posterior border of the orbits lies near the median transverse line of the skull. They are circular and are removed some distance from the margin of the cranium. Only the frontal and parietal can be determined with certainty.

The mandible is heavy and is provided with pleurodont, heterodont teeth. Near the anterior end of the mandible there is a very long fang-like tooth, longitudinally striated and slightly recurved, which arises from a broad base and attains to considerable prominence. The other teeth are smaller, though the next succeeding one is still of considerable size. All of the teeth preserved are longitudinally striated, but only the two anterior ones are recurved to any extent.

Measurements of the Type.

\begin{tabular}{|c|c|c|c|}
\hline & $\mathrm{mm}$. & & $\operatorname{mm}$. \\
\hline 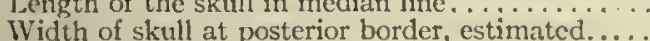 & $\begin{array}{l}75 \\
80\end{array}$ & Width of jaw, maximum.. & \\
\hline idth of skull across orbits. . . . . . . . . . . . . & 60 & length of largest tooth... & iv \\
\hline th of orbit............ & 10.6 & Width of longest tooth at base......... & 4. \\
\hline ngth of orbit. & 12 & Jength of shortest tooth. & 3 \\
\hline orbital space. & 16 & Width of shortest tooth at base.............. & 1 \\
\hline & 48 & & \\
\hline
\end{tabular}

\section{Sauropleura foveata Cope.}

Cope, Trans. Am. Phil. Soc., XIV, p. 24, 1869.

Cope, Geol. Surv. Ohio, I1, pt. II, p. 406, pl. xxxvi, fig. 1, 1875.

Type: Specimen No. 8676 G and obverse No. 8675 G, American Museum of Natural History.

Horizon and locality: Linton, Ohio, Coal Measures.

This species is represented by an interclavicle and its impression, which show a bcautiful sculpturing entirely distinct from that of the other species of this genus. In size it is intermediate between the largest of the interclavicles of S. scutellata and $S$. pauciraliata. The pattern of the sculpturing is, however, its main distinction. The plate is fincly pitted and there are few evidences of grooves. Near the posterior border of the plate the pits become somewhat defincd by ridges which take on a radiating pattern with the center of the plate as the center. The beveled margins are rugose, except at the edges.

Measuremexts of the Type Spechmen of Siuropleura foveata Cope.

Median length of interclavicle. 
Sauropleura enchodus Cope.

Cope, Proc. Am. Phil. Soc., p. 406, 1885 (Anisodexis).

Type: Specimen No. (5I) 2558, American Museum of Natural History, Newberry Collection.

Horizon and locality: Discovered by Sam Huston at the Linton, Ohio, Coal Measures.

An examination of the type specimen (plate 16, fig. 4) of this form resulted in no new facts. The reference of the species to the Permian genus Anisodexis by Cope is probably incorrect. Our knowledge of the two known species of this genus is not sufficient to separate them, but for the sake of convenience the Linton species is placed in the genus Sauropleura. It is located here principally on account of the form and structure of the teeth. Cope's original description is given below:

"The generic characters are apparent in the very unequally sized teeth with round section. The portion upon which the species is based is a part of the right ramus of the mandible, which is in the specimen viewed from the inner side. The jaw is obliquely and smoothly truncated from below, for the symphysis and surface of the bone is smooth. There is a very large tooth near the extremity of the dentary bone. Behind it is an interval equal to three times the diameter of its base, which is followed by a tooth of about onethird the length of the first tooth. Posterior to this one are two teeth of the same size as the second, all being separated from each other by about a tooth's diameter. These are followed by three subequal teeth of about two-thirds the length of the first tooth, and separated by about their own diameter from each other. They are all perfectly straight, very acute, and without the trace of a cutting-edge. The inflection-grooves extend to or a little beyond the middle of the length."

The present species is smaller than the type of Anisodexis imbrecarius from the Texas Permian, to which genus Cope originally referred the present species, and the apices of the teeth do not display the opposite cutting-edges seen in the Texas form.

Measuremexts of the Type Specimen.

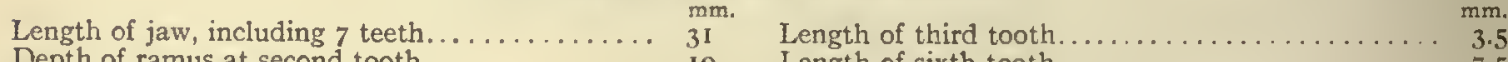

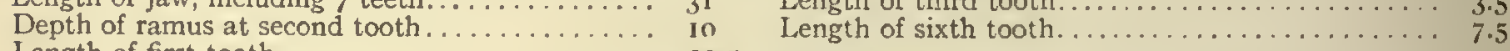

Length of first tooth................ 10.5

SK1N OF SAUROPLEURA SP.

Moonie, Bull. Am. Mus. Nat. Hist., xxv1, p. 355, pl. 1x, fig. I, 1909.

The present specimen is interesting on account of the presence of what I take to be a portion of the skin, which is preserved as a smooth mold over the ribs and ventral scutellæ. The skin was undoubtedly that of the back, since the creature is preserved on its belly, and is interesting in not showing the slightest trace of scales or other hard plates. The ventral scutellie are characteristic of the species of the genus Sauropleura. With one species of this genus, Sauropleura scutellata Newberry, the writer has found associated scutes of some size, and the same fact has been noted by Cope.

Genus SAURERPETON Moodie, 1909.

Moonis, Jour. Geol, xvi1, No. I, p. 80, fig. 23, 1909.

Type: Saurerpeton latithorax Cope.

This generic name is erected for the reception of a single species described by Cope in 1897 . The name is made necessary by the wide divergence of the characters exhibited by the present species from those of the species of the genus (Sauro- 
pleura) to which Cope ( 176 ) referred this species. The form is not a member of the genus Sauropleura, for reasons given below.

The species of the genus Sauropleura have a lanceolate head with homodont dentition or nearly so. The orbits are located well back in the skull. The form of the body is elongate and slender and the limbs where known are long and attenuated. The ventral scutellation consists of oat-shaped scutes arranged in a chevron series. The form here described as Saurerpeton latithora.x Cope has nearly the opposite of all of these characters, and it is incongruous to locate the form under the former genus. The skull of Saurerpeton latithorax Cope is broad and heavy. The teeth are heterodont. The body is broad and stout and the limbs are of unusually strong proportions. The character of the ventral armature is also of a very different type. In Saurerpeton it consists of very broad imbricating scutes which form a single piece across the abdomen and are angulated to form the chevron pattern which is so common among the Stegocephalia.

\section{Saurerpeton latithorax Cope.}

Cope, Proc. Am. Phil. Soc., xxxvi, p. 86, pl. iii, fig. 4 , I 897 .

Moodie, Jour. Geol., XVII, No. I, p. 80, fig. 23, 1909.

Type: Specimen No. 447I, U.S. National Museum.

Horizon and locality: Linton, Ohio, Coal Measures. Collected by R. D. Lacoe.

This species is indicated by remains of the anterior half of a large amphibian (plate 17) preserved on a block of bituminous coal from the Linton mine. The form is unusual in the proportions of the head and the width of the thoracic region. In these characters it stands alone among the Amphibia from this locality, where the forms are for the most part of rather slender build and tapering, pointed head.

The skull is represented in a fairly complete condition and shows the usual stegocephalian arrangement of the skull elements, as well as the sculpturing of the bones, which is similar to that found in other members of the Microsauria. The skull is broadly rounded, with the posterior border incised, the broad tympanic notches thus rendering the shape of the skull somewhat like that of the branchiosaurs. The orbits are broad ovals and lie well forward in the skull. They are separated by a space which is greater than the greatest diameter of the orbit. The pineal foramen lies well back and is clearly indicated as a circular opening which lies in the median suture in the posterior half of the parietals. The nostrils seem to be elongate and have an oblique position, as is represented in the diagram (fig. 35), but this character is not ascertained definitely.

The borders of the premaxillæ and the anterior suture of the nasal can not be determined, though they may have had some such arrangement as suggested. The nasal is represented, so far as is determinable, by an oblong element lying between the frontal and the anterior border of the skull. The frontals are very large and form a portion of the inner border of the orbit. The parietal is probably the largest bone in the cranium and together the two elements form a large quadrangular space in the posterior half of the skull. They inclose the circular pineal foramen. The postparietal is a small element lying on the posterior border of the skull and with the tabulare and a part of the supratemporal forms the projection. The prefrontal 
is probably a small element, especially if the lacrimal is present. There seems to be an indication of a suture separating the lacrimal from the prefrontal, but this character is not assured. The boundaries of the maxillæ are clear anteriorly. They indicate that this element was elongate, as is usual, and impressions of teeth borne on the mandible would indicate the probability that the teeth were heterodont. In the premaxillary region there is a long, strong tooth preserved, and on the maxillary near the posterior extremity of this bone there are impressions of teeth which are no more than one-fourth as large as the premaxillary one. The borders of the jugal can not be ascertained, since the skull is injured on both sides in this region. Likewise the quadratojugal is conjectural. The boundaries of the postfrontal and the postorbital are clearly ascertained. They together form the entire posterior border of the orbit and send prolongations along the lateral borders of these openings. They are both acuminate posteriorly and these points are inclosed by the tabulare and supratemporal for the postfrontal and by the squamosal and prosquamosal space for the postorbital. The boundaries of the tabulare show this element to be quite large and extending forward into an acumination which is inclosed by the parietal and

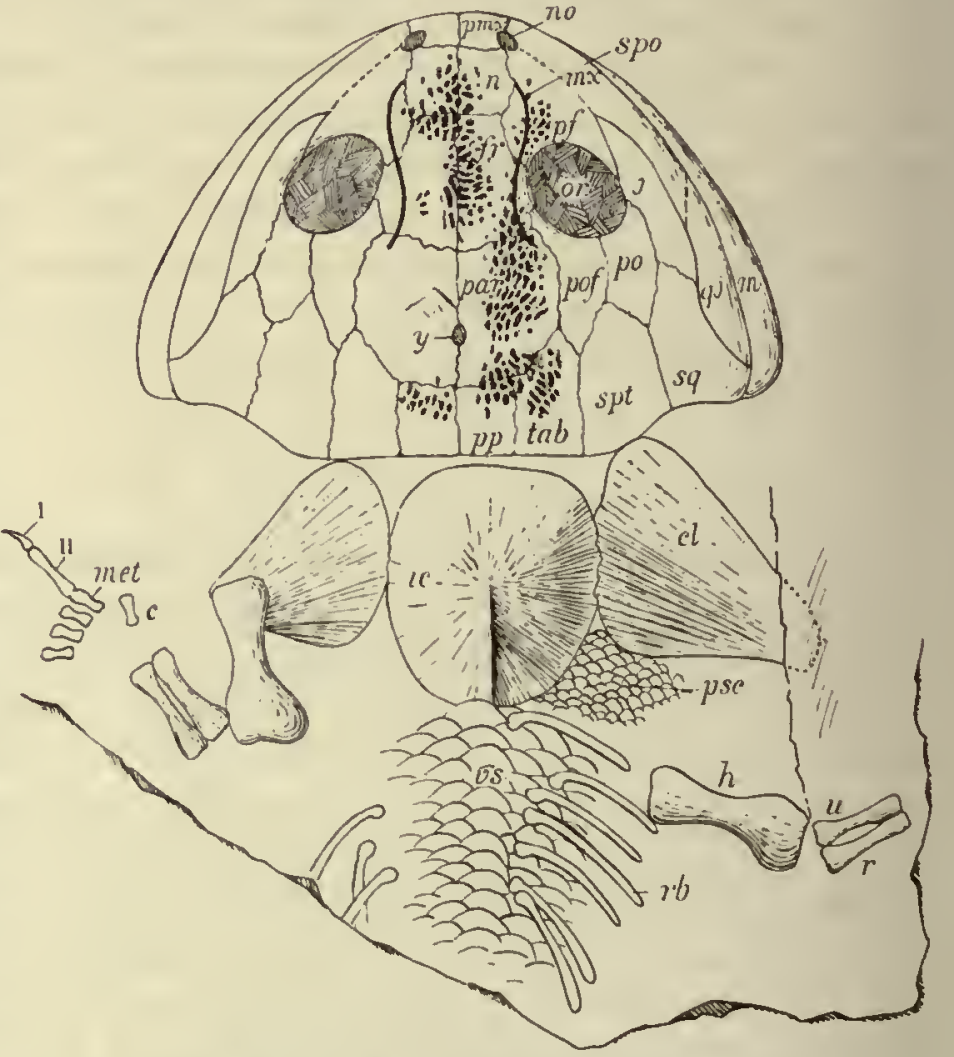

FIG. 35.-Outline drawing of the skull and skeleton, as preserved, of Saurer peton latithorax (Cope), from the Linton, Ohio, Coal Measures. Original in U. S. National Museum. $\times 0.75$.

Skull: $f r$, frontal; $j$, jugal; $m x$, maxilla; $n$, nasal; no, nostril; or, orbit; par, parietal; pof, postfrontal; po, postorbital; $p p$, postparietal; $p j$, prefrontal; $p m x$, premaxilla; $q j$, quadratojugal; $m$, mandible; $s p o$, supraorbital lateral-line canal; spt, supratemporal; $s q$, squamosal; $t a b$, tabulare; $y$, pineal foramen.

Skeleton: $c l$, clavicle: $c$, carpus; $r b$, ribs; $h$, humerus; $i c$, intcrclavicle; $m e t$, metacarpals; $p s c$, pectoral scutelli; $r$, radius; $v s$, ventral scutcllix; $u$, ulna. the postfrontal. The sutures bounding the squamosal have been obscured by injury in removing the specimen and are indeterminable.

The vertebral column is represented by a ridge showing along the median plane of the specimen. Its characters can not be ascertained. There are a few evidences of ribs. They represent long, slender, non-alate elements, their mode of articulation with the vertebræ being obscured by the plate-like ventral armature which covered the abdomen of the animal.

The pectoral girdle is represented by the remains of three elements which are interpreted as being the interclavicle and the two clavicles. The interclavicle is broad and is rounded posteriorly. There is no evidence of the usual acumination 
posteriorly. The element is nearly as wide as long. There is a prominent longitudinal keel on the ventral surface of the interclavicle and radiating lines which may indicate the courses of blood-vessels or nerves or may be the ornamentations of the element, probably the latter. The clavicle has the usual microsaurian form. It has three points and is truncate exteriorly. It is ornamented with radiating grooves of a shallow and not strongly pronounced character. There is no evidence of the coarse sculpture of the later forms. If the scapula is represented it is merely by an indeterminate fragment insufficient for description.

The pectoral limbs are preserved nearly entire. The left fore limb lacks only a few phalangeal bones, and these were preserved with the remainder of the skeleton but were lost in the mining process. The humerus is an extraordinary element on account of its robust dimensions. It is very stoutly built and represents a powerful limb. It is expanded at each extremity and the width of its shaft is about equal to one-fourth of its length. The ulna and radius present the same characters as the humerus, i.e., in being robust, with stout shaft and expanded ends. The ulna is slightly longer than the radius and has an expanded upper end. The radius is short and does not have the proximal expansion. The carpus was cartilaginous. Its position is represented by a blank space on the coal. There are 4 digits preserved and in all probability this was the entire number. The metacarpals are elongate and expanded at the extremities. The first and second digits are represented nearly complete. The first digit is extremely interesting in the possession of a claw-like terminal phalanx which much resembles that of some lizards. There are 3 phalanges in the first digit and 4 in the second. The phalangeal formula may have been $3-4-4$ ?

The ventral scutellation of this species is of an unusual character. It consists of broad, imbricated scutes which are in a single piece and which are arranged in the usual chevron pattern. The scutes were, apparently, broadest in the middle and tapered somewhat at the extremities. This character alone is sufficient for separating the genus from that of any other known form.

The genus finds its nearest allies in the forms of the species of the genus Sauropleura, in which Cope formerly located the present species. The skull of the form described as Tuditanus radiutus Cope is quite similar to the present form, both in the sculpturing and arrangement of the elements. The characters wherein the present form resembles the species of Sauropleura are the possession of broad pectoral plates and strong, digitate limbs. The general form of the body and skull is different in the two groups. It is slender in Sauropleura and decidedly stout, short, and heavy in Saurerpeton.

Measurements of tile Type.

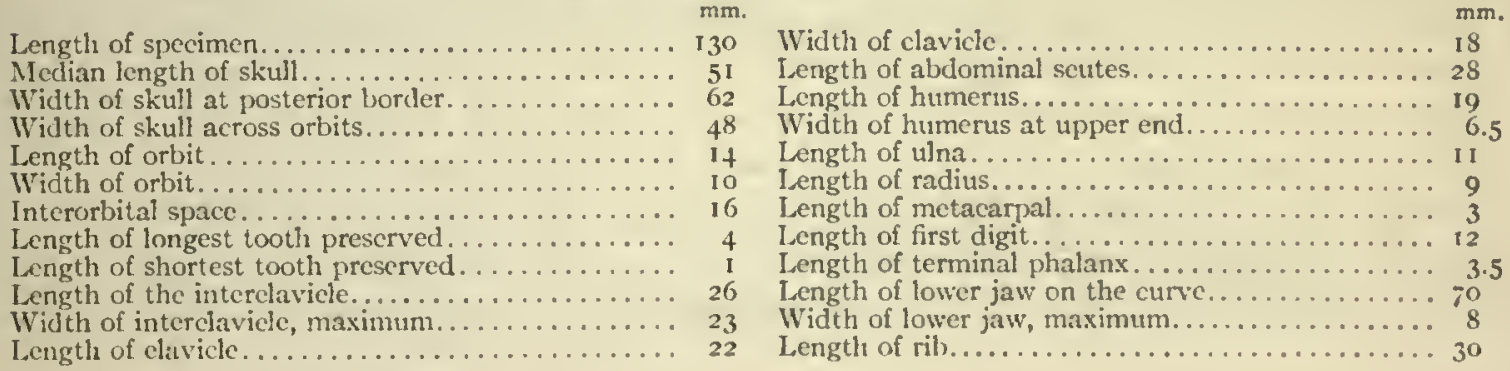


Genus CTENERPETON Cope, 1897.

Cope, Proc. Am. Phil. Soc., xxxvi, p. 83, pl. iii, fig. I, I 897.

\section{Type: Ctenerpeton alveolatum Cope.}

The genus Ctenerpeton was founded by Cope for the reception of a single species which presents some very unusual characters. The form shows close relationships to the genera Urocordylius (334), Estocephalus, and Ptyonius. These genera agree with the present one in the possession of very characteristic vertebrie which are signalized by the elongate and ornamented characters of the neural and hæmal spines. These project prominently from the body of the vertebra and have the ends of the projections truncate and divided into fine points, thus causing the spine to have much the appearance of a comb. The surface of the neural spine is sometimes marked with a shallow groove. The spines are longer and more slender in the genera CEstocephalus, Urocordylus, and Ctenerpeton than they are in the species of the genus Ptyonius, where they are short, although the usual pectinations are present.

The character on which this genus rests is the shelf-like extension (plate 23, fig. 2) of the abdominal plates. This is of a very unusual character and entirely unknown in any other species of Carboniferous Amphibia. The term Ctenerpeton has reference to the fact that the ends of these shelf-like plates project in a pectination along the side of the abdomen.

\section{Ctenerpeton alveolatum Cope.}

Cope, Proc. Am. Phil. Soc, xxxvi, p. 83, pl. iii, fig. $1,1897$.

Moodie, Proc. U. S. Nat. MIus., 37, p. 24, pl. 10, 1909.

Type: Specimen No. 4475, U. S. National Museum, Lacoe Collection.

Horizon and locality: Linton, Ohio, Coal Measures.

The species rests on a single specimen (plate 19) from Linton, Ohio, and is preserved on a block of bituminous coal. It is in a very good state of preservation. There are present on the block of coal a part of the right fore limb, the greater part of the dorsal portion of the animal, and the anterior part of the tail. There are no evidences of hind limbs, although this may not be taken as evidence that they were not present on the animal. No thoracic plates have been observed. The chevron armature is present beyond the cloacal region, but there are no evidences of the specialized clasping organs which are apparently developed from the abdominal armature in some forms (25I).

Each dermosseous rod of the abdominal scutellation consists of three piecesa median angulated portion and the two lateral parts which form the shelf-like projection along the side of the abdomen (plate 23, fig. 2). The marginal chevron differs in form from the other plate, aside from the fact that it is not angulated. The lateral shelf is composed of flattened plates which articulate with the median piece, and at the place of articulation there is a ridge present in the specimen. The exterior plates are curved backwards and are somewhat attenuated distally. They are broader than the median piece and differ also in the absence of the characteristic alveoli. The median plate is angulated and is of more slender proportions than the lateral pieces. Its ventral surface is ornamented with a single row of closely placed 

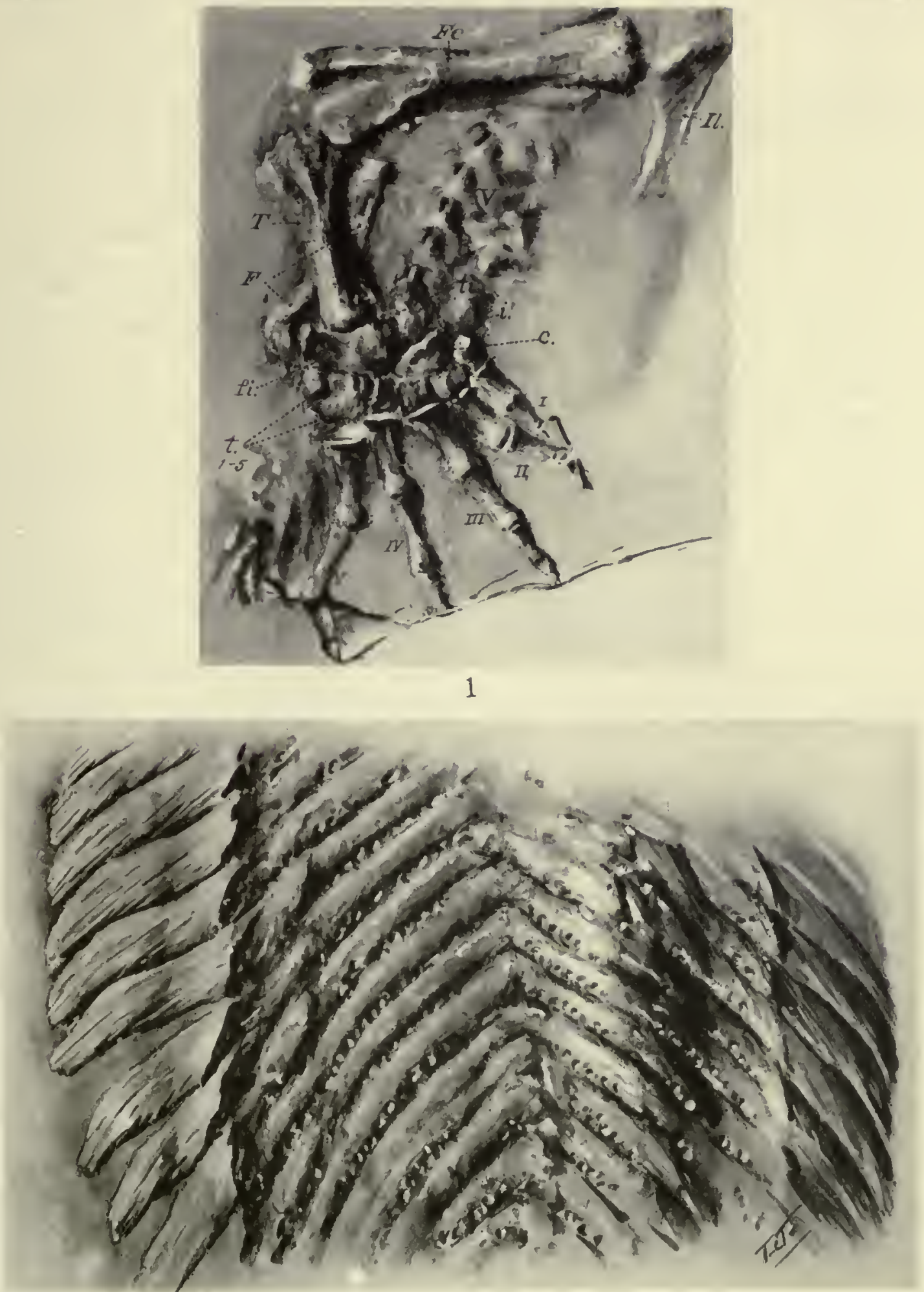

1. Left leg and pelvis of Ichlhycanthus platypus Cope, from the Coal Measures of Ohio. $\times$ 1.7. Original the property of the Department of (Geology of Columbia University. $c=$ centrale; $F=$ fibula; $f=$ fibulare: $F e=$ femur; $i=$ intermedium; $I l=$ ilium; $T=$ ibia; $t, 1-5=$ distal tarsalia; $t i=$ tibiale: $V=$ caudal vertebra; $I-V=$ digits.

2. Ventral scutellie of Clenerpelon alieolalum Cope, from the Coal Measures of Ohio. $\times 3.5$. Original in U. S. National Nuseum. 

alveoli which resemble in a great degree the alveoli of the jaw of some small animal. The ventral scutellation is broad anteriorly, but becomes more slender posteriorly and shortly posterior to the cloacal region disappears.

The fore limb is represented by the upper portions of the ulna and radius and 2 digits of the right hand. The digits are long and slender and seem to represent digits I and II, since they show evidences of 3 and 4 phalanges respectively. The portions of the fore arm preserved are too meager for description.

The vertebre have already been characterized as of the type first described in Urocordylus. 'The neural fans are not much, if any, wider than the hæmal fans. They are both situated on an elongate spine with a slender base. The edges of the two fans are pectinated and the dorsal spine is distinguished by the presence of a longitudinal groove in the center of the spine. The length of the tail may have been considerable, judging from the character of the vertebræ preserved

\begin{tabular}{|c|c|c|c|}
\hline \multicolumn{4}{|c|}{ MEASUREMENTS. } \\
\hline Length of specimen. & $\begin{array}{c}\mathrm{mm} . \\
150\end{array}$ & Width of the same vertebra with spines & $\begin{array}{c}\mathrm{mm} . \\
20\end{array}$ \\
\hline Width of belly, maximum. & 28 & Height of neural spine............ & 8 \\
\hline Length of lateral chevron plate.............. & 7 & Height of hæmal spine ............. & 8 \\
\hline Width of lateral chevron plate............. & 1.75 & Width at distal end of hremal spine............ & 3 \\
\hline Length from tip of lateral chevron to median & & Width at distal cnd of neural spine ............ & 3.5 \\
\hline 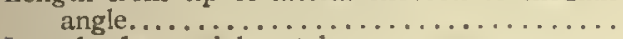 & 10 & Length of foot, as preserved......... & 12 \\
\hline ength of a caudal vertebra. . & Io & & \\
\hline
\end{tabular}

Genus LEPTOPHRACTUS Cope, 1873.

Cope, Proc. Phila. Acad. Nat. Sci., p. $340,1873$.

Cope, Geol. Surv. Ohio, II, pt. II, p. 399, 1875.

Cope, Proc. Am. Phil. Soc., Xx, p. $461,1882$.

Type: Leptophractus obsoletus Cope.

The genus was established on various parts of the cranium of a large amphibian. The only parts which can with certainty be referred to the genus are the upper and lower jaws of 3 specimens. These bear large teeth, round in section at the base, but with acute compressed apex, with a cutting-edge on the anterior face; the enamel is delicately grooved, as an external indication of the labyrinthic structure. A characteristic feature is seen in the presence of a large elongate tooth in the upper jaw, in the position of a canine which much exceeds in length any of the others. The sculpture of the cranium is but little marked in the known specimens. In the type the lower jaw is marked with inosculating grooves. Three species are known, which are among the largest of the Linton Amphibia.

Leptophractus obsoletus Cope.

Cope, Proc. Phila. Acad. Nat. Sci., p. 340, 1873.

CopE, Geol. Surv. Ohio, II, pt. II, p. 399, 1875.

Cope, Proc. Am. Phil. Soc., xx, p. 461, 1882.

Type: Specimen Nos. $55 \mathrm{G}$ and $57 \mathrm{G}$, American Museum of Natural History. Horizon and locality: Linton, Ohio, Coal Measures.

The species was about as large as an adult Florida alligator, and probably exceeded or at least equaled in size any of the Carboniferous Amphibia. The following account is taken direetly from Professor Cope's "Batrachia of the Ohio Coal Measures" (123). The description has been verified from an examination of the type material. 
"The teeth are rather distantly grooved for some distance above the base. They are of different sizes; the smaller are compressed, and with fore and aft cutting edges. The external surface of the dentary bone is marked with short oblique grooves along its middle region; above these are grooves which inosculate, forming a figure like an open net dragged in the long direction.

"Excepting the grooves the teeth are smooth. The smaller ones are close together and their crowns are curved backwards; the larger ones are at more remote intervals; both have enlarged bases. Whether both forms are in the same series I ean not determine. There are from four to five of the smaller to an inch.

Medsurements of Type of Leptophractus onsoletus Cope.

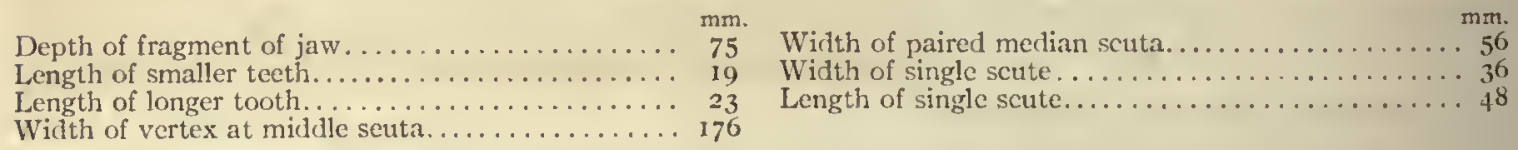

"Some vertebra were found at the same locality, but there is no evidence as to the species to which they may have pertained. They are short, concave on one end, and probably so on the other. The centrum of one is $12 \mathrm{~mm}$. in diameter ; neural spines injured." (Geol. Surv. Ohio, II, pt. II, pl. 39, fig. 3.)

"A third and larger specimen was found by Professor Newberry during the field season of 1874 . It includes an oblique view of one side, and the top of the cranium from the posterior part of the orbits to the end of the muzzle, with the corresponding part of the alveolar region of the dentary bone, with teeth. The bones of the skull appear to have been rather light, and though the surface is irregular, the sculpture consists only of shallow impressions of varying size and intervals. The orbits are also badly defined, but appear to have been large, and separated by a narrow frontal bone. The premaxillary bone is preserved, and shows clearly the sutures that separate it from its fellow and from the maxillary. A large foramen--perhaps the nostril-separates it from the maxillary, so that it forms an irregular crescent. It supports two teeth, of which the anterior is the larger, but there were perhaps others in advance, as the alveolar border is imperfect towards the end of the muzzle. The anterior two teeth of the maxillary bone are followed by a strong groove which rises towards the sides of the muzzle. At first sight this gives the impression of the maxillo-premaxillary suture, and makes it appear that both the premaxillary bones are preserved, and that the foramen above described separates the premaxillary spines, instead of representing the nostril. The cutting edges of the teeth of these bones have, however, one direction, whence they represent one side of the cranium only; were both sides represented, the directions of the tooth axes would be reversed.

"The premaxillary and maxillary teeth exhibit a cutting edge on the outer posterior margin of the distal half; the base of the crown is subround in section. The line-like grooves are distinet but not numerous, their intervals measuring $75 \mathrm{~mm}$. Beyond them the enamel is smooth. The second maxillary tooth is larger than the first, which is equal to the last premaxillary. The third and fourth maxillaries are equal to the second, but the fifth is larger and longer, exceeding all the others. The teeth of the dentary bone differ from those of the upper jaw in having the cutting edge of the crown on the anterior aspect, while the posterior border is obtuse. There is an obtuse cutting edge on the posterior margin of the anterior mandibular teeth.

"This description is derived from an adult animal, as the maxiilary teeth in some instances are partially worn away by friction on their anterior and outer faces."

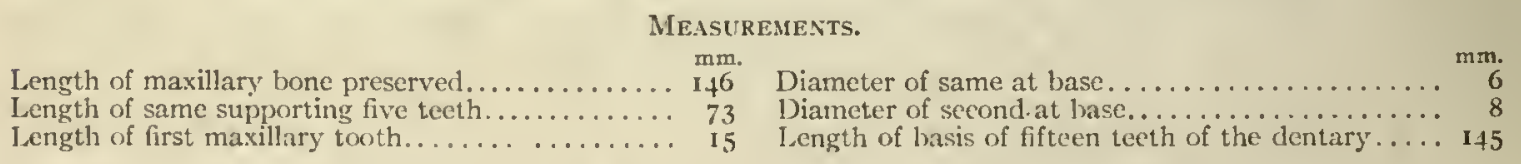


Leptophractus dentatus new species.

Type: Specimen No. 1085 G, American Museum of Natural History. Collected by Dr. J. S. Newberry.

Horizon and locality: Linton, Ohio, Coal Measures.

The type is a single right mandible, nearly entire, of a rather large animal. The specific characters for the separation of the new form from the previously described L. obsoletus and L. lineolatus are the smaller size and slenderness of the mandible, associated with uniform teeth, which are slender and delicately fluted.

There are $\mathbf{I} 7$ teeth preserved, the largest of which is $8 \mathrm{~mm}$. in length. From the posterior

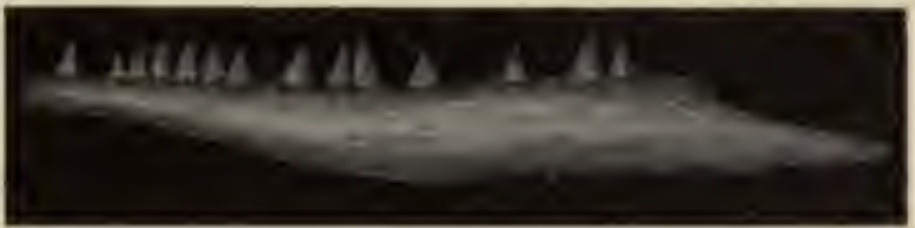

F1G. 36.-Mandible of Leptophractus dentatus new species, from the Linton, Ohio, Coal Measures. X $\mathbf{1}$. Original in American Museum of Natural History.

tooth the series gradually descends to half this length 0.5 inch from the anterior end of the mandible.

The exact form of the mandible can not be determined, but so far as can be seen it is very slender, coming almost to a point at the anterior end. The posterior portion is wide, but apparently not very heavy. There is a fragment associated with the specimen which discloses a few teeth, but its position in the cranium can not be determined.

Meisurenents of the Type of Leptophractus dextatus Moone.

Length of mandible, as preserved ......... $8{ }_{80}^{\mathrm{mm}}$

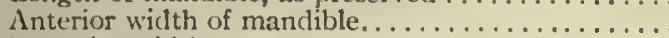

Posterior width. ....................... ${ }_{28}^{3}$

$\mathrm{mm}$.

Length of most anterior tooth.............. 4

Length of tenth posterior tooth............. 7

Width of this tooth at base............... 3

Leptophractus lineolatus Cope.

Cope, Proc. Am. Phil. Soc., xvi, p. 576, 1877.

Type: Specimen No. 1088 G, American Museum of Natural History.

Horizon and locality: Linton, Ohio, Coal Measures. (Plate 22, fig. I.)

Cope's description of this species, to which I have nothing to add, is as follows:

"This species is based on portions of the skull of two individuals of large size. Both upper and lower jaw with teeth are represented and the teeth are of very large size. The deepest element preserved has been provisionally referred to the mandible and will be so described. This element bears two types of teeth in very heterodont fashion. The teeth in the back portion of the jaw are rather short and slender. The teeth more anteriorly are, some of them, very long, rather stout, with their bases longitudinally fluted, as are they all. The longest tooth in the jaw measures slightly less than an inch. The bone is not well preserved, but seems to have been ornamented with grooves of no great depth. The most anterior teeth of the jaw are smaller than the posterior ones.

"The upper jaw is set with teeth which are more uniform in size and there is but little tendency to heterodonty. These teeth are also striated at their base and all end in a sharp point. They are all, apparently, straight. There is no tendeney to curve as there is in the genus Macrerpeton. The upper teeth are more elosely set than are those of the lower jaw, which are rather distantly placed.

"Another speeimen of a smaller individual presents the same portions of the skeleton and the same charaeters. It is possible that this skull will be found to belong to Ichthycanthus ohiensis Cope, which is based on very large vertebre and limb bones. The remains 
described as Leptophractus lineolatus are, however, unlike any other skull remains which are thus far known.

"This species represents one of the largest types of the Carboniferous Amphibia of Ohio. It probably attained a length of several feet. It was also the most carnivorous of any of the forms."

Measurements of the Type Specimen of Leptophractus lineolatus Cope.

$\mathrm{mm}$

Length of spccimen, as preserved ......... 98

Depth of dentary bone at the middle.......... 30

Anteroposterior diameter of mandibular tooth at

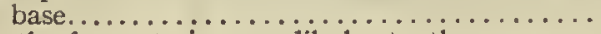

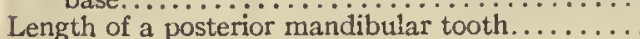

30

3.5 $\mathrm{mm}$.

Length of longest tooth in jaw............. 22

Anteroposterior diameter of the same at base....... 6

Length of small maxillary tooth............. 7

Anteroposterior diameter of same at base.......... ${ }_{2}$

Collected by Dr. J. S. Newberry. Other specimens of the species are Nos. I086 G and $1087 \mathrm{G}$, American Museum.

\section{Eurythorax sublævis Cope.*}

Cope, Proc. Am. Phil. Soc., p. 177, 1871.

Cope, Geol. Surv. Ohio, II, pt. 11, p. 401, pl. xl, fig. 4, 1875.

Type: Specimen No. 8605 G, American Museum of Natural History. Collection of Dr. J. S. Newberry.

Horizon and locality: Linton, Ohio, Coal Measures.

The genus and species were established on a single, large, almost perfect interclavicle of peculiar form. It may or may not be distinct, but it can not be associated definitely with any known genus, so that it will be designated as Cope described it. It exhibits on its outer or lateral borders broad, smooth surfaces for the contact of the overlapping margins of the lateral plates. The form is subround, with a large excavation from the posterior margin on each side. The narrowed portion left in the middle behind has a convex outline. Some delicate radiating grooves occur on the exposed surface, but they are very shallow.

Measurements of Type. Greatest interclavicle $\ldots \ldots \ldots \ldots \ldots \ldots \ldots \ldots \ldots \ldots \ldots .71 .5$

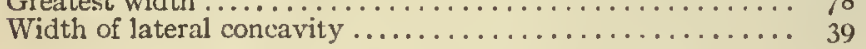

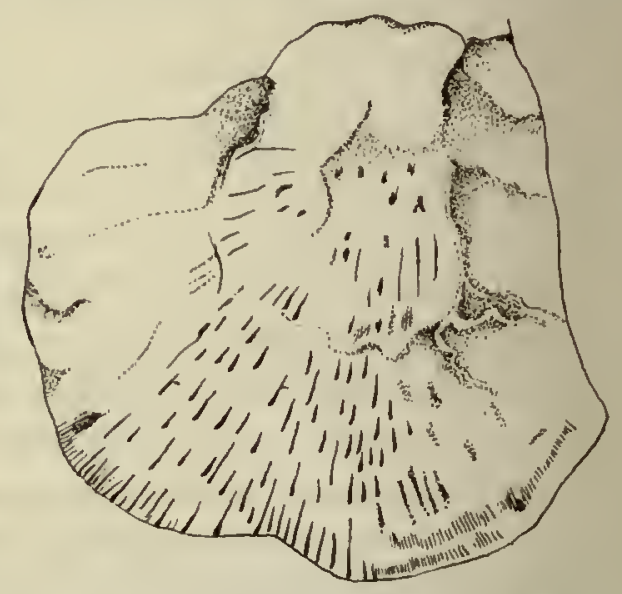

FIG. 37. - So-called interclavicle of Eurythorax sublcevis Cope. (Sagenodus.) $\times 0.75$. (After
Cope.)

* Dr. Hussakof now regards (Bull. Amer. Mus. Nat. Hist., vol. 35, p. 128, 1916) the type specimen of this species as an opercular element of one of the dipnoan fishes [Sagenodus sublcevis (Cope)]. The discussion is left here, however, as a matter of historical interest. 


\section{CHAPTER XXII.}

\section{THE MICROSAURIAN FAMILY ICHTHYCANTHIDA, FROM THE COAL MEASURES OF OHIO.}

\section{Family ICHTHYCANTHIDEE new family.}

This family is the most recently recognized group of the Linton fauna. Its members, of which there are two known species, are distinct from all other Coal Measures Amphibia in the possession of an osseous tarsus $(483,484)$, with its associated reptile-like limb bones. There are preserved fine scutellæ in a large patch near the vertebral column. The vertebral spines are broad and heavy, with the vertebral centra amphicœlous.

\section{Genus ICHTHYCANTHUS Cope, 1877.}

Cope, Proc. Am. Phil. Soc., p. 573, Feb. 3, I877 (Pal. Bull. 24).

BAUR, Beitrāge zur Morphogenic des Carpus und Tarsus der Vertebraten, I Theil, p. I6, I888.

CopE, Trans. Am. Phil. Soc., Xvi, p. 289, fig. I, I 888.

MoOdIE, Science, n. s., XLI, No. 1044, p. 34, I9I 5.

MoodiE, Am. Jour. Sci., XXXIX, pp. 509-5I2, fig. 2, May, 1915.

Type: Ichthycanthus ohiensis Cope.

The generic characters are derived from the characters presented by the posterior dorsal and caudal vertebræ, with adjacent parts. The posterior limbs are well developed, with distinct tibia and fibula, osseous tarsus, and 5 digits. Ribs elongate, simple, curved. Abdominal armature consisting of bristle-like rods in anteriorly directed chevrons. Dorsal vertebræ not elongate, with simple neural spines. Tail large, its vertebræ ossified, and furnished with slender chevron bones which terminate in a hæmal spine. Neural spines broad and directed backwards; the caudal series somewhat resembling that of a fish. All the centra are amphicœlous.

This genus differs from all those with enlarged and sculptured neural spines, and from those with abdominal scutes. It is equally distinct from those without ribs, abdominal rods, or limbs. It is possible that some of the species referred to Tuditamus, in which these parts are unknown, may belong to it, or that it may be established on a small species of Leptophractus, a genus known only as yet from the skull. With our present imperfect knowledge of the Linton forms it seems best to refer $I$. ohiensis and I. platypus to this distinct genus, Ichthycanthus.

Ichthycanthus ohiensis Cope.

Core, Proc. Am. Phil. Soc., 1877, p. 573 (Pal. Bull. 24).

Type: Specimen in the American Museum of Natural History.

Horizon and locality: Linton, Ohio, Coal Measures. Collected by Dr. J. S. Newberry, in the summer of 1876 .

The centra of the dorsal vertebræ are about as long as deep, and their sides are deeply concave; there are 4 anterior to the pelvis which are without ribs. The caudal vertebre are robust, and 7 , from the first, support a small tubercle-like diapophysis. The chevron bones are short and acuminate; the neural spines are a little shorter, narrow, and truncate, and dirceted backwards at the same angle as 
the chevron bones. They are much reduced on the eighteenth caudal vertebra, where the chevron bones are considerably longer.

The abdominal rods are quite slender. The hind limb is quite stout for this order. The femur is regularly expanded at both extremities, but the distal is deeply and openly grooved, distinguishing the condyles, while the proximal end is plane. There is no trochanter visible. The ulna and radius are well separated, and are three-fifths the length of the femur. There is a large fibular tarsal bone of a subquadrate outline. In immediate contact with it is probably the external digit with 5 phalanges or segments; the ungual is simply conic. The femur is as long as 5 dorsal vertebræ. The ribs have expanded, undivided heads, and extend to the abdominal armature.

Measurements of the TYPE of IChthycanthus ohiensis Cope.

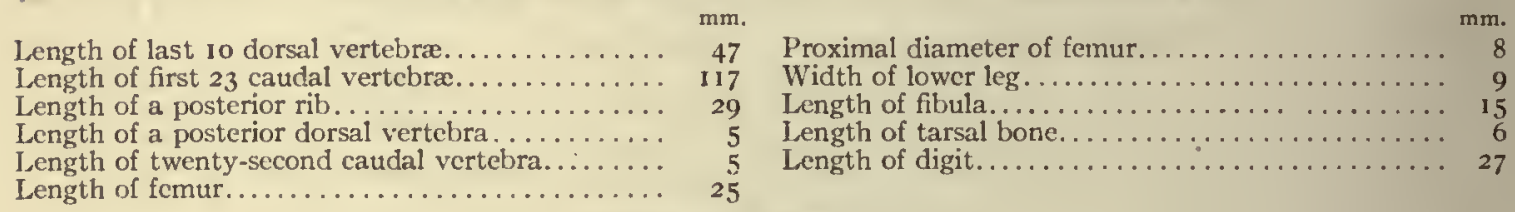

Ichthycanthus platypus Cope.

Cope, Proc. Am. Phil. Soc., pp. 574, 575, I 877.

Cope, Trans. Am. Phil. Soc., Xvi, p. 289 , fig. I, I 888.

BAu R, Beitrâge zur Morphogenie des Carpus und Tarsus der Vertebraten, I Theil, p. I6, I889.

MoODIE, Science, n.s., XLI, No. 1044, p. 34, 1915.

Moodie, Am. Jour. Sci., xxxix, pp. 509-5I 2 , fig. 2, 19 I 5.

Type: Specimen No. 7954 G, and obverse, Department of Geology, Columbia University. (Plate 23, fig. I.)

Horizon and locality: Linton, Ohio, Coal Measures.

This amphibian is represented by the same portions of the skeleton as the preceding species, furnishing a good basis for comparison. It is very well preserved, displaying the characters, especially of the hind foot, which is almost entirely represented.

Several features distinguish it from the $I$. ohiensis, one of which is of more than usual value if correctly indicated by the fossil. There are Io vertebræ from the anterior end to the sacrum preserved in place, and none of them supports a rib, nor are there any ribs visible anywhere on the block of shale. I suspect that they exist on more anterior vertebræ, or may have been displaced to a more anterior position than they normally occupy. The abdominal chevrons are more anterior in position than are those of the $I$. oliensis. The hind legs are longer than in that species; in this one the femur equals 7.5 vertebral centra in length. The external digit, on the other hand, while bearing 5 phalanges, is distinctly shorter. The fibular tarsal is of a transverse oval, not quadrate, form.

The dorsal centra are shorter and deeper than long; the neural arches are elevated, with short but distinct zygapophyses, and a flat, subquadrate, superiorly truncate, neural spine. They bear short, vertically compressed diapophyses near the base of the arches. The neural spines of the caudal vertebra become rapidly more slender, and also diminish in length, while the zygapophyses are continued to the fifteenth vertebra. The chevron bones are slender, and inclose a moderate hæmal opening.

The femur is gradually expanded to the extremities. Proximally there is a trochanteric ala, besides the obtuse head. Distally the condyles are well distinguished, 

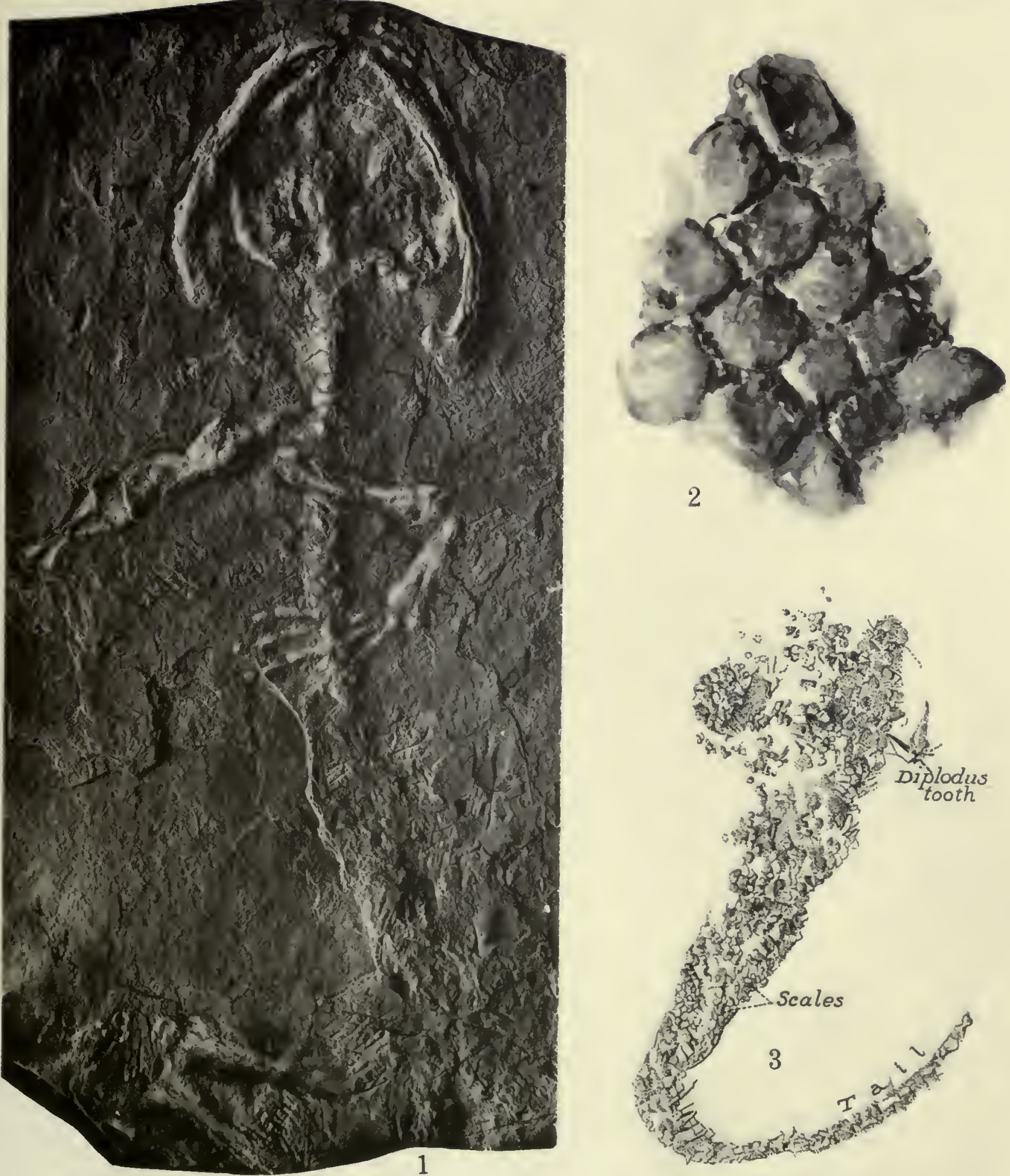

1. Photograph of the type specimen of Pelion Lyelli Wyman, from the Ohio Coal Measures. Supposed to represent the ancestral form of the Salientia. X2. Original in American Museum of Xatural History.

2. Scales of Cercariomorphus parvisguamis Cope, a microsaur from the Ohio Coal Measures. $\times 10$. Original in American Museum of Natural History.

3. Type specimen of Cercariomorphus parvisquamis Cope, from the Ohio Coal Measures. Original in American Museum of Natural History. $\times 0.75$. 

the external or fibular being truncate. The fibula is less than three-fifths the length of the fenur, and is expanded at both extremitics. Two proximal tarsals are distinct; the one next the fibula is larger than the other and transverse suboval in form. It has a median dividing ridge as though composed of fibulare and intermedium coössified. The tibiale is subtriangular. There are five distinct phalangeal tarsals. The toes are, in the order of their lengths, beginning with the shortest, 1-2-5-3-4. Their phalanges (including metatarsals) are, in the proper order, commencing with the hallux, $3-3-4-5$ ? -5 , the distal end of the fourth finger being lost. These bones are rather stout, and the unguals are simply conic. The form of the foot is short and wide. The number of the phalanges is nearly similar to that found in Amplibamus grandiceps, exccpting that in that species the fifth digit has but 4. They are more numerous on most of the digits in Sauropleura digitata. Cope (Trans. Am. Phil. Soc., xvi, 289, fig. I, I 888) contributed the following note on Ichthycanthus platypus:

"A reëxamination of the type specimen of this species from the Coal Measures of Ohio, preserved in the Muscum of Columbia College, New York, enables me to refer this species to the Rachitomi. The neural spines are distinct, showing that it belongs, probably, to the Eryopidx. As the skull is not preserved, I can not determine the genus positively, but refer it for the present to Eryops. I append a figure of the posterior foot, which displays the characters of the tarsus of this group for the first time. The number of tarsals is as in a Theromorph reptile, except that two elements represent the cuboid bone as in the reptile, Stereosternum tumidum Cope; giving five elements in the distal tarsal row. There is but one centrale and no intermedium. Two fragments of caudal vertebra adhere to the specimen."

Measurements of Ichthycanthus platypts Cope.

\begin{tabular}{|c|c|}
\hline 45 & ength of fibula. \\
\hline & ter of fibila proximially. \\
\hline 3.8 & Width of sole at second row of tarsal bones....... \\
\hline 14 & Length of foot to end of third digit............. \\
\hline 32 & Length of first digit. . \\
\hline 4. & Length of third digit. . \\
\hline & ength of fifth digit. \\
\hline
\end{tabular}

Length of 10 dorsal vertebre............. 45

Length of 15 caudal vertebra..

Length of centrum of a dorsal....

Total elevation of a posterior dorsal.............

Length of femur. .

Diameter of femur medially.

Diameter of femur distally

The writer has had the privilege of restudying this interesting specimen and has already (484) described the foot and tarsus, as follows:

The only known specimen of this anomalous amphibian is incomplete, representing the posterior half of the skeleton, and an abundance of ventral scutella or calcificd myocommata. The block of coal containing these interesting remains is from Linton, Ohio, and is preserved in the geological collections of Columbia University, from which institution Professor Grabau very courteously forwarded it for study.

Ichthycanthus platypus was described by Cope from the Linton, Ohio, Coal Measures, locating it doubtfully in the Permian genus Eryops on account of the unusual condition of the tarsus and reconsidering a former decision in favor of a Coal Measures genus Ichthycanthus. In this disposition of the species into the Permian genus he is followed by Hay (317); but Baur (28) regarded the form as a menber of the Coal Measures genus Ichthycanthus, after commenting on the later definition by Cope. The type of the genus, Ichthycanthus, to which Cope first allied the species under consideration, is I. ohiensis, a supposed amphibian from the Coal Measures of Linton, Ohio, founded on incomplete material. 
The form combines in an unusual and remarkable degree reptilian and amphibian characteristics. The leg bones, pelvis, and tarsus are all strikingly reptilian, but the phalanges in the arrangement of elements are so typically amphibian that if we had no other means of diagnosis we would incline to locate this Coal Measures species among the Amphibia. The leg (plate 23, fig. I) recalls in its structure that of another Coal Measures species, Eosanravus copei Williston, which is, however, clearly a reptile. While there is a general degree of similarity between the foot structure of Eosauravis copei and Ichthycanthus platypus, yet there are very great differences in the phalangeal formula and the arrangement of the tarsal elements. These differences are clear and indicate a separation of the two species into distinct classes. The phalangeal formula in the Eosauravus, 2-3-4-5-4, is typically reptilian; while in the Ichthycanthus, 2-2-3-3-3, it is amphibian. The tarsus of the Ichthycanthus is amphibian in the presence of an intermedium, but this is very small and the remaining tarsal structures have. nothing which might not be found in an early reptile. There may be a single or even two centralia in the reptilian tarsus among the early forms.

The amphibian nature of the species having thus been established, it remains to give a detailed account of its skeletal anatomy, with comparative references to such other ancient forms as are available. Little can be said of the vertebral column, since only the molds of a few vertebre remain, and these are so obscured by a closely adherent pellicle of carbonaceous material that their form can not be distinctly discerned. They are high, with relatively broad neural spines. There are no ribs preserved. The pelvis is obscured, but it is possible to determine the presence of an elongate ilium and an ischium. The leg of the left side is the best preserved of all the elements, and it is to this that our attention will be confined. The opposite leg is not so complete, yet all the long bones and a part of the tarsus are preserved with sufficient clearness to corroborate the findings of the left side.

The femur, as has been stated, is reptilian in appearance. This is due to the well-rounded articular surfaces, as though the endochondrium were well developed, and to the large development of the greater and lesser trochanters, which are quite prominent, though these are distorted and depressed in fossilization. The bone is stout and well built and its form suggests an active habit of life. The tibia and fibula are separate, and do not otherwise have sufficiently noteworthy characters to call for a special description in this place, except to note an unusual anterior crest on the tibia. To the lower ends of these bones articulate the first row of tarsal elements, the tibiale, intermedium, and fibulare. The tarsus is composed of 9 elements arranged in 3 rows. The proximal row is composed of the tibiale, the intermedium, and the fibulare. On the edge of the tibiale there lies a portion of one of the caudal vertebræ, so that the form of this tarsal element is slightly obscured. The intermedium is a small, rounded element lying between the larger elements. The fibulare is rectangular and projects a considerable distance out from the tibia, but articulates directly with the large lateral distal tarsal. The centrale is triangular in form and is opposed directly by the tibiale and tarsalia I to 3 . The phalanges are robust in appearance. The entire foot gives one the impression of a very broad structure. The ungual phalanges were apparently bluntly clawed. 


\section{CHAPTER XXIII.}

\section{SUPPOSED MICROSAURIAN SPECIES OF UNCERTAIN RELATIONSHIP.}

The following three species are so unusual and so incompletely known that they can not be considered with any of the above families: Brachydectes newberryi Cope, Linton, Ohio; Amblyodon problematicum Dawson, Nova Scotia; Proterpeton gurleyi Moodie, Danville, Illinois.

\section{Genus BRACHYDECTES Cope, 1868.}

Cope, Proc. Phila. Acad. Nat. Sci., I868, p. 214.

Cope, Trans. Am. Phil. Soc., I 868, p. I4.

Cope, Geol. Surv. Ohio, II, pt. II, p. 388, 1875, pl. xxvii, fig. 2.

Type: Brachydectes newberryi Cope.

Cope (Geol. Surv. Ohio, vol. II, pt. II, p. 388, I 875), says:

" This genus is indicated by two rami of a mandible and a portion of a premaxillary only. These, when compared with those of CEstocephalus and Tuditanus, from the same locality, and with others described by authors, are so much stouter, i.e., shorter and more elevated, that they evidently belong to a genus unlike either. The genus further differs from Estocephalus in having the teeth of equal size to the posterior part of the series; that is, to the base of the elevated coronoid process. The teeth are elongate cylindrical cones, with their acute tips turned a little posteriorly. The fractured ones display a large pulp cavity. The three premaxillaries preserved are similar, but without curvature at the tips. They do not exhibit striæ or any other sculpture.

"So far as the remains known go, the genus is nearer Hylerpeton than any other. According to Dawson, that genus is provided with a large canine-like tooth, at the anterior extremity of the maxillary, on the inner row, which is inserted into a distinct socket. No such tooth appears among those of this genus. The latter does not give any indication of the very elevated coronoid process of Brachydectes, though the external portion of the dentary bone in that region being lost, little can be said about it."

\section{Brachydectes newberryi Cope.}

Cope, Proc. Phila. Acad. Nat. Sci., p. 214 , I 868.

COPE, Trans. Am. Phil. Soc., I 868, p. I4.

Cope, Geol. Surv. Ohio, II, pt. Ir, p. 388 , pl. xxvii, fig. 2, 1875 .

Type: Specimen No. 8604 G, American Museum of Natural History.

Horizon and locality: Linton Ohio, Coal Measures.

Cope (Geol. Surv. Ohio, vol. II, pt II, p. 388, I875) says of this form:

"The species is represented by one nearly perfect ramus mandibuli, one dentary bone and one premaxillary, probably not complete.

"The dentary bone appears to have been attached by suture to the articular and angular, as its free margin has very much of the outline of that suture in Amphiuma and lizards. The coronoid process would also seem to be a part of the same bone as in Amphiuma and Menopcma, and not composed of the coronoid bone as in lizards. It rises immediately behind the last tooth, and displays no suture. 
"The lower portion of the dentary is prolonged into an acute angle. This is separated by a deep and wide concavity from the superior posterior prolongation, which is obtuse, and rises at once into the coronoid process. Teeth on this dentary, seven; the same number is on the preserved ramus; this number is suspected to be complete, or nearly so. The teeth terminate at the obvious termination of each ramus, which is, it is true, slightly obscured. These teeth are the longest in the Microsauria in relation to the depth of the ramus, equaling the largest in Estocephalus. They are doubtless exposed, as are some of those of the last-named genus, by the splitting away of the outer parapet of the dentary bone. As no traces of alveoli have been thus rendered visible I suspect the dentition to have been acrodont, as in some existing Batrachia.

"No external surface of the mandible remains, but there are no impressions of sculpture on the matrix. A little external face of the premaxillary displays none.

" The species is dedicated to Professor John S. Newberry, the able director of the Geological Survey of Ohio, and discoverer of most of the Batrachia herein described."

Measurements of the Type.

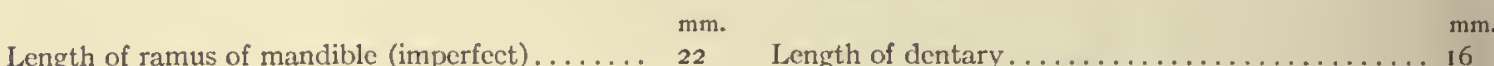

Depth of last tooth

Depth at last tooth..................... 5

Length of exposed tooth................... 3.5

Depth at coronoid process.................. 7.5

Depth at first tooth......................... 3

\section{Genus PROTERPETON new genus.}

Type: Proterpeton gurleyi Moodie.

Known from a single vertebra. Spine very high and heavy, the neural canal large.

Proterpeton gurleyi new species.

Type: Specimen No. 13,296, Walker Museum, University of Chicago.

Horizon and locality: Coal Measures near Danville, Illinois.

The vertebra, as preserved, is well characterized by the figure (plate 22, fig. 2). The spine is high and heavy, the neural canal is large, and the centrum reduced. The form is very unusual. It is apparently from the cervical region, as there are no indications of zygapophyses, transverse processes, or hæmal arches, although they may have been abraded; apparently not, however. The type specimen was discovered near Danville, Illinois, about the horizon of the Danville coal, so that it is quite high in the Allegheny series of the Pennsylvanian and of about the same horizon as the phalangeal bone from Breeze, Illinois, which may be provisionally associated with this form. There is no assurance that Proterpeton gurlcyi is an amphibian. The vertebra may have belonged to a fish.

Mieasurements of the Type of Proterpeton gurleyi Moode.

Entire height of vertebra............... ${ }_{24}^{\mathrm{mm}}$

Width at side of neural canal. . . . . . . . . . .

Width of neural canal. .
He $\mathrm{mm}$

Height of neural canal (erushed ?).......... 6.5

Width of vertebral centrum anteroposteriorly..... 5.5 Height of neural spine from top of sicural canal ... 9

\section{Genus AMBLYODON Dawson, 1882.}

Dawson, Phil. Trans. Roy. Soe. London, pt. II, p. 644, pl. 40, figs. 57-61, 1882.

Type: Amblyodon problematicum Dawson.

This genus was described by Dawson in $\mathrm{I} 882$ from very imperfect remains. He says that it is "characterized by stout cylindrical teeth, blunt at the apices; but otherwise imperfectly known." 
Amblyodon problematicum Dawson.

Dawson, Phil. Trans. Roy. Soc. London, pt. II, p. 644, pl. 40, figs. 57 to $6 \mathrm{r}, 1882$.

Type: Specimen No. 306I-Io, Peter Redpath Museum, McGill University.

Horizon and locality: Coal Measures of Nova Scotia.

A fragment of a jaw $I \mathrm{~cm}$. in length has Io cylindrical teeth, simple and smooth, with large pulp cavities and rounded regularly at the apices. With these are 4 vertebræ of the usual type, measuring together $\mathrm{I} \mathrm{cm}$. Fragments of cranial bones also occur and are obscurely pitted. There is also what seems to be the shaft of a limb bone and a few oval scales. A flat and somewhat rhombic bone, with a style at one side, may possibly be a thoracic plate or possibly a parasphenoid.

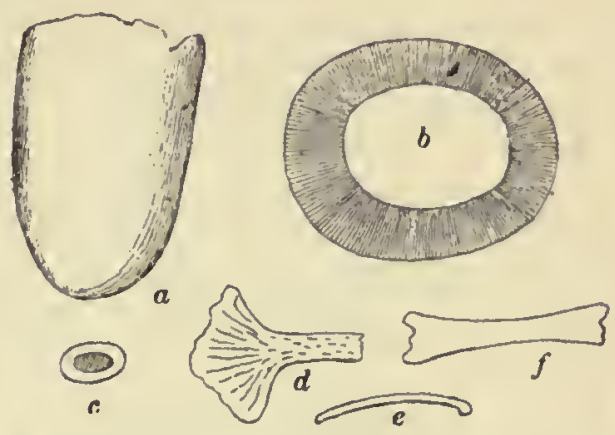

FIG. 38.-Skeletal elements of A mblyodon sp. from the Coal Measures of Nova Scotia. $a$, tooth, $\times 25 ; b$, section of tooth, $\times 25$; $d$, fragment of thoracic plate; $f$, shaft of limb bone; $e$, rib.

The material is too scanty for any satisfactory description of this animal, but it is provisionally named Amblyodon problematicum. 


\section{CHAPTER XXIV.}

\section{THE TEMNOSPONDYLOUS AMPHIBIA OF THE COAL MEASURES OF NORTH AMERICA.}

\section{DEFINITION OF THE ORDER TEMNOSPONDYLIA, ZITTEL, 1887.}

Zitre:, Handbuch der Paleontologie, Abth. I, Bd. 3, p. 384, I 887.

Terrestrial or semi-aquatic vertebrata; skull bones pitted and grooved; lateralline canals present in well-developed form; pineal foramen sometimes absent; sclerotic plates present; vertebræ rachitomous or embolomerous; notochord partly persistent; one or two sacral vertebræ; tail present, long or short; limbs and girdles well developed; limb bones well ossified and bones of arm and leg separate; pectoral and pelvic girdles composed of the usual stegocephalian elements; an osseous pubis present; a clcithrum present on the scapula; carpus and tarsus ossified, carpals i I and tarsals I 2 in one form; phalangeal formula, 2, 3, 3, 4, 2 for the hand and 2, 3, 3, 3, 2 for the foot; fore and hind limbs pentadactyl in a few forms; venter covered with an armature of osseous scutes, sometimes overlapping; skin of back bare or armored with heavy plates; rihs heavy, doubleheaded, curved and moderately long, or short; body short and heavy, as compared to skull about 2 to $\mathrm{I}$.

Range: Coal Measures to upper Permian.

Distribution: North America: Illinois, Kansas, Oklahoma, Texas, and Pennsylvania; Europe: Germany, Bohemia; France; Asia: India.

\section{Family CRICOTIDE Cope, I884.}

Cope, Am. Nat., XviII, p. 38, 1884 .

General form of the body elongate, with triangular skull and short, stout limbs. Snout narrow, orbits large, elongated oval, situated near the middle of the skull. External bones faintly sculptured, sensory canals conspicuous, parietal foramen large. Teeth conical, of unequal size. Presacral rertebræ composed of horseshoe-shaped pleurocentra and hypocentra, the former alone supporting the neural arch. In the caudals the pleurocentra and hypocentra form complete rings, and both elements take part in the support of the neural arch, but the hamal arch is borne exclusively by the hypocentra. A close ahdominal armor of imbricate scales, arranged in a chevron pattern. Caudal vertebra numerous. Chevrons coössified with the intercentra.

\section{Genus SPONDYLERPETON Moodie.}

Mloodie, Kans. Univ. Sei. Bull., vi, No. 2, p. 355, 1912.

Type: Spondylerpeton spinatum Moodie.

The genus is based on a specimen consisting of 9 imperfect vertebræ, from the caudal region of a relatively large amphibian. The present genus exceeds Diplospondylus from the Gaskohle of Bohemia (25r) by twice its size and is about twothirds the size of Cricotus heteroclitus Cope (98) from the Permian of Kansas. The vertebræ are twice as high as wide, differing thus from Cricotus, in which the vertebra are nearly circular. A character which is of great importance is the large size of the intercentrum, which almost equals the pleurocentrum in size. It is similar to the pleurocentrum in shape, except for the attached netrocentrum and chevron on the latter. The present genus differs from Diplospondylus in the greater length of 
the intercentrum and pleurocentrum, in the greater size, in the larger proportions of the neurocentrum, and the greater proportionate size of the intercentra.

\section{Spondylerpeton spinatum Mondie.}

Moodie, Kans. Univ. Sci. Bull., vi, No. 2, pp. 355-357, pl. 8, fiys. I and 2; pl. 9, fig. I, 1912.

Type: Specimen No. 793 (26) and obverse, Yale University Museum.

Horizon and locality: Mazon Creek, near Morris, Illinois.

The species is very imperfectly known. Sufficient is present, however, to show its wide generic differences from other forms of the Cricotidæ. These characters are of a phylogenetic nature and indicate the more primitive nature of the present form, as we would expect from its geological position. The sutures separating the four vertebral elements are clearly apparent. The pleurocentral-neurocentral suture is apparent in 4 vertebræ.

There is but a single pleurocentrum preserved complete. This shows the form of the attached neurocentrum and chevron, which corresponds to the hypocentrum pleurale according to Fritsch. The pleurocentrum is flattened laterally, with a rather large canal for the notochord. Its sides are marked with 4 longitudinal grooves. Surfaces for the attachment of the ribs are not present, and for this reason, as well as the presence of chevrons, the vertebræ are supposed to be caudals. As such they represent an animal of some 3 or 4 feet in length. It was the giant of the Mazon Creek Amphibia. (Plate 4, figs. I, 2.)

Attached to the upper side of the pleurocentrum by a sutural union occurs

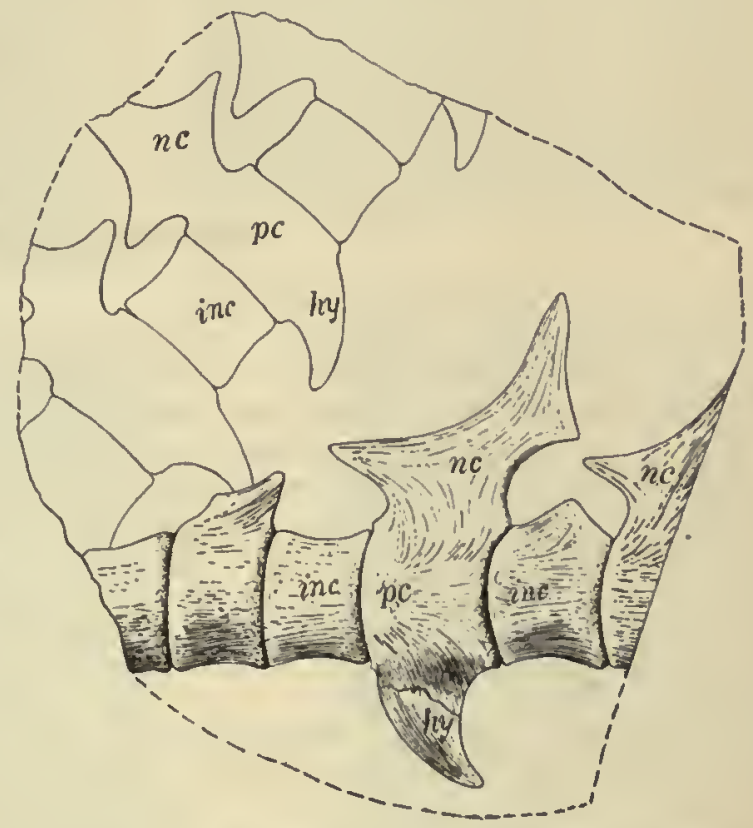

Fig. 39.-The vertebræ of Spandylerpeton spinatum Moodie, the only known temnospondyle from the Mazon Creek shales. $X$ 1. hy, hypocentrum; inc, intercentrum; $p c$, pleurocentrum; $n c$, neurocentrum.

the neurocentrum. The neural arch is quite large and is oval in outline, although somewhat constricted at the tip. The spine of the neurocentrum is rather long and broad at the base, measuring $12 \mathrm{~mm}$. across the anterior zygapophysis. The neurocentrum is laterally flattened and ends in a rather acute and somewhat rugose point. It was probably tipped with cartilage. The anterior zygapophysis occurs well down on the neurocentrum, its lower edge being $5 \mathrm{~mm}$. from the suture separating the pleurocentrum and the neurocentrum. The posterior zygapophysis occurs quite high up on the neurocentrum and lies at a distance of $15 \mathrm{~mm}$. from the pleuroneurocentral suture, thus indicating an extreme posterior inclination of the neural spine: The posterior zygapophysis of the best preserved vertebra is separated from its mate, the anterior zygapophysis, in the next succeeding vertebra by a space of $5 \mathrm{~mm}$. 
The ventral surface of the pleurocentrum bears a structure, which is, without doubt, a chevron, although the character of its opening can not be determined. It is elongated and is united by a broad base to the pleurocentrum. Its union is by a clearly defined suture, which is apparent in 3 vertebræ. The condition represented by the specimen duplicates almost exactly the condition figured by Cope for the caudal region of Cricotus Cope.*

The intercentrum of the present form is fully as large as the pleurocentrum. The significance of this has already been mentioned. The body of the centrum is pierced by a large notochordal canal.

Measurements of the Type of Sponnylerpeton spinatum Moodie.

Length of specimen................ 6

Length of pleurocentrum..................

Height of pleurocentrum to base of neurocentrum. 20

Length of neurocentrum.............. 3.3

Width of neurocentrum at base........... 9

Width across anterior zygapophysis.......... I

Width across posterior zygapophysis........... I0

Length of intercentrum............... Io

$\mathrm{mm}$.

Height of intercentrum............... 10.5

Height of chevron......................

Length of chevron................ 18

Width of notochordal opening in centrum...... 5

Height of same.................... 4.5

Height of neural canal............... 12

Family ERYOPID E Cope, I882.

CoPE, Am. Nat., xvi, p. 334, 1882.

Large, terrestrial or amphibious vertebrata; skull bones deeply marked with pits and grooves which take the form of lateral-line canals; infra- and supraorbital canals, antorbital commissure, jugal canal, and occipital cross-commissure of the lateral-line system present in Eryops megacephalus Cope; carpus and tarsus osscous; pubis an osseous plate, surrounded in life by a large amount of cartilage; fore and hind limbs pentadactyl; orbits, in the typical genus, located far back on the skull and near the median line; cleithrum present on the scapula; vertebræ rachitomous, the intercentrum supporting the arch in the dorsal region; parasphenoid well-developed or reduced; teeth on pterygoids, palatines, prevomers, and parasphenoid.

Range: Upper Pennsylvanian to Permian.

Distribution: America, Europe, Asia.

\section{Genus ERYOPS Cope, 1877.}

Type: Eryops megacephalus Cope.

Skull long, comparatively narrow; proportion of length to breadth about 9 to 7. Roof bones coarsely sculptured posteriorly, finely sculptured anteriorly. Nasals and premaxilla very large; frontals excluded from the orbits by junction of pre- and post-frontals. Pterygoids not mecting in the median line; parasphenoid dagger-shaped, tapering gradually to a point just in front of the palatine foramen; prevomers large. Orbits subcircular, situated in the posterior half of the skull; nares subovate, remote, at a considerable distance from the tip of the skull. Many minute denticles, on pterygoids, palatines, prevomers, and parasphenoid. Teeth circular in cross-section, strongly ribbed near the base, dentine strongly infolded. 'Three large teeth on each palatine. Mandible without postcotyloid process. Vertebræ rachitomous. Ribs double-headed. Pubis osseous. Three species (Permian), E. megacephalus, E. latus, and E. willistoni, are assigned to the genus.

Eryops is represented in the Carboniferous deposits of North America by incomplete vertebral remains described by Case (94) from near Pittsburgh, Pennsylvania. 

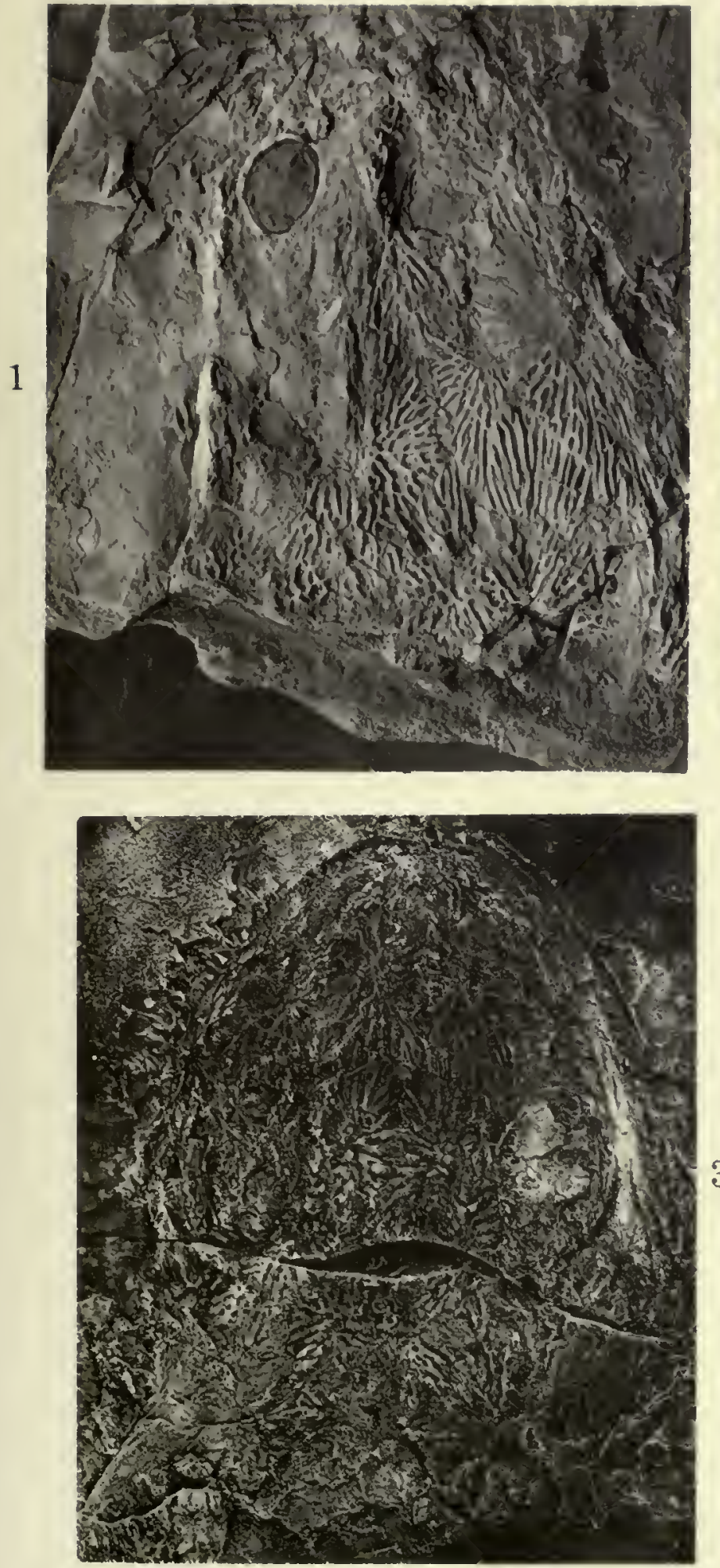
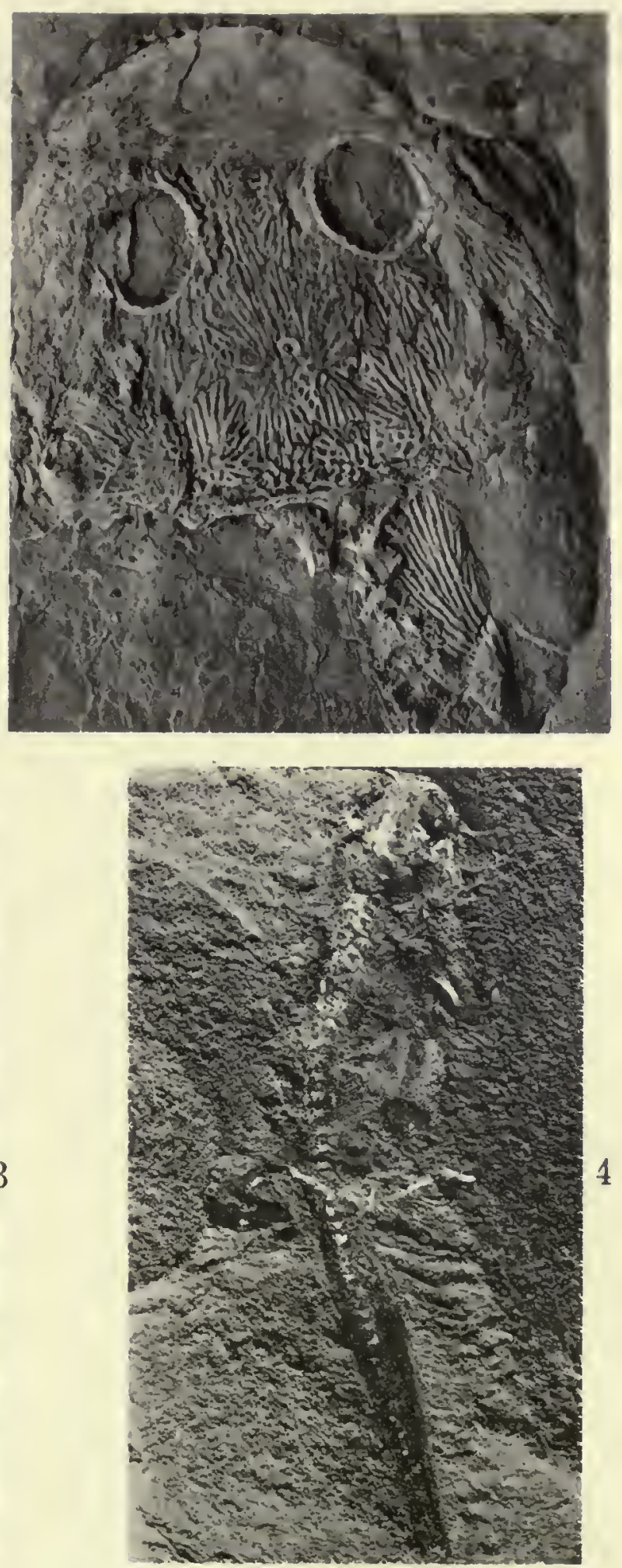

1. I'hotograph of type specinen of Erpefosumrus (Tuditanus) radialus Cope, from the Coal Measures of Linton, Ohio. $\times 1.3$. Original in American Museum of Natural History.

2. Photograph of type specimen of Erpetosaurus tabulatus Cope, from the Coal Measures of Linton, Ohio. $\times 2$. Original in the Zoological Collections of Columbia University.

3. Photograph of the impression of Stegops divaricala Cope, from the Coal Measures of Linton, Ohio. $\times 2$. The specimen figured is in the American Museun of Natural History. Its obverse is in the collections at Walker Museum, Cniversity of Chicago.

4. Type and only known specimen of Nicreppeton caudutum Moodie, a branchiosaur from the Coal Measures shales of Mazon Creek, Illinois. X 2. Original in collections at Walker Museum, University of Chicago. 

Eryops sp. indet. Case, 1908.

CASE, Annals Carnegie Mus., Iv, p. 234, pl. 59, 1908.

A dorsal vertebra is very probably from this genus. The specimen consists of a nearly perfect vertebra, lacking only the anterior zygapophysis and the upper portion of the neural spine (plate 18 , fig. 2). It shows no character that would warrant its separation from the genus, and indicates a medium-sized individual. The zygapophyses have clean-cut articular faces. The pleurocentra are thickened above, with just well-defined articular faces, which were applied to faces on the neural arch posterior to the origin of the transverse process. The intercentrum is of the familiar halfmoon-shape, thick and heavy below, and thinner toward the extremities; the anterior edge is marked near the top by the indentation found on the intercentra of Eryops.

Height of the vertebra from the middle of the lower face of the intercentrum to the middle of the neural canal, $0.035 \mathrm{~m}$.; width of intercentrum $0.026 \mathrm{~m}$.

The second recognizable specimen is a neural spine from the caudal series. This is without question a portion of the skeleton of an Eryops. Similar spines were described by Cope as Eryops (Epicordylus) erythrolithicus, but later discoveries seem to show that similar characters occur in other species of the genus as well. The apex of the spine is bifurcate; the space between extremities is concave and perfectly smooth; below the sides of the spine are rather rugose and marked with ridges. The lower portion of the spine is elongated anteroposteriorly and the edges are marked with sharp, double ridges.

Three ribs also belong, in all probability, to the genus Eryops. The head of each rib is broad and the articular edge is divided between two faces which meet at an angle somewhat greater than a right angle; the two faces are continuous. The shaft is somewhat flattened and in the undistorted specimens is gently curved. The length of the largest rib is about $0.07 \mathrm{~m}$.

Other than these specimens there are several small intercentra (94) and the neural spine of a caudal vertebra from some undetermined amphibian.

\section{Family MACRERPETID $Æ$ Moodie, I909.}

MOOdIE, Bull. Am. Mus. Nat. Iist., xxvı, art. xxv, p. 354, pl. lix, fig. I, 1909.

It has seemed necessary to propose a new family for the reception of the single species Macrerpeton (Tuditanus) huxleyi Cope. The characters exhibited by this species are so different from those offered by other members of the Carboniferous Microsauria that it is clearly distinct. In its cranial characters and the position of the orbits it approaches most nearly to Eryops megacephalus Cope from the Permian of Texas. In some of its characters the present form shows a similarity to Dasyceps bucklandi Lloyd (324), from the Permian of Kenilworth, England; more especially is this similarity found in the form of the skull, the size and shape of the teeth, and the posterior position of the orbits, and their wide removal from the border of the skull. Only a fragment of the skull has hitherto been known, but repeated study of this fragment.(123) has disclosed the wide diversity (462) of its characters. An almost complete skull, described below, stbstantiates the charac- 
ters based on the fragment. Another species is here added to the genus, based on a portion of a mandible and a portion of the skull.

The family, Macrerpetidæ, may be defined (465) as follows:

Skull larger than in any other known microsaurian, unless Baphetes proves to be microsaurian; cranial elements sculptured with pits and coarse grooves; lacrimal element present, teeth large, curved inwards and fluted; mandible heavy; orbits located far back on the skull and near the median line so that the interorbital space is about half the space from the outer edge of the orbit to the border of the skull, thus approaching the condition known in Eryops; the ribs (?) are strong, heavy, and curved, with an incipient tubercle.

Genus MACRERPETON Moodie, 1909.

Moodre, Jour. Geol., xvir, No. I, pp. 72-74, fig. 17, 1909.

Type: Macrerpeton huxleyi Cope.

The genus Macrerpeton was proposed for the reception of the amphibian species described by Cope as Tuditanus huxleyi (123). This form he placed provisionally in genus.Tuditanus, since it seemed to present the same type of sculpturing of the cranial elements similar to that found in $T$. radiatus Cope. But this species has been removed from Tuditanus and placed in a new genus, Erpetosaurus (462). A close study of the type specimen of Tuditanus huxleyi Cope shows (465) great variation and distinction from any of the species described from Linton, Ohio, or indeed from any Carboniferous form thus far known.

The specimen represents the left side of the face, and the characters exhibited by the fragment are supported by more complete material (No. 2933, Am. Mus. Nat. Hist.). The skull shows a close approach to the higher labyrinthodonts in its shape. The orbits are far removed from the border of the skull. The arrangement of the bones of the skull resembles that of Capitosaurus from the Keuper of Europe. The jaw is for the most part slender, with a pronounced downward inflection at the coronoidal part. The teeth are heavy and strong and are curved backwards. They have the strong longitudinal fluting which is characteristic of the labyrinthodonts. Another character which is distinctive is the pattern of cranial sculpture. This consists of inosculating pits and grooves of a coarse character and compares favorably with the sculpturing of Triassic labyrinthodonts. If Macrerpeton really represents a labyrinthodont form of Amphibia it is the oldest of the known Labyrinthodontidæ, since it seems probable that the Eosaurus vertebræ came from a higher horizon.

\section{Macrepeton huxleyi Cope, 1874.}

Cope, Trans. Am. Phil. Soc., xv, p. 274, 1874.

COPE, Geol. Surv. Ohio, II, pt. II, p. 397, pl. xxxiv, fig. 2, 1875 .

LESLEY, Dictionary of Fossils, p. 1237, 1890.

Moodre, Jour. Geol., XVII, No. 1, p. 72, fig. 17, rgog.

Moodie, Bull. Am. Mus. Nat. Hist., xxvi, art. xxv, p. 354, pl. lix, fig. I, 1909.

Type: Specimen No. I I9, American Museum of Natural History. Collection of Dr. J. S. Newberry. (Plate 26, fig. 2.)

Horizon and locality: Linton, Ohio, Coal Measures.

The first part of the following account of the species, Macrerpeton huxleyi Cope, is a quotation of Cope's description (I23) of the type specimen, and the second part deals with the description of the new material. Cope says the species is- 


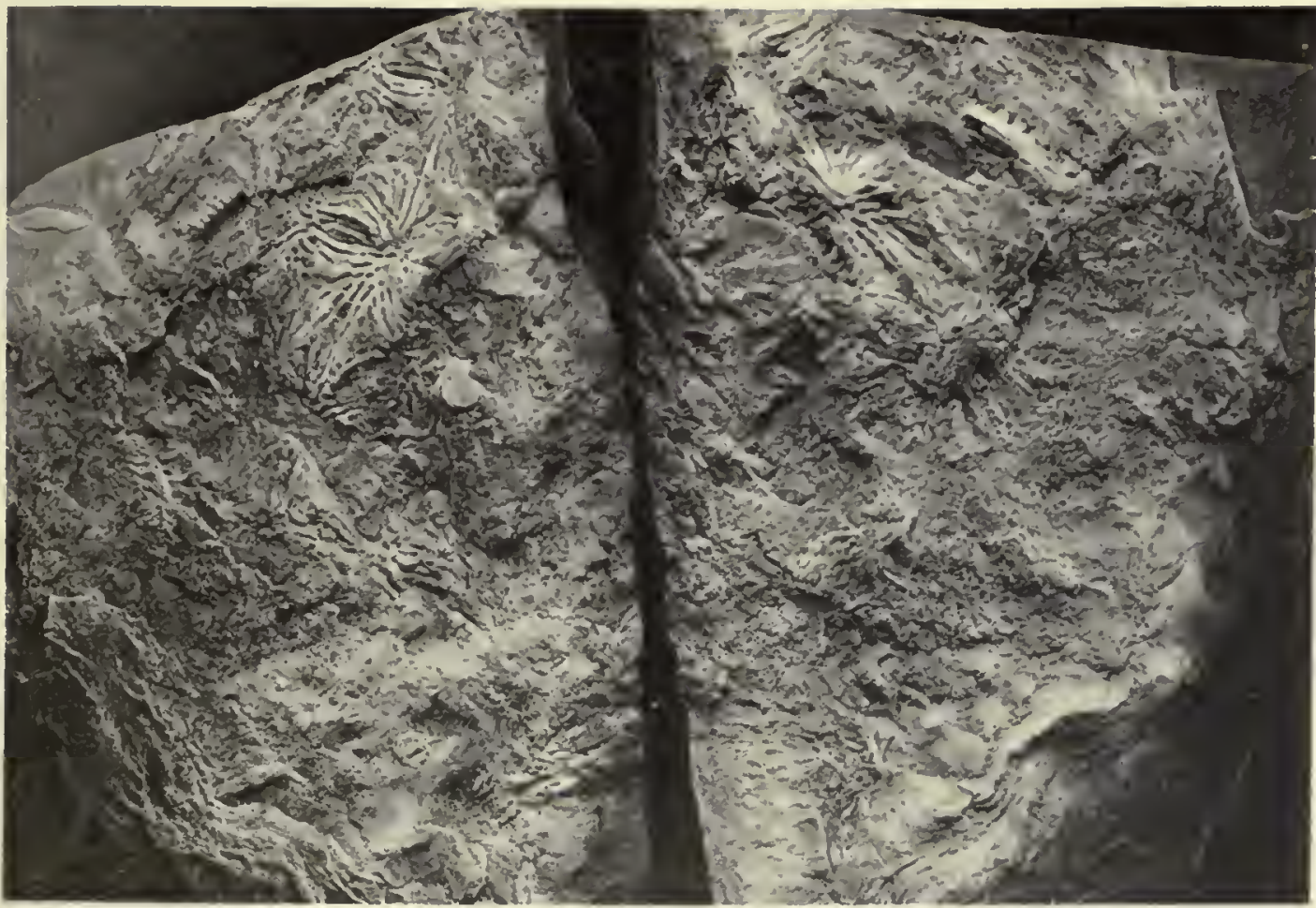

1

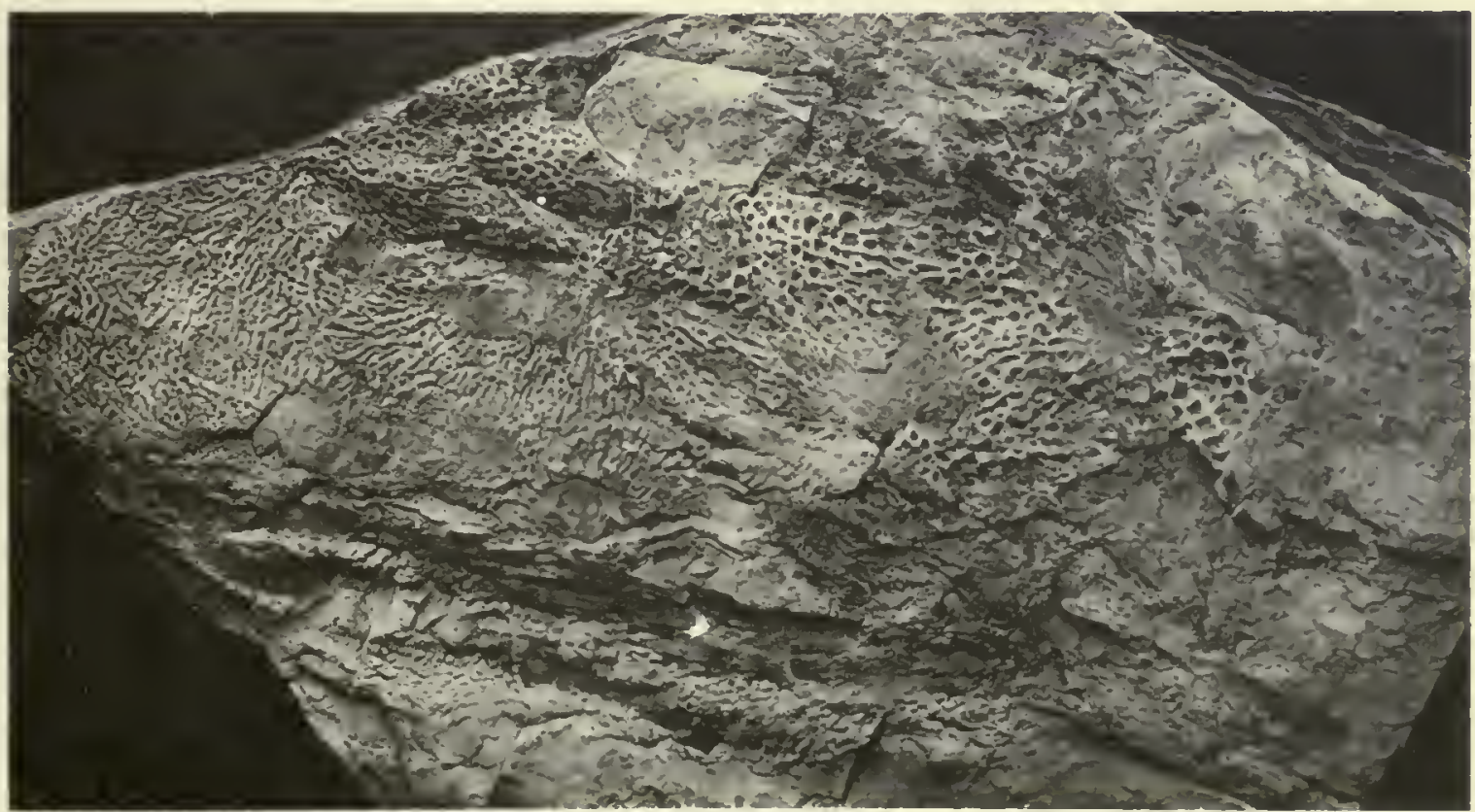

1. Photograph of type specimen of Erpetosanrus tuberculatus Moodie, from the Ohio Coal Measures. $\times 1$. Original in American Museum of Natural History.

2. Photograph of type of Macrerpeton huxleyi Cope, from the Ohio Coal Measures. $\times 1$. Original in American II useum of Natural History. 

"Represented by a considerable portion of the face and muzzle of a single individual. A portion of the left mandible, supporting three teeth, remains in place, and almost the entire boundary of the right orbit is preserved.

"The fragment indicates a much larger species than any other referred to the genus, and, next to the Leptophractus obsoletus, the largest of the Batrachians of the Ohio Coal Measures. Without more complete remains, it is not easy to determine its generic relations finally.

"The form of the head is probably elongate, and the muzzle neither very obtuse nor elongate. The orbit is rather small, and near the middle of the length of the specimen, which is, however, incomplete at both ends. The sculpture of the surface of the head posterior to the orbits, as well as round their borders and for some distance in front of them, consists of a rather coarse pitting. On the middle line, between the orbits and on the muzzle, the intervals become narrower, and are confluent into transverse ridges or a delicate reticulation. The surface of the mandible displays a coarse reticulation.

"The teeth are stoutly conic, and with delicately striate grooved cementum. They are slightly recurved.

"This species differs from the T. radiatus and T. obtusus in the absence of the area into which the sculpture is thrown.

"Longitudinal diameter of orbit, $19 \mathrm{~mm}$.; length of alveolar border supporting three teeth, I3 mm.; diameter of base of tooth, $3 \mathrm{~mm}$.; eight pits in $10 \mathrm{~mm}$.

“ Dedicated to Professor T. H. Huxley, facile princeps among English systematists, and an important contributor to the knowledge of the extinct Batrachia."

The following discussion of the cranial elements, based on the writer's studies $(462,465)$ of the type, may be appended to Professor Cope's original description. The sutures bounding a few of the elements have been made out in part. The prefrontal element seems well assured. It lies well in front of the orbit, much as in the skull of Capitosaurus from the Keuper of Europe. The lacrimal is, apparently, a very large bone, though its entire extent is not assured.

The maxilla is a long, narrow element on the border of the skull. The suture separating this from the lacrimal and jugal is quite clear. The teeth which the maxilla undoubtedly bore are hidden by the remains of the mandible, which lies partly on the edge of the skull. The jugal is a very large element and its boundaries seem well assured. Its size and relations recall the condition in Capitosaurus. It forms a part of the external boundary of the orbit. The lateral suture of the postorbital is evident and is, as shown in the figure, somewhat curved. The remaining elements preserved on the fragmentary skull can not be accurately determined, though their probable position is indicated in plate 30 , fig. 2, the lettering being based on the arrangement of these elements in Capitosaurus.

The lower jaw is poorly preserved, but what remains shows evidence of being sculptured somewhat after the manner of the cranial elements. It bore strong recurved teeth which are longitudinally striate.

Measurements of the Type Specimen of Macrerpeton huxley Cope.

Length of portion preserved . ............. $\mathrm{mm}$

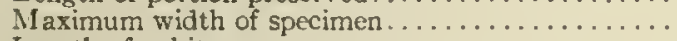

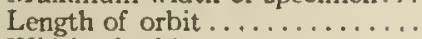

W:dth of orbit
120
58

20

14

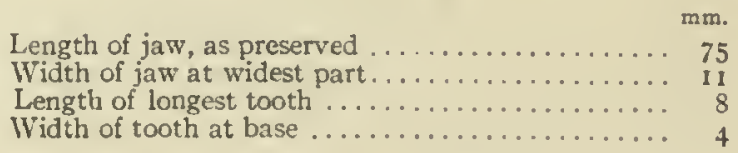




\section{DESCRIPTION OF ADDITIONAL MATERIAL OF MACRERPETON HUXLEYI.}

The additional material of this species which has come to hand consists of an almost complete skull (American Museum No. 2933, two portions); another fragmentary skull (American Museum No. $8572 \mathrm{G}$ and $8532 \mathrm{G}$ ); a portion of an interclavicle (American Museum No. 8006); two incomplete vertebræ (American Museum No. 8007); and another fragmentary element possibly representing a scapula of this species (American Museum No. 8008).

The skull has essentially the shape outlined (462) from a study of the fragmentary type specimen. The muzzle was drawn slightly too broad, but otherwise the restoration is fairly accurate. The specimen is distorted and imperfect, but enough is preserved to give a good idea of the shape and something of the structure of the skull. A portion of the obverse is preserved. The back part of the skull is broken, so that the occiput can not be studied.

The length of the skull is one and two-fifths the greatest breadth (across the orbits). The cranial elements are deeply marked with pits and short, shallow grooves. On the left mandible these pits are in a very distinct row, the operculomandibular lateral line.

\section{Macrerpeton deani new species.}

Type: Specimen No. 2934, American Museum of Natural History.

Horizon and locality: Linton, Ohio, Coal Measures. (Plate 2 I, figs. I, 2.)

The material for this species consists of the posterior half of the left mandible and a portion of the right antero-lateral surface of the skull, both incomplete. The reasons for regarding the species as distinct are the large size of the specimens and the manner of the sculpture, as well as the shape of the posterior end of the mandible.

The present species is the largest amphibian of the Linton, Ohio, Coal Measures, exceeding

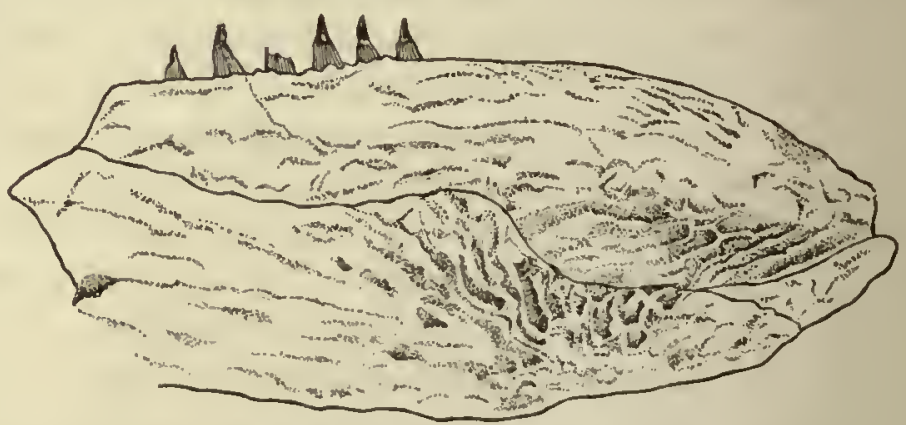
in skull length that of Macrer-FIG. 40.-Mandible of Macrerpeton deani new species, from Linton, peton huxkleyi by twice. The Olnio. $\times 0.75$.

largest skull of Macrerpeton huxleyi which has so far come under my notice is I 20 $\mathrm{mm}$. in median length. There are 3 skulls of this species known, all of approximately the same size. The skull of Macrerpeton deani must have reached or exceeded a foot in median length. The only species with which it can at all be compared are Eobaphetes kansensis Moodie and Baphetes planiceps Owen, but it is clearly distinct from all other genera of Linton Amphibia. It is possible that when better known Macrerpeton, Eobaphetes, Baphetes, Erpetosaurus, and possibly Dendrerpeton will form a natural group of early labyrinthodont-like Amphibia.

The mandible is similar in structure to that of the labyrinthodonts, with the elements marked by radiate flutings. I can detect no evidences of a lateral-line 
canal, such as is clearly marked in Macrerpeton huxleyi Cope by a series of rounded pits, occupying the usual position of the operculo-mandibular lateral-line canal The teeth, of which 6 are preserved, are minutely striate, with smooth apices. They are dissimilar in size, showing a variation of 2 or $3 \mathrm{~mm}$. in length.

The sculpture is a coarse fluting, with no indications of the sharply marked pits of Macrerpeton huxleyi Cope.

The fragment of a skull preserved shows characters of the sculpture which are identical with those of the mandible. The bones are so crushed that it is impossible to tell the limits of the elements. I believe a portion of one orbit is represented on one corner of the block. The cranium appears to have been broad, and the fragment preserved, which is only about one-sixth of the skull, is larger than the entire cranium and mandibles of Macrerpeton huxleyi.

The specific distinctness of the form can not be doubted, although it is a matter of regret that it is founded on so small a portion of the osteology of the animal.

The species is proposed in honor of Dr. Bashford Dean, to whom I am greatly indebted for many kindnesses during the past 5 years in connection with my studies on Carboniferous Amphibia, particularly in the loan of the entire Newberry collection of Linton, Ohio, Amphibia.

Measurements of the Type of Macrerpeton deani MoOde.

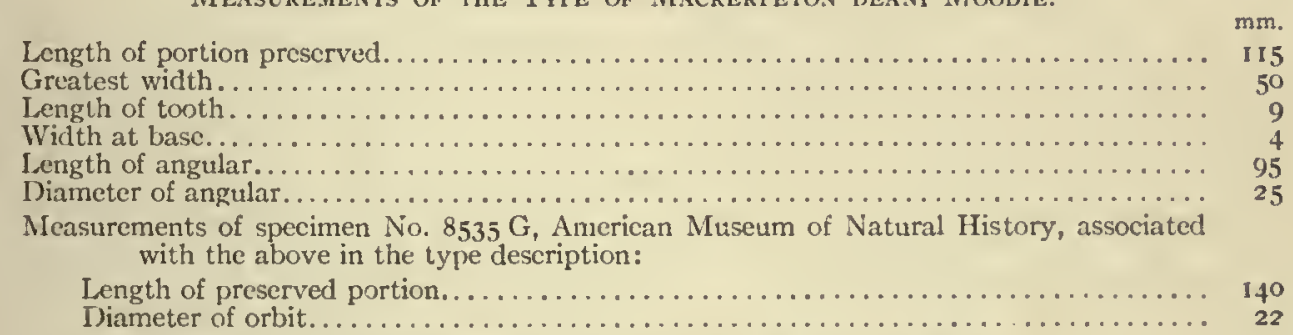

Family ANTHRACOSAURIDE Cope, 1875 .

Cope, Bull. U. S. Nat. Mus., I, p. Io, I 875.

LydekKer, R., I 890 , Cat. Fossil Reptilia and Amphibia, p. 157.

Slsull usually triangular and more or less angulated, with the cranial sculpture well marked, the occipital condyles ossified, and the palatine foramina very small and placed far back; dentine of the teeth more or less complexly plicated. A ventral armor of elongated dermal scutes, and probably a sclerotic ring. Bodies of vertebre fully ossified in the adult; intercentra present or absent. According to Atthey's figure ( $\mathrm{II}$ ) of the skull of the type genus, the palatine bears teeth which are situated immediately on the inner side of the maxilla, as in Mastodonsaurus $(242)$. In the typical forms there is no postarticular process to the mandible.

The North American species of this family are: Eosaurus acadianus Marsh, Eobaphetes kansensis Moodie, Dendrerpeton acadianum Owen, Dendrerpeton oweni Dawson, Platystegos loricatum Dawson, Baphetes planiceps Owen, Baphetes minor Dawson.

There is but little assurance that any of these species belong in this family. They are put there provisionally, pending future discoveries. Huxley suggests the relationship of Eosaurus and Anthracosaurus (Quart. Jour. Geol. Soc., xix, I863, p. 65; Scientific Memoirs, II, p. 566). 


\section{Genus BAPHETES Owen, 1854 .}

OWEn, Quart. Jour. Geol. Soc. London, x, p. 207, pl. ix, 1854.

Dawson, Air-breathers of the Coal Period, pp. 10-16, pl. ii, 1863.

\section{Type: Baphetes planiceps Owen.}

Known only from an incomplete skull, which is large, broader than long; squamosals prolonged into obtuse horns. Teeth rather large, heterodont, arranged in a single row. Orbits placed well forward, frontals small, surface bones sculptured.

Baphetes planiceps Owen.

OWen, Quart. Jour. Geol. Soc. London, x, p. 207, pl. ix, 1854.

DAwson, Air-breathers of the Coal Period, pp. 10-16, pl. ii, 1863.

Type: Specimen in the British Museum of Natural History.

Horizon and locality: Near Pictou, Nova Scotia (Coal Measures).

The parts preserved include the premaxillaries, nasals, and portions of the frontal, prefrontal, and maxillary bones. The fossil is embedded in a mass of Pictou Coal from Nova Scotia and consists of the anterior extremity of the cranium (plate 22, fig. 6) and with the exterior surface of the bone embedded in the matrix, and its substance, for the most part, reduced to a thin layer by abrasion of the exposed inner layer. It displays accurately the contour of the fore part of the upper jaw, which was broad, obtuse, and rounded.

The premaxillaries, which show some obscure traces of a symphysial suture at the median line, anterior to the nasal or naso-palatine vacuities, extend outwards, on each side, for an extent of 2.5 lines and there join the maxillaries. Traces of round alveoli for teeth, some of which are 2 lines in diameter, are visible on the alveolar border of the premaxillaries. The alveolar border is continued by the maxillary bone for an extent of 4.5 inches beyond the premaxillary border, and this border shows still more distinct traces of alveoli, of a circular form, about a line in diameter and rather close set in a single series. The fore part of the orbit is very unequivocally displayed, the smooth inner or under surface of the bone forming that part being entire; and this shows the fore part of the orbit to be formed, partly by the maxillary, partly by the lacrimal or prefrontal bone in close sutural union therewith, a structure which does not exist in any recent or fossil fish with a dentigerous superior maxillary bone. Where the substance of the bone has been detached so far as to expose the external layer in contact witl the coal, as, e.g., on the frontal and part of the prefrontal bones, the external surface of those bones is shown to have been impressed by subhemispherical or elliptical pits, from I line to I.5 lines in diameter, and with intervals of half of that extent. This coarsely pitted character agrees with that presented by the other surface of the similarly broad and flat cranium of the labyrinthodonts.

From the characters above specified, therefore, I conclude that this fossil is the fore part of the skull of an extinct family of the labyrinthodonts. It agrees with them in the number, size, and disposition of teeth; in the proportions and mode of connection of the premaxillaries, maxillaries, nasals, prefrontals, and frontals, and in the resultant peculiarly broad and depressed character of the skull. The traces of 
the nostrils are less definite and satisfactory than the remains of the orbits, but the latter appear to be decisive against the piscine nature of the fossil. The fossil also presents the same well-marked external sculpturing as in the labyrinthodonts; and among the genera that have been established in that family, the form of the end of the muzzle, or upper jaw, in the Pictou coal specimen best accords with that in the Capitosaurus and Metopias of von Meyer and Burmeister (80).

\section{Measurements of the Skull of Baphetes planiceps OWen. \\ (Type in the British Museum of Natural History, London.)}

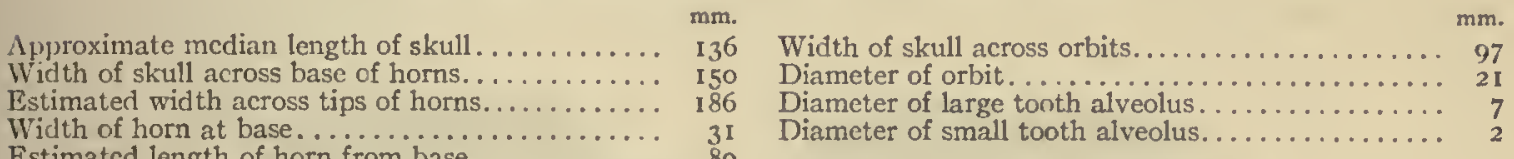

Estimated length of horn from base. .................

Pictou Coal, near Pictou, Nova Scotia, Canada, collected by Dr. J. William Dawson, I850, and presented by him to the Geological Society of London.

Baphetes minor Dawson.

DAwson, Canadian Nat. and Jour. Sci., n. s., 197o, v, pp. 98, 99.

'Type: Specimen in the Peter Redpath Museum, McGill University.

Horizon and locality: Coal formation of Nova Scotia.

The species was based on a lower jaw of an amphibian, of which a cast had occurred in the coarse sandstone of the coal formation between Ragged Reef and the Joggins Coal Mine. It measured 6 inches in length; its surface was marked on the lower and posterior part with a network of ridges inclosing rounded depressions. The anterior part of the jaw contained about 16 teeth, some of which remained in the matrix. These were stout, conical and blunt, with large pulp cavities, and about 32 longitudinal striæ, corresponding to the folds of the dentine. Dawson states that this jaw resembles most closely those of Baphetes and Dendrerpeton, but more especially the former. He regarded it as distinct from Baphetes planiceps, and proposed for it the name Baphetes minor.

\section{Eosaurus acadianus Marsh.}

MARsh, Am. Jour. Sci. (2), xxxIv, pp. I-I6, pls. i, ii, 1862.

AGAssiz, Am. Jour. Sci., XxxIII, p. $138,1862$.

MARsh, Quart. Jour. Geol. Soc., XIX, pp. 52-56.

HAy, Cat. Fossil Vertebrates (Bull. U. S. Geol. Surv. No. 179, p. 421, 1902).

Type: Specimen No. I648, Yale University Museım.

Horizon and locality: South Joggins, Nova Scotia (Coal Measures).

The genus and species are founded on two vertebral bodies of the stereospondylous type from the Coal Measures of the South Joggins, Nova Scotia. Marsh's description (404) is as follows:

"The general form of the vertebra is cylindrical, but their sides are compressed obliquely, which gives to the contour of the centra a subhexagonal appearance. They are much flattened in the direction of the anteroposterior diameter, which has to the transverse 
diameter the proportion of $\mathrm{I}$ to 3 . Both the articular terminal facets are deeply and equally concave; but from the center to the margin the surfaces are convex, and this convexity is greatest near the center. *** The cavities for the reception of the intervertcbral matter begin immediately from the margin, and are considerably deeper than the corresponding parts of the Ichthyosaurus, indicating a greater degree of flexibility in the vertebral column. The margins of the vertebra are somewhat raised, as if they had yielded to a forcible compression applied longitudinally; and hence the lateral surfaces of the centers are concave in an anteroposterior direction. This concavity is greater in the upper half of the vertebra and was undoubtedly more marked originally than at present, since the appearance of the margins indicates considerable abrasion. The non-articular surfaces of the centra are smooth and regular; and the external fibres of the osseous tissue are singularly reticulated.
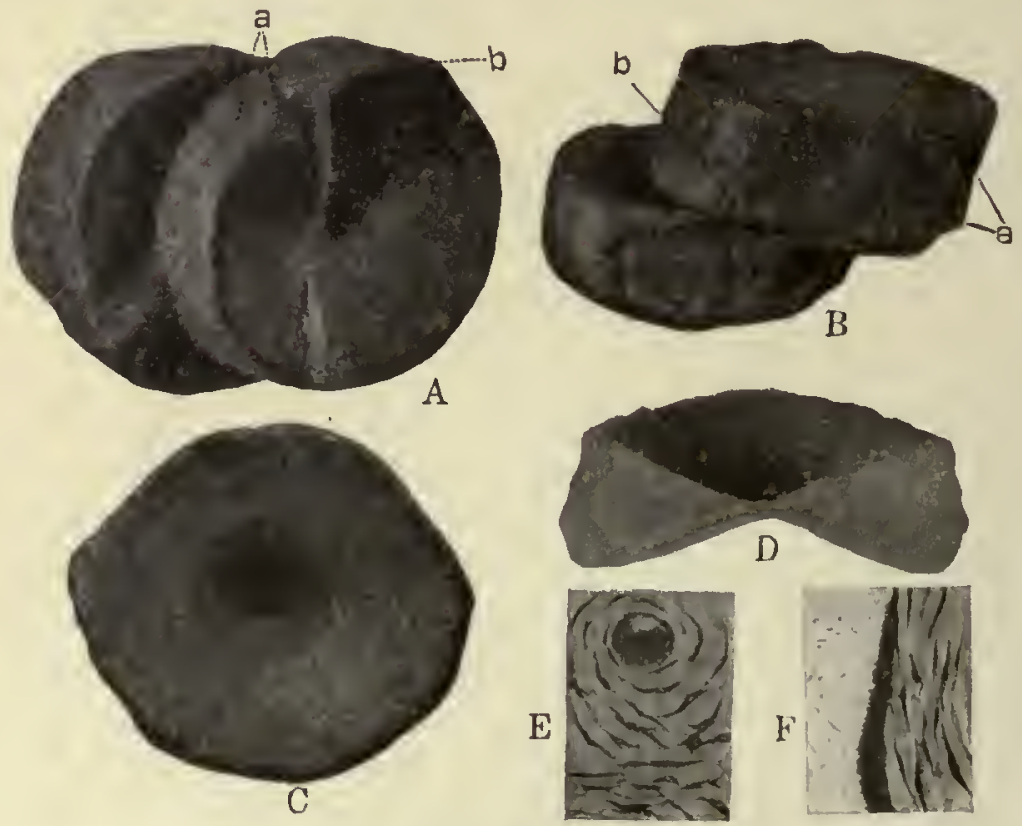

FIG. 41.-Nova Scotian Amphibia.

A. Oblique lateral view of vertebræ of Eosaurus acadianus Marsh. $a$, pits for articulation of neuropophyses; $b$, rudimentary transverse process on right lateral surface of eentrum.

B. Oblique view of vertebra. $a$, pits for articulation of netropophyses; $b$, rudimentary process on lateral surface.

C. Posterior view of nearly perfect centrum.

D. Transverse seetion of same vertebra, showing deep concavities of articular terminal facets.

$\mathrm{E}$ and $\mathrm{F}$. Microseopie sections near surface, showing lacunæ arranged around an Haversian canal. Magnified 200 diameters.

(All figures after Marsh. $\times 0.75$.

"The neuropophyses are not anchylosed to the centrum, as in the mammalia, nor connected to it by sutures, as in the crocodiles; but their union with the vertebra is indicated by two pits, which served for their articulating surfaces. These depressions are situated on the superior surface of the centrum intermediate between the anterior and posterior margins of the extremities. They are circular in form and sink directly into the body of the vertebra; instead of being elongated longitudinally and raised by ridges, as in Ichthyosaurus. The pits are about a line in depth, and in the more perfect of the fossils are not in their original position. The floor of the spinal canal is narrow, being but 5 lines in breadth. A rudimentary transverse process, or exogenous tubercle, is sent off from cach lateral surface of the centrum, at points equidistant from the extremities of the vertical diameter. Their 
position is near the margin of the anterior articular surface, and the edges of these parapophyses make the transverse diameter of this extremity somewhat greater than that of the corresponding posterior facet."

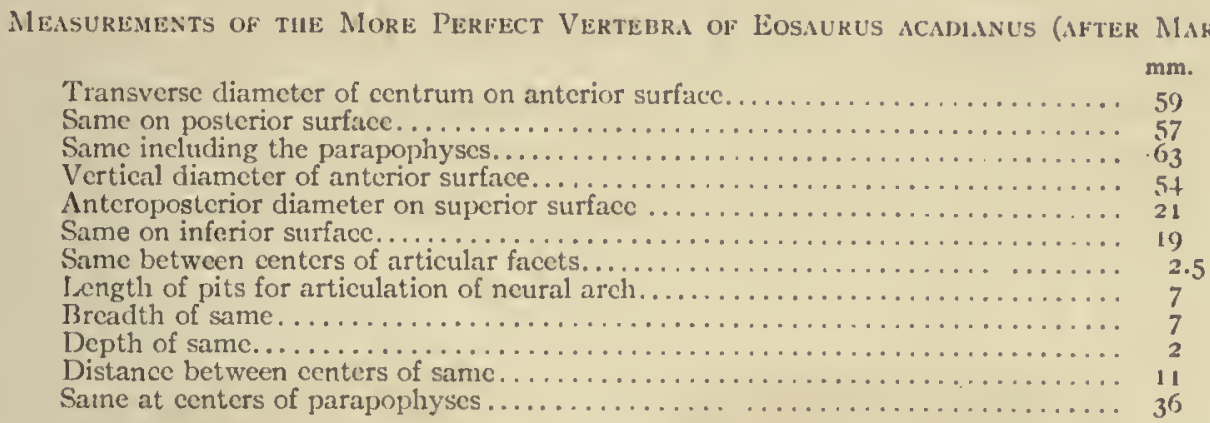

Collected by O. C. Marsh at the South Joggins, Nova Scotia.

Marsh regarded (404) the vertebræ as representing a new type of ichthyosaurian (2), but there can be no doubt that the vertebra belong to some form of the Amphibia, since the description applies equally well to them. In this connection mention must be made of a large rib from the Linton beds preserved in the U. S. National Museum. Only the proximal third of the rib is preserved, but it represents some large form of the Stegocephala. The rib is strongly curved backward, is heavy, and has an incipient tubercle. A cross-section shows that a longitudinal groove occupies the median line on the exposed surface of the rib. This may, however, be due to compression and thus indicate that the rib was hollow. The rib as preserved measures: length, I02 mm.; maximum width, $22 \mathrm{~mm}$.; minimum width, I4 mm. (Nos. 4490, 4489, U.S. National Museum.)

\section{Genus EOBAPHETES new name.}

Type: Eobaphetes kansensis Moodie.

The new name is proposed to replace the generic term Erpetosuchus used for the species E. kansensis described by the writer (Proc. U. S. Nat. Mus., 39, p. 491, I9I I), and which later was found to be preoccupied by Newton (Phil. Trans. Roy. Soc. London, I 85 , p. 573, I 894 B).

The genus is very readily distinguished by two prominent characters-the short; uniform dentition and the presence of two elongate, oval, internal mandibular foramina on the inner side of the jaw. The genus may be further distinguished by the great depth of the posterior portion of the jaw and the slender anterior part, as well as by the ornamentation, which is typically the rough tuberculated labyrinthodont sculpture on the anterior end of the mandible. This changes gradually to longitudinal grooves and ridges of a rather small size on the posterior portion, a very unusual arrangement for a labyrinthodont.

These characters are sustained by those of the skt1l fragment, in which the dentition is uniform and the sculpture very similar to that of the mandible. The ribs are long, curved, and solid, as in other labyrinthodonts. 
The internal surface of the mandible shows much similarity to that of the crocodiles and alligators of the present day. The resemblance is not due to homology of structures, but must be regarded as a parallel development of similar characters.

Eobaphetes kansensis Moodie.

Moodie, Proc. U.S. Nat. Mus., 39, pp. 491-494, figs. I to 3, I911 (Erpetosuchus).

Type: Specimen No. 6699, U. S. National Museum.

Horizon and locality: Coal Measures of Washington County, Kansas.

The species is represented in the collections of the U. S. National Museum by a fragment of the skull, with portions of two ribs (Cat. No. 6699, Vert. Pal. U. S. Nat. Mus.) and the larger part of the left ramus of the mandible (Cat. No. 6680, Vert. Pal. U. S. Nat. Mus.). The mandible was preserved in a large block of coal which contained the impression of the back portion of the mandible from which the bone had been weathered. It was possible to remove the bone and make a plaster cast of the impression. This shows in a very satisfactory manner all of the characters of the external surface.

Skull.-Only a portion of the left maxilla, with I 4 teeth, and a part of the nasal are preserved. The skull seems to have been laterally crushed and the right side of the skull has been crushed flat under the left. It has not seemed feasible to remove the skull from the matrix.

The teeth are uniform, rather short, bluntly conical, curved backward, and coarsely striate. They are somewhat crowded, the bases being separated from each other by only a fraction of a millimeter.

The maxilla and portion of the nasal are coarsely sculptured with elongate pits and ridges. A portion of the infraorbital lateral-line canal is preserved. It is simply a rounded groove with three short branches. It lies near the middle of the maxilla.

Mandible.-It has been possible to study both sides of the mandible. The left ramus was preserved in the coal, with its inner face exposed. This face is broken by two large oval openings, the internal mandibular foramina. This is the term used by Reynolds for the openings on the inner surface of the alligator jaw. So far as I can ascertain, no other known labyrinthodont mandible displays this character in such a marked degree. Dr. Branson has figured in Anaschismu browni Branson from the Triassic (49) of Wyoming the inner surface of the left ramus, on which there are likewise two openings but differęntly situated. A similarity between the two mandibles is observed in that the suture separating the prearticular and angular touches the posterior edge of the posterior foramen.

Several of the sutures are well preserved and they have been indicated in the drawing (fig. 42). The pillar separating the two foramina is cut by the suture separating the angular and prearticular very much as in Anaschisma, with the difference that in the latter form the angular and prearticular are not approximated. I believe I detect the suture as represented separating the anterior end of the angular from the dentary and splenial. I am assured of the portion near the anterior foramen and also of the part near the tip of the ramus. This shows the angular to be a very elongate element, running very nearly the entire length of the mandible, much 
as in Anaschisma and other labyrinthodont genera. The splenial is a small, slender clement located farther forward, where it has been shoved by the large-sized internal mandibular foramina. 'The prearticular is a rather long, broad element, of which only a portion is preserved. I am not sure as to the location of the suture for the dentary, unless it is represented by the line bounding the roughened area near the teeth. If this is true, the dentary is a large element, since it extends well down upon the outer side of the jaw. The dentary possesses evidences of 26 teeth, a few of which are completely preserved. Most of them are, however, represented either by bases or by impressions in the coal. The teeth are very similar to those of the maxilla, though slightly larger. The characters given for the maxillary teeth will suffice for those of the dentary.
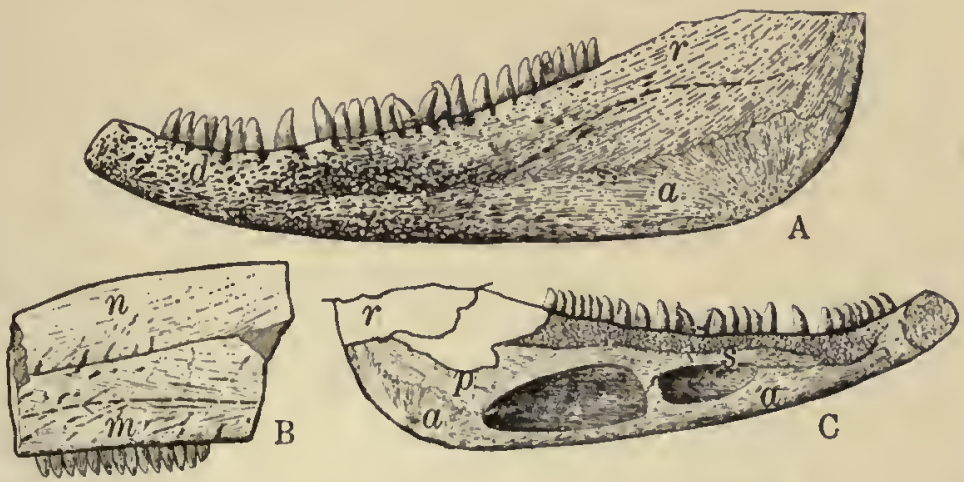

Fig. 42.

A. Outer view of mandible of Eobaphetes kansensis Moodie, from the Coal Measures of Washington County, Kansas. Original in U. S. National Museum. $\times 0.33$. Cat. No. 6680. a, angular; $r$, articular; $d$, dentary.

B. Portion of skull of Eobaphetes kansensis Moodie, from the Coal Measures of Washington County, Kansas. Original in U. S. National Museum. Cat. No. 6699. $\times 0.33$. Lateral-line canal represented by heavy broken line. $n$, nasal; $m$, maxilla.

C. Inner surface of mandible of Eobapheles kansensis Moodie, from the Coal Measures of Washington County, Kansas. $\times 0.33 . a$, angular; $p$, prearticular; $r$, articular; $s$, splenial.

The markings of the inner surface are as indicated in the drawing. The back portion of the angular shows a few radiating lines. The dentary is roughened in two portions: one near the teeth, the other at the tip, where there is a cartilaginous roughening for union with its mate. The remainder of the inner surface is relatively smooth.

The outer surface shows at the anterior end the typical labyrinthodont sculpturing, which becomes slight grooves and ridges posteriorly. I detect evidences of the operculo-mandibular lateral-line canal throughout the entire length of the mandible. Its location is indicated by the heavy broken line. The suture between the dentary and angular is quite clear. The suture separating the dentary and splenial joins the angular suture about midway of the length of the jaw.

Measurements of Skull. Fragment of Eobapiletes kansensis Moonie.

(Cat. No. 6699, U. S. Nat. Mus.)

Total length of portion preserved .......... 109

Maximum width of maxilla................ 45

Length of tooth

I hickness of maxilla.................... 7

Width of tooth at base....................... 4 
Measurements of Left Ramus of Maxdible of Eobaphetes kansensis Moodie.

(Cat. No. 6680, U. S. Nat. Mus.)

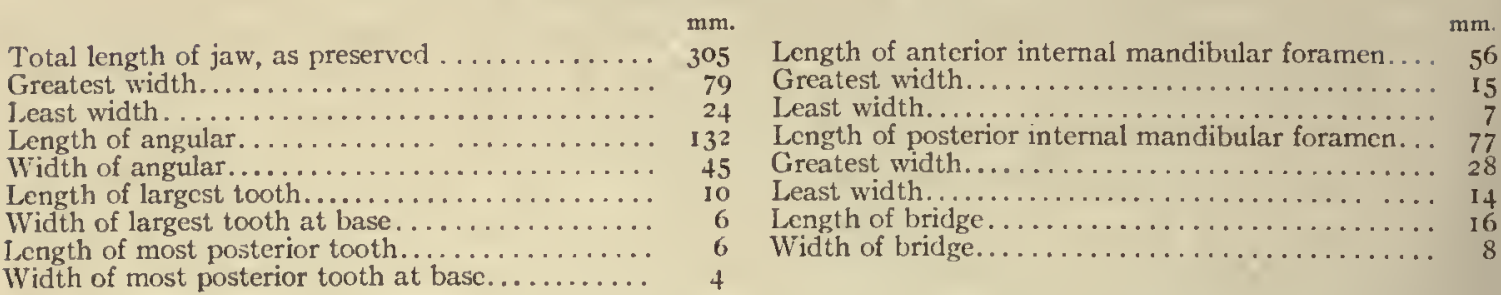

Ribs.-There are portions of two dorsal ribs preserved on the block of coal with the skull. These show characters very similar to those exhibited by the rib ascribed to Macrerpeton huxleyi Cope, and also those of Metoposaurus diagnosticus von Meyer (242) and Anaschisma. The ribs are solid, heavy, curved, and have a longitudinal groove on the middle of each side. The heads of the ribs in the present specimen are obscured and nothing can be said of them except that they appear to be large.

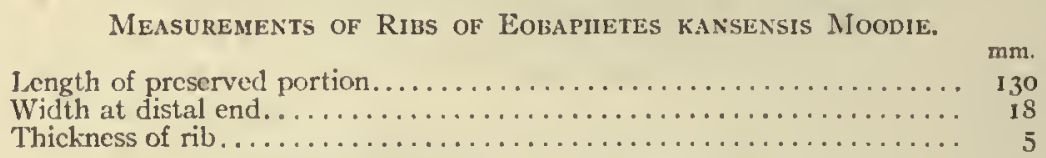

Genus DENDRERPETON Owen, 1853.

Owen, Quart. Jour. Geol. Soc. London, IX, p. 66, I853.

Type: Dendrerpeton acadianum Owen.

The genus is characterized by Dawson as follows (Phil. Trans., I 882, p. 635):

"Lizard-like, with anterior and posterior extremities nearly equal; the skull somewhat elongate with small orbits, and the nostrils placed at the front. The cranial bones sculptured. The teeth plicated at the base, more especially on their inner sides. A series of large tceth on the palate. The body was covered above with imbricated horny scales and had lappets or pendants at the sides. The abdomen was protected by thin bony scales semielliptical or oat-shaped in form, and arranged in a chevron pattern. There was probably also a thoracic plate. Two species: $D$. acadianum and D. oweni.

"Type: D. acadianum Owen."

\section{Dendrerpeton acadianum Owen.}

OWEn, Quart. Jour. Geol. Soc. London, IX, p. 66, 1853.

DAwson, Air-breathers of the Coal Period, p. 17, 1863 .

DAwson, Acadian Geology, 3d cd., p. 362.

Dawson, Phil. Trans. Roy. Soc. London, pt. If, p. 642 , pl. 40 , figs. 46 to 5 l; pl. 44 , figs. 129 to 137. I 882.

Type: Specimens Nos. 434-438, British Museum of Natural History.

Horizon and locality: Coal formation at South Joggins, Nova Scotia. (Plate 6.) This species has been fully described and figured by Dawson (Air-breathers of the Coal Period, pp. I7-30, pl. III, figs. I to 30, I863), who gives a detailed account of the discovery of the material of this species by himself and Sir Charles Lyell. He says, in part:

"In form, Dendrerpeton acadianum was probably lizard-like; with a broad flat head, short, stout limbsand an elongated tail; and having its skin, and more particularly that of the belly, protected by small bony plates closely overlapping each other. It may have attained the length of 2 feet. The form of the head is not unlike that of Baphetes, but longer in pro- 
portion; and much resembles that of the labyrinthodont reptiles of the Trias. The bones of the skull are sculptured as in Baphetes, but in a smaller pattern. The nostrils are small, and near the muzzle; the orbits are circular, and separated by a space of more than their own diameter. In the upper jaw there is a series of conical teeth on the maxillary and intermaxillary bones. Those on the intermaxillaries are much larger than the others, and have the aspect of canines or tusks. Within this outer scries of teeth, but implanted apparently in the same bones, there is as in Archegosaurus a second series of teeth, closely placed, or with intervals equal to the diameter of one tooth. These inner teeth are longer than the others, implanted in shallow sockets, to which they are anchylosed, and have the dentine plicated, except toward the point. A third group of teeth, blunt at the points, largely hollow in the interior, and with the dentine quite simple, appears in detached bones, which may represent the vomer. Only a part of this formidable armature of the teeth appears in the skull, as the bones of the roof of the mouth have been removed, adhering to the opposite side of the matrix; but the fact of the occurrence of two sets of teeth was ascertained by Professor Wyman, from the original specimens, and is manifest in the fragment *** whilc the other teeth, supposed to be vomerine, appear in fragments which must, from their size and collocation, have belonged to Dendrerpeton. It will be obscrved that all of these teeth are anchylosed to the bone; and that those of the vomer are thinly walled and simple, the outer series on the maxillaries and intermaxillaries simple and flattened, while the inner series of teeth are conical and plicated. In the lower jaw there was a uniform series of conical teeth, not perceptibly enlarged toward the front; at least this is the case in the only spccimen at present in my collection; which is, however, merely an imperfect cast in hard sandstone.

"The scapular and sternal bones seem to have been well developed and strong, but only portions of them are known. The fore limb of the adult animal, including the toes, must have been 4 or 5 inches in length, and is of massive proportions. The bones are hollow, and in the case of the phalanges the bony walls were thin, so that they are often found crushed flat. The humerus, however, was a strong bone, with thick walls and a cancellated structure toward its extremities; still, even these have sometimes yielded to the great pressure to which they have been subjected. The cavity of the interior of the limb-bones is usually filled with calc-spar stained with organic matter, but showing no structure; and the inner side of the bony wall is smooth, without any indications of cartilaginous matter lining it.

"The vertebra, in the external aspect of their bodies, remind one of those of fishes, expanding toward the extremities, and being deeply hollowed by conical cavities, which appear cven to meet in the center. There is, however, a large and flattened neural spine. The vertebræ are usually much crushed, and it is almost impossible to disengage them from the stone. $* * *$ in its long neural and hæmal spines, reminds us of the caudal vertebræ of those batrachians and reptiles which have tails flattened for swimming, and probably indicates that this was the case with Dendrerpeton. The ribs are long and curved, with an expanded head, near to which they are solid, but become hollow toward the middle; and the distal extremities are flattened and thin-walled. The posterior seems to have been not larger than the anterior, perhaps smaller. The tibia is much flattened at the extremity, as in some labyrinthodonts, and the foot must have been broad, and probably suited for swimming or walking on soft mud, or both. That the hind limb was adapted for walking is shown not mercly by the form of the bones, but also by that of the pelvis, the best preserved specimen of which I have represented (208, pl. 111, fig. 28).

"The external scales are thin, oblique-rhomboidal or elongated-oval, marked with slight concentric lines, but otherwise smooth, and having a thickened ridge or margin; in which they resemble those of Archegosaurus, and also those of Pholidogaster. *** The microscopic structure of the scales is quite similar to that of the other bones, and different from that of the scales of ganoid fishes *** :" 


\section{Dendrerpeton oweni Dawson.}

DAwson, Quart. Jour. Geol. Soc. London, Xvir, p. 469 .

DAwson, Air-breathers of the Coal Period, p. 32, 1863 .

Dawson, Acadian Geology, 3d ed., p. 368.

Dawson, Phil. Trans. Roy. Soc. London, pt. II, p. 643, pl. 44, figs. I3 I, I38, I 39, I 882.

A smaller species than the preceding. The form (plate 13 ) is fully described by Dawson (Air-breathers of the Coal Period, p. 32, pl. IV, I863) as follows:

"Among the reptilian remains found in erect trees at the South Joggins, there have occurred several portions of skeletons which, from their sculptural cranial bones, plicated teeth, and the forms of their scales and limb-bones, I have referred to the genus Dendrerpeton, but to individuals of much smaller size than the full-grown specimens of $D$. acadianum. It did not occur to me to suppose that these were specifically distinct from the larger individuals, until I observed that bones of this kind, contained in the collections sent by me to the Geological Society, or represented in the figures drawn to illustrate one of my papers, were referred by Professor Owen, in his notes on these specimens and figures, in the Journal of the Geological Society, to the genus Hylonomus; which is quite distinct from Dendrerpeton, as will be explained in sequel.

"I was thus induced to reëxamine all the specimens in my collection and the result has been to establish a strong probability that there is in reality a second species of Dendrerpeton, smaller than $D$. acadianum, and differing from it in several points. This species I propose to name $D$. oweni. It differs from $D$. acadianum in the following particulars: (I) its much smaller size; (2) its long and hooked teeth (it will be seen that these teeth differ very markedly in their proportions and form from those of the larger spccies); $(3)$ the greater plication of the ivory in the intermaxillary teeth (in $D$. acadianum these teeth are, on the outside, simple almost to the base, and plicated on the inner side, while in this species they are plicated all around like the inner maxillary teeth); (4) the form of the skull, which has the orbits larger in proportion, and is also shorter and broader. On the other hand, when we have described the species Hylonomus, it will be seen that this animal, except in size, differs from them quite as widely as does $D$. acadianum.

"The distinctness of $D$. oweni is further confirmed by the fact that I possess small jaw-bones of Dendrerpeton, about the size of those of this species, but having the teeth similar in form to those of the larger species; these I suppose to have belonged to young individuals.

"On examining the figures $(208$, pl. 1v) it will be seen that the bones of the skull were corrugated as in the large Dendrerpeton, but with a smaller pattern. The forms of the jawbones also, and of the vertebræ, ribs, scapular bone, bones of the limbs, and bony scales, are very similar, and indicate that in general form this creature was not far removed from its larger relative. The bones of the foot especially deserve attention. This is the most perfect foot of Dendrerpeton hitherto found; and I have enlarged it in the figure (208) in order more distinctly to show its parts. It presents three long toes with traces of a smaller one at each side, so that there were probably five in all. If these toes be compared with the footprints on the slab discovered by Dr. Harding, it will be seen that they very closely correspond, though the toes of the present species are much smaller. The footprints are precisely those which we may suppose an animal of the size of Dendrerpeton acadianum would have made if, as the bones found render in every way probable, this larger species had a foot similar to that of $D$. oweni. I suppose, for this reason, that thesc footprints are really those of Dendrerpeton acadianum and that this species continued to exist from the time of the lower Coal Measures to the period when those higher beds of the series, in which its bones are found at the Joggins, were deposited.

"The present species must have lived in the same places with its larger relative, but may have differed somewhat in its habits. Its longer and sharper teeth may have been 
better suited for devouring worms, larvæ, or soft-skinned fishes, while those of the larger Dendrerpeton were better adapted to deal with the mailed ganoids of the period, or with those smaller reptiles which were more or less protected with bony or horny scales.

\section{REMAINS OF SKIN AND HORNY SCALES.}

"In one of my earliest explorations of the reptile-bearing stumps of the Joggins, I observed on some of the surfaces patches of a shining black substance, which on minute examination proved to be the remains of cuticle, with horny scales and other appendages. The fragments were preserved; but I found it impossible to determine with certainty to which of the species whose bones occur with them they belonged, or even to ascertain the precise relations of the several fragments to each other. I therefore merely mentioned them in general terms, and stated my belief that they may have belonged to the species of $\mathrm{Hylono}$ mus. ${ }^{*}$ More recently other specimens have been obtained, and I have undertaken the detailed examination of the whole. I shall now endeavor to describe the principal or most continuous fragments, and afterward to consider the probabilities of their having belonged to certain of the reptiles entombed with them. I do this here, rather than under the titles of these several animals, on account of the uncertainty which still rests on the assignment of certain portions of this cuticle to the species in question, and which renders it more convenient to consider these peculiar remains in one place and to compare the different portions with each other.

"(I) One of my specimens is a flattened portion of cuticle 2.25 inches in length. The greater part of the surface is smooth and shining to the naked eye, and under the microscope shows only a minute granulation. A limited portion of the upper and, I suppose, anterior part is covered with imbricated scales, which must have been membranous or horny and generally have a small spot or pore near the outer margin, some having in addition smaller scales or points on their surfaces. In contact with the upper part of this specimen there were many fragments of the skull of Dendrerpeton oweni.

"(2) Another portion of the cuticle, similarly marked, appears to preserve the form of the posterior part of the body and tail of the animal, and also a mark representing the point of attachment of the hind leg; near to which, and along the dorsal ridge, is a portion of the skin covered with much smaller scales. This was found in close proximity to a mass of bones of Dendrerpeton oweni, mingled with some of Hylonomus lyelli.

"(3) A third and still larger surface of integument with similar markings has upon it a number of vertebræ and detached bones of the small reptile Hylonomus wymani, to be described in the sequel; for which species, however, it would be much too large a covering.

"(4) Another well-preserved fragment, less than 2 inches in length, exhibits very diferent markings. It is nearly covered with very small imbricated scales, thicker than those on the specimens previously described. On either side of what seems to have been the middle line of the back, there is a series of pointed flat horny processes, which probably formed a double spinous crest. Without these there are tufts of strong bristles, and exteriorly to these last are rows of flat, thick, horny plates, transversely wrinkled. Near to these was a row of conical truncated tubercles. Sections of these appendages show them to have been horny and attached to the cuticle. None of them have bony structure.

"(5) Near this last portion of cuticle, and possibly belonging to it, are pointed and probably membranous appendages, marked on each side with rows of scales not overlapping and each with a pore in its center. The manner in which these appendages are bent and wrinkled shows that they must have been soft, except at the tips, which seem to have been hard and horny, and they are arranged in scries, as if originally placed along the sides of the 
neck or abdomen, or both. The use of these appendages is not easy to conjecture. They remind us of the gular pouches of iguana, and of the lateral expansions of some geckos and of the Draco volans. Possibly they formed lateral parachutes, aiding the animal in moving over soft mud, or perhaps in leaping and swimming.

"(6) Some other fragments appear to have belonged to a different species from either of the foregoing. The best-preserved specimen, which is about $I$ inch in length and half an inch in breadth, is covered with very small imbricated scales. It is crossed by 6 or 7 obscure ridges, which both at the bottom and along a mesial line project into points covered with larger scales. A row of large scales with round pores connects these along the lower side. If, as seems probable, this fragment belonged to the side of the trunk or tail, it would perhaps indicate a division of the subcutaneous muscles into an upper and lower band, as in the newts. A separate fragment with transverse horny ridges and another with a longer lobe, similar in structure to those above mentioned, may perhaps be referred to the same animal. A larger patch of skin presents similar imbricated scales, but without a mesial line, and with an edging of larger scales.

"Six species of reptiles have left their bones in the repositories containing these remnants of cuticle. Of these, Dendrerpeton acadianum, was an animal of too great size to have been clothed with integument of this character and of such dimensions. Hylonomus aciedentatus and Hylerpeton dawsoni are each represented by only a single specimen, and these did not occur in proximity to any of the portions of cuticle, except that the appendages were found near a specimen of the former. Of the three remaining species, Dendrerpeton oweni, from its size, the number of specimens found, and the juxtaposition of their bones to the fragments of cuticle, appears to have the best claim to the integument included under Nos. I, 2, and 3; and in this case, while the creature had its throat, and perhaps its abdomen, armed with bony scales, its upper parts and tail, as well as its limbs, had a uniform covering of small, thin imbricated horny scales, in the manner of many modern reptiles.

"If the remaining portions of integument, Nos. 4 and 5, as would seem likely, belonged to two species, both of smaller dimensions, there would seem little reason to doubt that these were Hylonomus lyelli and $H$. wymani. In this case, both of these species must have possessed a highly ornate covering of horny scales and appendages, comparable with that of many of the modern lizards, while there seems good reason to believe, as stated in a previous paper, that they were in part protected by bony scales somewhat like those of Dendrerpeton. These points, however, we shall consider more in detail under the sections which refer to the species of Hylonomus.

"Before leaving these curious specimens of ancient skin, the most ancient I suppose known to exist, it is of interest to observe that the thicker portions, when broken across, have the aspect of jet, or of pure shining coal, and thin slices, under the microscope, have the same rich brown colour with that material, though rather more translucent. When burned, fragments of the substance give a strong flame, and a bituminous and ammoniacal odour. We have thus an example of the production of coal from animal membrane, no doubt gelatinous and horny in the first instance, but which has proved itself capable of the same chemical changes that have been experienced by the vegetable matter buried with it. In order that this substance should be preserved in this way, it would be necessary that it should either be kept dry and hard, or that it should be immediately buried in matter impervious to air and kept moist. The latter conditions are the more probable. The preservative qualities of the peaty vegetable matter imbedded with it must be considered; and it is possible that these hollow stumps, partly filled with fragments of Sigillaria bark, may have formed natural tan-pits, in which animal membranes would be preserved in a manner impossible in ordinary sediments. If this were the case, we may yet find an entire reptile, preserved as a flattened mummy, in one of these strange repositories." 
Genus PLATYSTEGOS Dawson, 1895.

Dawson, Proc. and Trans. Roy. Soc. Canada, I895, XII, p. 77 (sec. IV).

Type: Platystegos loricatum Dawson.

Dawson's description is as follows:

"Head broad and short, orbits very large, cranial bones deeply sculptured; teeth strongly plicated and curved, with sharp edges at apices, especially the inner palatal teeth, which are very large. Many minute teeth on the vomerine bones; vertebre ossified, biconcave; limb bones imperfectly ossified, short; lower surface protected with a thoracic plate and thick, densely imbricated bony scales in transverse rows; body above with thin, round scales, concentrically marked."

\section{Platystegos loricatum Dawson.}

DAwson, Proc. and Trans. Roy. Soc. Canada, XII, p. 77, I895.

Dawson describes the species:

"Head about $8 \mathrm{~cm}$. long; when flattened $9 \mathrm{~cm}$. broad across parietal foramen; squamosal and temporal bones projecting backwards in points much behind the condyles; parietal foramen small, orbits large; length of longest tooth seen $7 \mathrm{~mm}$.; cranial bones closely and deeply pitted; humerus with very thin bony walls, cartilaginous within, $3.5 \mathrm{~cm}$. long.'

Erect tree, coal formation, at the South Joggins; collected by P. W. McNaughton. Type in Peter Redpath Muscum at McGill University. Dawson regarded the form as of uncertain relationship. 


\title{
CHAPTER XXV.
}

\section{THE STEREOSPONDYLOUS AMPHIBIA FROM THE COAL MEASURES OF NORTH AMERICA.}

\author{
DEFINITION OF THE ORDER STEREOSPONDYLIA ZITTEL, 1887.
}

Zitrel, Handbuch der Paleontologie, Bd. 11, Abth. I, p. 397, ז887.

Large terrestrial vertebrates; largest of the class. Skull equal to one-fourth or one-third of the entire body in at least one species, Metoposaurus diagnosticus von Meyer (242). Lateral-line canals always present (458) on the skulls as deeply impressed grooves which, in life, were possibly roofed over by a cartilaginous or other connective-tissue membrane. The sensory organs undoubtedly being supplied by the superficial ophthalmic branch of the trigeminal nerve, branches of which pierced the cranial elements near the grooves, no evidence of such openings in the bottoms of the grooves; the condition probably being analogous to Hydrolagus colei and other chimæroids. Vertebræ stereospondylous, with well-developed neural arches from which projected the well-developed zygapophyses, sometimes slightly amphicoelous and pierced for the notochord, such forms being uncertainly placed in the group. Tail unknown, possibly short. Limbs and girdles well developed (243), phalangeal formula unknown; carpus osseous and tarsus unknown. Pectoral girdle composed of osseous scapulæ, clavicles, interclavicle, coracoid (?); clavicles and interclavicle ventrally sculptured. Pelvic girdle composed of osseous pubis, ischium, and ilium (242), the pubis a small plate, in life largely cartilaginous, the three uniting by cartilaginous union to form the acetabulim. Ventral armature unknown, possibly wanting.

Range: Pennsylvanian to Upper Triassic.

Distribution: North America, Europe, Asia, Africa, and Australia.

\section{Family MASTODONSAURID\& Huxley, I863.}

HuXLEY, Quart. Jour. Geol. Snc., Xix, p. 65, 1863.

Lydekker, R., Cat. Fossil Reptilia Amphibia, pt. 1v, p. I4I, I 890.

Skull triangular, and more or less elongated, with the cranial bones very strongly sculptured, the occipital condyles ossified (49), and large palatal vacuities; dentine of teeth with very complex plications (502); no bony rings (242) in sclerotic; and no ventral scutes. Bodies of vertebra (49) fully ossified in the adult. There are large palato-vomerine tusks on the inner side of the maxillary teeth; and the palatines run parallel to the maxilla. The mandible has a large postarticular process; and there is a small inner series of mandibular teeth. In the type genus the pubes are separate from the ischia, and do not enter into the formation of the acetabulum; and the sacral ribs forn kidney-shaped disks (393).

Represented in North America by a single tooth from the Carboniferous of Kansas. Described by Williston as Mastodonsaurus sp. (Kans. Univ. Quart., vi, pp. 209-2 Io, pl. XxI). Represented in the Triassic of Wyoming by Anaschisma browni, Branson (49).

Mastodonsaurus sp. indet.

Williston, Kans. Univ. Quart., vi, p. 209, 1897.

The specimen preserved comprises the entire crown of a single vomerine (?) tooth, $38 \mathrm{~mm}$. in length by $14 \mathrm{~mm}$. in diameter at base (pl.2 I, fig. 6). The immediate tip had been partly worn away in life, but was acuminate. It is composed of a dense 
blackish material, with the exterior smooth, shining black. It has about 20 narrow flutings, nearly straight, running from the base to the tip, separating shallow grooves. A transverse section of the base shows a narrow pulp-cavity not more than $5 \mathrm{~mm}$. in diameter which extends in about the same proportional width to beyond the middle of the tooth, and in all probability to near the apex. The cross-section of the tooth throughout is nearly or quite circular.

A hemisection of the tooth was made near the middle, showing a structure most remarkably like that of Mastodonsuurus; so nearly alike, in fact, that there is no difference from the large figure given by Owen of a section of Mastodonsaurus (502).

The discovery of this tooth in the Kansas Coal Measures is of great interest, proving, as it does, the presence of true labyrinthodonts from a lower horizon than elsewhere recorded. The discovery of Eobaphetes kansensis Moodie in the Carboniferous of Washington County (473) would seem to indicate another labyrinthodont. The tooth from Louisville was possibly not the first evidence of labyrinthodonts in North America, since the discovery by Marsh of Eosaurus acadianus from the Coal Measures of Nova Scotia, possibly a member of the Stereospondylia, antedates this discovery 30 years. The specimen is preserved in the Museum at the University of Kansas.

\section{AMPHIBIAN FOOTPRINTS FROM THE COAL MEASURES.}

Footprints may be said to be fairly common in the Coal Measures of North America. Especial attention has been given to the classification of these objects by G. F. Matthew (408-4I3), Dawson (208-210) and others. Hay (3I 7, pp. 538553 ) has given a catalogue of all the species described from the Coal Measures of North America, to which the reader is referred for further information in regard to these interesting evidences of former animal activities. The writer has not been interested in the taxonomy of footprints, but has studied such as have come to his notice (465). A description of the species Dromopus agilis Marsh (fig. 43) is given here, because there is a large slab in the University of Kansas Museum which has not been figured. Since the chief interest in the present contribution is morphology, footprints are thus scantily dealt with. Leidy (374), Dawson (207), Moodie (465, pl. Lxiv, fig. I) and others have given various brief descriptions of Coal Measures footprints, probably all of which are evidences of Amphibia which are otherwise unknown.

\section{Dromopus agilis Marsh.}

MARSh, Jour. Sci. (3), xLvir, p. 82, pl. ii, fig. 3; pl. iii, fig. 3, 1894.

Hay, Bull. U. S. Geol. Surv., No. 179, p. 543, 1902.

Type: Specimen in the Yale University Museum.

Horizon and locality: Osage limestone (Coal Measures), near Osage City, Kansas.

In I 894 Professor Marsh described a collection of footprints which he had secured from Professor B. F. Mudge, of Manhattan, Kansas, who had collected them in Osage County, Kansas, in a rock quarry, having purchased a large quantity of rock from the quarrymen for that purpose. A preliminary note by Mudge (490) 
was published in the Transactions of the Kansas Academy of Science and later copied in the American Journal of Science. Professor Marsh's description (406) of the remains is as follows:

"The impressions are well preserved in a calcareous shale, which separates readily into thin slabs, each representing a surface of the beach at the time the footprints were made upon it. A few shells in the shale are sufficient to prove that the formation is marine (no shells are evident in the slab at the Museum of the University of Kansas, but the slab is quite arenaceous). Trails of annelids, or perhaps of other invertebrates, are seen on some of the surfaces. The footprints of vertebrate animals, however, are of paramount importance, and the large number and variety of these here recorded on a single surface, if they could be rightly interpreted, would form an interesting chapter of land vertebrate life in the Carboniferous, about which so little is at present known."

Professor Marsh's description of Dromopus agilis is as follows:

"The third series of footprints is of special interest, and indicates an animal very distinct from the two already described. The diagram represents the impression of the phalanges sufficiently in detail to indicate (406) their number and general form. A striking feature in the fore and hind feet of this animal was the long, slender digits terminated by sharp claws. Another point of interest, as recorded in the footprints, is that the animal in walking swung the hind feet outward, and so near the ground that the ends of the longer toes sometimes made trails in the mud, marking accurately the sweep of the foot. This would seem to indicate a

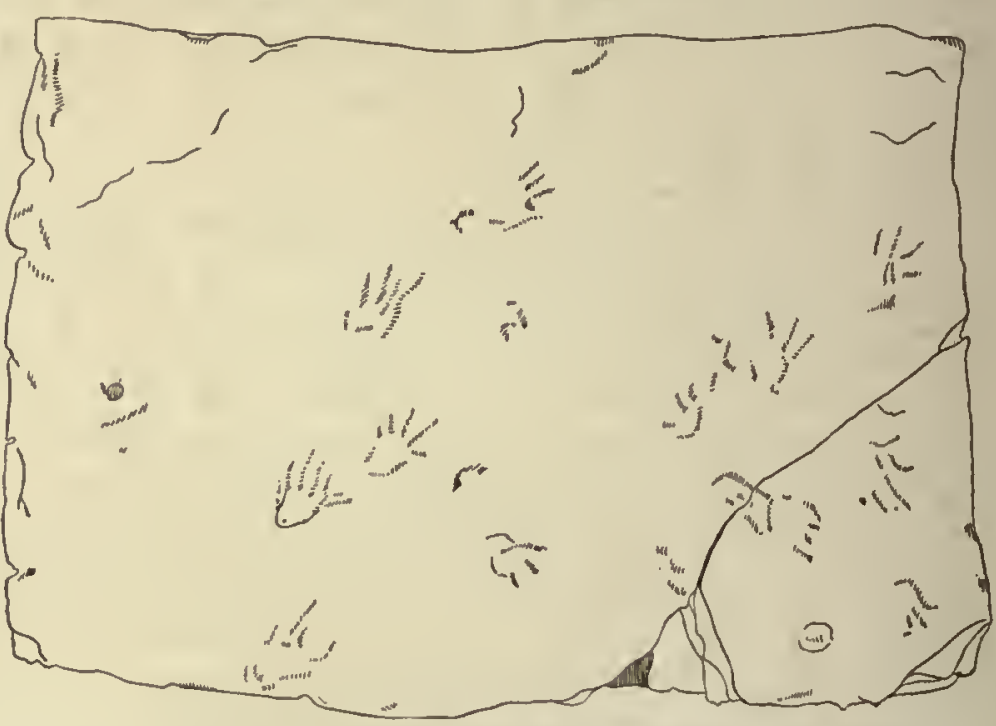

FIG. 43.-Footprints of Dromopus agilis Marsh, from the Coal Measures of Osage County, Kansas. Original slab in University of Kansas Museum. Greatly reduced. comparatively short hind leg, rather than the long, slender one which the footprints themselves naturally suggest.

"The animal which made these interesting footprints was probably a Lacertilian rather than an Amphibian, but there is also a possibility that it was a primitive Dinosaur."

Further on Professor Marsh remarks (p. 84):

"So far as at present known, land vertebrate life began in the Carboniferous age, no footprints of other remains of this kind having been detected below the Subcarboniferous. That such remains will eventually be found in the Devonian, there can be no reasonable doubt, and perhaps even in the Silurian, if the land surfaces then existing can be explored."

This last statement of Marsh's was, of course, partly demonstrated by the discovery of footprints in the Devonian rocks of Pennsylvania, which he described in I 896 as Thinopus anliquus. The footprints of Dromopus agilis Marsh which are 
preserved in obverse in the University of Kansas Museum are of considerably greater length than those described by Professor Marsh. The measurements of one of the larger impressions are appended. There appear to be series of footprints of two different animals preserved on the large slab ( 5 by 7 feet), but their nature is essentially the same.

\section{Mensurements of Large Footprint.}

$\mathrm{mm}$. $\mathrm{mm}$

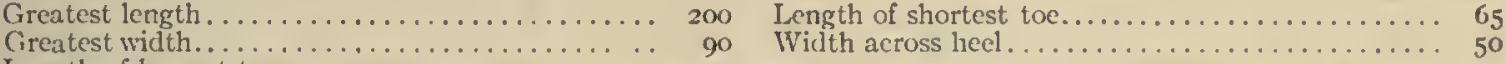

rength of longest toe...............

The slab is No. 5 of the University of Kansas Museum of Natural History, collected in 1873 by Professor B. F. Mudge at Osage, Kansas, and presented by him to the museum in 1875 .

The following list of Carboniferous amphibian (?) footprints is compiled from Hay's Catalogue of Fossil Vertebrates of North America. It is given here for the sake of completeness. Three types of amphibian footprints are described in the body of this work and they constitute the kind of material which an ichnologist has for the basis of his conclusions. The material is not very satisfactory for the morphologist, though much can be determined as to the foot structure.

\begin{tabular}{|c|c|c|c|}
\hline Genus and species. & Author. & Horizon. & Locality. \\
\hline 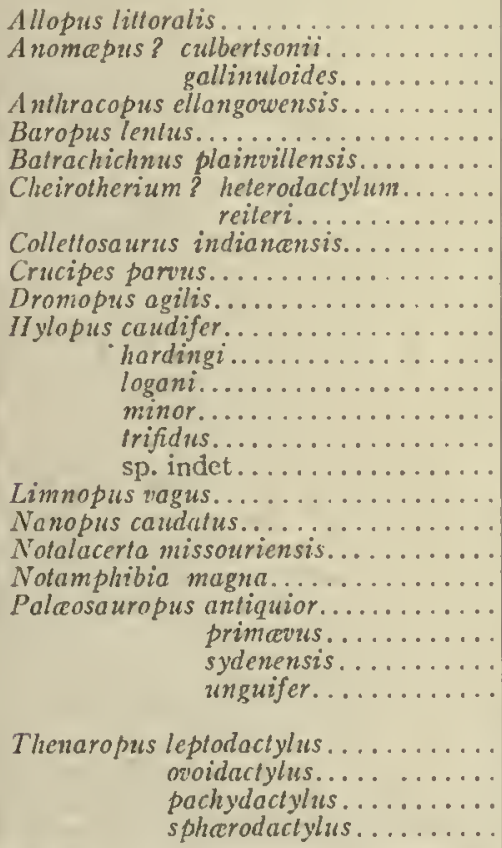 & 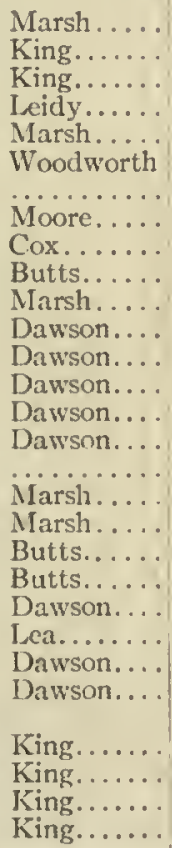 & 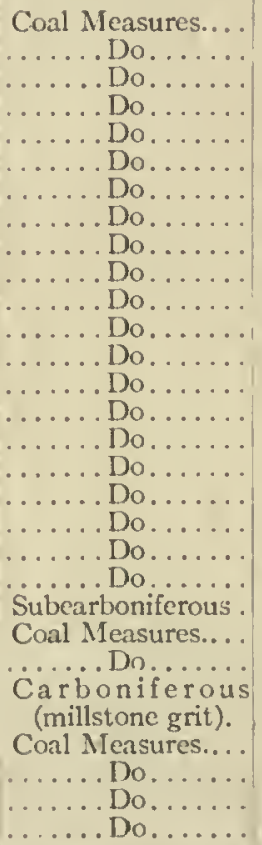 & $\begin{array}{l}\text { Osage County, Kansas. } \\
\text { Pennsylvania. } \\
\text { Do. } \\
\text { Do. } \\
\text { Osage County, Kansas. } \\
\text { Massachusetts. } \\
\text { Pennsylvania. } \\
\text { Do. } \\
\text { Indiana. } \\
\text { Mlissouri. } \\
\text { Osage County, Kansas. } \\
\text { Nova Scotia. } \\
\text { Do. } \\
\text { Do. } \\
\text { Do. } \\
\text { Do. } \\
\text { Do. } \\
\text { Osage County, Kansas. } \\
\text { Do. } \\
\text { Mlissouri. } \\
\text { Do. } \\
\text { Nova Scotia. } \\
\text { Pennsylvania. } \\
\text { Cape Breton Island. } \\
\text { Nova Seotia. } \\
\text { Pennsylvania. } \\
\text { Do. } \\
\text { Do. } \\
\text { Do. }\end{array}$ \\
\hline
\end{tabular}




\section{BIBLIOGRAPHY OF THE FOSSIL AMPHIBIA, WITH ESPECIAL REFERENCE TO THE AMPHIBIA FROM THE COAL MEASURES OF NORTH AMERICA.}

The following literature list, containing more than six hundred titles (1824-1916), is believed to be fairly complete. It certainly includes all of the important contributions to the subject of the fossil Amphibia. A few brief bibliographies of fossil Amphibia have appeared from time to time, in special memoirs on various faunas, such as: Broili (58), Schwarz (54r), Fraas (242), von Ammon (7), and Case (98). None of these have attempted a complete survey of the field. The references given below have all, or nearly all, been compiled from the original sources and every effort has been made to have them complete and accurate.

1. ABel, O. I9I2. Grundzüge der Paleobiologie der Wirbelthiere. 21 I-220, figs. I 44-1 50 .

2. AGASSIz, L. 1862. Highly interesting discovery of new Sauroid remains. Amer. Jour. Sci. and Arts, Jan., xxxiII, 138.

3. Albert, Fr. v. I834. Beitrag zu einer Monographie des bunten Sandsteins, Muschelkalks und Keuper.

4. - 1864. Ueberblick ueber die Trias. 235-24I.

5. AlBRECHT, P. I883. Note sur le Basioccipital des Batraciens Anoures. Bull. de Musee Roy. d'Hist. Nat. de Belgique, II, I95-I98, with figs. and a plate.

6. American Naturalist. I878. A new fauna. XII, 327-328 (Ed.).

7. ANMON, LUDWIG voN. 1889. Die permischen Amphibien der Rheinpfalz, Munich. I-117, pls. I-5, with extensive bibliography.

8. ANDREWS, C. W. 1895. Note on a specimen of Keraterpeton galvani Huxley, from Staffordshire. Geol. Mag., Dec., IV, II, 8 I-84, fig.

9. Arldt, Tueodor. 1907. Die Entwicklung der Kontinente und ihre Lebewelt. 333, Karte Io.

Io. - I - I909. Die Stegocephalen und ihre Stellung unter den Wirbelthieren. Naturw. Rundschau, XXIV, 353-355.

11. Atthey, T. 1876. On Antliracosaurus russelli. Ann and Mag. Nat. Hist., Ser. 4, XvıI, I 46-167, pls. 8-II.

12. BaIley, W. H. 1866. On the new discovery of fossil reptiles in the Carboniferous of southern Ireland. Geol. Mag., II, No. 20, 84 .

13. - 1875. Description of a new species of Labyrinthodont Amphibian from the Coal at Jarrow Colliery near Castlecomer, Kilkenny. Rept. Brit. Assn. Adv. Sci., 62. (Describes Anthracosaurus edgei.)

I4. - I884. Some additional notes on Anthracesaurus edgei Bailey. Rept. Brit. Assn. Adv. Sci., 96-97 (I 883).

15. BARKAS, T. P. I868. On the fauna of the low main Coal Seanl, Northumberland. Geol. Mag., v, 580 .

I6. - - I869. Unusual forms of Ctenoptychius. Geol. Mag., Jan., VI, 43, 2 woodcuts.

17. - 1869. On a supposed mamnalian tooth from the Coal Measures. Monthly Micros. Jour., II, IO
I8. BARKAS, T. P. I869. On the discovery of a molar of a large reptile in the Northumberland Coal Measures. Ann. and Mag. Nat. Hist., III, 419. (Pteroplax cornuta.)

19. - I 869 . Reptile Remains and Climadoxus. Ann. and Mag. Nat. Hist., IV, 438-440.

20. - 1873. A manual of Coal Measure paleontology. London.

2I. BARRELL, JOSEPH. 1906. Origin and significance of Mauch Chunk shale. Bull. Geol. Soc. Amer., XVIII, 460 .

22. Baur, George. I 886. Die älteste Tarsus (Archegosaurus). Zool. Anz., No. 216,9 Jahrg., 104-106.

23. - I 1886. The oldest Tarsus (Archegosaurus). Amer. Nat., Xx, $173-174$

24. - I 1886 . Ueber die Homologien einiger Schādelknochen der Stegocephalen und Reptilien. Anat. Anz., I, No. I3, 348-350.

25. - I I886. Ueber die Morphologie der Wirbelsāule der Amnioten. Biol. Centralb., vi, Nr. 1 I-I2, $322-342,353-363$

26. 1887 . On the morphology of ribs. Amer. Nat., Oct., 942-945 (Archegosaurus).

27. - - I 887. Nachträgliche Notiz zu meinen Bemerkungen ueber die Homologie der Schädelknochen der Stegocephalen und Reptilien. Anat. Anz., 2, No. 21, 657-658.

28. - -1888 . Morphogenie der Carpus und Tarsus der Wirbelthiere. Pt. I, Batrachia. Jena, Verlag von $\mathrm{G}$ ustav Fischer, $\mathrm{I}-88$, pls. I-3, figs.

29. - 1 1894. Bemerkungen über die Osteologie der Schlāfengegend der hōherer Wirbelthiere. Anat. Anz., $x, 315-330$.

30. - 1896. Bemerkungen über die Phylogenie der Schildkrōten. Anat. Anz., xIr, 561-570. (Dissorophus.)

31. - 1896. The Stegoceplali. A phylogenetic study. Anat. Anz., 2oten März, xi, No. 22, 657673 , with bibliography and eight figures:

32. - - 1897. Archegosaurus. Amer. Nat., XXXI, $975-980$.

32a.—. 1897. Ueber die systematische Stellung der Microsaurier. Amat. Anz., XIv, 148-I5I.

33. BAYER, Franz. I88o. Palæobatrachus bohemicus von Meyer, aus der Braunkohle von Freudenhain. Sitzber. d. k. böhm. Ges. Prag,, 29I-298, I taf. 
34. BEASLEY, II. C. 1900. Notes on the type specimen of Cheirotherium herculis Egerton. Proc. Liverpool Geol. Soc., XLII, 8 I, pl. v.

35. Bernard, Félix. I895. Elements de Paleontologie. Batraciens, $740-760$, with figs.

36. BeYrich, ERnst. 1850. Ueber einige organische Reste der Lettenkohlenbildung in Thueringen. Zeit. d. deutsch. geol. Gesell., II, 165.

37. Bieber, V. I880. Ueber zwei neue Batrachier der Böhm. Braunkohlenformation. Sitz. d. k. Akad. d. Wissen., Wien., LXxxı, abth. I, I17, taf. iii, fig. I.

38. Binney, E. W. 1883. Trans. Manchester Geol. Soc., vi, p. 42.

39. Blanchard, R. I881. Sur les Glandes cloacale et Pelvien et sur la Papille cloacale des Batraciens urodeles. Zool. Anz., Iv, 9, 34.

40. Blanford, W. T. 1884 . Address to the geological section of the British Association at Montreal 21 pp.; also Nature, $\mathrm{xxx}$.

4I. Bolkay, S. J. DE. 1911. On a Pleistocene predecessor of Rana fusca Rós. Mittheil. aus d. Jahrb. k. Ung. Geol. R., XIX, H. 3, 155-160, figs. I-7.

42. Bolton, H. I 896 . The animal life of the Lancashire Coal Measures. Trans. Manchester Micros. Soc., 123-135 (I 895).

43. 190. The paleontology of the Lancashire Coal Measures. Trans. Manchester Geol. Soc., xxvin, 378-420, 578-650, 668-689.

44. Boulenger, G. A. 1890. On the presence of pterygoid tecth in a tailless batrachian (Pelobates cultripes), with remarks on the localization of teeth on the palate in batrachians and reptiles. Proc. Zool. Soc. London, 664-666.

45. - r 1904 . On the characters and affinities of the Triassic reptile Telerpeton eligense. Proc. Zool. Soc. London, $470-480$, pl. $\mathrm{xxx}$.

46. - 1910. Les Batraciens et principalement ceux d'Europe. I. Paris.

47. Bradley, Frank H. 1870. Geology of Grundy County. Geol. Surv. Illinois, IV, Ig6.

48. BRANCo, W. I887. Weissia bavarica, nov. gen. et sp. von Stegocephalia, ein neuer Stegocephale aus dem unteren Rothliegenden. Jahrb. d. k. Preuss. Geol. Landesanstalt f. I 886, 22-39, taf. 1; also Neues Jahrb.f. Mineral., Geol. u. Paleon., 1888, 117.

49. Branson, E. B. I905. Structure and relationships of American Labyrinthodontidæ. Jour. Geol., XIrI, No. 7, 568-610, figs. 1-19.

50. - 1910. Amphibian footprints from the Mississippian of Virginia. Jour. Geol., xvıII, No.6, $356-358$, I fig.

51. Braun, M. von. 1841. Bericht über die Versammlung deutscher Naturforscher und Aertze. Braunschweig, 74-75. (Trematosaurus.)

52. BrAUN, M. 1878. Ueber āussere Hilfsorgane bei der Begattung von Triton viridescens. Zool. Anz., 1, 124.

53. British Museum. 1905. A guide to the fossil reptiles, amphibians and fishes in the department of gcology and paleontology in the British Museum (Natural History). 8 plates, I 6 figs., 8 th ed.

54. Brodie, P. B. I 859 . On the occurrence of foolsteps of Cheirotherium in the Upper Keuper of Warwickshire. Quart. Jour. Geol. Soc., XVI, 278.

55. Brolli, F. I 899 . Ein Beitrag zur Kenntniss von Eryops megacephalus Cope. Paleontographica, $\mathrm{XLVI}, 6 \mathrm{I}-84$, pls. $8-10$,
56. Broll1, F. 1902. Beiträgc zur Kenntniss von Diplocaulus Cope (D. magnicornis). (Paleontographica, $\mathrm{LI}$, 8.) Vorlåufige Mlitheilung, Centralb. f. Mineral., Geol. u. Paleon., 536-541, with figs.

57. - 1904. Stammreptilien. Ariat. Anz., xXV, No. $23,577-587$.

58. - 1904. Permische Stegocephalen und Reptilien. Paleontographica, LI, I-I 20, 5 pls.

59. - 1905. Beobachtungen an Cochleosaurus bohemicus. Paleontographica, $\mathbf{L}, \mathbf{I}-\mathbf{1} 6, \mathrm{pls} . \mathbf{1}-2$.

60. - 1906. Ein Stegocephalen Rest aus den Bayrischen Alpen. Centralb. f. Mineral., Geol. u. Paleon., No. 18, 568-571.

61. - 1908. Ueber die Rachitomen Wirbel der Stegocephalen. Monatsberichten d. deutsch. geol. Gesell., 60, Nr. 8/10, 235-240, figs. 1-7.

62. _- 1908. Ueber Sclerocephalus aus der Gaskohle von Nürschan und das Alter dieser Ablagerungen. Jahrb. d. k. k. Geol. Reichsanstalt, LVII, Heft I, 49-69, Taf. I.

63. - 1908. Systematische nnd Biologische Bemerkungen $\mathrm{zu}$ der permischen Gattung Lysorophus. Anat. Anz., XxxıII, Nr. I1/12, 290-298.

64. 1909. Reviews of Literature. Neues Jahrb. f. Mineral. Geol. u. Paleon., Bd. I1, Heft 1, 132-1 38.

65. - 1913. Ueber zwei Stegocephalenreste aus dem texanischen Pcrm. Neues Jahrb. f. Mineral., Geol. u. Paleon., Bd. 1, Heft 2, 96-100, Taf. Ix.

66. ___ 1913. Unser Wissen über die alltesten Tetra. poden. Fortschr. d. naturwissenschaftlichen Forschung, Halle, Bd. viII, 5i-93, figs. $14-62$.

67. Bronn, H. G. 1852-54. Lethea Geognostica, mit Atlas. Bd. I (2), Kohlen Periode, von F. Roemer.

68. Broom, R. I903. On a new Stegocephalian (Batrachosuchus browni) from the Karoo Beds of Aliwal North, South Africa. Geol. Mag., n.s., Dec., Iv, X, No. 473-499, I-2, figs.

69. - 1904. On a new South African Labyrinthodont (Cyclosaurus albertyni). Records of the Albany Museum, 1, No. 3 .

70. 1907. On the geological horizons of the vertebrate genera of the Karoo Formation. Records of the Albany Museum, I1, No. I.

71. - 1908. On a new Labyrinthodont (Rhinesuchus whaitsi) from the Permian beds of South Africa. Ann. So. African Museum, Iv, pt. virl, May 1908,373 .

72. - On the nomenclature of the elements of the amphibian shoulder girdle.

73. - 1910. A comparison of the Permian reptiles of North America with those of South Africa. Bull. Amer. Mus. Nat. Hist., xxvi1, art. xx, 197234.

74. 1913 . On the structure of the mandible in the Stegocephalia. Anat. Anz., Bd. 45, No. 2/3. $73-78$, figs.

75. 1913 . Studies on the Permian temnospondylous Stegocephalians of North America. Bull. Am. Mus. Nat. Ilist., xxxu, 563-595, 2 I figs.

76. Brown, Barnum. 1908. The Conard fissure, a Pleistocene bone deposit in northern Arkansas, witl description of two new genera and twenty new species of mainmals. Mem. Amer. Mus. Nat. Hist., IX, pt. Iv, 206, pl. XXIr.

77. BROWNE, M. 1893. On some vertebrate remains not hitherto recorded from the Rhxtic beds of Britain. Rept. Brit. Assn. Adv. Sci., 748. 
78. Brownrigg, W. B. I 865 . Jour. Roy. Geog. Soe. Ireland, I, pt. 2, I45.

79. BudGetT, J. S. I902. On the structure of the larval Polypterus. Trans. Zool. Soc. London, xvi, pt. vir, Oct.; also Works, $154-176$, pls. $x$-xii, I 907 .

80. Burmeister, H. I 840. Die Labyrinthodonten aus dem bunten Sandstein von Bernburg. 4 plates (same 1849) (?).

81. - I $\$$ - Die Labyrinthodonten aus dem Saarbrücken Steinkohlengebirge. Quarto, pls. 1-4.

82. BuTts, EDWARD. I $\$ 91$. Recently discovered footprints of the amphibian age in the Upper Coal Measure Group of Kansas City, Missouri. Kans. City Seientist, v, No. 2, I7-I9, figs.

83. - I89I. Footprints of new species of ampliibians in the Upper Coal Measure Group of Kansas City, Missouri. Kans. City Scientist, v, 44, figs.

84. Carus, J. Victor. 1875. Labyrinthodontia. Handbuch der Zoologie, Bd. I, 485-486.

85. CASE, E. C. 1898. The significance of eertain ehanges in the temporal region of the primitive reptilia. Amer. Nat., xxxir, No. $374,69$.

86. 1900 . The vertebrates from the Pcrmian bone bed of Vermilion County, Illinois. Jour. Geol., viII, 698-729, 5 plates.

87. - I902. On some vertebrate fossils from the Permian beds of Oklahoma. 2d Bieunial Rpt. Dept. Geol. and Nat. Hist. Territory Oklahoma, I90I-I902, 62-68.

88. — I I Po2. Paleontological notes. Jour. Geol., $\mathrm{x}$, $256-261$.

89. - I903. New or little-known vertebrates from the Permian of Texas. Jour. Geol, XI, 394-402.

90. - - 1907. Additional deseription of the genus Zatrachys Cope. Bull. Amer. Mus. Nat. Hist., xxIII, art. Xxix, 665-668.

91. — I907. Revision of the Pelyeosauria of North America. Pub. No. 55, Carnegie Inst. Washington, Stcgocephalia, I59.

92. - I908. On the value of the evidence furnished by vertebrate fossils of the age of certain so-called Permian beds in America. Jour. Geol., xvr, No. 6, $572-580$.

93. - 1908. Notes on the skull of Lysorophus tricarinatus Cope. Bull. Amer. Mus. Nat. Hist., XXIV, 53I-533, fig. I.

94. - 1908. Description of vertebrate fossils from the vicinity of Pittsburgh, $\mathrm{Pa}$. Annals of the Carnegic Museum, IV, Nos. III-IV, 234-24I, pl. lix, $\Lambda$ pr.

95. - I - I 08 . A great Permian delta and its verte. brate life, with restorations by the author. Pop. Sci. Month., Lxxir, No. 6, 557-568.

96. - 1910. New or little-known reptiles and amplibians from the Permian? of Texas. Bull. Amer. Mus. Nat. Hist., Xxvin, art. xviI, 163-I8I.

97. - I91I. A revision of the Cotylosauria of North America. Pub. No. 145, Carnegie Inst. Washington.

98. - I III. Revision of the Amphibia and Pisces of the Permian of North America. Pub. No. 146, Carnegie Inst. Washington, $1-148$, pls. $1-25,51$ text-figs.

99. - 1912. Palcozoic Reptilia and Amphibia. Bull. Geol. Soc. Amer., 23, 200-204.

100. - 1915. The Permo-earboniferous beds of North America and their vertebrate fauna. Pub. No. 207, Carnegic Inst. Washington, 1-176, pls. I-24.
10I. Chamberlin, T. C. 1900. On the habitat of the early vertebrates. Jour. Geol., vili, 400-412.

102. - and R. D. Salisbury. 1906. Geology, earth history. Amphibia, II, 606-6 Io.

103. Clark, C. T. 1847. On the neighborhood of Bombay and certain beds containing fossil frogs. Quart. Jour. Geol. Soc., III, 22I-224. (See Owen, I 847.)

I04. Colliery Guardian. Deseription of claspers of Amphibia. Mar. In, 187I. (Barkas.)

I05. COPE, IE. D. I 865. On $\Lambda$ mphibamus grandiceps, a new Batrachian fron the Coal Meastures. Proc. Acad. Nat. Sci, Phila., 134-137. Sce also Geol. Si1rv. Ill., Ir, I 35, fig., pl. 32, I 866 .

I06. - I 1866 . Remarks on extinct vertebrates of the Mesozoic Red Sandstone. Proc. Acad. Nat. Sci. Phila., 249. (Mastodonsaurus durus.)

107. - 1866. Supplement to the description of vertebrates. Geol. Surv. I11., II, 135-14I, fig., pl. 32, fig. 8. (Amphibamus.)

108. - I 866. On the structure and distribution of the genera of the arciferous Anura. Jour. Acad. Nat. Sci. Phila., 2d ser., v, 67-112.

I09. - I 1866 . On the families of Raniform Anura. Jour. Acad. Nat. Sci. Phila., 189 .

110. - 1868. Synopsis of the extinct Batrachia of North America. Proc. Acad. Nat. Sci. Phila., 208-221.

I I. - I 1868 . Two Batrachians from North Carolina. Proc. Acad. Nat. Sci. Phila., xx, 2 I I-212. (Pariostegus myops.)

112. - 1869. Synopsis of the cxtinct Batrachia, Reptilia, and $\Lambda$ ves of North America. Trans. Amer. Phil. Soc., xIv, 1-252, pls. I-14.

113. - 1871. Observations on extinct Batrachia. Proc. Acad. Nat. Sci. Phila., 53.

114. - I871. Supplement to the synopsis of the extinct Batrachia and Reptilia of North America. Proe. Amer. Phil. Soc., XII, 4I-52.

II5. - I 77 . Observations on the extinet Batrachian fauna of the Carboniferous of Ohin (Linton). Proc. Amer. Phil. Soc., xIr, 177.

116. - I872. Carboniferous reptiles of Ohio. Amer. Nat., vi, 46.

II7. - 1873. Observations on the distribution of eertain extinct Vertebrata in North Carolina. Proc. Ancr. Phil. Soc., xil, 2 IO-2 I6.

I18. - 1873. On some new Batrachia and Fishes from the Coal Measures of Linton, Ohio. Proc. Acad. Nat. Sei. Phila., 340-343.

I19. - I 874. Supplement to the extinct Batrachia, Reptilia and Aves of North Ameriea. I. Catalogue of the air-brcathing Vertebrata from the Coal Measures of Linton, Oliio. Trans. Amer. Plitl. Soc., xv, 26r -278 .

120. - I 1875 . Cheek-list of Nortl Ameriean Batrachia and Reptilia, with a systematic list of the higher groups and an essay on geographical distribution based on the spceimens contained in the U. S. National Muscum. Bull. U. S. Nat. Mus., I, 7-12.

121. - 1875. Synopsis of the Vcrtebrata whose remains have been preserved in the formations of North Carolina. Appendix " $\mathrm{b}$ " by Kerr, W. C. Rept. Geol. Surv. N. C., Raleigh, 29-52, pls. v-viii.

122. - I875. The extinet Batrachia of Ohio. Proc. Acad. Nat. Sci. Phila., 16. 
123. CurE, L. D. I875. Synopsis of the extinct Batrachia from the Coal Measures. Geol. Surv. Ohio, 11, pt. II, 35I-4I0, pls. xxvi-xlv.

124. - I876. On some extinet reptiles and Batraclia from the Judith River and Fox Hills Beds of Montana. Proc. Acad. Nat. Sci. Phila., 357; Pal. Bull. 23.

125. ——. 1876. Description of some vertebrate remains from the Fort Union Reds of Montana. Proc. Acad. Nat. Sci. Phila., 260. (Ccratodus hicroglyphus, an amphilian clasper?.)

126. - I877. On the fossil remains of Reptilia and fishes from Illinois. Proe. Acad. Nat. Sci. Phila., 405.

127. - 1877. On the Vertebrata of the Bone Bed of eastern Illinois. Proc. Amer. Phil. Soc., xvır, 53-64.

128. 1877 . Report on the geology of the region of the Judith River, Montana, and on vertebrate fossils obtained on or near the Missouri Rivcr. Bull. U. S. Geol. and Geog. Surv. of Territories, III, art. Xix, Batrachia, 573, 576 .

129. - 1877. Deseriptions of Vertebrata from the Permian and Triassic Formations. Proc. Amer. Phil. Soc., Xv11, I82-193.

130. - 1877. Extinct Vertebrata from Nortl Carolina. Proc. Amer. Phil. Soc., 17, 182.

131. - 1877. $\Lambda$ continuation of researches anong the Batrachia of the Coal Measures of Ohio. Proc. Amer. Phil. Soc, xvr, 57.3-578.

132. - 1 878 . Description of extinct Batrachia and Reptilia from the Permian of Texas. Proc. Amer. Phil. Soc., xvir, 522-526.

133. - 1878. The vertebra of Rachitomus. Amer. Nat., xIr, 63.3. (Eryops.)

134. - 1879. The relations of the horizons of extinct Vertebrata of Europe and North America. Bull. U. S. Geol. and Geog. Surv, of the Territories, V, No. 1, 33-34.

135. - 1880. Extinct Batrachia. Amer. Nat., Xrv, 609-610. Reviews Fritsch's and Wiedersheim's papers.

136. 1880 . The structure of the Permian Ganocephala. Amer. Nat., xIv, 383-384. (Eryops.)

137. - 1881. The Pennian Formation of New Mexico. Amer. Nat., xv, 1020-ro2I. (Eryops and Zatrachys.)

138. - I881. Catalogue of Vertebrata of the Permian Formation of the United States. Amer. Nat., $x v, 162-164$.

139. - 1881. Ein Uebergangsglied von den Amphibien zu den Reptilien (Cricotus). Auszug in Kosmos von Krause, Bd. 9, 230-23I.

140. - 1881. On some new Batrachia and Reptilia from the Perminn Beds of Texas. Bull. U. S. Geol. Surv. Terr., vi, art. II, 79-82.

141. - 1882. Third contribution to the history of the Vertebrata of the Permian Fornation of Texas. Proc. Amer. Phil. Soc., xx, 447-461: Pal. Bull. 35, 451.

142. 1882. The Rachitomous Stegocephalia. Aner. Nat., xvi, 335.

143. - 1882. Permian Vertebrata. Amer. Nat., $\mathrm{XVI}, 925$.

144. 1883 . Fourth contribution to the history of the Permian Formation of Texas. Proc. Amer. Phil. Soc., xx, 628-636.
I 45. Col'E, E. D. I883. On some Vertebrata from the Permian of Illinois. Proc. Acad. Nat. Sci. Phila., 108-110.

146. I 1 384. The Batrachia of the Jermian Period of North America. Amer. Nat., xvin, 26-39, pls. ii-v, 7 figs.

147. 1884 . Fifth contribution to the fauna of the Permian of Texas and Indian Territory. Proc. Amer. Phil. Soc., xxIr, 28-30, pl. I; Pal. Bull. 39.

148. - 1884. Note on the phylogeny of the Vertebrata. Amer. Nat., xviII, $1255^{-1256 .}$

149. 1885. The Batrachia of the Permian Beds of Bohemia and the Labyrinthodon from the Bijori Group, India. Amer. Nat., xix, 592-594. 150. - 1885. Paleontological nomenelature. Geol. Mag., London (3), II, 575. (Batrachia for Amphibia.)

151. - 1885. The Batrachia of the Permian Beds of Bohemia. Geol. Mag., london (3), 11, 527.

152. - 1885. Second continuation of researches among the Batrachia of the Coal Measures of Ohio. Proc. Amer. Phil. Soc., xxII, 405-408.

153. - 1885. On the evolution of the Vertebrata, progressive and retrogressive. Amer. Nat., dix, 244, Mar.

154. 1886 . On the structure and affinities of the Amphiumida. Proc. Amer. Phil. Soc., xxıI, No. 123, 442-445, July.

155. - 1886. The Batrachian intercentrum. Amer. Nat., $\mathrm{xx}, 76,175$.

I56. - 1886. Systematic catalogue of the species of vertebrates found in the Beds of the Permian Epoch of North America. Trans. Amer. Phil. Soc., XVI, 285-296, jls. ii-iii.

157. - I 1887. A contribution to the history of the Vertebrata of the Trias of North America. Proc. Amer. Phil. Soc., XxIv, 209. (Eupelor durus.)

158. - 1888. On the intercentrum of terrestrial vertebrates. Trans. Amer. Phil. Soc., Xvi, 243253. pI. I, 6 figs.

159. - I888. The Ossicula Auditus of the Batrachia. Amer. Nat., xxil, $464-467$, pl. vi.

160. - - I 888 . The pincal eye in extinct vertebrates. Amer. Nat., xxIt, 9I4-917, pls. xv-xviii.

I61. - - I888. On the shoulder girdle and extremities of Eryops. Trans. Amer. Phil. Soc., xvr, $362-367$, with plate.

162. 1888 . On the relation of the hyoid and otic elements of the skeleton in the Batrachia. Jour. Morphol., II, 297-310.

I63. I 1889. The Batrachia of North America. Bull. U.S. Nat. Mus., No. 34, I-v', $7-514$, pls. i-lxxxvi.

164. 1889. Synopsis of the families of Vertebrata. Amer. Nat., xxı11, 849-877. (Published in 1898 as "Syllabus of Lectures.")

165. 1892 . $\Lambda$ preliminary report on the vertebrate paleontology of the Llano Estacado. Geol. Surv. Texas, 4 th Ann. Rept., 12-17.

166. - 1892. On the phylogeny of Vertebrata. Proc. Amer. Phil. Soc., $\mathbf{x} x \mathrm{x}, 278-280$.

167. - I892. On some new and little-known Paleozoic vertebrates. Proc. Amer. Ihil. Soc., xxx, 221-229, pls. vii-viii.

168. - 1893. Fritsch's Fauna of the Gaskohle of Bohemia. Amer. Nat., xxvrr, 709.

169. - 1895 . Some new Batrachia from the Permian Beds of Texas. Proc. Amer. Phil. Soc., Xxxiv, 452-457, plate ix, Nov. 15 . 
170. CopE, E. D. I895. A Batra chianarmadillo. Amer. Nat., xxix, 998, Nov.

17 1. - 1 1896. The Paleozoic reptilian order Cotylosauria. Amer. Nat., $\mathrm{xxx}, 303$. (Describes Eosauravus copei Williston, oldest known reptile.)

172. - 1896. Permian land vertebrates with carapaces. Amer. Nat., xxx, 936, pl. xxi.

173. 1896 . The ancestry of the Testudinata. Amer. Nat., xxx, 399.

174. 1896. Appendix on a species of Trimerorhachis. Proc. Amer. Pliil. Soc., Xxxv, 137.

175. - 1896. The reptilian order Cotylosauria. Supplement: Some new Batrachia from the Permian beds of Texas. Proc. Amer. Phil. Soc., xxxiv, 455 .

176. - 1 1897. On new Paleozoic Vertebrata from Illinois, Ohio, and Pennsylvania. Proc. Amer. Phil. Soc., Xxxvi, 7I-90, three plates.

177. - 1898. Syllabus of Lectures on the Vertebrata. Batrachia, 43-51. Published for University of Pennsylvania.

178. Cox, E. T. 1874. Colettosaurus indianæensis. 5th Ann. Rept. Geol. Surv. Indiana, 24i, pl. 1.

179. Credner, HermanN. I881. Ueber Branchiosaurus amblystomus, einen neuen Stegocephalen aus den Rothliegenden-Kalke von Niederhässlich im Plauen'schen Gründe. ' Sitzungsb. naturf. Gesell. zu Leipzig, 43.

180. - 1881. Die Stegocephalen und Saurier aus dem Rothliegenden des Plauen'schen Grundes bei Dresden. I Theil: Einleitung und Branchiosaurus gracilis. Zeit. d. deutsch. geol. Gesell., xxxur, 298-329, taf. xV-xviii.

181. - 1881. Die Stegocephalen und Saurier, etc. II Theil: Branchiosaurus amblystomus. Zeit. d. deutsch. geol. Gesell., xxxiII, 574-603, taf. xxii-sxiv.

182. — 1881. Ueber einige Stegocephalen (Labyrinthodonten) aus dem sächsischen Rothliegenden. Sitzungsb. naturf. Gesell. Leipzig, 1-1 1. (Note on Branchiosaurus and Melanerpeton, 43. 45.)

183. - 1882. Ueber Melanerpeton Fritsch aus dem Rothliegenden-Kalk von Niederhāsslich im Plauen'schen Grundes. Sitzungsb. naturf. Gesell. Leipzig, 45-47.

184. - 1882. Die Stegocephalen und Saurier, etc. III Theil: Pelosaurus laticeps, Archegosaurus decheni, A. latirostris. Zeit. d. deutsch. geol. Gesell., Xxxıv, 21 3-237, tafeln xii-xiii.

185. - 1883. Die Stegocephalen und Saurier, etc. IV Theil: Branchiosaurus gracilis, Acanthostoma vorax, Melanerpeton, Discosaurus permianus. Zeit. d. deutsch. geol. Gesell., xxxv, 275300 , tafeln xi-xii.

186. 1885. Die Stegocephalen aus dem Roth. liegcnden des Planen'schen Grundes bei Dresden. $V$ Theil: Melanerpeton pulcherrimum, Pelosaurus laticeps, Archegosaurus; Sparagmites arciger, Hylonomus fritschii, Hyloplesion. Zeit. d. deutsch. geol. Gesell., xxxvir, 694-736, tafeln xxvii-xxix.

187. - I886. Die Stegocephalen aus dem Rothliegenden des Plauen'schen Grundes bei Dresden. VI Theil: Die Entwickelungsgeschichte von Branchiosaurus amblystomus Cred. Zeit. d. deutsch. geol. Gesell., xxxvır, 576-633, tafeln xvi-xix.
188. Credner, Hermann. 1886. Archegosaurus Reste ans dem Rothliegenden v. Offenhach. Zeit. d. dcutscls. geol. Gesell., xxxvin, 696.

189. 1 1890. Die Stegocephalen und Saurier aus dem Rothliegenden des Plauen'schen Grundes bei Dresden. IX Theil: Hylonomus geinitzi, Petrobates truncatus, Discosaurus permianus. Zeit. d. deutsch. geol. Gesell., XuII, 240-277, tafeln ix-xi, figs.

190. - 1887. Stegocephalen des Rothliegenden. Wandtafeln mit Erlâuterungen, Leipzig. Folio. Tafel i, Branchiosaurus amblystomus; Tafel ii, Pelosaurus laticeps and Melanerpeton pulcherrimum.

191. - 1888. Wandtafeln mit Stegocephalen des Rothliegenden. Neites Jahrb. f. Mineral. Geol. u. Paleon., Bd. 1, 67-69.

192. - I I - Die Urvierfüssler (Eotetrapoda) des Săchsischen Rothliegenden. Allgemein-verständliche naturwiss. Abhandl., Heft 15. SonderAbdruck aus der "Naturwisserschaftlichen Wochenschrift," 4-52, 53 figs.

193. - 1893. Die Stegocephalen und Saurier aus dem Rothliegenden des Planen'schen Grundes bei Dresden. X'Theil: Sclerocephalus labyrinthicus H. B. Geinitz. Zeit. d. deutsch. geol. Gesell., xLV, 639-704, tafeln xxx-xxxii.

194. - _ - 1893. Zur Histologie der Faltenzähnc Paleozoischer Stegoccphalen. Abhandl. Sāchs. Gesell. Wiss., $\mathrm{xx}, 545^{-55} \mathrm{I}$.

195. - 1897. Flemente der Geologie. Amplibia, 489-494.

196. Cummins, W. F. 1908. The localities and horizons of Permian vertebrate fossils in Texas. Jour. Geol., xvi, 737-745.

197. Cuvier, Georg. 1825. Des Batrachiens fossiles. Recherches sur les Ossemens Fossiles, 3 d ed., 431$444, \mathrm{v}, \mathrm{pt}$.11. (Homo diluvii test is et theoskopos.)

198. Davison, Alvis. 1895. A contribution to the anatomy and phylogeny of Amphiuma means. Jour. Morphol., NI, 375-410, 2 pls. (See Kingsley, Tufts College Studies, No. 7.)

199. DAVIS, JAMES W. I883. On the occurrence of remains of Labyrinthodonts in the Yorkdale rocks of Wensleydale (Carboniferous). Rept. 53d Meeting Brit. Assn. Adv. Sci., Southport, Sept., 492; see also Nature, Xxvili, 578.

200. DAwson, J. W. 1853. On the Coal Mcasures of the South Joggins, Nova Scotia. Quart. Jour. Geol. Soc., $x, I-4 I$, with bibliography of papers on the conl fields of Nova Scotia.

201. - I855. Acadian geology. Edinburgh, 1855 , Amphibia, 160.

202. - I887. Carboniferous quadrupeds. The Story of the Earth and Man, 143-150. 9th ed.

203. — - 1855. Notice of the discovery of a reptilian skull in the Coal Measures of Pictou (Nova Scotia). Quart. Jour. Geol. Soc., XI, 8-9.

204. - - I 859. New species of reptiles from the Coal Formution of Nova Scotia. Quart. Jour. Geol. Soc., Xvi, 273. (Describes Hylonomus.)

205. - I860. On the terrestrial Molluska, a chilognathus Myriapod and some new species from the Coal Formation of Nova Scotia. Quart. Jour. Geol. Soc., Xvi, 268.

206. - 1862. Additional remains of land animals in the Coal Mensures of Nova Scotia. Quart. Jour. Geol. Soc., Xvili, 5-7. 
206a. D.twso, J. W. 1862. Descriptions of specimens of fossil Reptilia discovered in the Coal Measures of the South Joggins, Nova Scotia. Quart. Jour. Geol. Soc., xvi11, 238-244, pls. ix, x.

207. - 1863. Note on the footprint of a reptile from the coal of Cape Breton. Canadian Naturalist and Geologist, vut, 430-431, I fig.; review in Neues Jahrb. f. Mlin., Geol, u. Paleon., 64,752 .

208. 186.3. Air-breathers of the Coal Period. Montreal, I-IV, 1-8I, pls. I-6. (A descriptive account of the remains of land animals found in the Coal Formation of Nova Scotia, with remarks on their bearing on the theories of the formation of coal and of the origin of species.] See also Jour. Geol. Soc., XVI, 273; Xvili, 5-19, 470; also Neues Jahrb. Mincral., Geol. u. Paleon., $1864,507$.

209. - 1863 . Notice of a new species of Dendrerpeton and of the dermal covering of certain Carboniferous reptiles. Quart. Jour. Geol. Soc., XI.x, $469-473$.

210. 1863 . Air-breathers of the Coal Period. Canadian Naturalist and Geologist, virr, 1-12, $81-92,161-175,268-295$, with pls. 1-6.

$211 .-1863$. The Air-breathers of the Coal Period. Amer. Jour. Sci. (2), XxxvI, 430-432.

212. - 1868. Land animals of the Coal Period. Acadian Geology, 1868, 2d ed., cliap. XviII, 353382.

213. 1870 . Note on some ncw animal remains from the Carboniferous and Devonian of Canada. Geol. Mlag., VII, 87: Quart. Jour. Geol. Soc., xxvı, J66-167; Canadian Naturalist (2), v, 98-99. (Same paper in all: Baphetes minor.)

$214 .-1876$. On a recent discovery of Carboniferous Batrachians in Nova Scotia. Amer. Jour. Sci. (3), XII, 440-447.

21.5. - 1878. Acadian geology. Supplement to 3 d edition, London, Amphibia, 57-65.

216. - 1882. On the results of the recent explorations of the erect trees containing animal remains in the Coal Formation of Nova Scotia. Phil. Trans. Roy. Soc. London, CLxxiI, pt. II, 621654 , pls. 39-47.

$217 .+1882$. On the results of recent explorations of the erect trees (Batrachia). Canadian Naturalist (2), x, 252-254. (Abstract.)

218 . 1891 . On new specimens of Dendrerpeton acadianum, with remarks on other Carboniferous Amphibians. Geol. Mag. (3), VIII, I45-156, 4 figs.

219. 4 . 189 I. Note on Hylonomous lyelli, with photographic reproduction of skeleton. Geol. Mag., n. s., Dec., III, virt, 258-259, pl. 8.

220. - 1891 . On the mode of occurrence of remains of land animals in erect trecs of Nova Scotia. Trans. Roy. Soc. Canada, IX. sec. IV, 127-128.

221. - I 189.4 . Some salient points in the seience of the earth. The Oldest Air-breathers, chap. $x$, 259-307, with restorations and figures.

222. 1894 . Preliminary note on the reent discoverics of Batrachians and other air-breathers in the Coal Formation of Nova Scotia. Canadian Record of Science, vi, 1-7, I fig.

223. - 1895. Synopsis of the air-breathing animals of the Paleozoic of Canada (up to 1894 ). Trans. Roy. Soc. Canada, $x I$, sec. Iv, $7 \mathrm{I}-78$.
224. Detchmuelter, J. V. 1882. Ueber "Die Stegocephalen aus dem Rothliegenden des Plauen'schen Grundes bei Dresden. III Theil: von H. Crcdner." Sitzungsb. Isis, Dresden, $7 \mathbf{t}$.

225. 1884. Ueber Branchiosaurus petrolei, Nachtrảge zur Dyas III. Mittheilungen des $\mathrm{kgl}$. mineral. geol. u. praehist. Musetum in Dresden, Heft 6, Paleontol. Abhandl. aus dem Dresdener Museum, 5-17, Taf. 1 .

226. Dollo, Lours. 1884 . Note sur le Batracien de Bernissart. Bull. Mus. Roy. Hist. Nat. Belg , IIt, 85-93, pl. iii. (Hylzobatrachus croyii from the Wealden.)

227. - 1885. Les Labyrinthorlontes. Rev. Quest. Scientif. Bruxelles, xvir, 305-312.

228. - 1895. Sur la Pbylogenic des Dipneustes. Bull. Soc. Belge de Geol. Paleont. Hydrol., rx, $79-178$, pls. $v-x$. (Disctisses relations to the Amphibia.)

229. DUNLOP, ROBERT. 1910. 'The fossil Amphibia in the Kilmarnock Museum previous to the fire of November 26, 1909. Annals Kilmarnock Glenfield Ramblers Society, No. 6, 10, 2 pls.

230. Eastman, Chas. R. 1902. The Carboniferous fish fauna of Mazon Creek, Illinois. Jour. Geol., X, 535-541, with list of fossil vertebrates.

231. 1902. Translation of Zittcl's Text-book of Paleontology, vol. II, 114-1 39, figs. 193-235.

232. 1907. Devonic fishes of the New York Formations. Memoir No. 10, New York State Mus., $180-183$.

233. Eichwald, E. I 848 . On Zygosaurus lucius from the Permian of Russia. Bull. de la Soc. imp. des Natl. de Moseors, XXI, 159.

234. - 1860. Lethæa rossica ou Paleontologie de la Russie, I, Stuttgart. 1620-1633, tafeln 57-59, Labyrinthodonten.

235. Embleton and Attuey. 1874. On the skull and other bones of Loxomma. Anr. and Mag. Nat. Hist., ser. 4, xiv, 38-63, pls. iv-vii.

236. Emery, C. 1897. Die fossilen Reste von Archegosaurus und Eryops und ihre Bedeutung für die Morphologie des Gliedmassenskelets. Anat. Anz., XIv, No. 8, 201-208, figs. 1-7.

237. Emmovs, E. 1857. Perm und Trias System in Nord Carolina. Edinb. n. Phil. Jour., v, 370.

238. - 1857. Dictyocephalus elegans Leidy. American Geology, pt. vi, Labyrinthodonts, 59, figs. $3 \mathrm{I}-32$.

239. - 1863. Dictyocephalus elegans Leidy. Mantwal of Geology, New York. labyrinthodonts, 180,184 .

240. EmMrich, A. 1852. Bericht ucher die Naturforscherversammlung in Gotha im Jahre 1851 . Jahrb. d. k. k. geol. Reichsanstalt, p. 155, Wien.

241. Etheridge, Robert, 1866. On the discovery of scveral new Labyrinthodont reptiles in the Coal Measures of J reland. Geol. Mlag., 11t, 4. (See Huxley, 1867.)

242. FraAs, E. 1889. Die Labyrintluodonten der Schwäb. ischen Trias. Palcontograplica, Xxxvi, I-I58, with bibliography.

243. - 1896. Die Schwäbischen T'rias-Saurier. Festgabe des konniglichen naturalien Cabinets in Stuttgart zur $\$ 2$ Versammlung der deutsch. geol. Gesell., Stuttgart, 1-8, pls. i-ji. 
244. FraAs, E. I90I. Labyrinthodon aus dem Buntsandstein von Teinach. Jahreshefte des Vereins $\mathbf{f}$. vaterlandische Naturkunde in Würtemberg, Jahr., LVII, 318-320.

245. - 1903. Die geognostische Sammlung Würtembergs im Parterre-Saal zugleich ein Leitfaden für die geologischen Verhăltnisse und die vorweltlichen Bewohner unseres Landes. 2 d Auflage.

246. - I903. Rana danubina H. von Meyer var. rara, O. Fraas aus dem Obermiocän von Stcinheim. Jahreshefte des Vereins f. vaterl. Naturkunde in Würtemberg, Jahr. 1903, I05-1 10, with fig.

247. - I9n9. Rana hauffiana n. sp. aus den Dysodilschiefern des Randecker Maares. Jahreshefte des Vereins f. vaterl. Naturk. in Würtemberg, Jahr. Igo9, 7 , with I fig.

247a. - 1913. Neue Labyrinthodonten aus der schwäbischen Trias. Palcontographica, Bd. LX, 275-294, pls. xvi-xxii, with text-figs. $1-5$.

248. Frech, Fritz. Igor. Lethaea geognostica oder Beschreibung und Abbildung der für die Gebirgsformation bezeichnendsten Versteinerungen. I Theil, Lethæa palæozoiea, 2 band. Die Dyas, 459-471, 22 figs., pl. 56.

249. FRITSCH, ANTON. 1870. Sitzungsberichte der k. Gesell. d. Wissen., April 27, 1870. (Describes 2 new species of Amphibia.)

250. - 1875. Ueber die Fauna des Pilsner und Rakonitzer Beckens. Sitzungsb. d. k. Boehm. ischen Gesell. d. Wissenschft., March.

251. - I883-1899. Fauna der Gaskohle und der Kalksteine der Permformation Boehmens. Bd. $x$, I-182, II 6 figs. Tafeln i-xlviii; Bd. II, I-64, figs. I 17-I 42, Tafeln xlix-lxx; Bd. IV, supplement 8598, figs. 383-394, Tafeln clxiii-clxiv. This is the chief work on extinct Amphibia.

252. - 1895. Ueber neue Wirbelthiere aus der Permformation Boehmens, nebst ciner Uebersicht der aus derselben bekannt gewordenen Arten. Sitzungsber. d. k. Boehmisch. Gesell. der Wissenschaften, Prag, $\mathbf{I}$.

253. - - 1905. Vorlāufige Notiz ueber Miscellanea Paleontologica aus Boehmen und America. Sitzungsber. d. k. Boehm. Gesell. der Wissenschaften, Prag, Kammplatten, 3.

254. Fritsch, KarL FreIherR. I 879. Referat ueber Gaudry's Sur les Reptiles des Temps primier; Nachweis von Protriton petrolei bei Oberhof in Thueringen. Neues Jahrb, f. Mineral. Geol. u. Paleon., 720.

255. Fuchs, Hugo, 1909. Betrachtungen ncber die Schläfengegend am Schädel der Quadrupeda. Anat. Anz., Xxxv, No. 5/7, II $3-167,25$ figs.

256. Gadow, Hans. 1896. On the evolution of the vertebral column of Amphibia and Amniota. Phil. Trans. Roy. Soc. London, ser. B, CLxxxvir, $1-57,56$ figs., and bibliography.

257. 1901. Amphibia and reptiles. Cambridge Nat. Hist., vin, Stegocephala, 8o. London.

258. Gaudry, Albert. I 866 . Note sur le Reptile découvert a Muse. Comptes Rendus de l'Academie de Science, August, 3+1.

239. - 1867. Mémoire sur le Reptile découvert par M. Frossard à Muse. Nouv. Archiv du Musce d'Hist. Nat., III, 22-40, pl. iii.

260. - 1868. Note sur L'Actinodon frossardi. Bull. Soc. Geol. de France, Ser. 2, xxv, 576 .
26I. Gaudry, Albert. 1874. Les Êtres de Temps primaire. Revue Scientifique, ser. 2, XIII, 993.

262. - - 1875. Les Reptiles des Schistes bitumineaux d'Autun. Bull. Soc. Geol. de France, 3d ser., IV, 720 .

263. - 1875. Sur la Découverte de Batraciens proprement dits dans le Terrain primaire. Comptes Rendus, Lxxx, 44I-443.

264. - 1875. Sur la Découverte de Batraciens dans le Terrain primaire. Bull. de la Soc. Geol. de France, ser. 3, III, 300-306, pls. vii-viii. (See also 263 above; Jour. Zool., Iv, 38-4I, 342.)

265. - 1876. Les Reptiles des Schistes bitumineux d'Autun. Bull. Soc. Geol. de France, ser. III, IV, 720-723, pl. xxii; 1879 , vII, $62 ; 1885,3$ d ser., xi11, 44 .

266. - 1878. Sur les Reptiles de Temps primaires. Comptes Rendus, Lxxxvir, 956.

267. - 1878. Les Vertebrés fossiles des environs d'Autun. Bull. Soc. Geol. France, vir, 62.

268. - I878. Les Reptiles d. l'Époque Permienne aux Environs d'Autun. Bull. Soc. Geol. de France, ser. 3 , vII, $62-76$, pls. iii-iv.

269. - I880. Sur un Reptile très perfectionné trouvé dans le terraine Permien. Comptes Rendus, $\mathrm{xCI}, 669-67 \mathrm{I}$.

270. - I881. Sur les plus anciens Reptiles trouvés en France. Comptes Rendus Acad. Sei. Paris XCII, II 43 -1 145 .

271. - I 881 . On a highly organized reptile from the Pcrmian Formation. Amer. Nat., viI, 67-71.

272. - 1883. Les Reptiles primaires. Arch. Zool. Exper., 2d ser., I, 5-30, pls. I-7. with figs.

273. - I883. Les Enchainements du Monde animal dans les Temps géologiques. Fossiles Primaires, with 4 figs. Paris.

274. - I 1884. Nouvelle Note sur les Reptiles Permiens. Bull. Soc. Geol. de France, 3 ser., xIII, 44-5I, pls. iv-v. Paris.

275. I I 1884 . Nouvelle Note sur les Reptiles Permiens. Comptes Rendus Acad. Sci. Paris, xcix, 737-738.

276. - 1885. Paleontology in. Germany and America. Revue Sci., 7, Paris; Geol. Mag. (3), II, London.

277. - - I886. Sur un nouveau Genre de Reptile du Permien d'Autun. Bull. Soc. Geol. de France, ser. III, XIV, 430-433, taf. 23 .

278. - 1887. L'Actinodon. Nouvelles Archives Mus. Hist. Nat., Paris, 2 d scr., x, 30 pp., 3 pls.

279. - 1888. Les Vertébrés fossiles des environs d'Autun. Mém. Soc. d'Hist. nat. d'Autun, 90 pp. et 6 planches.

280. - I 285 . Sur les Similitudes que plusiers Reptiles ont cues dans divers Pays de Monde ver la Fin des Temps primaires. Compte Rendus de la 3 d session Congrés géologique international a Berlin, $\mathbf{I}-4$.

281. - I L I Les Vértebrés fossiles des environs d'Autun. Autun.

282. —— I 890. Les Enchaînement du Monde Animal dans les Temps Géologiques, Fossiles Secondaires. Amphibia, 169.

283. Gaupp, Ernst. I895. Beiträge zur Morphologie des Schädels. III: Zur vergleichenden Anatomie der Schläfengegend am knôchernen WirbelthierSchădel. Morphologische Arbeiten herausgegeben von G. Schwalbe, IV, 1, 77-128. 
284. Gegenbaur, CARL, 1862. Untersucliungen zur vergleichen. Anatomic der Wirbelsăule bei Amphibien und Reptilien. Leipzig.

285. - I895. Clavicula und Cleithrum. Morphol. Jahrb., XXIII, 1-20.

286. GEIKIE, ARCIIJBALD, I905. Scheuchzer's "Fossil Man." Founders of Geology, 2d ed., 98-99. London.

287. GEINITz, H. B. 1864. Palxosiren beinertii Gein. ein neues Reptile aus der unteren Dyas von Oelberg bei Braman. Neues Jahrb. f. Mineral. Geol. u. Paleon., 513-516.

288. - 1885. Ueber Thierfährten in der Steinkohlenformation von Zwickau. Festschrift Natur. Gesell. Isis, 63-66, pl. 2.

289. und Deichmueller. I 882. Ueber die fossilen Saurier in dem Kalke des Rothliegenden bei Dresden. Sitzungsber. Isis, 6-9.

290. - 1882. Die Saurier des unterer Dyas von Sächsen. Paleontographica, XXIx, 9-46, pls. 1-9.

29i. Gergens, Dr. 1844. Letter to Professor Bronn announcing the discovery of the Apatheon described by von Meyer as an amphibian. The first announcement of Amphibia from Carboniferous. Neues Jahrb. f. Mineral., Geol. u. Paleon., 49.

292. Gieber, C. G. I 847 . Fauna der Vorwe!t mit steter Berücksichtigung der lebenden Thiere. Amphibia in Bd. I, Abth. 2, I65-2 I 3 .

293. - 1854. Odontography, Leipsic.

294. GoldenburG, Fr. 1873. Fauna Saræpontana fos silis-Die fossilen Thiere aus der Steinkohlenformation von Saarbrücken. Heft I, p. 4, Taf. I, fig. I. (Anthracosaurus raniceps.)

295. GoldFuss, DR. A. 1831. Beitrăge zur Kenntniss verschiedener Reptilien der Vorwelt. Reptilien aus der schieferigen Braunkohle. Verhandlungen der k. leop. Carol. Akad. d. Naturf., xv, Abth. I $117-126$, pls. xii-xiii.

296. - 1847. Ueber das ålteste der mit Bestimmtheit erkannten Reptilien. Neues Jahrb. f. Mineral. Geol. u. Paleon., 400, taf. 6. (Archegosaurus.)

297. 1847. Beitrăge zur vorweltlichen Fauna des Steinkohlengebirgen. Bonn, quarto, taf. I-3.

298. Goodrich, E. S. IgII. On the segmentation of the occipital region of the head in the Batrachia Urodela. Proc. Zool. Soc. London, I0I-120, figs.

299. Gregory, IV. K. I9II. The limbs of Eryops and the origin of paired limbs from fins. Science, n. s., XXXIII, No. 848, 508-509.

300. - 1913. Crossopterygian ancestry of the Amphibia. Science, n. S., XxxviI, No. 96o, 806808.

300a. - 1915. Present status of the problem of the origin of the Tetrapoda, with special reference to the skull and paired limbs. Ann. New York Academy of Science, Xxvi, 317-383, pl. iv. (Stegoccphali, p. 365.)

301. Günther, Albert. 1889. On sexual differences found in bones of some recent and fossil species of frogs and fishes. Ann. and Mag. Nat. Hist., ser. 3, IV, 377 .

302. GÜrICH, G. I884. Ueber cinige Saurier des oberschles. Muschelkalkes. Zeit. d. deutsch. geol. Gesell., Xxxvi, I4I.

303. HaNcock, A. 1869. Note on Anthracosaurus. Ann and Mag. Nat. Hist., $4^{\text {th }}$ scr., Iv, 270.
304. HANCock and Atruey. 1868. Notes on the remains of some reptiles and fislics from the shales of the Northumberland Coal Ficld. Ann. and Mag. Nat. Hist., 4 th Ser., 1, 266-278, pls. xiv-xvi.

305. - - 1869. On a new Labyrinthodont Amphibian from the Northumberland Coal Field and on the occurrence in the same locality of Anthracosaurus. Ann. and Mag. Nat. Hist., scr. 4, Iv, 182-189; also Nat. Hist. Trans. Northumberland and Durham, III, I869, 330. (Urocordylus reticulatus.)

306. - 1870. On Urocordylus, Ptcroplax. Nat. Hist. Trans. Northumberland and Durham, IIr $30,79$.

307. 1870. On the occurrence of Loxomma allmanni in the Northumberland Coal Field. Ann and Mag. Nat. Hist., ser. 4, v, 374-379.

308. - 1870. Description of a Labyrinthodont Amphibian; a ncw generic form obtained in the Coal Shales at Newsham. Ann. and Mag. Nat. Hist., ser. Iv, vi, 56-65, pl. i. (Batrachiderpeton lineatum.)

309. - 1871. Description of a considerable portion of a mandibular ramus of $\Lambda$ thracosaurus russelli, with notes on Loxomma and Archichthys. Ann. and Mag. Nat. Hist., 4th ser., vil, 73, pl. vi.

310. - 1871. Batrachiderpeton. Nat. Hist. Trans. Northumberland and Durham, Iv, 208.

3I I. HANCOCK and HowSE. 18;0. On a new Labyrinthodont Amphibian from the magnesium limestone of Midderidge, Durham. Quart. Jour. Geol. Soc., xxvi, 556-564, pl. 38. Permian of Eng. land, Lepidotosaurus duffii, a Labyrinthodont of some 3 to 4 fect in length.

312. HAECKel, ERNST. 1895. Systematische Phylogenic der Wirbelthiere (Vertebrata). Amphibia, 266283. Also History of Creation, Trans., 5 th ed. 1909, II, 295-300.

313. Hatch and Corstorpiline. 1905. The geology of South Africa. The Karoo System, 194.

314. Hatciler, J. B. 1905. The vertebrate fauna of the Judith River Beds. Bull. U. S. Geol. Surv., No. 257,67-103. (Scapherpeton and Hemitrypus.)

315. HAY, O. P. 1890. The skeletal anatomy of Amphiuma during its early stages. Jour. Morphol., Iv, 1 I-34, with pls.

316. - 1900. Description of some vertebrates of Carboniferous Age. Proc. Amer. Phil. Soc., Xxx1x, No. I61, 96-123. (Anphibamus grandiceps.)

317. 1902. Catalogue and bibliography of fossil Vertcbrata of North America. Bull. U. S. Geol. Surv., No. 179, Batrachia, 409-425.

318. Hrckling, G. Ig09. British Permian footprints Mem. and Proc. Manchester Lit. and Phil. Soc., 53,30, pl. 3 .

319. Hilton, Wis. A. 1902. A structural feature connected with the mating of Diemyctylus viridescens. Amer. Nat.. Xxxvi, 643.

320. Hoepen, E. C. N. va., 1915. Stegocephalia of Senekal. Ann. of the Transvaal Mfus., v, No. 2, 125-149, pls. xvi-xxiv.

321. Hoernes, RUd. 1884. Elemente der Palcontologie, 445-453. Lcipzig.

322. HoFFMAN, A. II. 1873-78. Amphibien. Bd. VI, 2d Abth., Bronn's Classen und Ordnungen des Thierreiches. 
323. HUENE, FRIEDRICH YON. 1902. Uebersicht ueber die Reptilien der Trias. Geol. u. Paleon. Abhandl., N. F., VI, H. I, 20, 21,8 I.

324. - I9 10. Neubeschreibung des Permischen Stegocephalen-Dašyceps bucklandi aus Kenilworth. Geol. u. Paleon. Abhandl. herausgegeben v. E. Koken, N. F., vir, H. 6, 33-46, fig. pl. i, ii.

325. — - 1912. Beiträge zur Kenntniss des Schādels von Eryops. Anat. Anz., Bd. 41, pp. 98-104, figs.

326. - 1913. Ueber Lysorophus aus dem Perm von Texas. Anat. Anz., Bd. 43, 389-396.

327. - 1913. The skull elements of the Permian Tetrapoda in the American Museum of Natural History, New York. Bull. Am. Mus. Nat. Hist., XXxi1, 315-386, 57 figs.

328. Huxley, Thomas Henry. 1859. On Dasyceps bucklandi (Labyrinthodon bucklandi Lloyd). Mem. Geol. Surv. United Kingdom, 52-56, figs. 1-2; Scientifie Memóirs, 11, 263, figs. $1-2$.

329. —- 1859. On a fragment of a lower jaw of a large Labyrinthodont from Cubbington. Mem. Geol. Surv. United Kingdom, 56-57; Scientific Memoirs, II, 269.

330. - 1859. On some Amphibian and reptilian remains from South Africa and Australia. Quart. Jour. Geol. Soc., xv, 642-649, pls. xxi-xxii; Scientific Memoirs, II, I20-129, pls. 7-8.

33I. - I862. On new Labyrinthodonts from the Edinburgh Coal Field. Quart. Jour. Geol. Soc. xviII, 29I-296, pl. xi; Scientific Memoirs, Ir, $530-535, \mathrm{pl} .37$.

332. 1863 . Description of Anthracosaurus russelli, a new Labyrinthodont from the Lanarkshire Coal-Field. Quart. Jour. Geol. Soc., XIX, 56-68, figs.; Scientific Memoirs, II, 558-572, figs. I-2.

333. - I 1865 . On a collection of vertebrate fossils from the Panchet Rocks, Ranigunj. Bengal. Mem. Geol. Surv. of India; Paleontologia Indica, ser. Iv; Indian Pretertiary Vertebrata, I, Amphibia, 3-8, pls. vi, and figs.; Scieutific Memoirs, III, 90-I 20, figs., pl. I6.

334. - I867. On a collection of fossil Vertebrata from the Jarrow Colliery, County of Kilkenny, Ireland. Trans. Roy. Irish Acnd., I871, xxiv, 35I-369 (Read Jan. 6, I866), pls. xix-xxiii; Scientific Memoirs, III, 180-I97, pls. I7-21.

335. - 1869. On a new Labyrinthodont from Bradford. Quart. Jour. Geol. Soc. London, xxy, 309-3I I, pl. xi; Scientific Memoirs, III, 39I-393, pl. 26.

336. - I875. Amphibia. Art. in "Encyclopedia Britannica," 9th ed., I, 750-77t.

337. - 1879. On the characters of the pelvis in the Mammalia and the conclusions respecting the origin of mammals which may be based on them. Proc. Roy. Soc. Lond., XxviII, 395-405, figs. ; Scientific Memoirs, $t v, 3+5-356$, figs.

338. JAEger, Dr. Georg Friedrick. 1824. De Ichthyosauri sive Proteosauri Fossilis Specimenibus in Agro Bollensi in Würtembergia. Folio, I I. (First mention of the discovery of Labyrinthodonts, a tooth and occipital region of a cranium, which in I 833 Jaeger designated Mastodonsaurus giganteus. This was and still is the largest known amphibian.)

339. - 1828. Ueber die fossilen Reptilien welche im Würtemburg aufgefunden worden sind. Quarto, 35-38, pls. iv-v.
340. JAEger, Dr. G. F. 1833. Mastodonsaurus giganteus. Bull. de la Soc. Geol. de France, III, 86.

34I. - 1850. Ueber die Uebereinstimmung des Pygopterus lucius Agassiz mit dem Archegosaurus decheni. Abh. Math-phys. Classe d. Bayr. Akad., v, 877, pl.

342. JAEKEL, OTTO. I 89.4. Ueber die sogennante Faltenzăhne und complicirte Zahnbildung ueberhaupt. Sitzb. d. Gesell. naturf. Freunde zu Berlin, No. 5, I 46.

343. 1896. Ueber die Körperform und Haut Bedeckung von Stegocephalen. Sitzungsber. d. Gesell. naturf. Freunde zu Berlin, I-8, I fig.

344. - I 896. Die Organization von Archegosaurus. Zeit. d. deutsch. geol. Gesell., xuviII, 505-52I, figs. I-Io.

345. - I902. Gephyrostegus bohemicus. Zeit. d. deutsch. geol. Gesell., LIV, Heft 3, I27-I 32 .

346. - I903. Ueber die Epiphyse und Hypophyse. Sitzungsb. d. Gesell. naturf. Freunde, No. 2, 27-58.

347. 1903. Ueber Ceraterpeton, Diceratosaurus und Diplocaulus. Neues Jahrb. f. Mineral., Geol. u. Paleon., Bd. I, 109-134, pls. ii-v.

348. ㄴ. I904. Ueber die Bildung der ersten Halswirbel und die Wirbelbildung im Allgemeinen. Zeit. d. deutsch. geol. Gesell., Lvi, 109-119, figs.

349. - I905. Ueber dic primare Glicderung des Unterkiefers. Sitzungsber. d. Gesell. naturf. Freunde, No. 4, 134.

350. - 1909. Ueber die Klassen der Tetrapoden. Zool. Anz., xxxiv, Nr. 7/8, Apr. 20, 193-212, figs. $1-15$.

35I. - I909. Ueber die Beurtheilung der paarigen Extremitāten. Sitzungsb. d. kōnig. Preuss. Akad. d. Wissen., xxvi, 707-724.

352. - I9I3. Ueber den Bau des Schaedels. Anat. Anz., Ergănzungsheft, Bd. 44, 77-94, mit figıren.

353. JORDAN, H. 1849. Ergänzende Bemerkungen zu der Abhandlung von Goldfuss ueber die Gattung Archegosaurus. Verhand1. d. naturhist. Vereines f. Rheinlande $u$. Westphalen, vi, 76-8I, taf. 4 .

354. KAYSER, Friedrich. 1902. Geologie von Boehmen. Verlag von I. Taussig, I074-1210. (Formations of Bohemia where Amphibia have becn found.)

355. Kinahan, G. H. 1878. Geology of Ireland, London; The Jarrow Colliery. II6-119.

356. KING, AliRED T. I844. Description of fossil footmarks supposed to be referable to the classes Birds, Reptilia, and Mammalia found in the Carboniferous series in Westmoreland County, Pennsylvania. Proc. Acad. Nat. Sci., Phila., 175-179.

357. - 1845. Description of a fossil footnuark of the quadruped Thenaropus. Amer. Jour. Sci., XlviII, 343-352, 12 figs.; also I (n. s.), 268.

358. Kingsley, J. S. Systematic position of Coccilians. Tufts Collcge Studies No. 7 ( $x x x)$; also No. 7 (xxvin), Amphiuma.

359. Klaatsch, Hermann. 1896. Die Brustflosse der Crossopterygier. Festschrift für Gegenbaur, Bd. 1, 259-391, 'Taf. i-iv.

360. KNIPE, HeNRY R. 1912. Amphibians of the Carboniferous. Evolution in the Past, 59, and plate.

36ז. Kunisch, Hermann. 1885. Ueber die Unterkicfer von Mastodonsaurus silesiacus Hun. Zeit. d. deutsch. geol. Gesell., Xxxvir, 528-533, with figs. 1-2. 
362. KUNISCH, HERMANN. 1890. Labyrinthodonten, Reste d. oberschles. Nuschelkalkes. Zeit. d. deutsch. geol. Gesell., XLII, 377-385, Taf. xx.

363. KutORGA, StEFH. 1838. Beitrag zur Kenntniss der organ. Ueberrestedes Kupfersandsteines am westlichen Abhange des Urals. St. Petersburg, mit tafeln.

364. LAKE, J. J. 1878. Reptiles of the primary pcriod. English Mechanic, xxvu, 438-439.

365. LAMBE, L. M. 1902. Scapherpeton tectum-a batrachian from the Cretaceous. Contr. Canadian Paleontology, III, pt, Is, 31 .

366. - 1904. Progress of vertebrate paleontology in Canada. 'Trans. Roy. Soc. Canada, $x$, sec. Iv, 13-56.

367. Laube, Gustav C. 1898. Andriasreste aus der Boehmischen Braunkohlenformation. Abhandl. d. deutsch. naturw.-med. Vereines f. Boehmen "Lotos," I, heft 2, 25.

368. - 1898. Amphibienreste aus dem Diatomaceenschiefer von Sulloditz. Abhandl. d. deutsch. naturw.-med. Vereines f. Boehmen "Lotos," I, heft 3,10 , taf. i, fig. 6 .

369. IgoI. Synopsis der Wirbelthierfauna der bōhm-Braunliohlenformation und Beschreibung neuer oder bisher unvollstāndig bekannter Arten. Abhandl. d. deutsch. naturw.-med. Vereines $\mathrm{f}$. Boehmen "Lotos," II, heft 4, 52-58.

370. 1909. Neue Andrias-reste aus dem Tonen von Preschen bei Bilin. "Lotos," Lvir, 6.

371. LEA, IsAAC. I849. On traces of a fossil reptile (Sauropus primevus) found in the old Red Sandstone (Pennsylvania). Rep. Brit. Assn. Adv. Sci., 56, 2d part; Proc. Amer. Phil. Soc., 91-94.

372. - 1855. Fossil footmarks in the Red Sandstone of Pottsville. I-16, with a large plate. Large folio; Trans. Amer. Phil. Soc., x, 1852, Apr. 1-13, pls. 31-33.

373. LeIDY, JOSEPH. 1856. Notices of remains of extinct vertebrated animals discovered by Professor E. Emmons. Proc. Acad. Nat. Sci. Phila., 256. (Dictyocephalus elegans.)

374. 1878. Fossil foot-tracks of the Anthracite Coal Measures. Proc. Acad. Nat. Sci. Phila., XXXI, 164-165.

375. LE Rox; J. J. 1874. Notiz weber Archegosaurus decheni Goldfuss und A. latirostris Jordan. Niederl. Archiv. f. Zoologie. 11, 89-98.

376. LesLEY, J. P. 1889. A dictionary of the fossils of Pennsylvania and neighboring states. In three volumes. Published by the Penn. Geol. Surv.

377. Leunis, Johannes. 1883. Synopsis der Thierkunde. 3d Auflage, Bd. I, 599-631. (Amphibia.)

378. Lillie, Frank R. 1908. The development of the chick. The Vertebra, 412-424, figs. 246, 249, 250.

379. Lloyd, G. 1849. On a new species of Labyrinthodon from the New Red Sandstone of Warwickshire. Rept. Brit. Assn. Adv. Science, 56. (Sce Huxley (328) and F. von Huene (324).)

380. Logan, William. 1842. Proc. Geol. Soc., London III, pt. 11, 707.

381. Lohest, Maximin. 1888. Découverte de plus ancien Amphibien connu et de quelques Fossiles remarquables de Famennien supérieur de Modave. Notice prelininaire. Ann. de la Soc. Geol. Belgique, $\mathrm{xv}, \mathrm{p}$. $\mathrm{cxx}$, fig. $\mathrm{T}$.
382. LORTET, Dr. L. 1892. Les Reptiles fossiles du Bassin du Rhone. Ordre des Amphibiens, 125-127, pl. xii; Archives du Muséum d'Hist. Natur. de Lyon, $\mathrm{v}$.

383. LuCAs, F. A. 1904. A new Batrachian and a new reptile from the Trias of Arizona. Proc. U. S. Nat. Mus., xxvi1, 193-195, pl. (Heterodontosuchus, a belodont; Metoposaurus frasii, a labyrinthodont.)

384. LYDEKKER, RiCIIARD. 1879. Reptilia and Batrachia (Amphibia). Paleontologia Inclica, ser. IV, I, 1-36, pls. i-vi; Amphibia, 17-20, pls. iii-vi. (Pachygonia, Gonioglyptus, Mastodonsaurus.)

385. 1 1880. A sketch of the history of the tossil Vertebrata of India. Jour. Asiatic Society Bengal, XLIX, pt. II, 8- fo: Fossil Batrachians, 16, list of species, 38-39.

386. - 1881. Note on some Gondwana vertebrates. Rec. Geol. Surv. India, XIV, 174. (Gonioglyptus, Pachygonia, Glyptognathus.)

387. - 1883. Note on the Bijori Labyrinthodont. Rec. Geol. Surv. India, xvi, 93.

388. - 1883. Synopsis of the fossil Vertebrata of India. Rec. Geol. Surv. India, Xvt, 61; Amphibia, $64,88$.

389. 1885. The Reptilia and Amphibia of the Maleri and Denwa Groups. Paleontologia Indica, ser. IV, I, pt. 5,6 pls.

390. 1885. The Bijori Labyrinthodont. Paleontologia Indica, ser. 1V, 1, 1-14, pt. 4 ; also, Cope, Amer. Nat., Xix, 592.

391. - 1887. The fossil Vertebrata of India. Rec. Geol. Surv. India, xx, p. 68.

392. - 1887. Dr. Hermann Credner on the development of Branchiosaurus. Geol. Mag., n. s., Dec. III, IV, 276-278.

393. 1 1890 . Catalogue of fossil Amphibia and Reptilia in the British Nuseun (Natural History). Amphibia, part IV, 121-225.

394. - 1891. On a Labyrinthodont skull from the Kilkenny Coal Measures (Ireland). Quart. Jour. Geol. Soc., xlvit, $3+3-3+7$, I fig.

395. - The new natural history. v, Amphibia, 257-310; Labyrinthodontia, 311. (See also Nicholson and Lydekker (499).)

396. Lyell, Ciras., and J. W. DawsoN. 1853. On the remains of the reptile (Dendrerpeton acadianum) and a land shell (Coal Mcasures). Quart. Jour. Geol. Soc., 1., 58-63, with pls.

397. MAGGi, LEOPOLDO. 1898. Placehe osteodermiche interparietali Stegocephali e rispondenti Centri Ossificazione interparietali dell 'Uomo. Reale Inst. Lombard. di Sci. Lett. (2), xxxi, 211,228 , pl. 1 .

398. — 1897. Résultats de Recherclıes morphologiques sur des Os et des Fontanelles du Crane humain. Arch. Ital. d. Biol., T. 27, 230-238.

399. Makowskr, AlEx. 1876. Ueber einen neuen Labyrinthodonten - Archegosaurus austricus. Sitzungsb. d. k. Akad. wiss. Wien. Math. Natur. Classe, Abth. 1, Lxxul, lleft 3, 155-166.

400. - und A. RzEIIAK. 1884. Die geologischen Verhāltnisse der Umgcbung von Brunen. Verhandlgn. d. Nat. Verein zu Brünn, xxu. (Die frühere Archegosaurus austricus wird zu Melanerpeton gestellt.) 
401. Malbranc, M. 1875. Von der Seitenlinie und ihre Sinnesorganen bei Amphibien. Leipzig. Zeit. f. wiss. Zool., Xxvi, 24, pls. I-4.

402. Mantel, , G. A. I851. Petrifactions and their teachings. Fossil Batrachians, 183.

403. - - 1866. Wonders of geology. Labyrinthodonts, 551 .

404. Marsh, O. C. 1862. Discovery of new Enaliosaurian remains in the Coal Formation of Nova Scotia. On the saurian vertebræ from Nova Scotia. Amer. Jotır. Sci. and Arts, xxxiv, Mar. I, pl. I, figs. 1-2. See also Neues Jahrb. Mineral., Geol. u. Paleon., 1863, 247; Canad. Nat. and Geol., vII, 205-2I3; Quart. Jour. Geol. Soc. London, Xıx, 52-56; Huxley, Scientific Memoirs, II, 566 .

405. 1887. Eobatrachus agilis in the (Como Beds) Jura of North America. Amer. Jour. Sci., Xxxin, 328; Vertebrate fossils of the Denver Basin, Monograph U. S. Geol. Surv., xxvi1, 508, 1897 .

406. 1894. Footprints of vertebrates in the Coal Measures of Kansas. Amer. Jour. Sci., XLvirI, 2d ser., July-Dec., 8I-84, pls. ii-iii.

407. - 1896. Amphibian footprints from the Devonian. Amer. Jour. Sci. (4), 11, 374-375, with fig.

408. Matthew, G. F. 1903. New genera of Batrachian footprints of the Carboniferous system of eastern Canada. Canadian Record of Science, $1 x$, No. 2 , 99-III, with figs.

409. - I903. An attempt to classify Paleozoic Batrachian footprints. Trans. Roy. Soc. Canada (2), IX (III), I903, I09-121.

410. - 1903. On Batrachian and other footprints from the Coal Measures of Joggins, N. S. Bull. Nat. Hist. New Brunswick, v, No. XxI, 103-108, with plate of excellent photos; No. xxII, 247 .

411. - 1905. Note in reference to Batrachian footprints. Bull. Soc. New Brunswick, XXI, 102.

412. I - No5. Note on the genus Hylopus of Dawson. Bull. Soc. New Brunswick, XxII, 247252, figs.

413. - 1904. New species and a new genus of Batrachian footprints of the Carboniferous system in Eastern Canada. Trans. Roy. Soc. Canada, X (Iv), 77-1 I0, pls. I-6.

414. Matrhew, W. D. Igog. The oldest land reptiles of North America. Amer. Mus. Jour., Ix, No. 4, 91-95, photos of Eryops and Diplocaulus.

415. 1911. The Amphibians of the great Coal Swamp. Amer. Mus. Jour., XI, No. 6, 197-200. (Restoration of Eryops.)

416. Merrill, Geo. P. 1907. Catalogue of the type and figured specimens of fossils, minerals, rocks, and ores. Part II: Fossil Vertebrates, 9-12. Bull. U. S. Nat. Mus., No. 53, pt. II. Two species of Amphibia are listed as fishes, 74,77 .

417. Metcalfe, A. T. I 884. On further discoveries of vertebrate remains in the Triassic strata of the South Coast of Devonshire, between Budleigh, Salterton and Lidmouth. Quart. Jour. Geol. Soc., XL, 257.

418. Meyer, Hermann von. 1838. Recherches sur les Ossem. foss. du gres bigarre de Soultz les Bains.

419. 1834. Odontosaurus voltzii. Mem. de la Soc. d'hist. nat. de Strasbourg.
420. Meyer, Hermann von. I842. Labyrinthodontia. Neucs Jahrb. f. Mineral., Geol. u. Paleon., 301304. (Proposes system of classification.)

421. ㄴ. 1844. Beiträge zur Paleontologie Würtembergs, I -4 I, mit I 2 tafeln. Enthaltend die fossilen Wirbelthierereste aus den Triasgebilden mit besonderer Rücksicht auf die Labyrinthodonten des Keupers.

422. _ _ 1844. Apatheon pedestris. Neues Jahrb. f. Mineral., Geol. u. Paleon., 336. (He regarded Apatheon as a salamander-like form, a Branchiosaurian.)

423. - 1845. System der fossilen Saurier. Neties Jahrb. f. Mineral., Geol. u. Paleon., 278-285.

424. - 1 1847. Die Steinbrücke von Oeningen. Fossile Batrachier. Fauna der Vorwelt, Bd. 1, I 8-40, pls. 9-10.

425. ㄴ. 1847-1855. Die Saurier des Muschclkalkes mit Rücksicht auf die Sauricr aus Bunten Sandstein und Keuper. Fauna der Vorwelt, Bd. II, I-I64, pls. 58-64. Large folio. (Mastodonsaurus, Metopias, Capitosaurus.)

426. - 1 848. Apateon pedestris aus der Steinkohlenformation von Münsterappel. Paleonto. graphica, Bd. I, I53-I 54, pl. xx, fig. I.

427. - I848. Mittheilung an Professor Bronn. Labyrinthodontia. Neues. Jahrb. f. Mineral., Geol. u. Paleon., 469. (Labyrinthodon ocella.)

428. ㄴ. 1849. Ueber den Archegosaurus der Stcin. kohlenformation. Paleontographica, Bd. 1, 209, Dec. (1851), pl. 33 .

429. - 1851. Mittheilung an Professor Bronn, Rana jaegeri. Neues Jahrb. f. Mineral., Geol. u. Paleon., 78.

430. - 1851. Beschrcibung der fossilen Decapoden, Fische, Batrachier, und Sâugethicre aus dem Tertiären Sùsswasscrgebilden des nördlichen Bochmens. Paleontographica, Bd. II, 43.

431. - 1852. Mittheilungen an Professor Bronn. Neues Jahrb. f. Mincral., Geol. u. Paleon.: Palreobatrachus gigas, 465; Rana nöggerathi, 58; R. troscheli, 466; R. salzhauserensis, 467 .

432. - 1853. Mittheilungen an Professor Bronn. Neues Jahrb. f. Mineral., Gcol. u. Paleon.: Rana meriani, 163, 185; Palæobatrachus gigas, 162.

433. - I 1 854 . Mittheilung ucber Archegosaurus. Nenes Jahrb. f. Mineral., Geol. u. Paleon., 424.

434. - 1856. Ueber Osteophorus roemeri, Briefl. Mittheil. an Professor Bronn. Neues Jahrb. f. Mincral., Geol. u. Paleon., 824.

435. - 1857. Mittheilung an Professor Bronn. Neues Jahrb. f. Mineral., Geol. u. Paleon.: Palæobatrachus gracilis, 555 .

436. - 1857. Reptilien aus der Steinkohlenformation in Deutschland. Palcontographica, Bd. vi, 219-220, text-n̂g. (Archegosaurus.)

437. - 1857. Osteophorus roemeri, Beschreibung derselben in Roemer: Ueber Fisch-und Pfanzenführende Mergelschiefer des Rothliegenden bei Neundorf. Zeit. d. deutsch. geol. Gesell., 1x, 61. 438. - 1858. Reptilien aus der Kohlsteinformation in Deutschland. Cassel, Folio; also Paleontographica, Bd. vi, 59-2I8, Tafeln viii-xxiii. (Archegosaurus.)

439. - I 858. Labyrinthodonten aus dem bunten Sandstein von Bernburg. Paleontographica, Bd. vi. 221-245, Tafeln xxiv-xxvii. 
440. Meyer, IIERMANN von. 1858. Mitheilung an Prolcssor Bronn. Neucs Jahrb. \&. Mineral. Geol. u. Palcon.: Rana danubina, 203.

441. 1859. Mittheilung an Professor Bronn. Ncues Jahrb. f. Mineral. Geol. u. Paleon.: Triton basalticus, 430; Andrias tschudii, 723 .

442. - 1860. Ueber Archegosaurus. Erwiderung auf dic Ausführungen von Quenstedt in " Epochen der Natur," p. 410. Brief. Mittheil. an Prolessor Bronn. Neues Jahrb. f. Mineral. Geol. u. Paleon., 71-72.

443. - 1860. Osteophorus roemeri aus dem Rothliegenden von klein Neundorf in Schliesen. Paleontographica, Bd. vir, 99-ro4, pl. xi.

444. 1860. Froesche aus Tertiar Gebilden Deutschlands. Palcontographica, Bd. VII, I 23182, pls. 16-22.

445. - 1860. Melosaurus uralensis aus der Pcrmische System des westlichen Urals. Paleontographica, Bd. vII, 90-98, pl. $x$.

4f6. - - I860. Salamandrinen aus der Braunkohle am Rhcin und in Boehmen. Paleontographica, Bd. vII, $47-73$, pls. viii, ix.

447. 1863. Heliarchon furcillatus, ein Batrachier aus der Braunkohle von Rutt in Siebengebirge. Paleontographica, Bd. X, 292-298, Taf. 50, figs. 5-6.

448. - 1866. Reptilien aus dem Kupfersandstein Russlands. Palcontographica, Bd. Xv, 97-130.

449. Mrate, L. C. 1873. Report on the Labyrinthodonts of the Coal Measures. Rept. Brit. Assn. Adv. Sci., 225, pls. 1-3.

450. - I874. On the classification of the Labyrinthodontia. Rept. Brit. Assn. Adv. Sci., I 49192, with 2 plates.

451. - 1874. The classification of the Labyrinthodonts. Geol. Mag., 2d ser., I, 5 I3.

452. - 1874. On the occurrence of a Labyrinthodont in the Yoredale Rocks of Wensleydale. Qunrt. Jour. Geol. Soc., Xxx, 775.

453. - 1874. On the remains of Labyrinthodontia from the Keuper Sandstone of Warwick, prescrved in the Warwick Museum. Quart. Jour. Geol. Soc., Xxx, 4I7-435, pls, 26-28. (Mastodonsaurus pachygnathus; Labyrinthodon leptognathus; Diadetognathus varvicensis.)

454. - 1875. Sur les Labyrinthodontes du Terrain houiller. Dcuxieme partic. Jour. de Zool., IV, 19-37.

455. NIU.LER, S. A. 1889. North American geology and paleontology. Amphibia, 614 .

456. Mivart, Geo. 1870. On the axial skeleton of the Urodela. Proc. Zool. Soc. London, 260-278.

457. MoOdie, Roy L. 1908. Dissorophus-A correction. Scicnce, n. s., xxvII, No. 679, 30.

458. - 1908. The lateral line system in extinct Amphibia. Jour. Morphol., xix, No. 2, 51 1-5ł0, I7 figs.

459. - 1908. The ancestry of the caudate Amphibia. Amcr. Nat., 42, 361-373, figs. 1-10.

460. … 1908. The dawn of quadrupeds in North America. Pop. Sci. Monthly, Lxxir, June, 558566,5 figs.

46r. - 1908. The clasping organs of extinct and recent Amphibia. Biol. Bull.. xiv, No. 4, Mar., 249-259, with 5 figs.
462. Moodis, Roy L. 1909. New forms (extinct Amphibia) from the Carboniferous. Jour. Geol., xvir, No. I, Jan.-Peb., 38-82, 24 figs.

463. - I909. The Carboniferous quadrupeds of Kansas, Ohio, Illinois, and Pennsylvania in their relation to the classification of the so-called Amphibia and Stegocephalia. Trans. Kans. Acad. Sci., XXII, $239^{-2}+3$, pls. I-3.

464. - 1909. Carboniferous air-breathing verte. brates of the United States National Museum. Proc. U. S. Nat. Mus., 37, $11-28$, pls. $4-10$.

465. - Ig09. New or little-known forms of Carboniferous Amphibia in the American Museum of Natural History. Bull. Amer. Mus. Nat. Hist., xxvr, art. xxv, 347-357, pls. lviii-lxv.

466. ㄴ. 1909. The Lysorophidx. Amer. Nat., xLII, I16. (Review.)

467. - 1909. The Stegocephala. Amer. Nat., XLIII, II9. (A review of paper by Hugo Schwarz.)

468. 1909. The morphology of the vertebrate sacral rib. Anat. Anz., xxxiv, No. 15, 361-364.

469. 1909. The Microsauria, ancestors of the Reptilia. Geol. Mag., Dec. v, vi, No. 539, 2 I6-220, I fig.

470. 1910. The Amphibia of the Mazon Creek Shales. Science, n. s., Xxxr, No. 789, p. 233.

471. - 1910. The alimentary canal of a Carboniferous salamander. Amer. Nat., Xulv, No. 522, $367-375,4$ figs.

472. 1910. A new Labyrinthodont Irom Kansas. Scicnce, n.s.. $\operatorname{xxxII}_{1}$ No. 829 , Nov. 18.

473. - I9I1. A new Labyrinthodont frons the Kansas Coal Measures. Proc. U. S. Nat. Mus., xxxix, 489-495, 4 figs.

474. - I911. Two Amphibians, one of them new, from the Carboniferous of Illinois. Proc. U. S. Nat. Mus., XL, 429-433, figs. I-2.

475. - I911. Recent contributions to a knowledge of the extinct Amphibia. Amer. Nat., xr.v, June, $375-384$.

476. 375e temnospondylous Amphibia, and a new species of Eryops from the Permian of Oklahoma. Kans. Univ. Sci. Bull., v, No. 13. 235-253. pls. xlix-liv.

477. - I912. The skull structure of Diplocaulus magnicornis and the amphibian order, Diplocanlia. Jour. Morphol., xxII, No. I, 31-39, pls. I-2.

478. I912. The Pennsylvanic Amphibia of the Mazon Creek, Illinois, Shales. Kans. Univ. Sci. Bull., vi, No. 2, 323-359, pls. 1-14.

479. ㄴ. Igr2. The Mazon Creek, Illinois, Shales and their amphibian fauna. Amcr. Jour. Sci., xxxıv, Sept., 277-285, figs. I-2.

480. - I912. An American Jurassic frog. Amer. Jour. Sci., xxxiv, Sept., 286-288.

481. . 1914. The fossil frogs of North America. Amer. Jour. Sci., Xxxviri, Dec., 531-536, figs. 1-2. 482. - 1914. A list of the described species of fossil Amphibia. Kans. Univ. Sci. Bull., 9, No. 2, 1.3-28.

483. $\frac{13-28 .}{1915 . ~ A ~ r e m a r k a b l e ~ M i c r o s a u r ~ f r o m ~ t h e ~}$ Coal Measures of Ohio. Science, n.s., xLI, No. $1044,34-35$.

484. 1915 . Coal Measures Amplibian with an osseous tarsus. Amer. Jour. Sci., xxxix, May, 509-512, figs. $1,2$. 
485. MoODIE, Roy L. 19 I 5. The scaled Amphibia of the Coal Measures. Science, n. S., xII, No. 1056, 463-464. 486. - 1915. Some recent studies on fossil Amphibia. Amer. Nat., xuIx, June, 369-376.

487. - 1915. A new fish brain from the Coal Measures of Kansas, with a review of other fossil brains. Jour. Comp. Neurol., xxv, No. 2, 164.

488. - 1915. A further contribution to a knowledge of the lateral line system in extinct Amphibia. Jour. Comp. Neurol, xxv, No. 4, 317-328, figs. I -9 .

489. - I915. Some methods of studying fossils embedded in coal. Kans. Univ. Sci. Bull., Ix, No. 16, 187-193, figs. 1-3, pl. L.

489a. The migrations and geographic distribution of the fossil Amphibia. Amer. Jour. Sci., XL, I86-I90, I map.

489b. - The Coal Measures Amphibia and the Crossopterygia. Amer. Nat., XLIX, 637-644.

490. MudGe, B. F. 1873. Recent discoveries of fossil footprints in Kansas. Trans. Kans. Acad. Sci., II, 7-9.

49I. Münster, Georg, Graf zU. 183\%. Vorlätufige Nachricht ueber einige neuen Reptilien im Muschelkalk von Baiern. Neues Jahrb. f. Mineral., Geol. u. Paleon., 527. (Mastodonsaurus.)

492. - 1836. Capitosaurus arenacens. Nenes Jahrb. f. Mineral., Geol. u. Paleon., 580.

493. ——. I839. Mastodonsaurus adriani. Beiträge zur Petrefactionkunde, I02.

494. MURCHISON, RODERICK I. 1872. Siluria-A history of the oldest rocks in the British Isles and other countries. 5th ed., 302,343 .

495. NewberRy, J. S. 1856. Description of several new genera and species of fossil fishes from the Carboniferous strata of Ohio. Proc. Acad. Nat. Sci. Phila., viII, 98.

496. - 1867. On some fossil reptiles and fishes from the coal strata of Ohio, Kentucky, and Illinois. Proc. Amer. Assn. Adv. Sci.; 144-1 46.

497. - 1878. Geology of Jefferson County, Ohio. Geol. Surv. Ohio, III, 736-737.

498. - 1889. Palæozoic fishes of North America. Monograph U. S. Geol. Surv., XVI, 228. (Discusses Kammplatten; Amphibia of Linton, Ohio, 21 I-214; Fauna of Mazon Creek, 214. See also Hodge, 1878, Geol. Surv. Ohio, III, 592.)

499. NiCiIOLSON and LydekKER. 1889. Manual of palcontology. Amphibia, II, 1018-1045.

500. OldhaM, Dr. R. D. 1875. On a salamandriform Labyrinthodont from the Coal Measures near Castlecomer, Ireland. Rept. Rugby School Nat. Hist. Soc., 74-76, pl. vii.

501. - 1893. Geology of India. $2 \mathrm{~d}$ ed. The Gondwana System, 149.

502. OWEN, Sir RICHARD. 1840-1845. Batrachians. Odontography, $187-218$, pls. $62,63,64$.

503. - 18.2. On the teeth of the species of the genus Labyrinthodon of Jaeger from the German Keuper and the sandstone of Warwick and Leamington. Ann. and Mag. Nat. Hist., viII, 58; also, Gcol. Trans. II, ser. vi, 503 .

504. 1842. Description of parts of the skcleton and teeth of the genus Labyrinthodon, with remarks on Cheirotherium. Trans. Geol. Soc. London, vi, pt. 2, 515-543, pls. xliii-xlvii.

505. - 1842. On the teeth of species of the genus Labyrinthodon. Trans. Geol. Soc. London, vi, pt. 2, 503-5I3, pl. 43, fig. I. (Discusses validity of term Mastodonsanrus. Read Jan. II, I8+1.)
506. OWEn, Sir RICHARD. 1847. On the Batracholites in dicative of a small species of frog (Rana pusilla). Quart. Jour. Geol. Soc., III, 224. (See Clark, I03. p. 221.)

507 . I853. Notice of a batrachoid fossil in the British Coal Shale. Quart. Jour. Geol. Soc. London, Ix, 67-70, pl. iii.

508. - I 853. Notice of a batrachoid fossil- Parabatrachus colei-in the British Coal Shale. Qunrt. Jour, Geol. Soc. London, x, 207.

509. - - 1853. Baphetes planiceps-a fossil ennbedded in a mass of coal from Nova Scotia. Quart. Jour. Geol. Soc. London, x, 207-208, pl. ix.

510. - 1854. Description of the cranium of a Labyrinthodont reptile (Brachyops) from the Triassic of Central India. Quart. Jour. Geol. Soc. London, $\mathrm{x}, 473$. (Abstract.)

511. - 1855. Description of the cranium of a Labyrinthodont reptile from Mangala, Central India. Quart. Jour. Gcol. Soc. London, XI, 37, pl. 512. - 1859. On the orders of fossil and recent Reptilia and their distribution in time. Rept. Brit. Assn. Adv. Sci., $153-166$.

513. - 186r. Paleontology, 2d ed., Amphibia, 193. 514. - 1862. Descriptions of specimens of fossil Reptilia discovered in the Coal Measures of the South Joggins, Nova Scotia. Quart. Jour. Geol. Soc. London, xvill, 238-244, pls. 9-10.

515. - 1865. Description of some remains of an air-breathing vertebrate (Anthrakcrpeton crassosteum) from the Coal Shale of Glamorganshire. Geol. Mag., II, 6-8, pls. i-ii.

516. - 1866. On the anatomy of the Vertebrata. Amphibia, 1, 8.

517. 1876. On Petrophryne granulata Ow., a Labyrinthodont reptile fiom the Trias of South Africa. Bull. de la Soc. Imp. de Nat. de Moscon. (Review.)

518. - 1876. Catalogue of the fossil Reptilia of South Africa in the collection of the British Musenm. Labyrinthodontia, $67-7 \mathrm{o}$, pl. xx, figs. I3-20; pl. lxx, fig. 3 .

519. - 1884. On a Labyrinthodont Amphibian from the Cape of Good Hope. Qttart. Jour. Cicol. Soc. I.ondon, XI., 333, 2 pls.

520. - - 1884. On Rhytidosteus capensis Ow., a I.abyrinthodont from the Trias of Cape of Good Hope. Ann. and Mag. Nat. Hist. (5), xir, 481.

521. PABST, WM. 1896-1905. Beiträge zur Kenntniss der Thierfährten in dem Rothliegenden Deutschlands. Zeit. der deutsch. geol. Gesell., I 896, xLVII, 638, 808 ; 1900 , LII, 48; LVII, I-I 4, 361-379, with pls. (Some of the tracks described may be amphibian.)

522. Pander, Chr. H. 1858. Ucber die Ctenodipterinen des devonischen Systems.

523. Pictet, F, J. 1853. Traitê de paléontologie, 2 d ed., tome premier.

52.4. Poli.ARD, H. B. I 891. On the anatomy and phylogenetic position of Polypterus. Anat. Anz.,vi,338; Zool. Jahrb. (Morphol. Abth.),v, I 893,387-428, with pls.

525. PoRtis, A. I 885. Resti di Batraci fossili Italiani: appunti paleontologi, pt. 2, p. 30.

526. Pusch, Bergrath. 18 $\$ 2$. Fossilc Batrachier und Ophidier Reste aus Podolien. Neues Jahrb. f. Mineral., Geol. u. Paleon., 179-180.

527. Quenstent, F. A. voN. 1850. Die Mastodonsaurier im grucnen Keupersandstein W Würtembergs sind Batrachier, 4to, I-34, + Tafeln. 
528. Qualen, Wangenhem von, 1845 and $\mathrm{I} 852$. Two papers on the skull of Zygosaurus lucius. Bull. Soc. Imp. Nat. Mloscon, xiri, 389 (1852), 472.

529. - 1861 . Bemerkungen zum Archegosaurus. Neues Jahrb.f. Mineral. Geol. u. Paleon., 294-300, with pl. iii. (Sec also Baur, 1886, Amer. Nat., 173, and Zool. Anz., 1886, Nr. 216.)

530. - 1885. Atlas zum Handbuch der Petrifactionskunde. Amphibia, pl. 18.

531. Ravmond, Percy E. 1907. On the discovery of reptilian remains in the Pennsylvanian near Pittsburgh, Pa. Scicnce, n. S., xxvi, 676, 835.

532. Rjabinin, M. A. 1911. Débris de Stegocephales trouvés aux Mines de Kargala Gouvernement d'Orembourg. Bull. du Comm. Geol. St. Petersburg, $\mathrm{xxx}$, No. 185 , pls. $1-2$.

533. - 1912. Ueber die Ueberreste der Stegocephalen aus den Kargalinokischen Bergwerken des Gouvernments Orenberg, St. Petersburg, 37 pages, pls. 1-2.

534. Roemer, Ferdinand. 1857. Ueber Fische und Pflanzenführende Mergelschiefer des Rothliegenden bei Klein-Neundorf und ucber Acanthodes gracilis. Zeit. d. deutsch. geol. Gesell., IX, 61.

535. SCheUChze R, J. J. 1726. Part of two human skeletons petrified. Phil. Trans. Roy. Soc. London, 1726, abridged edition, vil (1724-1734), 129. (Translated from the Latin of a letter to Sir Hans Sloan, a member of the Royal Society.)

536. Schmid, E. 1853. Die organischen Reste des Muschelkalks. Neues Jahrb. f. Mineral., Geol. u. Paleon., 15.

537. SCHмidr, M. 1907. I,abyrinthodontenreste aus dem Hauptkonglomerat von Altensteig im wurtembergischen Schwarzwald. Stuttgart. Mittheil. d. Geol. Abtlı., d. K. Würtemb. Statest. Landesamts, Jahrg. 63 , No. 2, I-10, with plate.

538. SCHöNFELD, G. 1911. Branchiosaurus tener Schönf. Ein neuer Stegocephal aus dem rothl. des Nordwest Sächsens. Isis, 19-43, with plate.

539. SCHröder, Henry. 1913. Ein Stegocephalen Sehādel von Helgoland. Jahresb. d. k. preuss. geol. Landesanstalt für 1912, 33, Theil Ir, Heft 2, Taf. 15-2I.

540. Schwarz, Hugo. 1908. Ueber die Morphologie der Wirbelsäule der Tetrapoden. Sitzungsb. d. Gesell. naturf. Freunde zu Berlin, 315-329.

541. - 1908. Ueber die Wirbelsäule und die Rippen holospondyler Stegocephalen (Lepospondyli, Zittel). Beiträge zur Geol. u. Paleon. Oesterreichs-Ungarns u. des Orients, Bd. xxI, Heft 1-2, 63-105, 36 figs. and Bibliography.

542. Scort, W. B. 1908. An introduction to geology. $2 \mathrm{~d}$ revised edition. Amphibia, 608, 636, 652, 674, 692.

543. SEDGWiCK, AdAm. 1905. Stegocephali in "Student's Text-book of Zoology." 11, 313.

544. SeELey, H. G. 1875 . On the posterior portion of a lower jaw of Labyrinthodon (L. lavisi) from the Trias of Lidmouth. Quart. Jnur. Geol. Soc., xxxIl, 278-284, pl, xix.

545. - 1879. Amphibians from the Permian Rocks of Bohemia. Geol. Mag., Dec. II, VI, 52 I-528, 4 woodcuts; $1885,80-87$. (A review of Fritsch's work.)

546. - 1892. Further observation on Pareiasaurus. Phil. Trans. Roy. Soc. I.ondon, CLxxxiII, 367
547. SEELEY, H.G. 1907. A new Labyrinthodont from the Karoo Beds, Cape Colony. Geol. Mag., Dec. v, IV, No. X, 433-434, pl. I.

548. 1908. A Labyrinthodont twoth from the upper Karoo Beds, South Africa. Geol. Mag.. Dec. v, v, No. vi, $24 I-2+3$, pl. $x$.

549. SMITI, John. Footprints in red calciferous sandstones in a railway cutting $21 / 4$ miles $N$. of West Kilbride. Trans. Geol. Soc. of Glasgow, IX, 201 .

550. Stejneger, Llonilard. I904. Amphibi: versus Batrachia. Science, n. S., $x x, 924$.

5.51. - 1907. Herpetology of Japan and adjacent territory. Bull. No. 58 , U. S. Nat. Mus., 1-576, pls. i-xxxv, and figs.

552. Steinmann-Döderlein. 1890. Elemente der Paleontologie. Amphibia, 601.

553. Steinmann, Gustav. 1907. Einfuhrung in die Paleontologie. Zweite Auflage. 2 Klasse: Amphihia, Lurche, $421-427$, figs.

554. Stephens, A. T. 1886. On the Biloela Labyrinthodont. Proc. Linn. Soc. New South Wales, II ser., I, II I 3 .

555. - 1888. On some additional Labyrinthodont fossils from the Hawksbury sandstone of New South Wales. Proc. Linn. Soc. New South Wales, I (2), I 1 75-1192.

556. - 1888. Note on a Labyrinthodont fossil from Cockatoo Island (Mastodonsaurus). Proc. Linn. Soc. New South Wales (2), I, 931-940.

557. - 1888. Second note on Platyceps wilkinsoni. Proc. Linn. Soc. New South Wales, II (2), 156-158, pl. I.

558. SternberG, C. H. J901. The Permian life of Texas. Trans. Kans. Acad. Sci., 94-98.

559. Stevenson, J. J. 1907. Carboniferous of the Appalachian basin. Bull. Geol. Soc. Amer., xvilr, 29178.

560. STORR1E, J. I 893-4. Notes on a tooth of a species of Mastodonsaurus. Trans. Cardif. Nat. Soc., xxvi, pt. 1I, 105, pl.

561. Stock, Tuomas. 1881 . On some Rritish specimens of the "Kammplatten" or "Kammleisten" of Professor Fritsch. Ann. and Mag. Nat. Hist., 5th ser., vill, yo-95, pl. vi.

562. 1882. Notice of some discoveries recently made in Carboniferous vertebrate paleontology. Nature, xxvII, Nov. 2d, 22. . (Describes new species of Ophiderpeton (nanum) and Pteroplax (cornuta).)

563 1882. Further observations on Kammplatten and Note on Ctenopthychius pectinatus. Ann. and Mag. Nat. Hist. (5), Ix, 253-257, pl. viii.

564. STRICKLER, LuDWIG. 1899. Ueber den microscopischen Bau der Fāltenzāhne von Eryops megacephalus. Paleontographica, XLVI, 85-94, I fig., Tafeln xi-xii.

565. Thevenin, Armand. 1905. Sur le Déeouverte d'Amphibiens dans le Terrain houiller de Commentry. Comptes Rendus Acad. Sci., CXLI (26), $1268-1269$.

566. 1906. Amphibiens et Reptile du Terrain Houiller de France. Annales de Paléntologie, Tome I, fas. III, I $-19,2$ pls.

567. 1909. Les Stades d'Evolution des plus anciens Quadrupèdes trouvés en France. Comptes rendus des Acad. Sci., CXL1X, 1222, Dec. 20. 
568. TheVenin, ARMand. 1910. Les plus anciens Quadrupèdes de France. Annales de Paléontogie, Tome v, $1-64$, pls. $i-i x$; v, fas. $1,1-40$, pls. $1-6$.

569 Thompson, James, and Professor Young. 1869. On new forms of Pteroplax and other Carboniferous Labyrinthodonts and other Megalichthys with notcs. Rcpt. Brit. Assn. Adv. Sci., pt. II, $10 \mathrm{I}$.

570. Thyng, F. W. 1906. The squamosal bone in Tetrapodous Vertebrata. Tufts College Studies, II, No. 2, scientific series, $35-74$.

571. Tomes, Chas. S. 1878. A manual of dental Anattomy, human and comparative. 5th ed., 65.

572. Tomes, John. 1850. On the structure of the dental tissues of the order Rodentia. Phil. Trans. Roy. Soc. London, 532. (Remarks on the structure of the teeth of Labyrinthodon jaegeri.)

573. Trautschold, H. 1884. Die Reste permischen Reptilien des Paleontologischen Cabinets der Universität Kasan. Nouv. Mem. de la Soc. Imp. Nat. Moscon, xv, 5-39, Taf. I-8.

574. Tschudi, Johannes J. von. I839. Classification der Batrachier mit Berücksichtigung der fossilen Thiere dieser Abtheilung der Reptilien. Mem. de la Soc. Scientif. Nat. de Neuchatel, 4to, II. Revicw: Neues Jahrb. f. Mineral. Geol. Paleon., I 84 I, 835-840.

575. - 1837. Ueber den Homo diluvii Testis A. Scheuchzer. Neues Jahrb. f. Mineral., Geol. u. Paleon., 545-547.

576. TwelvetreEs, W. H. I 880 . On a Labyrinthodont skull (Platyops ricardi Twel.) from the upper Permian cupriferous strata of Kargalinsk, near Orenburg. Bull. de la Soc. Imp. des Natl. de Moscou, LV, No. I, I1 7-122, with figs.

577. UDDEN, J. A. 1901. Gcology of Jefferson Co., Iowa. Iowa Gcol. Surv., xII, Ann. Rept., 406.

578. Versluys, J. 1909. Die Salamander und die ursprünglichsten vierbeinigen Landwirbelthiere. Naturwissenschaftliche Wochenschrift, Neue Folge, Bd. vin, No. $3, \mathrm{I}-28$, figs. I -5 .

579. VIDAL, LouIs MARIANO. I902. Sobre la presencia del tramo Kimeridgense en el Montseih y hallazgo de un Batracio en sus hiladas. Memorias Real Academ. Cienc. y Artes de Barcelona, IV, No. 18.

580. - 1902. Sur le prescnce de l'etage Kimeridgien an Montseih (Province de Lerida, Espagne) et découverte d'un Batracien dans ces assises. Memorias Real Academ. Cienc. y Artes de Barcelona, rv, No. I 8.

581. Vogt, CARL. 1854. Archegosaurus und all Labyrinthodonten sind Amphibien nicht Reptilien. Neues Jahrb. f. Mineral., Geol. u. Paleon., 676-677.

582. Wagner, A. I 861 . Neue Beiträge zur Kenntniss der vorweltlichen Fauna des lithograph. - Schiefers. Abhandl. der k. Bayer Akad. der Wissen. Classe, Bd. II, Abth. IX, 3-60 and 415-528.

583. WALDHEIM, FISCHER vov. I840. Nachtrag zu Herrn Major von Qualen's geognostischen Beiträgen zur Kenntniss des westlicher Urals. Bull. de la Soc. imp. des Natl. de Moscou, 488.

584. - 1847. Notice sur quelques Sauriens de l'Oolithe du Government de Simborsk. Bull. Soc. Nat. de Moscou, xx, pt. I, 364, pl. v.

585. WalterstorfF, W. I887. Ueber fossile Froesche insbesondere das Gattung Palreobatrachus. Theil I, Theil Ir, 8vo. - Jahresbericht d. naturw. Vereins zu Magdeburg, I-8I.
586. WalterstorfF, W. Igor. Ueber ein Exemplar von Rana meriani von Meyer in Senkenbergischen Museum zu Frankfurt. Bericht Senkenb. naturf. Gesell., 39-51, pl.

587. WARD, J. 1890. On the geological features of the North Staffordshire Coal-Field. Trans. North Staffordshire Inst. of Mining and Mechanical Engineers, $x$, pl.ix.

588. - 1900. On the occurrence of Labyrinthodont remains in the Keuper sandstone of Stanton. Trans. North Staffordshire Field Club, XxxIv, 108-1 12, pls. iv-v.

589. - Paleontology of the Patty Coal Field. Mem. Geol Surv. United Kingdom, pt. III, 285-357.

590. Watson, D. M. S. 1914. The Cheirotherium. Geol. Mag., VI, I, No. 603, 395-398.

591. - 1912. The larger Coal Measure Amphibia. Mem. and Proc. Manchester Lit. and Philos. Soc., Lvir, pt. 1, No. I, I-4, 1 pl.

592. - I913. Batrachiderpeton lineatum, Hancock and Atthey, a Coal-Measure Stegocephalian. Proc. Lond. Zool. Soc., pt. IV, 949-962, with 2 plates and figures in text.

59.3. - 1913. The early evolution of the Amphibia. Rept. 83d Meeting British Assn. Adv. Sci., 532.

594. - 1912. On some Reptilian lower jaws. Ann. and Mag. Nat. Hist., 8 th serics, vol. 10, July-Dec., 573-587, with figures.

595. - 1913. Micropholis Stowi Huxley, a temnospondylous amphibian from South Africa. Geol. Mag., 5th Dec., 10, 340-346, with figures.

596. WeIss, Ch. ERnst. 1871. Paleontologisch geognostische Untersuchungen aus dem Gebirge auf der Südseite der theinischen Devons. Bonn. Sitzungsb. Niederrhein Gesell., 33-35. (Archegosaurus extremity.)

597. - I 877 . Ueber Protriton petrolei von Fried richroda in Thurringen. Zeit. d. deutsch. geol. Gesell., XxIX, 202.

598. Wheatley, Chas. M. 1871. The bone cave of eastcrn Pennsylvania. Amcr. Jour. Sc. (3), 1, $384-385$.

599. Whirte, David. 1906. Geological position of the principal insect-bearing localities of the American Paleozoic, in "Handlirsch's Revision of American Paleozoic Insects." Proc. U. S. Nat. Mus., xxix, No. 1 441, 664-667.

600. - I907. Report of the field work in the coal districts of the state. Bull. No. 4, Illinois State Geol. Surv., 201. (Gives correlation of the Mazon Creek Beds.)

601. Wrede RSHEIM, Robert. 1876. Die āltcsten Formen des Carpus und Tarsus der heutigen Amphibien. Morphol. Jahrb., Bd. 2, 421-423, Taf. xxix, fig. 2.

602. - 1878 . Ueber Labyrinthodon ruetemeyeriAnatomie der Gehirn. Abhandl. d. schweizer paleontol. Gesell., v, I-56, mit 3 tafeln.

603. - 1 - 1879. Die Anatomie der Gymnophionen, pp. I-Ior, Tafeln i-ix. (Refers to extinct Amphibia in connection with phylogeny.)

604. - 1886. Lehrbuch der vergleichenden Anatomie der Wirbelthiere. 2 Auflage.

605. — and W. N. PARker. 1897. Elements of the comparative anatomy of vertebrates. Translated by W. N. Parker. Labyrinthodontia, 242, fig. $193 \mathrm{C}$.

606. WILDER, H. H. Ig09. History of the human body. Amphibia, 541-5 $t^{2}$. 
607. Williston, S. W. 1897. Some vertebrates from the Kansas Permian. Kans. Univ. Quart., ser. A, vi, No. I, 53, fig. Cricotus.

608. I I 1 . A new Labyrinthodont from the Kansas Carboniferous. Kans. Univ. Quart., vi, No. 4, ser. A, 30), fig. and pl. (Rcfers tooth and skull fragments to Mastodonsaurus.)

609. - 1899. The Red-Beds of Kansas. Science (2), IX, 22 I.

610. 1899. Notes on the coraco-seapula of Eryops Cope. Kans. Univ. Quart., viri, No. 4, I85-I86, pls. Xxvii-xxx. (See Moodie (476).)

611. - 1900. Some fish teeth from the Kansas Cretaceous. Kans. Univ. Quart., ser. A, IX, No. I, Jan., pl. vi, figs. 13, 13 .

612. - 1904. The temporal arches of the Reptilia. Biol. Bnll., vi1, No. 4, I 75-192.

613. - 1908. The faunal relations of the early vertebrates. Jour. Geol., XvIr, No. 5, 389-402. Also, Outlines of geologic history, Willis and Salisbury, 1910, 163-175.

614. - 1908. Lysorophus, a Permian Urodele. Biol. Bull., Xv, No. 5, 229-240. Review in Rev. crit. de Paleozoologie 13th Annee, No. 2, 82.

615. - 1909. The skull and extremities of Diplocaulus. Trans. Kans. Acad. Science, Xxrr, 122I3 I, pls. I-5.

616. - 1909. New or little-known Permian vertebrates, Trematops, new genus. Jour. Geol., xvir, No. 7 , Nov., 636-658, 7 figs.

617. - 1909. Principal characters of the Chelydosauria, a suborder of temnospondylous Amphibians from the Texas Permian. A. A. A. S. Soc. Vert. Paleon.

618. - 1910. Dissorophus. Jour. Geol., xvir1, No. 6, 526-535, pls. i-iii.

619. - I910. Cacops, Desmospondylus, new genera of Permian Vertebrates. Bull. Geol. Soc. Amer., XXI, 249-284, pls. 6-17.

620. 1910. New Permian Reptiles: Rachitomous vertebræ. Jour.Geol., Xvirr, No.7.585-600, with figs.

621. - 1911. American Permian vertebrates. Amphibia, 9-14, pls. xxxii, xxxviii.

622. - 1913. The primitive structure of the mandible in amphibians and reptiles. Jour. Geol., $\mathrm{xxI}, 625-627$, I fig.

623. - 1914. The osteology of some American Permian vertebrates. Jour. Geol., XxIr, No. 4, 416 , figs.

624. - 1914. Water reptiles of the past and pres. ent. Amphibia, 35, 47, and figures.

624a. - 1914. Broiliellus, a new genus of amphibians from the Permian of Texas. Jour. Geol., Xxir, No, $1,49-56$, figs. I-2.

624b. - 1914. Restorations of some American Permocarboniferous amphibians and reptiles. Jour. Geol., XXIr, No. I, 57-70, figs. I-I1.

62+c. - I915. Trimerorhachis, a Permian temnospondyl amphibian. Jour. Gcol., Xxirr, No. 3 , $246-255$, figs. $1-6$.

624d. - 1916. Synopsis of the Amcr. Permocarboniferous Tetrapoda. Contrib. from Walker Museum, vol. I, No. 9, pp. 200-2II, figs. 38-53.

625. WiMan, Carl. 1903. Ein Paar Labyrinthodontenreste aus der Trias Spitzbergens. Bull. Geol. Inst. Univ. of Upsala, Ix, 34-40, Tafeln II, Nos. 17, I 8.

626. - 1913. Ueber das Hinterhaupt der Labyrinthodonten. Bull. Geol. Inst. of Upsala, xu, $\mathbf{I}-7$, figs. $\mathbf{I}-8$.
627. Wimax CarL. 1914. Ueber die Stegocephalen aus der Trias Spitzbergens. Bull. Geol. Inst. of Upsala, xr11, 1-30, pls. i-ix, figs. I-10, bibliography.

628. Woodward, A. Smitir. 1891. Cataloguc of the fossil fishes in the British Museum, pt. II, 474. (Note on the synonymy of Pygopterus, Colosteus, and Archegosaurus.)

629. - 1891. On a Microsaurian (Hylonomus wildii) from the Lancashire Coal Field. Geol. Mag., n. s., Dec. III, viri, 211-213, with figs.

630. 1897 . On a new specimen of the Stegocephalian Ceraterpeton galvani Huxley. Geol. Mag., Dec. IV, Iv, No. 397, 293, with plate.

631. - 1904. On two new Labyrinthodont skulls of the genera Capitosaurus and Aphaneramma (from the Trias of Spitzbergen). Proc. Zool. Soc. London, 170-176, with 2 pls.

632. 1906. The relations of paleontology to biology. Ann, and Mag. Nat. Hist., xvirı, No. 106, 312-318.

633. 1905. Fishes and Labyrinthodonts. Palcontologica Indica, n.S., II, Memoir No. 2, 10, 2 pls.

634. 1909. On a new Labyrinthodont from Oil Shale, N. S. W. Rec. Geol. Surv. N. S. W., virı, pt. IV, 317-319, pl. 5I.

635. Woodward, H. B. 1887. The geology of England and Wales. The Northumberland Coal Ficld, I8o.

636. WOODWORTH, J. B. 1900. Vertebrate footprints on Carboniferous shales of Plainville, Mass. Bull. Geol. Soc. Amer., XI, 449-454, pl. 40, fig. I.

637. Wyman, JefFries. 1843. Analogies which exist between the structure of the teeth of the Lepidostei (Gars and Gar-pikes) and those of the Labyrinthodonts (extinct Amphibia). Proc. Bost. Nat. Hist. Soc., I, I 3 I-132; also Silliman's Journal, 843 .

638. - 1853. Notes on the Reptilian remains (Dendrerpeton). Quart. Jour. Geol. Soc. London, $1 x, 64-66$.

639. - 1856 . On a batrachian reptile from the Coal Formation. Proc. Amer. Assn. Adv. Sci., Ioth Mecting at Albany, 172-173. Revicws: Edinb. n. Philos. Jour. 1857, v, 360-36r; Neues Jahrb. f. Mineral., Gcol. u. Paleon., I. 857, 340. 640. - 1858. On some remains of batrachian reptiles discovered in the Coal Formation of Ohio. Amer. Jour. Science, Xxv (2), Mar., 158-164, fig. Review: Zeit. f. gesammt Naturwissensch., xIIr, 71 ; Neues Jahrb.f. Mineral., Geol. u. Paleon., 1858,340 .

641. Yakowlew, N. 1902. Neue Funde von TriasSaurier auf Spitzbergen. Verhandl. Russ. k. Min. Gesell., XL, I80; Nachtrag, XL1, 165.

642. ZITTEL, KARL vON, 1887-1890. Handbuch der Paleontologie, I Abth., Bd. III, 337-437, Anphibia. München u. Leipsic, R. Oldenbourg, also Eastman's translation of above, 2, I I4-139, figs.

643. 1888. Ueber Labyrinthodon ruetineycri (Wiedersheim). Neues Jahrb. f. Mineral., Geol.u. Paleon., Bd. 11, 17. (Regards the form as a reptile.)

644. - 1899. Amphibien. Geschichte der Geologie und Paleontologie. Misenchen น. Leipzig, 1899. 827.

645. Zwick, W. 1897. Beitrăge zur Kenntniss des Baues und der Entwickelung der Amphibicngliedmassen, besonders des Carpus und Tarsus. Zeitschr. wissen. Zool., Bd. 63, 62-144, Taf. 4-5. 


\section{AN INDEX TO THE BIBLIOGRAPHY OF FOSSIL AMPHIBIA.}

The following will be of assistance to those wishing aid in finding the literature on special phases, whether anatomical or geological, of the fossil Amphibia. The author's name and the number of his paper in the preceding bibliography are given in groups of classified subjects, beginning with distribution and ending with anatomy. The various anatomical notes of interest are especially widely scattered in papers which often deal with a variety of other subjects.

I. Geological and Geographical Distribution.

Devonian:

North America: Marsh, 407.

Europe: Lohest, 381; Weiss, 596; Thevenin, 566. Mississippian:

North America: Branson, 50; Barrell, 21 ; Lea, 371 372.

Scotland: Huxley, 331-334; Atthey, 11; Hancock and Atthey, 305.

Coal Measures (Pennsylvanian):

North America: Agassiz, 2; Butts, 82, 83; Case, 86 , $9+$ i Cope, 105, 107, I I5, I I 6, I 1 8, 122, 123, I26, I27, I 31, 145, I52, 167, 176; Dawson, 200-225: Eastman, 230; Hay, 316; Jaekel, 347; King, 356, 357; Marsh, 404, 406; G. F. Matthew, 408-413; Moodie, 458-465, 469-475, 478, 479, 482-486; Mudge, 490; Newberry, 495-498; Raymond, 531; Schwarz, 540, 541; Williston, 608; IVyman, 639, 640 .

Europe: Andrews, 8; Atthey, 11; Bailey, 12-13; Barkas, I5-20; Bolton, 42-43; Credner, 179-194 (see also under Permian); Davis, 199; Dunlop, 229; Embleton and Atthey, 235; Etheridge, 241; Fritsch, 251; Gaudry, 263-268, 278, 28I, 282; Gergens, 291; Goldfuss, 297; Hancock and Atthey, 304-310; Lydekker, 394; von Meyer, 422, 426, 436; Oldham, 500; Owen, 507-509, 514, 515; Schwarz, 540; Thevenin, 565-568; Weiss, 597; Woodward, 629, 630; Woodworth, 636.

Australia: Stephens, 557; Woodward, 634. Permian:

North America: Broili, 55, 56, 58, 63, 65; Case, 86-93, 95-100; Cope, 129, 132-I 33, 137, 138, 140-1 44 . 156, I 69, 170-175; Emmons, 237; Gregory, 299; W. D. Matthew, 414, 415 ; Moodie, 457,458 , 476, 477; Sternberg, 558; Strickler, 564; Williston, $607,609,610,614,615,616,617-624$.

Europe: Ammon, 7; Branco, 48; Broili, 59, 60, 61, 62, 66; Credner, 179-195; Deichmueller, 224, 225: Eichwald, 233; Emery, 236; Fritsch, 251; Gaudry, 258-261 , 269-282; Geinitz, 287; Geinitz und Deichmueiler, 289, 290; Goldfuss, 295, 296; von Huene, 324-327; Huxley, 328; Jaekel, 344 345; LeRoy, 375: Lloyd, 379; Lortet, 382; von Meyer, 428, 436, 4+2; Roemer, 537; Trautschold, 573; Twelvetrees, 576 .

Africa: Broom, 68-71-73, 74 .

Asia: Lydekker, 384, 386; Huxley, 333; Woodward, 633.
Triassic:

North America: Branson, 49; Cope, 106, 111, I21, 157; Emmons, 237; Leidy, 373; Lucas, 383.

Europe: Alberti, 4; Burmeister, 80, 81 ; Fraas, 242$245,247 a$; von Huene, 323; Huxley, 329 ; Jaeger, 338-341; Metcalfe, 417; von Meyer, 421,425 , 439; Miall, 453; Owen, 505; Quenstedt, 527; Seeley, 544; Storrie, 560; Ward, 588; Wiedersheim, 602; Woodward, 63I.

Spitzbergen: Wiman, 625-627; Woodward, 631; Yakowlew, 64I; Sceley, 547 .

Africa: Broom, 69; Huxley, 330; Owen, 517, 519-520. Asia: Lydekker, 38t-391; Owen, 510, 511.

Australia: Huxley, 330; Stephens, 554, 555

Jurassic:

Europe: Dollo, 226.

Comanchean:

North America: Marsh, 405: Moodie, 480, 481.

Europe: Vidal, 579, 580.

Cretaceous:

North America: Cope, 128; Hatcher, 314; Lambe, 365,$366 ;$ Williston, 611 .

Tertiary:

Europe: Beyrich, 36; Bieber, 37 ; Cuvier, 197; Fraas, 246, 247; Gunther, 301; Laube, 367-370; von Meyer, $424,430,444,446,447$; Portis, 525: Scheuchzer, 535; Tschudi, 574-575; Walterstorff, 585-586.

Pleistocene:

North America: Brown, 76; Wheatley, 598.

Soith America: Lydekker, 393.

Asia: Clark, 103; Lydekker, 393; Owen, 506.

Europe: Lydekker, 393.

\section{Phylogent of Amphibia.}

Arldt, I0; Baur, 22-25, 31; Boulenger, 44; Branson, 49; Budgett, 79; Cope, 153, 166, 173 ; Davison, 198; Dollo, 228; Gadow, 256; Gaudry, 280, 282; Gregory, 299, 300, 300a; Haeckel, 31 2 ; Huxley, 337; Kingslcy, 358; Moodie, 489b; Owen, 51 2; Pollard, 524; Quenstedt, 527: Thevenin, 567-568; Versluys, 578; Vogt, 581; Wiedersheim, 6oI.

III. ONtogeny OF AMphibi..

Ammon, 7; Credner, 187; Fritseh, 251; Hay, 315; von Meyer, +22; Thevenin, 566. 
IV. Structure AND Morplology of Ampibia.

Lateral-line System of Sensory Organs: Andrews, 8;Baur, 31; Branson, 49; Fraas, 242, 247a; Huxley, 333; Malbranc, 401 ; Mliall, 450 ; von Meyer, 436 ; Moodie, 458 , $465,478,488$; Thevenin, 568 .

Pineal Eye: Cope, I60; Credner, 187; Jaekel, 346.

Morphology of the Skull: Albrecht, 5; Baur, 24, 27, 29, 31; Boulenger, 44; Branson, 49; Broili, 55, 56, 66; Case, 85, 93, 98; Cope, 136, 177; Credner, 187-191; Fraas, 242, 247a; Fritsch, 251; Fuchs, 255; Gaupp, 283; Goodrich, 298; Jaekel, 347; Maggi, 397, 398; von Meyer, 428, 436, 439: Moodie, 458, 478; Owen, 511 ; Seeley, 546; Thevenin, 568; Thyng, 570; Williston, 6s2, 614, 615, 616, 619; Wiman, 626; Woodward, 631 .

Brain: Wiedersheim, 602; Moodie, 487.

Ear: Cope, 159; Broom, 75 .

Eye: Cope, 105, 107; Moodie, 478.

Teeth: Broili, 58; Credner, 194; Fraas, 242; Fritsel,, $25 \mathrm{~J}$; Jaekel, 342; Owen, 502, 503, 504, 505; Seeley, 548; Strickler, 564; Tomes, 571-572; Williston, 608; Wyman, 6.37 .

Gills: Budgett, 79; Credner, 187; Cope, 123; Fritsch, 251; Gaudry, 268; Thevenin, 566-568; von Meyer, 436.
Vertebræ and Ribs: Baur, 25, 26: Broili, 61: Case, 98: Cope, 133, 136, 142, 148, 15.3; Credner, 179-19.3: Fraas, 242; Fritsch, 251; Gadow, 256: Gegenbaur. 284; Jaekel, 344, 348; Lillic, 378; Marsh, 404; von Mleyer, 436; Mlivart, 456; Moodie, 468; Schwarz, 540, 541; Thevenin, 565-568; Williston, 620 .

Pectoral and Pelvic Arches: Broili, 62; Broom, 72; Cope, 161; Credner, 180-185; Fritsch, 251; Gregory, 299, 300a; Gegenbaur, 285; Jaekel, 347i Moodie, 478; Williston, 610,616 .

Limbs, Carpus, and Tarsus: Baur, 22, 23, 28; Cope, 161; Credner, 180-185; Emery, 236; Fritsch, 251; Gregory, 299-300a; Jaekel, 347; Wiedersheim, 601; Zwick, 645.

Clasping Organs: Barkas, 16; Blanchard, 39; Braun, 52; Hilton, 319; Moodie, 461; Fritsch, 251; Stock, 561; Newberry, 498.

Museles: Moodie, 464 .

Alimentary Canal: Moodie, 471, 474, 478.

Integument, Scales, and Structure of Bone: Jaekel, 343; Moodie, 464, 465, 478; Broili, 62; Dawson, 208.

Footprints: Barrell, 21; Branson, 50; Brodie, 54; Butts, 82-83; Duwson, 207, 208; Fritsch, 25 I ; Geinitz, 288; Hickling, 318; King, 356-357; Lea, 371, 372; Leidy, 374; Marsh, 406; G. F. Matthew, 408-413; Owen, 504; Moodie, 465; Pabst, 52I; Smith, 549; Wood. worth, 636 . 


\section{INDEX.}

Aistoporla $\quad$ PAGE.

Alinentary Canal. ............... 25, 58

Amblyodon..................... I 78

A. problematicum................ I 79

American Museım..................... I, 8

Ames Limestone. .................... 12

Amphibamus...................... I27

A. grandiceps.............. 2, 7, 15, 128

A. thoracatus................... 132

Amphibamida................... 127

Amphibia........................ 3

Classification................ 46

Definition................... 49

Discovery in Carboniferous.......... 6

Geographic and Geologic Distribution.... 9

History of Classification............ 39

Anaschisma, Lateral Line System of. . . . . . . . 35

Anisodexis............................ $16_{4}$

Anthracosaurida................... 187

Apoda.............................. 33

Archegosaurus.................... 1, 7, 35

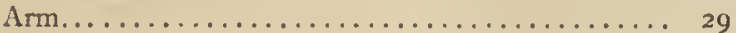

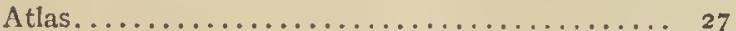

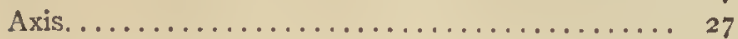

Baphetes......................... 188

B. $\operatorname{minor} \ldots \ldots \ldots \ldots \ldots \ldots \ldots \ldots \ldots \ldots$

B. planiceps.................. 6, 188

Baur, George........................ 39

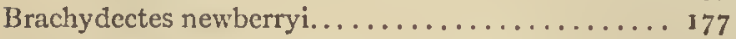

Branchiosauria.................... 4, 50

Branchiosaurida.................... 51

Branchiosaurus...................... 53

Branson, E. B.................. 38, 192

Brown, N. H..................... I2

Budgett, J. S..................... 78

Cannelton Slates.................. 10, 15

Carr, J. C.................... 13, 14, 22

Case, E. C..................... 9, 182

Caudata............................67 67

Cephalerpeton ventriarmatum............. 133

Cercariomorphus parvisquamis............. I I39

Clepsydrops Shales. .................. 9

Cocytinidæ........................ 67

Cocytinus gyrinoides................ 68

Cope, E. D............ 1, 7, 9, 34, 42, 43, 131, 207

Credner, Hermann................ 1, 24, 52

Cricotidæ........................... 180

Ctenerpeton alveolatuni................. 168

Dawson, Sir J. W....... 7,8, 19, 20, 32, 66, 194, 197

Dean, Bashford................... 32,187

Dendrerpeton.................... 19, 194

D. acadianum.................. 194

D. oweni.

196
Dermal Appendages................... 197

Devonian..................... 10,37

Diceratosaurus.................... 8, 116

D. lavis....................... 121

D. punctolineatus.................. 117

D. robustus.................. 123

Diplocaulia....................... 34

Dromopus.................... 37, 201

D. aduncus ................... 37

D. agilis................... 201

Eobaphetes........................ 191

E. kansensis.................. 192

Eosauravus..................... 87,176

Eosaurus acadianus. . . . . . . . . . . 189

Eoserpeton tenuicorne.................. 124

Erierpeton branchialis.................. 69

Erpetobrachium mazonensis............ 152

Erpetosaurus ..................... 97

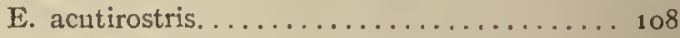

E. minutus.................... 105

E. obtusus....................... 99

E. radiatus.................... 98

E. sculptilis................... 106

E. tabulatus................... 101

E. tuberculatus.................... 110

Eryopida............................ I 182

Eryops.................... 23, 34, 182

Euamphibia.................... 46, 49

Eumicrerpeton parvum............... 57

Eury thorax sublevis................... 172

Eye..................... 25, 131

Footprints................... 15, 201

Fritsch, Anaton............... 5, 54, 77, 78

Fritschia curtidentata................ 85

Gergens, Dr...................... 6

Gurley, W. F. E.................. 9, 12

Hay, O. P..................... 8, 129

Hussakof, Louis.................. 1, 16, 172

Huxley, Thomas $H . \ldots \ldots \ldots \ldots \ldots \ldots \ldots, 137$

Hylerpeton...................... 83

H. dawsonii...................... 83

$\mathrm{H}$. intermedium................ 84

H. longidentatum.............. 84

Hylonomida..................... 79

Hylonomus..................... 79

H. latidens................... 81

H. lyelli..................... 80

H. multidens. . . . . . . . . . . . . . 81

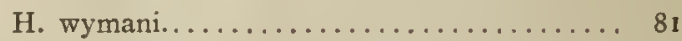

Hylopus logani................... 6

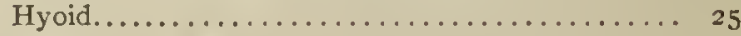

Hyphasma lavis................... 70 
Ichthycanthida.

173

Iclitliycanthus.

I. ohiensis.

I. platypus.

Ich thycrpeton squamosum.

Jxkel, Otto.

Joggins, The South (Nova Scotia).

8,118

Kammplatten..................... 5

Kittanning Coal................ 15, 16

Iacoe, R. D. (Collection of) . . . . . . . . . . I

Jatcral Line System. . . . . . . . . . . . . 32

l.cg.............................. 30, 95

Lepospondylia..................... 76

Leptophractus.......................... 169

L. dentatus.................. I71

L. lincolatus.................... I71

L. obsolctus...................... 169

Linton, Ohio, Coal Measures............... 16

Amphibia of. ................. 18

Logan, William.................... 6

Lonisville, Kansas. .................... 10

Lydekker, Richard................ 44,77

Lyell, Charles................... 19, 20

Macrerpetida...................... 183

Macrerpcton...................... 184

M. deani..................... 186

M. huxleyi..................... I 184

Mandible...................... 25, 103

Marsh, O. C................ 10, 37, 189, 202

Mastodonsauridx....................... 200

Mastodonsaurus sp. indet. . . . . . . . . . . 200

Matthew, G. F.................... 8, 22

Mauch Chunk.................... 37

Mazon Creck Shales.................. 7, 12

Amphibia of................ 13

Mazonerpeton......................6. 61

M. costatum....................... $6_{3}$

M. longicaudatum............... 61

Meyer, Hermann von. ................... 6

Micrerpeton. .................. 5 I

M. caudatum.................. 52

Microsauria.................. 4, 34,76

Relation to Reptilia............. 77

Mississippian Amphilia................ 37

Molgophida. ........................ 149

Molgophis. ........................ 149

M. brevicostatus................ 150

M. macrurus.................. 149

M. wheatleyi.................. 151

Morphology of Coal Mcasures $\Lambda$ mphibia........ 23

Musclc......................... 32

Myocommata..................... 30

Necturus..................... 33, 56

Newberry, J. S. (Collections of) ........ 1, 8, 17, 18

Nyraniida........................ 137

Occiput........................... 25

Odonterpeton triangularis.
CEstoccplialus..................... 145

O. rectidens................. 147

O. remcx....................... 145

Opcrculum..................... I72

Osage City, Kansas................... 10

Palate. ........................ 24, 104

Parabatrachus.................... 7

Pectoral Girdle.................. 29, 107

Pelion....................... 7,72

P. lycli....................... 73

Peliontidx........................ 72

Pelvic Girdle. . . . . . . . . . . . . . . . . 29

Phlegethontia....................... 155

P. linearis...................... 156

P. serpens.................... 156

Phønix Tunnel, Pennsylvania............. 10

Pholidogaster....................... 3

Pitcairn, Pcnnsylvania............... 12

Platystegos loricatum................. 199

Plcuroptyx clavatus. . . . . . . . . . . . 12, 19, 153

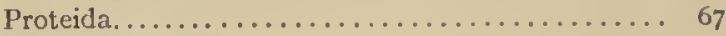

Proterpeton gurleyi.................12, 178

Ptyoniida...................... I 41

Ptyonius...................... 141

P. marshii..................... I43

P. nummifer................... I 44

P. pectinatus.................. I4I

P. serrula..................... 144

P. vinchellianus................. 143

Raniceps........................ 7

Ribs............................ 27

Salientia.................... $7^{2}$

Saurerpeton latithorax. ............... $16_{5}$

Sauropleura........................ 157

S. digitata..................... 159

S. (Anisodexis) enchodus.............. 164

S. foveata...................... $16_{3}$

S. longidentata................. 162

S. ncwberryi..................... 160

S. pauciradiata................... 160

S. scutellata..................... 158

Sauropleuridx................... 30, 157

Scales........................ 31, 197

Schwarz, Hugo.................... 8, 28

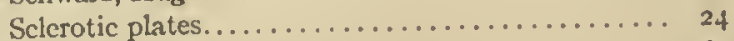

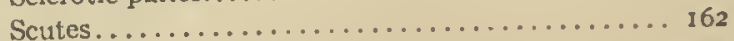

Skin....................... 164, 197

Skull........................... 23

Smilerpcton aciedentatum.............. 82

South Joggins, Nova Scotia.............. 7, 19

Sparodus sp....................... 66

Spondylcrpeton spinatum. .............. 181

Stegopida...........................113

Stegops......................... 113

S. divaricata..................... I14

Stereospondylia................. 5, 34, 200

Sternum.............................. 30 


\section{INDEX.}

Tarsus.......................... 176

Teeth

Temnospondylia. .

Thinopus antiquus.

Thyrsidium fasciculare.

Traquair, R. H.

Triton walthi.

Tuditanida.

Tuditanus.

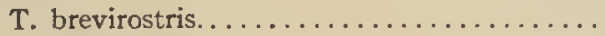

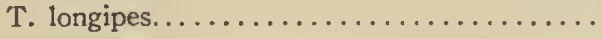

T. minimus.

T. punctulatus.

T. walcotti.

10,37
Twin Mounds, Kansas. .

Udden, J. A.......................

Urocordyliidæ.

116

Ventral Scutellix..................... 30

Vertebræ.................... 27, 181

Vertebral Column.................. 27

Wiedersheim, Robert................. 30

Williston, S. W.................. 2, 10, 200

Wyman, Jeffries.................. 7

Zamcnis flagcllum................ 5 

THIS BOOK IS DUE ON THE LAST DATE

STAMPED BELOW

RENEWED BOOKS ARE SUBJECT TO IMMEDIATE RECALL

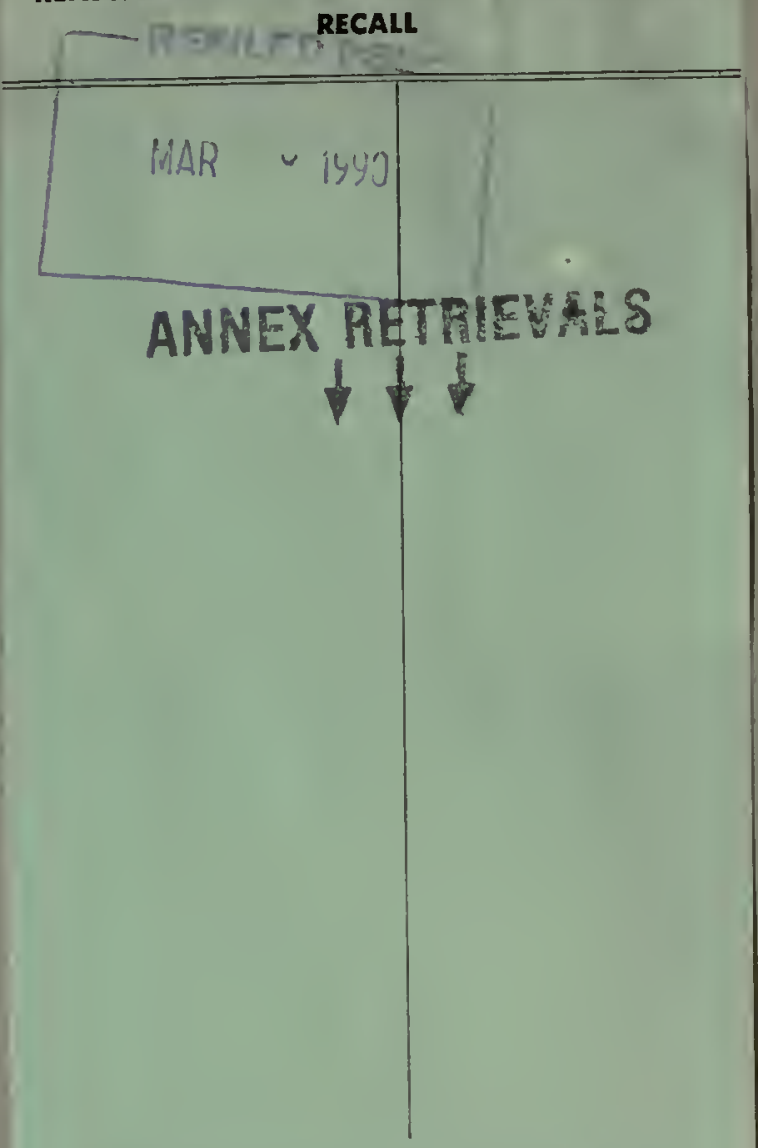

LIBRARY, UNIVERSITY OF CALIFORNIA, DAVIS 


\section{8}

Moodie, R.L.

The coal measures

Amphibia of North America.

PHYSICAL

SCIENCES

LIBRARY

UNIVERSITY LIBRARY

OF CALIFORNIA

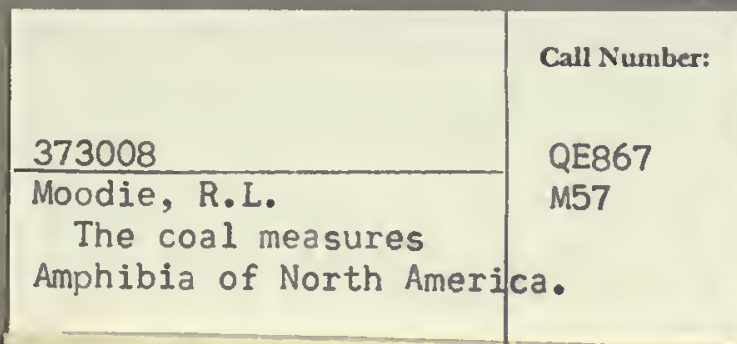


